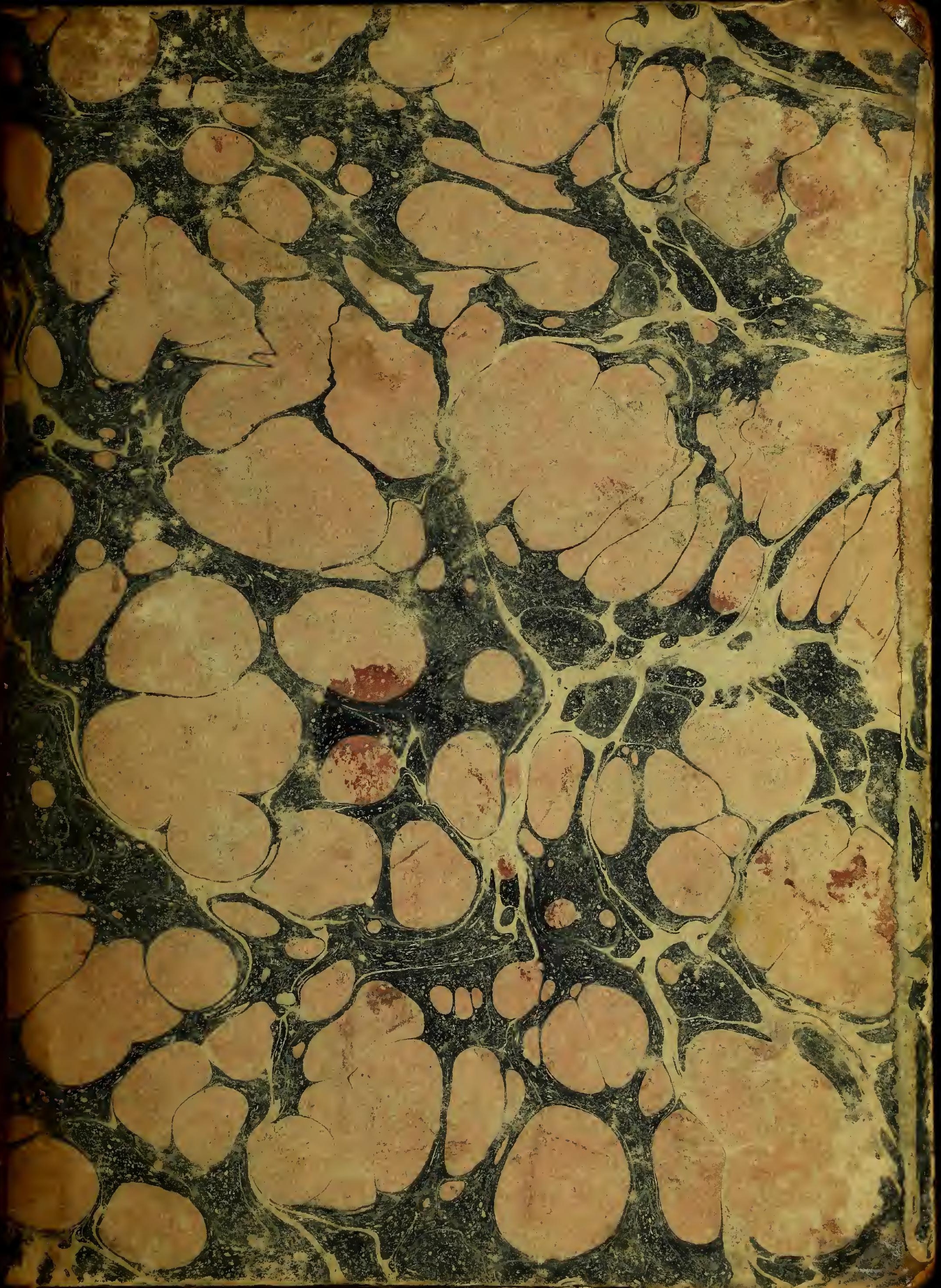




$$
\begin{aligned}
& -\operatorname{lit} / 18 \\
& \text { Cend }
\end{aligned}
$$




$$
11+\ldots
$$





\section{F U C I}

S I V E

\section{PLANTARUM FUGORUM GENERI}
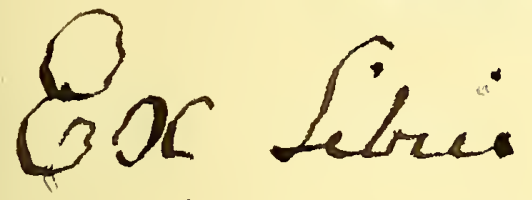

$\mathbf{A}$

BOTANIGIS ASGRIPTARUM

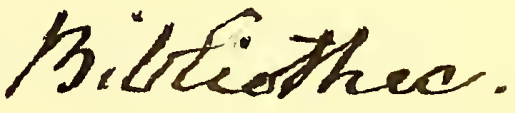

ICONES DESGRIPTIONES ET HISTORIA.

Gollegii

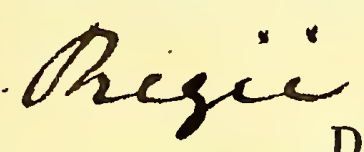

A UCTORE

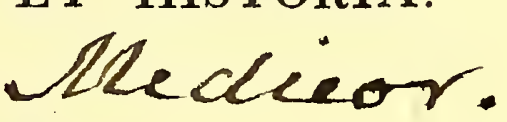

Baren

DAWSON TURNER, M. A.

REG. ANT. ET LINN. SOC. NECNON IMP. AC. NAT. CUR. REG. AC. HIB. ET ALIARUM SOCIETATUM SOCIO.

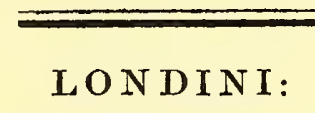

TYPIS J. M'CREERY.

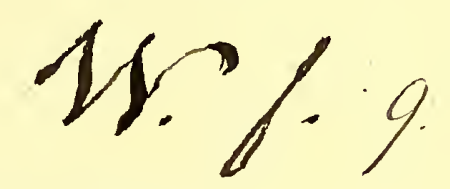

IMPENSIS J. ET A. ARCH, IN VICO CORNHILL DICTO.

MDCCCVIII

\section{F U C I; \\ OB,}

GOLORED FIGURES AND DESGRIPTIONS

\section{OF THE PLANTS}

REFERRED BY BOTANISTS TO THE GENUS FUCUS.

By DAWSON TURNER, A. M. F. R. A. \& L. S.

HONORARY MEMBER OF THE IMPERIAL ACADEMY NATURE CURIOSORUM, OF THE ROYAL IRISH ACADEMY, OF THE HONORABLE DUBLIN SOCIETY, OF THE NATURAL HISTORY AND WERNERIAN SOCIETIES

OF EDINBURGH, OF THE PHYSICAL SOCIETY OF GOTTINGEN, \&c. \&c.

VOL. I.

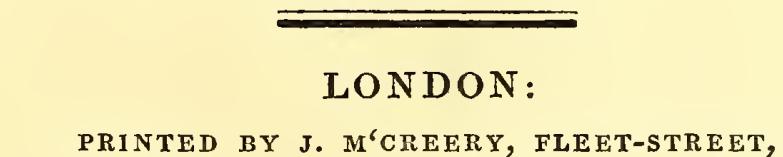

FOR JOHN AND ARTHUR ARCH, 61, CORNHILL.

1808. 
Digitized by the Internet Archive in 2015 
TO

THE RIGHT HONORABLE

\section{SIR JOSEPH BANKS, BART. K. B.}

\&c. \&c. \&c.

THE PATRON OF SGIENGE,

THIS WORK

IS INSCRIBED,

WITH GRATEFUL ESTEEM,

BY

THE AUTHOR. 


\section{N D E $\mathrm{X}$ 。}

The Names printed in Italics are Synonyms.

The first Number refers to the Plate, the second to the Page.

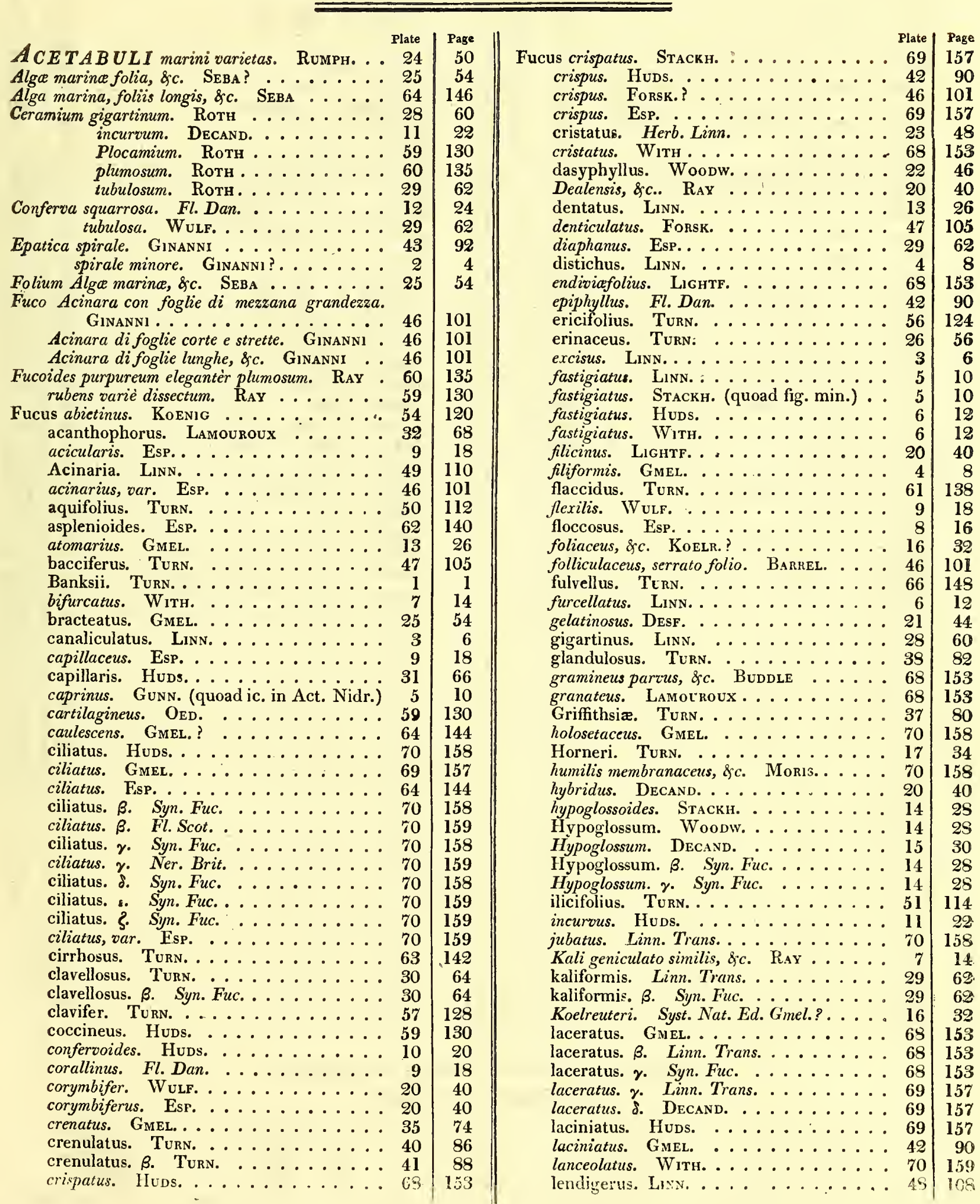


Fucus lendigerus, Esp. . . . . . . . . . . 46 Plate $^{\text {Page }}$ lichenoides. WiLLD. .......... 18 ligulatus. Gmé. ........... 70 lincaris. Fl. Dan. lumbricalis, GMEL. lumbricalis. B. Syn. Fuc. . . . . . . . Jycopodioides. Linn. . . . . . . . . . Lycopodium. Sтаски. (quoad descript.) . 12 Mackaii. Turn. ............ 52 marinus ramosus, \& c. Sева . . . . . . 64 marinus vesiculas habens, \&c. SloANE . . . 24 membranaceus acaulis, \&c. Moris. . . . . 20 membranaceus purpureus latifolius, \&c. $\mathrm{RAY} 35$ membranaceus purpureus varie ramosus. $\mathrm{R}_{\mathrm{AY}} 42$ membranaceus rubens angustifolius, \&c. $\mathrm{R}_{\mathrm{AY}} 70$ membranaceus rubens foliolis, \&c. MoRrs. . 13 Menziesii. Turn. .......... 27 miniatus. Fl. Dan. . . . . . . . . 49 minimus dentatus triangularis, \&c. SLOANE 33 multifidus. Huds. ............ 20 muricatus. GMEL. . . . . . . . . . 18 natans. Lins. ............. 46 natans. Esp. . . . . . . . . . 47 nervosus. Decand. ........... 43 nitidus. Wев. et Mонг .......... 39 Norvegicus. Gunn. .......... 41 obtusus. Huds. . . . . . . . . 21 obtusus. $\beta$. Syn. Fuc. . . . . . . . 21 ocellatus. Lamouroux .......... 71 Oederi. Esp. .............. 25 Ophioglossum. WE. et MoнR ...... 58 ornatus. Linn. . . . . . . . . . . . . 64 Osmunda. Gmel. . . . . . . . . 20 pallidus. Turn. ........... 67 palmaris angustifolius, \&c. Morrs. . . . . 3 palmaris tenuis, \&c. Moris. . . . . . . 6 Palmette, var. Esp. . . . . . . . 35 parvus, segmentis oblongis, \&c. Moris. . 6 papillosus. Forsk. ............ 21 papillosus. GmeL. . . . . . . . . . 16

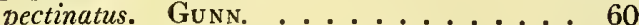
pilulifer. Turn. ........... 65 pinastroides. GMEr. ........... 11 pinnatifidus. Huds. .......... 20 pinnatifidus. Gмes. .......... 20 pinnatifidus. Fl. Dan. .................. 13 pinnatifidus. $\beta$. Syn. Fuc. . . . . . . . 20 pinnatifidus. $\gamma$. Syn. Fuc. . . . . . . . 20 pinnatifidus. $\delta$. Syn. Fuc. . . . . . . 20 pinnatus. LinN. ........... 53 pistillaris. WuLF.?.......... 21 pistillatus. GMEL. ........... 28 pistillatus. $\beta$. Lamou roux . . . . . . . . 28 Plocamium. Gmel. . . . . . . . . 59 plumaris. Forsk. . . . . . . . 53 plumosus. Huds. .......... 60 polymorphi, var. LaMoukoux?......4 41

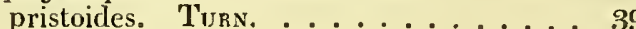
prolifer. IıIGHTF. . . . . . . . . . 42 prolifer. Fonsk. ............ 58 Ptilotus. Gunn. . .......... 60 pumilus dichotomus, \&c. $\operatorname{RAY}_{\mathrm{AY}} \ldots \ldots . .3$ punctatus. WІтн........... 71 purpurascens. Huds. ........... 9

$\begin{array}{r}101 \\ 36 \\ 158 \\ 8 \\ 12 \\ 12 \\ 24 \\ 24 \\ 116 \\ 144 \\ 50 \\ 40 \\ 74 \\ 90 \\ 158 \\ 26 \\ 58 \\ 90 \\ 70 \\ 40 \\ 36 \\ 101 \\ 103 \\ 92 \\ 84 \\ 88 \\ 44 \\ 44 \\ 164 \\ 60 \\ 198 \\ 144 \\ 40 \\ 150 \\ 6 \\ 12 \\ 74 \\ 12 \\ 44 \\ 32 \\ 135 \\ 164 \\ 135 \\ 18 \\ 22 \\ 40 \\ 40 \\ 26 \\ 40 \\ 40 \\ 40 \\ 118 \\ 44 \\ 60 \\ 130 \\ 119 \\ 135 \\ 89 \\ 84 \\ 90 \\ 129 \\ \hline\end{array}$

Fucus purpureus. Glate $\mid$ Page pycnocistus. МЕкт. ........... 49 racemosus, Forsk. . ......... 57 radiatus. Linn. Trans. . . . . . . . . 5 Radula. Herb. Banks. ........... 2554 ramosus, piperis sapore. $\mathrm{R}_{\mathrm{AY}} \ldots \ldots \ldots .2040$ roseus. Fl. Dan. . . . . . . . . 3574 rotundus. GMeL. ............ 5 rotundus. Ess. .................. 36 rotundus. $\beta$. Syn. Fuc. . . . . . . 5510 rotundus. $\gamma$. Syn. Fuc. ......... 5 rubens. Linn. ............. 42 rubens. Huds. ............. 35 ruscifolius. TURN. .......... 15 ruscifolius. $\beta$. Syn. Fuc. . . . . . : : 15 sanguineus. Huds. . . . . . . . . 36 78 Sargasso. GMel. ........... 47105

Sargasso, var. 1. GMEL. ......... 46101

Sarniensis. Mert. ............ 44

Selago. Turn. ............ 55122 serrulatus. Wев. et Mohr ......... 39 sertularioides. GMEL.? ......... 54120 setaceus. WuLr.? ........... 10 sinuosus. Linn. Trans. . . . . . . . 3574 sinuosus. ß. Syn. Fuc. . . . . . . . 3574 sinuosus. $\gamma$. Syn. Fuc. . . . . . . . $35 \quad 74$ $\begin{array}{llllll}\text { sive Alga exigua dichotomos, \&c. } & \mathrm{R}_{\mathrm{AX}} & \ldots & 6 & 12\end{array}$ sive Ulva folio membranaceo, \&c. Moris. . $36 \quad 78$ soboliferus. Fl. Dan. ......... 4598 spiciferus. VAHL. . . . . . . . . 32 spinosus. Lins. . . . . . . . . . . 18 spinosus. WuLF. ............. 2I 44 spiralis serratus. BarReL. . . . . . . . 2 stiriatus. MERT. ............ 16 subfuscus. Woodw. .......... 1020 subrepandus. Forsk.? .......... 46 101 taxifolius. VAHL. .......... 54120 tener gelatinosus, \&c. $\mathrm{R}_{\mathrm{AY}} \ldots \ldots \ldots \ldots 68$ teres albus tenuissimè divisus. $\mathrm{R}_{\mathrm{AY}} \ldots \ldots .996$ thyrsoides. Turn. . . . . . . . . . . . 19 triangularis. Syst. Nat. Ed. Gmel. . . . 3370 trifarius. Swartz. .......... 3370 triqueter. Lins. . . . . . . . . . 34 triqueter. GMEL. ........... 33 70 tuberculatus. Huds. ........... 7 tuberculatus. LightF. . . . . . . . . . 99 turbinatus. Linn. . . . . . . . . 24 ulvoides. Turn. ............. 72166 undulatus. Syst. Nat. Ed. Gmel.? . . . . 46101 uvifer. Fonsк. .............. 21 variabilis. Linn. Trans. . . . . . . . 10 verticillatus. Lightт. . . . . . . . . 2962 vittatus. Linn. . . . . . . . . . . . . 64144 volubilis. Linn. . . . . . . . . . . 2 volubilis. GMEL.? . . . . . . . . . 68 153 Lenticula marina vulgaris. PARK. . . . . . . 47 105

Pinus maritima, \&c. RAY ........... 11

Ulva ciliata. Decand. . . . . . . . . 70 158 lingulata. Decand. . . . . . . . . . 14 ocellata. Decand. ............ 71164 papillosa. Linn.? ........... 16 punctata. SтаскH. ............... 71 purpurascens. Huds. .......... 2962

\section{TYPOGRAPHICAL ERRORS.}

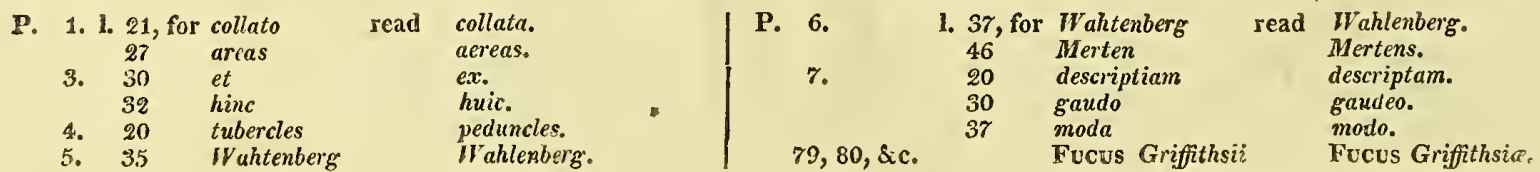




\section{HISTORIA FUGORUM.}

\section{1.-F U G US B A N K S II.}

Fucus fronde filiformi, coriaceâ, ramosissimâ, in receptacula sphærica, moniliformia, intervallo brevissimo disjuncta, per totam longitudinem inflatâ.

Ha bitat in Novæ Hollandiæ oris, copiosè. D. Menzies et Brown.

RADIX exigua, discoidea.

Frons pedalis, sesquipedalis, et interdum, teste D. Brown, bipedalis, ortu simplex, sed juxta basin divisa, et inde ramosissima ; rami divaricati, subreflexi, nunc dichotomè, nunc vagè, dispositi, elongati, simpliciusculi, minoribus brevioribus, ad angulum rectum exeuntibus, hic illic instructi: planta tota a basi usque ad apices e receptaculis constat innatis, monilis in formam dispositis, per frondem filiformem, pennâ passerinâ tenuiorem intervallo inter singula vix lineari connexis, junioribus oblongis, adultis sphæricis, omnibus siccitate enormitèr compressis, nec posthàc in formam pristinam ullâ arte revocandis, iis juxta basin et ramorum ad apices parvis, reliquis pruni insititia druparum magnitudine, superficie tuberculis sphæricis, immersis, prominulis, poro pertusis inæquali.

Fructificationem in tuberculis supradictis, quæ ea $F$. vesiculosi, nodosi, et reliquorum, cùm formâ, tùm structurâ referunt, includi, dubio prorsùs vacare mihi videtur, licet șemina nulla adhuc detexerim : lente acerrimâa observata e fibris adeo tenuibus ut oculum inermem fugiant intùs constant.

Co LOR plantæ recentis verisimillimè olivaceus; exsiccata nigerrinus ; in aquâ iterum immersa obscurè olivaceus, fusco immixtus; internè rufescit.

SUBSTANT1A mudefacta coriacea, tenacissima, exsiccata fragilis.

Fuci hujus perquam singularis exemplaria mea benevolentiæe illust. Josephi Banks, Baroneti, debeo, cujus, gratâ mente ob plurima in me ipsum et in hoc opus collato beneficia, nomine insignivi. In Novæ Hollandixe littoribus copiâ non minore, quàm Fucus vesiculosus, nodosus, et serratus, plantæ ibidem incognitæ, in his nostris, provenire traditur. Has species, harumque congeneres structurâ texturâque refert ; nec, ut in descriptione jampridem dixi, dubitari potest quin fructificandi modus sit idem, et tubercula, seminibus nondum sparsis, iis harum algarum respondeant. Ex hâc fucorum tribu amicissimi D. Weber et Mohr in tractatu eximio * distinctum genus, quod Fucum

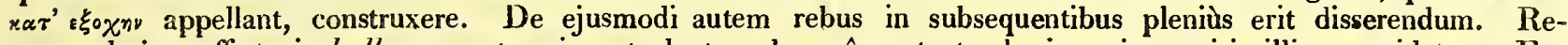
ceptacula jam effeta in bullas areas transire, et plantæ sub aquâ sustentandæ inservire verisimillimum videtur. Exsiccata seriei glandium calicum filo trajecto connexorum similitudinem quandam præ se ferunt. Est Fucus Banksii omnino sui generis planta, a reliquis omnibus habitu et formâ, necnon receptaculorum situ statim dignoscenda. Substantia ejus esî adeo crassa et tenax ut ad corium adpropinquet.
a. F. Banksii, nativâ magnitudine.
Ђ. Receptaculum obliquè sectum, magn. auct. : - 6 .
c. Tuberculum - - - - - - 2.
d. Tuberculum extrinsecus visum, ut porus conspiciatur - 5 .

\footnotetext{
* Einige Worte über wnsre bisherigen Lauptsächlich karpologischen Zergliederungen von kryptogamischer Seegewächsen. Beiträge zur Naturkunde, I. p. 204.
} 


\title{
HISTORY OF THE FUCI.
}

\author{
1.-F U C U S B A N K S I I.
}

Fucus Banksii, frond filiform, coriaceous, irregularly branched, and swollen throughout its whole length into spherical receptacles, arranged like the beads of a necklace placed at short distances.

On the shores of New Holland, plentiful. Mr. Menzies and Mr. Brown.

Root small, discoid.

Fron a foot, or a foot and half long, sometimes extending to two feet, simple at first, but very soon divided, and afterwards variously and repeatedly branched : branches divaricated, and almost reflexed, long, in general undivided, but here and there beset with smaller and shorter ones, issuing from them at right angles : the whole plant from base to summit is studded with receptacles innate in the frond, arranged like beads in a necklace, at intervals scarcely exceeding a line each, connected by the filiform frond, which is more thin than a sparrow's quill, the younger ones oblong, those more perfectly formed spherical, all irregularly flattened by drying, and never afterwards recovering their proper shape by immersion or any other means; those which are situated at the base and summit of the branches are small, the others about the size of a Bullace; the surface of all every where rough with globular tubercles, which, though immersed in the frond, are somewhat prominent, and are perforated with a very small pore.

From the resemblance of these tubercles io those of $F$. vesiculosus, nodosus, \&c. there can be no doubt of their containing the FRUCTIFICATION, though I have not at present been able to detect seeds in them: if examined by the highest powers of a compound microscope, they appear to be internally composed of fibres invisible to the naked eye.

CoLor of the recent plant in all probability olive, when dried intensely black, and if afterwards soaked in water, turning to a dark dull olive, mixed with brown; internally reddish.

SU BST A CE, while wet, leathery, extremely tough; when dried, brittle.

For my specimens of this most extraordinary Fucus, I am indebted to the Right Honourable Sir Joseph Banks, by whose name I have called it, in memory of the kindness which he has always shewn me, and of the exceeding liberality with which he has assisted me in the present publication. It is said to be no less abundant on the shores of New Holland than Fucus vesiculosus, serratus, and nodosus, plants unknown in that part of the world, are upon those of Britain. In its structure and texture, it resembles these species, and their congeners, and, as has already been remarked in the description, there can be no doubt of the fructification being the same, and of the innate tubercles having, before they discharged their seeds, been wholly similar to those of this tribe, out of which Dr. Weber and Dr. Mohr, in an excellent paper, ${ }^{*}$ have constituted a new genus, which they call exclusively Fucus. Upon this subject I shall soon have occasion to speak more fully. It is most probable that the receptacles, when they have fulfilled their. office as to the fructification, become filled with air, and perform the function of bladders designed to give buoyancy to the frond. In a dried state they may not inaptly be compared to a string of acorn-cups. In the situation of its receptacles, as well as in general habit and form, $F$. Banksii is altogether a plant sui generis, and differs from every other species yet known. Its substance is so extraordinarily tough that it almost resembles a piece of leather.

a. F. Banksii, natural size.

b. Receptacle transversely cut through, magnified - $\quad-6$.

c. Tubercle - - - - - - 2 .

d. Outside of tubercle, to shew the pore $\quad$ - $\quad-5$.

* Finige Worte über unsre bisherigen, hauptsächlich karpologischen Zergliederungen von kryptogamischen Scegewächsen. Beitrage zur Nuturtcunde, I. p. 204. 


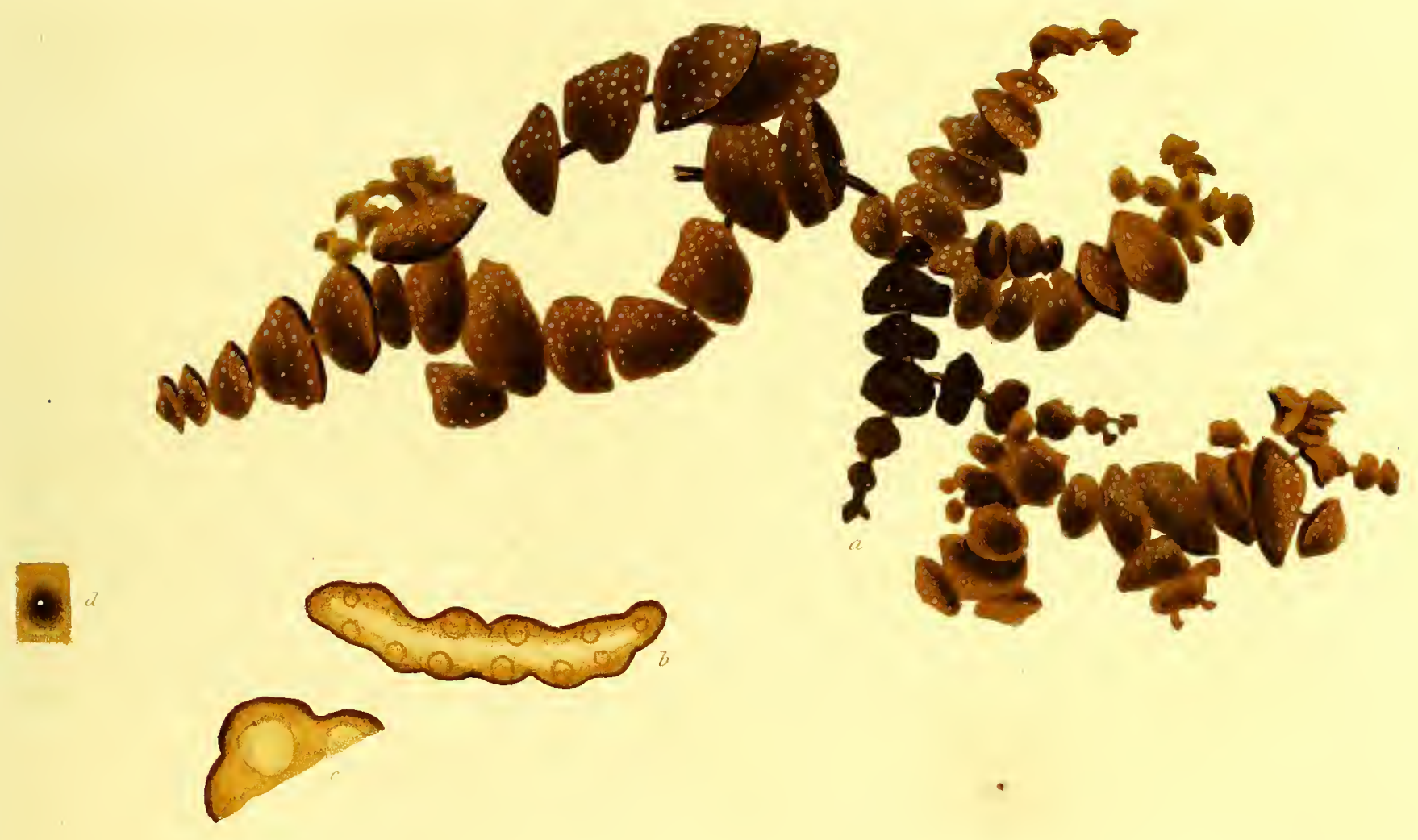


4 
Fucus, fronde membranaceâ, planâ, enervi, lineari, simpliciusculth, spiralitèr tortâ, margine repando dentatâ ; dentibus tuberculiferis; tuberculis exiguis pedunculatis.

Fucus volubilis. LinN. Syst. Nat. II. p. 715. Syst. Nat. Ed. Gmel. 1I. p. 1387. Wúpen, in Jacq. Coll. III. p. 149. Wulfen, Crypt. Aquat. n. 12. Esper, Ic. Fuc. I. p. 141. t. 71. (excl. Syn. Gmel.) AlL. Fl. Ped. II. p. 333. Fl. Fr. Ed.2da. II. p. 20.

F. spiralis serratus. BARREL1ER, p. 118. t. 1303.

Epatica spirale minore. GinanNI, I. p. 26. t. 27.?

Ha BITA in mari Mediterraneo. Linnaus. - In portu apud Tergestum, copiosè. Wulfen.-In sinu Napolitano, prope Paulisippo. Schmidel.-Ex Insulâ Ceylon accepit D. Smith.

RA DIX callus explanatus, coriaceus, tenuis, sub-orbicularis, diametro sesquiunguicularis, et ultra.

FrONDES ex eâdem radice plurimæ, cæspitosæ, longitudine tri vel quadri-pollicares, latitudine unguiculares, et ubique lineares, (excepto qudd juxta basin sæpe vi fluctuum terantur, atque idcirco angustiores sint) vel simplices: vel ramo uno alteroque, præsertim apices versus, vago, brevi, erecto, sub-fastigiato instructæ, a radice usque ad apices in Archimedæam longitudinalitèr convolutæ cochleam, nervo venisque prorsùs carentes, apice rotundatæ, margine repando-dentate, dentibus acutis, nunc solitarïs, nunc binis, et ultra.

Fructificatio tubercula perquam exigua, sphærica, atra, circitèr quina, vel sena, frondis dentibus, qui tunc temporis elongantur, attenuantur, et incurvantur, pedunculorum vice fungentes, apices versus innascentia : semina in his pauca, atra, subrotunda, limbo pellucido cincta.

SuBSTANTIA e membranaceâ coriacea.

Co sor atro-rubens, ${ }^{*}$ siccate ater.

Singulare admodùm videtur quod Fuci jamdudum a botanicis veteribus cogniti, nec infrequentis in Mari Mediterraneo, Adriaticoque, ubi, teste illustrissimo Wulfen, conchis, spongiis, lapidibusque accrescit, et a piscatoribus unà cum retibus extrahitur, fructificatio tamdiu visum fugerit. Recedit autem hæc in eo ab omnibus quæ vulgatissimè occurrunt Fucorum familiis, quòd tubercula, licet sphærica, multo minora sint quàm in globuliferis plerisque, et semina quæ continent pauca, majuscula, limbo cincta, figuræque certæ, ea Fucorum propriorum ut ita dicam, referunt. Frons ab ipsâ basi ad apices in omni ætatis stadio ita pertinacitèr in spiram intorquetur, ut nequeat, nisi natura maximè renitente, evolvi, seque relicta statim in formam pristinam retrahat. Sub microscopio visa pulcherrimè reticulata apparet. Gimannii figuram, ut quæ Wulfenio dubia videtur, plantæque formam perperàm exprimit, dubitantèr citavi. De Gmelini $\boldsymbol{F}$. volubili nequeo non stare a sententiâ in Fucorum Britannicorum Synopsi evulgatâ, et, ut et descriptione liquet, pro merâ $\boldsymbol{F}$. lacerati varietate habere. Plantam quam sub $\boldsymbol{F}$. volubilis nomine descripsit Hudsonus ad $F$. vesiculosum pertinere satis omnibus cognitun! : hinc autem speciei cum $\boldsymbol{F}$. volubili vero affinitatis aliquid intercedere ex eo suspicatus est M. Decandolle, quòd Linnæus vicinos disposuerat. Toto tamen coelo discrepant; et non modo fructificationi, verùm etiam habitui (sit verbo venia) hujus nostræe speciei quiddam ita sibi proprium inest, ut statìm a reliquis cunctis dignoscatur; imo difficile sit dictu cuinam omnium maximè accedat.

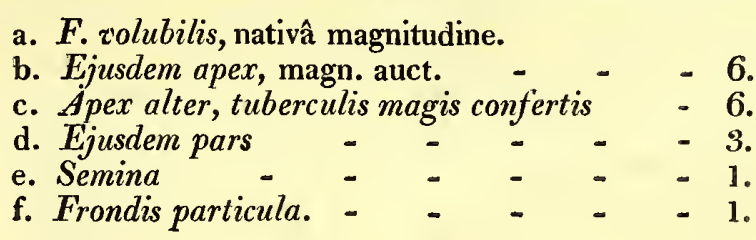

* D'un hrun verdâtre. Decandolle. 
Fucus volubilis, frond membranous, flat, nerveless, spirally twisted, mostly simple, its margins repando-dentate; teeth bearing small pedunculate tubercles.

Fucus volubilis. Linn. Syst. Nat. II. p. 715. Syst. Nat. Ed. Gmel. II. p. 1387. Wulfen, in. Jacq. Coll. III. p. 149. t. 13. f. 2. Wulfen, Crypt. Aquat. n. 12. EsPer, Ic. Fuc. I. p. 141. t. 71. (excl. Syn. Gmel.) Als. Fl. Ped. II. p. 333. Fl. Fr. Ed. 2da. II. p. 20.

F. spiralis serratus. BARRELIER, p. 118. t. 1303.

Epatica spirale minore. GinanNi, I. p. 26. t. 27.?

In the Meditenanean Sea. Linneus. - In the Harbor at Trieste, plentiful. Wulfen.-In the Bay of Naples near Paulisippo. Schmidel.-Sent from Ceylon to Dr. Smith.

Roo' an expanded, thin, coriaceous, suborbicular disk, a nail and half, or more, in diameter.

FRONDS from the same base numerous, forming tufts, three or four inches long, about a nail wide, and of equal width throughout, except that near the base, they are frequently worn by the action of the waves, and consequently more narrow, either sinsple, or here and there, especially towards the apices, furnished with one or two short, erect, sub-fastigiate branches, twisted for their whole length like a cork-screw, entirely destitute of veins or nerve, rounded at their apices, and at their margins repando-dentate, with sharp teeth sometimes solitary, sometimes placed two or more together.

Fructification, extremely small black, spherical tubercles, growing about five or six together, and placed towards the upper part of the frond upon the teeth, which are then lengthened, very narrow, and incurved, so as to perform the office of tubercles: in each of these tubercles lie a few black roundish seeds, surrounded by a pellucid limbus.

SUBSTANCE between membranaceous and coriaceous.

Color, * blackish red, when dried black.

It is not a little singular that, long as this Fucus has been known, and common as it appears to be in the Mediterranean and Adriatic, where, according to Baron Wulfen, it grows on shells, sponges, and stones, and is drawn out by the fishermen among their nets, the fructification should still have remained to the present day unnoticed. It does not altogether agree with that of any of the tribes more generally known, the tubercles being spherical, yet very much smaller than those of the globuliferous Fuci in general, and containing only a few largish regular seeds, altogether resembling those of $F$. vesiculosus and its congeners. The frond of this Fucus is so constantly and so naturally spiral, that it cannot be unrolled without difficulty, and immediately upon being left to itself returns to its former state. Examined under the microscope it is beautifully reticulated. I have quoted Ginanni's figure, with a mark of doubt, as being considered by Wulfen suspicious, and very ill expressing the character of the plant. With regard to Gmelin's F. volubilis, I cannot but adhere to the opinion expressed in the Synopsis of the British Fuci, that it is merely a variety of $F$. laceratus. The plant described under the name of $F$. volubilis by Hudson, is sufficiently known to belong to $F$. vesiculosus, with which species M. Decandolle was led to suppose that the present plant must have some connexion, from their being placed next each other by Linnæus. They are, however, most different, and indeed there is something so peculiar in the habit of $F$. volubilis as well as the fruit, that it is not only immediately distinguishable from every other, but it appears to me by no means easy to say which species are most properly its congeners.

a. F. volubilis, natural size.

b. Fructified end, magnified - $\quad$ - 6 .

c. Do. with fruit more in clusters -6 .

d. Portion of the same - $\quad-\quad$ - 3 .

e. Seeds - - - - - $\quad$ - 1 .

f. Portion of the frond - $\quad-\quad$ -

* Greenish-brown, according to M. Decandolle, in the Flore Française. 

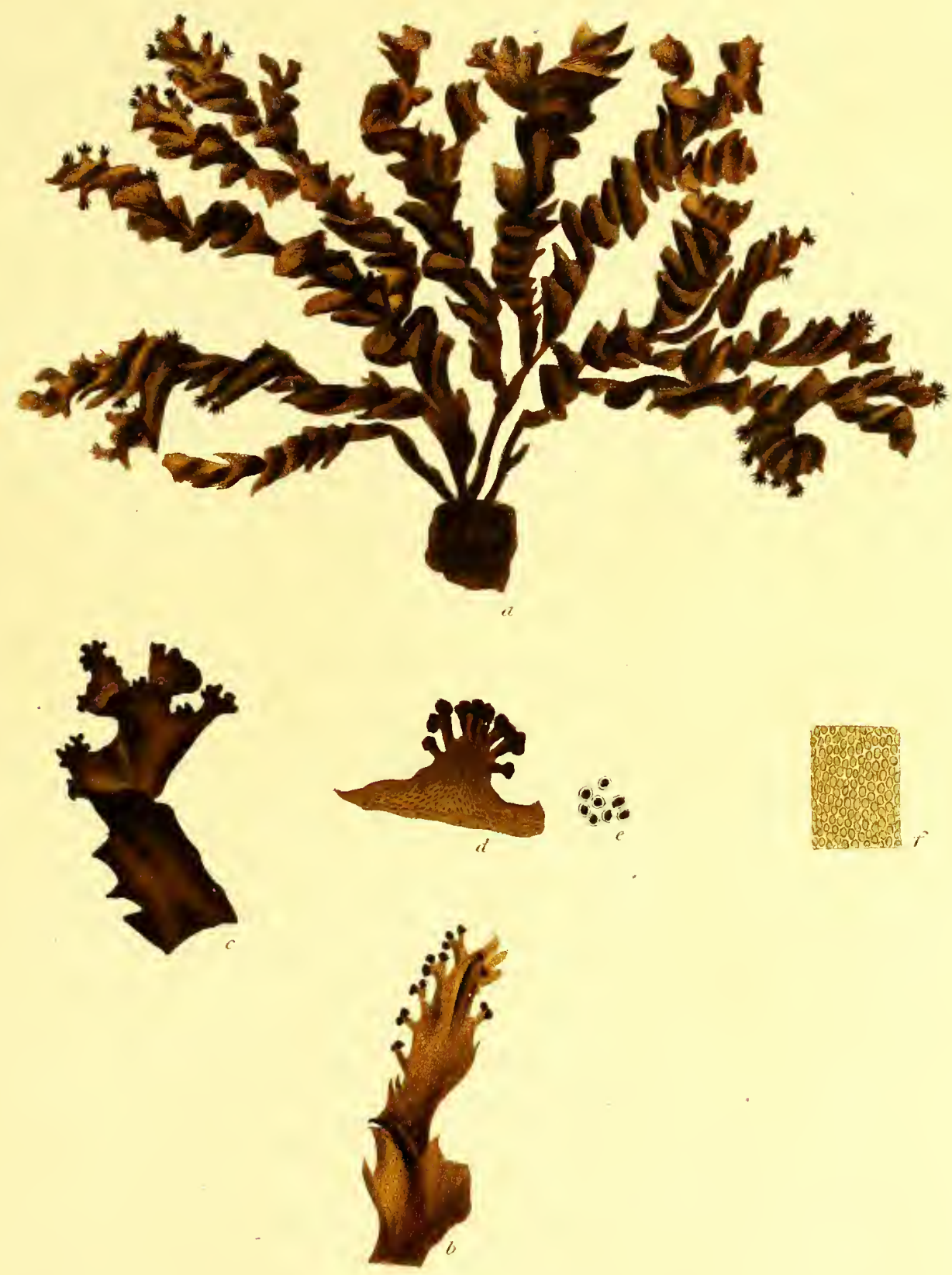

- Furees entulitis. 


\section{3.-F U C U S GA N A I C U L A T US.}

Fucus, fronde coriaceâ, lineari, enervi, hìnc canaliculatâ, dichotomâ, apice emarginatâ ; receptaculis terminalibus, oblongo-cuneiformibus, turgidis, bipartitis, obtusis.

Fucus canaliculatus. Linn. Syst. Nat. II. p. 716. Syst. Nat. Ed. Gmel. II. p. 1381. Fl. Dan. t. 214. Gmelin, Hist. Fuc. p. 73. t. 1. A. f. 2. Fl. Ang. p. 583. Fl. Scot. p. 917. Wiтh. IV. p. 99. Linn. Trans. III. p. 172. Roth, Fl. Germ. III. p. 451. Fl. Fr. ed. 2da. II. p. 21. Velley. t. 1. Eng. Bot. XII. t. 823. Syn. Fuc. II. p. 242.

F. excisus. Linn. Sp. Pl. II. p. 1627. Syst. Nat. II. p. 715. LinN. Mant. p. 508. Fl. Lapp. p. 366. Fl. Norv. I. p. 96. Fl. Fr. I. p. 96.

F. rotundus. Esper, Ic. Fuc. p. 40. t. 17. (excl. Syn.)

F. pumilus dichotomus, segmentis ex unâ parte gibbosis, ex alterả excavatis. Rarr Syn. p. 43. n. 12. (excl. Syn. Moris.)

F. palmaris angustifolius, ad extrema vesiculis rugosis bifurcatus. Moris. Hist. Ox. p. 647. s. 15. t. 8. f. 12.

Ha вıт a in Angliæ, Scotiæ, Hiberniæ, Galliæ, Hispaniæ, et Norvegiæ oris, et ubique in Oceano Septentrionali Europæo, satis frequens.

Perennis.- Estate et auctumno fert fructum.

RADIX callus explanatus, planiusculus, diametro ferè unguicularis.

FroN DES ex eâdem radice plurimæ, cæspitosæ, longitudine palmares, nec rarò spithamææ, latitudine unius circiter lineæ, costæ venarumve prorsùs expertes, ab ortu usque ad apices æquales, centro longitudiralitèr depressæe, marginibus lenitèr elevatis et incurvatis, ut tota planta, siccata æequè ac madida, canaliculata, et hìnc concava illìnc convexa evadat; frondes furcis repetitis per totam longitudinem dichotomæ, intervallis plerumque sub-pollicaribus, sed hoc incertum, inferioribus tamen magis approximatis, dichotomiarum angulis acutis: margines ubique integerrimi; apices emarginati, rotundato-truncati.

Fructificatro terminalis: frondis scilicet apices turgescunt, et in receptacula binata, oblonga, seu cuneiformia, obtusissima, compressa, plus unguem longa, duasque lineas lata, nunc integra, nunc bifida dilatantur: hæc intùs muco pellucido albo, fibris articulatis, pellucidis, reticulatis intertexto replentur, inter quem tubercula globosa, e fibris compactis constantia, decem vel duodecim semina oblongo-pyriformia, fusca, limbo pellucido cincta includentia reperies : receptacula extrinsecùs e tuberculis innatis hìc illìc torulosa, et supra tubercula poro minuto pertusa.

Coцor olivaceus, vel olivaceo-fuscescens, nec rarò lutescenti immixtus, praesertim in apicibus fructiferis, qui reliquâ fronde semper pallidiores; si luci exponatur diaphanus, in siccatâ niger, opacus.

SubSTa NTia lenta, coriacea, tenax.

Sint licet Fucorum plurimæ species, quarum frondes, ejusdem ubique reverà crassitiei, nihilominùs ob centrum depressum marginesque elevatos canalis longitudinalis speciem præ se ferant, datur tamen, quantum scio, nulla, quæe eodem quo hæc nostra fructu gaudet, quamobrem in specie ritè determinandâ difficultati vix est locus. Est $F$. $\bar{c}$ analiculatus magnitudinis perquam variæ; accepi enim exemplaria quaedam e Finmarkiâ a $M$. Wahtenbergio missa, quorum altitudo vix pollicem unum superabat, similemque reliqua partes rationem servabant, dum ea quæ in Britanniæ australis oris, præsertìm fluviorum ad ostia, nascuntur, altitudine spithamam latitudine duas lineas æequant. De reliquis nescio ut mutationi sit obnoxius, nec conjicere possum quâ de causâ auctores plerique in duas varietates dispertiverint, nisi quòd fortè Linnæum, qui sub duobus nominibus descriptum sic, ut errorem melius celaret, diviserat, temerê sint consecuti. A $F$. vesiculosi minoris staturæ speciminibus, quæ $F$. canaliculatus, cùm solito major occurrat, præsertìm exsiccatus gravitèrque pressatus, quodammodo refert, et quocum mirâ illâ proclivitate ad novas edendas frondes novaque ubicunque læditur receptacula convenit, costæ absentiâ nunquam non dignoscitur. Planta quam sub $F$. canaliculati nomine Wulfenius Esperusque, hic in Iconibus, ille in Cryptogamis Aquaticis, descripsenunt, ab hâc nostrâ evidentèr recedit, et vel ad Ulvam dichotomam, ut mihi, vel ad Fucum Fasciam, ut amicissimo Mertensio videtur, pertinet.

a. F. canaliculatus, nativâ magnitudine.

b. Frondis transversa sectio.

c. Receptaculum extrinsecus visum, magn. auct. - 5.

d. Idem intus visum, longitudinalitèr sectum - _ 4 .

e. Idem horizontalitèr sectum - - _ - $\quad 4$.

f. Tuberculum seorsum - _ - - - - - 2 .

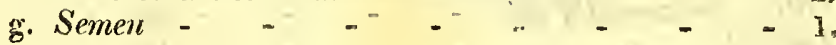


Fucus canaliculatus, frond coriaceous, linear, nerveless, channelled on one side, dichotomous, emarginate at the apices ; receptacles terminal, oblongo-cuneiform, turgid, bipartite, obtuse.

Fucus canaliculatus. Lin's. Syst. Nat. II. p. 716. Syst. Nat. Ed. Gmel. II. p. 1381. Fl. Dan. t. 214. Gmelin, Hist. Fuc. p. 73. t. 1. A. f. 2. Fl. Ang. p. 583. Fl. Scot. p. 917. With IV. p. 99. Linn. Tirans. III. p. 172. Roth, Fl. Germ. III. p. 451. Fl. Fr. Ed.2. II. p. 21. Velley, t. 1. Eng. Bot. XII. t. 823. Syn. Fuc. II. p. 242.

F. excisus. Lin N. Sp. Pl. II. p. 162\%. Syst. Nat. II. p. 715. Linn. Mant. p. 508. Fl. Lapp. p. 366. Ft. Norv. I. p. $96 . \quad$ Fl. Fr. I. p. 93.

F. rotundus. Esp. Ic. Fuc. p. 40. t. 17. (excl. Syn.)

F. pumilus dichotomus, segmentis ex una parte gibbosis, ex alterâ excavatis. RA11 Syn.p.43. n. 12. (excl. Syn. Moris.)

F: palmaris angustifolius, ad extrema vesiculis rugosis bifurcatus. Moris. Hist. Ox. p. 647. s. 15. t. 8. f. 12. On the shores of the British Isles, France, Spain, and throughout the Northern European seas, not uncommon.

Perennial.--Summer and autumnal months.

Root, an expanded, coriaceous disk, near a nail in diameter.

firon Ds, many from the same base, growing in tufts from three to seven inches long, about a line wide, without rib or veins, of the same width throughout, longitudinally depressed in the centre, and the margins slightly incurved, so that the whole plant, as well when wet as dry, appears channelled and concave on one side, and convex on the other: fronds divided at uncertain distances of about an inch each, throughout their whole length, with repeated dichotomies, the lower ones shorter; the angles of the dichotomies acute : margins constantly entire; apices rounded and slightly notched.

Fructification terminal, the apices of the frond swelling into oblong or cuneiform, compressed, very blunt, binate receptacles, more than a nail long, and two lines wide, entire or bifid, filled internally with colorless mucus, interwoven with pellucid jointed anastomosing fibres, among which, close to the outer coat, lie globular tubercles, composed of closely matted filaments, and containing ten or twelve brown, oblongo-pyriform seeds, surrounded with a pellucid limbus : the receptacles are externally uneven from the innate tubercles, and above each perforated with a minute pore.

Cóor, while recent, olive tinged with brown, not unfrequently yellowish, especially in the fructified summits, which are always paler than the rest of the frond, subdiaphanous when held to the light; in the dry plant, black and opaque.

SUBSTANCE, coriaceous, pliant, tough.

Although several Fuci are known, which have their frond marked with a longitudinal groove, not from the substance being hollowed out, but from the centre being concave, and the margins raised and inflexed, yet $I$ believe that the present plant affords a solitary instance of such a conformation, attended with a fruit similar to that which it bears, so that there can be no difficulty in distinguishing the species. In point of size it is extremely variable, some specimens which Mr. Wahtenberg has sent me from Finland, being scarcely more than an inch long, and in all their parts proportionably small, while on the Southern shores of England, especially near the mouths of rivers, it attains to half a foot in height, and is two or three lines wide. In other respects I am not aware that it is liable to any change, so that I cannot account for the circumstance of two varieties being enumerated by most authors, except they have merely followed Linnæus, who thus divided it to conceal the error he had made in describing it twice under different names. In its larger state, especially when barren, and after it has been dried and much pressed, it approaches the smaller varieties of $\boldsymbol{F}$. vesiculosus, with which species it also accords in the wonderfully proliferous tendency of both frond and pods when injured, but its want of mid rib will always distinguish it. 'The plant figured and described under the name of $\boldsymbol{F}$. canaliculatus, in Professor Esper's Icones, t. 73, and in Wulfen's Cryptogama aquatica, n. 12, is very evidently different from ours, and either belongs to Ulva dichotoma, or, as my friend Professor Merten suspects, to Fucus Fascia.

a. $\boldsymbol{F}$. canaliculatus, natural size.

b. Transverse section of frond.

c. Exterior of receptacle, magnified - $\quad 5$.

d. Interior of ditto, longitudinally cut - $\quad 4$.

e. Ditto, horizontally cut - - - - 4 .

f. Tubercle - - - - - - 2 .

g. Seed - - - - - - - 1 . 


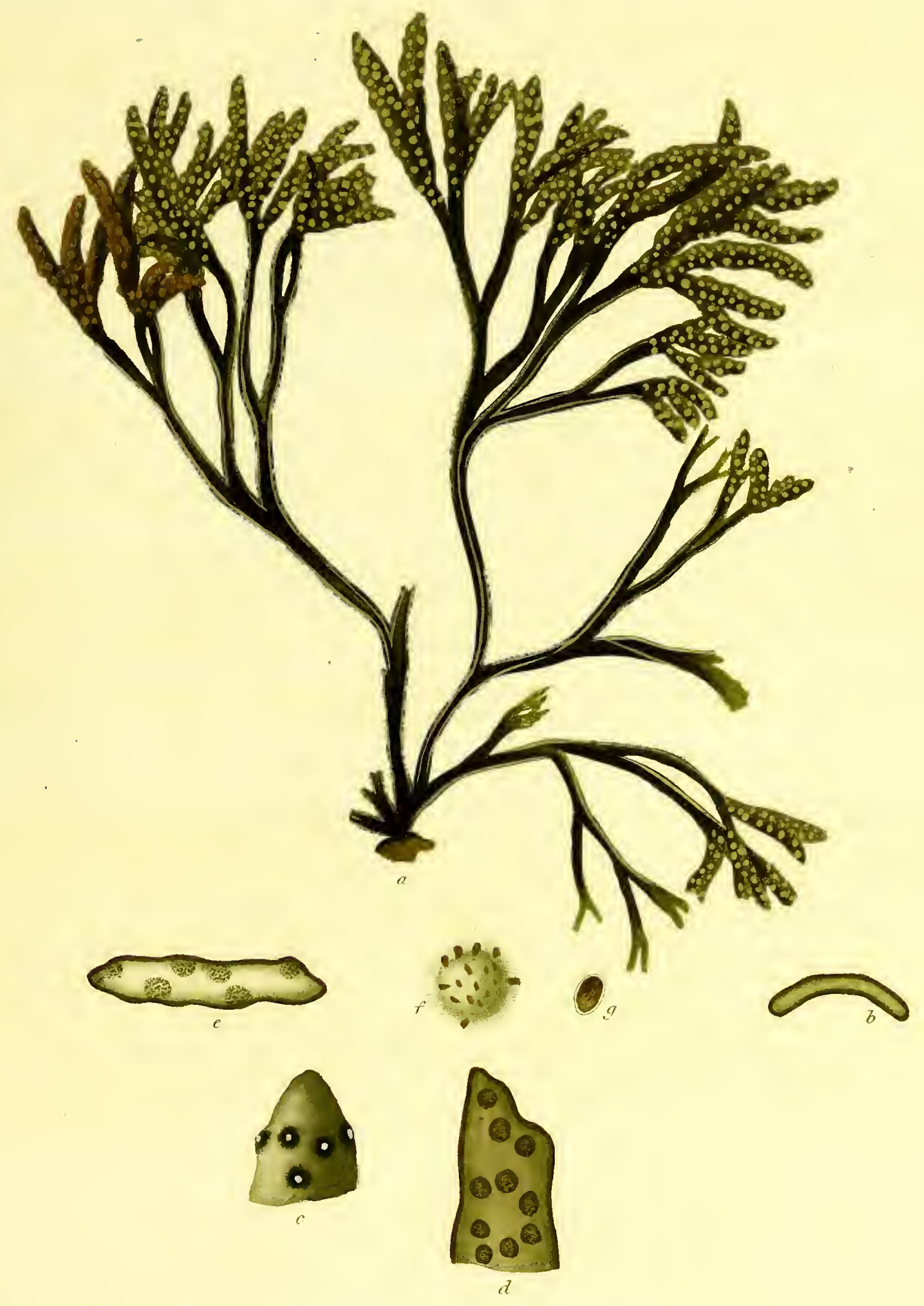

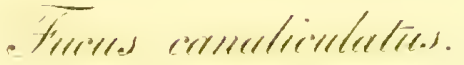



Fucus, fronde basi terete, mox planâ, lineari, dichotomâ, costatâ; costâ obsoleta ; receptaculis terminalibus, oblongis, tereti-compressis.

F. distichus. 'Linn.' Syst. Nat. II. p. 716. Syst. Nat. Ed. Gmel. II. p. 1381. Wurfen, Crypt. Aquat. n. 7.?

F. linearis. Fl. Dan. t. 351. (excl. Syn. Hudsoni.)

F. filiformis. Gmelin. Hist. Fuc. p. 72. t. 1. A. f. 1. Esper, Ic. Fuc. II. p. 87. t. 152. (excl. Syn. plerisq.)?

HАв вт т in fundo maris Islandici Oeder.-In Oceano septentrionali. Gmelin.

RADIX (teste Gmelino) orbicularis, 6 vel 7 circiter linearum diametro, lapidibus adglutinata.

Frons longitudine sesquipalmaris, vel fere spithamæa, basi teres, pennæque passerinæ crassitie, mox compressa, duumque a radice pollicum intervallo plana, hìc omnino linearis, unamque circiter lineam lata, dichotomis sexies vel sæpiùs repetitis ramosa, costâ tenuissimâ obsoletâ, et vix nisi in madidâ conspiciendâ percursa, poris mucifluis minutissimis hic illic pertusa, margine integerrima, apicibus sterilibus emargillatis, segmentis obtusis, subtruncatis.

Fructificatio frondis ad apices, tunc unguiculares, teretes, et in receptacula conversos, sita; tubercula in his globosa, poro exiguo pertusa, seminibus aliquot oblongis fuscis instructa.

CoLon in recente olivaceus; in siccatâ niger, nequaquam vel nitens vel subdiaphanus.

SU BSTA NTIA coriacea, cartilaginea, tenax, sed tenuis.

Fucum Gmelini filiformem reverà eandem esse speciem quam ad ipsum in Herbario Linnæano asservatum exemplar hìc depictam descriptiamque sisto, res est quam extra dubitationem positam nequaquam duco; plerorumque tamen Botanicorum sententiis obsequens pro synonymo in presens habeo, sumque ab ejus descriptione radicis adumbrationem mutuatus. Nec tamen idcirco desistendum puto ab observando, quòd Ícon ejus specimen latitudine omnia quæ ego unquam vidi longè superans exhibeat; quod de fronde basi terete, notâ maximi in specie discriminandâ ponderis, nihil dixerit; quòd costam, vix in $F$. disticho nisi summâ curâ et in exemplaribus vel exsiccatis vel lente auctis detegendam, perquam manifestam depinxerit; et qudd denique frondis apices fructiferos reapse teretiusculos, planos delineaverit. Ex omnibus hisce mihi quidem dubium videtur, annon potius vel $F$. vesiculosi varietatem quandam singularem, vel distinctam speciem coram oculis habuerit. Icon etiam in Florâ Danicâ depicta nequaquam ita dilucidè ut vellem $\boldsymbol{F}$. distichum respicit, et æquo fere jure ad $\boldsymbol{F}$. linearem $F$ l. Ang. quem in Fuc. Brit. Syn. pro $F$. vesiculosi var. n descripsi, referri possit. Hæc duo tantùm synonyma ad Fucum hunc nostrum ab auctoribus citari solent, et, cùm utrumque pró ancipite ducam, eo magis gaudo qudd stirpis a reliquis satis distinctæ, sed quâ vix ulla minus sit cognita, illustrandæ occasio mihi suppeditetur. De Esperi icone quam citavi, licet haud bonâ, paulum dubito, sed de synonymis ferè omnibus erravit. Linnæus, ut ex Herbario suo patet, cum $F$. membranaceo Stackh. commiscuerat, texturamque hâc de causâ herbaceam, à quâ Fuci hujus indoles quam longè abhorret, in Systemate Plantarum dixit. Maximam autem certè habet $F$. distichus cum $F$. vesiculoso affinitatem, sed ab omnibus hujus speciei quantumvis mutabilis varietatibus, caulis basi teres, quod neutiquam a casu vel injuriâ sed ab ipsâ plantæ naturâ pendet, substantia tenuis, costa obsoleta, et receptacula longa filiformia citò dignoscunt. A $F$. ceranoide, qui $F$. distichus, Esp. t. 139, crescendi moda toto coelo discrepat. Magnitudine habituque $F$. canaliculato quodammodo affinis videtur, cavendumque imprimis putavit $\mathbf{I}$ innæus ne cum illo commisceretur ; sed fronde plana, formâ, substantiâque alieıâ, et receptaculorum figurâ satis a se invicem recedunt. Dolendım est quod nulla extet in Herbario Linnæano nota, per quanı unde $F$. distichi exemplaria sua acceperit cognoscas; lìnc patria ejus incerta manet: specimina etiam Stackhousii, qui à M. Desfontaines, et Mertensii, qui à Thunbergio accepit, neutro tamen locum natalem adjiciente, benevolentiæ debeo.
a. Fucus distichus, nat. magn.
b. Apex frondis cum fiuct. magn. auct. - $\quad 6$.
c. Receptaculum horizont. sectum - $\quad-\quad-3$.

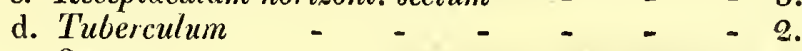
e. Semen - - $-\quad-\quad-\quad-\quad-1$. 
Fucus distichus, frond cylindrical at the base, thence flat, linear, dichotomous, furnished with an obsolete midrib; receptacles terminal, oblong, between cylindrical and compressed.

Fucus distichus. Linn. Syst. Nat. II. p. 716. Syst. Nat. Ed. Gmel. II. p. 1381. Wutfen, Crypt. Aquat. n. 7.?

F. linearis. Fl. Dan. t. 351. (excl. Syn. Huds.)

F. filiformis. Gmelin, Hist. Fuc. p. 72. t. 1. A. f. 1. Esper, Ic. Fuc. II. p. 87. t.152. (excl. Syn. plerisq.)?

In the Arctic Ocean, near Iceland. Oeder.-In the North Sea. Grmelin.

RooT, according to Gmelin, orbicular, six or seven lines in diameter.

FRON D, from five to seven inches long, at the base cylindrical, and about the size of a sparrow's quill, then compressed, and at the distance of two inches from the root becoming quite flat, after which it is about a line wide, and completely linear, divided by dichotomies six or seven times repeated, perforated here and there with extremely minute mucifluous pores, furnished with a very thin midrib scarcely visible, except in the plant when wet, entire at the margins, the barren summits emarginate, with short, blunt, alnost truncated segments.

FRUCTIFICATION situated in the apices of the frond, which are then lengthened to half an inch or more, and become receptacles, containing globular tubercles, placed immediately under their surface, perforated with a: small pore, and furnished with a few oblong brown seeds surrounded with a pellucid limbus.

CoLOR, in the plant when recent, olive, when dried black, by no means inclining to glossy or subdiaphanous.

Substance, between coriaceous and cartilaginous, tough, but thin.

That Gmelin's $F$. filiformis is really intended for the same Fucus here described, and figured from one of the original specimens preserved in the Linnæan Herbarium, is a point upon which $I$ by. no means feel certain, but $I$ have followed the opinion of the greater number of Botanists in regarding it as such; and have ventured to borrow from him the account of the root. At the same time; I consider it right to remark that his plate represents a plant whose frond is more wide than any I have seen, that he has omitted the extraordinary circumstance of its being cylindrical at the base, that he makes the midrib very visible, whereas in $F$. distichus it is scarcely to be discovered with the most attentive observation, except in dry or m.gnified specimens, and that he figures the apices as flat instead of nearly cylindrical, from all which circumstances it pay fairly be doubted whether he did not intend either $a$ singular variety of F. Vesiculos us or a different species. The plate in the Flora Danica is by no means so satisfactory as I. could wish, and almost equally applicable to $F$. linearis, Fl. Ang. which in the Synopsis of the British Fuci I have described as $F$. vesiculosus, var. $n$. These are the only two synonyms that have been regarded as belonging to the present plant, which I am peculiarly gratified at having the opportunity of illustrating, as I consider it a species satisfactorily distinct from all others, but at the same time most imperfectly known. About Esper's figure, though indifferent, I have very little doubt, but his synonymy is for the most part erroneous. It appears by Limnæus's Herbarium, that he had himself confounded it with $F$. membranaceus of Stackhouse, and this accounts for the observation in the Systema Plantarum that the texture is herbaceous. The nearest affinity of $F$. distichus is unquestionably with $F$. vesiculosus, from every variety of which it is distinguished by the shape of the stem at the base, a circumstance evidently not arising from accident or injury, but from the very nature of the plant, in addition to which, the thin texture, inconspicuous midrib, and long filiform pods afford ready marks of discrimination. With $F$. ceranoides, which is figured under the name of distichus by Esper, t. 139, the different mode of growth precludes any fear of its being confounded. Linnæus thought it more requisite to separate the present plant from $F$. canaliculatus, to which in size and habit it bears some affinity, but its flat frond, dissinilar texture, and structure, and differently shaped fruit, render it unnecessary to dwell upon this circumstance. There is unfortunately no note in the Limman Herbarium to ascertain whence the specimens came, so that the habitat of the plant is in some wise doubtful. I have received it, but without any locus natalis affixed, from Mr. Stackhouse, to whoin it was communicated by M. Desfontaines, and from Professor Mertens, who had it from Sir P. C. Thunberg.

a. Fucus distichus, natural size.

b. Fructified apex, nagnified - - 6 .

c. Horizontal section of ditto - $\quad-4$.

d. Tubercle - - - - $\quad$ - 2.

e. Seeds - - - $-\infty 1$.




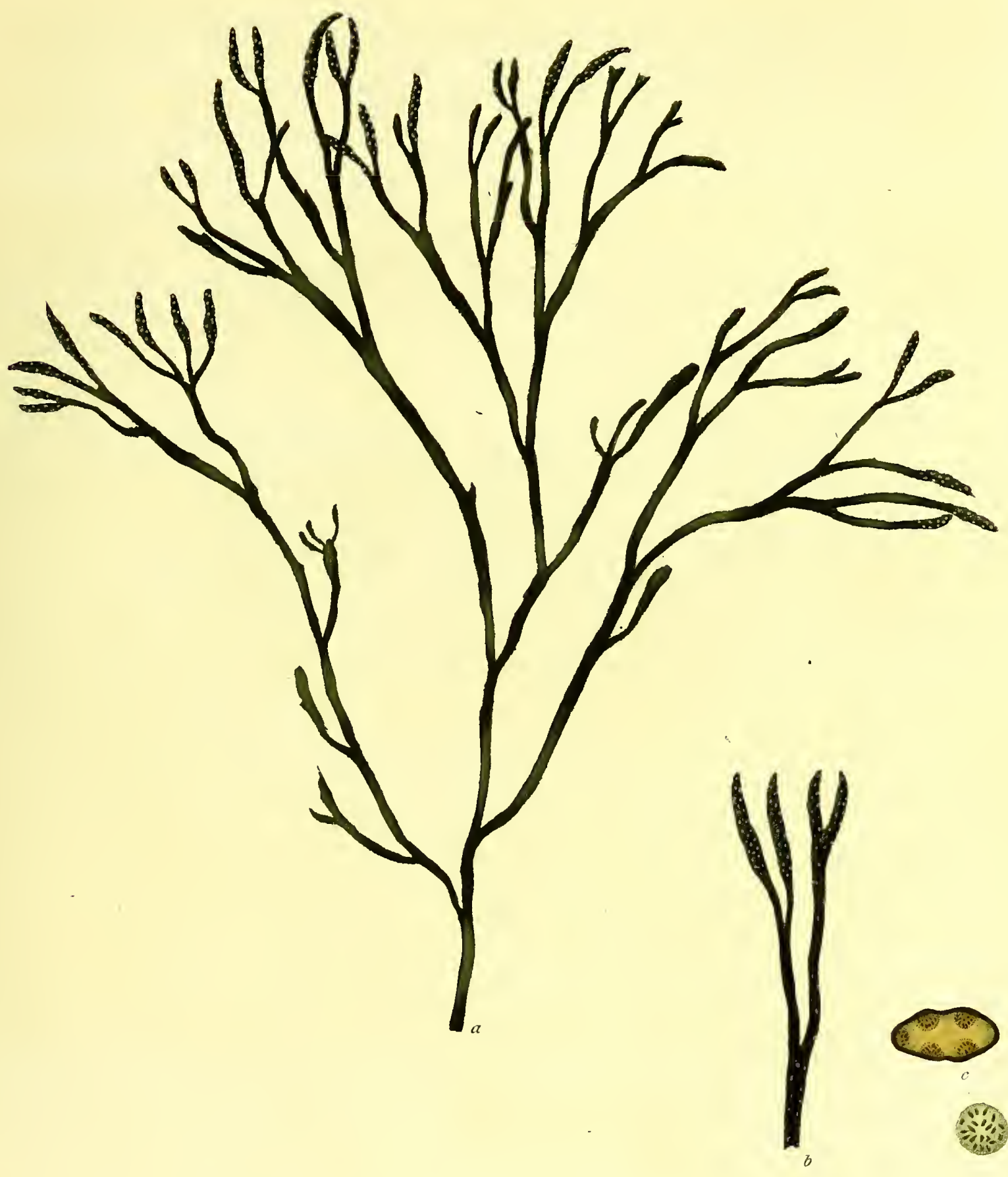

1 

Fucus, fronde cartilagineâ, filiformi, dichotomâ, fastigiatâ; dichotomiarum angulis obtusiusculis ; apicibus bifurcis acutis ; capsulis difformibus, lateralibus, spongiosis, frondis epidermide non tectis.

Fucus rotundus. Gmér, Hist. Fuc. p. 110. t.6. f. 3. (excl. syn. Huds. et Raii.) Lrnn. Syst. Nat. Ed Gmel. II. p. 1383. Wiтн. IV. p. 110. Syn. Fuc. II. p. 309. Eng. Bot. XXV. t. 1738.

F. radiatus. Linn. Trans. III. p. 202. Ner. Brit. p. 89. t. 14.

F. fastigiatus. Ner. Brit.p. 15. t. 6. (quoad fig. min.)

F. caprinus. Fl. Norv. I. p. 96. (quoad icon. in Act. Nidros.)

ß. tenuior; apicibus elongatis, linearibus, obtusiusculis.

F. rotundus. B. Syn. Fuc. II. p. 310.

$\gamma \cdot$ fastigiatus; fronde tenuissimâ, vix bipollicari.

F. rotundus. $\gamma$. Syn. Fuc. II. p. 310.

F. fastigiatus. Herb. Linn.Sp. Pl. II. p. 1631. Esper, Ic. Fuc. I. p. 38. t. 16. (excl. Syn.) Wulfen, in Jacq.-Coll. III. p. 152. t. 14. f.2. Wulfen, Crypt. Aquat. n. 30.

Hав вталт $\alpha$ et $\beta$ in Insularum Britannicarum oris, haud raro. $\gamma$ in Angliæ australis oris.-in Mari Adriatico. Wulfen.

Perennis. Sept.-Feb.

RA DIX discus explanatus, solidus.

FroN ves ex eâdem basi plurimae, palmares vel dodrantales, filiformes, cylindraceæ, pennæ nunc corvinæ nunc coracinæ crassitie, semper juxta basin, et sæpe per pollicis et ultra spatium, indivisi, hinc bifurci, et dichotomïs octies noviesve ad apices usque repetitis ramosi: apices bifurci, incurvi, et, præsertim exsiccati, acuminati: rami omnes fastigiati: dichotomiarum anguli plus minus obtusi, et rotundati.

Fructificatro tubercula verruciforınia, in ramis superioribus sessilia, ortu sphærica, nec Brassica Rapa seminibus majora, mox figuræ incertæ, frondem nunc ambientia, nunc seriatìm decurrentia, coloris recentia dilutè rosei, exsiccata fusci, substantia spongiosa, glutinosa, superficies granulata et inæqualis, quandoque sulcata, frondis epidermide non tecta; dissecta, et lenti maximè augenti subjecta constare cernes e fibris parallelis, articulatis, pellucidis, densissimè compactis, angulos cum ramis rectos servantibus, et semina plurima, fusca, subrotunda, limbo pellucido cincta, singula perpressionem granulorum sphericorum minutissimorum congeriem effundentia, includentibus.

Co Lor plantæ recentis fuscus, purpurascente tinctus, luci diu objecta albellus, marcescentis dilutè roseus: colorem exsiccata servat, et diaphana evadit.

Su вs t a N T a cartilaginea, flexilis.

$\beta$ est multo tenuior, apicibusque gaudet elongatis, linearibus, et obtusis, nec brevibus et acuminatis.

$\gamma$ utrâque præcedente minor, longitudine vix bipollicari.

Fuci rotundi exemplar hic depictum, Sussexiæ ad littora, ubi majorem quam in borealibus eoisve nostris oris statu ram attingit, lectum, amicissimi $D^{\text {ni }}$ Borrer benevolentiæ debeo. Planta est quoad magnitudinem summoperè variabilis, nec, quò magìs ad mitiores accedit plagas, eo necessariè procerior esse videtur, cùm varietas $\gamma$ omnium minima in meridionalibus etiam Angliæ littoribus reperiatur, nec ulla alia stirpis hujus species in mari Mediterraneo aut Adriatico provenire tradatur. Fucum Linnæi fastigiatum ad hanc $F$. rotundi varietatem esse referendum jampridem, herbarii sui fide, in Fucorum Britannicorum Synopsi asserui; sed a F.lumbricali non distinxisse satis superque e scriptis suis constat. E contrario nobilissimus Wulfenius Fuci sui fastigiati descriptionem iconemque ab hâc eâdem $F$. rotundi varietate deprompsisse liquidd videtur, sequentis licet speciei exemplaria eodem nomine insignita in Herbario servaverit. Memorari tamen oportet quod pusillæ hujus stirpis exemplaria nulla fructu donata adhuc viderim, simque eấ de causâ incertus annon planta sit reapse distincta, quamvìs a $F$. rotundi quotidianâ facie non nisi staturâ minore discrepare sterilis appareat. Reperitur in Britannix australibus oris alia necdum descripta Fuci species, quæ inter $F$. rotundum et plicatum est ferè intermedia mihique sub utroque nomine missa, cui proximè hæc varietas accedit. Tantum habet $F$. rotundus, quum sterilis modo occurrit, cum $F$. lumbricali affinitatis, ut Tyronibus fucum sæpe faciat, et synonymorum inter hos error sit ferè inextricabilis. Notæ ad utrumque certo dignoscendum tunc maximè valeut sequentes: de fructiferis difficultati non datur locus, et quidem ab omnibus hucusque descriptis fucorum familiis ainborum fructificatio longè recedit.

$F$. rotundi radix solida; dichotomiarum anguli obtusi, plerumq. rotundati; apices acuminati; color in exsiccato fuscus diaphanus.

F. lumbricalis radix fibrosa; dichotomiarum anguii acuti; apices obtusi; color in exsiccato nigerrimus opacus.

a. $F$. rotundus, magn. nat.

b. var. $\gamma$.

c. apex fructifer.

d. idem, horizontalitèr sectus, magn. auct. - - $\quad 3$

e. idem, longitudinalitèr sectus - - $\quad$ - 3.

f. tuberculum longitudinalitèr exäadverso sectum

g. tuberculi pars - $\quad$ - $\quad$ - $\quad$ - $\quad$ - $\quad$ - $\mathbf{Q}$.

h. sèmen, seorsim - $\quad$ - $\quad$ - $\quad$ - $\quad$ - $\quad$ - 1 .

i. granula in semine contenta - . - _ - - $\quad 1$.

VoJ.I.

k. una e fibris seminibus immixtis - 1 . 
Fucus rotundus, frond cartilaginous, filiform, dichotomous, fastigiate; angles of the dichotomies bluntısli; aplces forked, acute; capsules lateral, of irregular form, spongy, not covered with the epidermis of the frond.

Fucus rotundus. Gmelin, Hist. Fuc. p. 110. t. 6. f. 3. (excl. syn. Huds. et Raii.) Lin w. Syst. Nat. Ed. Gmel. II. p. 1383. W1тн. IV. p. 110. Syn. Fuc. II. p. 309. Eng. Bot. XXV. t. 1738.

F. radiatus. Limn. Trans. III. p. 202. Ner. Brit. p. 89. t. 14.

F. fastigiatus, Ner. Brit.p. 15.t. 6. (quoad fig. mim.)

F. caprinus. Fl. Norv. I. p.96. (quoad ic. in Act. Nidros.)

B. tenuior-with the extreme segments long and linear, the apices bluntish.

F. rotundus. $\beta$. Syn. Fuc. II. p. 310.

$\gamma$. fastigiatus - with frond very thin, scarcely two inches long.

F. rotundus. $\gamma$. Syn. Fuc. II. p. 310 .

F. fastigiatus. Herb. Linn. Sp. Pl. II. p. 1631. Esper. Ic. Fuc. I. p. 38. t. 16. (excl. syn.) Wulfen, in Jacq. Coll. III. p. 152. t. 14. f. 2. Wulfen, Crypt. Aquat. n. 30.

a \& $\beta$ are not uncommon on the shores of the British Isles: $\gamma$ is found on the southern shores of England, also in the Adriatic. Wulfen.

Perennial. September-February.

Root a solid, expanded, disk.

FroN DS very numerous from the same base, from 4 to 8 inches high, filiform, cylindrical, varying in size from that: of a crow's-quill to that of a raven's, simple at the base, and continuing so for an inch or more, then becoming forked, and proceeding by dichotomies 8 or 9 times repeated to the apices, which are bifurcate, incurved, and acuminated, especially when dry; the branches are all fastigiate; the angles of the dichotomies more or less obtuse and rounded.

Fructification, wart-like tubercles, sessile upon the upper branches, at first spherical, and not larger than turnip-seed, afterwards taking an irregular form, sometimes extending two or three lines down the frond, and sometimes surrounding it : their color when fresh, pale pink; when dry, brown; and their substance spongy and glutinous; their surface uneven, granulated, frequently furrowed, not covered with the epidermis of the plant; if cut through and highly magnified, they are seen to be composed of parallel jointed colorless fibres, closely matted together, lying at right angles with the branches, and containing numerous brown roundish seeds, surrounded with a pellucid limbus, each of which when pressed, discharges a mass of very minute globular granules.

CoLOR of the fresh plant brown, strongly tinged with purple; passing, when long exposed to. the air, to white; when in decay, to pale pink: it preserves its color after it is dried, and is diaphanous.

Su BSTANCE, cartilaginous, flexible.

$\beta$ is much more slender, and the apices, instead of being short and pointed, are long, linear, and blunt.

$\gamma$ is still more small, scarcely rising above two inches.

For the specimen of $\mathrm{F}$. rotundus, here figured, I am indebted to my friend Mr. Borrer, who gatliered it upon the shores of Sussex, where it usually attains a considerably greater size than on the more northern and eastern coasts of England. It is, however, in this respect liable to considerable variation; nor does its stature seem to bear any regular proportion to the climate it grows in, as the variety $\gamma$ is also a native of our southern shores, and no other appearance of the plant is described as found in the Mediterranean or Adriatic. That this latter is the true F. fastigiatus of Linnæus I have already stated in the Synopsis of the British Fuci, upon the authority of his own herbarium, though it is sufficiently plain from his writings that he did not distinguish it from $F$. lumbricalis. Nearly the converse appears to have been the case with Baron Wulfen, whose description and figure of his F. fastigiatus were obviously taken from the present plant, thougl in his Herbarium were preserved, under the same name, speciniens of the following, one. I ought, however, to mention, that I have never seen any of this small variety in fruit, and consequently am by no means sure that it may not prove a distinct species, though I at present discover no difference except the diminutive size. It approaches very nearly to a species of Fucus found on the southern coast of England, and not yet described, but in texture and habit intermediate between $F$. rotundus and plicatus, under both which names $I$ have received it. When barren, $F$. rotundus bears so strong an affinity to $F$.lumbricalis, that it is by no means easy for an eye unused to the observation of Fuci to distinguish them; and the perplexity of the synonymy between these two plants is extremely great. The characters tending most essentially to distinguish them, when barren, are as follows; when in fruit there can be no difficulty whatever upon the subject, and indeed in this state they both seem to stand quite distinct from any of the families of marine algre at present described.

F. rotundus: root solid; angles of dichotomies blunt, generally rounded; apices acuninated; color, when dry, brown and transparent.

F. lumbricalis: root fibrous; angles of dichotomies acute, apices blunt; color, when dry, black and opaque.

a. F. rotundus, natural size.

b. var. $\gamma$. do.

c. fructified apex, do.

d. horizontal section of do. magnified - - - 3 .

e. longitudinal section of do. - - $\quad$ - $\quad-\quad-\quad 3$.

f. tubercle longitudinal'y cut in the opposite direction - 3 .

g. part of tubercle - $-{ }_{-}-{ }_{-}-\mathbf{2}$.

$\begin{array}{llllllll}\text { h. } \text { seed } & - & - & - & - & - & - & - \\ 2\end{array}$

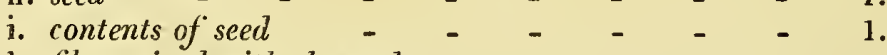

k. fibre mixed with the seeds - _ _ _ _ 1 . 


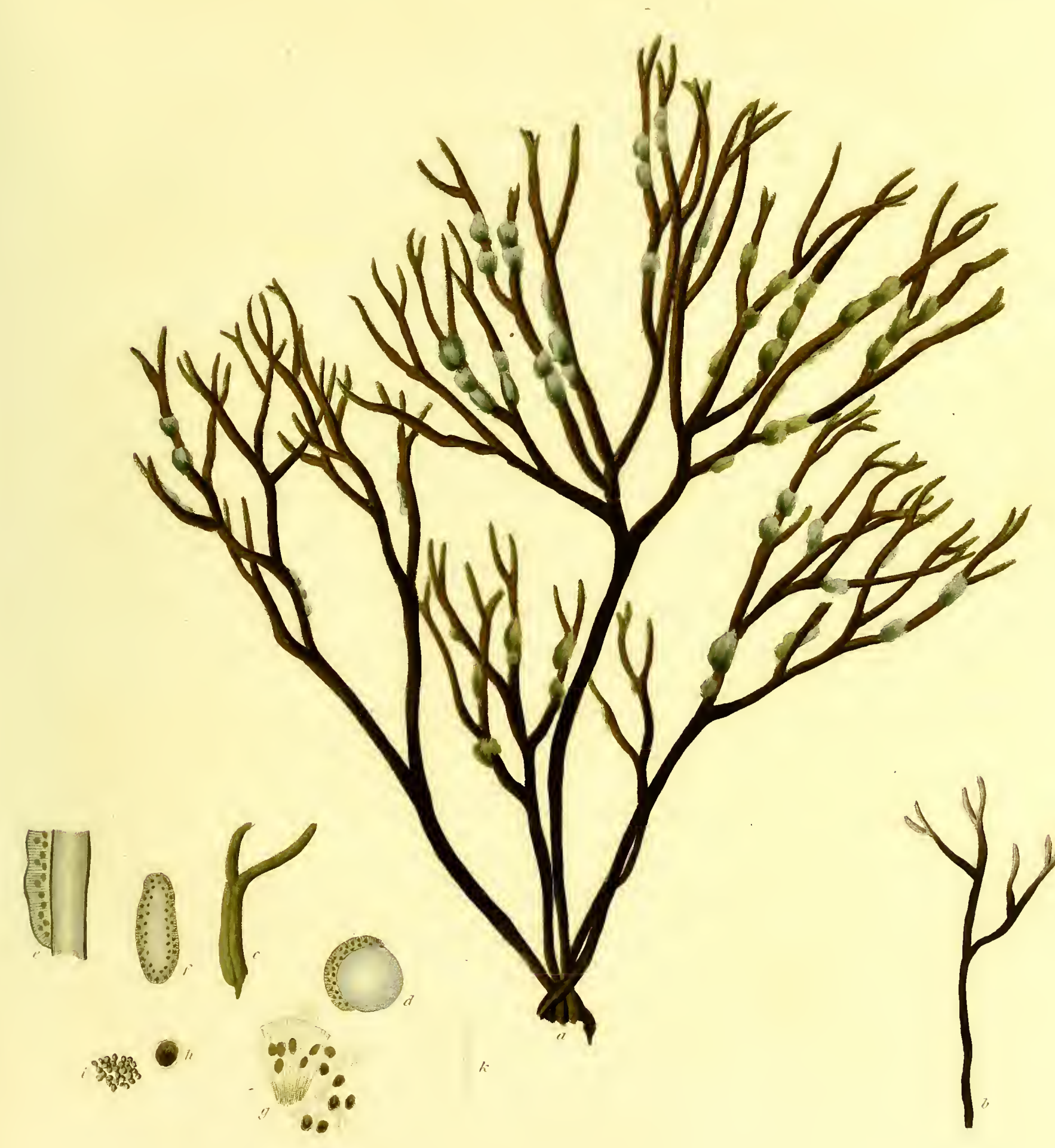



Fucus fronde cartilagineâ, filiformi, dichotomâ, fastigiatâ; dichotomiarum angulis acutis; apicibus bifurcis obtusis; fructu in apicibus elongatis teretibus.

Fucus lumbricalis. Gmelin, Hist. Fuc. p. 108. t. 6. f. 2. Linn. Trans. ILI. p. 204. Syn. Fuc. II. p. 317. Eng: Bot. XII. t. 824. Fl. Fr. Ed. 2 da. II. p. 22.

F. fastigiatus. Wiтн. IV. p. 110. Ner. Brit. p. 15. t. 6. (quoad Fig. maj.) Velley.t:4.

F. furcellatus. Linn. Sp. Pl. II. p. 1631. Syst. Nat. II. p. 718. Syst. Nat. Ed. Gmel. II. p. 1383. Fl. Ang. p.589. Fl. Scot. II. p. 932. Fl. Dan. t. 419. Fl. Germ. III. p. 456. Fl. Norv. II. p.78. Es Per, Ic. Fuc. I. p. 86. t. 41.

F. parvus segmentis pralongis teretibus acutis. Monis. Hist. Ox. III. p. 648. s. 15. t. 9. f. 4. Rair. Syn. p. 45. n. 24.

B. fastigiatus; apicibus compressis, ovato-lanceolatis, abbreviatis, acutis, diaphanis.

F. lumbricalis. ß. Syn. Fuc. II. p. 318.

F. fastigiatus. Fl. Ang. p. 588. Fl. Scot. II. p. 990. GMeliN, Hist. Fuc. p. 106. t.6. f. 1. Ner. Brit. p. 88. t. 14. Fl. Dan. t. 393 . Fl. Germ. III. p. 455. Fl. Fr. Ed. 2da. II. p. 35. Linn. Trans. III. p. 199.

F. sive alga exigua dichotomos, foliorum segmentis longiusculis crassis et subrotundis. RArr. Syn. p. 45. n. 25.

F. palmaris tenuis in orbem expansus, in segmenta bifida vel trifida breviora teretia divisus. Moris. Hist. Ox. III. s. 15. t. 9. f. 9 .

Навıта'т in Britanniæ, Hiberniæ, Hispaniæ, Galliæ, et Europæ borealis littoribus, frequens.

Perenuis. Nov.-Feb.

RADIX e plurimis constans, fibris, dilutè roseis, cylindraceis, pennæ passerinæ crassitie, densissime intricatis, ramosis, et assurgentibus in catervam.

Fro d I U M longitudine spithamæarum vel dodrantalium, cylindracearum, fliformium, pennæ corvinæ crassitie, divisarum dichotomiis prope basin incipientibus, hinc octies aut novies repetitis, et ad apices, qui in plantâ sterili sunt bifidi, obtusi, pallidè rubentes, et lenitêr incurvi, spaties brevibus in certis pergentibus: rami sub-fastigiati: dichotomiarum anguli per acuti.

FrUCtificatio terminalis: frondis scilicet apices at pollicarem et ultra producuntur longitudinem, et in pericarpia cylindracea, acuminata, reliquâ fronde duplò crassiora, extrinsecùs lævia, et poro nullo pertusa turgescunt : hæc intùs constant e muco duro solido diaphano, intra quem peripheriam versus jacet series seminum fuscorum, oblongorum, non limbo cinctorum, sed, ut sub lente apparet, in partes tres dehiscentium: receptacula, fructûs tempore jam elapso, in mucum obsçurè virentem putrescunt, demùmque decidunt, frondis apices, quasi in unum collecti cultro essent abscissi, truncatos relinquentia. Horum apicum e centro exoriri solent surculi novi reliquâ stirpe principio tenuiores, unde plantæ facies illa annulata, de quâa tantum est al auctoribus disceptatum, et quâ varietas $\beta$ in Actis Linnæanis descripta nititur, evadit.

Co Lo r rufo-fuscus, magis in recente, quàm in $F$. tuberculato vel rotundo, diaphanus, in exsiccatâ nigerrimus: in marcescente dilutè virens aut albidus.

Substantia cartilaginea.

$\beta^{*}$ apices habet plerosque circitèr duos pollices longos, ramis dupld̀ crassiores, ovato-lanceolatos, compressos, gelatinosos, et dilutê roseos: cæetera cunn plantæ facie usitatâ conveniunt.

Notas eas, quæ hanc stirpem a $F$. rotundo, quocum uno ne commisceretur magnæ curæ est opus, præcipæè distinguunt, jam sub specie præcedente exposui. Duæ tamen insunt $F$. lumbbricalis naturæ proprietates, de quibus hic seorsim animadvertendum puto. Harum prima quidem et princeps est singularis illa apicum facies, quâ nitens varietatem $\beta$ suprà descriptam construxi; non quòd ego hanc pro varietatis, nedìm pro distinctæe speciei, sicut a botanicis veteribus est habita, fundamento propriè ducam, sed quòd sic disjungendo sperem me Historia naturalis cultorum animos hùc efficaciùs esse allecturum, et ita forsan phænomeno maximè singulari lıcem aliquam offusurum. Ovatos hosce apices e fructu aliquo modo pendere, tùm e sıbstantiâ, tùm e tempore quo apparent, cum pericarpïs orientes et cum iisdem marcescentes, frondisque apices truncatos relinquentes, nullus dubito. Dissecti nilhilo secius seminum granulorumve vestigia nulla exhibent, sed e muco pellucido fibris reticulatis maculis circularibus intertexto toti constant. In eâdem quæ pericarpia cylindracea fert fronde nunquan vidi, conjunctosque aliquando occurrere ex errore dictum credo. Licet enim F. lumbricalis specimina utrâque apicum figurà instructa viderim, attentiùs, tamen inspiciens e radicibus distinctis ortas semper deprehendi, et, ut in descriptione dixi, plurimæ semper interteste sunt radices, ut idem exemplar non tantum frons unica quantum frondium distinctarum congeries videatur. Altera illa F. lumbricalis proprietas in tuberculis constat, que vel per ramos sparsa, vel etiam in radice, nunc solitaria, nunc varie conglomerata, Fuçorum globuliferorum capsulis non absimilia, quandoque occurrunt. Hæc sese omnibus anni tempestatibus nullo discrimine conspicienda prebent; textura dura et uniformis; indoles prorsis eadem cum is quæ in $\mathbb{E}$ : subfusco et plurimis aliis sunt obvia; quas ob causas ab insectorum quorundum marinoruṇ punctis pendere suspicor, et verrucas in præsenti appello. Non tamen illud idcircò me fallit multorum Botanicorum sententias ab hâc meâ discrepare, et $e$

septem

* Errabam cùm hos apices dissepimentis iis Confervarum instar a reliquâ fronde disjunga in Fucorum Britar nicorum Synopsi dicerem : talii șnim septa specie modò existere rami longitudinalitèr secti ostendunt. Texturâ tamen discrepant. 
septem illis speciebus in quas Stackhousius $F$. rotundum et $F$. lumbricalem dividendos autumat, unam saltém ex his tuberculis pendere.

$$
\begin{aligned}
& \text { a. F. lumbricalis, nat. mag. } \\
& \text { b. var. } \beta \text {. } \\
& \text { c. apex fructifer, magn. auct. - - - - - - _ - - - } 6 \text { - } 6 \text { - }
\end{aligned}
$$

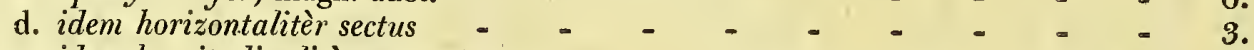

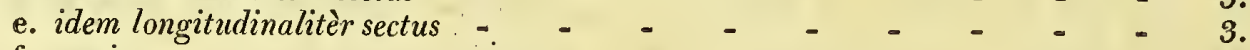

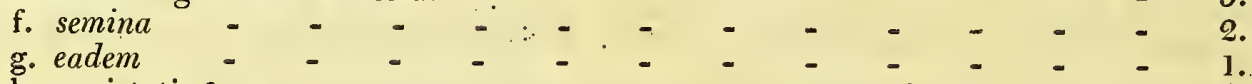

$$
\begin{aligned}
& \text { h. varietatis } \beta \text { apex - - - - - - - - - - - } 6 \text { - } 6 \text {. } \\
& \begin{array}{lllll}
\text { i. eadem marcescens, ut faciei annulatre origo conspiciatur - } & - & - & - & \\
\text { k. eadem horizontalitèr secta - }- & - & -
\end{array} \\
& \text { 1. frondis portio cum verrucis solitariis lateralibus, et congestis terminalibus, nat. magn. } \\
& \text { m. verruca dissecta, magn. auct. _. . - _ _ - _ - } 3 \text {. }
\end{aligned}
$$

\section{6.-F U G U L L M B R I A L I S.}

Fucus lumbricalis, frond cartilaginous, filiform, dichotomous, fastigiate; angles of the dichotomies acute; apices forked blunt; fruit in the elongated cylindrical acuminated apices.

Fucus lumbricalis. Gmelin, Hist. Fuc. p. 108. t.6. f.2. Linu. Trans. III.p. 204. Syn. Fuc. II. p. 317. Eng. Bot. XII. t. 824. Fl. Fr. Ed. $2 d a$. II. p. 22.

F.fastigiatus. Wiтн. IV: p. 110. Ner Brit. p. 15. t.6. (quoad Fig. maj.) VelLey.t.4.

F. furcellatus. Linn. Sp.Pl. II. p. 1631. Syst. Nat. II. p. 718. Syst. Nat. Ed. Gmel. II. p. $1383 . \quad F l$. Ang. p. 589. Fl. Scot. II. p. 932. Fl. Dan. t. 419. Fl. Germ. III. p. 456. Fl. Norv. II. p. 78. EsPer, Ic. Fuc. I. p. 86. t. 41 .

F. parvus segnentis pralongis teretibus acutis. Moris. Hist. Ox. III. p. 648. s. 15. t. 9. f.4. Rair. Syn. p.45.11. 24 .

B. fastigiatus, apices compressed, transparent, ovato-lanceolate, short, acute.

F. lumbricalis. $\beta$. Syn. Fuc. II. p.318.

F. fastigiatus. Fl. Ang. p. 388. Fl. Scot. 1I. p. 930. Gmeur, Hist. Fuc. p. 106. t. 6. f. 1. Ner. Brit. p. 88. t. 14. Fl. Dan. t. 393. Fl. Germ. III. p. 455. Fl. Fr. Ed. 2da. II. p. 35. Linn. Trans. III. p. 199.

$F$. sive alga exigua dichotomos, foliorum segmentis longiusculis crassis et subrotundis. RArr. Syn. p. 45 . n. 25.

F. palmaris tenuis in orbem expansus, in segmenta bifida vel trifida breviora teretia divisus. MoRIs. Hist. Ox. III. p. 649 . s. 15 . t.9. f.9.

On the shores of Britain, Ireland, Spain, France, and the northern parts of Europe, common.

Perennial. November-February.

Root, consisting of very numerous, pale-pink, cylindrical fibres, about the size of a sparrow's quill, thickly matted together, branching, and rising into a multitude of

FroNDs, from six to nine inches high, cylindrical, filiform, about the thickness of a crow's quill, eight or nine times divided by dichotomies beginning near the root, and continued, at short but uncertain distances, to the summits, which are, when barren, bifid, blunt, pale-red, and slightly incurved: the branches are nearly of the same height; angles of the dichotomies very acute.

FRUCTIFICATI ON terminal: the apices lengthening to an inch or more, and swelling into cylindrical acuminated pods, twice as thick as the rest of the plant, externally quite smooth, and perforated with no pores; internally composed of a hard solid transparent mucus, within which near the circumference lies a row of dark oblong seeds, not surrounded by a limbus, but under a high microscope appearing to be each composed of three parts; as the time of fructification passes away the pods turn to a mass of dark green mucilage, and drop off, leaving the apices of the plant truncated, as if they had been laid together and chopped off at once with a knife; out of these rise new shoots, at first much more thin than the rest of the frond, giving the plant that annular appearance which has been often noticed by authors, and upon which the var. $\beta$ in the Linnzan transactions is founded.

CoLOR reddish brown, more transparent in a recent state than either $F$. tuberculatus or rotundus, but turning when dry to an intense black; in decay it becomes light green or white.

SU BST A N C E cartilaginous.

In $\beta$ most of the *apices are about two lines long, twice as wide as the rest of the frond, ovato-lanceolate, compressed

* I was mistaken when I said in the Synopsis of the British Fuci that these apices were divided from the branches by a dissepiment similas to that of the Conferva, for on cutting the branches longitudinally it is plain that such a division exists only in appearance. They are, hewever, of a texture different from the rest of the frond. 


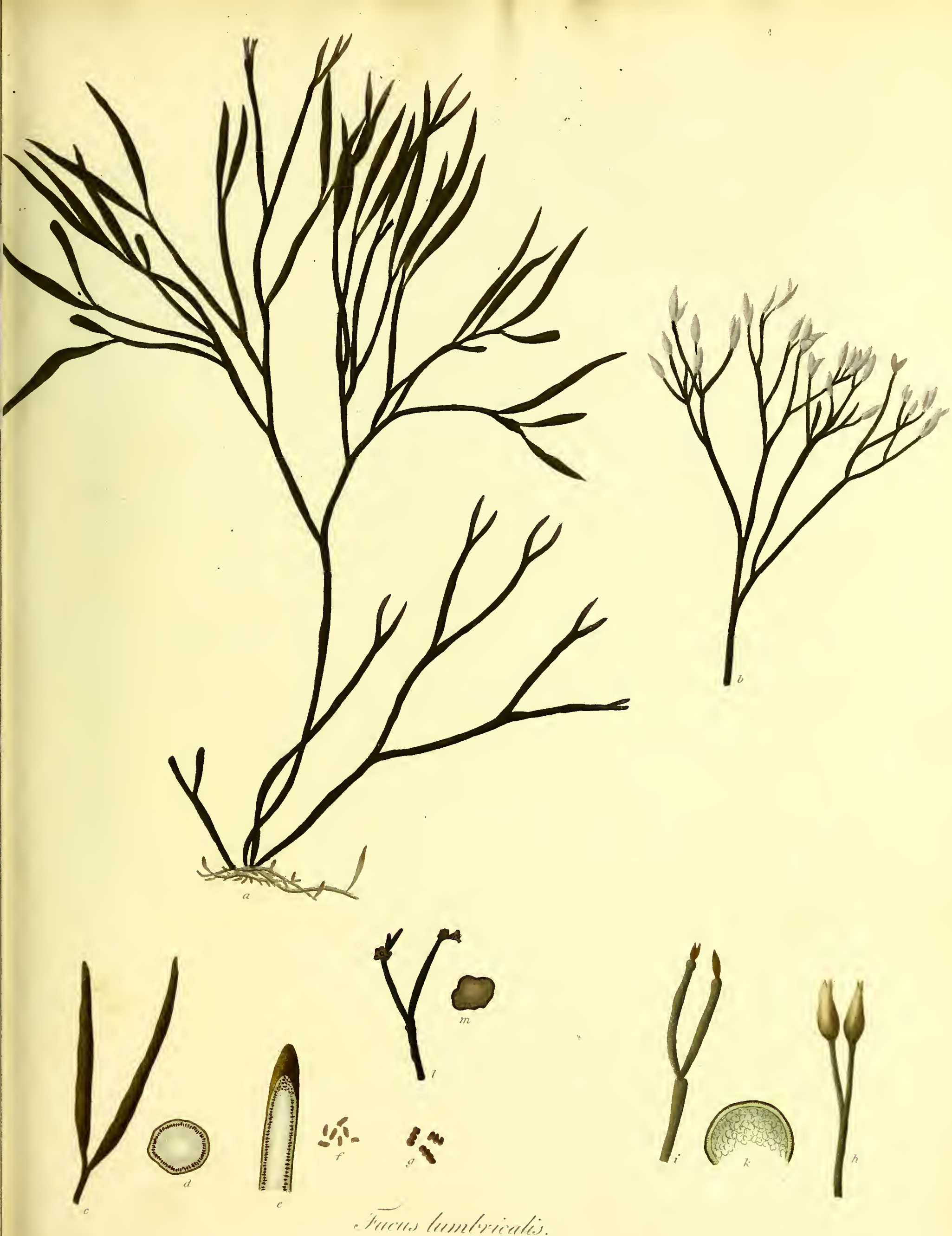



pressed, of a gelatinous nature; and very pale pink color; in other respects it agrees with the common appearance of the plant.

Upon the several points that distinguish $F$. lumbricalis from $\boldsymbol{F}$. rotundus, with which alone there is reason to fear its being confounded, I have already dwelt in the account of the preceding Fucus; but there are two circumstances connected with the history of the present plant, which it is more particularly necessary here to notice. The first and principal of these is the singular appearance of the apices upon which I have constructed my variety $\beta$, not indeed regarding it properly as a variety, and still less as a distinct species, which it was considered by the elder Botanists, but looking upon the thus separating it as the most effectual method of attracting to it the attention of Naturalists, and probably procuring some light to be thrown upon its nature. That these ovate transparent tips are in reality connected with the fructification, is what I cannot allow myself to doubt, as well from their peculiar form and substance, as from their appearing only at the season of the cylindrical pods, and, like them, withering and falling off, leaving the frond truncated. At the same time, when cut through, they exhibit no appearance of seeds or granules, but are full of a transparent mucus, interwoven with reticulated fibres in circular meshes. I do not believe that they ever occur on the same plant as the cylindrical pods; for, though I have gathered masses of this species, containing either kind of apex, yet in every suclı case they originated from really distinct roots, of which, as noticed in the description, many are always found matted together. The other peculiarity is the tubercles, which are occasionally met with on different parts of the stem, or even on the root, sometimes single, and sometimes clustered, in appearance not unlike the fructification of some of the globuliferous Fuci. These are equally present at all times of the year, their texture is hard and uniform, and they are evidently of the same nature as those observable on $\boldsymbol{F}$. subfuscus and several other species, so that $\mathbf{I}$ rather regard them as depending upon the puncture of some marine insect, and have for the present called them warts. I am nevertheless aware that many Botanists entertain an opinion different from mine upon this subject, and that it is on these warts that Mr. Stackhouse has fousded one at least of the seven* species into which he proposes to divide F. rotundus and lumbricalis.

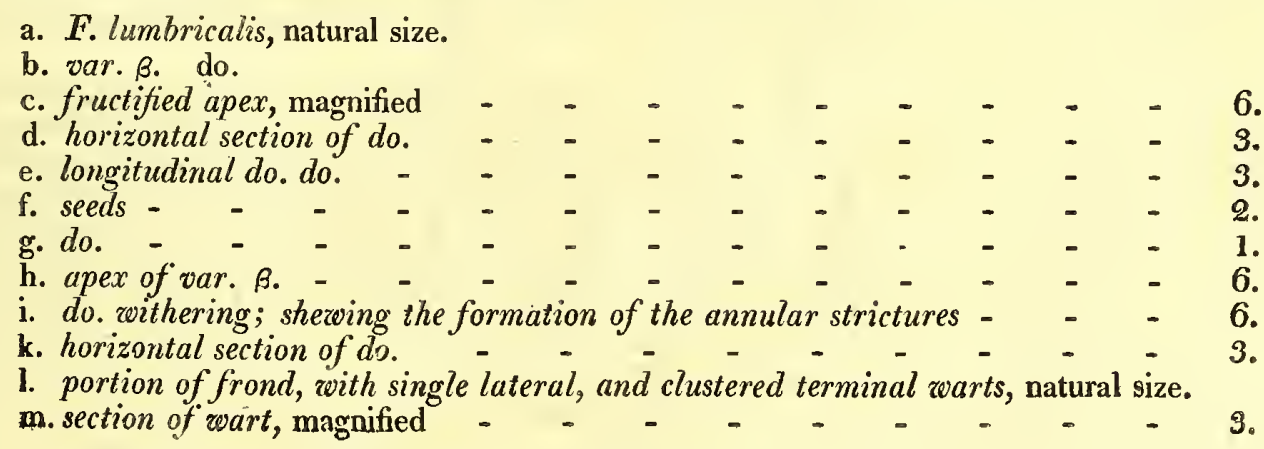

- See Nereis Britannica, p. 89. 
Fucus tuberculatus, frond between coriaceous and cartilaginous, filiform, irregularly dichotomous; angles of the dichotomies rounded; apices forked, blunt; receptacles terminal, between oblong and cylindrical, obtuse.

Fucus tuberculatus. Fl. Ang. p. 588. Linn. Trans. III. p. 198. Syn. Fuc. II. p. 305. Esper. Ic. Fuc. II. p. 20. t. 121. Eng. Bot. XI. t. 726.

F. bifurcatus. Wiтн. IV. p. 109. t. 17. f. 1. Fl. Fr. Ed. 2da. II. p. 23. (excl. syn. Gmel.)

F. Kali geniculato similis, non tamen geniculatus. Rair. Syn. p. 43. n. 13.

Rocks in Dorsetshire, Devonshire, and Cornwall.-North of Ireland. Dr. Scott.-Shores near Brest. M. Decundolle.... Coast of Barbary. Drs. Weber and Mohr.

Perennial. June-October.

Rooт a small callous disk, furnished with a few very short, thickish, creeping fibres, each rising at right angles into a

FROND cylindrical, nine inches or a foot high, equal in thickness when wet to a goose- quill, when dry to not more than a crow's, always undivided near the base, and not unfrequently extending so for half its length, there becoming forked, and afterwards branching with dichotomies six or seven times repeated, at uncertain, generally short intervals, till it reaches the summit: angles of the forks obtuse, and slightly rounded: length of the branches irregular, but the lowest always shortest, the upper ones sub-fastigiate: apices obtuse, the barren ones short and alivays incurved.

Fnuctification terminal; the ends of the frond at the period of fruit-bearing extending to an inch or more in length, and taking the form of cylindrical receptacles, twice as thick as the rest of the plant, externally made uneven, by the immersed ovate tubercles that they are filled with, in which, especially towards the lower part, lie pyriform, brownish seeds, surrounded with a pellucid limbus, intermixed with fibres, their points in general turned to the pore of the receptacle, between which and them are observable numerous white, pellucid, roundish bodies, many times less than the sceds themselves.

CoL OR of the plant when fresh, olive, when dry quite black; never recovering its former tint.

SUBSTANCE between coriaceous and cartilaginous, tough: in a dry state rigid and brittle.

OBS. The specimens of this plant, which I gathered fresh in Cornwall, had a more unpleasant and biting flavour than those of any other Fucus which I ever tasted.

The description here given of the fruit of $F$. tuberculatus extends as far as the powers of my compound microscope would enable me to discover, but as this is the identical Fucus in which Drs. Weber and Mohr say that they found the parts of fructification more distinctly visible than in any other of the tribe of their Fuci proprii, I trust that it will not be regarded as an improper or unnecessary digression, if $I$ avail myself of this opportunity of extracting from their excellent treatise, which has already been quoted under the hcad of $F$. Banksii, the generic character laid down by them. Their analysis of the parts of fructification must be reserved for that portion of this work in which $I$ shall endeavour to throw as much lightwas lies in my power upon the division of the submersed Algæ into new genera. The character is, "Seeds furnished with an arillus, immersed in various manners in a naturally perforated receptacle." Upon this subject I beg leave to remark, that if, as I understand from other parts of their tract, it is their intention to call the common receptacles spikes of fructification, and on the other hand the smaller ones receptacles, I cannot but think that the word spikes is here inaptly applied; in consequence of which I propose to term these latter receptacles, and those which are called by them receptacles, tubercles. At the same time I should be extremely sorry to be considered as speaking at present with any positiveness upon this subject, or as wishing to hide the doubts I feel whether those parts that have hitherto gone by general consent under the denomination of seeds may not themselves be properly receptacles. In $F$. vesiculosus and some others $I$ have clearly observed that they contained spherical granules. With regard to the extremely minute pellucid bodies discernible in the tubercles of $F$. tuberculatus, and called by Webe: and Mohr small bladders (bläschen) I am utterly at a loss to form a conjecture what purpose they are intended to answer in the occonomy of the plant, and can say nothing more than that they have at present been detected in a very few species. It will require a long time and attentive observation before we arrive at an accurate knowledge of these plants, and before we are able to reform and finally to fix the synonomy, which is at present most imperfect and unsatisfactory. I must be allowed to indulge in one more remark connected with this subject: that of all the generi suggested by Weber and Mohr, none appcars to include so natural a tribe of plants as the present. F. tuberculatus of the Flora Scotica is only a synonym to $F$. purpurascens. The unequal height of the branches, the root, the color after it is dried, and the fructification sufficiently distinguish this plant from the two preceding ones with which it is sometimes confounded.

a. Fucus tuberculatus, natural size.

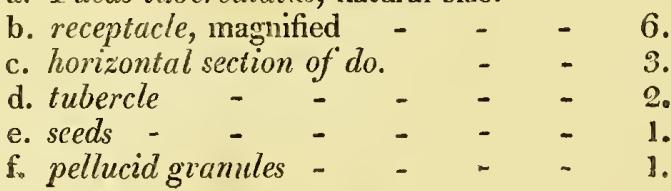




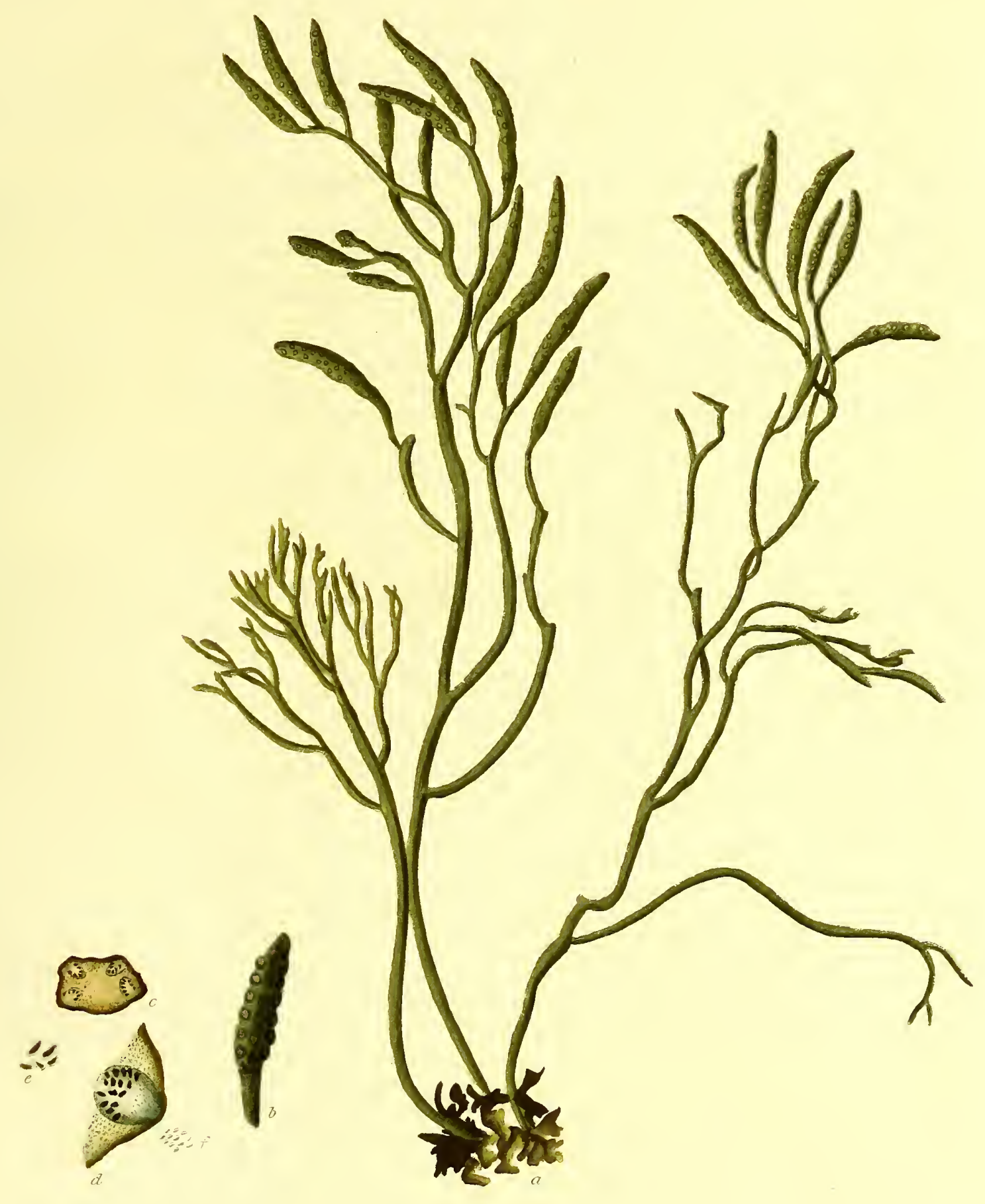





\section{7.-F U G US T U B R G U A T US.}

Fucus, fronde coriaceo-cartilagineâ, filiformi, subdichotomâ ; dichotomiarum angulis rotundatis : apicibus bifurcis obtusis; receptaculis terminalibus oblongo-cylindraceis obtusis.

Frucus tuberculutus. Fl. Ang. p. 588. Limn. Trans. III. p. 198. Syn. Fuc. II. p. 305. Es Per, Ic. Fuc. II. p. 20. t. 121. Eng. Bot. XI. t. 726 .

F. bifurcatus. WІтн. IV. p. 109. t. 17. f. 1. Fl. Fr. ed. 2da. II. p. 23. (excl. syn. Gmel.)

F. Kali geniculato similis, non tamen geniculatus. Ra11. Syn. p. 43. n. 13.

Ha в IтA in Dorsetiæ, Devoniæ, et Comubiæ rupibus submarinis.-In Hiberniâ Septentrionali. D. Scott.Ad littora prope Brest. Decandolle.-In Barbariæ oris. Weber et Mohr.

Perennis.-A Julio ad Octobrem fert fructum.

RADIX callus exiguus, fibris aliquot instructus crassiusculis, perquàm brevibus, repentibus, horizontalibus, singulis apice ad angulum rectum assurgentibus in

FRONDEM teretem, dodrantalem, vel pedalem, pennæ anserinæ madefactam, exsiccatam corvinæ crassitiem æquantem, semper juxta basin, nec rard per dimidium longitudinis indivisam, inde bifurcam, et dichotomiis intervallis incertis plerumque tamen brevibus, ad apices usque repetitis sexcies vel septies divisa; dichotomiarum anguli obtusi, rotundati; ramorum longitudo incerta, inferiores tamen semper breviores, superiores subfastigiati; apices obtusi, steriles lenitèr incurvati, abbreviati.

FRUCTIFICATIo terminalis; apices fructûs tempore ad pollicarem et ultra longitudinem protenduntur, receptaculorumque formam cylindraceorum, reliquâ fronde duplo fere crassiorum assumunt: tubercula in his ovata sunt immersa, in quibus præsertim basin versus jacent semina pyriformia, fibris immixta, limbo pellucido cincta, apicibus plerumque tuberculi porum spectantibus ; spatium inter porum et semina occupant corpuscula quædam allba, pellucida, stibglobosa, his multotiès minora.

Co LoR recentis olivaceus, exsiccate nigerrimus nunquam in pristinum revocandus.

Su BST A NTr A e coriaceâ cartilaginea, tenax, exsiccata rigida, fragilis.

Ors. Exemplaria hujus Fuci, quæ in Cornubiæ oris recentia legi, ingratius acriùsque ullis aliis a me unquam degustatis algis sapuerunt.

F. tuberculati fructûs, quantum microscopii compositi ope detegere mihi licuit, descriptionem hìc dedi, sed cùm hæc sit ipsa species, in quâ viri acutissimi, Weberus Mohriusque, organa fructificationi inservientia præ cæteris, quas Fucos $x \alpha \tau^{\prime} \varepsilon \xi \alpha x \eta v$ appellant, distincta viderint, non supervacaneum fore spero si ex eximio tractatu jamjam sub $F$. Banksii laudato, characterem huic generi ab ipsis inditum hujus loci repetam, fructûs quam tradiderunt analysi ad eam operis hujus partem relictâ, ubi de algis marinis in plura genera dispertiendis disserere conabor. Est igitur generis character, "Semina arillata, receptaculo poro naturalitèr pertuso variè immersa." De quibus observandum puto, ut si, quemadmodum per alias tractatûs partes intelligo, receptacula communia fructificationis spicarum; contra ea minora receptaculorum nomine insignire pergant, nihi quidem videtur terminum spicas hìc vix satis aptè adhiberi, idedque eorum spicas receptacula, receptacula tubercula noninavi. Nec tamen ego is sum qui aliquid de his rebus adhuc extripode asseram, vel dissimulare vellem quàm in dubio est aninıus, annon ea quæ semina ab omnibus hactenùs appellentur sint ipsa reverà receptacula, cùm in $F$. vesiculoso et quibusdam aliis grana aliquot sphærica in illis inclusa dilucidè conspiciantur. Cuinam autem usui inserviant minora ea in F. tuberculati receptaculo observanda corpuscula, quæ vesiculas (bläschen) nuncupant Weberus Mohruisque, nihil sanè conjicere possum, nec est aliud quod nunc dicam, nisi quòd in paucis tantummodo speciebus hactenùs sint reperta. Longo tempore maximâque curâ erit opus, priusquam ad harum stirpium fructificationis cognitionem accuratam perveniamus, et a terminologiâ, vitiosâ in præsens imperfectâque, talis erit cognitio, ut penitùs reformetur firméque stabiliatur, expectanda. Liceat mihi unum modd adjicere, scilicet ex omnibus qux Weberus Mohriusque proposuerunt generibus hoc plurimun mihi quantum adhuc vidi arridere, et stirpium familiam inter se naturâ maxime connexarum includere. Planta sub F. tuberculati nomine in Florâ Scoticâ descripta ad $F$. purpurascentem pertinet. Ramorum altitudo inæqualis, radix, exsiccatæ color, necnon fructificatio hanc speciem a duabus præcedentibus, quibuscum interdum commiscetur, satis superque distinguunt.

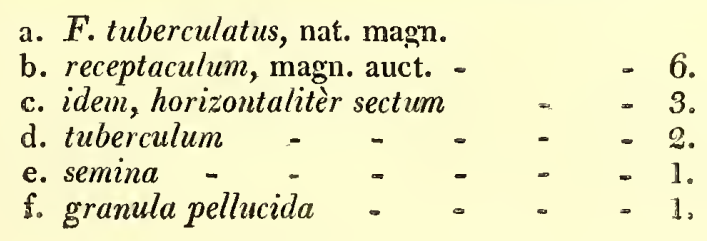


Fucus floccosus, frond compressed; branches alternate distichous; ramuli setaceous, generally simple, placed in alternate clusters ; capsules lineari-lanceolate, panicled.

Fucus floccosus. Es PER, Ic. Fuc. II. p. 42. t. 100.

At Port Trinidad, North-west coast of America. Mr. Menzies.

Roот, a small expanded disk.

Fron DS, many from the same root, nine or twelve inches long, flexuose, rising with a stem cylindrical at the base, and as large as a blackbird's quill, but soon becoming compressed, and thence gradually tapering to the apices, so that at the summit it is scarcely thicker than thread, either simple, or once or twice divided without regularity near the root, beset throughout its whole length, at short distances, with alternate, distichous, flexuose, long, sub-fastigiate branches, which are again in the same manner furnished with smaller ones: along the stem and all the branches grow setaceous ramuli, generally simple, not above two or three lines long, collected into distichous, alternate, panicled clusters, which appear as if about to lengthen into new branches.

Fructification, situated near the base of the ramuli, composed of five or six lineari-lanceolate, panicled, incurved capsules.

Co LOR of the plant when wetted brown, intensely black when dry.

SUBSTANCE, in the stem and branches inclining to ligneous, in the ramuli between membranous and coriaceous; every where pliant and flexible, yet tough.

This fucus when put into water expands considerably, but recovers its original form so reluctantly and imperfectly after it has been pressed and dried, that no drawing can give an adequate idea of its elegant and beautiful appearance; and the ramuli, especially those in a fructified state, look, in spite of the greatest care, a mass of confusion. That the parts which $I$ have supposed to contain the fructification do so in reality, is a point, that admits, in my opinion, of no doubt, as well from their peculiar form and appearance, as from the analogy they bear to the capsules of $F$. subfuscus, with which species the present seems to have a closer affinity than with any other Fucus yet described: at the same time, I must freely own that I have found in them no seeds. In the ramuli, under the highest powers of the microscope, some faint traces of septa are discernible. Professor Esper, who has figured this plant, as well as many others, from small specimens that I sent him without any expectation of seeing them published, has erroneously assigned Nootka Sound to it as its, habitat, and observed that it was brought home by Cook; in which also he is mistaken; as, I believe, that no specimens of it exist in Britain, except those gathered in America by my friend Mr. Menzies, to whose kindness I am indebted for that here figured.
a. Fucus floccosus, natural size.
b. barren ramulus, magnified
c. fruit-bearing, ditto -
d. portion of ditto -
e. smaller piece of ditto
5.
$-5$.
$-3$. 


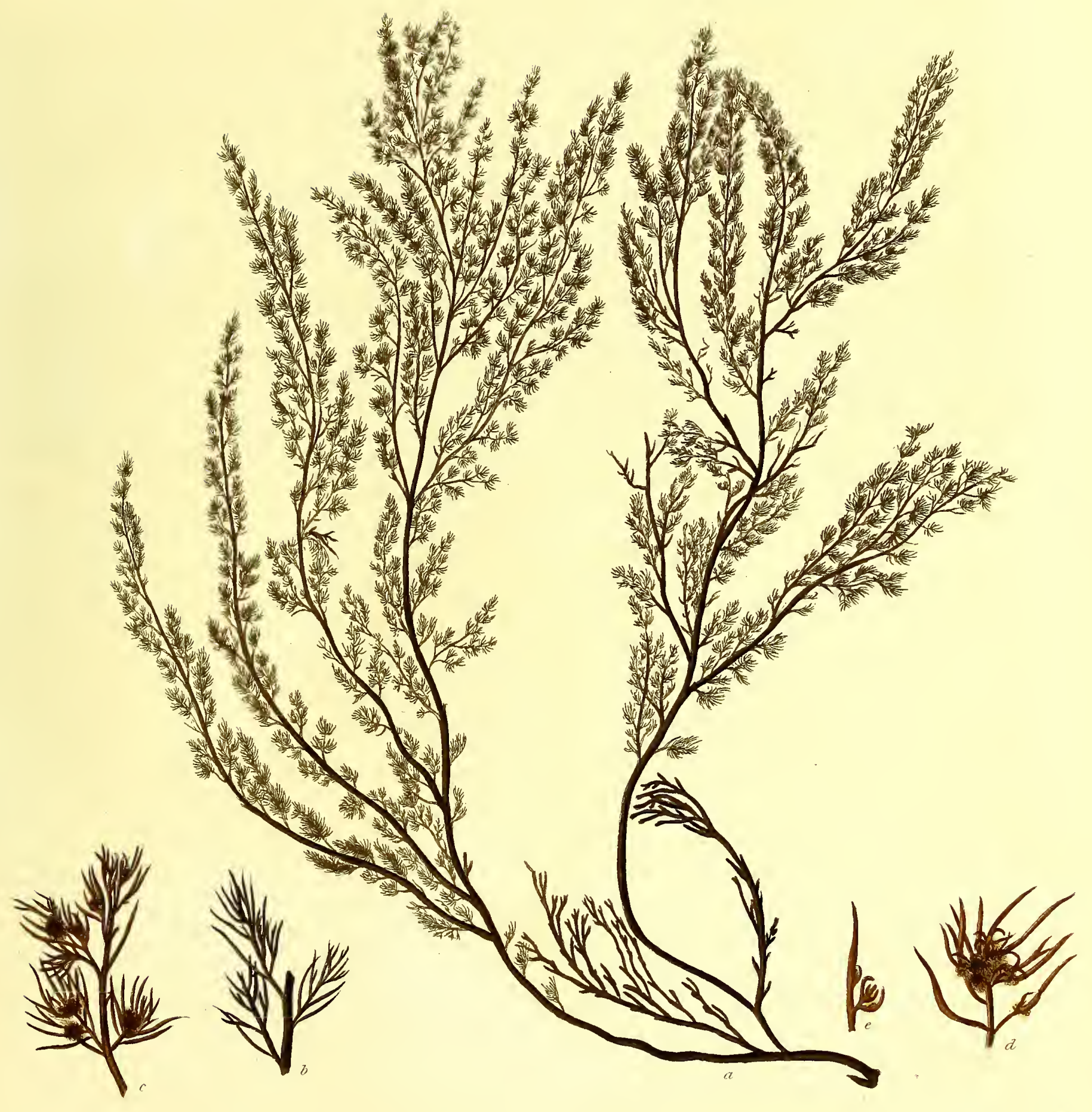



Fucus, caule compresso ; ramis alternis, distichis ; ramulis setaceis; simpliciusculis, alternatim fasciculatis ; capsulis lineari-lanceolatis paniculatis.

Fucus floccosus. Es PER, Ic. Fuc. II. p. 42. t. 100.

Ha в Iт a apud Port Trinidad, in Americæ borealis, quæ Occidenitem spectant, littoribus. D. Menzies.

RADix callus parvus, explanatus.

Fron DEs plurima, dodrantales, vel pedales, flexuosè erectæ, caule assurgentes basi terete, penne merulina crassitie, mox compresso, et inde ad apices usque sensim angustato, ut cacumen vix filum æquet, simplice vel semel iterùmque infernè vagè diviso, ramis remotiusculis, alternis, distichis, elongatis, flexuosis, subfastigiatis per totam longitudinem obsito, et his aliis minoribus eodem modo instructis; ramulis per caulem ramosque satis frequentibus, setaceis, vix duas tresve lineas longis, simpliciusculis, in fasciculos distichos, alternos, sese mox, ut videtur, in novos ramos porrecturos, paniculatim coactis.

FR UCTIFICATIO ramulorum prope basin orta, e capsulis quinque vel sex lineari-lanceolatis, paniculatis, in curvis constat.

Co Lor plantæ nadefacte fuscus, exsiccate nigerrimus.

SU BSTANTIA in caule et ramis sub-lignea, in ramulis membranaceo-coriacea; ubique lenta, flexilis, tenax.

Molem suam licet magnoperè augeant hujus Fuci exemplaria aquâ dulci immersa, dolendum tamen est quòd in formam nativam tam ægrè tamque imperfectè redeant, ut nulla, nisi ad stirpem vivam delineata, icon habitum perpulchrum elegantemque adæquè exprimat, nec summâ prohiberi potest curâ, ne ramuli presertìm fructiferi, meræ et inextricabilis confusionis speciem præbeant. Partes eas, quas suprà in descriptione pro fructificatione assumpsi, quamvis semina in illis nulla detexerim, esse nihilominùs reverâ capsulas, cùm ob formam speciemque sibi propriam, tùm ob magnam quam habent cum $F$. subfusci, cui cæteroquin affinis hæc species, fructu analogiam, dubitare nequeo. Septorum in ramulis lente acerrinâ auctis, obsoleta quædam vestigia detexi. F. floccosum compluresque alios ad specimina plus æquo manca, quæ ipse nulłâ ut publici juris fierent spe ductus misi, depingendos curavit cl. Esperus, simulque pro loco hujus speciei natali Nootka Sound tribuit: haud rectè quidem; nec minus erravit cùm in Furopam a Cook deportatum diceret, persuasum enim habeo nulla dari in Britanniâ exemplaria, exceptis iis, quæe ex Americã boreali redux amicissimus Menzies, cujus benevolentiæ hæc mea accepta refero, secum attulit.

a. Fucus floccosus, nativâ magnitudine.

b. ramuli steriles, magn. auct. - $\quad-5$.

c. ramuli fructiferi - - - -5 .

d. eorundem pars - - - - 3,

e. pars minor - - - - - 2 
Fucus purpurnscens, frond filiform, irregularly branched; ramuli setaceous, scattered, bearing spherical tubercles immersed in their substance.

Fucus purpurascens. Fl. Ang. p.589. Wiтh.IV. p. 11.3. Eng. Bot. XVIII t. 1943. VeLLey, t. 2. Linn. Trans. III. p. 295 . Syn. Finc. II. p. 357. Fl. Fr. ed. 2da. II. p. 36.

F. tuberculatus. F\%. Scot. II. p. 926.

F. corallimus. F\%. Dan. t. 709 .

F. capillnceous. EsPer, Ic. Fuc. I. p. 75. t. 35. (excl. syn.)

F. acicularis. EsPer, Ic. Fuc. 1. p. 132. t. y1.

F. purpureus. Livn. Syst. Nat. Ed. Gmel. II. p. 1384. GMELIN, Hist. Fuc. p. 139 ?

F. flexilis. Wu lfen, Crypt. Aquat. n. 42 ?

Fucus teres albus tenuissimè divisus. RaII Syn. p. 50. n. 51. Moris. Hist. Ox. III. p. 648.

$\beta$ cirrosus, apices of the ramuli capillary, twisted spirally like tendrils.

Slıores of Britain, Ireland, France, and Spain. - $\beta$ in Dorsetshire, Mr. Pigott.-Devonshire, Mrs. Griffiths.

Perernial? September-December.

Rooт, a small, solid, fleshy disk, throwing out several incurved fibres, as thick as a sparrow's quill, and above a. nail long, strongly clasping the stones on which it grows.

FroN D, filiform, cylindrical, from nine inches to a foot, or sometimes two feet, in length, preserving throughout a stem about the thickness of a crow's quill, generally simple, but sometimes occasionally divided, beset from base to summit with branches similar to it, except in size, of very uncertain length, disposed irregularly at short distances, between erect and patent, again furnished in the same manner with another series still smaller, and these either naked or bearing setaceous ramuli from three to six lines, or more, long, most frequently simple, but sometimes forked, the angles always very acute. All the branches are slightly attenuated at their base, and remarkably acuminated at the apices.

FRUCTIFICATION, globular tubercles, at first pale pink, afterwards crimson, nearly as large as mustard seeds, immersed in the substance of the smaller branches, sometimes solitary, at other times two, three, or four in the same branch at short distances, so as to give a sort of jointed appearance; occasionally confluent: at maturity they become gibbous, and burst laterally, discharging a great quantity of very minute, dark-red seeds of irregular form.

Color, light brown, always tinged with purple, very diaphanous, paler in the smaller branches, and not unfrequently verging to green, to which it turns in decay.

SU BSTA NCE, between gelatinous and cartilaginous, fleshy and tender.

The fructification of this plant is so remarkable, that it will always be sufficient immediately to distinguish it from any other species with which I am at present acquainted, but at the same time, there is scarcely any Fucus less understood in its barren state, whence arises the multiplicity and confusion of the synonyms above quoted. With regard to F. purpureus, Gmel. I have already stated in the Synopsis of the British Fuci, that I consider it as doubtful how far it is intended for our plant, and, adhering to that opinion, I should not have ventured to introduce it, had not my friend Professor Mertens, in whose judgment I have the highest confidence, entertained opposite sentiments. The size, the black spots, and the color it gives out are all different from our plant.-.The var. $\beta$, which is a very reinarkable appearance, is found climbing upon other Fuci, and, according to the remarks of Mrs. Griffiths, seldom bears fruit. I received it many years ago from Mr. Pigott._Fucus purpurascens is often found with swellings on the stem and branches, like those of $\boldsymbol{F}$. lumbricalis, which, though unconnected with the fruit, require, nevertheless, to be mentioned, lest they should occasion error. They are about the size of the seeds of Vicia sativa, of an irregularly spherical form, and a pale whitish color, not covered with the epidermis of the frond, but in appearance resembling the warts of the human hand. This species is particularly liable to be infested with Conferva confervicola of Dillwyn.

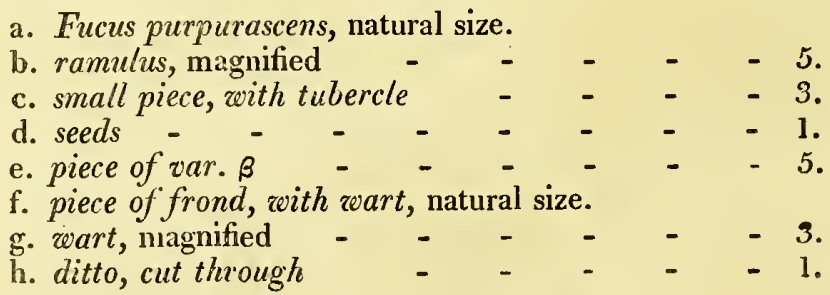




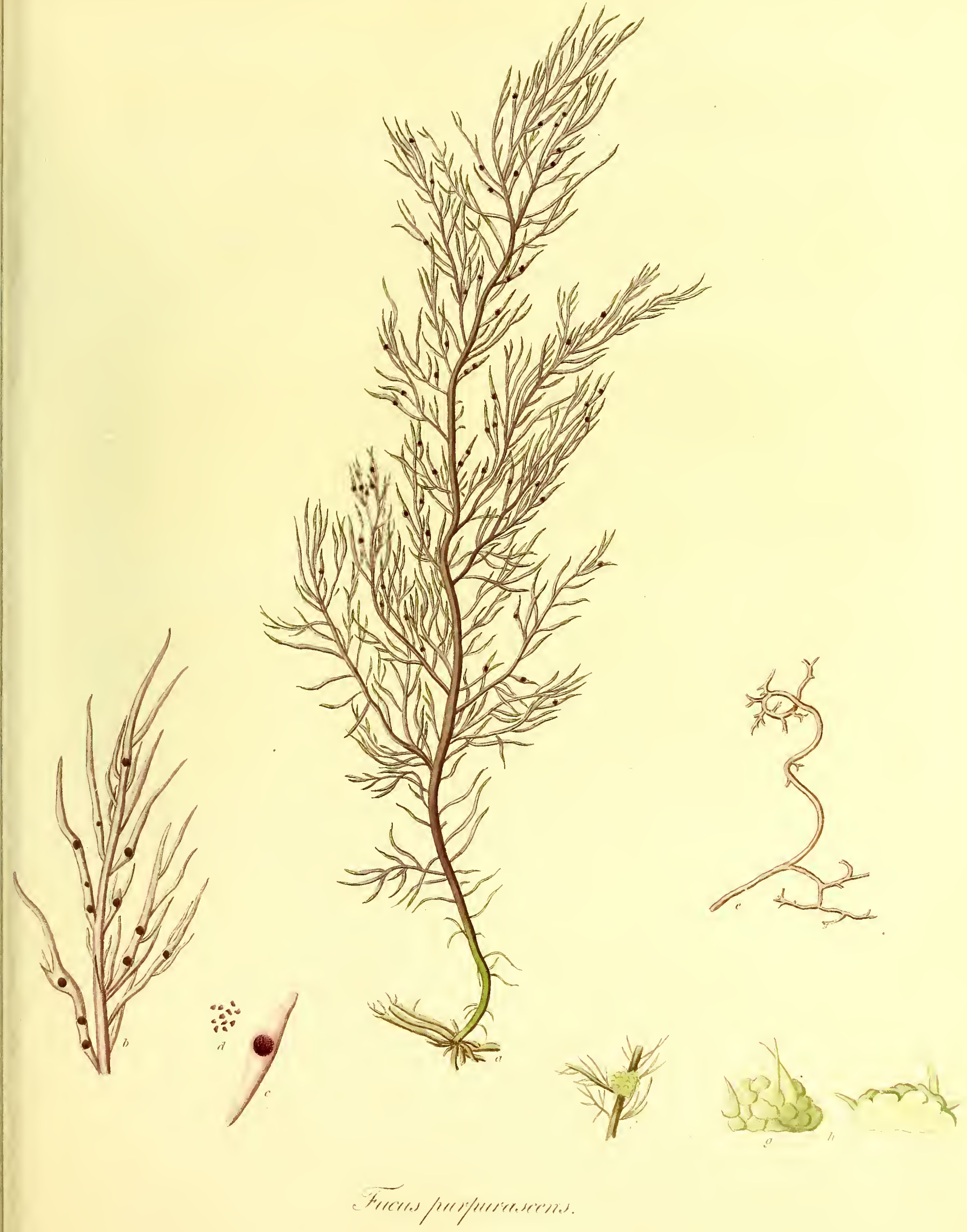





\section{9.-F U G S P URPUR A S E N S.}

Fucus, fronde filiformi, ramosissimâ, ramulis setaceis sparsis ; tuberculis sphæricis in ramulis innatis.

Fucus purpurascens. Fl. Ang. p. 589. Wrth. IV. p. 113. Eng. Bot. XVIII. t. 1243. Velley. t. 2. Linn. Trans. III. p. 225. Sign. Fuc. II. p. 357. Fl. Fr. Ed.2da. II. p. 36.

F. tuberculatus. $\quad F l$. Scot. II. p. 926.

F. corallinus. Fl. Dan.t. 709.

F. capillaceus. EsPER, Ic. Fuc. I. p. 75. t. 35. (excl. Syn.)

F. acicularis. ESPER, Ic. Fuc. I. p. 132. t. 91.

F. purpureus. Linn. Syst. Nat. Ed. Gmel. II. p. 1384. Gmelin, Hist. Fuc. p. 139.?

F. flexilis. Wu n E e , Crypt. Aquat. 11. 42.?

Fucus'teres, albus, tenuissimè divisus, RaII Syn. p. 50. n. 51. Moris. Hist. Ox. III. p. 648.

ß. cirrosus; ramulorum apicibus capillaceis, spiral tèr cirrhorum instar tortis.

Ha BIт A in Britanniæ, Hiberniæ, Galliæ, et Hispaniæ oris.- $\beta$ in Dorsetiâ. D. Pigott.-in Devoniâ. Dna. Gmiffiths.

Perennis? Sept.-Decemb.

RA DIX discus exiguus, carnosus, fibras, emittens plurimas, incurvas, pennæ passerimæ crassitie, plus ungue longas, saxis, quibus innascitur, arctè adhærentes.

FRONS filiformis, cylindracea, longitudine dodrantalis vel pedalis, interdùm etiam bipedalis, caule instructa pennæ corvinæ crassitie, ut plurimum simplice, quandoque hìc illic diviso, a basi usque ad apices obsito ramis sibi, staturâ minore demptâ, similibus, longitudinis perquam variæ, spatiis brevibus haud æquis dispositis, erecto-patentibus, aliorum minorum serie eodem modo instructis, qui vel sunt nudi, vel ramulis tecti setaceis, tres sexve lineas longis, plerumque simplicibus, at nonnunquam bifurcis, furcarum angulis semper acutis. Rami omnes lenitèr ad basin attenuantur, apicibus insignitèr acuminatis.

FRUCTIFICATIO tubercula sphærica, juniora dilutè rosea adulta punicea, Sinapis nigra seninum ferè magnitudine, in ramis minoribus innata, nunc solitaria, nunc duo, tria, vel quatuor in eodem ramulo, aliquando confluentia, sed sæpiùs intervallis brevibus disjuncta, ut ranuli articulati videantur; matura gibbosa fiunt, et lateralitèr dissilientia semina plurima intensè rubra, niıutissima, figuræ haud certæ emittunt.

Co Lor dilutè fuscus, purpurascente semper immixtus, diaphanus, in ramis minoribus pallidior, nec rarò virescente, in quem marcescens transit, tinctus.

Substantid gelatinoso-cartilaginea, carnosa, tenera.

Fructificatione quamvis singulari donetur hic Fucus qui ab omnibus hucusque descriptis piimo aspectu distinguat, vix tamen est ulla in Algarum catalogo species, quæ tot tantisque erroribus ansam sterilis præbeat, unde multiplex illa inter auctores synonymorum supra citatorum confusio. Fucum Gmelini purpureum hùc ægrè esse referendum jampridèm in Fucorum Britannicorum Synopsi sententiam meam retuli, idemque cùm nunc sentirem, hìc adducere non sim ausus, nisi e partibus contrariis Mertensius, acerrimus in ejusmodi rebus judex, se stare profiteretur. Magnitudine, naculis nigris, et eâ, quam largiter fundit, tincturâ differt. Varietas mea $\beta$, quam a $\mathrm{D}^{\text {no. Pigott pluribus }}$ abhinc annis accepi, formâ suâ, crescendique modo quàm maximè notabilis, Fucus majores scandit, et ex animadver-

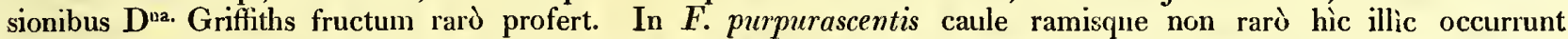
tumores ejusdem, ut videtur, cum iis in $\boldsymbol{F}$. lumbricali observatis naturæ, qui e fructificatione nequaquam pendentes, nec ullo modo cum illâ nexi, ob summam nihilominùs quam habent cum specierum quarundam capsulis tyronibus erroris causæ existunt. Figura his abnormitèr sphærica, magnitudo Vicia sative seminum, color albellus, pallescens, frondis epidermide non teguntur, nec manûs humanæ verrucis facie externâ sunt absimiles. Hunc Fucum præaliis colere amat Conferva Dillwynii confervicoli.

a. Fucus purpurascens, nativâ magnitudine.

b. ramulus, magn. auct. - - $\quad-\quad-\quad-5$.

c. pars ejus paria cum tuberculo - $\quad$ - 3 .

d. semina - $\quad$ - $\quad$ - $\quad$ - $\quad$ - 1 .

e. var. $\beta$ pars - $\quad-\quad-\quad$ - $\quad$ - 5 .

f. fiondis pars cum verrucá, nat. magn.

$\begin{array}{llllll}\text { g. verruca, magn. auct. } & - & - & - & - & 3 . \\ \text { h. eadem dissecta } & - & - & - & - & -\end{array}$ 
Fucus subfusius, frond filiform, much and irregularly branched; ramuli subulate, pinmated, sub-alternate ; capsules axillary; panicled, both lanceolate and spherical.

Fucus subfuscus. Wooow. il Linn. Trans. I. p. 131. t. 12. Linn. Trans. III. p. 212. W1TH. IV. p. 116. Syn. Fuc. II. p. 350. Eng. Bat. XVII. t. 1164. Es Per, Ic. Fuc. II. p. 11. t. 117.

C. confervoides. Fl. Ang. p. 591 .

I. variabilis. Linn. Trans. III. p. 220.

F. setaceus. WuLfe N, Crypt. Aquat. n. 40.?

On the shores of the British Isles, most common about Yarmouth.-Bahus, in Norway. Mr. Wahtenberg.

Perennial February-May.

Root, a solid, expanded, thin, pale-brown disk.

Fionds, numerous from the same base, cylindrical, filiform, six or eight inclies high, preserving throughout a main stem, for the most part undivided, about the thickness of a blackbird's quill, beset from base to summit at short distances with branches sometimes alternate, but more commonly scattered without order, of uncertain length, the lowest generally longest, and four or five inches long, the highest shortest, so that the whole plant has a subfastigiate appearance; these braiches are again clothed in the same manner with smaller ones, and these with a third or fourth series, each more small than the preceding one, all of them constantly patent, giving the plant, especially towards the suminits, a pinnated appearance : the ultimate ramuli are seldom more than two or three lines long, not at all attenuated at the base, subulate, and either simple or pinnated at their apices with a few very minute distichous setæ.

Frucpification of two kinds on different individuals; in either case generally axillary, but sometimes lateral, and principally growing on the smaller branches, composed either of globular or lanceolate capsules, the former containing a few pyriform, the latter about six spherical dark-brown seeds, disposed in two rows; the capsules are panicled, and supported upon a most minute peduncle. To the naked eye, the fruit resembles small specks of a palepink jelly.

CoLOR, reddish-brown, lighter at the extremities, turning black when dried, or exposed long to the air.

SuBSTA NCE, cartilaginous, rather stiff.

The appearance of this Fucus at different seasons of the year are so singularly dissimilar, that it well deserves the name of variabilis given to it in the Linnæan Transactions, nor is it by any means surprizing that it should have been in the same work twice described as two distinct species. In winter, and the early months of spring, the stem and leading branches alone remain, beset with fragments of the others, the snbstance is rigid the color dark-brown, and the apices almost constantly broken off, so that it looks battered, rough, and spinous: in July, August, and September, the color becomes more pale, inclining to red, and sub-diaphanous, the texture is soft, and the whole plant covered with a profusion of young vigorous shoots, terminating in acuminated apices, and not unfrequently throwing out at their extremities tufts of the finest fibres particularly conspicuous in dried specimens. In either case it preserves the pinnated habit for which it is remarkable, and which, as well as its root, color, and smaller size, will distinguish it, even when barren, from $\boldsymbol{F}$. purpurascens. It is liable, like that species, to warts in different parts, unconnected with the fruit, and most probably caused by some insect, but what is singular, is that, in either plant these always preserve their appropriate form, appearance, and color. Some specimens that I have received from the Isle of Wight, have been curiously tipped with small globules, at first sight not unlike the male fruit of a Mnium. 'The ramuli occasionally exhibit faint traces of septa, but this is most uncertain. It was not till very lately that I received through the kindness of Mrs. Griffiths, and since found myself on Yarmouth beach specimens bearing globular capsules, and pyriform seeds, but resembling in every other respect the common appearance of the plant. Something similar had been previously observed in $F$. dentatus, but this was then considered an unique instance. So far, however, from its being so, I am of opinion that it extends to a conssiderable tribe of Fuci, and may hereafter serve to throw new light upon their fructification.

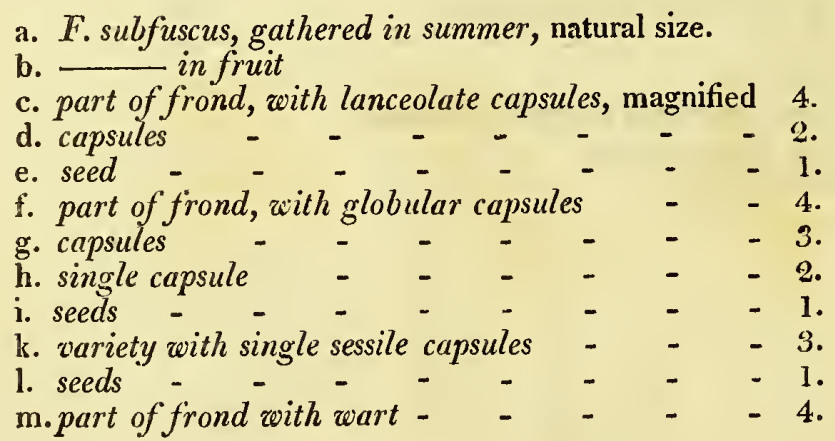

* Dr. Gcolenough and Mr. Woodward have described it as fibious, for which I am unable to account, as I never saw any tendeney to throw out fibres. 


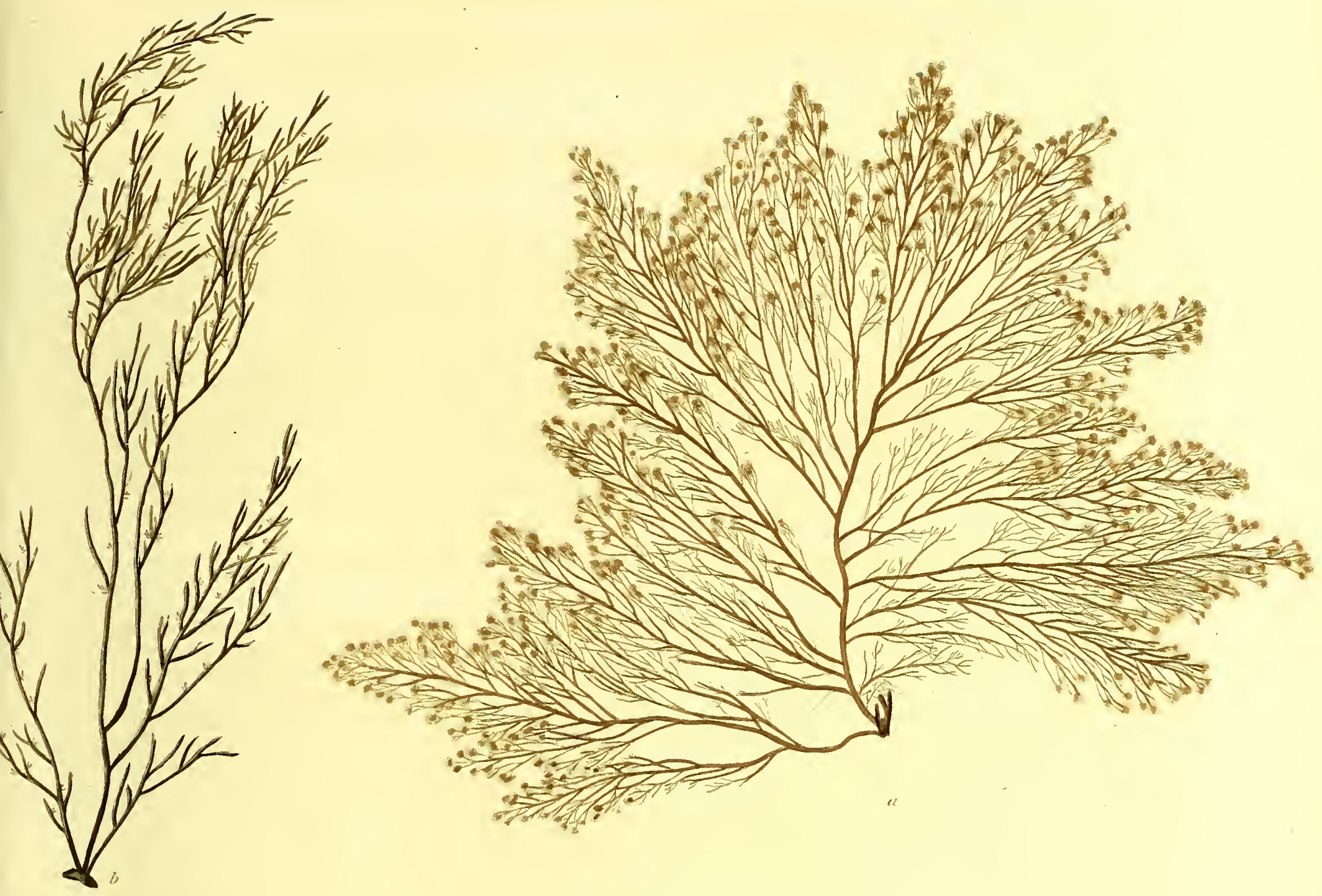

H. 

Fucus fronde filiformi, ramosissinâ; ramulis sub-alternis, subulatis, pinnatis; capsulis arillaribus, paniculatis, lauctolatis spharicisque.

Fucus subfuscus. Woo Dw. in Linn. Trans. I. p. 131. t. 12. Linn. Trans. III. p. 212. WrTH. IV. p. 16. Syn. Fuc. II. p. 350. Eng. Bot. XVII. t. 1164. EsPer, Ic. Fuc. II. p. 11. t. 117.

F. confervoides. Fl. Ang. p. 591 .

F. variabilis. Linn. Trans. III. p. 220.

F. setaceus. Wulfen, Crypt. Aquat. n. 40.

H B B т T in Britaniæe et Hiberniæ oris: circa Yarmouth, copiosissime.-Bahusiæ. D. Wahtenberg.

Perennis. a Feb.-Majum.

RAD1X* solida, e disco constans expanso, tenui, dilutè fusco.

Frondes ex eadem basi plurimæ, cylindraceæ, filiformes, spithameæ vel dodrantales, caule instructæ Merulæ pennæ crassitie, plerunque indiviso, utrinque per totam longitudinem obsesso ramis, vel alternis, vel, ut sæpiùs accidit absque ordine sparsis, longitudinis incertæ, sed infimis ut plurimum longioribus, et $4-5$ pollicaribus, summis brevibus, ita ut tota stirps subfastigiata evadat: rami primarii aliis minoribus hisque iterum tertiâ vel quarta serie utrâque præcedente minore, et omnibus nunquam noll patentibus similiter instructi, unde plantæ præsertim apices versus facies pinnata : ramuli longitudine duas tresve lineas raro superant, nequaquam basi attenuati, subulati, et vel simplices, vel prope extremitates setis aliquot minutissimis distichis pinnati.

Fructificatio duplex in diversis individuis; utraque paniculata, et plerumque axillaris, quandoque tamen lateralis, ramis, presertim minoribus, innascens, e capsulis aliquot constans sphæricis aut lanceolatis, pedunculo perquam brevi communi fultis, his semina pauca pyriformia, illis circiter 6 globosa, duplici serie disposita includentibus. Planta fructifera gelatinæ dilutè roseæ maculis hìc illìc aspersa videtur.

Co con rufo-fuscus, juxta apices pallidior, exsiccate, vel diu aeri objectæ, nigricans.

Súbștant a cartilaginẹ, rigidiuscula.

Facies tam diversas diversis anni tempestatibus hic Fucus induit, ut $F$. variabilis nomen in actis Linnæanis impositum optimo jure mereatur, nec mirum si ab auctoribus quibusdam bis in eodem opere pro distinctis speciebus describatur. Hyeme, et ineunte vere caulis ramique primarii aliorum frustulis obsiti tantummodd supersunt, substantia rigida, color intensè subfuscus, apicesque prope omnes abrupti, unde collisus, rudis, spinosus evadit. Per Julium, Augustum, Septembrem tinctus pallidior, subdiaphanus, magis rufescens, substantia mollis, et tota stirps surculis vegetis, novellis, acuminatis, non rarò terminatis fibrillarum fasciculis, maximè in siccâ conspicuis, germinat. Habitum pinnatum sibi proprium, per quem aquè ac per radicem, colorem, staturamque minorem a $F$. purpurascente vel sterilis dignoscitur, in alterutro statu servat. Illius instar speciei obnoxius est verrucis hìc illic sparsis, nihil cum fructu commune habentibus, sed ab insectorum quorundam marinorum punctis verisimilitèr pendentibus quae nihilominùs, quod mireris, figuram, speciem coloremque certum in utrâque stirpe conservant. Exemplaria quædam ex Insulâ Vectis accepta globulis exiguis, Mnii cujusdem flores masculos primâ facie quodammodo referentibus, sunt terminati. Ramuli septis obsoletis, quod tamen incertum, aliquando distinguuntur. Specinina supra descripta, quorum, capsulæ sphæricæ, semina pyriformia, cæteroquin ab usitatâ plantæ specie nequaquam abludentia, non

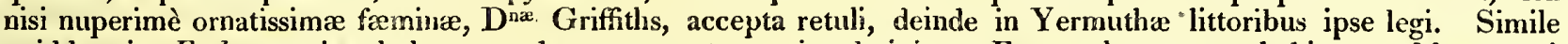
quiddam in $F$. dentato jamdudan est observatum, et pro singulari inter Fucos phænomeno habitum. Magnoperè tamen me mea fallit opinio nisi per magnam Fucorum diffundatur familiam, et forsan fructificationi novam inexpectatamque lucem mox offundet.

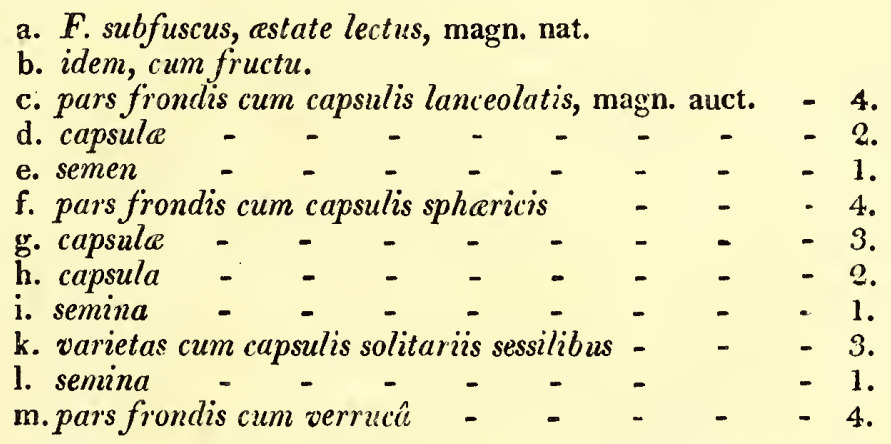

\footnotetext{
* Radicem fibrosam dixerunt D. Goodenough \& Woodward, sed quâ de eausâ nescio, cum adfibras emittendas procliven nunquam viderim.
} 
Fucus pinastroides, frond filiform, much and irregularly branched; branches rolled in at the apices; ramali simple, subulate, tiled on every side, the upper ones growing in pairs, on one side only; capsules pedunculated, both lanceolate and spherical.

Fucus pinastroides. Gmelin, Hist. Fuc. p. 127. t. 1.1. f. 1. Linn. Trans. III. p. 222. Syn. Fuc. II. p. 346. Ner. Brit. p. 74. t. 13. Eng. Bot. XV. t. 104c.

F. incurvus. Fl. Ang. p. 590. Wiтн. IV. p. 115.

C'erumium incurvum. F\%. Fr. Ed. 2da. II. 43.

Pinus maritima, sive Fucus teres, cujus ramuli setis sursùm tendentibus sunt obsiti. RÅ I Syn. p. 50. n. 46 .

On the shores of the southern counties of England, not uncommon.-Coast of Ireland, near Dublin. Dr. Scott.Western coast of France. M. Decandolle.-Mediterranean. Professor Mertens.-New Zealand. Sir Jos. Banks.-Ceylon. Dr. Smith.

Perennial. November-February.

Rоот, in all the specimens which I have seen, a solid, flat, dilated disk; but described in the Linnæean Transactions, in the Nereis Britannica, and in the Flore Française, as fibrous, so that I presume it is liable to variation.

Fon Ds, many from the same base, filiform, about the size of a crow's quill, six or eight inches high, irregularly divided into numerous, long, sub-fastigiate shoots, and these again and again branched in a similar manner, the whole of them, but especially the younger ones, more or less recurved, with their apices rolled in: the plant is naked immediately adjoining the root, but all the rest of it covered with a profusion of subulate, frequently incurved ramuli, niuch more closely imbricated in some specimens than in others, generally about half an inch long, and simple, but occasionally pinnated, and lengthening into new branches, pointing principally to one side, but disposed without order, except in the upper shoots, where they grow regularly in pairs, gradually shortening as they approach the apices, and attached to one side only; in these pairs one is frequently longer than the other: sometimes but very rarely, I have seen three together: the younger branches and ramuli are regularly divided. into extremely short cylindrical joints, visible in the recent piant to the naked eye.

FruIt, of two kinds, each placed upon the upper side of the ramuli; the one consisting of spherical capsules, * supported upon peduncles scarcely half a line long, containing several pyriform seeds, the other consisting of lanceolate pods, about a line long, and slightly incurved, containing a row of irregularly globular seeds; in either case three or four capsules fixed on the sanie ramulus : besides these, I have also received many years ago from $\mathrm{Mr}$. Pigott, and lately from Mr. Borrer, specimens, on which were lying what appear naked spherical seeds unlike those contained in either kind of capsule, and surrounded with a pellucid limbus.

Color, dull red, soon turning black from drying, or exposure to the air, or being kept in fresh water, and never afterwards recovering its proper tint: when the plant grows in so shallow water as to be left on the recess of the tide, the apices are pale green, but turn equally black on drying.

SU BSTANCE, between cartilaginous and woody, flexible, and tough : when dry, hard and brittle.

So long as the present distinction of the two great marine genera, Fucus and Conferva, depending almost wholly upon the jointed or unjointed frond, is allowed to exist, the species now before us must be considered as an highly interesting one, possessing in çommon with Conferva elongata, altogether the structure of the one, and the habit and texture of the other. In point of fructification it seems to be chiefly connected with the Fuci, but I must take this opportunity of declaring that, however the characters of the two genera may have been made by Linæus and other writers, who have trodden in his footsteps, to depend upon the fiuit, yet, that nothing can be more uncertain or fallacious than the marks of discrimination that they luave given, nor any thing more vague and inclefinite than the present distribution of the species. Much indeed has been done by Roth, Vauclier, and Mertens torvards establishing upon philosophical bases the families of the more minute fresh-ivater Conferva, but those more beautiful species which approach to the Fuci, have been in this point of view almost wholly disregarded. Singular as it may appear, it is nevertheless certainly true, that vary young specimens of this plant bear, when dried and pressed, considerable resemblance to those of $F$. cristitus, var, $\gamma$; but the two closest affinities of $F$. pinastroides are undoubtedly $F$. lycopodioides and $F$. subjuscus, from both which its habit is very different, and its mode of growth still more so. There is scarcely any plant invre disguised by drying; its flexible substance then changing to rigid, and its red color to an intense unvaried black. In other points of view it is liable to but little alteration, except that specimens are found, in some of which, the disposition of the ramuli is so crowded as wholly to cover the stem and branches, while in otliers they are loosely scattered at considerable distances. The plant figured by Professor Esper, under the name of $F$. pinastroides, is only a young specimen of $F$. mucronatus, Syn. Fuc. nor does this species seem to be generally known by foreign atihors, though none appears to be a native of more distant seas. "rhe specimen, which, through the kindness of Sir $J$ os. Banks, I have received from New Zealand, and those sent to Lir. Sinith fiom Ceylon, exactiy agree with such as are found upon our shores.

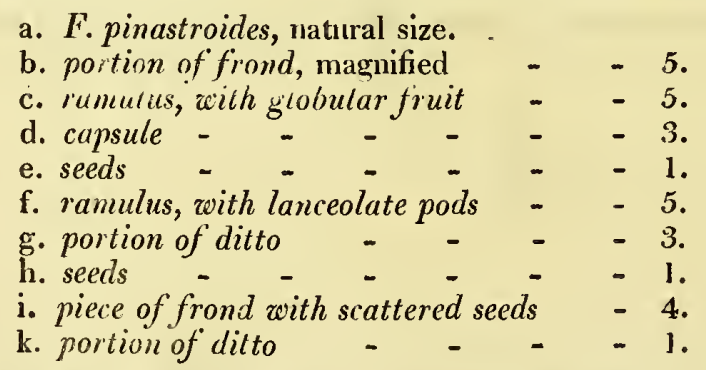

* Mr. Borrer suspects that these capsules a re never in reality pedunculate, but sessile near the ends of very minute shoots, which curl in under them, and afterwards leng then iuto new ramlui. 

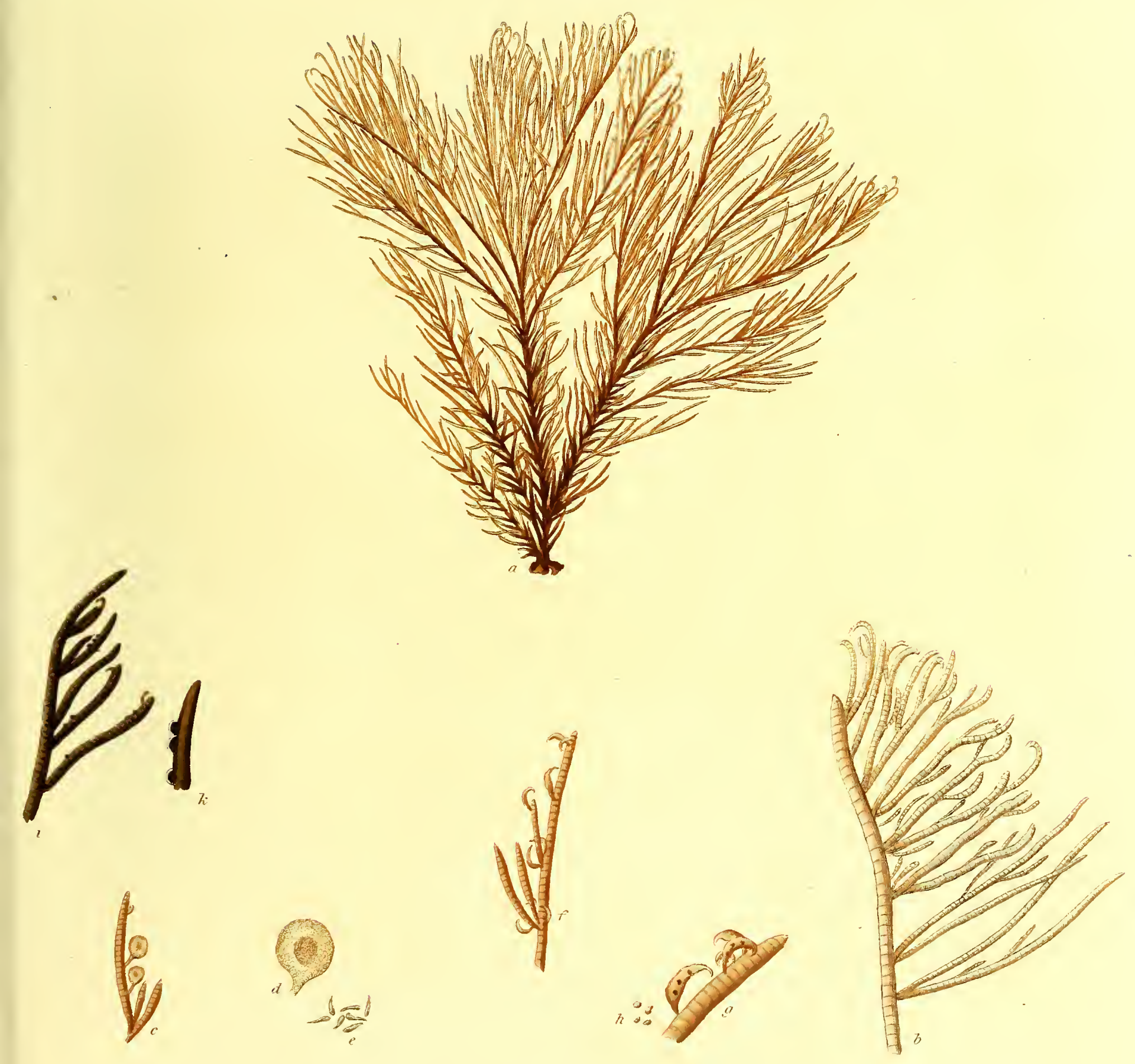

ctucrus fismestionites. 

Fucus fronde hliformi, ramosissimâ; ramis apice involutis; ramulis simplicibus, subulatis undique imbricatis, summis sub-secundis, binis ; capsulis pedunculatis, lanceolatis sphæricisque.

Fucus pinastroides. GMELIN, Hist. Fuc. p. 197. t. 11. f. 1. Linn. Trans. IU. p. 229. Syn. Fuc. II. p. 346. Ner. Brit. p. 74. t. 15. Eng. Bot. XV. t. 1042.

F. incurvus. Fl. Ang. p. 590. Wiтн. IV. p. 115.

Ceramium incurvum. Fl. Fr. Ed. $2 d a$. II. p. 43.

Pinus maritima, sive Fucus teres, cujus ranıuli setis sursum tendentibus sunt obsiti. RaII Syn. p. 50. n. 46.

Ha вітат in Hiberniæ oris, prope Eblanam. D. Scott.-In Galliæ occidentalis oris. Decandolle.-In Mari Mediterraneo. Mertens.-In Novâ Selandiâ D. J. Banks. Bar.--In Zeylonâ. D. Smith.-In meridionalibus Angliæe littoribus, non infrequens.

Perennis. Nov.-Febr.

RADIx, in oinnibus quæ ego vidi exemplaribus, callus solidus, explanatus, expansus; sed, cùm in Societatis Linnæanæ Actis, in Nereide Britannicâ, et in Flộâ Gallicâ pro fibrosâ describatur, mutationi esse obnoxiam conjicio.

FRON DES ex eâdem basi plurimæ, filiformes, pennæ corvinæ crassitie, sex vel octo pollices altæ, ill ramos plurimos, elongatos, subfastigiatos, iterùm atque iterùm similitèr divisos fissæ; rami omnes, præsertìm juniores, plùs minùs recurvi, apicibus involutis: frons ad ipsam basin nuda, cæetera obsita ramulis plurimis, subulatis, sæepius incurvis, nunc densissimè, nunc laxè imbricatis, plerumque circitèr unguem longis et simplicibus, interdùm pinnatis seque in novos ramos protendentibus, unum pracipuè latus spectantibus, sed sine ordine dispositis, excepto quod in ramis summis semper bini et secundi nascantur, superioribus nunquam non brevioribus : in his paribus unus altero quandoque longior : ternos interdùm, sed rarissimè, vidi : rami juniores et ramuli articulis brevissimis cylindraceis nudo oculo in recente conspiciendis distinguuntur.

FrUCtificatio duplex, utraque in ramulorum parte superiore sita: hac e capsulis sphæricis, $*$ pedunculo vix semilineari fultis, semina aliquot pyriformia includentibus; illa e capsulis lanceolatis constans, lineam circitèr longis, lenitèr incurvis, seminum irregularitèr globosorum serie instructis; alterutrarum tres vel quatuor eidem ramulo insident. Prater hos fructificandi modos accepi pluribus abhinc annis a $D^{\text {no }}$ Pigott et nupèr a $D^{\text {no }}$ Borrer hujus $F u c i$ exemplaria, quibus semina, ut sunt visa, sphærica, nuda, iis in utrâvis capsulâ absimilia, et limbo pellucido cinctạ, insidebant.

Colon obscurè ruber; in exsiccatâ, aut diutius æquo in aquâ dulci servatâ, seu luci objectâ, nigerrimus, nec posthàc ullâ arte in pristinum revocandus : frondis aquarum brevibus innascentis apices coloris fiunt æeruginosi, sed et hi etiam exsiccati nigrescunt.

Su BST A N T I cartilagineo-lignea, flexilis, tenax ; exsiccate rigida, fragilis.

Tandiu quam, ut sese res nunc habet, ad Fucos a Confervis distinguendos frons articulata vel non articulata præcipue valebit, $F$. pinastroides, qui una cum Confervấ elongatâ harum structurâ illorum vero indole et habitu gaudet, pro catei:æ utrosque conjungentis summi momenti annulo necessariè est habendus. Quoad fructum maximam cum Fucis affinitatem sibi vindicat, monendus autem hujus loci est Tyro, ut quantumvis characteres his generibus a Limmo et iis vestigia ejus prementibus impositi e fructus pendere videantur, nihil tamen magis eorum indiciis incertun esse vel fallax, nihil specierum, quâ nunc utimur, distributione minus definitum. Ad minutarum aquæe dulci inuascentium Confervarum familias ritè stabiliendas multum Rothius, Vaucherus, Mertensius, et alii elaborârunt, sed species illæ longe pulchriores et Fuci propriores, quasi nullius momenti hactenus sunt ab omnibus fere prætermissæ. Singulare quidem sonat, attamen est verissimum, inter $F$. pinastroidis exemplaria æatate primâ lecta, exsiccata gravitèrque pressata, et $F$. cristati varietatem y similitudinis quiddam intercedere : illæ autem quæ ad lianc nostram proximè accedunt Fucorum species sunt $F$. lycopodioides et $F$. subfuscus, a quibus cùm habitu tùm præesertìn crescendi modo discrepat. Vix ulla exstat planta cujus facies exsiccatione insigniìs mutatur; substantia flexilis tunc in rigidam, color ruber tunc in nigerrimum transit. De çeteris variationi perpaullùm est obnoxia, nisi quod in quibusdam exemplaribus ramuli tam densè imbricati ut caulem ramosque omnino cooperiant disponantur, dum in aliis laxè sparsi nec nisi intervallis satis magnis occurrant. Planta, quam sub $\boldsymbol{F}$. pinastroides nonine depinxit cl. Esperus est tantummodò $F$. mucronatus atate minus provectâ nec, licet per maria quàm longè dissita reperiatur plerumque inter auctores exíeros innotescere hæc species videtur. Exemplar illud quod e novẩ Selandiâ acceptum nobilissimi Jos. Banks Baroneti benevolentiæ debeo, et illa quæ e Zeylonâ accepit cl. Smithius cum iis Britanniæ ad littora repertis omnibus numeris conveniunt.

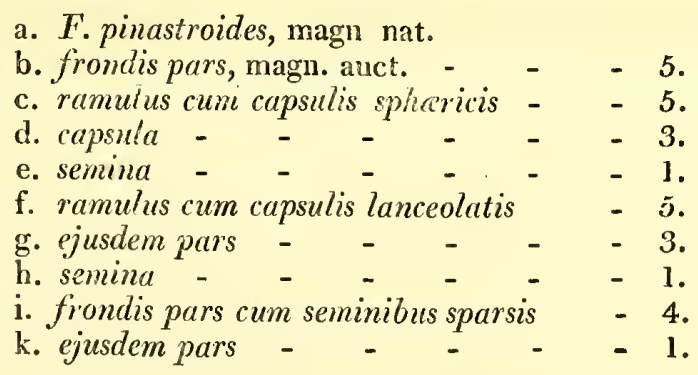

\footnotetext{
${ }^{*}$ Hasce capsulas esse reverà nunquam pedunculatas, sed surculorum brevissimorum, sub is intortorum, et mox in novos ramulos elongan-
} dorum juxta apices sessiles suspicatur Dnus Borrer. 
Fucus lycopodioides, frond filiform, mostly simple, every where covered with closely imbricated, filiform, patent ramuli, generally forked at their apices, and swelling into lanceolate paniculated capsules.

Fucus lycopodioides. LiN.. Syst. Nat. II. p. 717. Syst. Nat. Ed. Gmel. II. p. 1384. Fl. Norv. II. p. 80. Linn. Trans. III. p. 223. Syn. Fuc. II. p. 343. W1тн. IV. p. 107. Eng. Bot. XVII. t. 1163.

F. Lycopodium. Ner. Brit. p. 107. t. 17. (e descript. nec icone.)

Conferza squarrosa. Fl. Dan. t. 357 . Fl. Norv. II. p. 105.

In the North Sea.-At Scarborough. Sir T. Frankland.-Coast of Northumberland. Mr. Winch.-North of Scotland. Mr. Brodie.-Antrim coast. Dr. Scott.-Seas of Finmark and Iceland. Gunner.

Perennial. January-March.

Root, a thin caltous disk.

Frok bs, many from the same base, cylindrical, filiform, about the thickness of a blackbird's quill, from ten to twenty inches high, generally simple to the distance of about an inch from the root, and then divided into a few long sub-fastigiate branches, for the most part wholly simple, but sometimes furuished with one or two very short ones; the stem near the base is naked, but all the branches, except at the very lowest part, are entirely covered with closely imbricated ramuli * scarcely thicker than hog's bristles, either patent, or between erect and patent, about half an inch long, quite filiform, disposed equally on every side, and pointing in every direction, frequently forked at the apices, and occasionally pinnated with a series of others very minute.

Fructification, terminal in the ramuli, which are at that time almost as thin as human hair, and of a pale reddish brown color, elongated and pinnated, as if extending into a profusion of young shoots, and giving the plant quite a different appearance, their apices swelling into lanceolate siliquæ, each containing three or four black irregularly globular seeds.

CoLor, a dark reddish brown in the ramuli; in the stem, a dull, livid, semitransparent brown; when dried intensely black.

SU BSTA NCE, cartilaginous; flexible, white, moist, but rigid, and brittle after it is dried.

It is only four years ago that scarcely a single specimen of this Fucts, which had been certainly found upon the shores of Britain, was known to exist, but since that time, its claim to a place in our Flora has been established beyond a doubt, and lately by the zeal of $\mathrm{Mr}$. Brodie, whose kind assistance and activity in the pursuit of marine Botany, in the course of this work, I shall have constant occasions to acknowledge, it has been gathered in considerable abundance upon the northern coast of Scotland, and the fructification has also been detected. In this last particular, it bears, as might be expected, a considerable resemblance to $F$. subfuscus, and from its affinity to that plant and $F$. pinastroides, it appears to me most probable, that at some future time it will be discovered also to produce like them seeds in globular capsules. Its habit in water is peculiarly feathery and elegant, and in this respect as well as in the disposition of the ramuli which are on all sides equally imbricated, in their want of joints, and in their uniform size from top to bottom, it essentially differs from $F$. pinastroides, to which it is considered by most Botanists as more nearly related than is by any means really the case. It seems to be generally parasitic upon the stems of F. dig tatus, and the larger species. In its habit, it approaches considerably the tribe of verticillate Conferva, but still more so to the Fucus figured by Mr. Stackhouse under the name of F. Lycopodium, which is in reality a very different species, and a native of the Red Sea, whence I lately received it by the kindness of Lord Valentia. It is this latter that Mr. Woodward has preserved in his Herbarium, as gathered on the Norfolk coast, but I should rather apprehend that he was in this respect in error.

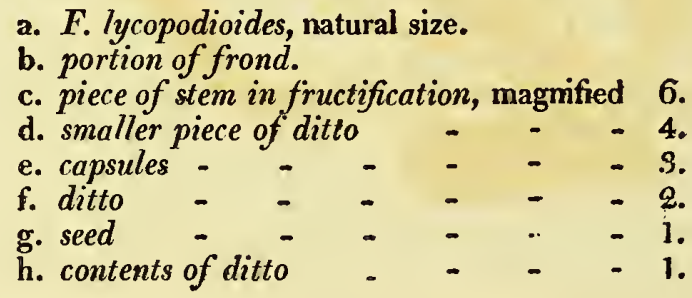

\footnotetext{
- In the Synopsis of the British Fuci $\mathbf{I}$ have described these ramuli as jointed, which is quite erroneons, asd $I$ am at a loss to conceive how $\mathbf{I}$
} fell into such a nistake. 

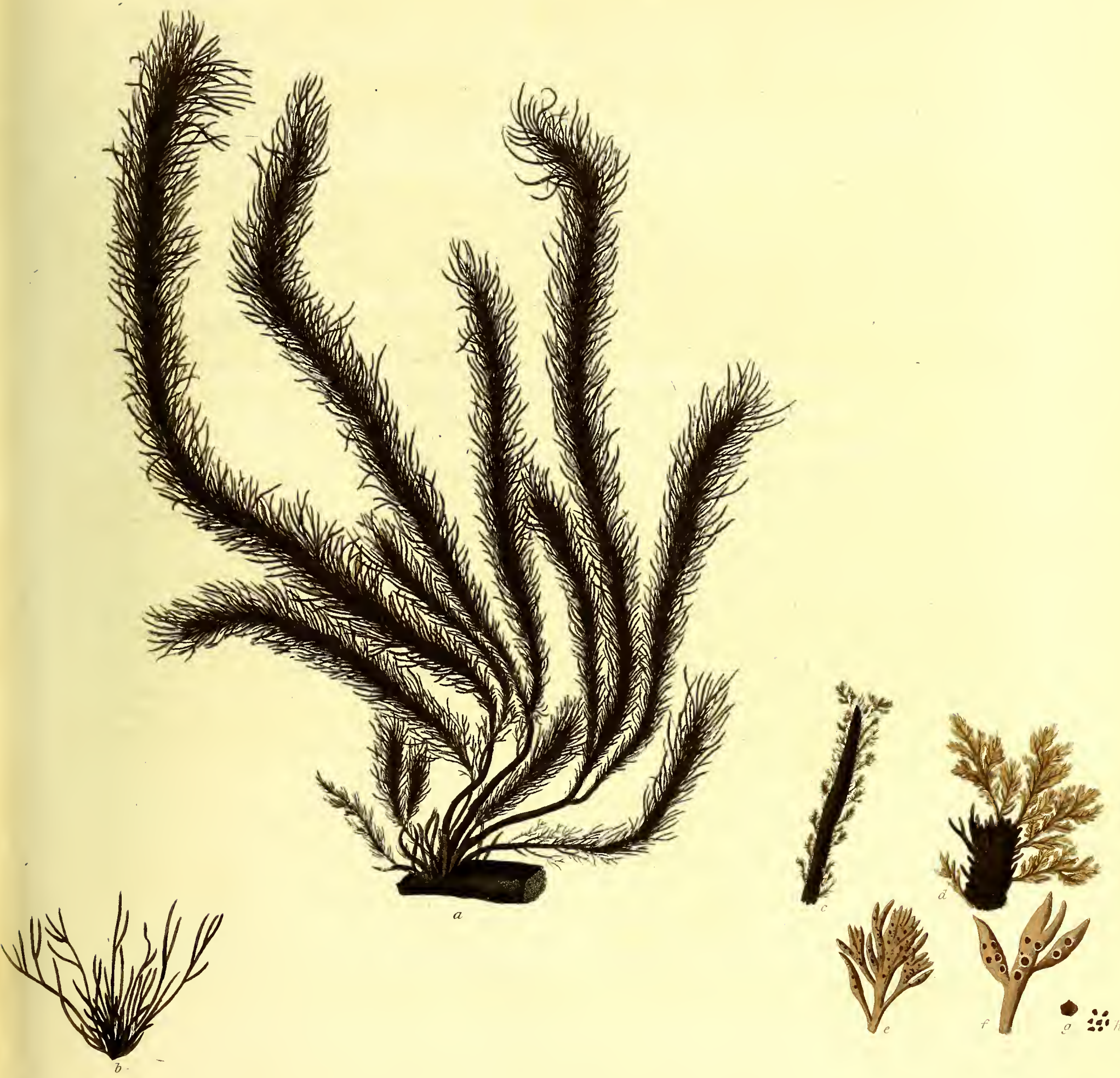

Fucus fronde filiformi, simpliciusculâ; ramulis filiformibus, undique et ubique densè imbricatis, patentibus, in capsulas lanceolatas paniculatas intumescentibus.

Fucus lycopodioides. Linn. Syst. Nat. II. p. 717. Syst. Nat. Ed. Gmel. II. p. 1384. F7. Norv. II. p. 80. Linn. Trans. III. p. 223. Syn. Fuc. II. p. 343. Wiтн. IV. p. 107. Eng. Bot. XVII. t. 1163.

F. Lycopodium. Ner. Brit. p. 107. t. 17. (e descript. nec icone.)

Conferva squarrosa. Fl. Dan. t. 357. Fl. Norv. II. p. 105.

Habitat in Oceano Septentrionali.-Apud Scarborough. D. T. Frankland, Baronet.-In Northumbriæ oris. D. Winch.-In Scotix Septentrionalis oris. D. Brodie.-Ad Antrimi littora. D. Scott.-In Finmarkii et Islandici maris rupibus. Gunner.

Perennis. Jan.-Mart.

RADIX discus callosus, expansus, tenuis.

FroNDEs ex eâdem basi plurimæ, cylindraceæ, filiformes, pennæ Merula crassitie, dodrantales vel cubitales, plerumque simplices donec pollicis a radice unius altitudinem attigerint, atque ibidem in ramos aliquot elongatos, fastigiatos, ut plurimum simplicissimos, sed interdum ramo uno atque altero brevissimo instructos divisæ: frons ad ipsam basin nuda, inde tota cooperta* ramulis densè imbricatis, setâ porcinâ vix crassioribus, patentibus, vel erectopatentibus, unguem circitèr longis, examussim filiformibus, utrinque ex æquo dispositis, et quoquoversùm spectantibus, sæpiùs apice bifurcis, et interdùm aliis minutis pinnatis.

Fructificatio terminalis in ramulis, qui tunc temporis capillo vix crassiores, coloris dilutè rufo-fusci, elongati, et piunati, quasi in novos surculos abituri, evadunt, unde toti plantæ facies mutatur: horum apices in capsulas lanceolatas, singulas semina tria vel quatuor nigra sub-globosa includentes, turgescunt.

CoLor obscurè rufo-fuscus, in caule lividus, et subdiaphanus, exsiccata nigerrimus.

Substanta cartilaginea, madentis flexilis, exsiccate rigida et fragilis.

Cùm Fucorum Britannicorum Synopsin quatuor modò abhinc annis scriberem, vix unum hujus Fuci exemplar Britanniæ ad oras certè lectum innotuit, nec an ritè Fucis Britannicis annumeretur inter Botanicos constitit : talés autem tempus insequens exemit scrupulos, et nuperrimè per amicissimi $D^{\text {ni }}$ Brodie studium, qui cùm algis marinis investigandis, tùm præesertim huic libro adjuvando maximam operam navavit, in Scotiâ septentrionali copiosè est lectus, et fructificatio omnibus antehàc incognita latere desiit. Fructus, ut e stirpis indole suspicari licuerit, ab eo F. subfusci non multùm recedit, nec forsan nimis auderem, si ex affinitate quam habet $\boldsymbol{F}$. lycopodioides cum hâc specie et $\boldsymbol{F}$. pinastroide capsulas sphæricas quoque ferre conjicerem. Sub aquâ observati häbitus elegans est et plumosus, per quod, non minùs quàm per ramulorum exactè cylindraceorum, articulis expertium, et undique ex æquo dispositorum, naturam, se a $F$. pinastroide dignoscendum præstat. Nec est quidem inter has species similitudo tàm arcta quàm Botanici plurimi autumant. Fucorum majorum stipitibus plerumque parasiticè innasci traditur. Ad Confervarum verticillatarum familiam habitu accedit, longè tamen propiùs ad illam Fuci speciem quam sub $F$. Lycopodii nomine depinxit Stackhousius, quæ tamen est ab hâc nostrâ reverà distinctissima, et maris Erythræi, unde per nobilissimi Vicecomitis de Valentia liberalitatem nupèr accepi incola. Hæc est eadem cujus exemplar in Phytophylacio suo sub " $F$. lycopodioidis Norfolciæ ad oras lecti" nomine servat D. Woodward, sed esse e longinquo aliquo mari deportatum, talique per errorem titulo insignitum, nequeo non suspicari.

a. F. lycopodioides, nat. magn.

b. frondis portio.

c. frondis portio fructifera, magn. auct. - 6 .

d. ejusden pars minor - $\quad$ - $\quad$ - 4 .

e. capsula - - - - - $\quad 3$.

f. eadem - - - - - - - 2 .

g. semen - - - - - - - 1 .

h. granula in semine contenta - $\quad-\quad 1$.

* In Fucorum Britannicorum Synopsi hos ramulos articulatos dixi, quod a vero prorsis abhor rere videtur, nec quomodo in talem errorem inciderim mente nunc capio.

Vox. I. 
Fucus dentatus, frond flat, membranaceous,- branched, aiternately pinnatifid; ramuli alternate, linear, sharply toothed at the apices ; capsules pedunculate, panicled, axillary, lanceolate and urceolate.

Fucus dentatus. Linn. Syst. Nat. II. p. 718. Syst. Nat. Ed. Gmel. II. p. 1383. Linn. Mant. p. 135. Fl. Ang. p. 582. F\%. Scot. II. p. 952. WrTH. IV. p. 102. F\%. Norv. II. p. 91. Linn. Trans. III. p. 158. Syn. Fuc. I. p. 149. Ner. Brit. p. 95. t. 15. Eng. Bot. XVIII. t. 1241.

F. pinnatifidus. Fl. Dan. t. 354. (excl. Syn. Huds.)

F. atomarius. GMEL.1 N, Hist. Fuc. p. 12j. t. 10. f. I.

F. membranaceus rubens, foliolis latiusculis, ad extremitates dentatis. Moris. Hist. Ox. III. p. 646. s. 15. t. S. f. 5 .

On the coasts of Northumberland, Scotland, and Ireland.-In the Atlantic Ocean. Linnaus.-North Sea, near Iceland. Oeder.-Shores of America. Gmelin.

\section{Perennial. February-April.}

Roor, a small, callous, somewhat conical disk.

Fro N D, in general solitary, from five inches to a foot high, compressed, and scarcely more than half a line wide immediately adjoining the base, in all its other parts flat, and preserving tlroughout a width of about two lines; divided by a few dichotomies which begin very near the root ; the primary branches long, of almost equal height, and irregularly beset with others more short, patent, and distichous, which are again frequently furnished with a series of still smaller ones, all of them pinnatifid throughout their whole length with alternate ramuli, placed at very short distances, generally about half a nail long, but shortening as they approach the summits, their margins for the most part quite entire, though sometimes again pinnatifid, as if they were lengthening into new branches, their apices always cleft with three or four very short acuminated segments: the sinuses of the ramuli bluntish.

Fi UCTIFICATI O N, of two kinds; the one consisting of small lineari-lanceolate capsules, either growing solitary, like cilia, along the margin of the frond, or collected into panicles supported upon an extremely short peduncle, and placed at the alæ of the ramuli, containing several roundish seeds disposed in a single or double row; the other composed of pedunculate capsules of an urceolate form, with open orifice, growing in axillary clusters, and furnished with a few pyriform seeds.

Color, a dark brownish red, deeper in the centre of the frond; pale pink in the very young shoots, and blackish wear the base.

SuBSTANCE, thin and membranaceous, but with a tendency to coriaceous; rigid and rather thick near the base, an the young shoots extremely tender.

Between the Fuci provided with a flat veinless frond, and those furnished with a midrib, the present species may be regarded as an intermediate link, nor is it in my opinion by any means clear, though it has been by all authors classed with the former, that it has not an equal pretension to a place among those of the latter division. The frond, especially if held to a strong light, evidently appears to be furnished in its centre with a wide line thicker and darker than the rest, agreeing in this respect with $F$. rubens, a plant with which it has scarcely any other point in common, except the singular substance that is peculiar to both of them. The-fructification, after remaining . very long undetected, was discovered only a very few years ago by Mr. Brown, a botanist of singular acuteness, but for my specimens, I am indebted to Mr. Brodie, who has found it in plenty, and who first observed the solitary capsules arranged along the margins. It appears probable that these capsules are occasionally, perhaps not unfrequently, barren, and that this may be the origin of that ciliated appearance of the plant, already noticed in the Linnæan Transactions, and the Synopsis of the British Fuci. The fruit of $F$. dentatus differs from that of $F$. subfuscus, and the other species that are furnished with a similar twofold fructification, in the circumstance of the capsules which contain the pyriform seeds, being urceolate instead of spherical, and provided in all stages of their growth, as far as I lave seen, with a wide open orifice. It appears particularly deserving of remark, that the seeds in the lineari-lanceolate capsules are in their early state very small, and disposed in tivo rows separated by a longitutinal line, but that this line vanishes as they grow older, and each seed becomes joined into one with that which lies opposite to it. Gmelin's $F$. atomarius was long ago referred to this species in the Systema Plantarum, and coincides very well as to the description, but by no means so as to the plate. I have nevertheless here quoted it, yet not without some doubt, as he received his specimen from America, and lays a particular stress upon the frond being every where covered with dots, which must have arisen from chance, or we must allow that he intended some other species which may probably agree better with his figure.

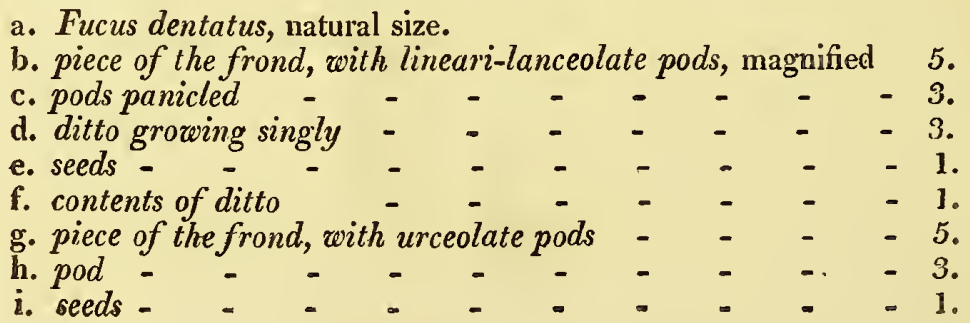



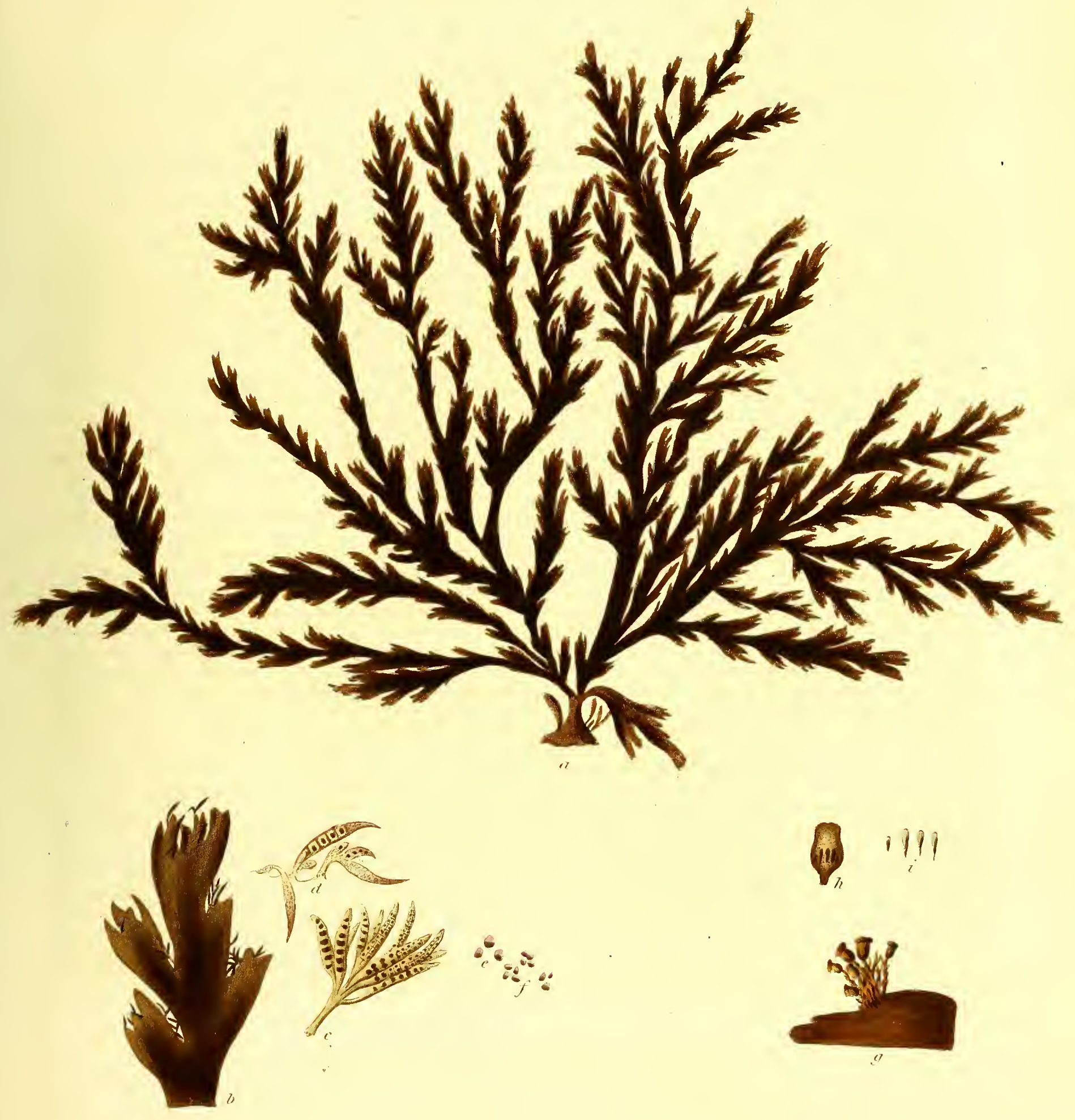

Q. 
Fucus, fronde planâ, membranaceâ, ramosâ, alternatìm pinnatifidâ ; ramulis alternis, linearibus, apice incisis, lacinulis acutis ; capsulis pedunculatis, axillaribus, lanceolatis, urceolatisque.

Fucus dentatus. Linn. Syst. Nat. II. p. 718. Syst. Nat. Ed. Gmel. II. p. 1383. Linn. Mant. p. 135. Fl. Ang. p. 582. Fl. Scot. II. p. 952. W1тн. IV. p. 102. Fl. Norv. II. p. 91. Linn. Trans. III. p. 158. Syn. Fuc. I. p. 149. Ner. Brit. p. 95. t. 15. Eng. Bot. XVIII. t. 1241.

F. pinnatifidus. Fl. Dan. t. 354. (excl. Syn. Huds.)

F. atomarius. GMELIN, Hist. Fuc. p. 125. t. 10. f. 1.

F. membranaceus rubens, foliolis latiusculis, ad extremitates dentatis. Moris. Hist. Ox. III. p. 646. s. 15. t. 8. f. 5 .

Haвıтат in Northumbriæ, Scotiæ, et Hiberniæ oris.-In Oceano Atlantico. Linnaus.-In Mari 1slandico. Oeder.-Ad Americæ littora. Gmelin.

Perennis. Febr.-Apr.

RA Dix callus parvus, expansus, sub-conicus.

Frons plerumque solitaria, spithamæa, vel etiam pedalis, juxta basin compressa, ibique vix semilineam lata, cæetera plana, duarum circitèr linearum latitudine, et ubique ad apices usque æqualis, dichotomïs aliquot sub ipso ortu incipientibus ramosa; rami primarii elongati, subfastigiati, aliis brevioribus distichis patentibus vagè obsiti, qui Interdùm serie minorum tertiâ similitèr sunt instructi ; rami omnes per totam longitudinem pinnatifidi ramulis alternis, approximatis, sub-semiunguicularibus, iis summitates versus brevissimis, margine plerumque integerrimis, quandoque tamen iterum pinnatifidis, quasi in novos ramos sint abituri, apicibus semper incisis, lacinulis tribus vel quatuor, brevibus, acuminatis : ramulorum sinus obtusiusculi.

Fructificatio duplex: una e capsulis constans exiguis, lineari-lanceolatis, nunc solitariis frondis margini, ciliorum instar, innascentibus, nunc in paniculas pedunculo perbrevi fultas, et ramulorum ad sinus dispositas congestis, semina plurima subrotunda serie simplice vel duplici ordinata includentibus; altera capsulæ urceolatæ, pedunculatæ, samulorum ad sinus conglomeratìm collocatæ, ore aperto, seminibus intùs pyriformibus instructæ.

Color e fusco obscurè ruber, in surculis tantummodo jam primùm ortis roseus; ramorum in medio intensior; prope basin nigricans.

Su BSTANTIA tenuis, membranacea, ad coriaceam tamen accedens, prope basin rigida et crassiuscula, in surculis junioribus tenerrima.

Fucorum familiam fronde planâ aveniâ præditorum, cum illis fronde costatâ instructis hæc species connectit, quæ, licet a cunctis auctoribus inter illos censeatur, æquo tamen jure his annumerandus mihi videtur; cùm totius plantæ, præsertim si lucernæ objiciatur, partem mediam linea lata incrassata nudo oculo conspicienda percurrat. Consentit in hoc cum $F$. rubente, stirpe cæteroquin absimillimâ, nisi quod substantiâ, in utrâque singulari, eâdem propemodùm gaudeant. Fructificationem diù incognitam primus paucis modo abhinc annis detexit vir acutissimus $\mathbf{D}$. Brown; specimina autem mea benevolentiæ debeo $\mathbf{D}^{\text {ni }}$ Brodie, qui copiosè legit, et capsulas solitarias margini innascentes non antehàc visas patefecit. Capsulas hasce steriles quandoque evadere, et hìnc ciliatam illam plantæ faciem jamdudùm in Societatis Linnæanæ Actis et in Fucorum Britannicorum Synopsi memoratan pendere, verisimile videtur. $F$. dentati fructus ab eo $\boldsymbol{F}$. subfusci et reliquorum fructificatione duplici præditorum in hoc discrepat, quod capsulæ quæ semina pyriformia includunt non, ut in illis, globosæ, sed urceolatæ, ore semper, quantum vidi, lato et aperto instructæ evadant. Notatu quoque est dignissimum, semina in capsulis lineari-lanceolatis reperta principio esse parva, et duplici serie lineâ longitudinali distinctâ disponi, hanc autem lineam in adultioribus sensìm evanescere, et singula semina cum iis sibi invicem oppositis in unum coalescere. Fucum Gmelini atomarium jampridèm in Systemate Plantarum sub hâc specie citatum, et perperàm quoad iconem sed bene quoad descriptionenı cum $F$. dentato convenienteln hutc retuli, nec tamen pro synonymo indubio habeo; ex Americâ enim accepit Gmelinus, et " universam plantæ superficiem punctis sive atomis creberrimis obsitam" dicit, quod nisi casu evenisse credamus, aliam Fuci speciem hoc nomine esse desiguatam satis mili constare videtur.

a. Fucus dentatus, nat. magn.
b. pars frondis, cum capsulis lineari-lanceolatis, magn. auct.
c. capsula ha paniculatce
d. alia singulatim disposite -
e. semina -


Fucus Hypoglsssum, stem branched, winged; leaves between linear and lanceolate, flat, undivided, entire, reticulated, proliferous from the midrib; spherical capsules on the midrib, and scattered seeds on the leaf.

Fucus Hypoglossum. Woodw. in Linn. Trans. 11. p. 30. t. 7. Liun. Trans. III. p. 113. WITH. IV. p.95. Fing. Bot. XX. t. 1396. Syn. Fuc. I. p. 17. EsPer, Ic. Fuc. II. p. 17. t. 120. (nalè.)

Vlva lingulata. Fl. Fr. Ed. $2 d a$. II. p. 14.

B. minor; leaves extrenely narrow.

F. Hypoglossum. B. Syn. Fuc. I. p. 17.

I'. hypoglossoides, Ner. Brit. p. 76. t. 13.

Hypoglossum. r. Syn. Fuc. I. p. 17.

$\%$ incrassutus; narrow linear leaves, scarcely visibly reticulated.

a on the shores of England, Ireland, and France.- $\beta$ in Devonshire, Cornwall, and Anglesea.- $\gamma$ at Torquay. Mrs. Griffiths.

Annual. June-September.

RooT, a very minute callus.

FRONDS, lumerous, two or three inches long, rising at first with a single undivided leaf, in general almost linear; occasionally approaching to lanceolate, about two lines wide, furnished with a cylindrical filiform midrib, scarcely thicker than thread at the base, and soon becoming faint, so that it is quite obsolete towards the apices, out of which, at uncertain distances throughout its whole length, issue other leaves, similar to the primary one in every respect, except their smaller size, the lowest constantly longest, and thence gradually shortening, producing in the same manner a series of still smaller ones, the youngest always lanceolate; towards the base of the frond the foliaceous membrane is generally worn away, leaving the midrib naked, and thus giving the plant the appearance of being naturally provided with a stem : the leaves are constantly undivided, and quite flat, except that the margins, which are always entire, are sometimes beautifully crisped with minute undulations : the apices are more or less acute.

Fructification, of two kinds, in different individuals; the one consisting of spherical capsules, smaller than turnip seed, sessile on the midrib, especially towards the ends of the younger leaves, often four or five on each; of a deep red color, full of sub-globose seeds, surrounded with a pellucid limbus; the other of very minute naked seeds, irregular both as to shape and size, lying- on the leaf on each side of the midrib in small patches of a lanceolate form, the part of the frond on which they lie being apparently thicker than the rest.

Color, of the leaf, a most beautiful transparent pale pink, of the midrib, darker.

SUBSTANCE, membranaceous, extremely thin and delicate, under a microscope elegantly reticulated.

- $\beta$ differs in its habit which is more clustered : has its leaves scarcely more than half a line wide, in general not more than a nail long, and inclining to lanceolate, but sometimes much longer and quite linear.

$\gamma$ is also much smaller than $a$; its leaves very narrow and linear, but its strongest character is the darker color inclining to scarlet, and the substance so much thicker than in the other varieties that no reticulations are visible.

The two different appearances of this plant described in the Synopsis of the British Fuci, I have here upon a comparison of a greater number of individuals thought it best to unite, but 1 lately received from Mrs. Griffiths somé specimens so very unlike any others which I had previously seen, that I have still found myself under the necessity of separating it into three varieties. In the two first of these the frond is most strikingly reticulated, appearing when viewed with a common magnitier to be every where composed of net-work, forming irregularly hexagonal meshes, and bearing some resemblance to the Hydrodictyon of Roth, or the Ulva stellata of Wulfen. That Mr. Stackhouse finding this reticulated structure unnoticed by preceding authors, should have been led from it to regard his $F$. hypoglossoides as a distinct species, cannot be inatter of wonder; but as the same is now known to be equally observable in the more common appearances of the plant, no doubt as to their identity can any longer exist. * 'The undivided frond, entire at the margins, proliferous from the midrib, and destitute of any lateral nerves or veins sufficiently distinguish this Fucus from its congeners. With regard to its fruit some short observations will be found under the following species. M. Decandolle; who seems to be acquainted with $F$. Iypoglossum only with scattered seeds, and with $F$. ruscifolius only with capsules, has been led from this circumstance to refer them to different genera, and has erred in his application of the names; his description, however, of both is so accurate that there can be no doubt as to his synonyms.

a. Fucus Iypoglossum, natural size.
b. leaf with scattered seeds.
c. part of ditto, magnified -
d. seeds -
e. leaf with capsule, natural size.
f. summit of ditto, magnified
g. seeds -

* It ought to be noticed that the apex of the frond is occasioually, but very rarely, forked, as sometimes appears in Scolopendriun vilgure, sut this seems merely the effect of injury 

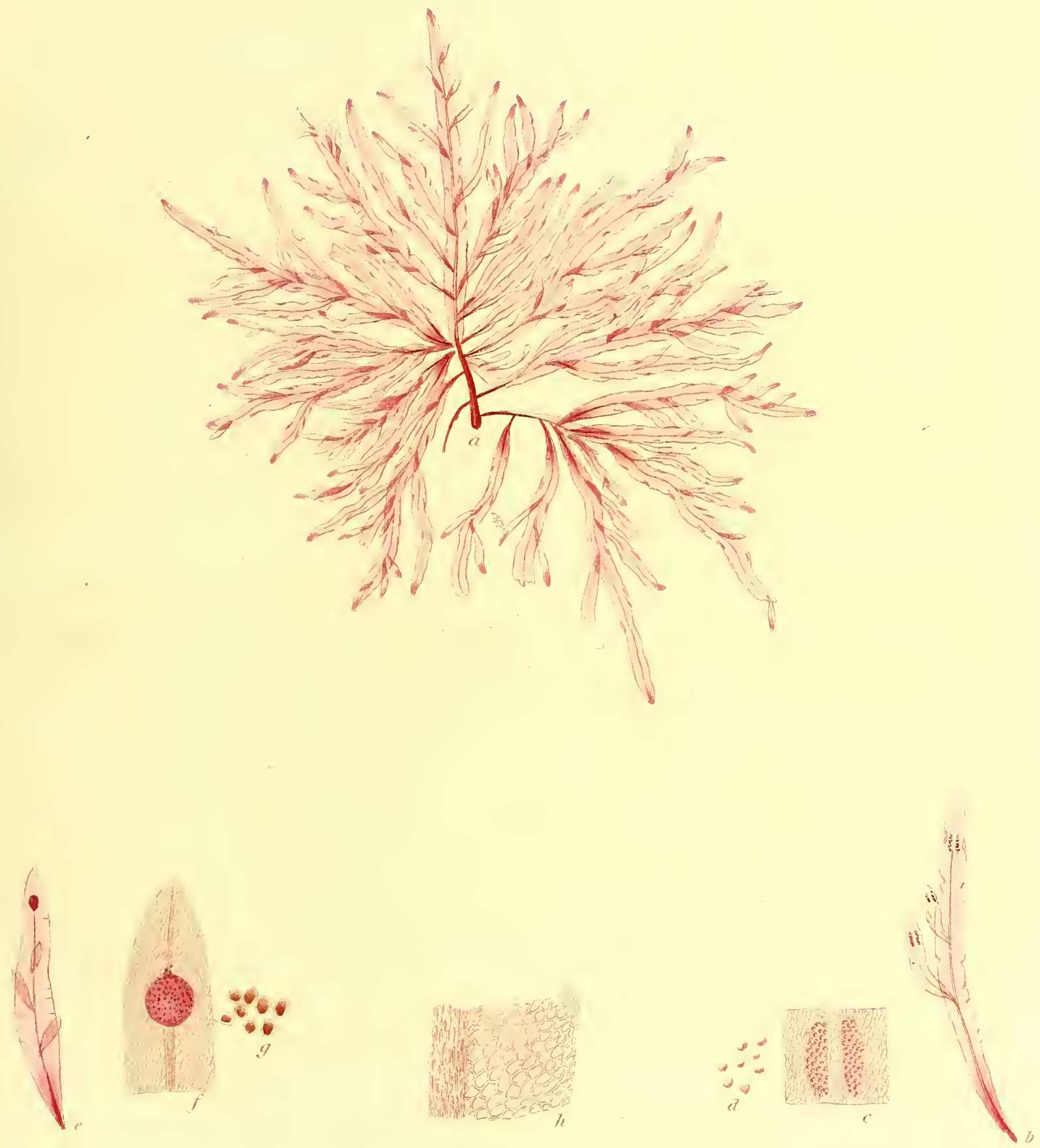

Fucus caule ramoso, alato ; foliis lineari-lanceolatis, planis, simplicibus, integerrimis. reticulatis, e costâ proliferis ; capsulis in costâ splıæricis, seminibusque in follo sparsis.

Fucus Hypoglossum. Woodw. in Linn. Trans. If. p. 30. t. 7. Linm. Trans. III. p. 113. WIт. IV. p. 95. Eng. Bot. XX. t. 1396. Syn. F'tc.. I. p. 17. ESPEn, IC. Fu. I1. p. 17. t. 120. (malè.)

Ulva lingulata. Fl. Fr. Ed. 2da. I. p. 14.

$\beta$ minor ; foliis angustissimis.

F. Hypoglossum. \& Syn. Fuc. I. p. 17.

F. hypoglossoides. Ner. Brit. p. 76. t. 13.

F. Hypoglossum. r. Syn. Fuc. I. p. 17.

${ }_{\gamma}$ incrassatus; foliis angustis lineari-lanceolatis, vix evidentìr reticulatis. "

Ha Bıт a in Angliæ, Hiberniæ, et Galliæ oris. $-\beta$ in Devoniâ, Cornubiâ, et Insula Monâ.- $\gamma$ apud Torquay in Devoniâ. $D^{\text {na }}$ Griffiths.

Annua. Jun.-Sept.

RADIX callus perquam minutus.

FroN DEs ex eâdem basi plurimæ, bi-tri-pollicares, folio assurgentes primùm unico simplicissimo, figuræ plerumque linearis, interdùm ad lanceolatam accedentis, duas circitèr lineas lato, costâ instructo cylindraceâ filiformi, vix filo tenuissimo ad ipsam basin crassiore, citdque deficiente, ut apices versus prorsùs evanescat : intervallis incertis per totam longitudinem ex hâc oriuntur folia alia, primarii, staturâ minore demptâ, omnind similia, infèriora semper longissima, et quo magis ad apices appropinquant eo breviora, omnia minorum seriem simili modo edentia, júniora numquam non lancèolata: membrana foliacea frondis.basin versus sæpiùs atteritur, unde costa denudata caulis speciem præbet: folia omni ætatis stadio indivisa sunt et plana, nisi quodd margines, semper integerrimi, aliquando minutissimè undılati et crispatuli evadant: apices plus minus acuti.

Fructificatio duplex: hac e capsulis constans sphæricis, intensè rubris, papaveris semine ninoribus, in costa, præsertìm foliorum juniorum apices versus sessilibus, seminibus sub-globosis limbo pellucido cinctis refertis; illa $\mathrm{e}$ seminibus constans nudis, minutissimis, neque figuræ neque magnitudinis certæ, folii superficiei impositis, in maculas exiguas. lanceolatas costâ percursas congestis: eầ quibus insident frondis parte incrassatâ.

Co Lo R folii amœenissimus, dilutè roseus, diaphanus; coste intensior.

SuBsTA NTI A membranacea, tenuissima, et tenerrima; sub lente pulchrè reticulata.

Varietas $\beta$ habitu magis conferto discrepat, et folia habet vix plus quam semilineam lata, sæpissimè circitèr unguem longa et lanceolata, interdum elongata et prorsùs linearia.

Varietas $\gamma$ quoque minor quàm $\alpha$; folia perangusta et linearia : in hoc autem pracipuè a præceảentibus differt, quòd color intensior ad coccineum accedat, et substantia tantum sit incrassata ut structura reticulata penitùs lateat.

Duas illas perpulchre lujus speciei varietates in Fucorum Britannicorum Synopsi descriptas, hìc in unam,' plưibus comparatis exemplaribus reque accuratiùs perpensâ, reduxi: nuperrimè autem a $\mathbf{D}^{\text {:a }}$ Griffitlis speciminä aliqnot tantùm reliquis absimilia accepi, ut tertian vel nunc varietatem describere necesse habeam. Indole suâ hæc. a præcedentibus insignitèr differt, quarum structura reticulata, maculis abnonitèr hexagonis distincta, adeo usque conspicua apparet, ut, vel sub lente mediocri observata, Hydrodictyi Rothiani aut Ulve stellatce Wulf. similitudinis. aliquid præ se ferant. Reticulatanı hanc faciem ab omnibus autehàc prætermissanı Stackhousio maximè notabilem, esse visam, et quæ ad Fucum suum hypoglossoidem pro distinctâ specie stabiliendun sutliceret quis mirabitur? * Cum autenı iu eâ etiam quæ creberrimè occurrit plantæe formâ non minùs evidentèr posse conspici observationes nuperæ edocueriut, rite esse conjungendos nullus dubito. Frous integerrima, e costâ proliêera, et nervorum vel. venarum lateralitèr excurrentium absentia hanc plantam satis a congeneribus distiıguunt. De fructu sub insequente. specie paucis erit disserendum. $F$. Hypoglosstum tantunmodd seminibus sparsis preditum, contıà autem $F$. ruscifolium non nisi capsulis splıæricis instructum, reperisse videtur cl. Decandolle, qui e:m ob causam ad diversa genera. relegavit, descriptione tamen utriusque accuratissimâ adjuinctâ, unde de synonymis nulla dubitatio.
a. F. Hypoglossum, magn. nat.
b. folium cum seminibus sparsis.
c. ejusdem pars, magn. auct. - - $\quad 3$.
d. semina - - - - - - 1 .
e. fólium cum capsulâ, magn. nat.
f. ejusdem apex, nnagn. auct. - - S.
g. semina - - - - - - 1 .
h. parsfrondis - - - - 1 .

\footnotetext{
* Memorari debet frondis apicem quandoque, sed rarissimè, codem modo qui in Scolopendrio villgari nonnunquan aecidit, bifurcan occurrere, sed hoe ex injuriâ pendere pro ccrto labeo.
} 
Fucus ruscifotius, stem branched, winged; leaves widely oblong, obtuse, flat, undivided, entire, proliferous from the midrib, marked with pellucid, jointed veins; spherical capsules sessile on the midrib, and scattered seeds on the leaf.

Fucus ruscifolits. Tunner, in Linn. Trans. VI. p. 127. t. 8. f. 1. Syn. Fuc. I. p. 11. Eng. Bot. XX. t. 1395.

F. Hypoglossun. Fl. Fr. Ed. 2da. II. p. 27. (excl. Syn. omn.)

ß. minor; with ovato-lanceolate leaves, about a nail long.

F. ruscifolius. B. Syn. Fuc. I. p. 11 .

On the shore at Yarmouth.-Coasts of Cornwall and Devonshire, both varieties. Mirs. Griffiths.

Perennial? January-April.

Rоот, a very minute callous * disk.

FroN DS, numerons, two or three inches long, rising with a single flat undivided leaf, at first sub-orbicular, afterwards oblong, about four lines wide, the apices constantly blunt, and the margins quite entire, furnished with a deep red midrib, blackish at the base, as thick as horse-hair, clearly visible to the very apices, proliferous throughout its whole length with other leaves precisely similar to the primary one, except in their smaller size, and these again with a third or sometimes with a fourth series, each less than the preceding, the middle ones generally longest, but this is uncertain, the youngest roundish or inversely ovate: the leafy membrane, at the base of the frond, is generally worn away by the action of the sea, so that the midrib is left naked, and the plant has the appearance of being naturally provided with a stem : from either side of the midrib, at rather acute angles and short distances, issue rows of pellucid colorless veins, visible to the naked eye in a recent plant, intersected at regular distances by joints like the dissepiments of Conferve, and generally running to the margins of the leaf in a direction parallel to each other and undivided, but sometimes branched and anastomosing.

Fructification, of two kinds, on different plants; the one consisting of dark-red spherical capsules, smaller than poppy seed, sessile on the midrib, especially towards the apices of the younger leaves, and containing a great quantity of. globular seeds, surrounded by a pellucid limbus; the other consisting of extremely minute naked seeds, of uncertain size and form, disposed in small patches of an irregularly lanceolate shape on each side of the midrib, the frond being apparently thickened where they lie.

CoLOR, of the leaf, transparent, blood-red; when dry, crimson: of the midrib, darker.

SubSTANCE, thin and membranaceous, but elastic and stiff compared with that of $F$. Hypoglossum.

$\beta$ differs only in its smaller size, having its leaves not more than half an inch long, and one or two lines wide.

Upon the characters which separate this species from the preceding, I have already dwelt so much at large in the Transactions of the Iinnæan Society, and Synopsis of the British Fuci, that there can be no necessity here to repeat them, farther than by saying that the two plants are distinguishable by the form, color, and substance of the leaves, but still more certainly by the texture, which in $F$. Hypoglossum is uniform, and composed of most beautiful reticulations, forming oblong meshes, while in $F$. ruscifolius the reticulations are sq minute as to require a compound microscope to discern them, but the frond is very visibly streaked with pellucid veins, as mentioned in the description. I am sorry to be under the necessity of adding, that I now see reason to believe that the whole of the opinion I formerly stated respecting the fructification of these plants, that the scattered seeds are in reality those which were contained in the tubercles, is erroneous. Their regular disposition had led me always to feel some doubt on this point, and more attentive observation, with higher microscopical powers, has shewn me that in this, as in most of the Fuci known to possess this double fruit, the capsular granules differ as to shape from those which lie naked on the frond, so that it is impossible they should ever have been the same; and I am fearful I was also in error when I said that plants were occasionally found, in which the two modes of fructification may be seen on the same individual. It is sufficiently known that different marine algæ often arise from one basis, and I now believe that the specimens on which I have seen both the capsules and scattered seeds were in reality distiuct, though originating fron the same point. I therefore incline to consider these plants as diocious, and lament in common with the excellent Authors of Observations on the British Fuci, that in the present imperfect knowledge of the nature and properties of marine plants; it is impossible for us positively to determine how far the suspicion first entertained by Dr. Solander of their being male and female is well founded; and that from the impracticability of examining these plants whilst actually growing in their native element, it is probable that the manner in which the impregnation is performed may ever remain aniong the arcana of nature.

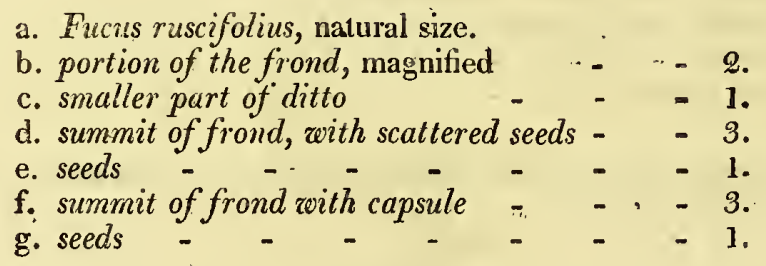




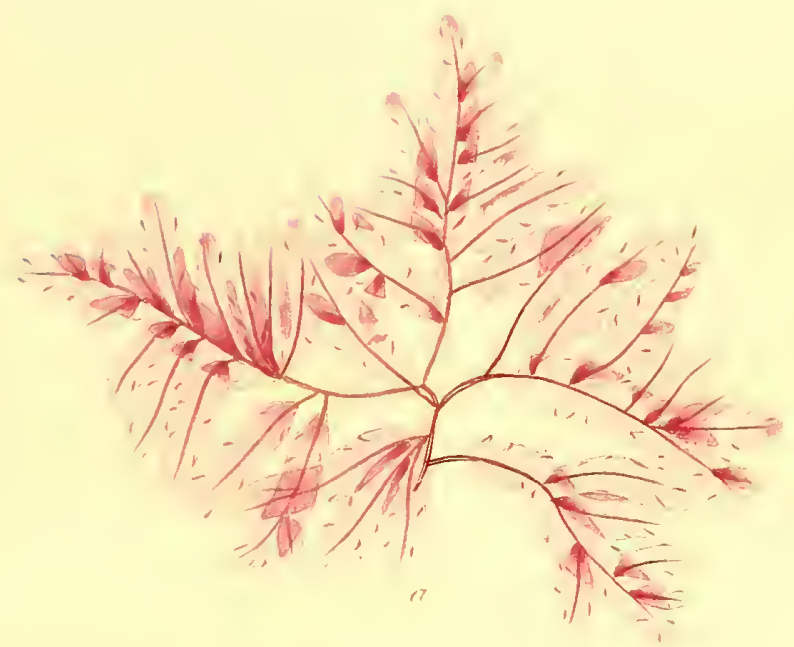

$\because 0$

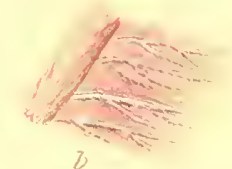



Fucus, caule ramoso alato ; foliis latè oblongis, obtusis, planis, simplicibus, e costâ proliferis; venulis diaphaăis catenatis ; capsulis in costâ sphæricis, seminibusque sparsis.

Fucus ruscifolius. Turner, in Linn. Trans. VI. p. 127. t. 8.f.7. Syn. Fec. I. p. 11. Eng. Bot. XX. t. 1395.

F. Hypoglossum. Fl. Fr. Ed. 2da. II. p. 27. (excl. Syn, omn.)

в. minor; foliis ovato-lanceolatis, unguicularibus.

F. ruscifolius. B. Syn. Fuc. I. p. 11 .

Ha віт Aт in Cornubiæ et Devoniæ oris, utraque varietas. D ${ }^{\text {na }}$ Griffiths- $\alpha$ inter rejectamenta maris apud Yermutham.

Perennis? Jan.-Apr.

RA DIX * callus explanatus, exiguus.

Fron des ex eâdem basi plurimæ, bi-tri-pollicares, folio unico, plano, sub-orbiculari, simplice, primùm assurgentes, apicibus nunquam non obtusis, marginibusque integerrimis : hoc folium costâ percurritur sanguineâ, basin versus nigricante; setæe equinæ crassitie, ad apices usque conspiciendâ, per totam longitudinem proliferâ, folia alia primariis, staturâ minore demptâ, omnimodè convenientia emittente, quæ tertiâ vel interdùm quartâ serie, utrâque præcedente minore, sunt instructa ; media plerumque longissima, sed hoc inconstans, juniora subrotunda vel obovata; membrana frondis ad basin foliacea vi fluctuum sæpiùs atteritur, unde costa denudata caulis speciem præbet. Ex utroque costæ latere emanant venarum pellucidarum albarum series, intervallis brevibus distinctæ, patentes, oculo inermi in recente conspiciendæ, Confervarum instar geniculatæ, et ad foliorum margines plerumque simplices et parallelæ, sed quandoque ramosæ et anastomosantes, decurrentes.

Fructificatio duplex : hac e capsulis intensè rubris, sphæricis, papaveris semine minoribus, in costâ, presertìm foliorum juniorum apices versus, sessilibus, semina plurima globosa limbo pellucido cincta includentibus, illa e seminibus constans minutissimis, nudis, figuræ magnitudinisque incertæ, in maculas abnormitèr lanceolatas costâ percursas dispositis; frondis cui insident parte incrassatâ.

Co sor folii e roseo sanguineus, diaphanus, exsiccati puniceus ; costæ intensior.

Substantia tenuis et membranacea, sin cum eâ $F$. Hypoglossi conferatur rigidiuscula.

Varietas $\beta$ non nisi staturâ minore discrepat : folia huic longitudine unguem, latitudine lineam unam atque alteram vix exsuperant.

De iis quæ hanc speciem a præcedente secernunt notis jampridem in Societatis Linnæanæ Actis et in Fucorum Britannicorum Synopsi tam fusè disserui, ut nihil hìc aliud repetendụm ducam, nisi quodd foliorum figurâ, colore, et substantiâ, certissimè autem texturâ discrepent, quæ in $F$. Hypoglosso uniformis est et pulcherrimè reticulata, maculis oblongis, dum $F$. ruscifolii frons tantummodo microscopii compositi ope reticulata apparet, contrà autem venulis pellucidis jamjam in descriptione memoratis per totam longitudinem notata evadit. Invitum fateri cogit veritas, totam illam hypothesin quam de harum plantarum fructu olim struxeram, scilicet semina sparsa eadem esse quæ anteà in capsulis erant inclusa, observationibus nuperis nequaquam esse confirmatam. Dispositio regularis scrupulos semper injecerat, lentisque acrioris usus tandem edocuit, semina nuda, in hâc, sicut in aliis plurimis speciebus fructificatione duplici præditis, figurâ ab iis quæ capsulâ continentur discrepare, unde eadem unquam extitisse prorsùs impossibile. Illud etiam vereor, ne, cùm utrumque fructificandi modum in eodem individuo quandoque occurrere assererem, vix satis cautè dixerim. Diversas ex eâdem basi algarum species non rarò oriri satis Botanicis notum; easque frondes, in quibus cùm capsulas tùm semina sparsa vidi, licet ex uno puncto sint natæ, reverà distinctas fuisse suspicor. Hasce igitur plantas pro dioicis in præsens habere nunc propendeo, et unà cum viris amicissimis, Goodenovio et Woodwardio, lugeo, quod in mancâ illâ, quâ solâ nunc fruimur, algarum marinarum indolis atque proprietatum cognitione, non nobis detur ritè dijudicare, quatenùs opinio primùm a Solandro excogitata fructificationem duplicem ad duplicem sexım pertinere re ipsâ sanciatur, et qudd impossibile sit has stirpes in solo nativo nascentes observare, unde impregnandi modus inter arcana naturæ arcanum forsàn perpetuo permanebit.

a. F. ruscifolius, magn. nat.

b. frondis pars, magn. auct. $\quad-\quad-\quad-\quad$ -

c. ejusdem pars minor - $\quad$ - $\quad$ - $\quad$ - 1 .

d. frondis apex seminibus sparsis - $\quad-\quad-3$.

e. semina - - - - $\quad$ - 1 .

f. frondis apex cum capsulâ - - $\quad-\quad 3$.

g. semina - - $\quad-\quad-\quad-1$.

* Eibras quas in Fuc. Brit. Syn, radice adhærentes descripsi a plantâ alienas fuisse nunc credo, 
Facus stiviatus, frono flat, sub-gelatinous, cuneiform, palmate, every where beset with compressed strap-shaped ramuli, generally simple, longitudinally furrowed; capsules spherical, half-immersed.

Tucus papillosus. GuElin, Hist. Fuc. p. 18s.?

fi. Koelreuteri. IIN N. Syst. Nat. Ed. Gmel. II. p. 1388.?

Ulva papillosa. Lin N. Mant. p. 311 .? (excl. Syn. Gmel.)

F. folinceus, fiondibus finctificantibus papillatis. Koenreuter in Nov. Comment. Petrop. XI. p. 424. t. 13. ?

At the Cape of Good Hope. Thunberg.

RoOT, composed of branched, creeping, entengled fibres, gradually rising into new fronds.

FroNDs, niany from the same base, three or four inches long, immediately at their origin cylindrical, and about the size of a sparrow's quill, then becoming compresserl, and insensibly widening. into a flat leaf, of a shape between oblong and cuneiform, at first' simple, but afterwards once or twice irregularly palmate. Either side of the frond, and eves the margins, are covered with a profusion of ligulate ramuli, between erect and patent, an inch or more long, in general simple, compressed, irregularly wrinkled, and longitudinally furrowed; their summits cylindrical, and attenuated, so that in ary specimens they have almost an acuminated appearanee.

Fructification, spherical capsules, about the size of the seeds of Ervm tetraspermum, placed without any certain order, sometimes at the apices, sometinies on the surface of the ramuli, and half immersed in the substance of them, containing a compact purplish globule, full of extremely small seeds of no regular form: the apices of the capsules perforated with a minute pore.

Coco i, brownish purple, semitransparent; more dark in the plant when dry, soon fading to a dull dirty yellow, to which it also turns in decay.

SUBSTANCE, between gelatinous and cartilaginous, extremely tender and pulpy : when dry, horny and rigid: when moistened, it imbibes a great deal of water, and shrinks considerably in drying.

The specimens of this Fucus here figured were taken from Ellis's Herbarium, where, when I first saw them, their nature and appearance struck me altogether as so particular, that I could scarcely refrain from regarding them as a mere lusus naturæ; nor was it till I again met with similar ones in the Linnæan Collection, and received others under the very apt name of $F$. stiriatus froin Professor Mertens, that I could reconcile myself to considering it a distinct species. Neither to Ellis's nor Linnæus's plants were any habitats affixed, but those sent by Professor Mertens were gathered by Sir C. P. Thunberg at the Cape of Good Hope. It is in compliance with the opinion of my friend, Dr. Mohr, that I have quoted $F$. papillosus, Gmel. under the present Fucus; but I could not regard Gmelin's synonym as sufficiently indisputable to warrant the introducing of it without a mark of doubt, or to justify me ill adopting his name; as his description by no means applies, either with regard to the stbstance, the stem, the reflexed margins, or the form of the papillæ, and I rather incline to suspect that Koelreuter's figure was intended to represent one of the appearances of $F$. bracteatus, Gmel. ( $F$. Radula, Esp.) a plant particularly liable to variation. Linuæus's account of his Ulva papillosa agrees much better with $F$. stiriatus, and was probably taken from it in a dried state: there are no specimens under this name in his Herbarium, so that those alluded to above may possibly be what he described; but, if this conjecture be well founded, he has made a strange error in taking for a synonym F. muricatis, Gmel. which belongs to his own $F$. spinosus. The plant introduced by Forskäl under the name of $F$. papillosus is merely a variety of $F$. obtusus. F. stiriatus is distinguished from its congeners by its ligulate ramuli, and gelatinous substance: its capsules also are larger than those of most of the Fuci, and, what is singular, are perforated at their apices with a pore which is distinguishable even in dry specimens. I have sought in vain for those reticulated anastomosing fibres, which Weber and Mohr say they found particularly evident mixed with the globule of granules in this species.

a. F. stiriatus, natural size.

b. young plant, with root, but no ramuli yet appearing.

c. plant in fruit.

d. part of the same, magnified - $\quad$ - $\quad$ - 4 .

e, e. globules of granules taken out of the capsules - 2 .

f. seeds - - - $\quad$ - _ - - 1 . 

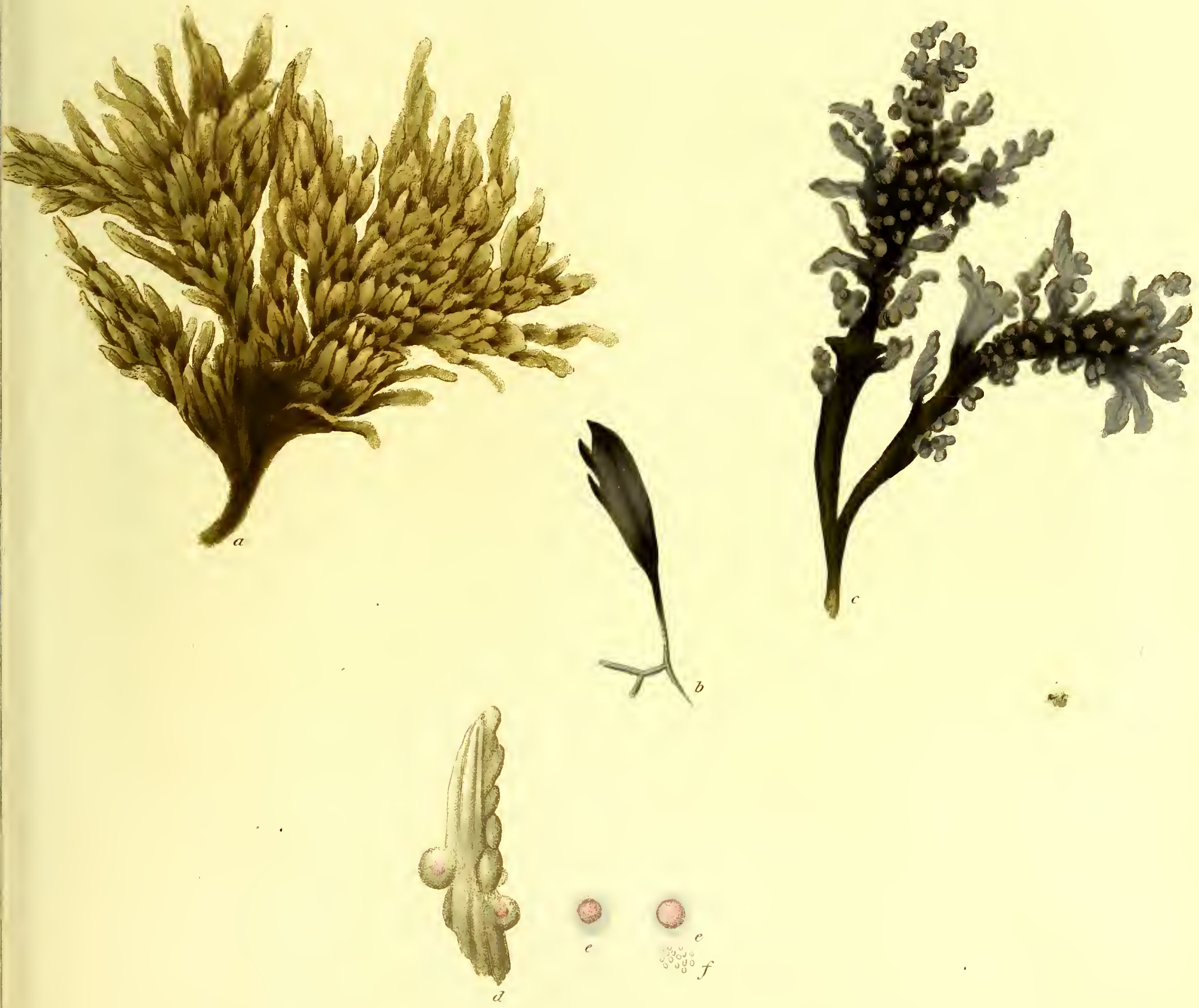

Freces stivicates 

Fucus fronde planâ, subgelatinosâ, cuneiformi, palmatâ, ramulis compressis, ligulatis, simpliciusculis, longitudinalitèr sulcatis undique et utrinque densè obsitâ ; capsulis sphæricis semi-immersis.

Fucus papillosus. Gmelí, Hist. Fuc. p. 188.?

F. Koelreuteri. Lin N. Syst. Nat. Ed. Gmel. II. p. 1388.?

Ulia papillosa. Lín n. Mant. p. 311. ? (excl. Syn. Gmel.)

F. foliaceus, frondibus fructificantibus papillatis. Koelreuter, in Nov. Comment. Petrop. XI. p. 424. t. 13.?

Habitat apud Promontorium Bonæ Spei. Thunberg.

RAD1X fibrosa, fibris ramosis, repentibus, intertextis, in novas frondes paullatim crescentibus.

FRONDES, ex eâdem radice plurimæ, circitèr palmares, sub ipso ortu pennæ passerinæ crassitie, et teretes, inde statìm ferè compressæ, seque sensìm in folium planum, enerve, ex oblongo cuneiforme, principio simplex, mox iterùm atque iterùm sine ordine palmatum, segmentis unguem vel pollicem latis, dilatantes. Utramque frondis paginam, atque etiam margines, densissimè obsident ramuli ligulati, erecto-patuli, plerumque simplices, pollicares et ultrà, compressi, irregularitèr rugosi et longitudinalitèr sulcati, apice teretes, et attenuati, ut in plantâ exsiccatâ acuminati propemodùm videantur.

FruCtificatro capsulæ sphæricæ, Ervi tetraspermi seminumı ferè magnitudine, ramulorum nunc apicibus, nunc superficiei absque ordine insidentes, et semi-immersæ, globulum compactum purpurascentem e seminibus miuutissimis, figuræ nequaquam certæ constantem includentes, apice poro exiguo pertusæ.

CoLOR fusco-purpurascens, sub-diaphanus; exsiccata intensior; marcescentis sordidè lutescens.

SUBSTANT1A inter gelatinosam et cartilagineam, tenerrima, succosa; exsiccata cornea, rigida :madefacta imbibit, et exsiccando magnoperè contrahitur.

Cùm hujus Fuci exemplar hìc depictum in Ellisii Herbario primùm cernerem, figura et indoles adeò mihi singulares sunt visæ, ut pro lusu quodam naturæ, ut aiunt, habere propenderim. Postea verò phytophylacium Linnæanum perlustranti plura sese specimina obtulerunt, (neque tamelı his neque Ellisianis loco ullo natali adjecto,) et tandem a Mertensio eandem stirpem, F. stiriati nomine aptissimo designatam, ad Caput Bonæ Spei lectam accepi, nec distinctam esse reverà speciem e tot partibus missan ampliùs dubitare licuit. Amicissimi Mohrii, qui se in eâ esse sententiâ nuperrimè me per literas certiorem fecit, monitui obsequens, $\boldsymbol{F}$. papillosum Gmel. sub hâc specie citavi ; dubitationis tamen signo postposito: neque enim viro acutissimo edusque assentiri sim ausus, ut synonymum pro indubio habens nomen a Gmelino impositum asciscam, cùm ejus descriptio, quoad substantiam, caulem, margines reflexos, et papillarum formam, nequaquàm tantum quantum vellem $F$. stiriato respondeat, et Koelreuteri icon, dubia, $F$. bracteatum Gmel. (qui $F$. Radula Esp.) stirpem præ cæteris plerisque variabilem potiùs respicere mili videatur. Linnæi Ulva suæ papillosa descriptio tantò meliùs cum hoc Fuco nostro convenit, ut ab exsiccato depromi possit, nec extant ulla in Herbario suo hoc nomine insignita exemplaria :- sin ita sit, mirè de synonymo erravit, $F$. muricatum Gmel., qui ipsissimus est $F$. spinosus, ad hanc speciem referens. F. papillosus Forsk. est tantummodd F. obtusi varietas. Ramuli ligulati et substantia gelatinosa F. stiriatum a congeneribus distinguere semper valebunt; capsulæ quoque iis plurimorum Fucorum multò majores, et, quod singulare, poro, vel in siccâ conspiciendo, ad apices pertusæ. Filamenta reticulata anastomosantia, qux granulorum glomerulo immista evidentissimè in hâc stirpe per spexerunt Weberus Mohriusque, ipse frustra conquisivi.
a. F. stiriatus, magn. nat.
b. planta junior, cum radice; ramulis nondum exortis.
c. planta fructifera.
d. ejusdem pars, magn. auct. : - - - - 4.
e. granulorum glonieruli capsulis deprompti - $\quad$ - $\mathbf{Q}$.
f. semina - - - - - $=1$. 
Fucus Horneri, with sub-cylindrical frond, and branches long, compressed, generally simple, ending in cylindrical pod; vesicles oblong, terminated by a linear decurrently pinnatifid leaf.

In the Straits of Corea. Dr. Horner.

I am unable to say any thing as to the Root or length of the frond of this Fucus.

Sre a, nearly cylindrical, furrowed in places, thicker than a crow's quill, sending out branches at intervals of three or four inches, whether ever divided or not I am ignorant, but I have seen it entire for three feet.

Branches, disposed round the stem in an irregularly spiral order, a little thickened at their origin, after which they become compressed, and preserve throughout their whole length the size of a sparrow's quill, sometimes one fo ot, sometmes two, or more long, undivided, but beset with other smaller ones, arranged at distances not exceeding a nail each, all of them terminated by a pod, if I may use the expression, about an inch and laalf long, cylindrical, simple, and as thick as the quill of a blackbird.

VEsicLEs placed in tolerable plenty upon the branches, especially the smaller ones, between oblong and cylindrical, supported upon extremely short stalks, in size and shape not unlike the pods of Sisymbrium Nasturtium, quite bollow within, ending in linear leaves, fixed upon short petioli, an inch or more long, but scarcely a line wide; pinnatifid with alternate decurrent lacinix, and furnished with an obsolete midrib, which disappears near the apices.

Fructification, in my opinion, unquestionably placed in the pods, most of which I found solid within, but some having a row of cavities near the circumference, in which, though I could discover no seeds, there were observable pellucid granules.

Color, in the leaves and vesicles, a tawny green; in the pods, brown.

SUBSTANCE, of the stem coriaceous, pliant and tough; of the leaves membranaceous.

In compliance with the wishes of ny highly valued friend, Professor Mertens, I have named the present very. beautiful Fucus in memory of Dr. Horner, who, in the quality of astronomer, accompanied the Russian expedition. lately sent round the world in the ships Nerva and Nadeshda, and brought with lim, from the coasts of Corea and Kamtchatka, a variety of species not yet described. 'The whole of these I have received from Professor Mertens, who was many years since termed by $*$ Weber and Mohr the most able Algologist of our times, and to whom I am exceedingly indebted for the assistance he has rendered me towards the present publication, in which I trust they will 'all soon make their appearance. These Asiatic Fuci constitute a tribe naturally allied among themselves, but very. different, both as to form and nature, from those which are found in our seas, and none of them more strikingly so than that which is the subject of the present plate. As to the fructification, I have already observed in the description; that I can say nothing positively; but at the same time I entertain no doubts whatever of its being unlike that of any of the families of European Fuci, or of its being contained in the long terminal pods, which in their form, and their smooth exterior, perforated with no pores, resemble those of $F$. lumbricalis, while the pellucid granules observable within them are like those of $F$. tuberculatus and erinaceus. From the mode of growth of this Fucus, the almost. ligneous stem, and the vesicles, a suspicion might be entertained that it belongs to the tribe of $F$. matans, but the thin. membranaceons texture of the leaves and the fructification forbid such a conjecture.

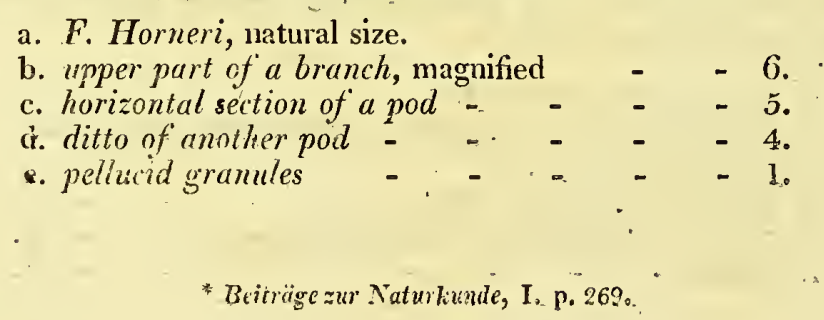




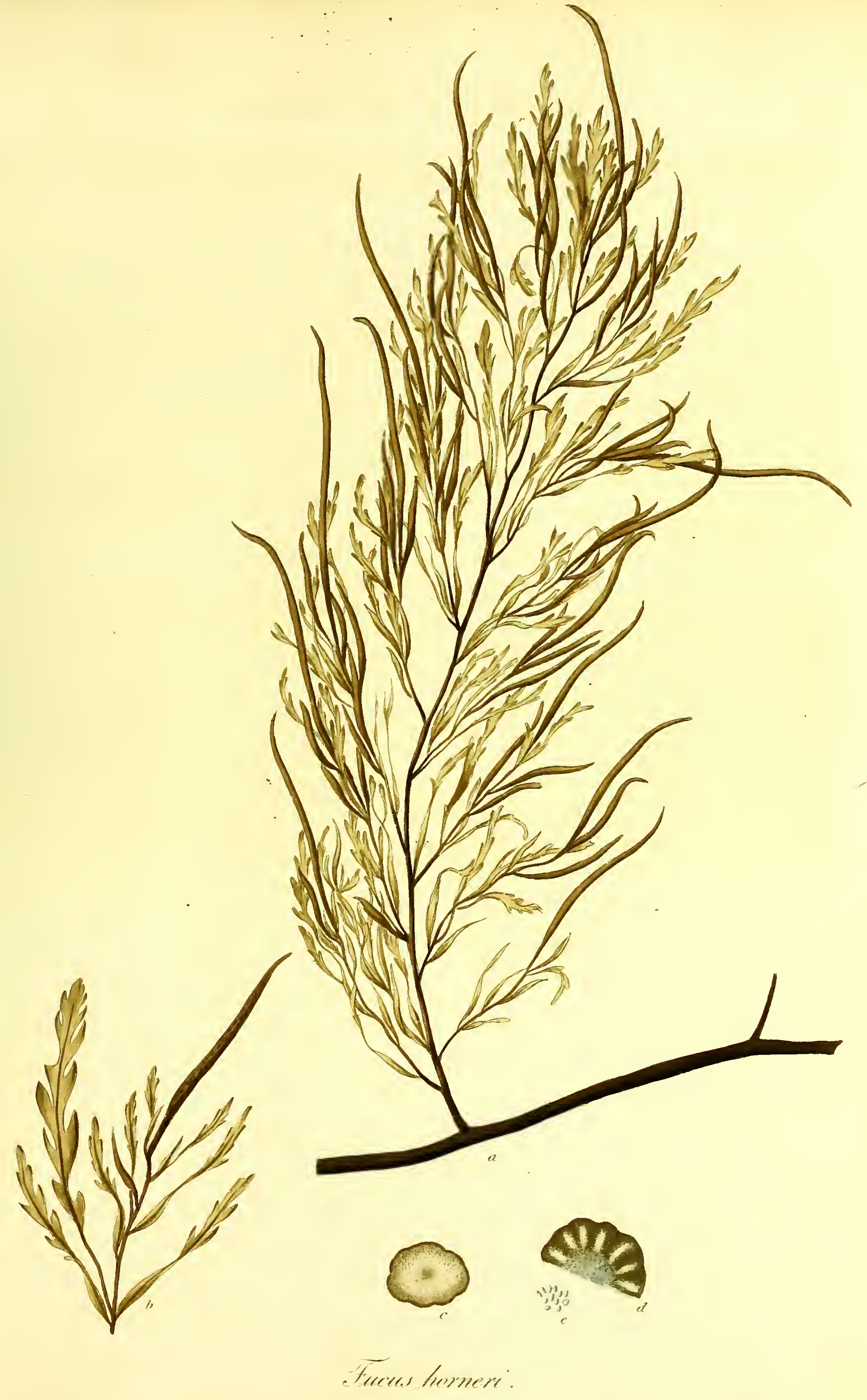



Fucus caule teretiusculo; ramis elongatis; compressis, simpliciusculis, in siliquam longam teretern abeuntibus; vesiculis oblongo-cylindraceis, folio lineari decursivè pinnatifido, terminatis.

\section{Habitat in Mari Coreano. D. Horner.}

Nec de RADICE, nec de frondis longitudine, utrâque milhi adhuc incognitâ, aliquid proferre posssum.

CAULIS teretiusculus, hìc illìc sulcatus, pennâ corvinâ crassior, simplex necne dicere nequeo, sed per trium pedum, longitudinem indivisum vidi, ramos intervallis sub-palmaribus emittens.

RAMI circa caulem ordine irregularitèr spirali dispositi, ortu levitèr incrassati, hìnc compressi, peunæque passerinæ crassitiem ubique æqualem servantes, longitudine pedales, bipedales, et ultra, indivisi, sed aliis minoribus brevibus, intervallis sub-unguicularibus absque ordine positis, instructi ; omnes terminati siliquâ, ut ita dicam, sesquipollicari, tereti, simplice, Merulæ pennæ crassitie.

VESICULA ramis, præsertim minoribus, satis copiosè innascentes, oblongo-cylindraceæ, brevissimè pedicellatæ, Sisymbrii Nasturtii siliquarum haud absimiles, intùs cavæ, apice in folia abeuntes linearia, brevitèr petiolata, pollicem et ultrà longa, vix lineam lata, pinnatifida, laciniis alternis decurrentibus, costâ obsoletâ prope apicem evanescente instructa.

Fructificationem in siliquis, quarum plurimas intùs solidas, quasdam vero instructas vidi cellulis juxta peripheriam cavis, reperiri dubitari nequit, sed semina nulla adhuc detexi.

CoLOR foliorum et vesicularum e viridi fulvescens, siliquarum fuscus.

Su BSTANTIA caulis coriacea, lenta, tenax, foliorum membranacea, tenuis.

Amici suavissimi Mertensii votis obsequens perpulchrum hunc Fucum, quem e Mari Coreano secum attulit D. Horner, Russicæ circa orbem expeditioni, a navibus Nerva et Nadeshda nuper habitæ, astronomus adjunctus, Horneri nomine insignivi. Plures quoque alias nondum cognitas, sed mox in hoc opere evulgandas species, Coreæ Kamtchatkæque ad littora legit D. Horner. Has omnes Mertensio meo, quem jamdudum algologorum hujus revi principem * Weberus Mohriusque salutârunt, et cui plus quàm quod verbis exprimi potest debeo, acceptas refero. $\mathrm{Ab}$ iis quæ in Europæ nostræ nascuntur maribus Asiaticæ hæ species formâ et indole longè recedunt, non ulla tamen longiùs quàm ea quam hìc depictam sisto. De fructificatione, ut in descriptione dixi, nihil pro certo affirmare ausim, nec tamen dubito quin ab omnibus hucusque notis Fucorum familiis recedat, et in siliquis terminalibus elongatis, quæ extrinsecus læves, poris nullis pertusæ, eas $\boldsymbol{F}$. lumbricalis referunt, contineantur. Granula pellucida in his inclusa eorum in F. tuberculato, erinaceo, et quibusdam aliis observatorum similia videntur. A crescendi modo, caule sub-ligneo, vesiculisque, huic Fuco cum $\boldsymbol{F}$. natantis tribu similitudinem aliquam intercedere suspicari liceret, vi foliorum textura membranacea tenuis et fructificatio vetarent.

a. F. Horneri, nat. magn.

b. rami pars superior, magn. auct. $\quad-\quad-6$.

c. siliqua sectio horizontalis - - $\quad$ - 5.

d. alius siligua sectio horizont. - - $\quad 4$.

e. granula pellucida - - - - - 1 . 
Fucus spinosus, frond sub-gelatinous, cylindrical, much and irregularly branched; branches flexuose, almost horizontal, acuminated; ramuli short, conical, horizontal, bearing spherical capsules at their apices.

Fucus spinosus. Lin n. Mant. p. 313. Syst. Nat. Ed. Gmel.II. p. 1386. (excl. Syn. Wulf.)

F. muricatus. Gmelin, Hist. Fuc. p. 111 . t. 6. f. 4.

F. lichenoides. WI L L. Phytog.

At the Cape of Good Hope. Linnaus.-In the Indian Ocean. Gmelin.-In Sumatra. Swartz.

Root, a small, expanded, whitish callus, throwing out a few fibres, and thence becoming creeping.

Fron D, about nine inches long, and as thick as a goose-quill, cylindrical, much branched, the branches sometimes irregularly dichotomous, sometimes alternate, either simple, or furnished here and there, especially towvards the apices, with a few shorter ones, all of them between horizontal and patent, flexuose, remarkably acuminated, and more or less copiously beset with extreniely short horizontal ramuli, either conical, or between subulate and conical, disposed on every side over the whole frond, sometimes growing solitary, sometimes two or three together, occasionally studded with others much more minute, and lengthening into new branches, thus forming the natural increase of the plant.

Fructification, terminal, placed at the ends of the ramuli, which then swell into pale-red globular capsules, about the size of turnip seed, containing a mass of irregularly formed minute granules: two capsules are sometines found on the same ranulus.

Color, in the specimens which I have seen, a dirty yellowish white, nore or less tinged with green.

SuBSTA N E, between cartilaginous and gelatinous; horny when the plant is dry.

Having never had an opportunity of examining Professor Wildenow's Phytographia, I have admitted his Synonym, which is quoted above, wholly upon the authority of Dr. Weber and Dr. Mohr, and have borrowed from the same Botanists, the information given to them by Dr. O. Swartz, that this plant is eaten by the natives of Sumatra.: To the kindness of my friend, Dr. Smith, I am indebted for the being able here to figure the very specimens preserved in the Linnzan Herbarium, so that there can be no farther doubt as to the plant designed by Linueus under the name of $F$. spinosus, a point that has been hitherto much contested. The two individuals represented in the present plate will serve sufficiently to shew how great a difference exists between the barren and fructified state of the species before us, and the change which it undergoes in drying is scarcely less striking, as may easily be conceived from the circumstance of their having then lost near two inches of their length, and more than the lialf of their thickness. At the same time, I am far from intending to deny that specimens may occasionally occur, which, though barren, may be furnished with ramuli no less copiously than those which are in fructification, but I believe the cuntrary to be the case in general. $F$. spinosus agrees in its internal structure with $F$. stiriatus, figured above. t. 16 , and unquestionably belongs to the same tribe of Fuci ; its nearest affinity however is with F.gelatimus, Esp. and the following species, from the former of which it is principally distinguished by its labit, stature, and mode of growth, and from the latter, by the form of the ramuli and solitary capsules. 'The whole of the specimens that $I$ have yet seen were, as $I$ have observed in the description, of the same color as those here figured, but I should nevertheless be led by analogy to suspect that the natural hue of the plant is either red, or reddish brown, colors particularly liable to change. The error into which Baron Wulfen fell, and in which he has been followed by most succeeding Botanists, mistaking Hudson's F. obtusus for the $F$. spinosus of Linnæus, has already been noticed in the Synopsis of the British Fuci, and may serve as a striking proof how impossible it is to convey by the very best descriptions, unless they are copious, an adequate idea of plants like these.

a. F. spinosus, barren, natural size.

b. ditto in firuit.

c. part of the frond, magnified - - 5.

d. capsule - - - - - $\quad$ - 4 .

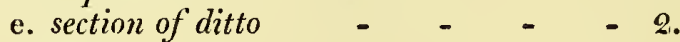

f. seeds - - - - $-\quad-1$.

g. longitudinal section of frond - $\quad$ - 2 .

h. horizontal section of ditto - - - 2 . 


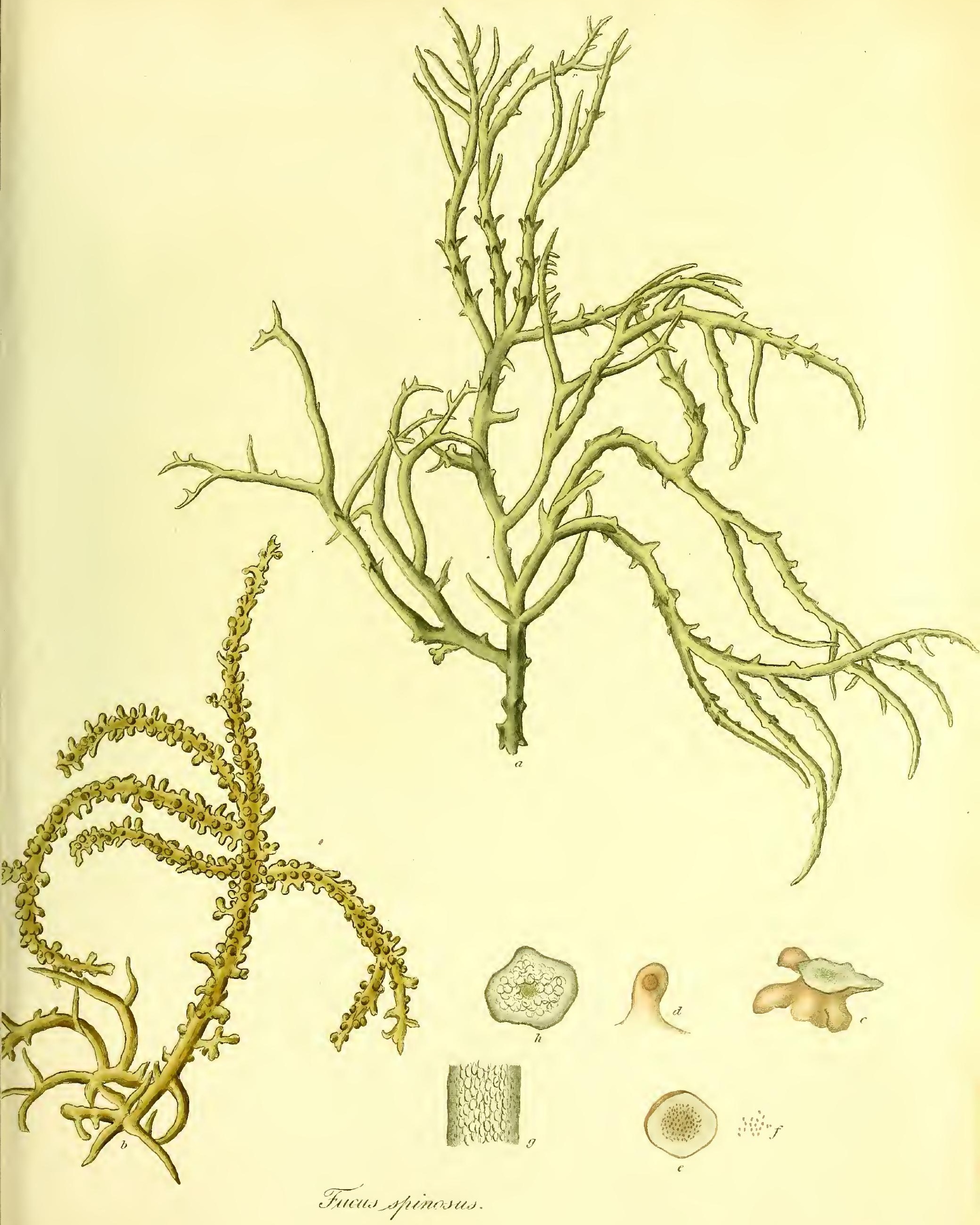



Fucus fronde sub-gelatinosâ tereti ramosissimâ ; ramis flexuosis, sub-horizontalibus, acuminatis ; ramulis brevibus, conicis, apice globuliferis.

Fucus spinosus. LiNn. Mant. p. 313. Syst. Nat. Ed. Gmel. II. p. 1386. (excl. Syn. Wulf.)

F. muricatus. Gmelin, IIist. Fuc. p. 11 1. t. 6. f. 4.

F. lichenoides. WiLLD. Phytog.

Hн вітат ad Caput Bonæ Spei. Linnæus.-In Oceano Indico, Gmelin.-In Sumatrâ. Sžartzius.

RADIX callus exiguus, dilatatus, albicans, fibras aliquot crassiusculas emittens, et inde repens.

FroNs dodrantalis et ultra, pennæ anserinæ crassitie, teres, ramosissima, ramis elongatis, nunc irregularitèr dichotomis, nunc sub-alternis, vel simplicibus, vel hìc illic, præsertim apices versus, in breviores aliquot divisis : rami omnes horizontalitèr patuli, flexuosi, insignitèr acuminati, ramulis brevissimis, conicis, aut subulato-conicis, horizontalibus, vel solitariis, vel binis ternisve, undique et ubique dispositis, nunc densè nunc sparsim obsiti : hi ramuli aliis minoribus aliquando pullulant, et in novos ramos elongantur:

FrUCTIFICATIo terminalis, ramulorum ad apices, tunc in capsulas sphæricas, solitarias, vel etiam binas, Brassica $R a p \mathfrak{R}$ seminum magnitudine, dilutè rubras, intumescentes, sita: congeries in his seminum minutissimorum, nullius certæ figuræ.

Color, in omnibus qux vidi exemplaribus, e luteo sordidè albicans, viredine tinctus.

SuBSTANTi gelatinoso-cartilaginea, in exsiccatố cornea.

Willdenovii synonymon ex opere nondum a me viso suprà citatum Weberi Mohrïque fide hùc retuli, et plantam: Sunıtræab incolis comedi eosdem viros, quibus a Swartzio est traditum, auctores habeo. Quod exemplarium ex ipsius I innæi Herbario depromptorum hic depingendi facultas mihi detur amicissimi Smithii singulari benevolentiæ debeo, unde ut icon nostra $F$. spinosum I. reverà sistat dubitationi non datur locus. Quantum stirps fructifera a sterili discrepet satis per individua hic delineata liquet, vixque inter madentem et exsiccatam minus interest; cùn perpaucæ aliæ Fucorum species sese exsiccatione magis contrahat, et specimina hæc Linnæana longitudine duos pollices, crassitiem plusquam dimidiam tunc perderent: non tamen is ego sum qui asseram exemplaria sterilia nunquam dari, qua ramulis aquè ac in fructiferis copiosè dispositis sint obsita, sed plerurnque parciùs instructa credo. Structurâ suâ internâ cum $F$. stiriato, supra delineato, t. 16, magnoperè convenit, et ad eandem Fucorum familiam certè attinet; plurimum autem affinitatis habet cum $F$.gelatino Esp. et cum insequente specie, quorum a primo habitus, statura, et crescendi modus, ab altero ramulorum forma et capsulæ solitariæ distinguunt. Specimina, ut in descriptione dixi, tantummodo sordidè albicantia vel virentia vidi, colorem tamen planta recenti proprium esse rubentem, aut subfuscum rubedine tinctum ex analogiâ crederem. Hic quoque color præ cæateris fugacissimus. Quantum de $l$.

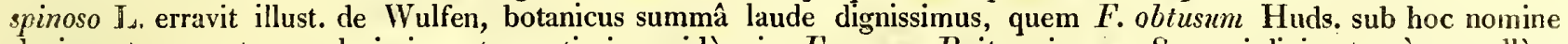
depingentem auctores plurimi sunt secuti, jampridèm in Fucorum Britannicorum Syuopsi dixi, et quàm paullùm harum plantarum descriptionibus brevibus, quamvis optimis, sit fidendum, post talem talis viri errorem, fieri nequit quin masti confiteamur.
a. F. spinosus, sterilis, magn. nat.
b. idem, fructifer.
c. frondis portio, magn. auct. - - $\quad$ - 5 .
d. capsula - $\quad$ - $\quad$ - $\quad$ - $\quad$ - 4.
e. eadem dissecta $\quad$ - $\quad$ - $\quad$ - $\quad$ - $\quad$ - 2
f. semina - - - - $\quad$ - $\quad$ - 1 .
g. frons longitudinalitèr secta - $\quad-\quad$ - 2 .
b. eadem horizontalitèr secta - - - 2. 
Fucus thyrsoides, frond cylindrical, filiform, irregularly pinnated; branches between horizontal and patent, cylin, drical, obtuse ; ramuli cylindrical, horizontal, short, bearing at their apices clustered capsules.

ß. major; frond much and irregularly branched; branches very long.

New Zealand. Sir Joseph Banks._Jamaica. Dr. Wright.- $\beta$ in the Red Sea. Viscount Valentia.

Rоoт, creeping, consisting of many thickish, entangled fibres, which lengthen and rise into new fronds.

FR ONDs, numerous from the same root, cylindrical, filiform, nearly equal in thickness to a crow's quill, in general simple and undivided for the half of their length nearest the base, then frequently di- or tri-chotomous, and towards their apices irregularly pinnated with a few branches between horizontal and patent, disposed in a sub-distichous manner, and mostly simple: the part of the frond nearest the base is commonly naked, but the rest thickly covered on all sides with horizontal, cylindrical, obtuse, truncated ramuli, undivided, and scarcely a line long.

Fructification, terminal in the ramuli, which then swell towards the apices, and bear from three to seven small, spherical, clustered, sessile tubercles, in each of which lie several purplish seeds, of an irregularly roundish form, and large when compared to the size of the capsule.

CoLOR, pale brown, tinged with purplish, semitransparent.

SUBSTANCE, cartilaginous, pulpy, horny when dry.

$\beta$, both in size and mode of growth, is remarkably different: its length extends to above a foot, its thickness is equal to that of a goose-quill: the frond is much and irregularly branched from the very root, divided without any order into long sub-fastigiate branches, and is throughout thickly clothed with raniuli.

Finding no mention of the present plant in ány preceding author, $I$ have ventured here to describe it as a new species, and have derived the name from the resemblance which fructified specimens bear in miniature to the figures of the Thyrsi used by the Mrnades in their Bacchanalia. Its nearest affinity is with $\boldsymbol{F}$. spinosus, from which, as already observed under that plant, it differs in the form of its ramuli and clustered capsules; two circumstances upon which its most essential specific characters depend, and which will also serve to distinguish it from $\boldsymbol{F}$. pinnatifidus, to some varieties of which it bears a resemblance at first sight. I am not aware that there is any other Fucus with which it is liable to be confounded.

a. $\boldsymbol{F}$. thyrsoides, barren, natural size.

b. branch, magnified - - - $\quad 6$.

c. plant in fruit - - - - - 6 .

d. part of the same - - - $\quad-4$.

e. cluster of capsules - $\quad-\quad-\quad$ - 3 .

f. seeds - $-\quad \ldots \quad-1$. 

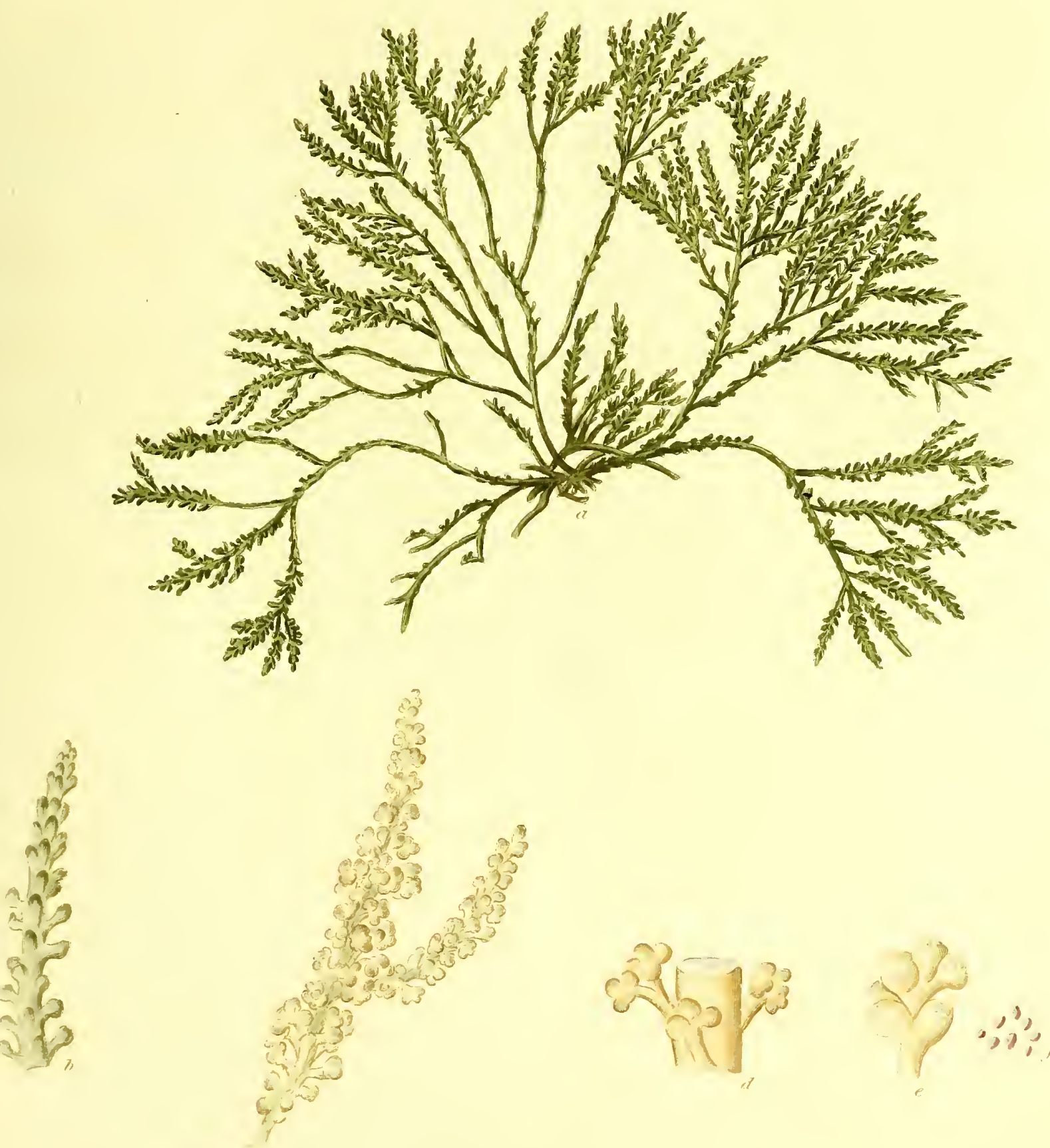

Fucus fronde terete, filiformi, vagè pinnatâ ; ramis horizontalitèr patulis, cylindraceis, obtusis ; ramulis cylindraceis, horizontalibus, abbreviatis, apice capsuifferis; capsulis congestis.

B. major ; fronde ramosissimâ ; ramis elongatis.

Ha bitat in Novâ Zealandiâ. D.J. Banks, Baronet.-In Jamaicâ, D. Wright.- $\beta$ in Mari Rubro. Vicecomes de Talentia.

RADIx repens, e fibris plurimis, crassiusculis, implexis, demùm elongatis, et in novas frondes assurgentibus, constans.

FRONDES ex eâdem basi plurimæ, palmares, vel sesquipalmares, teretes, filiformes, pennæ corvinæ ferè crassitie, plerumque simplices et indivisæ, donec longitudinis dimidium attigerint, ibi sæpe di-tri-chotomæ, et prope apices ramis aliquot vagis, horizontalitèr patulis, sub-distichis, ut plurimum simplicibus, irregularitèr pinnatæ : frondes, quà radici proximæ, sæpiùs nudiusculæ, inde ramulis horizontalibus, cylindraceis, abbreviatis, vix lineam longis, obtusis, simplicibus, truncatis, undiqque densè obsitæ.

FRUCTIFICATIO terminalis in ramulis, qui tunc intumescunt, et tubercula tria, quatuor, vel interdum sex, septemve, globosa, congesta, sessilia, exigua ferunt : semina in singulis aliquot subrotunda, figuræ tamen sub lente incertæ, pro capsulæ ratione magna, purpurascentia.

Co Lor dilutè fuscus, purpurascente tinctus, subdiaphanus.

SUBSTANT1A cartilaginea, pulposa; exsiccate cornea.

$\beta$ magnitudine et crescendi modo insignitèr differt: longitudo plusquam pedalis, crassities pennæ anserinæ; frons. a radice usque ramosissima, in ramos longos sub-fastigiatos abnormitèr divisa, ramulis a basi ad apices vestita.

Stirpem hanc, ab omuibus quantum reperio, auctoribus prætermissam, hìc pro novâ specie proponere sum ausus; nomenque indidi ab eâ depromptum similitudine, quam, si parva licet componere magnis, formầ præ se fert planta fructifera cum Thyrsis quibus Mænades in Bacchanalibus uti solitæ. Arctissimam habet cum F. spinoso affinitatem, sed, ut sub illâ specie jamjàm cst observatuni, ramulorum forma et capsulæ congestæ distinguunt : his quoque nituntur characteres specifici naximè essentiales, et qui ad dignoscendum a $F$.pinnatifido, e cujus varietatibus quibusdam primo aspectu non absimilis, semper valebunt, A reliquis hactenùs descriptis Fucis satis diversus.
a. F. thyrsoides, sterilis, magn, nat.
b. ejusdem ramus, magn. auct. - $\quad-6$.
c. stirps fructifera - - - - 6 .
d. ejusdem portio - $\quad$ - $\quad$ - $\quad 4$.
e. capsularum racemus - - - - 3 ,
f. semina - - + - = 1. 
Fucus pinnatifidus, frond compressed, cartilaginous, branched; branches mostly alternate, doubly pirnatifid; ramuli blunt, callous; capsules ovate, sessile, and naked seeds on the ramuli.

Fucus pimnatifidus. Lin N. Syst. Nat. Ed. Gmel. II. p. 1385. Fl. Ang. p. 581 . Fl. Scot. p. 953. Linn. Trans. III. p. 167. Wiтн. IV. p. 106. Ner. Brit. p. 48. t. 11. Syn. Fuc. II. p. 267. Eng. Bot. XVII. t. 1202. Esper, Ic. Fuc. II. p. 44. t. 132. Fl. Fr. Ed. 2da. II. p. 30.

F. corymbiferus. Esper, Ic. Fuc. I. p. 196. t. 94. (excl. syn.)

F. corymbifer. Wulfen, Crypt. Aquat. n. 32. (excl. syn. Ginel.)

F. multifidus. Fl. Ang. p. 581 .

F. membranaceus acaulis angustior, foliis palnec ferè in modum divisis, marginibus laciniatis et veluti crispis. Monis. Hist. Ox. III. p. 646. s. 15. t. 8. f. 2 .

F. Dealcnsis Pedicularis rubrifolio. Ra11 Syn. p. 48. n. 37.

F. ramosns piperis sapore. Ra1ı Syn. p. 51 . n. 55.

5. Osmunda; frond flat, generally undivided; ramuli short and multifid.

F. pimnatifidus. B. Syn. Fuc. II. p. 267.

F. Osmunda. Linn. Syst. Nat. Ed. Gneel. II. p. 1985. Gmelin, Hist. Fuc. p. 155. t. 16. E. 2. Ner Brit. p. 46. t. 11. Esper, 1c. Fuc. I. p. 121. t.62. Fl. Fr. Ed. $2 d a$. II p. 31.

F. filicinus. F\%. Scot. p. 954. (excl. syn. Huds.)

r. augustas; frond roundish; ramuli cylindrical, thickened upwards, clustered, generally simple.

F. pimnatifidus. $r$. Syn. Fuc. II. p. 268.

F. pimnatifidus. G M ELIN, Hist. Fuc. p. 156. t. 16. f. 3.

F. hybridus. Fl. Fr. Ed. $2 d a$. II. p. 30.?

8. temnissimus; frond flat; ramuli very thin, and much branched; the branches divaricated.

F. pimatifidus. So Syn. Fuc. II. p. 268.

s. muricatus; frond roundish ; ramuli cylindrical, clustered, generally simple; the stem and branches here and there rough with extremely short rudiments of ramuli.

$\zeta$. major; frond roundish; ramuli short, erect, every where imbricated.

$\alpha, \beta$, and $\gamma$ are sufficiently common on the shores of the British Isles, and France, and in the Mediterranean.$\delta$ on the coasts of Devonshire and Cornvall. Mr. Stackhouse and Mrs. Griffiths. ${ }_{E}$ in the Red Sea. Vis. count Valentia. - $\zeta$ on the shores of Egypt. Sir Joseph Banks.

Annual. July-September.

Roor, an expanded disk, here and there furnished with a few short creeping fibres.

FrovDs, numerous from the same base, growing in tufts, from three to seven, or even nine inches long, every where compressed, and preserving from root to summit an equal width of about one line. The mode of growth is different in different individuals, but in general the stems are twice or thrice dichotonous with branches of nearly equal height; sometimes they are altogether undivided. In its early stage the plant is pinnatifid throughout its whole length; when more advanced, it becomes naked towards the base, but in the upper part, and at least from the middle upwards, it is constantly pinnatifid, with branches all disposed in the same plane, distichous, patent, mostly alternate, separated by a short but very uncertain space, sometimes long, and again divided in a similar manner, sometimes short and simple; the apices always are rounded; the ramuli short, obtuse, most frequently simple, but sometimes multifid.

Fructification, of two kinds, each situated on the ramuli, either terminal or lateral ; the one consisting of ovate, pale, diaphanous, sessile capsules, about the size of poppy seed, containing a few brown pyriform seeds; the other of naked, brown seeds, of very uncertain form, scattered over the ramuli, and immersed in their very substance.

COLOR, purplish, tinged with brown, somewhat transparent; when turning to decay pale pink; if exposed to the sun, a * dirty greenish yellow.

Su bsta NCE, cartilaginous, juicy; thin and membranous after drying.

$\beta$ has a frond of nearly the same length as $\alpha$, not however every where linear and compressed, but flat, and wider towards the centre, where its diameter frequently equals three or four lines; nor is the stem divided into several long branches in a pinnated manner, but is beset with extremely short distichous, generally multifid ramuli : the color is a deep purplish brown.

In $\gamma$ the frond is about two inches long, roundish, filiform, scarcely thicker than a sparrow's quill, in its lower part naked, in its upper, furnished with long, simple, crowded ramuli, cylindrical, but slightly thickened towards their apices, and less regularly distichous than in the two preceding varieties : the color is a pale puplish, very fugitive.

$\delta$ is a small variety, scarcely above an inch long; the stem flat, about a line wide; the ramuli distichous, mostly alternate, three or four times narrower than the stem, and multifid, with remarkably divaricated segments.

The red color of $\varepsilon$ makes it a beautiful plant: the mode of growth is the same as in $\gamma$; the frond roundish, three or four inches long; the stem and branches here and there rougl with very short roundish ramuli, scarcely discernible in a dried state without the aid of a glass.

- Gmelin Iightfoot, and Decandolle have regarded this as the proper hue of the plant, which is certainly erroneons. Wulfen, whose deacription is in other respects, a usual, excellent, has erred surprisingly, in saying that the color is " at first green, then greenish red, and, when dry, blackigh.", 

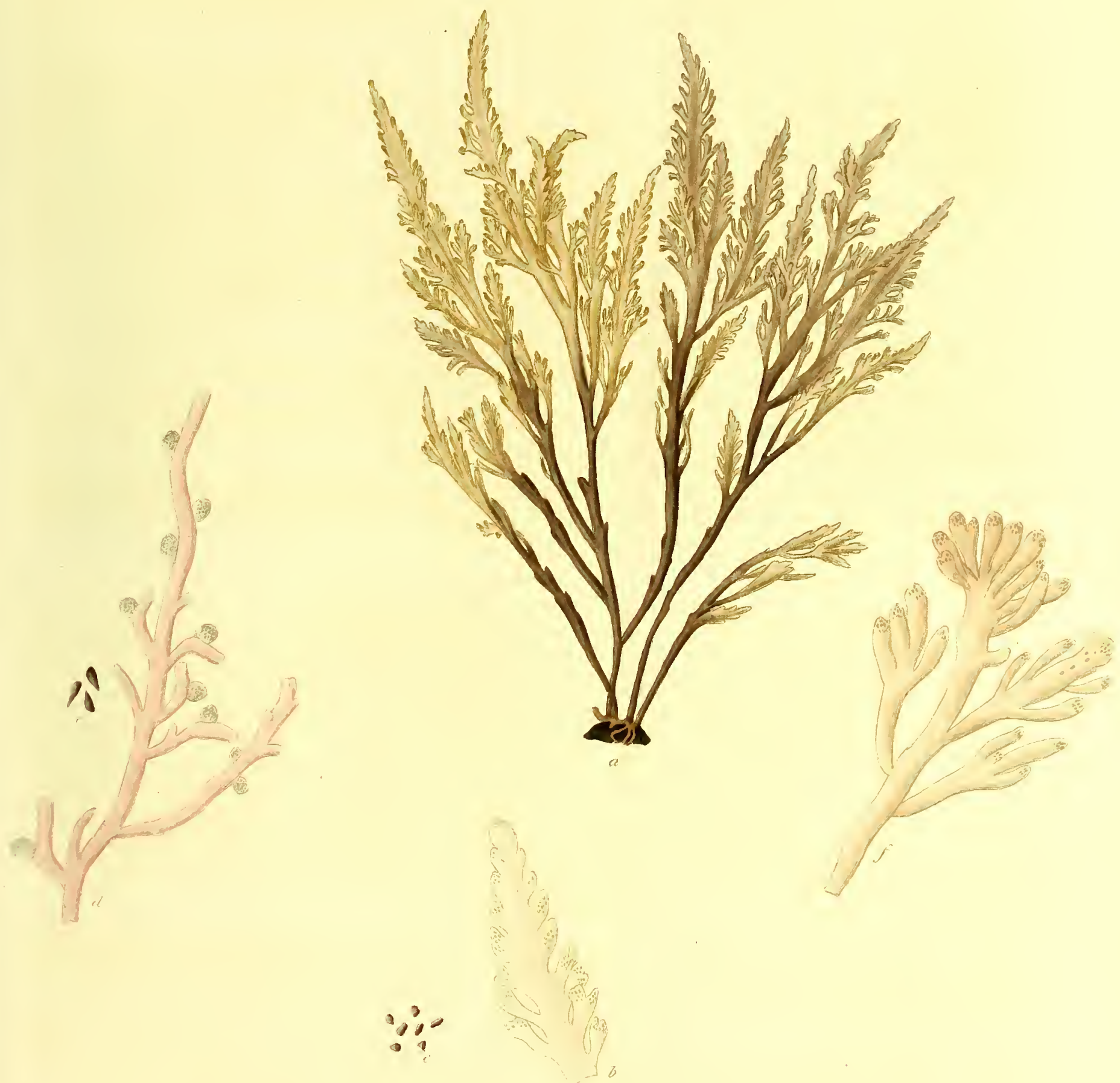
$\xi$ is thicker and larger than all the rest: its frond about five inches long, of the size of a goose-quill, roundish, much and irregularly branched; its ramuli short and erect, not disposed, as in the others, in a distichous, but rather in a tetrastichous order, or imbricated on all sides : the color is purplish, inclining to livid.

The specimens of Fucus pimatifidus here figured unay be regarded as intermediate between the varicties $\alpha$ and $\beta$, and may serve to illustrate the transition of its form from one of these appearances to the other. That a plant so.extremely liable to such striking variations should have been divided by preceding authors into a number of species is far from being matter of astonishment; it would have been more surprising if it had not been so ; but at the same time, I am fully persuaded from a long and attentive observation, as well is from the comparing of many specimens, that the whole of what is here included under it form in reality but one individual. I have noticed in all the varieties (excepting a alone) the double fructification, similar to that already described under $F$. Hypoglossum and ruscifolius, nor have I any doubt of its extending over a considerable family of the Fuci. The taste of $\boldsymbol{F}$. pinnatifidus is singularly hot and biting, and the smell far from pleasant, whence the Scotch have distinguished it by the name of $\dot{P}$ epper $\dot{D}$ ulse, but this, according to Lightfoot, does not prevent their eating it as a salad. I ought to mention, from my own observation, that this flavor is by no means constantly to be perceived, so that $\mathrm{Mr}$. Stackhouse's attempt to separate $F$. pinnatifidus and Osmunda, on the ground of one being tasteless and the other acrid, necessarily fails. Among the numerous varieties of the present Fucus, none in point of beauty or elegance of form can vie with the Osmunda of Gmelin, the appearance of which, as has been justly remarked in the Nereis Britannica, is singularly handsome, and bears considerable resemblance to the fructified apex of Osmunda regalis, from which circunstance it derives its name. Stackhouse's var. $\beta$ " which covers the rocks like a moss with a thick carpeting, and does not rise above an inch in height," I am persuaded, as well from his figure as from specimens sent by himself, is nothing more than the early state of the plant. There is some general resemblance between $F$. pinnatifidus and $F$. dentatus, which has led to the latter being figured under the name of the former in the Flora Danica : their mode of growtl, however, texture, and fruit are too different for it to be necessary to dwell on the subject. Between the present and following species there is a much closer affinity, and on this some remarks will be found under $F$, obtusus. The error of Wulfen and Esper in confounding it with $F$. corymbiferus is really surprising. With regard to $F$. hybridus, of Decandolle, I would not venture to say any thing positively; for, though I have been led by the description to refer it to my variety $\gamma$, I have done it with doubt, on account of Gmelin's t. 16. f. 3. being quoted in the Flore Française under F. pinnatifidus. May it not possibly belong to F. dasyphyllus?

a $F$. pinnatifidus, natural size.

b. apex of frond with scattered seeds, magnified $\quad-6$.

c. seeds - - - - - - - - i.

d. variety with capsules - $\quad$ - $\quad-\quad-\quad-6$.

e. seeds - - - - - - - - 1 .

f. piece of variety $\gamma$ with scattered seeds - $\quad$ - 4 . 
Fucus fronde compressâ, cartilagineâ, ramosâ; ramis sub-alternis, decomposito-pinnatifidis; ramulis obtusis,

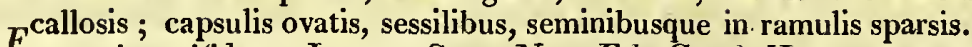

ucus pinnatifidus. Linn. Syst. Nat. Ed. Gmel. II. p. 1385. Fl. Ang. p. 581. Fl. Scot. p. 953. Linn. Trans. III. p. 167. Wrтн. IV. p. 106. Ner. Brit. p. 48. t. 11. Syn. Fuc. II. p. 267. Eng. Bot. XVII. t. 1202. EsPER, Ic. Fuc. II. p. 44. t. 132. Fl. Fr. Ed. 2da. II. p. 90.

F. corymbiferus. Es PER, Ic. Fuc. I. p. 136. t. 94. (excl. syn.)

F. corymbifer. Wulfen, Crypt. Aquat. n. 32. (excl. syn. Gmel.)

F. multifidus. Fl. Ang. p. 581 .

F. membranaceus acaulos angustior, foliis palme ferè in modum divisis, murginibus laciniatis et veluti crispis. Moris. Hist. Ox. III. p. 646. s. 15. t. 8. f. 2.

F. Dealensis Pedicularis rubrifolio. Rax1 Syn. p. 48. n. 37.

F. ramosus piperis sapore. RaII Syn. p. 51.n. 55.

ß. Osmunda; fronde planâ sub.indivisâ ; ramulis brevibus multifidis.

F. pinnatifidus. $\beta$. Syn. Fuc. II. p. 267.

F. Osmunda. Linn. Syst. Nat. Ed. Gmel. II. p. 1385. Gmelin, Hist. Fuc. p. 155. t. 16. f. 2. Ner.

Bri. p. 46. t. 11. EsPe R, Ic. Fuc. I. p. 121. t. 62. Fl. Fr. Ed. 2da. II. p. 31.

F. filictimu. Fl. Scot. p. 954. (excl. syn. Huds.)

r. angustus; fronde teretiusculâ; ramulis cylindraceis, sursùm incrassatis, confertis, sub-simplicibus.

F. pinnatifidus. $\gamma$. Syn. Fuc. II. p. 268.

F. pinnatifidus. GMelin, Hist. Fuc. p. 156. t. 16. f.s.

F. hybridus. Fl. Fr. Ed.2da. II. p. so.?

8. tenuissimus; fronde planâ; ramulis ramosis, divaricatis, tenuissimis.

F. pinnatifidus. \& Syn. Fuc. II. p. 268.

.. muricatus; fronde teretiusculâ; ramulis cylindraceis, confertis, simpliciusculis ; caule ramisque ramulorum rudimentis brevissimis hìc illic scabris.

そ. major ; fronde teretıusculâ ; ramulis abbreviatis, erectis, undique et ubique imbricatis.

HA BITAT, $\alpha, \beta$, et $\gamma$ in Britanniarum, et Gallize oris, necnon in Mari Mediterraneo, satis copiosè._ $\delta$ in Connubix et Devonia oris. D. Stackhouse et $D^{n a}$ Griffiths.—ః in Mari Rubro. Vicecomes de Valentia.— $\zeta$ in Egypti oris. D. J. Banks, Baronet.

Annua. Auctumno fert fructum.

RADIX discus explanatus; fibris tamen aliquot brevibus, repentibus hìc illic instructa.

FrONDES ex eâdem basi plurimæ, cæspitosæ, longitudine palmares, vel spithameæ, interdùm etiam dodrantales, ubique compressæ, crassitiemque æqualem unius circitèr lineæ a radice ad apicem servantes. Crescendi modus non omnibus idem; sæpissimè tamen caules bis terve sunt dichotomi, ramis sub-fastigiatis; aliquando omnino indivisi evadunt; stirps junior per totam longitudinem pinnatifida; adultior basin versus denudata; semper autem in parte superiore, et ad minimum a medio usque ad apices pinnatifida, ramis in eodem plano progredientibus, distichis, patulis, sub-alternis, spatio inter singulos brevi, attamen incertissimo, nunc elongatis, iterum atque iterum simili ratione divisis, nunc brevibus, simpliciusculis : apices semper sunt rotundati: ramuli breves, obtusi, ut plurimum simplices, quandoque multifidi.

FRUCTIFICATIO duplex; utraque in ramulis sita, nunc terminalis nunc lateralis; hrec e capsulis constans ovatis, diaphanis, pallidis, papaveris seminis magnitudine, sessilibus, semina aliquot fusca pyriformia includentibus; illa $\mathrm{e}$ seminibus nudis, fuscis, figuræ perquàm variæ, per ramulos sparsis, et in ipsâ substantiâ immersis.

Color purpurascens, fusco tinctus, subdiaphanus; marcescentis dilutè roseus; Soli exposita $\mathbf{e}$ * luteo sordidè virescens.

SuBSTAN11 a cartilaginea, succoša; exsiccate tenuis, membranacea.

$\beta$ frondem habet ejusdem ferè quæ in a longitudinis, non tamen ubique linearem et compressam, sed planam, et centrum versus dilatatam, ubi sæepe trium quatuorve linearum est diametro; nec caulis in ramos multos longos pinnatìm finditur, verùm ramulis brevissimis, distichis, ut plurimum multifidis, cingitur : color intensè purpurascens.

Frons in $\gamma$ circiter bipollicaris, teretiuscula, filiformis, pennâ passerinâ vix crassior, infernè nuda, supernè ramulis longis, simplicibus, approximatis, apices versus levitèr incrassatis, minùs regularitèr quam in varietatibus præcedentibus distichis obsita : color dilutè purpurascens, citissimè evanidus.

$\delta$, quæ pusilla est varietas, et vix pollicem unum longitudine superat, caule gaudet plano, circiter lineam lato, ramulisque sub-alternis, caule ter quater angustioribus, multifidis, distichis, segmentis insignitèr divaricatis.

\& planta est pulcherima ob colorem rubrum ; crescendi modo eodem qui in $\gamma$, fronde teretiusculâ, palmari, vel sesquipalmari, caule ramisque hic illic muriculatis ramulis brevissimis subrotundis, vix nisi lentis ope in exsiccata conspiciendis.

* Hunc pro genuino plantæe colore habent Gmelinus, Lightfootius, et Decandollius, quod tamen certè ex errore creditum. "Colorem prinùm viridem, seriùs e viridi ıufescentem, per desiccationem nigrescentem," quod mireris, dixit Wulfenius, cujus descriptio cảteróquin pro more, optinga. 
$\zeta$ omnibus crassior et major, fronde circitèr sesquipalmari, pennæ anserinæ crassitie, teretiusculâ, ramosissima, ramulis brevibus, erectis, non, ut in reliquis, distiche, sed potiùs tetrastichè, vel undique dispositis: color purpurascens magis ad lividum vergens.

Fuci pinnatifidi exemplar hic depictum inter varietates a et $\beta$ locum quasi medium obtinet, et quomodo stirpis natura ab hàc in illam transeat non malè exprimit. Plantam mutationibus tantoperè obnoxiam in plures ab auctoribus distribui species nequaquàm mirum; esse tamen omnes quas hìc recensui reverà easdem, re diu observatâ pluribusque collatis exemplaribus, pro certo habeo. Fructum duplicem, ejus sub $F$. Hypoglosso et ruscifolio jan in hoc opere descripti similem, in singulis, var. $\varepsilon$ exceptâ, vidi, nec dubito quin per magnam Fucorum familiam diffundatur. Sapor F. pirinatifidi mordax piperatus, odor quoque ingratus, unde apud Scotos nomen "Pepper Dulse" obtinuit, quod tamen, teste Lightfootio, neutiquadm prohibet quo minus ab iis oleris loco sæpe comedatur: nec ut ipse observavi, hic sapor semper adest, unde Stackhousii, $F$. pinnatifidum et Osmundam, quia ille gustatu acer, hic prorsùs insulsus, disjungere quærentis, nil valet discrimen. Inter omnes hujus Fuci varietates formæ pulchritudine et elegantiâ longè eminet Gmelini Osmunda, cujus, ut notavit Stackhousius, speciosa admodùm frondis forma, floridum Osmunda regalis apicem non male referens, unde quoque nomen. Varietas $\beta$ in Nereide Britannicâ descripta, quæ " rupes musci ad instar operit cæespite densissimo, altitudinis tamen vix uncialis," cùn ex icone, tùm e speciminibus ab ipso auctore missis, plantæ junior status tantummodd mihi videtur. Interest quiddam inter $\boldsymbol{F}$. pinnatifidum et $\boldsymbol{F}$. dentatum similitudinis, et hic illius nomine in Florâ Danicâ depictus extat : crescendi autem modo, texturâ, et fructu satis superque discrepant. Longè propiorem habet hæc species cum insequente affinitatem, de quâ sub $F$. obtuso erit dicenduin. Wulfenium Fsperumque cum $F$. corymbifero confudisse sanè miror. De F. hybrido Dec. nihil pro certo affirmare ausim: descriptione adductus sub varietate $\gamma$ citavi, dubius tamen, qquia Gmelini t. 16. f. 3. ad Fucorum suum pinnatifidum retulit.-fierine potest ut ad F. dasyphyllum pertineat?

a. F. pinnatifidus, magn. nat.

b. frondis apex cum seminibus sparsis, magn. auct. - 6 .

c. semina - - - - - - - 1.

d. F. pinnatifidi varietatis portio cum capsulis -6.

e. semina - - - - - - - - 1 .

f. varietatis $\gamma$ portio cum seminibus sparsis - - 4 . 
Fucus obtusus, frond cartilaginous, cylindrical, filiform, repeatedly pinnated; branches generally opposite ; ramuli cylindrical, short, between horizontal and patent, truncated; capsules ovate sessile, and naked seeds on the ramuli.

Fucuis obtusus. Fl. Ang. p. 586 . Linn. Trans. III. p. 191. 'Weтr. IV. p. 119. Syn. Fuc. I. p. 49. VIrLtey. t. 8. Eng. Bot. XVII. t. 1901. Fl. Fr. Ed. 2da. II. p. 32.

F. spinosus. WulfeN, in Jacq. Coll. III. p. 156. t. 15. f. 1. (excl. Syu.) Wu lren, Crypt. Aquat. n. 33 . (excl. Sya. Linn. et Burm.) Es PE r, Ic. Fuc. I. p. 76. t. 36. (excl. Syn. Linn. et. Burm.)

F. gelatizosus. Fl. Atl. II. p. 427 .

F. papillosus. ForsKA L, Fl. Egypt. p. 190.

F. pistillaris. Wulfen, Crypt. Aquat. n. 34.? (excl. Syn. Gmel.)

3. hybridus; frond almost cylindrical, sub-gelatinous; ramuli slightly attenuated at the base, and rounded at the apices.

F. obtusus, в. Syn. Fuc. 1. p. 44.

y. uvifer; ramuli clustered, short, at their apices rounded and club-shapect.

F. zuvifer. ForsKÅL, Fl. Egypt. p. 192.?

On the southern shores of England, especially at the Isle of Wight; and on the coasts of Ireland, France, Spain, and Egypt.-In the Adriatic. Wulfen.-New Zealand. Sir Joseph Banks. $-\beta$ on the southern shores of England.-(Both varieties are generally found parasitical on the stenss of $F$. digitatus, or some of the larger. Fuci.)

Annual. May-October.

Root, a callous disk, occasionally provided with a few thick creeping fibres.

Fronns, in general solitary, but sometimes growing two or three, or even more, together, from three to six inches long, filiform, cylindrical, about the thickness of a sparrow's quill, between flexuose and erect, rising with an undivided stem, loosely beset with branches, disposed in a direction between patent and horizontal, generally distichous, and most frequently placed either in pairs or by threes, though sometimes alternately, the lowest longest, and three or four inches long, the rest gradually decreasing, till the uppermost scarcely exceed! two lines: all the branches are truncated at their apices, and irregularly pinnated with one or two series of others similar to them, but smaller, placed at short distances, so that the appearance of the whole plant is tri-, or quadri-, pinnate; the ramuli are very short, numerous towards the ends of the branches, somewhat thickened upwards, truncated, mestly simple, but, "occasionally," to use the words of Wulfen, " near their extremities proliferous on either side, with a new denticle similar to them, so that they may be called trifid or tridenticulated."

Fructinication, of two kinds, both placed near the extrenities of the branches; the oxe, consisting of ovate sessile capsules, about the size of poppy. seed, containing a few brown: pyriform. seeds, surrounded with a pellucid limbus; the other, of five or six naked oblong seeds, of a deep flesh color, immersed in the frond itself.

CoLon, a beautiful pinkish yellow, semitransparent, extremely fugitive; if exposed to the sun, a dirty white ; when decaying, pink.

Substa NCE, cartilaginous, flexible, tender; in old and dry specimens somewhat rigid and tough; in the young plant approaching to gelatinous.

In $\beta$ the frond is thicker throughout than in $\alpha$; and the ramali are longer, and not truncated at their apices, but slightly rounded. It is almost intermediate between F. obtusus and dasyphyllus, but, in my opinion, certainly $a_{\text {. }}$ variety of the former, and sufficiently distinct from the latter.

$y$ is larger than either of the preceding varieties: its stem is equal in size to a crow's quilt, and the shape of its branches bears some resemblance in miniature to the clusters of Vitis vinifera. I have at present seen only: one. specimen of it, which is preserved in the Elisian Herbarium without any locus natalis annexed.

The whole catalogue of Fuci scarcely affords an instance of a single species, which, at the same time that it is $\mathrm{z}$ : native of such distant parts, still, whether found towards the novthern or southern poles, or within the tropics, seems liable to so little variation, either in its form or size as the present. It appears to be most abundant on the coasts of the Mediterranean and Adriatic, on which account it is singular that it should have been entirely omitted by Gmelin, who described so many Euci from those seas. Its nearest affinity is with $F$. pinnatifidus and dasyphyllus, to the latter of which it approaches by its own variety $\beta$, and to the former by the var. $\gamma$ of that species; but it is vistinguished from both by the form and horizontal direction of its extremely short, linear, and remarkably blunt ramuli. The color, too, and habit are unlike. M. Decandolle is of opinion that is allied to $F$. corneus and hypnoides of Desfontaines, to neither of which, however, does it bear the least resemblance, either in color, substance, mode of growtb, or fructification. When fresh it has in general a strong smell of violets, but this, as was observed by the late Col. Velley, is by no means constant.

a. F. obtusus. natural size.

b. upper part of the frond, with naked seeds, magnified - 6 .

c. seeds -

d. part of the frond of var. $\beta$ with capsules, natwral size.

e. smaller part of the same, magnified - _ - - 3.

f. seets - - - - - - - - 1. 


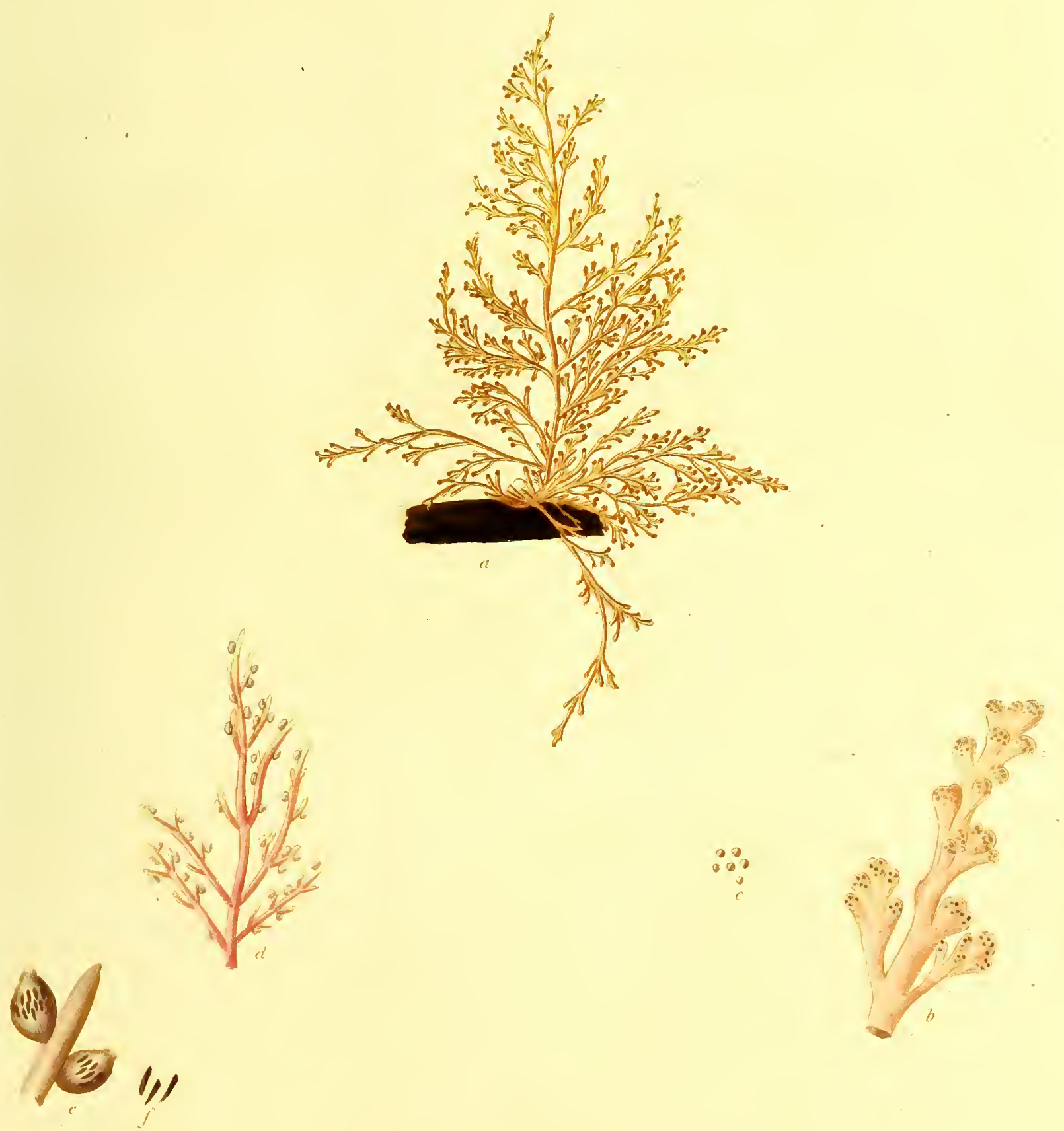


. 


\section{1.-F U CUS OBTUSUS.}

Fucus fronde cartilagineâ, tereti, filiformi, decoinposito-pinnatâ ;; ramis sub-oppositis; ramulis cylindraceis, abbreviatis, horizontalitèr patulis, truncatis ; capsulis ovatis sessilibus, seminibusque in ramulis sparsis.

Fucus obtusus. Fl. Ang. p. 586 . Linn. Trans. III. p. 191. Wıтн. IV. p. 119. Syn. Fuc. I. p. 43. VELLEY. t. 3. Eng. Bot. XVII. t. 1201. Fl. Fr. Ed. 2da. II. p. 32.

F. spinosus. Wulfen, in Jacq. Coll. III. p. 156. t. 15. f. 1. (excl. Syn.) WulfeN, Crypt. Aquat. n. 33, (excl. Syn. Linn et Burm.) EsPer, Ic. Fuc. I. p. 76. t..36. (excl. Syn. Linn. et Burm.)

F. gelatinosus. Fl. Atl. II. p. 427.

F. papillosus. Forsк̊̊ , Fl. AEgyt. p. 190.

F. pistillaris. WU U RE N, Crypt. Aquat. n. 34.? (excl. Syn. Ginel.)

ß. hybridus. Fronde teretiusculâ sub-gelatinosâ; ; ramulis. basi levitèr attenuatis, apice rotundatis. F. obtusus. $\beta$. Syn. Fuc. I. p. 44 .

y. uvifer; ramulis coufertis brevibus, apice rotundato-clavatis.

F. uvifer. Forsк Å, Fl. Rgypt. p. 192.?

Ha BrT At in Angliæ meridionalis, præsertim ad Insulam Vectis, in Hiberniæ, Galliæ, Hispaniæ, et Egypti oris.In Mari Adriatico. Wulfen.-In Novâ Zealandiâ. D. J. Banks, Baronet. $-\beta$ in Angliæ meridionalis oriš (Utraque varietas in stipitibus Fuci digitati, vel alicujus e Fucis majoribus plerumque parasitica.).

Annua. Æstate fert fructum.

RADIX callus explanatus, fibrầ unâ alterầve crassẩ repente interdùm instructus.

FroNDEs nunc solitariæ, nunc binæ ternæve, quandòque ex eâdem radice plurimæ, palmares, aut semipedales, filiformes, teretes, pennæ passerinæ crassitie, flexuosè erectæ, caule assurgentes indiviso, ramis obsito horizontalitèr patulis, sæpiùs distichis, plerumque oppositis, vel ternis, rariùs alternis, laxiusculè dispositis, inferioribus longissimis, tri-quadri-pollicaribus, hìnc sensìm decrescentibus, summis vix bilinearibus: rami onnes apice sunt truncati, aliis sibi similibus, sed minoribus, iterum atque iterum brevia per intervalla vagè pinnati, ut toti plantæ facies decomposito-pinnata evadat : ramuli brevissini, ramorum ad apices frequentes et approximati, sursim tantispèr incrassati, truncati, plerumque simplices, tamen et "sub apice interdùm," ut Wulfenii verbis uter, "novo utrinque aucti consimili. denticulo ut jam trifidi etiam, aut tridenticulati dici possunt."

Frvetificatio duplex, utraque ramorum prope extremitates sita, hac e capsulis ovatis, sessilibus, papaveris seminum magnitudine, semina aliquot fusca angustè pyriformia limbo pellucido cincta includentibus; illa constans e seminibus quinque vel sex nudis oblongis, coloris intensè carnei, îl ipsâ fronde immersis.

Color amoenè e carnen flavescens, subdiaphanus, fugacissimus; Soli exposita sordidè albescens; marcescentis roseus.

SUbSTA NTI A cartilaginea, lenta, tenera; velusta et exsiccat $a$ rigidiuscula tenax; junioris ad gelatinosam accedens.

$\beta$ frondem habet ubique crassiorem quàm $\alpha$, ramulisque gaudet longioribus, apice non truncatis, sed levitè̀ rotundatis : est inter $F$. obtusum et $F$. dasyphyllum quasi media, illius tanien, uti credo, certè varietas, et satis ab hoc distincta.

y utrâque præcedente est major; caule pennæ corvinæ crassitie, ramis Fitis vinifer a racemos formâ quodammodò referentibus. Exemplar hujus varietatis unicum modd adliuc vidi, quod, loco natali nullo adjecto, in Herbario Ellisiano servatur.

Vix una datur in Fucorum familia species, quæ, marium tam longè dissitorum incola, et quæ, cùm in Septentrionalibus tùm in Australibus terræ plagis, ac inter tropicos, qui dicuntur, eirculos paritèr inventa, formam tamen minds quàm $F$ obtusus mutare videtur. In Mari Mediterraneo et Adriatico copiâ maximâ provenire crederem, quare a Gmelino, qui tot Fucos inde acceptos descripsit, prætervisum miror. Cum $\boldsymbol{F}$. pinnatifido et dasyphyllo summan habet affinitatem, per varietatem illius $\gamma$ ad illam, per varietatem suam $\beta$ ad hanc appropinquans; sed ab utroque ramulorum brevium linearium insignitèr obtusorum forma et horizontalis dispositio distinguunt. Color quoque habitusque diversus. A $\boldsymbol{F}$. corneo et hypnoide Desf. inter quos et lunc nostrum sinilitudinem quandam interesse credit cl. Decandollins, colore, substantiâ, crescendi modo, fructificatione, denique omnibus fcrè modis, differt. Recens odorem violaceum sxpiùs spirat, quod tamen, ut notavit $b$. Velleius, non sempcr adest.

a. F. obtusus, magn. nat.

b. frondis apex cum seminibus nudis, magn. auct. 6 .

c. semina - - - - - _ - J.

d. varietatis $\beta$ portio cum capsulis, magn. nat.

e. ejusdem pars, magn. auct. - - - - 3.

$\mathrm{f}$. semina $\rightarrow+\mathbf{I}_{\mathrm{B}}$ 
Fucus dasyphyllus, frond filiform, cylindrical, branched in an irregularly pinnated manner; branches between horizontal and patent, inostly simple; ramuli cylindrical, scattered, attenuated at the base, proliferous; capsules ovate sessile, and naked seeds on the ramuli.

Fucus dasyphyllus. Woodw. in Linn. Trans. II. p. 239. t. 23. f. 1.-3. Linn. Trans. III. p. 119. Syn. Fuc. I. p. 38. Wiтн. IV. p. 112. Eng. Bot. XII. t. 847.

ß. articulatus; frond jointed; joints short.

On the British coast.-Both varieties among the rejectamenta of the sea at Yarmouth; and on the rocks at Cromer and Sheringham, in Norfolk.-Dorsetshire. Mr. Bryer.-Cornwall."Mr. Stackhouse.-Dawlish. Mr. Pigott.-Lossie-mouth, in Scotland. $M r$. Brodie.

Annual. June-September.

Roor, a thin expanded disk, frequently provided with a few matted creeping fibres.

FronDs, numerous from the same root, growing in tufts, cylindrical, filiform, from three to six inches long, and about the thickness of a blackbird's quill, towards the base and apices acuminated, in other respects of equal size, rising with a stem in general undivided, but sometimes, though seldom, bifid or trifid, beset throughout its whole length with branches between horizontal and patent, most frequeutly alternate, loosely arranged on every side, gradually shortening from the lowest upwards, but of most uncertain lengths, in some specimens three inches or more, in others scarcely a nail long: these branches are again in a similar manner furnished with a series of smaller ones, and these again sometimes, but not often, with a third: the last branches, or ramuli, in their earliest state are roundish, after which they become oblong, at their bases they are always remarkably attenuated, at their apices obtuse, their direction is horizontal, and they are not uncommonly proliferous with one or two smaller ones.

Fructification, of two kinds, each placed on the ramuli, or at the extremities of the branches; the one composed of ovate, sessile capsules, about the size of poppy seed, of a light red color, paler than the rest of the frond, and containing a mass of deep-red pyriform seeds; the other, of nakcd spherical seeds, immersed in the substance of the frond.

CoLOR, pale red, tinged with brown, extremely fugitive; when dry, much darker, and often altogether brownish; as it turus to decay, of a dirty whitish hue.

SuBSTANCE, between cartilaginous and gelatinous; when perfectly fresh not without a remarkable elasticity, which, however, it soon loses : it dries to a thin membrane.

$\beta$ differs from $\alpha$ in no respect except the jointed structure.

With regard to the jointed appearance of this Fucus, figured at the letters $g, h, I$ am altogether at a loss what opinion to entertain. I had noticed it for many years, but witlout bestowing upon the subject any particular attention, and even at the time of writing the Synopsis of the British Fuci, had regarded the joints as having no existence farther than in the exterior of the plant, and as being nothing more than the casual effect of advanced age or accident. A more attentive examination, however, has proved that the froud in every stage of its growth is internally divided into short and regular joints by real septa; but, what is most extraordinary, that these septa are to be found only in certain individuals, the number of which is not so great as that of those which are destitute of them. This circumstance would almost be sufficient to justify the opinion that there are in fact two species, the one jointed, the other not so, an opinion to swhich I should be most unvilling to lend an assent, as in every other respect the plants wholly agree, and specimens may occasionally be found in which the septa are so obsolete that it would be difficult to decide whether they actually exist or not. The saine too is occasionally observed in other Fuci, on which accounts, I have considered it as the safest plan to regard the two appearances for the present as varieties, and thus to leave the matter, in hopes that the researches of future Botanists may throw light on this most singular phenomenon. F. dasyphyllus differs from all the Fuci by its oblong, obtuse, and short ramuli, so much attenuated at the base that their connection with the frond is scarcely perceptible : it is a species sufticiently distinguisable at first sight, except from $F$. tenuissimus, which is not more than half as thick, and has its ramuli attenuated and acuminated at either end. It docs not appeas to have been gathered beyond the bounds of Britain, nor can 1 discover that it is known to any forcign author. It was originally found by my friend, Mr. Wigg, and first described by Mr. Woodward. I am assured by Sir T. Frankland, whose opinion is of the highest authority in these points, that the suspicion which $I$ formerly entertained, that $U$. rubens of Hudson is only a synonym of this plant, is erroneous. There is a striking peculiarity in the fructification of F. dasyphyllus, that some of the scattered seeds, when examined under the highest powers of a compound microscope, are quite entire, but others, and these the most numerous, split into three equal parts, with a regularity that it is impossible to consider the effect of accident.

a. $F$. dasyphyllus, natural size.

b. upper part of the frond, magnified

c. ramulus with naked seeds - -

d. seed - - - - -

e. apex of the frond with capsules -
f. seeds -

g. part of the frond jointed -
h. piece of the same, cut through -

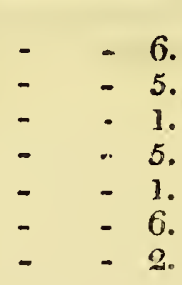



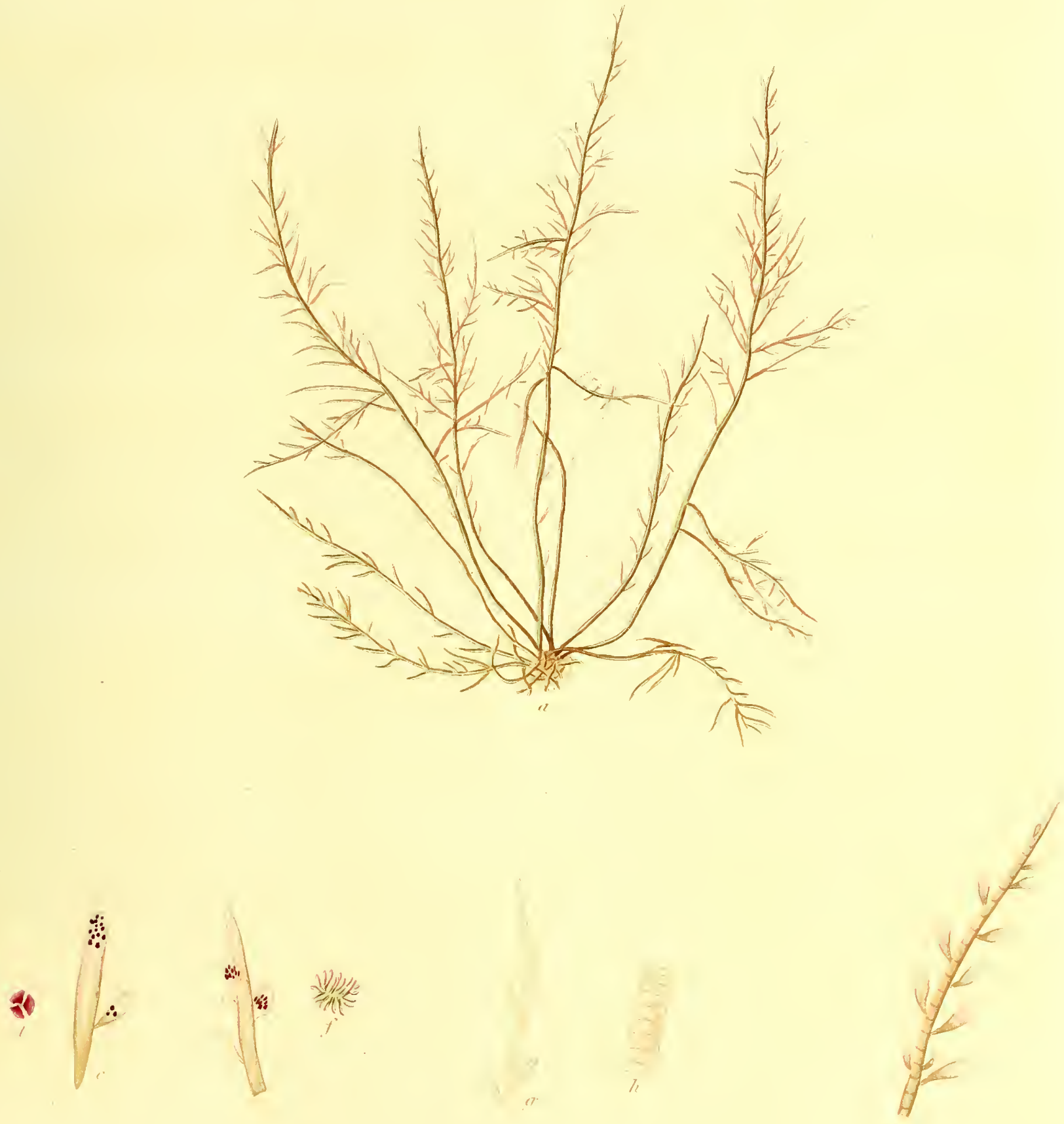

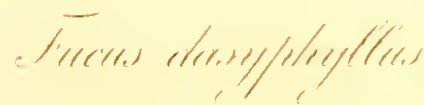


Fucus fronde filiformi, tereti, sub-pinnatim ramosâ ; ramis horizontalitèr patulis, simpliciusculis; ramulis cylindraceis,.sparsis, basi attenuatis, proliferis ; capsulis ovatis sessilibus, seminibusque in fronde sparsis.

Fucus dasyphyllus. Woodw. in Linn. Trans. II. p. 239. t. 23. f. 1-3. Linn. Trans. III. p. 119. Syn. Fuc. I. p. 38. Wiтh. IV. p. 112. Eng. Bot. XII. t. 847.

B. articulatus; fronde articulatâ; articulis brevibus.

HABITAт in Britanniæ oris-Utraque varietas inter rejectamenta maris apud Yarmouth; et in saxis submarinis apud Cromer, et Sheringham, in Norfolciâ.-A pud Weymouth. D. Bryer.-In Cornubiâ. D. Stackhouse. -Apud Dawlish in Devouiâ. D. Pigott.-Apud Lossie-mouth in Scotiâ. D. Brodie.

Annua. Jun.-Septemb.

RADIX discus tenuis, explanatus, fibris repentibus implexis sæpe instructus.

FrONDES ex eâdem basi plurimæ, cæspitosæe, teretes, filiformes, longitudine palmares, vel semipedales, Meruld pennæ crassitie, basin et apices versus acuminatæ, cæteroquin æquales, caule assurgentes plerumque indiviso, rariùs bi-tri-fido, per totam longitudinem obsito ramis horizontalitèr patulis, sub-alternis, undequấque laxè dispositis, a basi surstun brevioribus, longitudinis quam maximè variæ, nunc tripollicaribus et ultra, nunc vix unguicularibus: hi rami iterum simili ratione minorum serie, hique iterum aliquando, nec tamen frequentèr, tertî̀ sunt instructi : rami ultimi, seu * ramuli, xtate primâ subrotundi, mox oblongi, basi semper insignitèr attenuati, apice obtusi, horizontales, uno alterove minore sæpiùs proliferi.

FRUCTIFICATIO duplex, utraque in ramulis, vel ramorum ad extremitates sita; hac e capsulis constans ovatis, dilutè rubentibus, reliquâ fronde pallidioribus, sessilibus, papaveris seminis magnitudine, seminum angustè pyriformium, intensè rubrorum congeriem includentibus; illa e seminibus nudis globosis, in ipsâ frondis substantiâ immersis.

Color dilutè rubens, fusco tinctus, diaphanus, fugacissimus; exsiccata multo intensior, et sæpe totus fuscescens; marcescentis sordidè albescens.

SuBSTA NTIA e cartilagineấ gelatinosa, tenerrima, recentis non sine resiliendi vi quâdam singulari, quam tamen citissimè æemittit; exsiccatce membranacea.

\section{ß.nequaquam ab a differt, structurâ articulatâ demptâ.}

De articulatâ hujus plantæ facie, quam hìc ad literas $g, h$, depingendam curavi, nescio omnind quid dicam aut sentiam. Credideam cùm Fucorum Britannicorum Synopsin scriberem septa specie externâ tantùm existere, et ab xtate provectâ pendere; rem verd magis solicite inquirens, in omni atatis stadio detexi, et stirpis substantiam intùs verè articulatam vidi. Nec tamen sunt articuli in cunctis, vel etiam in pluribus, exemplaribus conspiciendi. Quid ergo ?-an duæ sunt species, hæc articulata, illa continua?-Vix credo; in cæteris enim prorsùs conveniunt, et vidi quorum septa aded erant obsoleta, ut an reipsâ adessent ægrè diceres. In aliis quoque Fucorum speciebus idem sese observandum præstat, quầ de re pro varietatibus in præsens habere tutissimum duxi, sperans Botanicorum posterorum investigationes phænomeno maximè singulari lucem esse objecturas. 'A reliquis Fucis differt $F$. dasyphyllus ramulis oblongis, obtusis, brevibus, basi tantum attenuatis ut per punctum tantummodd minutissimum cum fronde connexi videantur; et est species primo visu ab omnibus dignoscenda, nisi fortè a $F$. tenuissimo, qui duplo tenuior est, et ramulos habet utrinque attenuatos acuminatosque. Extra Britanniæ fines nondum reperiri videtur, nec auctorum exterorum ulli, quantum ego reperi, innotuit. Primus invenit amicissimus D. Wigg, descripsit D. Woodward. Quod in Facorum Britannicorum Synopsi sum suspicatus, Ulvam Hudsoni rubentem hùc pro synonymo adduci debere, est, teste D. Frankland, viro summi in his rebus ponderis, certè ex errore dictum. F. dasyphylli fructificationi illud notatu dignum inest, quædam e seminibus nudis per lentem maximè augentem observatis esse integerrima, reliqua, et ea plurima, in tres aquales partes esse fissa; quod quidem nimis fit ad normam ut casu aliquo evenire credatur.
a. F. dasyphyllus, magn. nat.
b. pars frondis superior, magn. auct. $\quad-\quad-6$.
c. ramulus cum seminibus nudes - $\quad-5$.
d. semen - - - - - -1 .
e. frondis apex cum capsulis - $\quad-\quad-\quad-5$.
f. semina - - - - - -1 .
g. pars frondis articulate - $\quad-\quad-6$.
h. ejusdem portio dissecta - $-\quad-2$.

\footnotetext{
- Hi ramnli, prasertim exsiccati, folia referunt, et ita $\mathrm{D}$. Woodward et aliis Botanicis andiunt; perperàm tamen, cùns nihil sint aliud quam primordia ramorum, in quos progrediente stirpis atate elongantur: malè igitur bie Fucus inter eos foliis distinctis praditos hartenùs enacoerari solet.
} 
Fucus cristalus, frond membranaceous, Aat, veinless, sub-dichotomons; branches alternate, decurrent, somewhat dilated upwards, cleft at the apices; segments short, obtuse, bearing small, globular, sessile capsules.

Pucus (gigartin:ts?) Fl. Dan. t. 394.

B. Valentic; branches all linear : tubercles both lateral and terminal.

$\gamma$. articulatus; branches linear, jointed; joints very short.

F. confervoides. GmeLin, Hist. Fuc. p. 147. t. 15. f. 2.? (according to the figure.)

$\%$ in the Arctic Ocean, near Iceland. J. G. Koenig.- $\beta$ in the Red Sea. Viscount Valentia.- $\gamma$ in the Mediterranean, and in the Bay of Biscay, near Bayonne.' Professor RiLertens.

Moor, an expanded callous disk.

IroNDs, numerous from the same base, growing in tufts, fiat, wholly destitute of veins or midrib, nearly linear, sout two inches long, and scarcely a line wide, divided from the very base throughout, with alternate decurrent branches, again and again divided in a similar manner; their extremities bifid or trifid with extremely short, obtuse, patent segments; their margins quite entire, except that close to the extremities they are occasionally furnished with one or two sniall horizontal teeth : the branches are all slightly dilated upwards.

Fructificdtion, spherical tubercles, so minute as scarcely to be visible to the naked eye, of a deep-red color, sessile on the ends of the frond, and containing several oblong seeds.

Colon, scarlet, tinged with pink, very beautiful; turning, if exposed to the sun, to a dirty yellow, or whitish.

SUBSTANCE, thin, membranaceous, extremely tender.

$\beta$ has a frond consicierably more narrow than $\alpha$, and linear throughout: the tubercles are larger, and frequently placed on the sides as well as the ends, of the snialler branches.

$y$ is of so dark a color, that, unless held to the light, it looks almost black: I have never seen it in fruit: in its form and mode of growth it agrees with $\beta$, but the frond is divided by black lines throughout its whole length into extremely short joints.

For the specimens here represented at the letters $a-f, \mathrm{I}$ am obliged to my friend, Dr. Smith, who kindly communicated them to me from the Linnaan Herbarium, in which repository of Botanical treasures are preserved four pieces of the present plant, all fastened on one sheet of paper, which also contains four morsels of $F$. alatus, and one of $F$. sinuosus. At the bottom of this is written, by Linnæus himself, “ $F$. cristatus," a name which, as I have* elsewhere taken an opportunity of remarking, occurs in none of his works, so that it cannot be doubted but that he either regarded it as a new species, and intended hereafter giving it this title, or that he really meant to have written $F$. crispatus; to which latter opinion I should have no hesitation in acceding, but that the description of $F$. crispatus in the Systema Nature accords better with what has been generally so called by Wulfen and other botanists. $F$. corymbiferus, Gmel. was always regarded as a synonym of the plant before us, till Mr. Brown lately brought from New Holland another species different from this, but altogether agreeing, as well in size and fruit, as in every other particular, with Gmelin's figure. Of this, I trust, that before the conclusion of the present work, I shall, through Mr. Brown's kindness, be enabled to give a representation. Should the three appearances, here considered varietiek, be regarded by future botanists as specifically distinct, I should not feel surprised, nor would I be understood as speaking with any positiveness on the subject of a plant of which $I$ have at present seen very few specimens. Linnæus has united the two first in his Herbarium, and, if we attentively observe their parts, we shall be puzzled to point out any mark of difference between them; though it must be admitted that their habit is dissimilar, and the branches in $\beta$ constantly preserve their linear form without widening upwards. This is a most beautiful and elegant plant, and, should it hereafter prove a distinct species, I should wish it to bear the name of Lord Valentia, who gathered it in the Red Sea, together with a rich harvest of other marine Algæ, and to whom botany in general, and this work in parvicular, lies under many obligations. Dr. Mohr is of opinion that Gmelin's $\boldsymbol{F}$. confervoides ought to be quoted as a synonym of the var. $\gamma$, and the figure, though far from good, certainly agrees in many respects, but the description appears to be designed for a very different plant. In its mode of growth, form, and habit, it agrees with var. $\beta$, but differs in its color and jointed frond. The joints, however, are sometimes wanting, nor onght too much confidence to be placed in then.

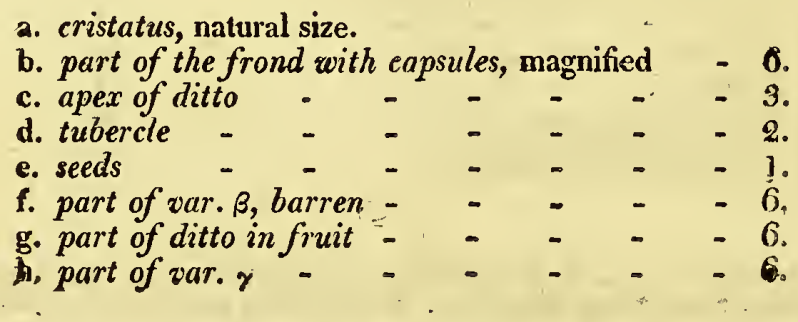

: Syn. Fuc. I. p. 1ă1.
3.

2.

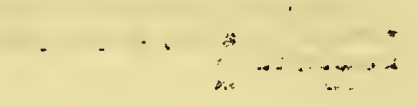



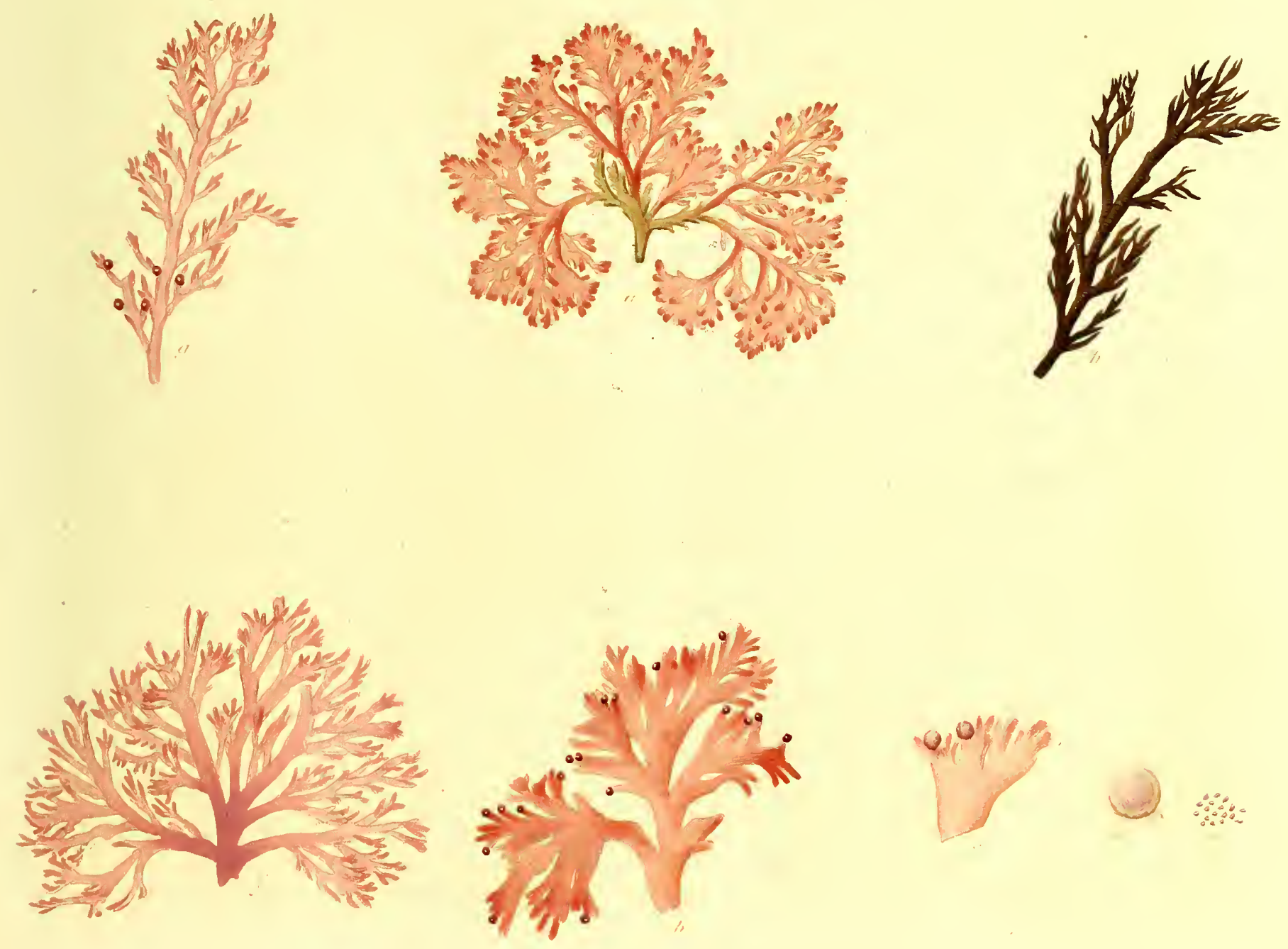

Fucus fronde membranaceâ, planâ, aveniâ, sub-dichotomà ; ramis alternis, decurrentibus, sursùm aliquantulum dilatatis, apice incisis; laciniis brevibus, obtusis, tubercula exigua, globosa, sessilia sustentantibus.

Fucus (gigartinus)? Fl. Dan. t. 394.

ß.Valentia; ramis omnibus linearibus; tuberculis lateralibus terminalibusque.

\%. articulatus; ramis linearibus articulatis; articulis brevissimis. F. confervoides. Gmenin, Hist. Fuc. p. 147. t. 15. f. 2.? (ex icone.)

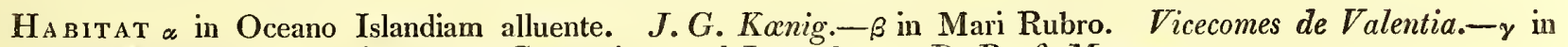
Mari Mediterraneo, et in Oceano Cantabrico apud Lapurdum. D. Prof. Mertens.

RADIX callus expansus.

FroN DES ex eâdem basi plurimæ, cæspitosæ, planæ, venarum costæve expertes, sub-lineares, longitudine bipollicares, latitudine vix unius lineæ, a basi usque ramosæ, ramis alternis, approximatis, decurrentibus, iterum atque iterum simili ratione divisis, apicibus bi- tri- fidis, segmentis perquam brevibus, obtusis, patentibus : margines frondis integerrimi, excepto quòd juxta extremitates dente uno alterove exiguo horizontali sæpe instruantur: rami omnes sursùm aliquantùm dilatati.

FRUCTIFICATIO tubercula sphærica, adeo minuta ut vix nisi oculo armato conspici possint, intensè rubra, frondis apicibus insidentia, et semina plurima oblonga includentia.

Color coccineus, roseo immixtus, amœenissimus; Soli exposita sordidè flavescens, vel albellus.

Substantia tenuis, membranacea, tenerrima.

$\beta$ frondem habet multo angustiorem quam $\alpha$, et ubique linearem: tubercula seminifera sunt majora, nec tantùm ramulorum apicibus insident, sed sæpiùs laterales evadunt.

$\gamma$ coloris est aded intensi, ut, nisi luci objiciatur, nigricans videatur: fructiferam non vidi : formâ et crescendi modo cum $\beta$ convenit; sed frons per totam longitudinem lineis transver salibusatris in articulos brevissimos dividitur.

Exemplaria hìc ad literas $a-f$ depicta cl. Smithii amicitiæ debeo, qui in Herbario Linnæano servata mecum benevolè communicavit, Ditissimus ille plantarum thesaurus quatuor hujus Algæ includit specimina, omnia eidem agglutinata chartæ, quæ quatuor quoque $F$. alati, et unum $F$. sinuosi frustula continet. Ad basin scripserat Linnæus "F. cristatus," quod cùm nomen, ut * alibi occasionem observandi sum amplexus, nuspiam in operibus suis, quantum reperio, occurrat, dubitari nequit quin pro novâ specie mox hoc titulo insigniendâ habuerit, nisi potiùs $\boldsymbol{F}$. crispatum scripsisse voluisse credamus, in quam ire sententiam nullus dubitarem, ni F. crispati in Systemate Natura descriptio illi plantæ cui nomen idem indidit Wulfenius aptiùs quadraret. F. Gmelini corymbiferum sub hâc specie pro synonymo esse citandum diu est a Botanicis creditum, donec nuperrimè aliam Fuci speciem, magnitudine et fructu cum eâ Gmelini omnimodè convenientem et ab hâc nostrâ diversam, e Novâ Hollandiâ redux attulit $\mathrm{D}$. Brown, cujus per benevolentiam, priusquàm hoc opus clauserim, iconem exhibere spero. Si tres illas hìc descriptas varietates specie potiùs distinctas credant Botanici, fatebor libens meum in dubio esse animum, nec de plantâ cujus perpauca modò exemplaria observandi adhuc data est facultas aliquid pervicaciùs affirmare ausim. Linnæus in phytophylacio suo priores duas conjunxerat, et si in earum partes attentè inquiramus vix ullum discrimen reperiemus. Habitus tamen eorum est longè diversus, nec sunt in $\beta$ rami unquam sursùm dilatati : perpulchra quidem est hæc stirps, et, si pro distinctâ olìm sit enumeranda, nobilissimi Vicecomitis de Valentia, qui in Mari Rubro unà cum divite algarum messe legit, et cui, cùm scientia Botanica, tùm præcipuè hoc opus plurimum debèt, nomine insignitam optarem. Ad varietatem $\gamma$ censet Mohrius Gmelini $F$. confervoidem esse adducendum, nec multum sanè repugnat icon, sed descriptio plantam alienam innuere videtur. Colore et specie articulatâ a $\beta$, quâcum crescendi modo, formâ, et habitu convenit, recedit; sed articuli sæpe desunt, neque his nimis fidendum.

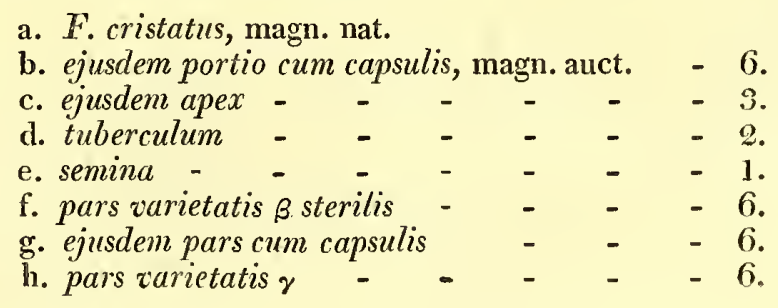


Fucus turbinatus, stem sub-cylindrical, undivided, beset with short simple branches, supporting top-shaped, petiolated vesicles, terminated by a membrane larger than their surface, and toothed at its margin.

Fucus turbinatus. Lrnn. Sp. Pl. II. p. 1629. Syst. Nat. II. p. 715. Syst. Nat. Ed. Gmel. II. p. 1380. Hort. Cliff. p. 4\%8. GMElin, Hist. Fuc. p. 97. t. 5. f. 1. EsPER, Ic. Fuc. I. p. 29. t. 9. VAнL, Skrivt. af Naturhistorie-Selskabet. V. p. 36.

Fucus marinus vesiculas habens membranis extantibus. Slo a f, Hist. Jamaic. I. p. 58. t. 20. f. 6.

Acetabuli marini varietas. Rumpн. Hist. Amboin. VI. p. 85.

B. ornatus; membrane covering the vesicles furnished with a double row of spines, the outer horizontal, the inner erect.

On the shores of the East and West Indies, America, Sumatra, and Kamtschatka; also in the sea by Ceylon, and in the Red Sea.

\section{Perennial.}

Roот, a thill, expanded disk, sending out several long, branched, incurved fibres, which adhere closely to the rocks.

FRONDS, numerous from the same base, a foot, or foot and half, sometimes even two feet, or more, long; provided with a filiform, flexuose undivided stem, about the size of a crow's quill, between cylindrical and compressed, beset from the root to the apex with branches disposed in an irregularly spiral direction, much more numerous in some specimens than in others: branches all simple, those nearest the root in general longest, and three inches or more long, the rest gradually shortening, so that the outline of the whole plant is sub-pyramidal; near their bases they are naked, or only rough with the remains of broken peduncles, the rest of them is covered with vesicles and fruit, as is also the top of the stem.

VESICLES, supported upon a compressed petiolus about three lines long, perforated with mucifluous pores, topshaped, triangular, (the angles sometimes acute, slightly winged, and toothed, at other times nearly obsolete, hollow within, terminated by a triangular or cordate membrane, either flat or convex, wider than the vesicles, and notched all round, with minute teeth.

Fructification, growing on the branches, and on the petioli of the vesicles, clustered, composed of cylindrical receptacles, a line, or line and half long, either simple or forked, collected into a racemus: the outside of the receptacles, when viewed through a glass, is every where uneven with innate spherical tubercles, perforated in their centre, and containing small brown irregularly globular seeds, surrounded by a pellucid limbus.

Color, of the plant when moistened olive-brown, when dried a perfect black : in the fresh state, according to. Gmelin, yellow. I should liave supposed it olive.

SUBSTA NCE, coriaceous, flexible, tough; woody in the stem.

$\beta$ has a discoid root, destitute of fibres: the whole plant is scarcely four inches long, thicker and more rigid than $\alpha$; what, however, is most remarkable, is that the membrane placed upon the vesicles is concave instead of being flat, and has two rows of spines, the outer one horizontal, the inner one erect: the clusters of fructification also are more branched, and thicker, and the receptacles almost club-shaped.

The form of the * vesicles in $F$.turbinatus, whence it derives its name, is equalled by those of no other Fucus that I am acquainted with, and will always be sufficient at first sight to distinguish the species. Their nature, too, is very remarkable, for they appear designed to answer the purpose not merely of air bladders, but also of leaves, no others having ever been found upon the plant, though from its affinities they might be expected. Within they are hollow, not even, as far as I have seen, containing the jointed filaments observable in those of $F$. vesiculosus, nodosus, \&c. The size and stiffness of the teeth, with which their margin is beset, vary considerably in different individuals, as does also the circumstance of their being found upon the winged edges of the angles, along some of which they are most regularly disposed, but in others altogether wanting. Sir Hans Sloane in his History of Jamaica appears to have been the first author who uoticed this plant. In the Flora Egyptiaco-Arabica is described a Fucus, under the name of $F$. conoides, which from the character nust be nearly akin to $F$. turbinatus, and which I should have considered as the same, but for the assurance of Dr. Weber and Dr. Mohr, who have had an opportunity of examining Forskâl's Herbarium, to the contrary. 'The fruit exactly resembles that of $F$. natans, to which, and its congeners, this species is nost nearly allied, and it appears likely that the pods, having performed their office, become elongated into new branches, but that the vesicles also have their origin from these is more than $I$ would venture to say $\dagger$, nor do $I$ indeed consider it

probable.

\footnotetext{
* It onght to be mentioned that Lirnzus and Vall considered thesc vesicles as the fruit, and the true fruit as the rudiments of branclies. Gmelin was of opinion that the seeds were to be found in the triangular tube or disk.

$+\mathrm{My}$ reason for this opinion is, that, if I am not greatly mistaken, the vesicles exist before the fructification in the natural growth of the ylant. In a new Fucus, which I intend soon to describe under the name of $F$. ilicifolizs, the changing of the fruit into bladders is nost apparent, but $I$ am persuaded that this is not a regular law in the economy of the Fuci, nor do $I$ believe that it holds good in the present species, thongh, as Dr. Wcber and Dr. Mohr entertain contrary sentiments, I think it riglit herc to extract what they have written on the sulject."Vahl hat in den Storitt. af Noturh. Setsk, a. a. O.S. 36. vom F. natans und diescm $F$. turbinatus schon angefihrt, dass die Frnchtären in nene Zweige des Gewäiclıses sich ausbilden. Dass die Luftblasen bei manchen Tangen über ausgeleerten Fruchtstanden, an denen sich die Pori ধler Warzen alsdann schliessen, das Innere aber so weit sich auflösst, dass eine räumliche Höle entstcht, werden, hat ab\&r schon längst Prof. Mertens behauptet. Pide Beobachtungen bestätigen sich uns namentlich auch an den drei angefühten Tang speciminibus. Die Blasen dieser Tange, dic die Gestalt cines Kreisels, oder eines dreieckigen Fintes von alter Form liaben, werden hier gewiss, in gleicher Anzahl, aus don Entspitzen der Fruchtracemi, subald diese ihre Frucht ansgeleert haben. Man sieht auf den Blasen voch deutlich die fast verlarsehren
} 


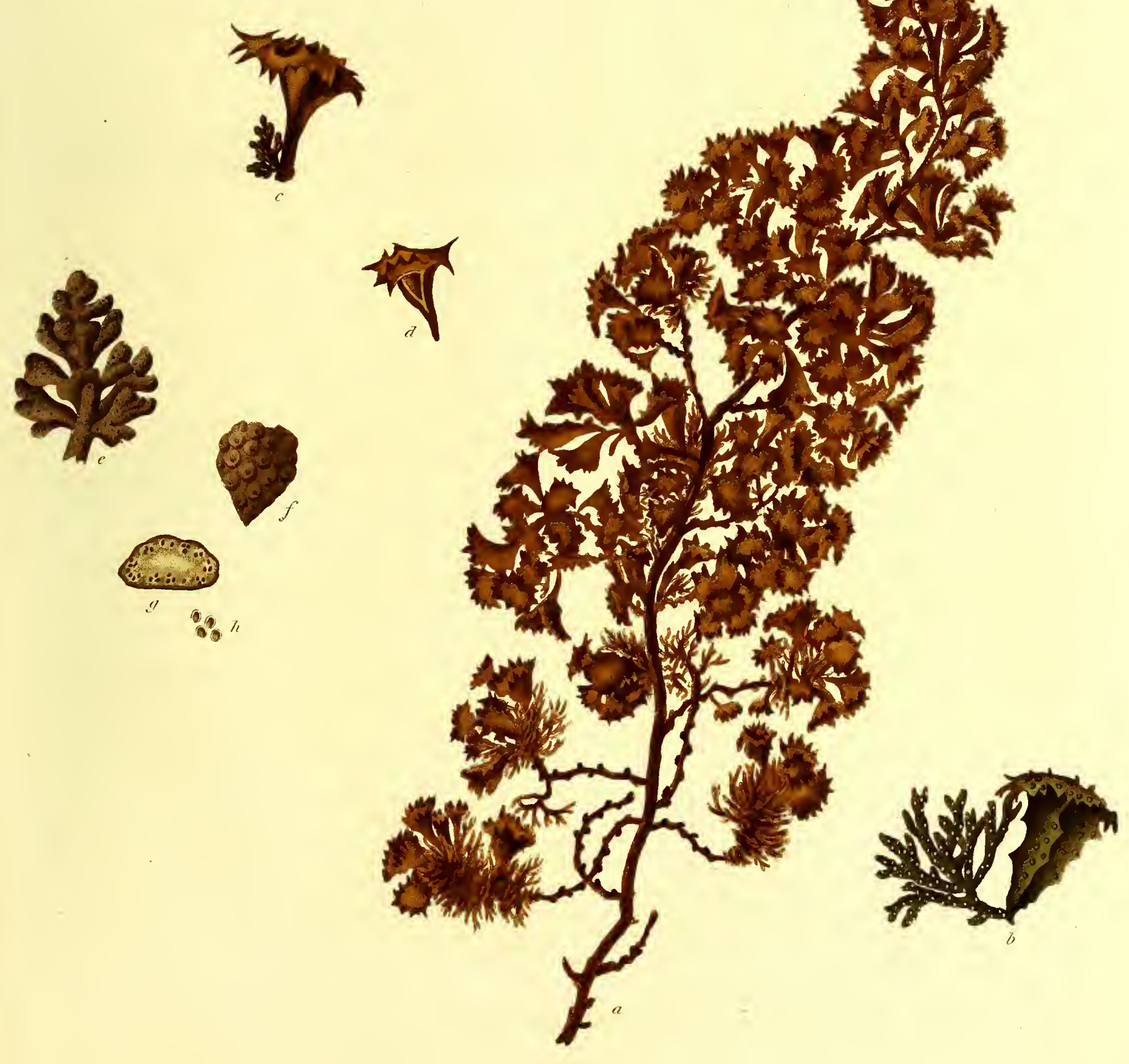

cheres terdisiertess. 
probable. The var. $\beta$, above described, was found by Dr. Smith among some loose papers in the Liunæan Collection, but without any remark, or any clue that might lead to discover whence it came. There is also another variety mentioned by Dr. Weber and Dr. Mohr in the Index to their Museum, and in their * Neue Beiträge, called "coronatus," which may possibly be the same, but, as they say nothing more about it than it is a singular appearance, and as $I$ have seen no specimens, I have no means of judging.
a. F. turbinatus, natural size.
b. vesicle, and cluster of receptacles, magnified - - 6 .
c. vesicle of var. $\beta$, and cluster of receptacles, natural size.
d. the same vesicle, cut through.
e. cluster of receptacles, magnified - - $\quad$ - 5 .
f. part of the exterior of a receptacle - $\quad-\quad-\quad-3$.
g. horizontal section of the same $\quad$ - $\quad \ldots \quad \ldots \quad-3$ -

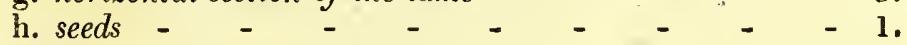

Narben der Pori. Aus jedem einzelnen Fruchtracemus wird ein neuer traubenartiger, zuweilen in seinem ganzen Umriss kolbenförmiger Ast des Gewächses. Ist diese eiumalige Ausbildung bewerkstelligt, so tritt eine Periode ein, wo keine Fruchtracemi da sind. (Gmelin's Fig. des $F$. turbinatus T. v. f. 1.) Dergleichen Aeste finden wir mit solchen, die, zugleich Frucht haben, auch an unsern Exemplaren." I. p. 23x.

* I. p. 236 .

\section{4.-F U C US T U R B I N A T US.}

Fucus caule teretiusculo, indiviso, ramis brevibus, simplicibus obsito; vesicnlis in ramis petiolatis, turbinatis, membranâ extante ambitu denticulatâ terminatis.

Fucus turbinatus. Linn. Sp. Pl. II. p. 1629. Syst. Nat. II. p. 715. Syst. Nat. Ed. Gmel. II. p. 1380. Hort. Cliff. p. 478. Gmér, Hist. Fuc. p. 97. t. 5. f. 1. Esper, Ic. Fuc. I. p. 29. t.9. VAhu. Skrivt. af Naturhistorie-Selskabet. V. p. 36.

Fucus marinus vesiculas habens membranis extantibus. Slon e, Hist. Jamaic. I. p. 58. t. 20 . f. 6.

Acetabuli marini varietas. Ruмr H. Hist. Amboin. VI. p. 85.

B. ornatus; membranâ vesiculas terminante spinarum serie duplice, exterioribus liorizontalibus, interioribus erectis, instructâ.

Ha вıтат in utriusque Indiæ, Americæ, Sumatra, et Kamtschaticæ littoribus; necnon in Freto Zeylanico, et in Mari Erythræo.

Perenuis.

RADIX discus callosus, expansus, tenuis, fibras plurimas clongatas, ramosas, incurvas, rupibus arctè adhærentes emittens.

FRONDES ex eâdem basi plurimæ, pedales, vel sesquipedales, quandoque etiam bipedales, et ultra; caule instructæe iudiviso, pennæ corvinæ ferè crassitie, filiformi, flexuosè erecto, e tereti compresso, a basi usque ad apices ramis subspiralitèr dispositis, nunc densè nunc laxè obsito : rami omnes simplices, quo magis radici proximi eo plerumque longiores, tripollicares et ultra, hìc sensim breviores, ut toti stirpi peripheria sit enormitèr pyramidalis, infernè nudi, aut pedunculorum diffractorum reliquiis exasperati, supernè, ut quoque caulis apex, vesiculis fructuque copiosè onusti.

VEsıULe petiolo circitèr trilineari compresso fultæ, turbinatæ, triquetræ, angulis nunc acutis, sub-alatis, et denticulatis, nunc ferè obsolctis, poris mucifuis pertusæ, intus cavæe, et terminatæ membranâ triangulari seu cordatâ, vel planâ, vel convexâ, vesiculis ipsis ampliore, per omnen sum ambitum emarginatâ, dentibus exiguis.

Fructificatio ramis et vesicularum petiohs iunata, racemosa; scilicet e receptaculis teretibus, lineam vel sesquilineam longis, simplicibus vel bifurcis, in racemum congregatis constans : receptacula per lentem observata tuberculis innatis globosis, centro pero pertusis, undique et ubique torulosa apparent; semina in tuberculis exigua, fusca, abnormitèr sphærica, limbo pellucido cincta.

Color madefacte olivaceo-fuscus; exsiccata nigerrimus; recentis, teste Gmelino, flavescens : olivaceum credidissem.

Substanti a coriacea, lenta, tenax; in caule lignea.

B radicem labet discoideanı, fibrarum expertem : tota stirps vix quadripollicaris, ubique crassior et rigidior quàm s; quod autem notatu dignissimum, membrana vesicularum apici imposita concava est, nec plana, et spinarum serie

duplice, 
duplice, exteriore horizontali, interiore erectâ, est prædita : fructificationis racemi quoque magis ramosi et crassiores, receptaculis sub-clavatis.

* Vesicularum in $F$. turbinato forma, unde nomen suum aptissimum ducit, tantum ab eâ reliquorum hactenùs descriptorum Fucorum differt, ut in specie discriminandâ nulla detur dubitationi occasio. Est quoque earum natura admodùm singularis, cùm non modo bullarum aerearum, verùm etiam foliorum, quæ, licet a stirpis indole rite expectari possint, nondùm sunt detecta, officiis inservire videantur. Intùs sunt omninò cavæ, nec vel fibras illas in $F$. vesiculoso et congeneribus observandas includunt. Dentes per ambitum dispositi magnitudinis et duritiæ in diversis individuis sunt diversissimæ; nec minus est incertum, an per angulorum margines ex ordine disponantur, an prorsùs desint. Primus hunc Fucum in Historiâ Jamaicensi cel. Sloanius descripsit. F. conoidem Forsk. hujus nostri valdè esse similem e characteribus in Florâ ÆEgyptiaco-Arabicâ datis constat, et utrumque eundem mutato tantùm nomine putavissem, nisi Weberus Mohriusque, quibus phytophylacii Forskaliani perlustrandi data est facultas, diversum statuerent. Quoad fructum F. turbinatus convenit cum $F$.natante, cujus familiæ certè præ cæteris affinis : verisimile quoque est receptacula jam effoeta in ramos producta transire; sed vesiculas etiam hisce originem suum debere nec dicere sum ausus, nec, ut verum fatear, + possum mihi persuadere. Exemplar illud, quo nitens varietatem $\beta$ suprà descriptam struxi, in Museo Linnæano, nullo tamen nomine vel loco natali adjecto, reperit Smithius. Est quoque varietas a Webero Mohrioque in Musei Indice, necnon in libro, cui titulus “ Neue Beiträge," memorata, quam " coronatam" nominant, et quæ forsàn est eadem ac hæc nostra; sed, cùm descriptionem adjecerint nullam, nec mihi specimina ulla videndi contigerit occasio, rem in medio relinquere, quantumvìs invitus, cogor.
a. F. turbinatus, magn. nat.
b. vesicula, et receptaculorum racemus, magn. auct. - 6 .
c. var. $\beta$ vesicula et receptaculorum racemus, magn. nat.
d. vesicula eadem dissecta.
e. receptaculorum racemus, magn. auct. - - $\quad 5$.
f. receptaculi pars, extrinsecus visa - $\quad$ - $\quad$ - 3 .
g. idem, horizontalitèr dissectum - - - - $\quad 3$.
h. semina - - - _ - - - - 1 .

* Memorari debet Linnæum Vahliumque las vesiculas pro fructificatione, contrà veram fructificationem pro ramorum rudimentis habuisse. Semina in tubo triangulari vel disco esse reperienda censuit Gmelinus.

† Hæcce receptaculorum in vesiculas metamorphosis in novâ quâdam Fuci specie, mox sub F. ilicifolii nomine in lioc opere describendâ, liquido patet: persuasum verò mihi habeo talem non esse fixam in Fucorum œconomiâ legem; et in $\boldsymbol{F}$. turbinato vesiculas fructificationi præire vehementèr suspicor. Diversum tamen sentientibus Webero Mohrioque, quid ipsi de hâc re scripserunt hic repetere æequum duc'o,-.-" Vahl hat in den Slcrivt. of Naturh, Selsk. a. a. O. S. 36. vom F. natans und diesem F. turbinatus schon angeführt, dass die Fruchtährcn in nene Zweige des Gewächses sich ausbilden. Dass dic Luftblasen bei manchen T'angen über ausgeleerten Fruchtständen, an denen sich die Pori der warzen alsdans schliessen, das Innere aber so weit sich auflösst, dass cine räumliche Höle entsteht, werden, hat aber schon längst Prof. Mertens bchauptct. Beide Beobachtungen bestätigen sich uus namentlich auch an den drei angeführten Tang-speciminious. Die Blasen dieser Tange, die die Gestalt eines Kreisels, oder eines dreicckigen Hutes von alter Form haben, werden hier gewiss, in glcicher Anzahl, aus den Endspitzen der Fruchtracemi, sobald diese ilre Frucht ausgeleert habcn. Man sieht auf den Blasen noch deutlich die fast vcrharschten Narben der Pori. Aus jedem einzelnen Frnchtracemus wird cin neuer traubenartiger, zuweilen in seinem ganzen Umriss kolbenförmiger Ast des Gewächses. Ist diese einmalige Ausbildung bcwerkstelligt, so tritt eine Periode ein, wo keine Fruclitracemi da sind. (Gmelin's Fig. des F. turbinatus T. v. f. 1.) Dergleichen Aeste finden wir mit solchen, die zugleich Frucht haben, auch an unsern Exemplaren." I. p. 237. $\ddagger$ I. p. 236 . 
Fucus fronde planâ, enervi, latè ellipticâ, simplice, apice et basi attenuatâ, papillis brevibus, subulatis, apice capsuliferis, utrinque et undique muricatâ.

Fucus bracteatus. GMelin, Hist. Fuc. p. 212.

F. Radula. Herb. Banks. EsPer, Ic. Fuc. II. p. 3. t. 113.

Folium Alga marine, cribriforme, latum, orbiculare. SEB A, Thes. III. p. 192. t. 103. f 1.

Alga marina folia magna, lata, reticulata. Sе в A, Thes. III. p. 192. t. 103. f. 2, 3.?

Ha вiтat ad Caput Bonæ Spei. D. Robertson.-In Americæ Septentrionalis oris Occidentalibus. D. Menzies.

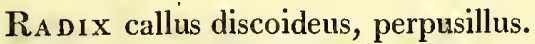

Frondes ex eâdem basi plurimæ, singulæ e folio constantes unico simplice, plano, costæ venarumque experte, longitudine spithanæo, vel dodrantali, latitudine, ubi maxima, vix palmari, lineam et ultrà crasso, juniore obovato lævi, adulto elliptico, apice acutiusculo, infernè in stipitem perbrevem compressum attenuato, superficie utrâque papillis teretibus acutis, lineam circitèr longis, densè obsitâ, margine incrassato et integerrimo, nisi quod papillas interdùm ferat, et inde incautiùs observanti serrata videatur.

Fructificatio tebercula exigua sphærica, sita ad apices papillarum, tunc pedunculorum vice fungentium; hæc si dissecentur globulum in medio intensè purpureum reperies, e duplici corpusculorum genere, horum globosorum, illorum ellipticorum, constantem.

Co Lor purpurens, fusco tinctus, sub-diaphanus; marcescentis dilutior, et demùm in sordidè lutescentem transiens.

Substant a cartilaginea, succosa tamen, lenta; exsiccate cornea, tenax.

Oвs. Quandoque, sed rariùs, accidit stipitem juxta radicem dividi, et duas vel tres sustentare frondes.

Videatur quamvis hæc fuci species ob formam simplicissimam primo aspectu ab omnibus dignoscenda, vereor ne reperiatur in hoc dolosa; ideoque magis doleo quòd non mihi sit data facultas conferendi plurima inter se exemplaria, vel discendi a Botanico quovis qui nascentem viderit quantis qualibusque mutationibus sit obnoxia. Si ex analogiấ F. edulis, quem inter species Britannicas figurâ et indole maximè refert, sententiam ferre liceat, dicerem nullo modo nisi laceratam variare ; et hoc forsitàn verum, tametsi de re perpaullùm cognitâ nihil est quod pro certo affimare ausim : sin iconas Sebanas omnes suprà citatas, præsertim secundam, ad hanc speciem pertinere concedatur, reverà ramosam quandoque evadere, iujuriâ tamen aliquâ fortassìs prinùm exceptâ, fateri cogemur. Idem quoque exemplaria a D. Brown, qui maxime variabilem dicit, nuper in Angliam reportata comprobare videntur; et quædam ex his figurâ suâ hanc nostram speciem cum sequente quodammodò connectunt; distinctissimas tamen esse papillarum natura, ut alia taceam, ostendit. De $\boldsymbol{F}$. bracteati fructu structurâque internâ multum et optimè in * tractatu suprà sæpe laudato disseruerunt Weberus Mohriusque, quod tamen hìc omne pretermittendum duco, cùm in præfatione hujus operis de Fucorum fructificatione fusiùs tractante idem ferè reperietur. Illud quidem præter opinionem accidit, quòd duo ea corpusulorum genera, quæ sese mihi in capsulis obtulerunt, illi † nicroscopio accerrimo summâque curâ usi non viderint; egó autem tam evidentèr perspexerim ut persuadere mihi nequeam me de hâc re erravisse. Utraque inter se mixta jacuerunt; mixta tamen figuram certam, quantum ego detegere potui, servaverunt. Fierine potest ut globosa sint vera semina, elliptica contrà sint vesicula eorum in F. tuberculato jampridèm observatorum similes, et at hæc omnibus adsint Fucis, licet ob parvitatem aut aliam quamlibet causam visum plerumque effugiant?-Diffidentissimè quæro.-Bene observaverunt Weberus Mohriusque substantiam hujus Fuci e tribus laminis constare, et exteriores stirpe jam marcescente deglubi; quod idem aliarum etiam est proprium specierum, et in F. rotundo valere jamdudùm in $\ddagger$ Fucorum Britannicorum Synopsi docui. F. Radula nomen huic stirpi in Herbario Banksiano inditum, et, præsertim exsiccatæ, tactu visuque convenientissimum, bracteato Gmeliniano, nihil, quantum reperio, significanti, sed antiquitatis jure præferendo, invitè postposui; nec enim de Gmelini, iconas Sebanas citantis, et bonas appellantis, synonymo dubitare licuit, quamvis descriptio, præcipuè quod ad caulem spithamæum attinet, nequaqnam omnibus numeris conveniat. De Rumphii stirpe a Gmelino addıctâ nilil est quod dicam, cùn Herbarium ejus Amboinense adeundi non detur facultas. "Folium cribri instar foraminulis densè stipatis pertusum suæ plantæ ascribit Seba; hoc autem e casu posse pendere et ad specien discriminandam paullum valere persuasum habeo. Idem quoque sentiunt Weberus Mohriusque, sed an, ut ipsi suspicantur, foraminula hrec e papillis fructu jam maturo delapsis originem ducant, an Fucorum pericarpia ab insectis marinis pro cibo avidissimè petantur, aliis dijudicandum relinquo. $F$. papillosum Gincl., ut sub $\boldsymbol{F}$. stiriato dixi, ad hanc stirpem referri debere suspicor, nec tamen pro synonymo citare proprio Marte, aliis repugnantibus, sustinui. Multum quoque habet $F$. bracteatus cum $F$. stiriato quoad substantiam et fructum affinitatis, ejusque instar madefactus aquæ tantum haurit, ut exsiccatus ad dimidiam ferè magnitudinem contrakatur.
a. F. bracteatus, magn. nat.
b. papilla, magn. auct. - - _ - 6 .
c. capsula horizontalitir dissecta - $\quad$ - 4 .
d. semina? - - $\quad$ - $\quad$ - 1 .
e. resicule? - $\quad$ - $\quad$ - $\quad$ - $\quad$ - $\quad$ - 1 .

* Beitrüge zur Naturhunde, I. p. 286.

† Reticulatam fibrarum seriem seminibus immixtam ab is descriptam frustrà ego in hâc specie, tit et in $F$. stir iato conguikivri

†11. p. 312 . 
Fucus bracteatus, frond flat, nerveless, widely elliptical, simple, attenuated at the base and summit, and muricated on each side, and all over with short subulate papillæ, bearing capsules at their ends.

Fucus bracteatus. GMeL1N, Hist. Fuc. p. 212.

F. Radula. Herb. Banks. Es PER, Ic. Fuc. II. p. 3. t. 113.

Folium Alga marina, cribriforme, latum, orbiculare. SЕBA, Thes. III. p. 192. t. 103. f. 1.

Alga marina folia magna, lata, reticulata. SE в A, Thes. III. p. 192. t. 103. f. 2, 3.?

At the Cape of Good Hope. Mr. Robertson.-On the western shores of North America. Mr. Menzies.

Root, an extremely small, discoid callus.

Fronds, numerous from the same base, each consisting of a single, undivided, flat leaf, destitute of midrib or veins, about six or nine inches long, and in its broadest part near four inches wide; a line and more thick, obovate and smooth in its earliest state, but when more advanced elliptical, sharpish at the apex, and at its lowest part narrowed into an extremely short compressed stem : each side of the frond is thickly beset with cylindrical sharp papillæ, about a line long; the margin is considerably thickened, and quite entire, except that it sometimes produces papillæ, and thence to a hasty observer may appear serrated.

FRUCTIFICATION, small spherical tubercles, placed at the ends of the papillæ, which then perform the office of peduncles, on cutting these open there is observable in their centre a globule of a deep-purple color, composed of exceedingly minute granules, of two kinds, the one round, the others elliptical.

CoLor, purple, linged with brown, semitransparent; more pale in the plant when decaying, and at last turning to a dull dirty yellow.

SU BSTANCE, cartilaginous, but full of juice, pliant; in a dry state much more thin, horny and tough.

Oвs. It sometimes, though rarely, happens, that the stem is divided near the root, and bears two or three fronds.

Although from the extremely simple form of the present Fucus, we may be led to imagine that no species may more readily be distinguished at first view, I am nevertheless apprehensive that appearances are in this respect deceitful; and I therefore particularly regret that I have not been fortunate enough to meet with the opportunity of comparing myself a number of specimens, or of learning from any Botanist, who has seen it in its place of growth, what are the changes to which it is liable. If I might be allowed to judge from the analogy of $F$. edulis, to which it bears more resemblance in figure and in nature than to any other British Fucus, I should say that its various forms depend only on its being torn; and such may probably be the case : but it would be rash to venture a decisive opinion upon a matter which I have had no means of determining, and, if the whole of the figures in Seba's Thesaurus, especially the second, really belong to this plant, we must be compelled to adinit that the frond is sometimes actually branched, however such an appearance may be the result of previous injury. Some specimens lately brought to England by Mr. Brown, who says that it is a very variable Fucus, seem to prove the same thing, and even to tend to connect it with the following species, from which, however, the nature of the papillæ, not to mention any other circumstance, proves it sufficientty distinct. Many excellent observations upon the fructification and internal structure of F. bracteatus may be seen in Weber's and Mohr's* 'Treatise, already frequently quoted, the whole of which I think it best here to omit, as nearly the same will be found in that part of the preface of this work which treats particularly upon the physiology of the Fuci. I was indeed surprized to find that, in spite of the great care and excellent t glasses employed by these able Botanists, in the investigation of this plant, they did not discover the two kinds of granules, which I, on the contrary, saw so plainly in the capsules, that I cannot believe it possible for me to have been in error on the subject. Both of them lay mixed together, but still preserved their separate figures. Is it possible that the globular ones shonld be the true seeds, and the elliptical ones vesicles, similar to those already noticed under F. tuberculatus; and that these really should exist in every species of Fucus, though on account of their diminutive size, or some other cause, they generally escape observation?-I submit this question with extreme diffidence.Weber and Mohr have very justly remarked, that the substance of this Fucus is composed of three laminæ, and that the external ones peel off as the plant decays, in the same manner as happens in some other species, and was noticed in F. rotundus in the + Synopsis of the British Fuci. It is with great regret that, on account of its prior date, I have been forced to substitute Gmelin's unmeaning name of $\boldsymbol{F}$. bracteatus for that of $F$. Radula, which is given to the present plant ia the Banksian Herbarium, and is most happy both as to look and touch. The Synonym of Gmelin, who quotes Seba's figures, and calls them good, appears to me indispntable, although some parts of his description, and especially that in which he calls the stem a span long, do not altogether apply. With regard to Rumphius's plant which he quotes, I can say nothing, having had no opportunity of consulting the Herbarium Amboinense. Seba observes, that what he has described, has a "leaf pierced like a sieve with a number of small holes," a circumstance which I never saw, but which I am persuaded may have arisen from accident, and can have little weight in determining a species. The same is also the opinion of Weber and Mohr, but how far their conjecture is well founded, that these holes originate from the papilli falling out as the fruit ripens, or that the pericarps of Fuci constitnte a food particularly acceptable to marine insects, 1 must leave others to determine. A suspicion has already been stated under 


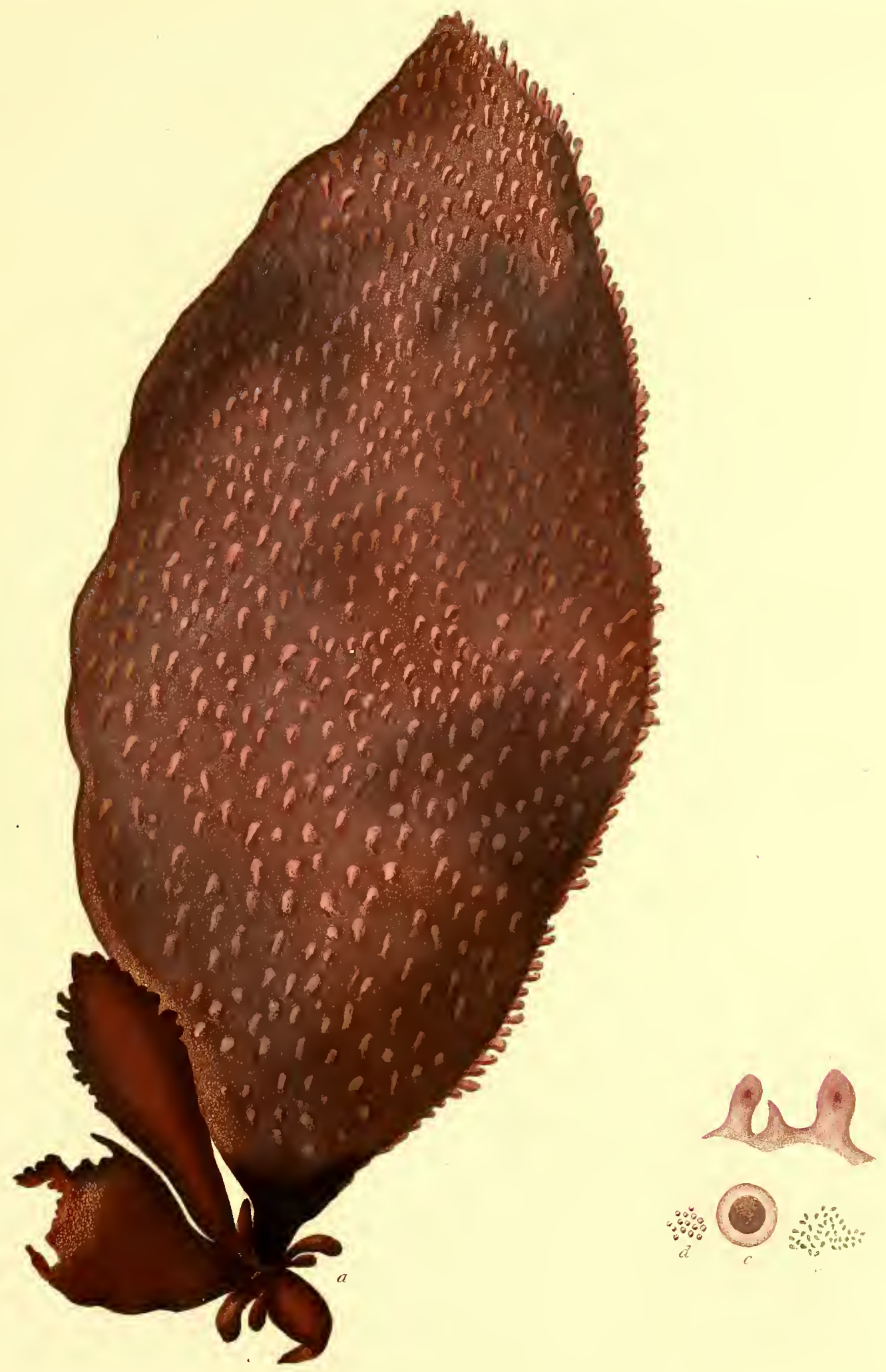

seresterendereles. 

$\boldsymbol{F}$. stiriatus, that $F$. papillosus, Gmel. ought, as well as his $F$. bracteatus, to be referred to this plant; but $I$ have still not ventured upon quoting it as a synonym in opposition to the opinion of others. F. bracteatus is in its fructification and substance nearly allied to $\boldsymbol{F}$. stiriatus, and, like that species, imbibes so much water when moistened, that in drying it shrinks to little more than half its original size.

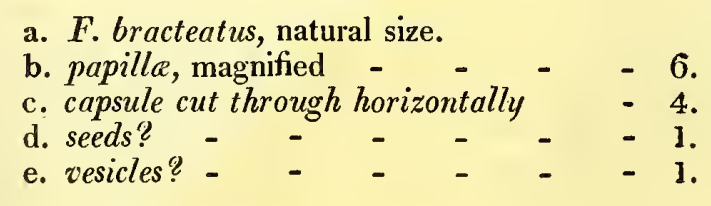

\section{6.-F U C U E R I N A E U S.}

Fucus fronde planâ, enervi, oblongo-lineari, simplice, ramentis lingulatis tuberculiferis utrinque et undique muri catâ; tuberculis in ramentis immersis.

Habitat ad Caput Bonæ Spei. Herb. Banks.

RADIX callus exiguus, explanatus, fuscus.

FrON DES ex eâdem basi plurimæ, singulæ e folio constantes unico simplice, ex oblongo lineari, longitudine pedali et ultrà, latitudine pollicari vel sesquipollicari, plano, sed hìc illìc rugoso, costæ venarumve experte, apice lenitèr rotundato, basi aliquantùm attenuato, nec ita tamen ut stipitem ullo modo simulet, margine undulato, integerrimo, et levissimè incrassato : frons ætate primâ lævis et nuda; adultioris utrique paginæ et marginibus copiosè innascuntur ramenta lingulata, sub-linearia, duas tresve lineas longa, compressa, horizontalia, ejusdem cum fronde coloris et substantiæ, basi attenuata, ut pedicellata videantur.

Fructificatio in ramulis sita; e tuberculis constans exiguis, sphæricis, immersis, plurima in singulis, foramine minutissimo extrinsecùs pertusa : nihil in his, nisi corpuscula illa elliptica pellucida, jam sub $F$. tuberculato et $F$. bracteato memorata, hactenùs detegere potui.

CoLOr fusco-purpurascens, sub-diaphanus; exsiccata intensior; marcescentis in roseum, et demùm in sordidè lutescentem transiens.

Sumstantia cartilaginea, crassiuscula, tenax; exsiccate cornea.

Ors. Ramenta in longitudinem unguicularem et ultrà aliquando producuntur: exsiccatione contorta et crispa evadunt.

Similitudinem illam, quæ inter hunc Fucum et precedentem interest, jam sub eâ specie attigi, memorans simùl papillarum figuram et indolem, ut quæe ad utramque primo aspectu dignoscendan nunquam non sufficerent. Huic quoque accedit discrimini substantia frondis, quæ in $F$. erinaceo nequaquàm ita succi est plena ut in $F$. bracteato, nec sese exsiccatione tantum contrahit; accedit etiam fructificatio, per quam $F$. erinaceus a reliquis aliis fronde planâ enervi praditis Fucis insignitèr discrepat, et de quâ, licet a mancis illis solis hactenùs detectis exemplaribus nihil quoad ejus naturam satis certum vel definitum asseri possit, illud tamen liquet, differre facie externâ toto cælo ab eâ Fucorum globuliferorum, propiùsque videri accedere ad eam Fucorım, qui dicuitur, propriorum, a quibus omnibus stirps ipsa substantiâ et habitu quàm longissimè recedit. Duo modò hujus Fuci hucùsque vidi specimina; unum in Herbario Banksiano inclusum, et $F$. ramentacei nomine, jamdudùm in Systemate Vegetabilium alii speciei indito, insignitun ; alterum in Herbario Linnæano, eidem chartæ, cui $F$. vittatus, agglutinatum; unde constat hasce duas a Linnæo commixtas esse species, fierique potest ut, cùm $F$. vittati var. $\gamma$, ornatam, describeret, F. erinaceum respexerit. Favet huic opinioni quòd folia suæ plantæ oblonga et avenia ascripserit : repugnat autem quòd cilia margini tantummodò innascentia memoraverit. Costæ absentia, frondis forma, et ramentorum dispositio $F$. erinaceum a $F$. vittato distinguunt. Quoad figuram iisdem prorsùs, quibus F. bracteatus, mutationibus obnoxius videtur: sed, cùm unun atque alterum e ramentis, quorum singula totam plautam magnitudine comminutam referunt, reverà bifurcum viderim, adducor ut folia quandòque naturâ divisa crederem. Ex amplificatione illorum suprà memoratâ suspicari ferè liceret vim crescendi proliferam stirpi esse insitanı.

a. F. erinaceus, magn. nat.

b. ramentum, magn. auct. - $\quad$ - $\quad-6$.

c. idem horizontal tèr dissectum - $\quad$ - 4.

d. vesiculc? - $\quad$ - $\quad$ - $\quad$ - $\quad$ - $\quad$ - 1 .

e. ramenti pars interioris longitudinalitèr secti 4 . 
Fucus erinaceus, frond flat, nerveless, between oblong and linear, simple, muricated on each side, and all over with lingulate tuberculiferous ramenta: tubercles immersed in the ramenta.

At the Cape of Good Hope. Herb. Banks.

Rоот, a small, expanded, brown callous disk.

Fron Ds, many from the same base, each consisting of a single undivided leaf, between oblong and linear, a foot or more long, and an inch, or inch and half wide, flat, but wrinkled in places, destitute of midrib or veins, somewhat rounded at the apex, and slightly attenuated at the base, but by no means so as to give the appearance of a stipes; the margin undulated, entire, and a little thickened: the frond in its younger state is smooth and naked; when full grown each side of it, and the edges also, are copiously beset with lingulate, almost linear, compressed ramenta, two or three lines long, disposed in a horizontal direction, of the same color and substance as the frond, and so much narrowed at the base as to look pedicellate.

Fructification, situated in the ramuli ; consisting of several minute, spherical tubercles immersed in each of them, perforated extemally with an extremely small pore : in these I have hitherto been able to detect nothing but those ellipitical pellucid granules, already noticed under F. tuberculatus and F. bracteatus.

Color, brownish purple, semitransparent; darker when the plant is dry, and turning in a state of decay to pink, and afterwards to a dirty yellow.

SubSTANCE, cartilaginous, thickish, tough; horny in dry specimens.

Oвs. The ramenta are sometimes found half an inch or more long; and in drying become variously twisted and curled.

In treating of the preceding Fucus, I have already noticed the resemblance which there exists between that species and the present, and have observed that the form and nature of the papillæ are sufficient to keep them distinct at first sight; in addition to which, I think it necessary here to remark that they differ no less essentially in the substance of the leaf, which in $F$. erinaceus is by no means of the same juicy gelatinous structure, or liable to the same contraction when dry, as that of $F$. bracteatus, and in the fructification, which in the plant before us is altogether very unlike what might be expected from its connection with the tribe of Fuci provided with a flat and nerveless frond. It is indeed impossible from the imperfect specimens that I have hitherto seen to speak with the precision that could be wished upon the subject; but thus much is certain, that it has in external appearance no affinity to that of the globuliferous Fuci, and seems rather to approach to that of the Fuci proprï, from which the plant itself is in substance and habit as widely removed as possible. The only specimens that $I$ have yet met with of $F$. erinaceus are contained in the Banksian and Linnæan Herbaria; in the former of which, it is called F. ramentaceus, a name already appropriated in the Systema Vegetabilium to a very different plant, and in the latter it is attached to the same paper as $\Gamma$. vittatus, so that it is evident that Linnæus confounded these two species, and it is possible that he meant to allude to the present under his $F$. vittatus, var. $\beta$, ornatus, a supposition that is strengthened by his attributing to it oblong veinless leaves, though his confining the cilia to the margin seems to render it improbable. F. erinaceus differs most essentially from $F$. vittatus in the want of a midrib, the shape of the frond, and the disposition of the ramenta; in point of form it appears liable to precisely the same variations as $F$. bracteatus, except that, from having noticed one or two of the ramenta naturally forked, I am inclined to think that the frond itself may occasionally be found divided, as each of these ramenta resemble it in miniature. Their sometimes enlarging themselves, as mentioned above, miglst lead to the idea that the plant is gifted with a proliferous tendency.

a. F. erinaceus, natural size.

b. a ramentum separate, magnified - $\quad-\quad-6$.

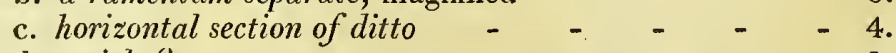

d. vesicles? - $\quad$ - $\quad$ - $\quad$ - $\quad$ - $\quad$ - $\quad$ - 1 .

e. interior of part of a ramentum cut longitudinally - 4 . 


$$
U
$$



Fucus fronde coriaceâ, compressâ, lineari, ramosâ ; ramis elongatis simplicibus, foliis lineari-cuneiformibus, membranaceis, distichis, approximatis, vesiculisque ellipticis obsitis.

Навьтат in Americæ Septentrionalis oris Occidentalibus, aquæ profundioris plerumque incola: apud Nootka: Trinidad; Monterrey. D. Menzies.

Perennis.

RADIX fibrosa ; fibris plurimis, incurvis, ramosis.

Frons viginti ulnarum et ultrà longitudine, stipite assurgens brevi teretiusculo, in ramos diviso aliquot elongatos, sub-fastigiatos, simplices, tuberculis exiguis nigris tactu visuque scabros, planos, semiunguem latos, et latitudinem ubique æqualem servantes, nisi quod juxta apices aliquantum sint dilatati, et inde rursùs attenuati, ita ut extremitates obtusè lanceolatæ evadant. Per totam ramorum longitudinem ex utroque horum latere enascuntur foliA approximata, disticha, horizontalia, plana; e basi filiformi sensìm dilatata, figuræ elongatè et angustè cuneiformis, margine abnormitèr, minutè tamen, crenulata, rariùs dente uno alteroque instructa, longitudine bipollicaria, ea frondis basin apicesque versus breviora, superficie poris mucifluis pertusa; hisce immixtæe hic et illìc occurrunt VESICULE, nullo certo ordine dispositæ, spatio inter singulas nunc dodrantali, nunc unguiculari, ellipticæ, Olece Europece druparum magnitudine, extrinsecùs laves, intra cavæ, petiolo insidentes tereti, bilineari, ramorum instar scabro, apice folio reliquorum simili mucronatæ.

Fructificatio adhùc incognita.

Co LOR in foliis olivaceus, sub-diaphanus, in ramis obscurior, opacus.

Su BSTA NTIA foliorum e membranaceâ cartilaginea, tenuis ; ramorum coriaceo-lignea, tenax.

Oвs. Folia vesiculæque in exsiccatâ sæpe decidunt, unde stirps quandoque hìc illìc denudata apparet.

Dolendum est quòd sit impossibile in operibus ad vegetabilia depingenda destinatis plantarum omnium iconas ejusdem quâ ipsæ fruuntur magnitudinis delineatas sistere; et quòd nihil ultrà restet quàm vel parte tantummodd exiguâ esse contenti, vel totam stirpen adeo usque imminutam adumbrare it character et indoles sæpe penitùs deleantur. Fucorum Historiam illustrare conanti hoc crebrò necessariè occurrit ; sed Botanicos plerosque mecum consensuros spero, si in iis speciebus, quarum, sicut ejus nunc tractandæ, habitus et crescendi modus per totam frondem est uniformis, pars toti anteponatur, quod superest e descriptione supplendunı relicto. Multa ex iis qua de hoc Fuco suprà traduitur, simul et exemplar hìc depictum, amicissimo Menziesio debeo, qui post primam circa orbem expeditionem secum redux attulit, et qui solus adhuc reperisse videtur. Magno mihi fuit gaudio qudd talem stirpem talis viri nomine insigniendi sese obtulerit occasio ; quoniam persuasum babeo esse paucos de scientiâ botanicâa melius promeritoş, cùn $o b$ indefessum studium quo in plantis quærendis et scrutandis est usus, tùm ob eximiam liberalitatem quâ quæsita et scrutata dispertiit. $F$. Menziesii est stirps perelegans, maximèque singularis, et quæ $a b$ omnibus hactenùs descriptis formâ habituque tantum abludit, ut non modo primo aspectu dignoscatur, quin etiam difficile sit dictu cuinam familia rectiùs associaretur. Arctissimam, nec tamen valdè arctam, ei cum $\boldsymbol{F}$. natantis tribu affinitatem intercedere censerem, fructificationemque esse eandem quâ hi gaudent crederem : nequaquàm tamen hariolari licet qualis sit hujus fructûs figura, vel in quâ frondis parte reperiri possit. Crescendi modum in hoc Fuco inspicienti impossibile videbitur produci in novos ramos vel folia vel vesiculas, quorum illa figurâ et substantiâ $F$. esculenti pinnas multum referuit.

a. F. Menziesii frondis portio, magn. nat.

b. vesicula folio terminata.

c. ejusdem dissecta pars.

d. vesicula petiolus, magn. anct. - - - - 5 .

e. folium - - - - - - - - 6 .

f. ramus horizontalitèr sectus - - $\quad$ - $\quad$ - $\quad 6$.

g. tubercula ramo innata - - - - - 3.

h. rami longitudinalitèr secti partis interioris portio 1 . 
Fucus Menziesii, frond coriaceous, compressed, linear, branched; branches long, simple, beset with membrtnaceous, distichous leaves, between linear and cuneifornı, placed near each other, and with elliptical vesicles.

On the western coast of North America, generally in deep. water: at Nootka; Trinidad; Monterrey. Mr. Menzies.

\section{Perennial.}

Roот, fibrous, with several incurved, branching fibres.

Frons, twenty fathoms and more long, rising with a short roundish stipes divided into several long simple branches, of almost equal height, rough all over both to the touch and sight with minute black tubercles, flat, every where preserving an equal width of about a quarter of an inch, except that towards the apices they are slightly dilated, and then again narrowed, so that the extremities are of an obtusely lanceolate form. The branches thronghout their whole length produce on either side a series of distichous, horizontal leaves, placed near to each other, flat, gradually widening from a filiform base, so as to be of a long and narrow cuneiform figure, their margins irregularly and minutely crenulated, sometimes, but seldom, provided with one or two teeth, their length about two inches, but those near the base and end of the frond shortest, their surface perforated with mucifluous pores; mixed with these here and there grow vesicles, arranged without any certain order, and with an interval of nine inches in some cases, and of not above half an inch in others, between them, elliptical, about the size of an olive, smooth without, hollow and empty within, producing at their ends a leaf similar to the others, and supported upon cylindrical petioli, two lines long, and rough like the branches.

Fructification, at present unknown.

COLOR, in the leaves olive, semitransparent; in the branches darker, opaque.

Substance, of the leaves, between membranaceous and cartilaginous, thin; of the branches, between coriaceous and woody, tough.

Овs. In a dried state the leaves and vesicles frequently fall off, which gives the plant a naked appearance in places.

It is greatly to be lamented, that in all works containing figures of plants it is impossible to represent every species of its natural size, and that authors are consequently reduced to the alternative of either confining themselves to a part alone, or of giving a representation of the whole so much reduced that the character of the original is often altogether lost. Among the Fuci, such a case must not unfrequently occur, and I trust I shall be considered as having determined rightly, if in those instances where the mode of growth is uniform throughout, I prefer the figuring of a portion only, and leave it to the imagination of my readers to supply the remainder from the description. For many of the particulars in the account of the present Fucus, as well as for the specimens from which the drawing is made, I ant entirely indebted to Mr. Menzies, who brought it home with him in his first expedition round the world, and after whose name I have had a peculiar pleasure in calling it, being convinced that no man better deserves to be enumerated among the promoters of botanical science, from the zeal with which he has prosecuted it, and the liberality which he has shewn in dispersing his treasures. F. Menziesii is a very singular and elegant species, so much removed from every other hitherto described, that there is not only no fear of confounding it, but.that it would even be difficult to say to which it is most a-kin. I should be inclined to place it near to the tribe of F. natuns, and should from its color and texture apprehend its fructification to be similar to that of the Fuci proprii of Weber and Mohr, but where this fructitication is borne, or what is likely to be its figure, I am unable to form any conjecture. From the mode of growth of the plant, it appears impossible that either the leaves or the vesicles should lengthen into new branches: the former bear a considerable resemblance to the pinnæ of $F$. esculentus.

a. part of F. Menziesii, natural size.

b. vesicle with terminating leaf.

c. vesicle cut open.

d. stalk of vesicle, magnified - - - $\quad 5$

e. leaf - - - - - - - -6 .

f. horizontal section of a branch - - - - $\quad 6$.

g. tubercles that grow on it - - - $\quad$ - $\quad 3$.

b. longitudinal section of the interior of a branch - 1 . 

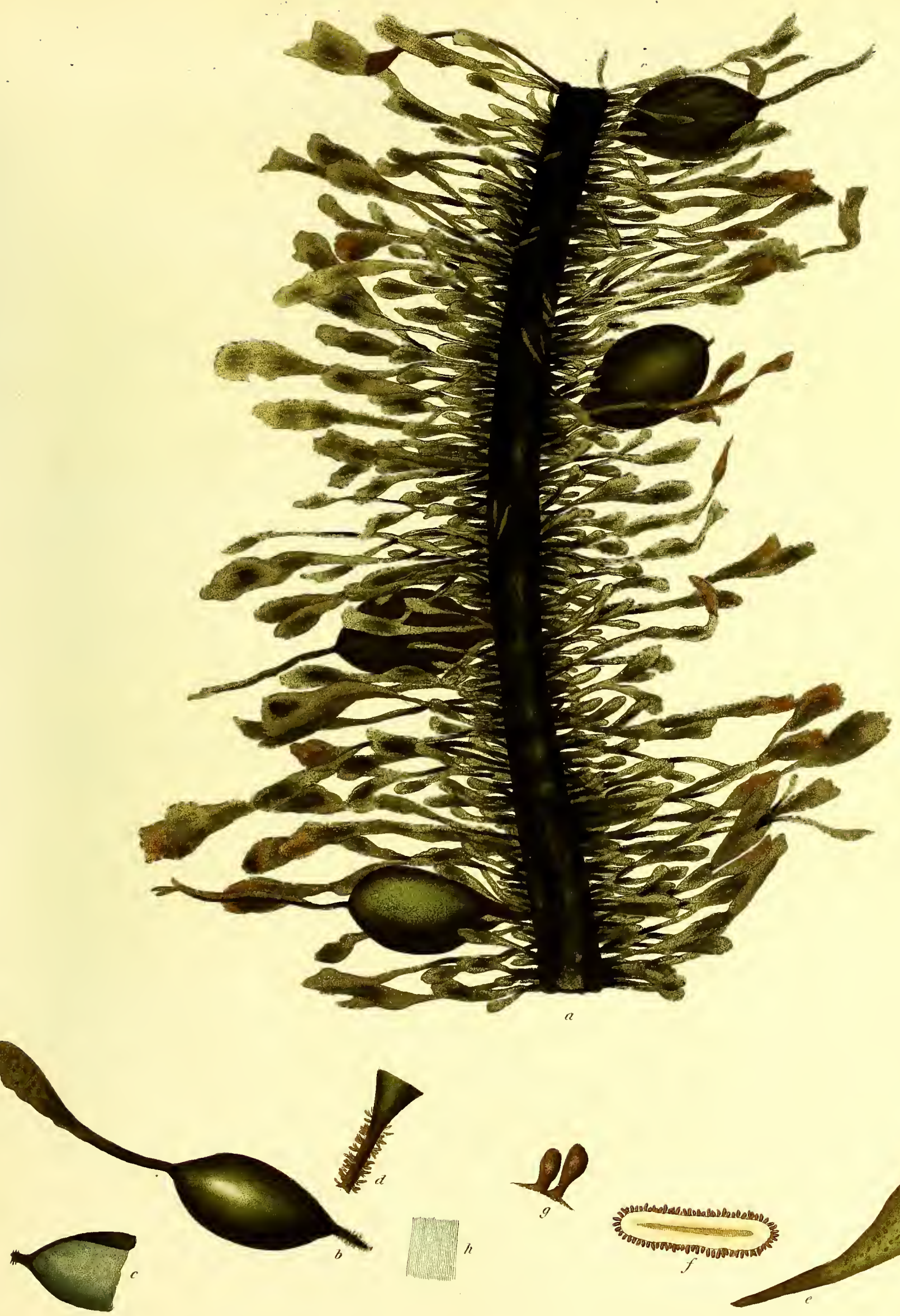

Fucus fronde cartilagineâ, compressâ, lineari, vagè dichotomâ ; ramulis subulatis, horizontalibus, sub-distichis, tuberculiferis; tuberculis globosis, sessilibus, terminalibus lateralibusque.

Fucus gigartinus. Lins. Syst. Nat. II. p. 719. Syst. Nat. Ed. Gmel. II. p. 1336. Linn. Trans. III. p. 183. t. 17. f. 3, 4. Witr. IV. p. 111. Eng. Bot. XIII. t. 908. Syn. Fuc. II. p. 280. Fl. Fr. Ed. 2da. II. p. 33.

F. pistillatus. Gmelin, Hist. Fuc. p. 159. t. 18. f. 1. LaM. Diss. Fuc.p. 51. t. 27.

F. Oederi. Esper, Ic. Fuc. II. p. 52. t. 135.

Ceramium gigartimum. Rотн, Cat. Bot. III. p. 109.

B. minimus; fronde planâ, tenerâ, ramosissimâ, flexibili ; tuberculis minutissimis. F. pistillatus. B. La m. Diss. Fuc. p. 51. t. 28.

Ha bitat in Cornubiæ oris.--In rupibus submarinis prope Padstow. $D^{n a}$ Hill.-In oris Franciæ secus oceanum. Lamouroux._Copiosissimè ad Scalas ascensîs in ponte marino St. Ubes. D. Leofing, in Herb. Linn.In Hispaniæ oris. D. Link. - $\beta$. in Francix oris. Lamouroux.

\section{Perennis? * Vere fert fructum.}

RADIX callus tenuis, explanatus, fuscus.

FRONDES ex eâdem radice plurimæ, compressæ, in quibusdam autem individuis teretiusculæ, in aliis propemodùm planæ, longitudine palmares, vel semipedales, latitudine ıbique ferè æequales, et lineam unam alteramve latæ, caule assurgentes basin versus indiviso, sursùm ter, quater, vel pluries vagè dichotomo, segmentis fastigiatis, dichotomiarum angulis erecto-patulis, infernè nudo, supernè, præsertim apices versus, † ramulis instructo pluribus, subulatis, dentiformibus, sub-distichis, oppositis alternisque, horizontalibus, caule multo angustioribus, plerumque simplicibus brevibusque, ut vix trium linearum longitudinem æquent, aliquandò tamen elongatis, et bifurcis, seu vagè divisis, apice semper acuminatis, excepto si sint, ut sæpe accidit, tuberculis terminati.

FRUCT1F1CAT1O tubercula sphærica, papaveris seminis magnitudine, ramulorum nune apici nunc lateri insidentia, s:epiǹs solitaria, sed interdum bina vel terna, globulum e seminibus subrotundis minutissimis densè compactis constantem intùs foventia.

Co LOR intensè purpureus; soli objecta lutescens, marcescentis dilutior, et sordidè fusco-virescens ; tuberculorum nigricans.

Sunsta NTIA cartilaginea, lenta; exsiccata rigidiuscula.

Var. $\beta$, quam, nunquam a me ipso visam, cl. Lamouroux fide hìc recenseo, est, ut ejus verbis utar, minor quàm $\alpha$, fronde magis ramosâ, ramis lateralibus, ramulis in totâ plantæe paginâ sparsis; tuberculis tenuitate tantùm a var. \& tuberculis differentibus. Substantia tenera, submembranacea, nonnihil gelatinosa. Color a viridi ad rubro-purpureum variat.

F. gigartinus, species inter Britannicas omnium ferè rarissima, et a nemine, quantùm scio, nisi semel a $D^{\text {na }}$ Hill adhuc in littoribus nostris nascens detecta, nequaquàm ita infrequentèr in Galliæ Septentrionalis vel Hispaniæ oris occurrit; sed in illis tantummodò quæ oceano alluuntur hactenùs est reperta, quare, quodd locum ei natalem Norvegiam tribuerit Esperus, ex errore factum suspicor. Primus et optime hanc stirpem in Systemate Natura descripsit I.innæus, cujus tamen descriptio eam ob causam Rothio minùs arridet, quia fructificationes terminales snbjacente aristâ dixerit. Fst autem hoc, pace viri accuratissimi, nota plantæ præ cæeteris propria : quamvis enim capsulæ non rarò sunt terminales nihil ultrà progrediente, crebriùs tamen occurrunt laterales juxta apicem rąmulorum, qui sub tuberculis exerti et in mucronem longiorem producti aristæ formam mentiuntur. Nomen quoque a Linnæo impositum

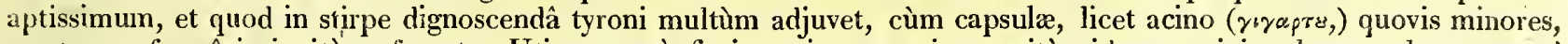
eos tamen formâ insignitèr referunt. Utinam sanè fieri possit ut nomina paritèr idonea cuivis plantæ adaptarentur! piocederet res botanica multo suaviùs quàm nunc, et synonymorum illâ multiplicatâ confusione, scientiæ maximo impedinento simul et dedecore, in posterum careremus. Exemplar modd unicum, idque parvum, fluctibus diu illisum, tempestatisque mutationibus objectum, vidit Gmelinus, unde descriptio ejus et icon necessariè manca, nec tamen idcircò est de synonymo dubitandum. Sub $F$. pistillaris nomine plantan longè alienam, $F$. obtusi, uti videtur, varietatem, sub quâ nihilominus stirpem Gmelinianam citavit, Wulfenius descripsit. Ad F. cristatum pertinet $F$. gigartinıs Fl. Dan. ut jam sub illâ memoratur specie. Granulorum in capsulis congeriem, semper arctissimè compactam, et in pulpâ fibris parallelis undique a superficie radiantibus repletâ inclusan, pró sensine unico ex errore labuit Lamouroux, qui plantæ historiam uberem simum et accuratam tradidit. Suspicatur idem var. $\beta$ specie ab $\alpha$ differre. Ramuli horizontales dentiformes in fronde dichotomâ, spinosa facies, et capsularum sphæricarum dispositio hanc stirpem a congeneribus distingumt.
a F. gigartimes, magn. nat.
b. rami pars superior, magi. auct. $\quad-\quad-6$.
c. copsula - - - - - $\quad-4$.
d. Ładem longitudinalitèr disșecta - $-\quad-$ e.
e. semina - - - - - - . i.

- Mense Martio 1803 capsulis maturis instructam legit Dna Hill.

+ Lene de ramulis dixit Lamonronx, "ces petits rameanx, simples on rameux, presque tous fructiferès, ressemblent à des aiguillons épars sur" teute la surface de la piante, lorsquelle est ronde ou presque ronde, et seulement sur les côtès lorsqu'elle est très comprimée." 
Fucus gigartinus, frond cartilaginous, compressed, linear, irregularly dichotomous ; ramuli subulate, sub-distichous, horizontal, tuberculiferous; tubercles globular, sessile, lateral, and terminal.

Fucus gigartinus. Linn. Syst. Nat. II. p. 719. Syst. Nat. Ed. Gmel. II. p. 1386. Linn. Trans. III. p. 183. t. 17. f. 3, 4. WITH. IV. p. 111 . Eng. Bot. XIII. t. 908. Syn. Fuc. II. p. 280. Fl. Fr. Ed. $2 d a$. II. p. 33.

F. pistillatus. Guelin, Hist. Fuc. p. 159. t. 18. f. 1. LaM. Diss. Fuc. p. 51, t. 27.

F. Oederi. Es Per, Ic. Fuc. II. p. 52. t. 135.

Ceramium gigartinum. Roтн, Cat. Bot. III. p. 109.

B minimus; frond flat, tender, nuch and irregularly branched, flexible; tubercles very minute.

F. pistillatus. $\beta$. Lam. Diss. Fuc. p. 51. t. 28.

Shores of Cornwall.-Rocks near Padstow. Miss Hill.-Most abundantly on the Stairs of the Jetty at St. Ubes. Leofling in Linncan Herbarium.-Shores of Spain. Professor Link.- $\beta$, with $\alpha$, on the coast of France by the ocean. Lamouroux.

Perenuial? In the * Spring.

Roor, a thin, expanded, brown, callous disk.

FRONDS, numerous from the same base, generally compressed, but in some specimens roundish, in others nearly flat, from three to six inches long, and preserving throughout an equal width of one or two lines, rising with a stem which is undivided near the root, but in its upper part three or four times, or still more frequently, irregularly dichotomous, the segments of equal height, the angles of the dichotomies between erect and patent: the stem is naked below, but upwards, especially towards the apices, furnished with several subulate, dentiform, sub-distichous $\uparrow$ ramuli, placed in a horizontal direction, both alternately and oppositely, much more narrow than the stem, and generally simple, and not above three lines long, but sometimes lengthened out, ind forked or divided in an uncertain manner, always acuminated at the apices, except, as frequently happens, they are terminated with a tubercle.

Fructification, spherical tubercles, about the size of poppy-seed, sessile either at the ends or sides of the ramuli, most frequently solitary, but occasionally growing two or three together, containing a compact globule formed of very minute roundisl seeds.

CoLOR, a deep purple; turning yellowisl when exposed to the stin; paler and dirty brownish green as the plant decays : the tubercles are blackish.

SUBSTANCE, cartilaginous, and pliant, but rather rigid after drying.

Var. $\beta$, which I never saw, stands here on the authority of M. Lamouroux, and is, to use his words, less than $a$; the frond more branched, the branches lateral, the ramuli scattered over the whole surface of the plant; the tubercles differ from those of var. $\alpha$ only in their smaller size; the substance is tender, sub-membranaceous, and approaching. to gelatinous; the color varies from green to reddish purple.

However scarce a plant $F$. gigartinus may be regarded, if considered only as a native of the British shores, where. I believe it was never found growing, except once by Miss Hill, it does not appear to be by any means equally. unfrequent upon the coast of France and Spain; though even in those countries it seems to be confined to those parts alone which border upon the ocean, so that it can scarcely be doubted but Professor Lsper has been mistaken in publishing it as a native of Norway. Linnæus was the first author who noticed this species, and his description of it in the Systema Natura is excellent, though Dr. Roth finds fault with it on account of his calling the fructification terminal subtended by an arista. This very circumstance, however, far from deserving censure, affords, in my opinion, the strongest character of the plant; for, though the capsules are not unfrequently terminal in the proper sense of the word, they are still more frequently sessile on the sides of the ramuli near the apices,'and the points extending beyond them give them the appearance noticed by Linnæus. The name too assigned to the plant by this celebrated writer is peculiarly happy, and may be of essential service to the young botanist in distinguishing the species, as the capstiles, though smaller than any grape-stones (y;y oprov) bear a striking resemblance to them in figure. I heartily wish it were possible to apply to every plant an appellation equally descriptive. The study of Botany would go on far more smoothly than it does at present, and we should be relieved from that eternal multiplication of synonymy which is at once the greatest disgrace to the science and impediment to its progress. The only specimen of $F$. gigartinus that Gmelin had an opportunity of seeing, was in itself small, and had sustained great injury from having been long battered about by the waves, and exposed to the action of the sun and air, which may account for the necessary imperfections in his description and figure, but there is still no room for doubt as to the synonym. The plant described by Baron Wulfen, under the title of $\pi$. pistillaris, to which he referred Gmelin's Fucus of the sane name, is in reality a very different one, and appasently a variety of $F$. obtusus. The $F$. gigartinus of the Flora Danica belongs, as has already been mentioned, to $F$. cristatus. From the extreme compactness of the globule of granules in this species, which is placed in the nidst of a transparent pulpy natter, full of fibres radiating in every direction from the interior to the surface, Iamouroux was led to regard it as producing only a single seed. His description

\footnotetext{
* I know nothing as to the time of fruiting of this Fuctis, except that wiss Elingrathered specimens with ripe capsules on the 23d March 1803.

t Lamouroux has observed well respecting these, " $r e s$ petits rameanx, simples ou jameux, presque tons tinctiferès, ressembient à des aiguillons épars sur toute la surface de la plante, lorsqu'eilc est ronde ou presque ronde, et seulement sur les côtés lorsqu'elle est tres eomprimée."
} 


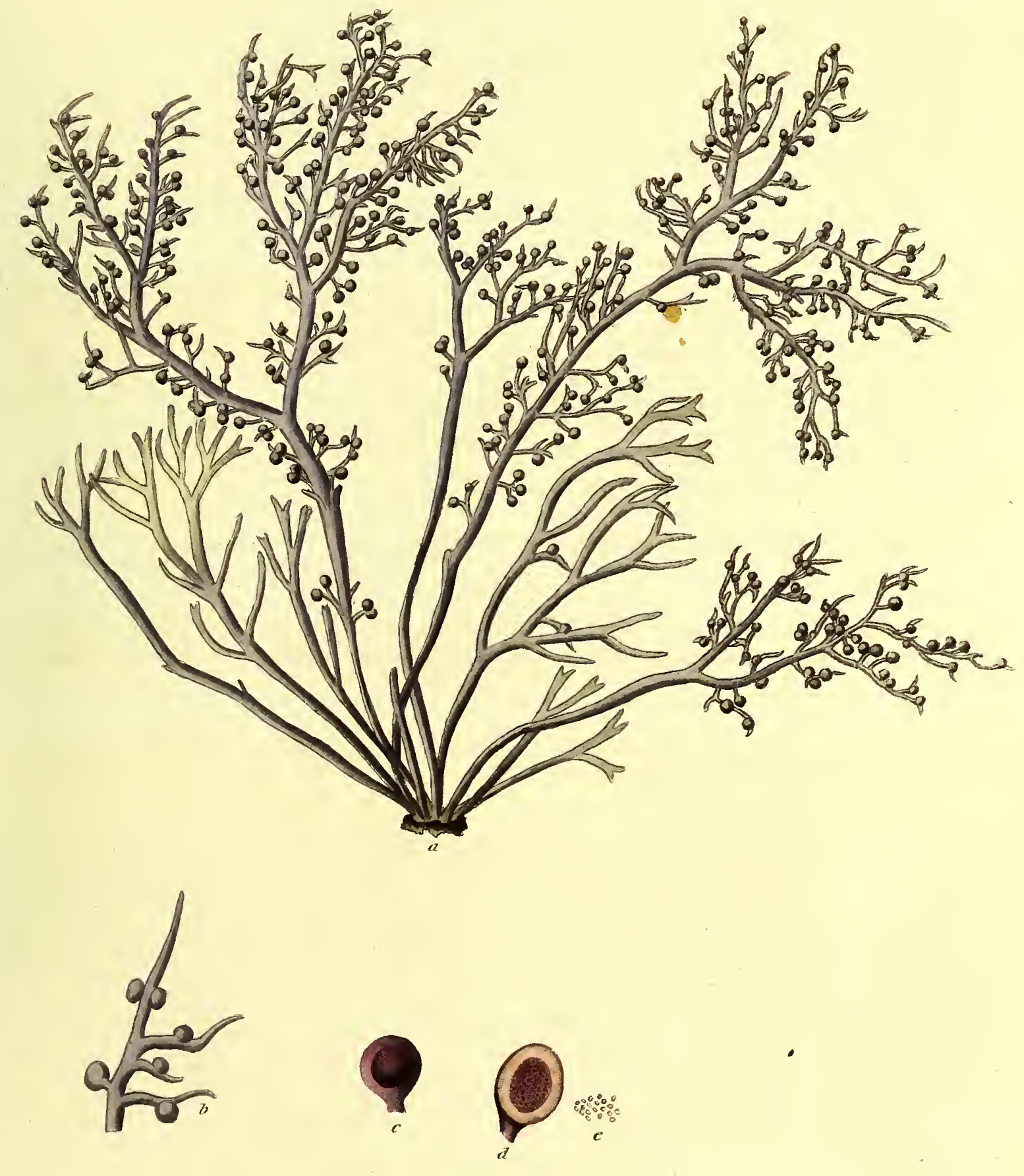



description is both full and accurate. The var. $\beta$ he suspects may prove really distinct. The horizontal tooth-like ramuli placed oll the dichotomous frond, joined to the thorny appearance of this plant, and to the disposition of the spherical capsules, will distinguish it from its congeners.

a. F. gigartinus, natural size.
b. upper part of a branch, magnified. -
c. capsule - 6 .
d. longitudinal section of the same - - -
e. seeds - - -4.

\section{9.-F U C US KA L IF ORMIS.}

Fucus fronde sub-gelatinosâ, filiformi, tubulosâ, ramosissimâ; ramis ramulisque sub-verticillatis, articulato-contractis; tuberculis sessilibus, seminibusque in ramulis sparsis.

Fucus kaliformis. Linn. Trans. III. p. 206. t. 18. Wiтн. IV. p. 89. Eng. Bot. IX. t. 640. Syn. Fuc. II. p. 377. Lam. Diss. Fuc. p. 57. t. 29.

F. verticillatus. Fl. Scot. p. 962. t. 31. Wiтн. IV. p. 90.

Ulva purpurascens. Fl. Ang. p. 569.

ß. diaphanus; fronde teretiusculầ; ramulis productis, sub-simplicibus; contractionibus obsoletis.

F. kaliformis. $\beta$. Syn. Fuc. II. p. 378.

F. diaphanus. EsPER, 1c. Fuc. I. p. 150. t. 102.

Ceramium tubulosum. Roтн, Cat. Bot. II. p. 164. (excl. syn.) III. p. 124.

Conferva tubulosa. Wulfen, Crypt. Aquat. n. 14. (excl. syn.)

r. nanus; fronde implexâ, articulatâ; ramis ramulisque horizontalibus articulatis; articulis fasciatis.

Hа вітат in Angliæ australis et Egypti oris.-In Galliæ oris. Lamouroux.- $\beta$ ad Insulam Monam. $D . H$. Davies.-In Scotiæ occidentalis oris. D. Menzies.-Prope Eblanam, cum var. «. D. Scott.-In Hiberniæ septentrionalis oris, prope Belfast, cum var. a. D. Templeton.-In Mari Adriatico. Wulfen.-y apud Torquay in Devoniâ. $D^{n a}$ Griffiths.-Inter rejectamenta maris apud Brighton. D. Borrer.

Annua. Jun.-Sept.

RADIX callus exiguus, expansus, fibris aliquot brevibus, teretibus, ramosis saxo affixus, et inde sub-repens.

Fronnes nunc solitariæ, nunc binæ ternæve, tubulosæ, filiformes, longitudine pedales aut sesquipedales, caule iristructæ indiviso, crassitiem pennæ ut plurimum corvinæ, quanddque autem anserinæ, aut olorinæ, æquante, basi attenuato, cæetera æquali, risi quòd hic illic interdùm vagè contractus appareat, ramis per totam longitudinem laxè obsito oppositis alternisque, sæpiùs autem sub-verticillatis, elongatis, iis medium versus plerumque longissimis, sed hoc incertum, apice obtusis, basi attenuatis, haud ita teretibus ut caulis, sed incerta per intervalla evidentiùs constrictis, minorum serie obsitis, qui eâdem, quâ primarii ratione ibi copiosissimè ubi frons contrahitur sunt dispositi, seriemque tertiam non rarò gignunt : ramuli in caule ramisque sparsi, simplices, abbreviati, obtusi, ita manifestè constricti ut contractiones genicula mentiantur, et ex articulis brevibus oblongo-ovatis omninò compositi videantur; attentiùs tamen inspicienti istlımis nullis intùs sunt intercepti.

FruCT1F1CATIo duplex, utraque in ramulis sita; hac e seminibus constans subrotundis, nudis, in ipsâ frondis substantiâ immersis; illa e capsulis sessilibus, junioribus sphæricis, adultis oburceolatis, et apice apertis, globulum intensè rubrum e seminibus oblongo-pyriformibus compositum includentibus.

* Color amøè̀ roseus, fugacissimus; soli exposite lutescens, vel virescens, quandòque etiam albicans.

Substantia admodùm tellera, sub-gelatinosa, lubrica.

$\beta$ tenuior quàm $\alpha$, ramos habet pauciores, minùs evidentèr constrictos, ranulosque elongatos sub-simplices, adeo. obsoletè contractos ut propemódùm teretes videantur.

y varietas est notatu dignissima, et quæ pro distinctâ specie facilè possit haberi : densis multumque implexis cæespitibus nascitur : frondes longitudine vix tres pollices crassitie vix Merula pennam æquant; rami omnes sparsi, horizon-

tales,

* Colorem huic plantre dilutè vel albescenti-viridem Lightfootius, primùm dilutè virentem, seriùs albentem, quandoque et dilıtâ rubeciine tinctan Wulfenus, in juniore statu viridem, in provectiore pallicie virentem, in perfecto album Rothius tribuit. 
tales, oculo inermi nequaquam magis liquido contracti quam in var. $\alpha$ et $\beta$, sed sub lente observati verè articulati; articulis fasciatis, longitudine diametrum duplo superante.

Lightfootii, qui primus hunc Fucum in Florâ Scoticâ adumbravit, descriptio et icon ad exemplar exsiccalum, et absque pressurầ exsiccatum, confectæ, erroribus plurimis ansam præbuerunt, unde Witheringius $F$. kaliformem et verticillatum pro distinctis speciebus habuit, et cùm Goodenovius Woodwardiusque eum in Societatis Limnæanæ Actis optimè describerent hunc pro synonymo citare non sunt ausi. Hi sunt qui $F$. lialiformem primi extra dubitationem posuerunt, nec tamen, quod mireris, articulatam illam memorârunt faciem, quât character specificus præcipuè nititur. Cum $F$. clazelloso scilicet commiscuerant, et, licet veranı tabula plantam sistat, descriptio partim ex alterâ parata videtur. Sunt quidem hæ stirpes reverà quam maximè affines; me tamen judice certè distinctæ; in îs discrepant, quod $F$. clavellosi habitus magis ad pinnatum accedat, quod rami ramulique ad basin nequaquàm sint attenuati, quor oppositi alternique, sed nunquam, quatenus vidi, verticillati, disponantur, et qudd contractionibus istis in $F$. kaliformi primo aspectu notabilibus omninò teretes careant. Varietas $\beta$, suprà memorata, multum ad utrumque conjungendums facit, sed vel hæc habitu a $F$. clavelloso longè recedit. Discrimen quod in tuberculorum formâ positum speraveram, pluribus observatis exemplaribus, evanuit, et capsulas ortu sphæricas mox progrediente ætate oburceolatas evadere, ut primus docuit D. Borrer, non modò in hoc Fuco sed et in $F$. confervoide et aliis, nuper ex autopsiâ ipse scivi. Inter $F$. kaliformem et $F$. articulatum multum affinitatis interest, et reperiuntur aliquando frustula illisa et diffracta, de quibus difficile sit dictu utri rectiùs associarentur: articulorum in $\boldsymbol{F}$. articulato per totam frondem ad amnssim ellipticorum formâ et habitu dissimili certissimè dignoscuntur.

a. F. kaliformis, magn. nat.

b. pars frondis cum capsulis, magn. auct. - 6 .

c. ejusdem portio cum capsulis jam primùm ortis 5 .

d. ejusdem portio cum capsulá atatis provectioris 3 .

e. semina - - - - - - - 1 .

f. frondis portio cum seminibus sparsis - $\quad 3$.

g. semina - - $\quad$ - $\quad$ - $\quad-\quad$ - 1

h. varietatis $\beta$ portio - - $\quad-\quad$ - $\quad-6$.

i. ejusdem pars cam capsulis adultis - $\quad 3$.

\section{9.-F U C US KALIF O R I S.}

Fucus kaliformis, frond subgelatinous, filiform, tubular, much and irregularly branched; branches and ramuli generally verticillate, contracted as if jointed; tubercles sessile, and scattered seeds on the ramuli.

Facus kaliformis. Linn. Trans. III. p. 206. t. 18. Wiтн. IV. p. 89. Eng. Bot. IX. t. 640. Syn. Fuc. II. p. 377. Laм. Diss. Fuc. p. 57. t. 29.

F. verticillatus. Fl. Scot. p. 962. t. 31 . Wітн. IV. p. 90.

Ulva purpurascens. Fl. Ang. p. 569.

8. diaphanus; frond roundish ; rannuli long, generally simple; contractions obsolete.

F. kaliformis. $\beta$. Syn. Fuc. II. p. 378.

F. diaphanus. EsPer, Ic. Fuc. I. p. 150. t. 102.

Ceramium tubulosum. Roth, Cat. Bot. II. p. 164. (excl. syn.) III. p. 124.

Conferva tubulosa. Wulfen, Crypt. Aquat. n. 14. (excl. syn.)

\%. nanas; frond entangled, jointed; branches and ramuli horizontal.

On the shores of Egypt and the South of England.-Coast of France. Lamouroux.- $\beta$ at the Isle of Anglesea. Rev. H. Davies. - Western coast of Scotland. Mr. Menzies.-Near Dublin, with $\alpha$. Dr. Scott.-North of Ireland, about Belfast. Mr. Templeton.-In the Adriatic. Wulfen.-r at Torquay. Mrs. Griffiths.Among the rejectamenta of the sea at Brighton. Mr. Borrer.

Anmual. June-September.

Roот; a small, expanded callus, fixed to the rocks by a few short cylindrical fibres, and inclined to creeping.

Fronds, sometimes solitary, sometimes two or three from the same base, tubular, filiform, a foot or foot and half long, furnished with an undivided stem, in general about the thickness of a crow's-quill, but occasionally equal to that of a goose or swan, attenuated near the root, in other parts equal, except that it is sometimes here and there slightly contracted: 

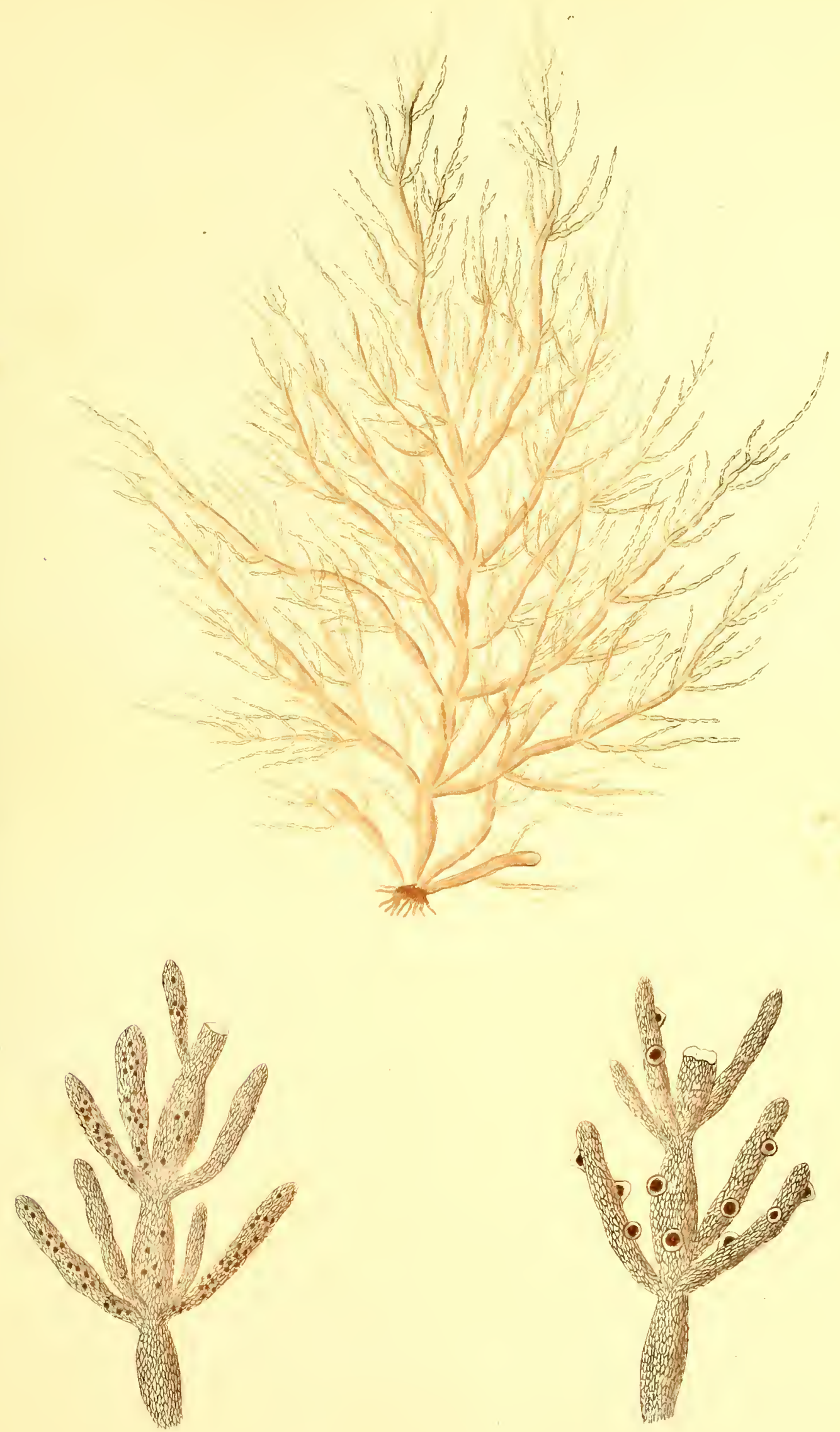

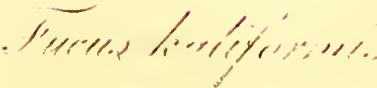





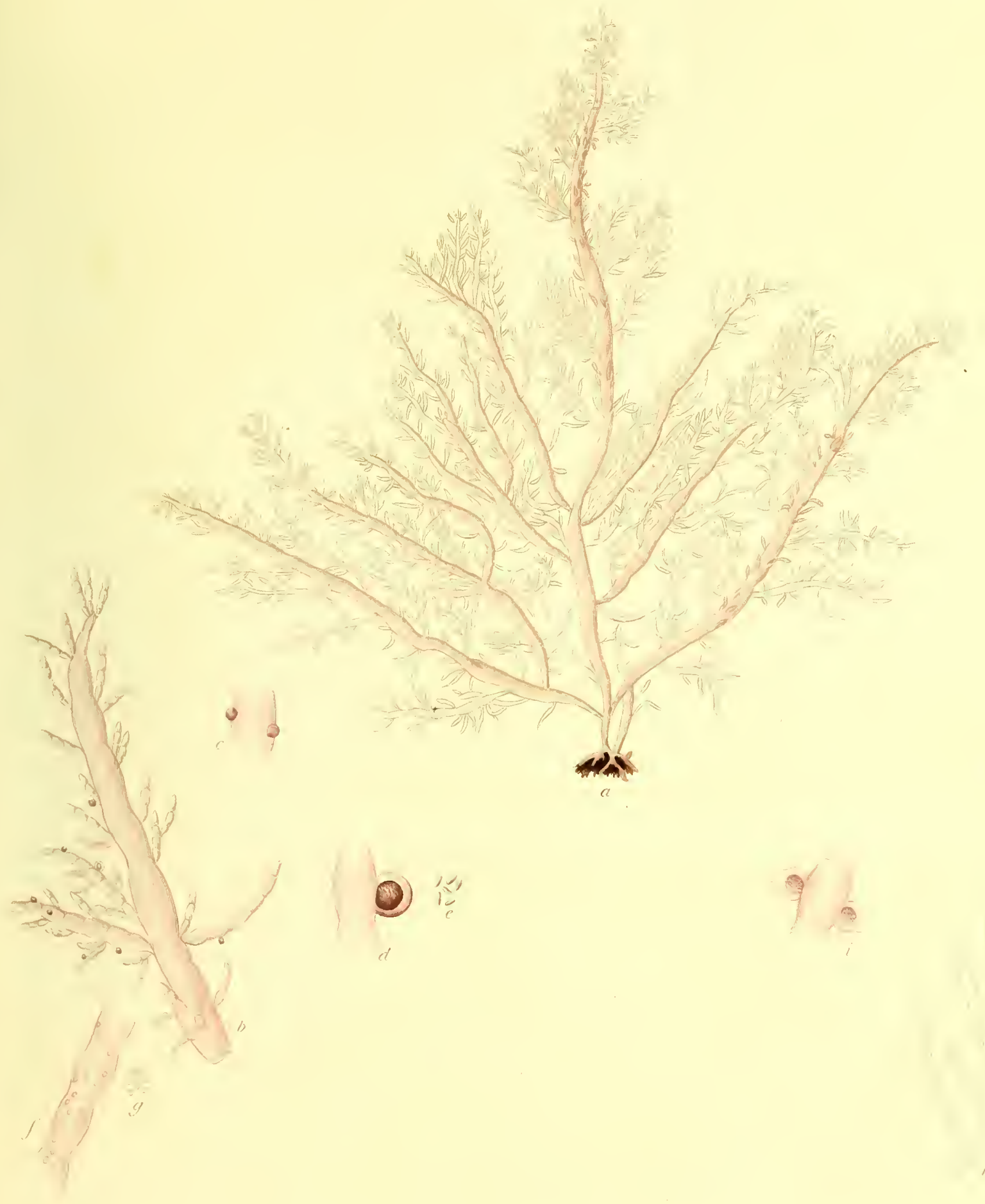

- tueves ficeliferomes. 
contracted: this stem from base to summit is luosely beset with long branches, either opposite or alternate, or, as more commonly happens, placed in whorls, the middle ones in general longest, but this is uncertain, all blunt at their apices, and attenuated at their origin, not so cylindrical as the stem, but marked at uncertain intervals with more evident contractions, provided with a set of smaller ones, arranged like the primary ones, originating most copiously at the contractions, and not unfrequently themselves producing a third series : the ramuli are scattered over the stem and branches, simple, short, and blunt; so visibly and regularly contracted, that they look like a string of short, oblong, ovate joints, but, if more carefully examined, they will be found to be unprovided with septa within.

FRUCTIFICATION, of two sorts, both placed on the ramuli; the one, consisting of naked, roundish seeds, immersed in the substance of the frond; the other, of sessile capsules, spherical in their younger state, but when full grown inversely urceolate and open at their apices, containing a globule composed of seeds of a shape between oblong and pyriform.

CoLOR, beautiful pink, *xtremely fugitive; when exposed to the sun yellowisl, or greenish, and sometimes almost white.

SuBSTA NCE, extremely tender, slippery, and sub-gelatinous.

$\beta$ is thinner than $\alpha$, has fewer branches, less evidently contracted, and long almost simple ramuli, with their contractions so obsolete that they look nearly cylindrical.

$\gamma$ is a most remarkable variety, and might easily be taken for a distinct species : it grows in densely matted tufts, with fronds scarcely three inches long, and not thicker than a blackbird's quill : the branches are all scattered, horizontal, and to the naked eye not more visibly contracted than those of $\alpha$ and $\beta$, but under a glass really divided into joints about twice as long as they are wide.

The description and tigure of this plant, given by Lightfoot in the Flora Scotica, where it was originally described, having unfortunately been taken, not only from a dried specimen, but from one dried without sufficient pressure, have been the cause of numerous errors; so that Withering was led to regard $F$. kaliformis and F. verticillatus as distinct species, and when Dr. Goodenough and Mr. Woodward wrote their excellent history of the former in the Linnæan Transactions, they did not venture upon quoting the latter as a synonym. It was these gentlemen who first removed the present Fucus beyond the reach of doubt, but, what is singular, rever noticed the jointed appearance, on which its essential specific character principally rests. The cause lay in their not having separated it from $F$. clavellosus, from which their description appears to have been in part taken, though their figure represents the true plant. These two species are in reality very closely allied, but still, in my opinion, unquestionably distinct. They differ in the following circumstances:- the habit of $F$. clavellosus is more inclined to pinnated; the branches and ramuli are by no means attenuated at the base; and, though they vary in being both opposite and alternate, are never, as far as I have seen, verticillate; nor are they marked with those joint-like contractions, so apparent at first sight in $\boldsymbol{F}$. kaliformis. 'The variety $\beta$, mentioned above, is somewhat intermediate between them, but even this has a habit very unlike that of $F$. clavellosus. An exannination of several specimens has proved to me that the difference which I had hoped to find in the shape of the capsules of these two plants does not exist; but that the tubercles in either are at first spherical, and as they ripen become inversely urceolate; a circumstance originally pointed out to me by Mr. Borrer, and which I have since had repeated opportunities of observing myself, not only in this Fucus, but in $F$. conferzoides, and some others. There is a considerable resemblance between $F$. kaliformis and $F$.articulatus, and battered fragments may occasionally be met with, which it would not be easy to refer positively to either of them: the exactly elliptical shape, however, of the joints of $F$. articulatus throughout the whole frond, and the very dissimilar habit will certainly distinguish them.
a. F. kaliformis, natural size.
b. upper part of frond, with capsules, magnified - 6 .
c. piece of ditto with very young capsules - - 5.
d. ditto with a capsule more advanced - $\quad$ - $\quad 3$.
e. seeds - - - $\quad$ - $\quad$ - $\quad$ - $\quad-1$.
f. portion of frond with scattered seeds $-\overline{-} \quad-3$.

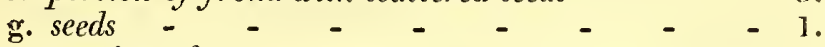
h. portion of var. $\beta$ - $\quad$ - $\quad$ - $\quad$ - $\quad-\quad$ - 6 .
i. small piece of ditto with capsules - $\quad$ - 3 .

* So fugitive that it has been called by Lightfoot whitish-green; by Wulfen pale-green at frst, then whitish, and somctine linged with a bight reddish hue; by Roth, green in its youngest state, pale-greenish when more advanced, and white in perfection. 
Fucus clavellosus, frond sub-gelatinous, filiform, cylindrical, tubular, much and irregularly branched ; branches and ramuli mostly alternate and distichous; tubercles sessile, and scattered seeds on the ramuli.

Fucus clavellosus. Turner, in Linn. Trans. VI. p. 133. t. 9. Syn. Fuc. II. p. 373. Eng. Bot. XVII. t. 1203. (malè.)

ß. sedifolius; ramuli between oblong and oval, crowded, undivided.

F. clavellosus. $\beta$. Syn. Fuc. II. p. 373.

On the eastern shores of England. - In Dublin Bay. Dr. Scott. $-\beta$ at Lossiemouth in Scotland. Mr. Brodie.Cornwall. Mrs. Griffiths._-Bantry Bay, with var. a. Mr. J. T. Mackay.

Annual. July-September.

Rоoт, an extremely small, blackish, callous disk.

FRONDS, in general solitary, cylindrical, filiform, tubular, from three to seven inches long, preserving from base to summit an equal thickness of about a sparrow's quill, and rising with a stem in general undivided, but occasionally forked, every where beset with elongated branches, frequently not inferior to the stem itself, but of very different length in different individuals, either opposite or alternate, but never, as far as I have seen, verticillate, furnished with a series of smaller ones disposed in a similar manner, and these again in their turns often with a third: the ramuli are: two or three lines long, cylindrical, sometimes simple, and sometimes irregularly divided, in some specimens clustered, in others placed in a loose sub-pinnated mamner. Neither in the branches nor the ramuli are any traces of joints or contractions observable.

Fructification, of two kinds, both situated on the ramuli; the one, composed of scattered, roundish, naked seeds, inmersed in the very substance of the frond; the other, of capsules sessile on the sides, or at the axillæ of the ramuli, at first spherical, afterwards inversely urceolate, perforated at their apices, containing a globular niass of roundish seeds.

CoLOR, pale-red, approaching to that of bricks, less fugitive than in $F$. kaliformis; when exposed to the sun, or decaying, turning to a whitish-green.

SUBSTANCE, tender, slippery, sub-gelatinous.

$\beta$ is so singular a variety that it appears a distinct species, nor am $I$ at present fully certain whether it ought not to be regarded as such : the frond is in general scarcely three inches long, but sometimes extends to half a foot; it is not, as in a, every where cylindrical, but thickened in the middle, and narrowed towards the base and apices: the ramuli are very numerous, arranged close to each other, between oblong and elliptical, and undivided.

Although from the circumstance of this very elegant Fucus having remained till within a few years undescribed, it has escaped the attention of most Botanists, there have long been specimens of it in the Linnæan and Banksian Herbaria, communicated by Sir Thomas Frankland, who found it growing upon the rocks near Scarborough, and appears to deserve the merit of being its original discoverer. The same gentleman had also sent it to Hudson and Lightfoot, both of whom acknowledged it to be a new species, and purposed introducing it in future editions of their works, the one under the name of $F$. clavellosus, the other under that of Ulva pinnata. Nor ought we, as it has * elsewhere been observed, to wonder that plants like the present should have been by different authors referred to different genera, their texture and habit approaching no less to the Ulva than to the Fuci, so that, if those individuals were only found which bear the scattered seeds, they would infallibly be referred to the former. Upon the marks which principally tend to separate $\boldsymbol{F}$. clavellosus from $\boldsymbol{F}$. kaliformis enough has already been said under the preceding species, nor is there the least room for doubt of their being sufficiently distinct, although many naturalists have confounded them. The present Fucus may still more easily be mistaken for the following one, especially if only hastily looked at; the leading characters of distinction will be found under $F$. capillaris. Subsequently to the publication of the Synopsis of the British Fuci, Mr. Brodie has met with the var. $\beta$, above described, very abundantly in Scotland, where the appearance of the plant that is more common with us never occurs : the ramuli strongly resemble in form the leaves of Sedum sexangulare, and afford an additional proof that $F$. ovalis and its congenerg ought to be separated from the tribe of Fuci with distinct leaves. The mode of growth in this differs from that of var. $\alpha$, particularly in the branches never being multifid, but furnished with a series of smaller ones, so that the whole plant has a proliferous appearance.

$$
\begin{aligned}
& \text { a. F. claveilosns, natural size. } \\
& \text { b. part of a branch, with ramuli, magnified.-- - 5. } \\
& \text { c. ramulus with scattered seeds - - - - } 3 \text {. } \\
& \text { d. ramulus with capsule - } \quad \text { - } \quad \text { - } \quad \text { - } \quad 3 .
\end{aligned}
$$

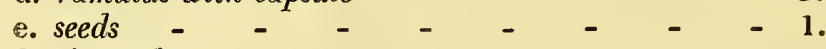

$$
\begin{aligned}
& \text { f. piece of var. } \beta \quad-\quad-\quad-\quad-\quad-5 \text {. }
\end{aligned}
$$



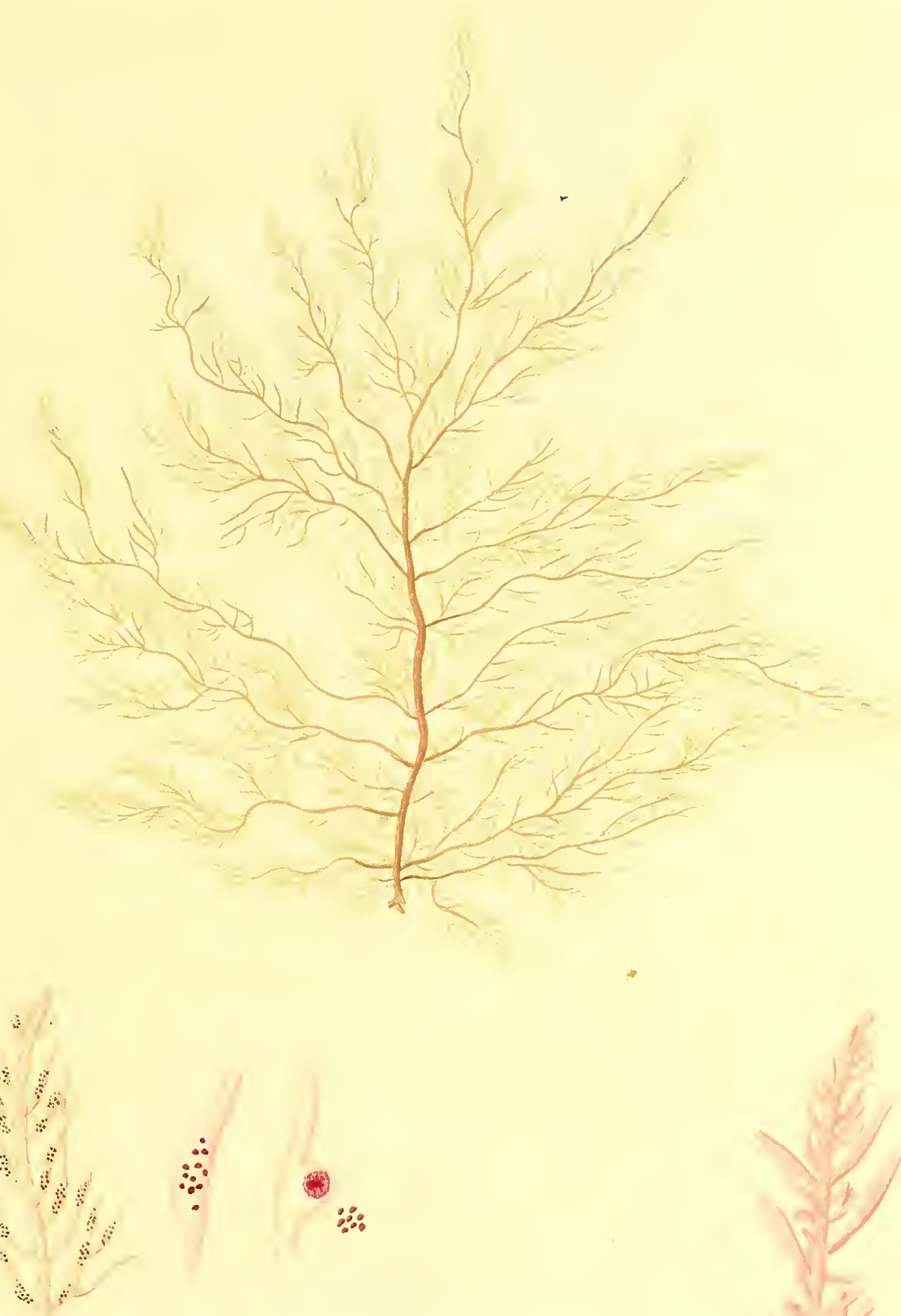

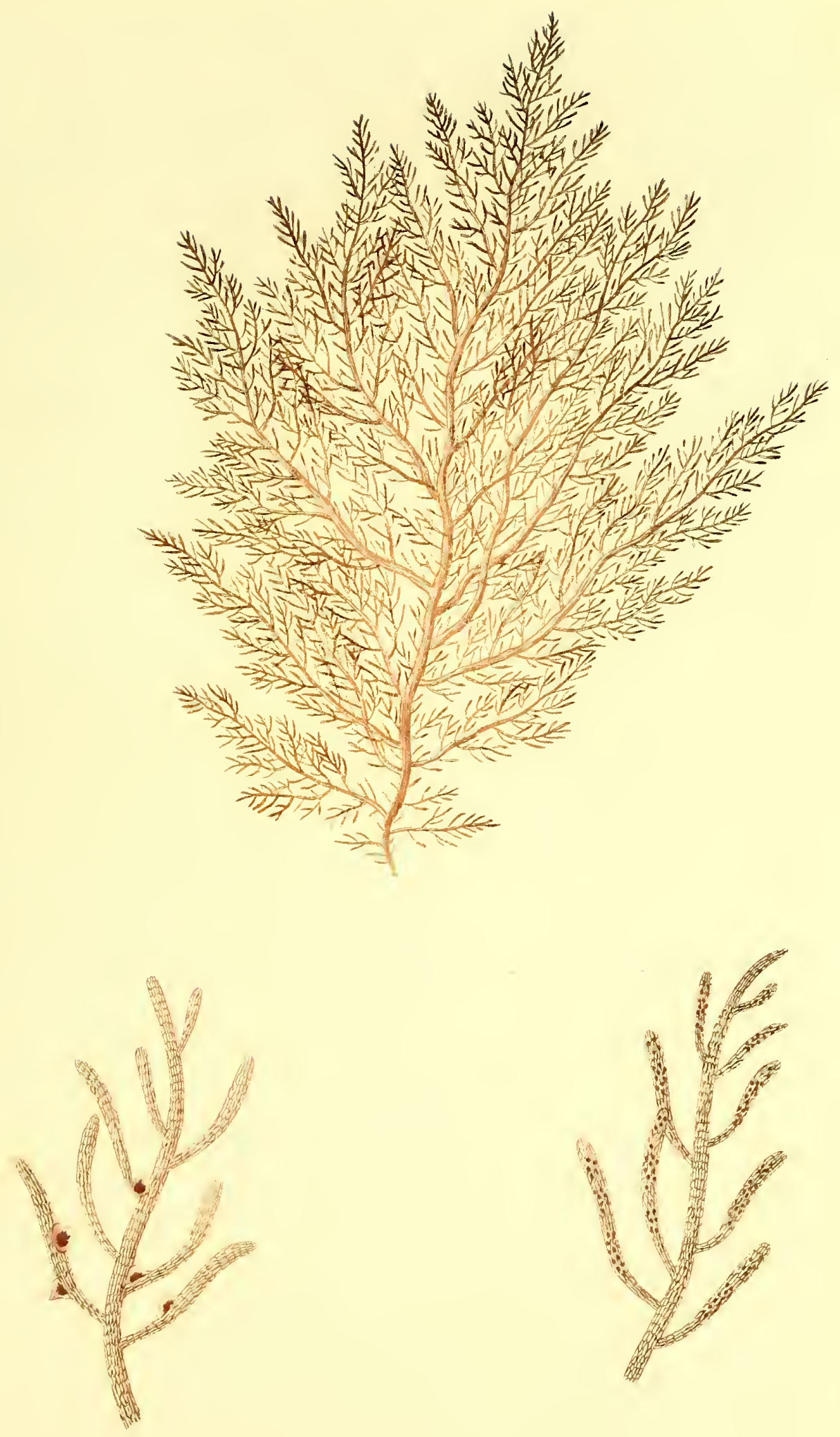

Fucus fronde sub-gelatinosâ, filiformi, tereti, tubulosâ, ramosissimâ ; ramis ramulisque sub-alternis, sub-distichis ; tuberculis sessilibus, seminibusque in ramulis sparsis.

Fucus clavellosus. Turner, in Linn. Trans. VI. p. 133. t. 9. Syn. Fuc. II. p. 373. Eng. Bot. XVII. t. 1203. (malè.).

B. sedifolius; ramulis oblongo-ovalibus, confertis, indivisis. F. clavellosus. B. Syn. Fuc. II. p. 373.

Habitat in Anglize orientalis oris.-In Sinu Eblanensi. D. Scott. $\beta$ apud Lossiemouth in Scotiâ. $D$. Brodie.-In Cornubiâ. $D^{n a}$ Griffiths.-Apud Bantry Bay, unà cum var.. . D. I. T. Mackay.

Annua. Jul.-Sept.

RADIX callus perquam exiguus, nigricans.

FroNDEs subsolitariæ, teretes, filiformes, tubulosæ, longitudine palmares, vel spithamre, crassitie a basi ad apices usque æquali, pennam passerinam æquante, caule instructæ plerumque indiviso, rariùs bifurco, ubique obsito ramis elongatis, caulem ipsum sæpe æquantibus, longitudinis tamen in diversis individuis quàm diversissimæ, nunc oppositè nunc alternè, sed nunquam, quantum vidi, verticillatìm dispositis, minorum simili ratione dispositorum serie instructis, qui tertiam quoque non rarò ferunt ; ramuli duas tresve lineas longi, cylindracei, vel simplices vel enormitèr divisi, in quibusdam exemplaribus laxè sub-pinnatim positi, in aliis congesti.-Neque in ramis nec in ramulis articulorum vel contractionum vestigia ulla sunt detegenda.

FruCTificatio duplex, utraque in ramulis sita; hac e seminibus constans sparsis, subrotundis, nudis, in ipsâ frondis substantiâ immersis; illa e capsulis ramulorum ad latus vel ad alas sessilibus, ortu sphæricis, mox oburceolatis, apice pertusis, seminum subrotundorum congeriem globosam includentibus.

CoLor dilutè lateritius, multo minus quam in F. kaliformi fugax; soli expositc aut marcescentis albo-virescens.

Su BSTA NTIA tenera, sub-gelatinosa, lubrica.

$\beta$ varietas est adeo singularis ut diversa species videatur, nec annon pro distinctâ haberi debeat satis mihi liquet: frons plerumque vix tripollicaris, aliquando tamen semipedalis, non, ut in $\alpha$, ubique cylindracea, sed medio incrassata, et basin et apices versus attenuata, ramulis frequentissimis, approximatis, ex oblongo ellipticis, simplicibus.

Perelegans quamvis hæcce Fuci species ad nostrum usque tempus descriptione caruerit, idedque Botanicorum plurimorum notitiam fugerit, extitere tamen jamdudum in Herbario Linnæeano et Banksiano exemplaria ab illust. $T$. Frankland, Baroneto missa, qui primus omnium multos abhinc annos rupibus submarinis prope Scarborough innascentem detexisse videtur; et qui cum Hudsono Lightfootioque communicârat, quorum uterque pro novâ plantâ agnovit, et hic $F$. clavellosi, ille Ulve pinnata nomine insignire staiuit. Neque, sicut* alias est observatum, nirari debemus qudd hæc stirps eique congeneres ad diversa genera ab auctoribus diversis fuerint relatæ, quippe quæ quoad texturam et habitum tantum inter Fucos et Ulvas ambigunt, ut, si exemplaria seminibus modd sparsis prædita reperiantur, absque dubio his annumerentur. Notæ quæ $F$. clavellosum a $F$. kaliformi secernunt jam sub illâ specie exponuntur, nec dubitare licet de differentiis inter utrumque specificis, quamvis sint a multis commixti : arctiorem adhuc habet hæc planta primo aspectu cum insequente affinitatem, de quâ sub F. capillari erit dicendum. Fucorum Britannicorum Synopsi jam evulgatâ, varietatem $\beta$, suprà descriptam, in Scotiæ oris, ubi stirpis facies nobiscum magis vulgata nunquam occurrit, copiosè legit $\mathrm{D}$. Brodie : ramuli Sedi sexangularis folia referunt, novumque præbent testimonium $F$. ovalem sibique affines a Fucorum foliis distinctis præditorum familiâ esse disjungendos. Crescedi modus in hâc ab eâ var. a diversus, quoniam ranıuli nunquam sunt nultifidi, sed aliis minoribus instructi, adeoque proliferi.

a. F. clavellosus, magn, nat.

b. rami pars, cum ramulis, magn. auct. - 5 .

c. ramulus cum seminibus sparsis - $-\mathbf{3}$.

d. ramulus cum capsulâ - - - 3 .

e. semina - - - - $\quad$ - 1 .

f. portio var. $\beta$ - - - - 5 .

* Syn. Fuc. II. p. 377. 
Fucus capillaris, frond sub-gelatinous, filiform, much and irregularly branched; ramuli subulate, jointed; seedg. imbedded in the ramuli.

Fucus capillaris. Fl. Ang. p. 591. WIтн. IV. p. 115. Syn. Fuc. II. p. 370.

Rocks in the sea near Sheerness, in the Isle of Shepey; and in Devonshire and Cornwall. Hudson.-At Scarborough. Sir Thomas Frankland.-Shores of the Isle of Anglesea. Rev. H. Davies.

Annual. In the summer Months.

Rоот, a small, dilated, blackish, callous disk.

FRONDS, numerous from the same base, from seven to nine inches long, cylindrical, filiform, tubular, as thick as a blackbird's quill, rising with a single undivided stem, beset from base to summit with branches rather loosely disposed, sometimes opposite, at others alternate, an inch, or inch and half long, the central ones generally longest, the whole furnished with a series of smaller ones similar to them in every respect, except size, and these again with simple, short, subulate, jointed ramuli, for the most part rather remote, but placed without any regular order: the branches. and ramuli are all between erect and patent, slightly attenuated at their bases, and remarkably acuminated at their apices.

Fructification, I have at present seen none, except largish, spherical, dark-purple seeds, internally dotted. under the microscope, immersed in the middle of the substance of the ramuli, which then swell, and apparently discharge the office of capsules.

COLOR, a beautiful semitransparent pink: in a dried state darker and more approacling to scarlet: turning in decay to a dirty white.

SUBSTANCE, very tender, slippery, and almost gelatinous:-in a state of decay the ramuli break into very small oblong or elliptical granules, and the plant has then somewhat the look of a Rivularia.

The whole catalogue of British Fuci does not contain a single plant that has been so much involved in doubt as: F. capillaris, for being known only by Hudson's short and * unsatisfactory description, and being a plant of un-. frequent occurrence even on the British shores, to which alone it appears to be confined, its very existence as a distinct species has been considered so questionable, that neither Dr. Goodenough and Mr. Woodward in their. Observations on the British Fuci, nor Mr. Stackhouse in his Nereis Britanica, nor Professor Gmelin in his Edition of the Systema Natura, have ventured upon introducing it; and even at the time of publishing the Synopsis of the British Fuci, I had seen nothing more than two small specimens, so that I could say littla respecting it, which: might be satisfactory either to my readers or myself. I have therefore felt a particular pleasure at being now enabled to remove it beyond the reach of doubt, through the kindness of my friends, Sir Thomas Frankland, and Rev. H. Davies, both of whom, by communications with. Hudson himself, know it to be the plant designed by that author, and both find it upon their own shores: to the former of these gentlemen 1 am indebted for the subject of the present plate, respecting which I feel it incumbent upon me to remark that the engraving is taken from a dried specinen, it being impossible to receive from any considerable distance a Fucus so extremely tender in a state fit for drawing. I: am also indebted to him for the two uncolored magnified sketches at $c$ and $d$, which, being done by himself in a: recent state, were too valuable to be omitted. How far the fructification represented in the ligure before us is the only one belonging to the plant is what I have no means of knowing: no other has yet been found, but from the natural affinities of the Fucus it may fairly be presumed that it produces also seeds in capsules. At the same time it is necessary to observe, that the granules here represented are very unlike those in F. clavellosus, \&c. both in their shape, nature, and situation. They seem rather to resemble those produced in the lanceolate capsules of $F$. dentatus, and the ramuli, which, when barren, are remarkably jointed, lose this appearance in fructification. The whole substance of the frond, in a state of decay, is most singular; it then falls into small oblong pieces, so as to have the woolly look of a Rivularia. In this respect it differs strikingly from $F$. kaliformis and clavellosus, to which, and especially the latter, it is more nearly related than to any other of the British Fuci. Sir Thomas Frankland finds these two species growing together on the rocks at Scarborough, and says that he can distinguish them in that state from the difference in their color: that of $F$. capillaris being of the tint of lake, whilst $F$. clavellosus is more of a yellow red: the latter, too, he observes, is a firmer plant, but $F$. capillaris is extremely tender and flexible, and plays about horizontally. To place, however, the characters which distinguish the three species from each other in the strongest point of view, it may not be amiss here to repeat them.

F. kaliformis: color, pale pink; branches and ramuli whorled, attenuated at the base ; ramuli blunt, contracted at intervals, so as to appear like a string of oblong joints.

F. clavellosus: color, yellowish red: branches and ramuli scattered, sub-distichous; ramuli cylindrical, blunt.

F. capillaris: color, pale pink : branches and ramuli scattered, sub-distichous; ramuli cylindrical, but acuminated at the apices, divided internally with very short joints.

a. $F$. capillaris, natural size.

b. small branch, magnified - - - - - $\quad 6$.

c. part of ditlo barren - $\quad$ - $\quad$ - $\quad-5$.

d. part of ditto in fruit - $\quad-\quad-\quad-5$.

e. ramulus, with seeds - - - - - 3 .

f. seeds surrounded with part of the frond decaying 1.

\footnotetext{
* This description does not altogether agree with the plant, for he calls the color blackish-purple, and speaks of the branches as always
} atternate. 

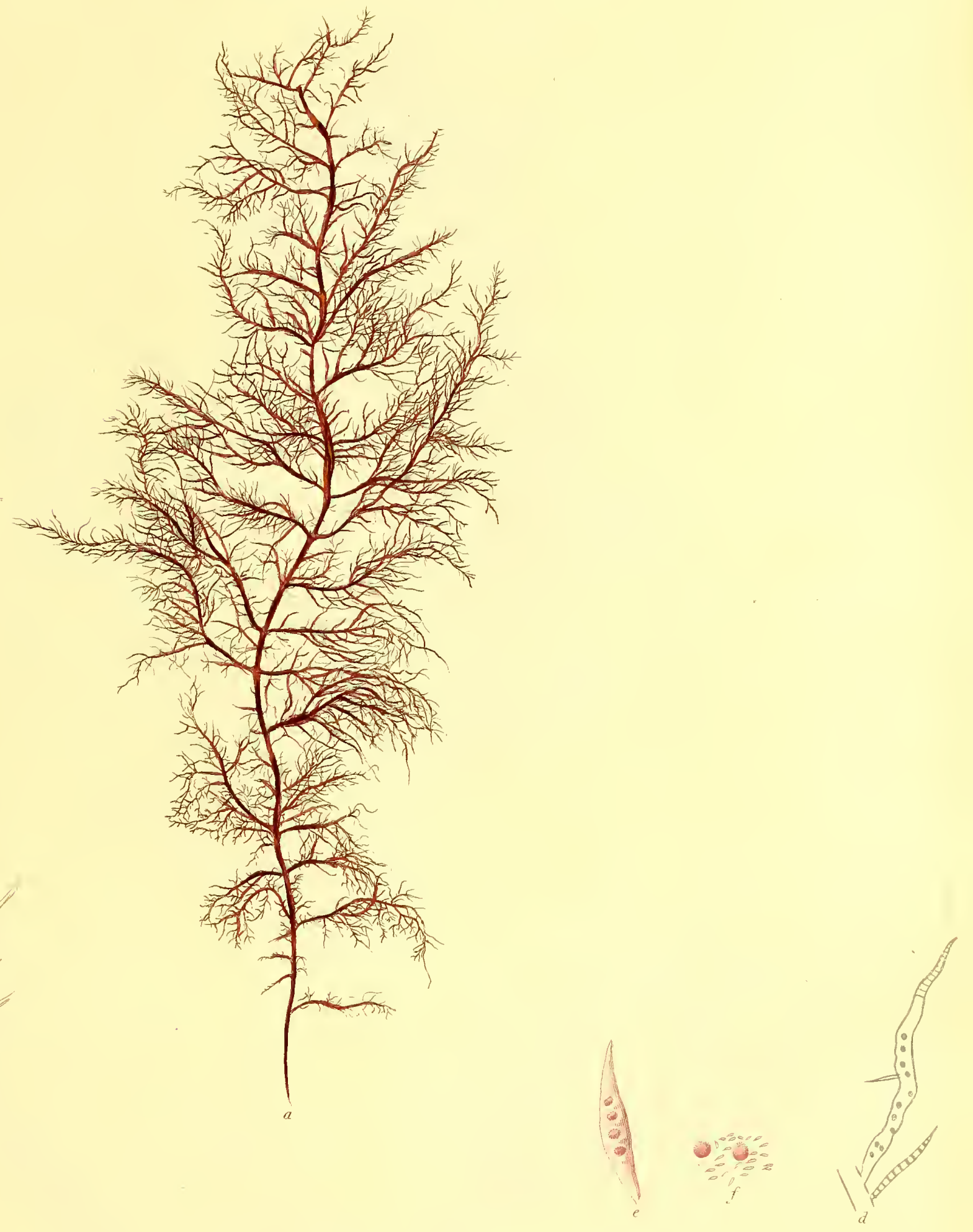

Fucues cafiellaris 



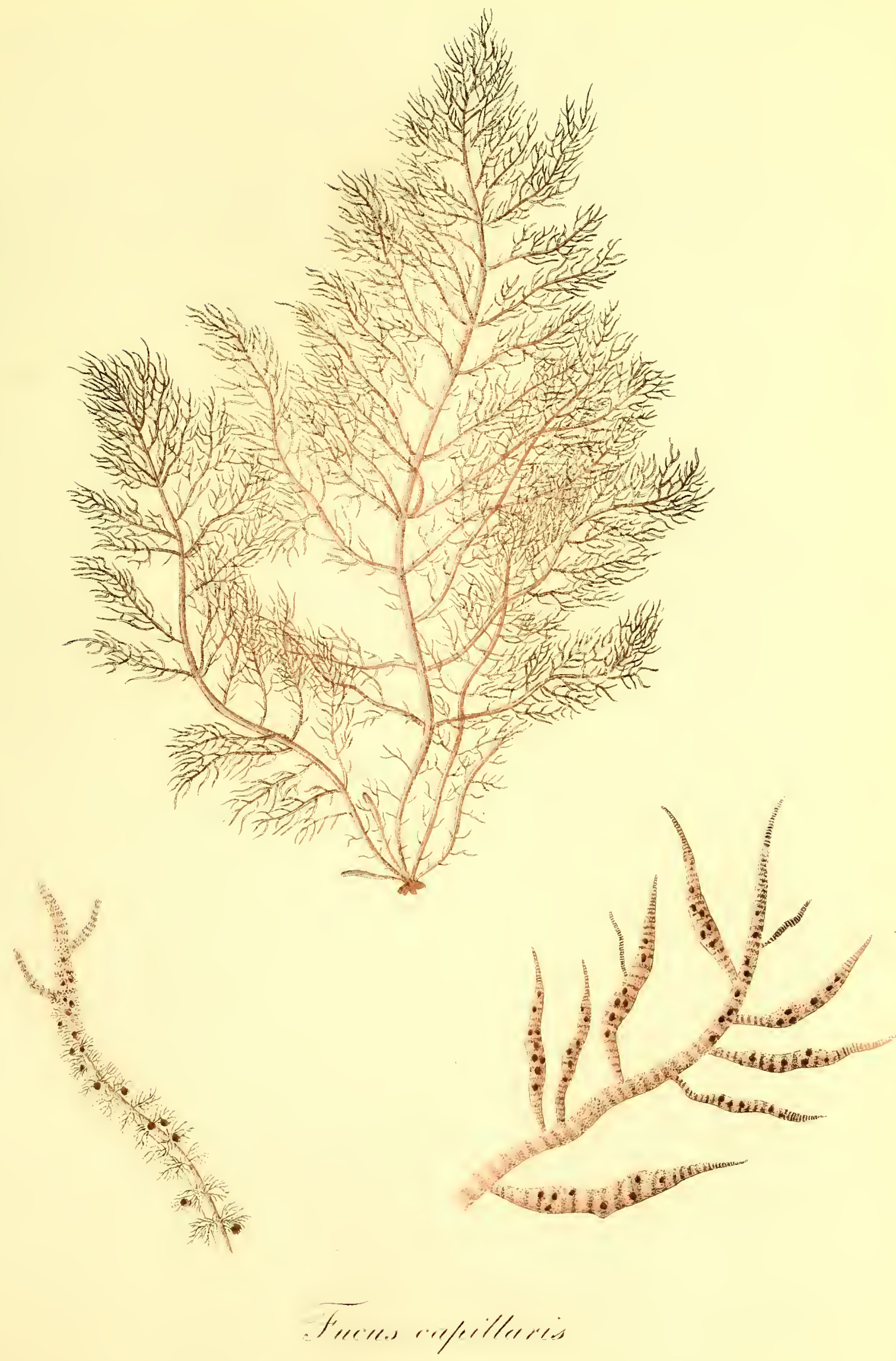



Fucus, fronde sub-gelatinosâ, filiformi, ramosissimâ ; ramulis subulatis, articulatis ; seminibus in ramulis immersis. Fucus capillaris. Fl. Ang. p. 591 . Wiтн. IV. p. 115. Syn. Fuc. II. p. 370.

Ha biт a in saxis submarinis prope Sheerness, in Insulâ Shepey; in Devoniâ et Cornubiâ, passìm. Hudson.Apud Scarborough. D. T. Frankland, Baronet.-In Insulæ Monæ oris. D. H. Dazies.

Annua. Æstate fert fructum.

Ra Drx callus exiguus, dilatatus, nigricans.

Frondes ex eâdem basi plurimæ, spithamææ, vel dodrantales, filiformes, teretes, tubulosæ, Merulce pennæ crassitie, caule assurgentes unico, indiviso, obsito a radice usque ad apices ramis laxiusculè dispositis, nunc alternis, nunc oppositis, pollicem unum alterumque longis, mediisque, ut videtur, plerumque longissimis, omnibus minorum sui, magnitudine exceptâ, similium serie instructis, qui ramulos simplices, breves, subulatos, ut plurimùm remotiusculos, attamen absque ordine certo dispositos, articulatos sustentant: rami ramulique cuncti erecto-patuli, basi levitèr attenuati, apice insignitèr acuminati.

FRUCTIFICATIONEM hactenùs nullam vidi, exceptis seminibus majusculis sphæricis, intensè purpureis, intùs sule lente punctatis, immersis in mediầ substantiâ ranulorum tunc intumescentium, et, ut videtur, capsularum vice fungentium.

COLOR amcenè roseus, sub-diaphanus; exsiccate intensior, magisque ad̉ miniatum accedens; marscescentis sordidè albicans.

SU BSTANTia tenerrima, sub-gelatinosa, lubrica :-ramuli marcescentes in granula oblonga, vel elliptica, solvuntur, et in hoc statu planta Rivularias quodanmodo refert.

Ne una datur inter Fucos Britannicos species dubïs tantum vexata quàm $F$. capillaris, utpote qui vix nisi per Hudsoni nimis * brevem descriptionem hactenùs sit cognitus, et, nunquam extra Angliæ oras repertus, infrequentissimè vel in iis occurrat. Inde accidit ut diu est inter Botannicos dubitatum num pro distinctâ specie jure sit enumerandus; nec vel Goodenovius Woodwardiusque, cùm Observationes de Fucis Britannicis in Societatis Linnæanæ Actis ederent, vel in Nereide Britannicâ Stackhousius, vel Gmelinus in Systemate Natura pro tali censere sustinuerunt: et quando ipse, aliquot inde annis elapsis, Fucorum Britannicorum Synopsin scriberem duo modo specimina eaque aded manca videram, ut nihil quod mihi ipsi aut lectori satisfaceret proferre fuit in promptu. Magnopere igitur sum gavisus, quòd per benevolentiam virorum amicissimorum, D. T. Frankland Baroneti et Reverendi H. Davies, tandem sit oblata facultas hanc stirpem ritè stabiliendi. Uterque horum $F$. capillarem in littoribus suis nascentem reperit, et uterque olim cum Hudsono literarum commercio connexus plantas ab ipso designatas ad unguem cognovit. Exemplar, quod nostra sistit tabula, horum priori debeo; memorare autem necesse duco iconem exsiccatum exhibere, cùm non foret possibile stirpem tan teneram ad locos longè dissitos madentem illæsamque portare. Eidem quoque debeo adumbrationes lente auctas ad literas $c$ et $d$ exsculptas, quas ipse in statu recenti delineaverat, et quæ nimii erant momenti ut omitterentur. Præter fructificationem hìc depictam nulla est hucusque in hâc plantâ detecta, suspicandum autem est, ex iis quibus maximè est affinis Fucorum speciebus, ferre quoque semina in capsulis inclusa. Neque tamen silentio præterire debeo $F$. capillaris granula esse quoad formam indolem situmque absimilia iis in $F$. clavelloso et congeneribus occurrentibus; potiùsque referre ea quibus $F$. dentati capsulæ lanceolatæ sunt instructæe. Ramuli quoque, qui steriles insignitèr sunt geniculati, hanc facien fructiferi exuunt. Frondis marcescentis substantia est notatu dignissima; lanatam Rivulariæ speciem tunc temporis præ se fert, et in frustula minutissima oblonga omnis solvitur. 'Toto cælo differt $F$. capillaris in hoc a $F$. lialiformi et $F$. clacelloso, cum quibus, et presertim cum posteriore, affinitate arctiore quàm cum ullâ aliâ inter species Britunicas deviṇcitur. Memorat D. Frankland, qui ambas unà in rupibus submarinis prope Scarboroug! nascentes legere solet, se posse hanc ab illâ vel intra aquam dignoscere, cùm ob colorem, qui in F. capillari laccé tincturam simulit, dum $F$. clavellosi ruber luteo est immixtus, tùm quia hæc planta magis firna, illa vero tenerrima et fiexibilis quoquoversùm horizontalitèr fluitat. Ut tamen hæe tres species nunquam in posterum commisceantur, et ut not:e qux illas a se invicem distinguunt quàm dilucidè exponantur, characteres cujusvis proprios hìc repetere operæ fore pretium existimo.

F. kaliformis; color dilute roseus : rami ramulique subverticillati; ramuli basi, attenuati, obusi per totan longisudinem articulato-contracti.

F. clavellosus; color ruber luteo tinctus : rami ramulique sparsi, sub-distichi, ramuli cylindracei, obtusi.

$F$. capillaris; color dilutè roseus : rami ramulique sparsi, sub-distichi, apice acuminati, intùs geniculati, articulis brevibus.
a. F. capillaris, magn. nat.
b. rami pars, magn. auct. - - - $\quad-6$.
c. ejusdem portio sterilis - $\quad-\quad-\quad-5$.
d. ejusdem pars cum fructı - $\quad$ - $\quad-5$.
e. ramulus cum seminibus - $\quad$ - $\quad-3$.
f. semina fronde marcescente cinctu - - 1 .

* Neque hac descriptio, quantumvis brevis, omnibus numeris convenit, colorem enim frondis atro-purpurascentem ramosque alternos dicit. 
Fucus acanthophorus, frond cartilaginous, filiform, much and irregularly branched, beset with very short spine-like ramuli ; on the ramuli ovate capsules, and others oblong and thorny.

Fucus acanthophorus. La mo v oux, Diss. Fuc. p. 61. t. 30, 31. f. 1.

F. spiciferus. VAнL, in Skrift. af Naturhistorie Selskabet. V.pars 2da. p. 44.

On the coast of North America. Lamouroux-Island of St. Croix. Vahl.-Shores of Jamaica. Dr. Wright. - In the Red Sea. Lord Valentia.

\section{Annual?}

Root, which according to Lamouroux is a minute callus, consists in my specimens of several cylindrical, thickish, branched, matted, creeping fibres.

Fronds, numerous from the same base, five inches and more long, *cylindrical, filiform, provided with a stem about the thickness of a sparrow's quill, undivided in some specimens, in others bifid or trifid with long segments nearly of equal height, always beset from base to summit with branches, of which in old plants the lowermost are often broken off: branches scattered, either alternate, or subverticillate, generally numerous towards the apices of the frond, between erect and patent, most frequently simple, shortish, and furnished on all sides with ramuli: ramuli scarcely a line long, resembling thorns, patent, occasionally solitary, but more commonly growing tivo or three together, numerous and placed near to each other in the smaller branches, in the larger ones disposed at greater distances : sonietimes they are lengthened into new branches.

Fructification, of two kinds, each placed at the apices of the ramuli; the one, consisting of small ovate capsules, containing a few minute roundish seeds mixed with long fibres; the other, of oblong capsules, tipped with one or two spines, inclosing rather large seeds, which under the microscope appear composed of three parts.

Color, a pleasing, semitransparent brown: blackish when dry; and turning to a dirty white from decay, or long exposure to the air.

SUBSTANCE, cartilaginous, but so tender as to approach to gelatinous; thin and membranaceous after it is dried.

Mr. Stackhouse received some years since from the late celebrated Spanish botanist, Cavanilles, a variety of the present Fucus, of a substance very nearly gelatinous, and a color far more pale than the common appearance of the plant: its branches, too, were all elongated; but what was most remarkable about it was, that the apices of the ramuli were incurved, and contained a dark-coloured globule, destitute of any membranous covering, and altogether conıposed of granules so minute, that the highest powers of a compound microscope were indequate to the discovery of their forn. A small piece of this specimen is represented at the letters, $e, f$, but whether the globules are accidental, arising from some injury received by the frond, or whether they are in any wise connected with the fructification, is what I have no means of determining. Of the two kinds of the fruit described above, it appears that one only was known to Vahl, and the other only to Lamouroux; and it is this latter alone which is noticed by Weber, and Mohr, who, in their Treatise, already often alluded to in the course of this work, liave stated many particulars respecting the present Fucus. To illustrate the fructification also, as well of this, as of many other marine Algæ, they have long taken infinite pains in procuring a set of highly magnified drawings, and it is earnestly to be hoped by every lover of this department of Botany that they may soon be prevailed upon to give them to the public. Tlie prickly appearance of $F$. acanthophorus from which Lamouroux has derived his highly appropriate name, serves well to distinguish it at first sight from its congeners. The appellation given by Vahl, might, in my opinion, be improved by the changing of a single letter; thus turning spiciferus to spiniferus: it is, however, far from objectionable as it now stands, the young branches having to the uaked eye something the appearance of spikes of fructification.

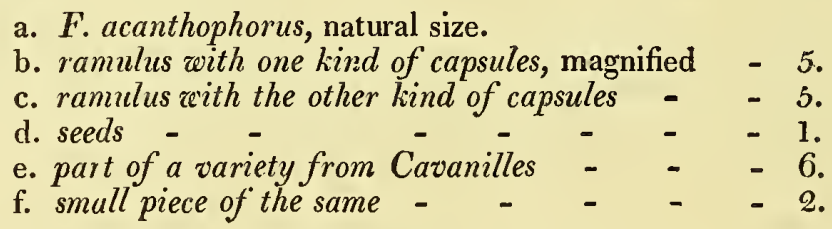

\footnotetext{
* Vahl says that they are angular with decurrent branches, but this is the ease only in dried specimens, or in such as have not sufficiently recovered themselves in water.

+ As they lave observed some points which had escaped my attention, and have seen the whole matter in a different point of view from that in which it appeared to me, I think it best here to transeribe their description, which is, as usual, full and excellent.trägt in der axillen der spinen, womit seine letzten Aeste besetzt sind, oder unter diesen spinen, oder doch sonst in ilirer Nähe, anfangs sphärische, nachlıer sich oval verlängernde, dann selbst wiederum mit spinen besetzt werdende, und endlieh in neue Aestchen auswachsende, geschlossne Pericarpien, die, besonders in ihrer ursprünglichen sphärischen Gestalt, den Globulis der Gmelinschen Fuci Glabuliferi, oder Spharvococci Stackh., äusserlich völlig gleichen. Man erkennt indess schon mit starkern Loupen in den Periearpien einzeln gestellte dunkle, verhaltnissmassig ziemlich grosse Körner, und das Pericarpium ist wirklich, wie die Durehsehnitte lehren, inwendig durch Scheidewände aus einem düunen Fasergewebe in mehrere Fächer getheilt, in deren jene Körner fast-einzeln (sub-singula) zu liegen scheinen. Auf schou in neue Vegetationstheile ausgewachsenen chemaligen Pericarpien fanden sir irregulare, dureh Ruption entstandne Löcher, aus dencn die fortpflanzenden Körner wahrscheinlich entschlüpft waren "-Beiträge zur Naturkunde. I. p. 305.
} 

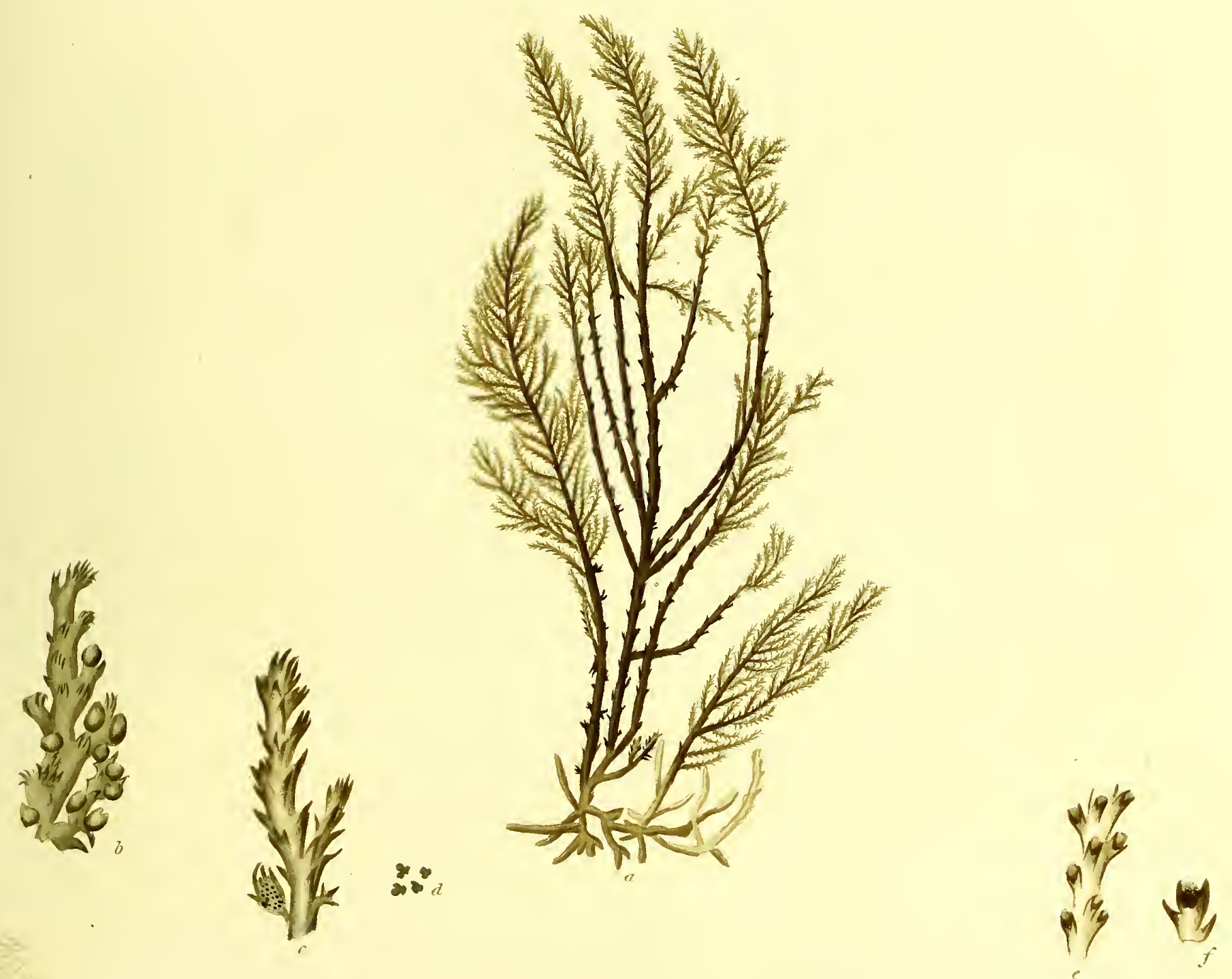


\section{2.-F U C US A G A T HOPHORUS.}

Fucus fronde cartilagineâ, filiformi, ramosissimâ, ramulis brevissimis, aculeiformibus obsitâ; capsulis oblongis spinosis, ovatisque in ramulis.

Fucus acanthophorus. Lamouroux, Diss. Fuc. p. 61. t. 30, 31. f. 1.

F. spiciferus. VA L, in Strift. af Naturhistorie Selskabet. V. pars 2da. p. 44.

Habitat in Americæ Septentrionalis littoribus. Lamouroux.-In Insulâ, St. Croix. Vahr.-In Jamaicæ oris. D. Wright.-In Mari Rubro. Vicecomes de Valentia.

Annua?

RADIx (quæ, teste Lamouroux, est callus minutus) in nostris exemplaribus e fibris aliquot teretibus, crassiusculis, ramosis, implexis, repentibus constat.

FroNDES ex eâdem basi plurimæ, sesquipalmares et ultra, teretes,* filiformes, caule instructæ pennæ passerinæ crassitie, nunc indiviso, nunc bi-tri-fido, segmentis elongatis subfastigiatis, ramis a basi usque ad apices obsito; inferiores tamen in stirpe vetustâ sæpe diffracti evadunt: rami sparsi, vel alterni vel subverticillati, plerumque frondis apices versus frequentes, erecto-patuli, ut plurimum simplices, breviusculi, ramulis undequáque obsiti : ramuli brevissimi, vix lineam longi, aculeiformes, patentes, interdum solitarii, sed sæpiùs bini ternive, in ramis minoribus frequentes et approximati, in majoribus laxiusculè dispositi: aliquando etiam elongati occurrunt, et in novos ramos producuntur.

FRUCTIFICATIO duplex, utraque ramulorum ad apices sita: hac e capsulis constans ovatis, exiguis, intra quas semina aliquot minutissima subrotunda fibris longiusculis immixta latent; illa e capsulis oblongis, spinâ unâ alterâve coronatis, semina majuscula sub lente tripartita includentibus.

CoLOR amœenè fuscus, sub-diaphanus: exsiccata nigricans: Soli exposita aut marcescentis sordidè albescens.

SUBSTANTIA cartilaginea, sed ita tenera ut ad gelatinosam accedat: in exsiccatâ tenuis et membranacea.

Varietatem hujus Fuci fronde longe teneriore propemodùm gelatinosâ, et colore dilutiore quam vulgaris plantæ facies olim ad Stackhousium misit b. Cavanilles : rami quoque in hâc omnes elongati, et, quod maximè singulare, ramulorum apices erant incurvi, globulumque includebant opacum, membranâ nullâ coopertum, sed totum e granulis constantem adeò exiguis ut singulorum forma visum sub lente acerrimâ effugeret. Hujus stirpis frustulum ad literas $e, f$, depictum extat: anne autem globuli e casu, fronde aliquo modo læsâ, pendeant, an quiddam cum fructificatione commune habeant non est quod dicere ausim. E fructu illo duplice suprà descripto unus modo Vahlio alter Lamourouxio innotuisse videtur. Hunce tantummodd memorant Weberus et Mohrius, 'qui tradiderumt multa in tractatu $\uparrow^{-}$ jam sæpe laudato de $F$. acanthophori fructificatione, quæ omnia, simul et plurima alia ad Fucorum fructum illustrandum destinata, jam olim depingi curaverunt, et de quorum iconibus debet Botanici cujusvis quam maximè esse in votis ut mox publici juris fiant. Aculeata plantæ facies, unde nomen aptissimum deduxit Lamouroux, optimè et statìm hanc stirpem a congeneribus distinguit. Titulus a Vahlio impositus meliùs quadraret, si, unâ modò literâ mutatâ, spiniferus evaderet; nec tamen spiciferus omninò displicet, cùm rami juniores oculo inermi spicas primo aspectu quodammodò referant.

a. F. acanthophorus, magn. nat.

b. ramulus cum unâ capsularum specie, magn. auct. 5 .

c. ramulus cum alterâ capsularum specie - -5 .

d. semina - - - - - - -1 .

e. varietatis portio $\quad-\quad-\quad-\quad-\quad-\quad-6$.

f. ejusdem pars - $\quad-\quad-\quad-\quad 2$.

* E ramis decurrentibus angulatas dicit Vahlius, quod tantummodò de exsiccatâ vel nondum satis aquâ emollitâ valet.

+ Cum illi quæedanı de hâc fructificatione quæe me effugerunt memoraverint, renique ipsam alitèr quam ipse viderint; descriptionem ab iis datam pro more absolutam hic repetendam duco, "Dcr $F$. spiciferus Valıl trägt in der Axillen der Spinen, womit seine letzten Aeste besetzt sind, oder unter diesen spinen, oder doch sonst in ihrer Nähe, anfangs sphärische, nachher sich oval verlängernde, dann selbst wiederum mit Spinen besetzt werdende, und endlich in neue Aestchen auswaclisende, geschlossne Pericarpien, die besonders in ilirer ursprünglichen sphäris. chen Gestalt, den Globulis der Gmelinschen Fuci globuliferi, oder Spharococci Stackl, äussertich völlig gleichen. Man erkennt indess schon mit starkern Loupen in den Pericarpien einzeln gesteltte dunkle, verhaltnissmassig ziemlich grosse körner, und das Pericarpium ist wirklich, wie die Durchschnitie lehren, inwendig darch Scheidewände aus einem dïnnen Fasergewebe in mehrer Fächer getheilt, in deren jene körner fast-einzeln (sub-singula) zu liegen scheinen. Auf sclıon in neue Vegetatioustheile ausgewachsenen ehemaligen Pericarpien fanden wir irreguläre, durch Ruption entstandne Löeher, aus denen die fortpflanzenden körner wahrscheinlich entschlïpft waren.” Beiträge zur Naturkunde, I. p. 305 . 
Fucus triangularis, frond cartilaginous, three-sided, sub-dichotomous, beset with a triple series of bi- or tri-mucronated, imbricated denticles; capsules lanceolate, panicled at the axillæ of the denticles.

Fucus triqueter. Gmelin, Hist. Fuc. p. 122. t. 8. f. 4. EsPer, Ic. Fuc. II. p. 15. t. 119.

F. triangularis. Linn. Syst. Nat. Ed. Gmel. II. p. 1383.

F. trifarius. Swartz, Prodr. p. 148. VAн L, Skrift. af Naturhistorie Selskabet. V. pars 2da.p. 39.

liucus minimus dentatus triangularis. SLOANE, Jam. p. 61. t. 20. f. 9 .

Island of Jamaica. Sloane.-New Zealand. Sir Joseph Banks.-On the shores of Barbadoes. Dr. Wright. -On the Shores of New Holland. Mr. Brown.

\section{Perennial.}

Root, I have not yet seen.

Fron D, seven inches and more long; every where of the same thickness, about equal to that of a crow's quill, irregularly divided from the very base, with * branches alternate or dichotomous, again and again divided in a similar manner, the segments nearly of equal height; the part of the frond nearest to the root is sub-cylindrical, after which it becomes three-sided, the angles being sharp, and serrated througlout their whole length with imbricated teeth placed upon them: the teeth are scarcely a line long, patent, slightly incurved, their apices cleft into + two or three cylindrical points, of the same substance as the frond. In old specimens the frond is sometimes furnished with a short cylindrical ligneous stipes, out of which the branches issue without order.

Fructification, situated at the axilla of the teeth, composed of three or four minute lanceolate capsules, supported upon an extremely short common peduncle, and each containing a few largish globular brown seeds, surrounded by a very conspicuous pellucid limbus.

Couor, reddish-brown, soon turning to a yellowish-white, if kept in fresh water, or exposed to the sun, or approaching a state of decay; and in such cases sometimes becoming quite white.

Substance, cartilaginous, soft, flexible.

Oвs. It by no means adheres to paper when dried. - The teeth in sonıe specimens are very evidently jointed, if observed under a microscope ; the septa being dark, the joints not equal in length to their breadth.

The fructification attributed to this plant by Gmelin, who originally described it in his excellent work upon the Fuci, is so extremely + different from that observed by me, and so unlike any thing with which I have ever met among the submersed Algæ, that I am altogether at a loss to imagine what he could have seen, and consequently what opinion to entertain upon the subject. Were it allowable to form any conjecture from analogy, I should be inclined to suspect that the fruit of the present species was of two kinds, and similar to that already described under $F$. subfuscus and dentatus. At the same time, I am fully aware that our knowledge of these plants is at present altogether in its infancy, and that it is the part of a wise man not to give way to similar reasonings, but to confine his observations simply to the facts he sees. Not having an opportunity of referring at present to Sloane's History of Jamaica, I have introduced his synonym, above quoted, on the authority of Gmelin and VAHL; the former of whom subjoins to it a mark of doubt, but the latter says respecting it, "Fucus minimus, \&c. of Sloane either belongs here or to $F$. cupressoides, but as its mode of growth is the same as in F.trifarius, I think it should rather be referred to this, although in his figure the leaves have the appearance of being undivided." The difference between $F$. triangularis and $F$.triqueter, L. is sufficiently manifest from the following plate. $F$. cupressoides, which rather belongs to the family of $F$. pinnatus, is distinguished from both of them by its creeping root and stem, its undivided leaves, and its green color, not to mention other particulars. 'These three Fuci alone are known to possess a triangular frond, so that this one circumstance is sufficient to separate the present from every other species. Care however nıust be taken lest a young botanist, in judging from dried specimens, be deceived by such as have been too much pressed, and appear consequently like a thin membrane. It was necessary to change the name given in the first instance to this plant by Gmelin, the same having been by Linnæus applied to the subject of the following plate.
a. F. triangularis, natural size.
b. a branch, magnified - - - 6 .
c. capsules - - - $\quad-\quad 2$.

\footnotetext{
* Gmelin says, that "the branches take root here and there, with branching fibres, as in Plocamium, and others," a circumstance that I have never seen.

† Generally bifid, sometimes trifid, and less frequently undivided, according to Vahl: Gmelin calls them bimucronate.

† It oughe in candour to be observed, that I do not exactly understand either from his figure or language the nature of the fruit he means to describe: his words are "Fructificatiunes planæ, discoideæ, mucronatæ, ab uno rami latere plures in seriem congestæ, sessiles, singnlares."
} 


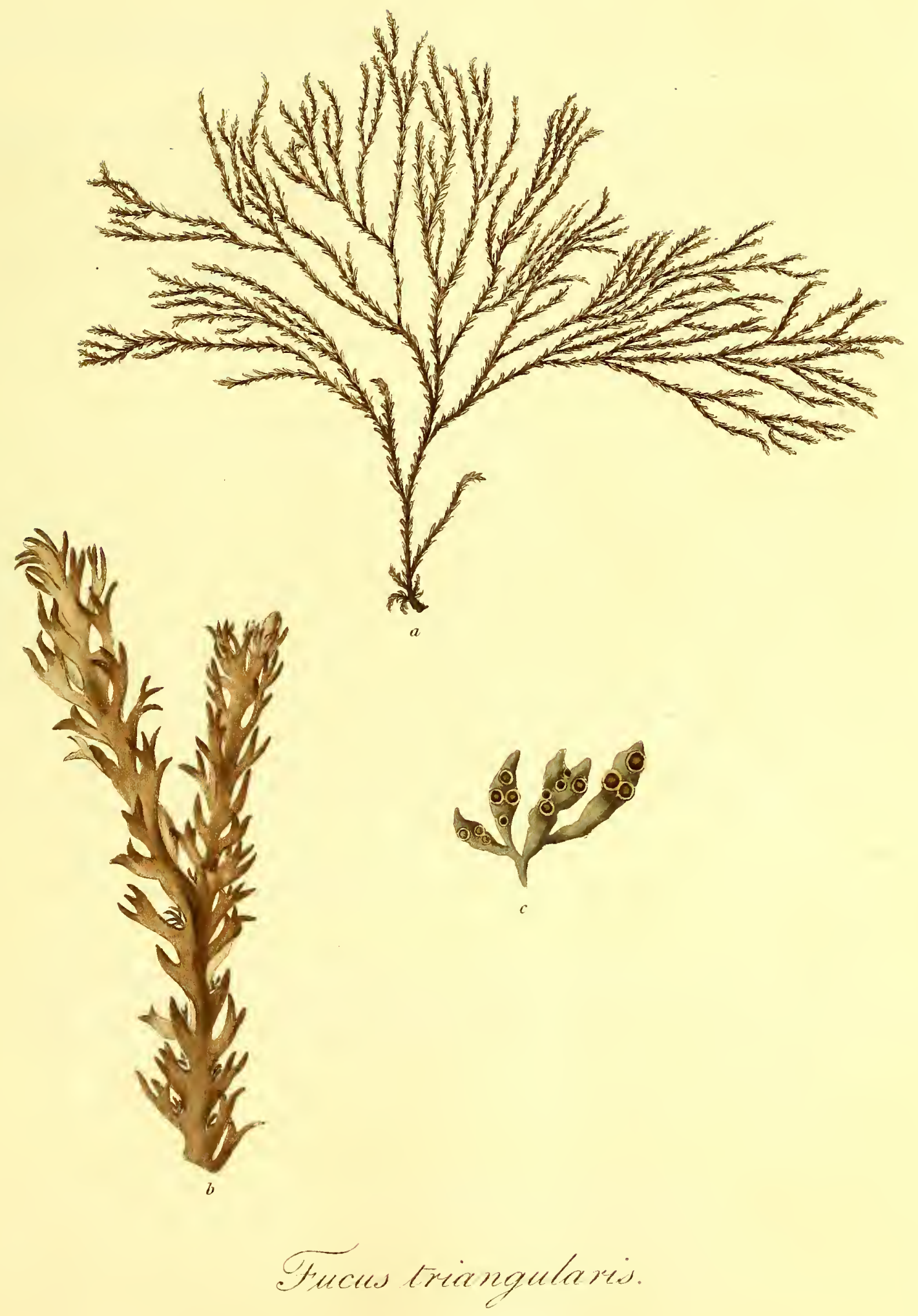



Fueus fronde cartilagineâ, triquetrâ, sub-dichotomâ, denticulis trifariàm imbricatis, bi-tri-mucronatis obsita ; capsulis denticulorum ad alas lanceolatis, paniculatis.

Fucus triqueter. Gmelin, Hist. Fuc. p. 122. t. 8. f. 4. Esper, Ic. Fuc. II. p. 15. t. 119.

F. triangularis. Linn. Syst. Nat. Ed. Gmel. II. p. 1383.

F. trifarius. Swartz. Prodr. p. 148. VAhL, Skrift. af Naturhistorie Selskabet. V. pars 2da. p. 39.

Fucus minimus dentatus triangularis. Sloane, Jam. p.61. t. 20. f. 9.

HA втт Aт in Insulâ Jamaicâ. Sloane.-In Novâ Selandiầ. D. J. Banks, Baronet.-In oris Insulæe Barbadoes. D. Wright.-In Novæ Hollandiæ oris. D. Brown.

Perennis.

RADIX nondum a me visa.

FroNs, spithamæa, et ultrà, crassitieï ubïque æqualis, pennam corvinam subæquantis, statìm a basi vagè ramosa, * ramis nunc alternis, nunc dichotomis, iterum atque iterum simili ratione divisis, subfastigiatis; frons quà radici proxima teretiuscula, mox acutè triquetra, denticulis supra angulos per totam longitudinem imbricatim dispositis trifariàm serrata ; denticuli vix lineam longi, patentes, lenitèr incurvi, apice + bi- tri- mucronati, mucronibus teretibus, ejusdem cum fronde substantiæ. Frons vetusta quandoque stipite est instructa brevi, tereti, ligneo, pennæ anserinæ crassitie, unde rami absque ordine exsurgunt.

Fructificatio, denticulorum ad alas sita, e tribus vel quatuor capsulis lanceolatis, perquàm exiguis, singulis semina aliquot globosa majuscula fusca limbo pellucido valde conspicuo cincta includentibus, pedunculo brevissimo cominuni fultis, constat.

Color rufo-fuscus; aquâ dulci retenta, aut soli exposita, aut marcescentis cito in albo-flavescentem transiens, quandoque etiam tunc albissimus.

Substantia cartilaginea, mollis, flexilis.

OBs. Exsiccata chartæ nequaquàm adhæret.-Denticuli in quibusdam exemplaribus sub lente observati evidentissimè geniculati conspiciuntur, septis obscuris, articulis diametro brevioribus.

Gmelinus, qui primus hunc Fucum in opere eximio memoravit, fructificationem ei tribuit $\ddagger$ diversissimam ab illâ a me visâ, talemque qualis non datur, quod scio, ullum aliud inter Algas marinas exemplum : quid ille viderit prorsùs nescio, remque in medio relinquo; sin liceret aliquid ex analogiâ conjicere, suspicarer hanc stirpem gaudere duplici fructu, ejus simili jam sub $F$. subfusco et dentato descripti. Scio tamen perbene cognitionem nostram de rebus ejusmodi adhuc in cunabulis versari, sapientisque esse nihil hariolari, nec in præsens ultrà quàm quæ sunt oculis subjecta fidelibus progredi velle: Sloanii synonymon suprà citatum, Historiâ ejus Jamaicensi nondùm a me visâ, Gmelini et Vahlii fide hùc retuli. Gmelinus quidem dubitantèr citat, at de illo dicit Vahlius, "Fucus minimus, \&c. Sloane vel hùc vel ad $F$. cupressoidem pertinet, cùm verò modus crescendi idem ac in $F$. trifario, potiùs ad hunc spectare credo, quamvis folia in figurâ indivisa appareant." Quantum F. triqueter L. ab hoc nostro discrepat satis e sequente liquebit tabulâ : ab utroque dignoscitur $F$. cupressoides, qui ad $F$. pirmati familiam pertinere videtur, caule et radice repente, necnon foliis a pice indivis's, et colore viridi, ut alia taceam. F. triangularem a reliquis omnibus r̂nons triquetra, horum trium propria distinguit; cavendum verò est ne exemplar pressurâ graviore æquo exsiccatum, quando nil nisi menbbrana tenuis apparet, deperitque stirpis character specificus, tyronibus fucum faciat. Exsiccatione sese multùm contrahit, et plus quam dimidium magnitudinis perdit. Nomen huic stirpi primitùs a Gmelino impositum mutare ideò sum coactus quia idem insequenti indiderat Linnæus.

a. F. triangularis. magn. nat

b. ramus, magn. auct. - - $\quad-\quad 6$.

c. capsula - - - - - -2.

".. "Ramos hine inde radicantes, fibris ramosis, ut in Plocamio et aliis" tradit Gmelinus, quod tamen ipse nunquam vidi.

$\dagger$ Plerunque bifidos, interdùm trifidos, raro indivisos dicit Vahlius : bimucronatos dicit Gmelinus.

$\ddagger$ Ut verum fatear neque e descriptione nec ex icone mente bene capio quæ sit hujus Fructûs natura. Dic.t seilicet, "Fructificationes planæ, discoideæ, mucronatæ, ab uno rami latere plures in seriem cougestæ, sessiles, singulares" 
Fucus triqueter, frond between coriaceous and cartilaginous, linear, much and irregularly branched, winged with a triple toothed membrane, and containing oblong imbedded vesicles.

Fucus triqueter. LinN. Mant. p. 312. Syst. Nat. Ed. Gmel. II. p. 1382.

In the sea near the Cape of Good Hope. Koenig.

\section{Perennial.}

Root, I have not yet seen.

Frond, a foot and more long, preserving throughout an equal breadth of a line and half, much and irregularly branched, three-sided from its very origin, and apparently composed of slender cylindrical midrib, winged with a triple membrane the margin of which is here and there toothed with small teeth : the branches arise from the angles of the frond, and are consequently disposed in a triple row; their length is very variable, they grow either clustered or remote, some simple, others again divided, at first cylindrical and thin, but at the distance of a line from their origin, winged with a triple membrane, whence they have the appearance of being supported upon an extremely short footstalk.

VES1CLES, immersed in the middle of the substance of the branches, and most frequently of the smaller ones, oblong, solitary, about the size of the seeds of the Abrus precatorius, separated from each other by a space, which is in some instances considerable, in others, does not exceed two lines, so that the whole branch has a moniliform appearance, three-sided like the rest of the frond from being winged with a triple membrane, which is perforated with numerous mucifluous pores, internally quite hollow.

Fructification, at present unknown.

CoLOR, in the recent plant most probably olive, in the specimens that I have seen brown : blackish in a dry state, turning paler and reddish when too long exposed to the sun.

SUBSTA NCE, between coriaceous and cartilaginous, but thin.

Oвs. When dried it does not adhere in the least to paper. As many botanists may be led to suppose that there must necessarily be a considerable resemblance between the present and the preceding Fucus, from the circumstance of the name given by Linnæus to the one having been formerly applied by Gmelin to the other, though in reality they have scarcely any thing in common except the triangular frond, $I$ have been induced to figure them together, for the purpose of removing such an impression; but, at the same time, I have done it with reluctance, in consequence of being still unacquainted with the fructification of $\boldsymbol{F}$. triqueter. With regard to the nature of this fructification there can be no doubt that it resembles that of the Fuci proprii, and perhaps it would not be going too far to say, that the receptacles are most probably placed at the apices of the frond. The present plant is more nearly allied to the tribe of $\boldsymbol{F}$. natans than to any other family of Fuci hitherto known, but even from these is separated by such strong characters, that it could not be arranged in the same subdivision: nor is there in the whole genus a single individual for which it is possible it should be mistaken. On this account $I$ have felt less regret at figuring it without fruit, and also on account of no plate of it having ever yet been published, and of its appearing an extremely rare species; as it is not noticed either by Gmelin or Esper, nor have I seen any specimens of it excepting those preserved in the Linnæan and Ellisian Herbaria, the former of which is here represented; but with an addition of a portion of the latter, at the letters $b$, in consequence of its being in all its parts of a larger size.

a. F. triqueter; natural size.

b. a branch, magnified -

c. part of the same

d. vesicle cut open

$-$

$\begin{array}{ll}-\quad & -6 . \\ - & -\end{array}$ 

Fucus fronde coriaceo-cartilagineâ, lineari, ramosissimâ, membranâa trifariâ dentatâ alatâ, vesiculis oblongis imr mersis.

Fucus triqueter. Lin n. Mant. p. 312. Syst. Nat. Ed. Gmel. II. p. 1382.

\section{Habitatin Mari Capensi. Koenig.}

Perennis.

RADIX nondum a me visa.

FroNs longitudine pedalis et ultra, latitudine sesquilineari, ubique æquali, absque ullâ normâ ramosa, ab ipso ortu triquetra, et, ut videtur, e costâ tenui, terete, membranâ triplice alatâ constans, membranâ margine sparsìn vagèque dentatâ, dentibus exiguis: rami e frondis angulis orti, atque inde serie triplici dispositi, longitudinis sunt perquàm variæ, nunc conferti, nunc remoti, et vel simplices vel iterum ramosi, primùm cylindracei et tenues, sed intervallo unius ab ortu linex, membranâ triplice alati, unde petiolo brevissimo insidere videntur.

VESICULE in ipsâ ramorum, et frequentissimè in eâ minorum, substantiâ immersæ, oblongæ, solitariæ, Abri precatorii seminum magnitudine, spatio inter singulas nunc longiusculo, nunc vix bilineari, ut ramus integer moniliformis appareat, membranâ triplici, poris mucifluis frequentibus pertusâ, frondis reliquæ instar, cinctæ, intùs omnind cavæ.

FRUCTIFICATIO hactenùs latet.

CoLor plantæ recentis verisimillimè olivaceus, in is quæe ego vidi exemplaribus fuscus: exsiccata nigricans: Soli nimium exposita pallidior et rufescens.

Su вsтаNтіA inter coriaceam et cartilagineam, tenuis.

Oвs. Exsiccata chartæ nequaquàm adhæret.

Nomen huic speciei a Linnæo impositum præcedenti olìm indiderat Gmelinus, cum quâ præter formam triquetram nihil commune habet. $\mathrm{Ne}$ verò essent qui ob titulorum similitudinem reverà arctissimè conjunctos suspicarentur, ambos hìc unà exhibere statui; quod nolens quidem feci, quia $F$. triquetri fructificationem nondùm vidi. De hujus fructificationis naturâ dubitari nequit quin sit ejus Fucorum, qui dicuntur, propriorum similis, nec forsàn nimis auderem si receptacula frondis ad apices sita conjicerem. Arctiorem cum $F$. natantis quàm cum ullâ aliầ Algarum marinarum hactenùs detectarum tribu affinitatem habet F. triqueter : sed vel ab his tantis modis discrepat, ut ne quidem eidem familiæ adjungi possit, nec datur una in toto Fucorun genere species cum quâ fieri potest ut ullo modo commisceatur. Hâc de causâ sterilem delineare minùs sum gravatus. Accessit etiam quòd nulla ejus extet icon, et quòd perrara videatur planta, cùm neque in Gmelini nec in Esperi operibus recenseatur, et ea tantummodò exemplaria hucusque viderim, quæ in Herbario Linnæano et Ellisiano servantur. Horum prius hæe sistit tabula : alterius vero, quia omnibus partibus erat majus, portionem ad literam $b$ delineatam exhibet.

a. F. triqueter, magn. nat.

b. ramus, magn. auct.

c. ejusdem pars

d. vesicula dissecta -

Vor. T. 
Fucus sinuosus, stem cylindrical, branched, supporting oblong, membranaceous lcaves, either sinuated, or pinuatifid, their margins crenate, and ciliated; spherical tubercles imbedded in the frond, and scattered sceds in the cilia. Fucus sinuosus. Linn. Trans. III. p. 111. Eng. Bot. XII. t. 822. Syu. Fuc. I. p. 1.

F. crenatus. Gmelin, Hist. Fuc. p. 184. t. 24. f. 1. Linn. Syst. Nat. Ed. Gmel. II. p. $138 s$.

F. rubens. Fl. Ang. p. 573. Fl. Scot. II. p. 943. W1тн. IV. p. 94. Ner. Brit. p. 18. 't. 7.

F. roseus. Fl. Dan. t. 652 .

F. Palmetta var. Esper, Ic. Fuc. I. p. 84. t. 42.

F. membranaceus purpureus latifolius pinnatus. RAII Syu. p. 47. 11. 34.

$\beta$. incrassatus; frond inclining to cartilaginous; cilia obovate.

F. sinuosus. B. Syn. Fuc. I. p. 2 .

$\gamma$. quercifolius; lacinize of the frond rounded, margins naked.

F. sinuosus. $\gamma_{0}$ Syu. Fuc. I. p. 2.

On the sliores of the British Isles, not very uncommon.-In the Bay of Christiana, in Norway. Miuller.-Sent from Kamtschatka to Gmeliu. $-\beta$ among the rejectamenta of the sea at Yarmouth. - $\gamma$ at the Isle of Anglesea. Rev. H. Davies.

Perennial. January-May.

RooT, a very small, brown, callous disk, occasionally furnished with one or two pink-colored, creeping fibres.

FRONDS, numerous from the same base, rising at first with a single, undivided, elliptical leaf, two or three inches long, and about one wide, the top bluntish, the margin sinuated, with sinuses in some instances slight, in others so deep that the frond is rather pinnatifid, and the laciniæ frequently again sinuated in a similar manner: in addition to this the margin is here and there irregularly crenated, and fringed with ninute oblong cilia: through the whole leaf passes a cylindirical nerve, not half so thick as a sparrow's quill, pinnated with other smaller ones, rather remote, between horizontal and patent, parallel, and generally simple, and opposite; thesc in their turn are frequently pinnated with others, so that, as the plant advances in age, when the lacinia of the leaf lengthen into new leaves, and when the membrane is worn away, the midrib wears thc appearance of a branched stem, and the frond in this state is often not less than a foot long, and as much wide: specimens are not uncommonly found, in which the midrib is stripped of its leafy part every where except at the apices, and is proliferous with small leaves.

Fructification, of two kinds; the one, situated in the cilia above mentioned, which at that time perform the office of capsules, and are compressed, containing a number of roundish sceds, internally dotted; in a young plant they are placed only upon the margins, but in an old one also upon the midrib, and sometimes even upont the membrane itself : the other, consisting of spherical tubercles, immersed in obovate processes, sometimes growing on the margins, sometimes on the midrib, full of globular seeds surrounded with a pellucid limbus : the spherical tubcrcles are also occasionally, but very rarely, found immersed in the substance of the frond.

Color, a beautiful transparent pink; darker and more inclining to a dull red when dry: in decay turning to is dirty yellow, tinged with green.

SUBSTANCE, membranaceous, extremely tender.

Oвs. In a dried state it adhercs slightly to paper:-the frond under a ligh microscope is most beautifully reticulated with minute meshes.

$\beta$ differs in the substance of the frond being thicker, inclining to cartilaginuus; in the color being darker; and tle cilia obovate.

$\gamma$ is smaller than either of the two preceding varicties, and has the apices of its lacinia always rounded and naked: in form it much resembles an oak leaf.

To what remarkable changes of form the present very elegant Fucus is liable in different stages of growth may be sufficiently collected from the foregoing description, but will be still more strikingly apparent from a comparison of the figures in English Botany and the Nereis Britannica, of which the former represcnts it at an early, the latter at an advanced period of its existence. To unite both these, as far as possible, a specimen of middle age has been selected for the plate before us, in which the frond has not altogether lost its foliaceous membrane, though it lias already matcrially changed its primary form, and the nerves of the midrib have begun to lengthen into new leaves. The representation of this plant in the Flora Danica is tolerably good; but that given by Gmelin exhibits it in so singular a state, and is so dissimilar to its general appearance, that it is more likely to lead to error than to answer the purpose of illustrating. I am in doubt low far I have done right in dividing $F$. sinuosus into three varieties; as the second is constantly to be found with the spherical capsules, which 1 * never saw in the more tcider frond of the first, so that it ought probably to be regarded as a different sex, rather than as a different varicty; and many botanists may be inclined to believe that the third is nothing more than a specimen destitute of fructification : in answer to which, I have wnly to observe, that the several appearances are materially unlike each other at first sight, and that $I$ am of opinion that the thus separating them may lead to the better understanding of the species. It appears certain that the obovate processes, in which the spherical tubercles are imbedded, beconc leugthened into lcaves, after they have discliarged 


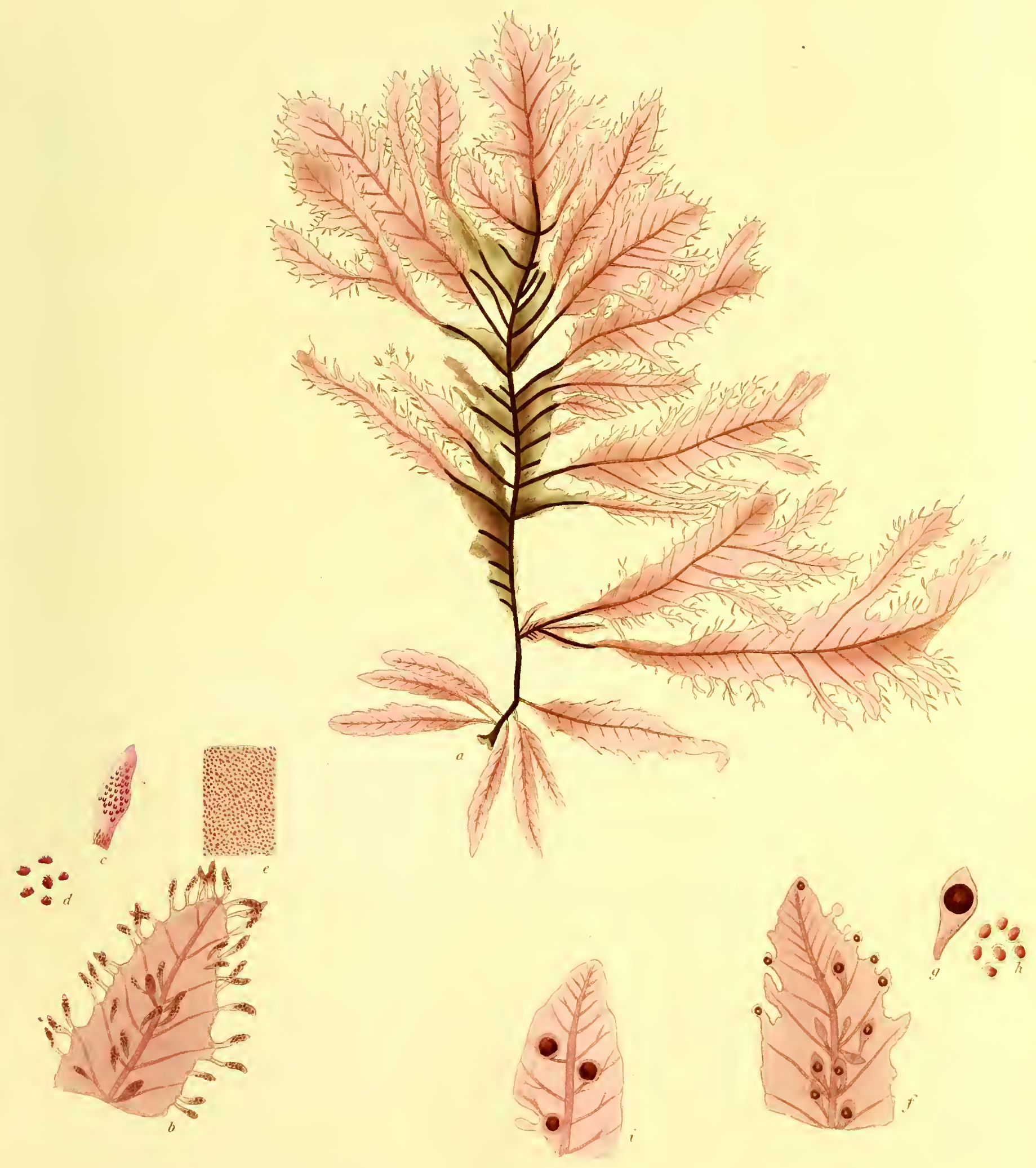

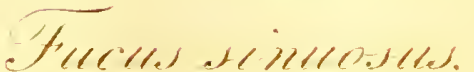



their office of fructification, but I can scarcely suffer myself to be persuaded that the same is the case with the marginal cilia, which may often be observed both in the very earliest and in the very latest stage of the frond, and seem liable to no variation of form. In opposition to the opinion entertained by Hudson, and most other authors, who had taken this plant for the F. rubens of Linnæus, Dr. Goodenough and Mr. Woodward first proved from his Herbarium that Liglitfoot's $F$. prolifer was the Fucus really designed under that name, and that the present was unknown to that great naturalist. The description in the Species Plantarum appears indeed to contradict such a conclusion, and I cannot but think that too great a reliance has been placed upon his Herbarium, which with regard to Fuci is but of little weight. I leave the matter, however, as I found it, and must refer any botanist who wishes for more information on this head to the Synopsis of the British Fuci. Esper, most unfortunately, received a specimen of F. sinuosus growing from the same base as his F. Palmetta, and was hence led to consider these two as varieties of each other, though in reality they differ in almost every particular. There is no one to which the species before us is so much allied as to $F$. sangninens, from which its ciliated and sinuated margin, as well as its mode of growth and fructification, will always be sufficient at first sight to distinguish it.
a. $F$. simuosus, natural size.
b. apex of the frond with capsules, magnified - 6 .
c. capsule - - - - - - - - 3.
d. seeds - - - - - - - $\quad$ - $\quad$ - 1 .
e. part of the frond, to shew the reticulated structure 1 .
f. apex of the frond with tubercles - - - 6 .
g. tubercle imbedded in an obovate process of the frond 3.
h. seeds - - - - - - -1 -
i. apex of the frond with tubercles imbedded in it - 6 .

\section{5.-F U C U S S I N U O S U S.}

Fucus caule tereti, ramoso; foliis membranaceis, oblongis, simuoso-pinnatifidis, marginibus crenatis ciliatisque ; tuberculis sphæricis immersis, seminibusque in ciliis sparsis.

Fucus sinuosus. Linn. Trans. III. p. 111. Eng. Bot. XII. t. 892. Syn. Fuc.1. p. 1.

F. crenatus. Gateln, Hist. Fuc. p. 184. t. 24. f. 1. Lin . Syst. Nat. Ed. Gmel. II. p. 1388.

F. mubens. 1\%. Ang. p. 573. F. Ścot. II. p. 943. Wiтн. IV. p. 94. Ner. Brit. p. 18. t. 7.

F. rosens. F. Dan. t. 659 .

F. Palmetta var. Es Per, Ic. Fuc. I. p. 84. t. 42.

F. membranaceus purpureus latifolius pinnatus. RaII Syn. p. 47. n. 54.

в. incrassatus; fronde subcartilagineâ; ciliis obovatis.

l'. sinuosus; $\beta$. Syn. Fuc. 1. p. 2.

\%. quercifolius; frondis laciniis rotundatis, marginibus nudis. F. sinuosus. $\gamma$. Syn. Fuc. 1. p. 2.

HА вгтат in Britanniarum littoribus, haud ita infrequens-In Sinu Christianiensi Norvegiæ. Müller.-E Kamtschatka allatum accepit Gmelin.- $\beta$ inter rejectamênta maris apud Yarmouth.— $\gamma$ in Insulâ Monâ. D. Ij. Daries.

Perennis. A Jan.-Majum.

RaDıx callus perquàm exiguus, discoideus, fuscus, fibrâ aliquando unâ alterâve roseâ repente instructus.

Froñs ex tâdem basi plurimie, folio assurgentes primùm unico, indiviso, elliptico, duos tresve pollices long - t circiter unm lato, apice obtusiusculo, margine sinuato, sinubus nunc tantummodò levibus, nunc ita profundis $\$: ;$ frons potins pinuatifida evadat, et lacinia sæe sint iterùm similitèr sinuata: margo quoque præeter hoc enormitèr hic et illic crenatus, et ciliis minutis oblongis cinctus : folium totum percurrit nervus teres pemnâ passerinâ duplo tenuior, aiiis minoribus horizontalitir patulis remotiusculis parallelis subsimplicibus plerumque oppositis pinuatus, hique non raro alis, unde, progrediente stirpis xtate, folii lacinïs in nova folia elongatis membranâque illisâ, caulis ramosi speciem prabet, et frons longitudine pedalis latitudine vix minore quandòque evadit : haud raro occurrunt exemplaria nervo ubique, nisi prope apices, denudato, et foliis parvis prolifero.

Fructificatro duplex; hac e ciliis constans suprà memoratis, qua tunc capsularum vice funguntur, et sunt compressa, includuntque semina plurima, subrotunda, intus punctata; foliorun tantummodo margini in stirpe juniore, 
in aduitiore nervo etiam, et quanddque ipsi membranæ insident; illa e tuberculis sphæricis, immersis in frondis processubus obovatis, nunc marginalibus, nunc e nervo ortis, refertis seminibus globosis nervo pellucido cinctis : tubercula sphærica quoque interdùm, sed rarissimè, in ipsâ frondis substantiâ immersa occurrunt.

CoLor amoenè roseus, diaphanus; exsiccaía intensior, et lateritio immixtus; marcescentis sordidè lutescens, viredine tinctus.

Substantia membranacea, tenerrima.

Oвs. Exsiccata chartæ laxè adhæeret :-frons suł lente acri pulcherrimè reticulata apparet, maculis minutissinis.

B differt frondis substantiâ crassiore, subcartilagineâ; colore intensiore; et ciliis obovatis.

\% varietas est minor, laciniarumque apices semper habet rotundatos et nudos : formâ folium quercinum refert.

Quantum in diversis ætatis suæ stadiis variare solet hæcce perelegans Fuci species non magis e descriptione supra traditâ, quàm ex iconibus Sowerbæi et Stackhousii, quarum illa juniorem hæc vetustiorem stirpem sistit, intra se collatis, liquebit. Media plantæ ætas in hâc nostrâ delineatur figurâ, quum frons, membranâ nondùm totâ deperditâ, jam formam primariam maximâ ex parte exuit, costaque nervi elongati in nova folia sunt transituri. Icon in Florć Danicâ satis bona; contrà ea Gmelini statum adeò singularem repræsentat, ut, ne potiùs hallucinationibus sit causæ, quàm ad aliquid illustrandum conferat, est timendum. Dubito quidem ut rectè fecerion, quod hanc stirpem in tres dispertiverim varietates, cùm secunda *semper capsulis sphæricis, nunquam in plantâ teneriore conspiciendis, donata occurrat, eâque de causâ forsàn rectiùs pro diverso sexu quànı pro distinctâ varietate censeri mereatur; fierique potest ut sint qui credant tertiam esse tantummodd Fuci conditionem sterilem. Contra hæc nilil habeo quod arguam, nisi eas multum inter se primo aspectu discrepare, meque sic disjungendo ad plantæ cognitionem ritè obtinendam maximè prodesse credidisse. Frondis processus, in quibus tubercula sphærica immersa jacent, fructificatione jam peractâ, in nova producuntur folia; vix tamen puto idem valere de ciliis marginalibus, quæ sese sæpe vel in primâ frondis ætate conspicienda præbent, formamque nunquam mutare videntur. $F$. sinuosum esse Linnæo incognitum, et illum Fucum lightfootii proliferum sub F. rubentis nomine respicere voluisse primi e phytophylacio suo edocu-. erunt viri optimi, Goodenovius Woodwardiusque. Repugnat sanè descriptio in Speciebus Plantarum, nimiumque est, me judice, confisum Herbario exigui in his rebus momenti. Rem tamen ut reperi relinquo; et si quis plura de hoc discere velit Fucorum Britannicorum Synopsin consulat. Esperus infaustis avibus $F$. sinuosi exemplar eidem, cui $F$. Palmetta, agglutinatum basi accepit, et hoc adductus pro varietate ejus stirpis omnibus partibus absimillima habuit. Maxima autem inter hanc plantam et $F$. sanguineum similitudo sinterest, a quo margines sinuati, ciliatique crescendi modus, et fructificatio statim distinguunt.

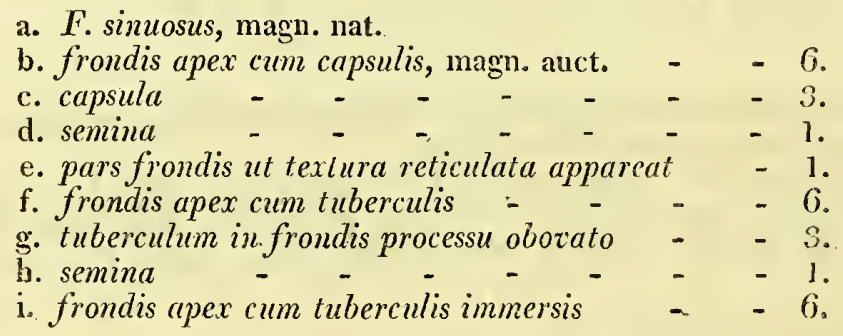


Fucus caule terete, ramoso; foliis petiolatis, membranaceis, oblongo-ovatis, simplicibus, integerrimis; e costâ tuberculis sphæricis petiolatis, seminibusque sparsis in processubus foliaceis oblongis.

Fucus sanguineus. Linn. Mant. p. 136. Syst. Nat. II. p. 718. Syst. Nat. Ed. Gmel. II. p. $1387 . \quad F 7$. Ang. p. 573. Fl. Scot. II. p. 942. GMELIN, Hist. Fuc. p. 185. t. 24. f. 2. Wiтh. IV. p. 94. Fl. Dan. t. 349. EsPer, Ic. Fuc. I. p. 79. t. 38. Fl. Norv. II. p. 91. Limu. Trans. III. p. 109. Ner. Brit. p. 20. t. 7. Syn. Fuc. 1. p.7. Eng. Bot. XV. t. 1041. Fl. Fr. Ed. 2da. II. p. 27. Fl. Germ. III. p. 439 .

Fucus, sive Alga, folio membranaceo purpureo, Lapathi sanguinei figurâ et magnitudine. Moris. Hist. Ox. III. p. 645. s. 15. t. 8. f. 6. RAII Syn. p. 47. n. 45.

Haвıтат in Britanniarum oris, satis frequens. In Galliæe oris, ubi alluitur Oceano; necnon in fundo Oceani Islandici.

Perennis. Jan.-Apr.

RA DIX callus subconicus, figuræ tamen incertze, ejusdem cum caule substantiæ et coloris.

Frons longitudine numc palmaris, nunc pedalis, et ultra, stipite instructa brevi, raro unguiculari, crassitie pennam corvinam vel anserinam minorem æequante, ortu simplice, mox semel et sæpe iterum diviso: rami ad basin nudi et petiolorum vice fungentes, inde per folia transeuntes, et in costas immutati, stipitis principio similes, magnitudine paullùm minore demptâ, fiunt sensim ut progrediuntur compressi, attenuati, et dilutiores, donec juxta apices propemodùm evanescunt : folia longitudine a palmari ad dodrantalem, latitudine a pollicari ad tripollicarem variant, semper *indivisa, figuræ nunc oblongæ, nunc lanceolatæ, vel propemodùm ovatæ, aliquando diversæ in eodem individuo, quandoque etiam utrinque acuminata, nnargine integerrima, et pulchrè undulata, costâ aliquando, nec tamen frequentèr, proliferâ foliis reliquorum similibus sed multo minoribus, semper pinnatâ nervis compressis, prominulis, intensioris quàm folium coloris, plerumque oppositis, spatio inter singulos circitèr lineari, qui horizontalitèr ad foliorum margines paralleli excurrunt, et sunt simplices donec margini adpropinquant, ubi sæpiùs lenitèr ramosi evadunt.

Fructificatio duplex, utraque costæ tunc temporis ut plurimum denudatæ insidens; hac e tuberculis constans sphæricis, acutis, Phasci recti capsulas haud malè referentibus; pedunculo perbrevi fultis, et semina plurima, oblonga, figuræ tamen nequaquam certæ, includentibus; illa e frondis processubus oblongis, basi attenuatis, semina subrotunda forentibus.- hos jam effoetos in folia produci pro certo duco.

Color foliorum anœuissimè roseus, diaphanus, intensior in lis quàm in illis; et semper in exsiccaíâ, quando ad sanguineum accedit; marscescentinım sordidè lutescens, et demùm albicans : caulis dilutior, opacus.

Substantra in folïs membranacea, tenuissima, et tenerrima; in caule cartilaginea, junioris tenera, vetusti rigidiuscula et tenax.

Ов . Chartæe exsiccata adhæret:-recens odoren acrem ingratum spirat :-frons sub lente nequaquam reticulata.

Pulcherrima stirps! et quæ formæ elegantiâ foliorumque exquisitè venosorum colore tantum omnibus aliis antecellat, ut, sicut inter plantas terrigenas rosa flos florum salutatur, hac sibi inter marmas jure non miuus æequo partes priores vindicet! Utinam sanè similem jactare posset odorem! Originem ducit, ut $F$. Hypoglossum et F. ruscifolius, quibus arctissimè est affinis, a folio unico, neque tamen crescendi modus omninò est idem, cùm non capiat incrementa sua e costâ iterùm atque iterùm proliferâ, et, licet hac folio uno alterove minore sape sit instructa, videatur tamen tunc tantùm vi proliferâ ad sese augendam uti, quando membrana penitùs deperiit, in quo statu, novâ foliorum serie per totam longitudinem editâ, frondis lassa jacturam resarcire pergit. Longiùs adhuc quoad crescendi modum recedit a $F$. sinuoso, cujus margines ipsi proliferi evadunt; et ab omnibus his differt in eo qudd membrana foliacea caulis basin nunquam attingit, unde pars illa, quam stipitem suprà dixi, rectìs in hoc quam in reliquis id nomen mereatur. Varietatem, quam $\beta$ dixit, recensuit cl. Decandollius, quam tamen hìc omisi, quoniam nihil de illâ tradit, nisi foliis minoribus esse instructam; varietque licet plurimum $\hat{F}$. sanguineus, cùm foliorum magnitudine, tum quoque figurâ, limites intra varietates nullos unquam statuere potui. Variat etiam stipitis longitudine, et an ramosus necne evadat; semper tamen sibi ita constat, tantunque a reliquis recedit, ut nullus detur in specie discriminandâ dubitationi locus, nisi fortè caules lyeme prorsus denudati tyronem decipiaut.

$$
\begin{aligned}
& \text { a. F. scuguineus, magn. nat. } \\
& \text { b. frondis apex, magn. auct. - } \quad \text { - } \quad \text { - } \quad \text { - } \quad-1 \text {. } \\
& \text { c. coste pars cum tuberculis - } \quad-\quad-\quad-\quad-\quad-\quad-5 \text {. }
\end{aligned}
$$

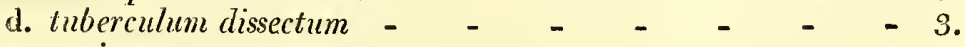

$$
\begin{aligned}
& \text { e. semina - - } \quad \text { - } \quad \text { - } \quad \text { - } \quad \text { - } \quad \text { - } \quad \text { - } 1 \text {. } \\
& \text { f. cosice pars cum processubus foliaceis scmina includentibus - } 5 \text {. } \\
& \text { g. unus e processubus - } \quad \text { - } \quad \text { - } \quad \text { - } \quad \text { - } \quad \text { - } \quad \text { - } 3 \text {. }
\end{aligned}
$$

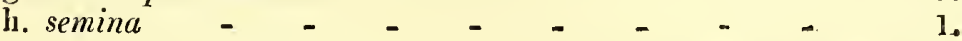

Vidi quidem quorum apices crant bifidi, sicut in Scolopendrio aulgari, cujus frons simplieissima, quandoque couspicitur : sed hoc ex injurib accidisse persuasum habeo. 
Fu'us sanguineus, stem cylindrical, branclied, supporting simple, membranaceous, petiolate leaves, betwcen oblcrus and ovate, quite entire; the midrib producing spherical, pedunculated capsules, and scattered seeds in oblong leafy processes.

Fucus sanguineus. Linn. Mant. p. 136. Syst. Nat. II. p. 718. Syst. Nat. Ed. Gmel. II. p. 1987. Fl. Ang. p. 573. Fl. Scot. II. p. 942. GMELIN, Hist. Fice. II. p. 185. t. 24. f. 2. WITH. IV. p. 94. Fl. Dan. t. 349. Esper, Ic. Fuc. I. p. 79. t. 38. Fl. Norv. II. p. 91. Limn. Trans. III. p. 109. Ner. Brit. p. 20. t. 7. Syu. Fuc. 1. p.7. Eng. Bot. XV. t. 1041. Fl. Fr. Ed. 2da. 1I. p. 2\%. F\%. Germ. III. p. 439.

Fucus, sive Alga, folio membranaceo purpureo Lapathi sanguineifigurâ el magnitudine. Moris. Hist. Or. III. p. 645. s. 15. t. 8. f. 6. RAII Syn. p. 47. n. 45.

On the shores of the British Isles, not uncommon. On the coast of France opposite to the Ocean, and at the bottom of the Northern Ocean.

Perennial? Jamuary-April.

Roот, a callus, inclining to conical, but of no fixed form, of the same substance and color as the stem.

FroN D, varying in length from three inches to a foot or more, furnished witl a stipes seldom half an inch long; and equal in thickness to a crow's quill, or small goose-quill, simple at first, but soon once or twice divided : lranche naked at their base, and performing the office of petioli, then passing through the leaves, and becoming midribs, similar in their origin to the stipes, except their, somewhat smaller size, but, as they advance, gradually growing compressed, and more thin, and pale, till towards the apices they nearly vanish : leaves from three to nine inches long, and from one to three wide, always *undivided, either oblong or lanceolate, or approaching to ovate, sometimes acuminated at both ends, and occasionally of different shape on the same individual; their margins quite entire, but beautifully undulated; their midrib sometimes, though not frequently, proliferous with leaves like the others; but smaller, always pinnated with compressed, rather prominent nerves, of a-deeper color than the leaf, generally opposite, placed at intervals of about a line from each other, running parallel in a horizontal direction to the margins, and simple till they approach them, when they are commonly a little branched.

Fructification, of two kinds, both placed on the midrib, which at the season of the year when it is produced is most frequently quite naked; the one consisting of spherical pointed tubercles, not unlike the capsules of Phascum rectum, supported upon an extremely short peduncle, and containing several irregularly oblong seeds; the other, of oblong processes of the frond, attenuated at the base, and full of rouidish seeds. - I have no doubt but these latter after the seeds are fallen turn into leaves.

Color of the leaves, a most beautiful transparent pink, darker in some than in others, and always deepest in a dry state, when it approaches to a blood-red, turning in decay to a dirty yellow, and finally to white; of the stem, paler and opaque.

Substance, membranaceous, extremely thin, and tender in the leaves; in the stem cartilaginous, tender while young, but stiff and tough when old.

O вs. When dry, it adheres to paper:-when fresh, it has an unpleasant pungent smell;- the leaf under the microscope exhibits no reticulations.

In the elegance of its appearance, and the exquisite color of its most delicately veined leaves, this beautiful Fucus so mucl excels all its congeners, that it carries away the palm with no less justice from the vegetables of the ocean, than the rose, the flower of the poets, from its rivals in the garden. It is a pity, indeed, that it is unable to boast an equally delicious perfume! With regard to its mode of growth, it so far agrees with $F$. Hypoglussum and rusrifolius, that all equally take their origin from a single leaf, but, however closely allied to these species, $F$. sanguineus does not like them depend for its increase upon the repeatedly proliferous midrib; for this, though frequently furnished with one or two smaller leaves, seems never materially to affect the growth of the plant, except when the foliaceous membrane is altogether destroyed, in which case it strives to repair the injury it has sustained, by throwing out a series of new leaves, that soon equal in size the primary ones. It differs still more strikingly in this particular firom $F$. sinuosus, of which the principal proliferous tendency lies in the margins, and it has a separate character from all these, in the membrane never reaching the base of the stem, so that the part, which is above called a stipes, receives that name with more propriety in the present plant than in the others. Decardolle, in the Flore Française, has mentioned a variety $\beta$, which $I$ have been under the necessity of omitting, as he says nothing farther respecting it than that it has smaller leaves; and, though $F$. sanguineus is liable to considerable variations, both as to the figure and size of the leaves, 1 never found it possible to prescribe to these appearances any certain limits. It varies also in the length of the stem, and in its being either branched or simple, but preserves so much in all cases its own character, and approaches so little to that of any other Fucus, that there can be no difficulty in discriminating the species, except it should happen that battered stems, quite stripped of their leafy part, chance to puzzle a beginner.

a. F. sangnimeus, natural size.

b. apex of the fiond, magnified - + - + - 1 . 

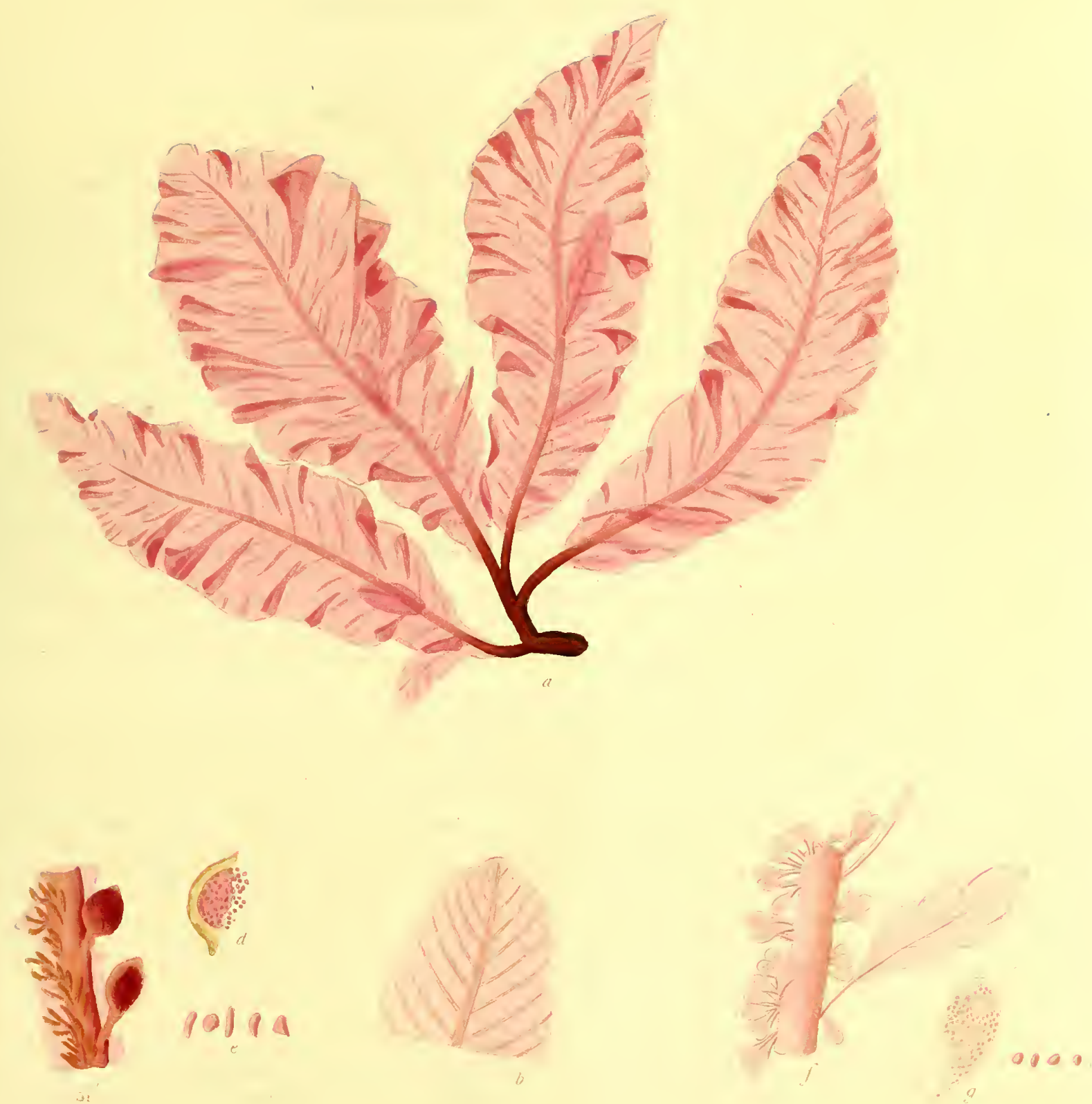



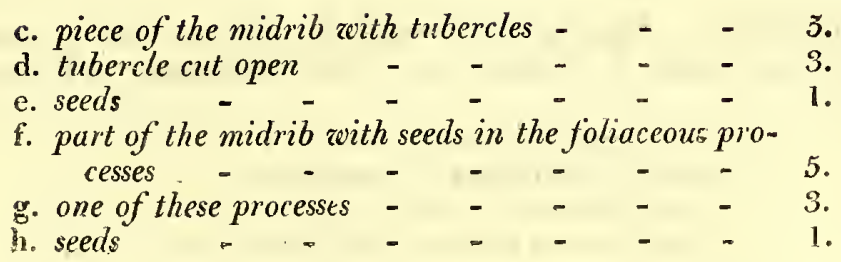

\section{$37 .-F$ U C US G R I F F I T H S I.}

Fucus fronde cartilagineâ, tereti, filiformi, dichotomâ, fastigiatâ ; tubèculis oblongis frondem amplectentibus.

H н вıтат apud Sidmouth, in Devoniâ, prope rupem, "Chit-Rock" dictam. Dna Grifflths. Apud Balbriggen, prope Eblanam. D. R. Scott, M.D.

Annua?-Oct.-Dec.

RADIX callus exiguus, dilatatus, nigricans.

Fro N DEs ex eâdem basi plurimæ, teretcs, filiformes, longitudine bi-tri-pollicares, crassitie setam porcinam non ita multùm superantes, dichotomiis juxta radicem incipientibus, et inde sexies septiesve repetitis, divisæ, intervallo inter singulas brevi, attamen incerto, furcis patentibus, summis divaricatis, et quandòque deflexis, segmentis fastigiatis, apicibus haud rarò incrassatis, et compressis.

FRUCTIFICATIO tubercula oblonga, atro-purpurescentia, vel etiam atra, ramos superiores annulorum instar amplectentia, sæpe duo aut tria in singulis, eâdem quâ frons epidermide tecta, et verrucas simulantia: hæc si dissecentur, e filamentis articulatis, articulis oblongis, parallelis, densissimè compactis,* seminibus subrotundis immixtis tota constare videntur.

Color purpurascens, subdiaphanus, quandòque etiam atro-purpurascens: exsiccate intensior: Soli expositce albescens.

Substantia cartilaginea, lenta, tenax : exsiccata cornea.

OBS. Frons ramis aliquot lateralibus, brevibus, horizontailibus, interdùm, sed, ut videtur, rard, instructa evadit : - exsiccata chartæ nequaquàm adhæret.

Ex ommibus iis qui in Fucorum Anglicorum hịtoriâ illıstrandâ navaverunt operam, ne unum datur nomen quod

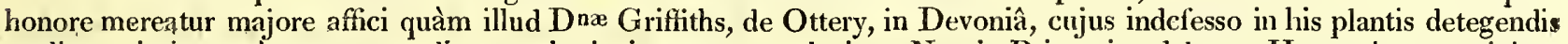
studio, eximiæque in perscrutandis sagacitati, incrementa plurima Nereis Britannica debet. Hanc stirpem, ei jure optimo dicatam, primùm ipsa aliquot abhinc annis nascentem reperit; perrara tamen videtur, quoniam hactenus in uno tantum invenerit loco, $\uparrow$ neque extent, quod scio, ulla alia ejus cxemplaria, preter unum quod in littorc Hibernico propre Balbriggen legit vir amicissimus, D. Scott, Botanices in Academiâ Eblanensi Professor, et quod illa in Devoniâ detecta magnitudine duplò exsuperat. F. Griffithsii est planta, quam, cùm F. rotındum tractarem, dixcram medium quasi locum inter eam speciem et $F$. plicatum tenere, diuque, ut verum fatcar, dubius hrsi an satis ab his differret. Differt verò certissimè; et per colorem purpurcum substantiamque conneam ab illo, per ramos onnes fastigiatos crescendique modum semper dichotomum ab hoc, per fructificationem ab ittroque dignoscitur. Nota longè certissima e fructu depromitur, nec mirum si, hoc deficiente, vel cautos exercitosquc in his rebus fallat. Suspicor sauè sic fefellisse Wulfenium, † iconernque suam, quam $F$. fastigiatum ipse dixit, et quam ego § suprà sub $F$. rotundo

citavi,

* An ea qux hic semina dixi sint reverà seinina dubito, fieri enim potest ut sint tantummodò filamentorum diffractorum articuli soluti ; sin ita se res habeat fateri necesse est me semina nulla in hâc stirpe detexisse, nisi forte concedatur filamenta esse senina. Utut loc sit, filamenta certé quiddam cum fructu conmune habere videntur, quonian reperiuntur in plurimorum Fucorum capsulis, nec in tuberculis $F$. crenulat $i$, $t .40$, vel. $F$. Norvegici, t. 41, aliquid prater hac occurrit. F. Griffithsii tubercula dissecta, eorum F. Norvegici instar e duobus stratis diversa substantix sub lcnte contexta sunt visa, sed differentianı nullam inter liac detegere potui.

+ Descriptione lujus Fuci typis jam mandatâ, certiorem me fecit amicus suavissimus, J. Gulielmus Hooker, cui hoc opus quidquid habct pulchrum quoad iconas debet, esse quoque a D. J. Jervis prope Exmouth nascentem detectum.

¥ Haud omuinò ex icone pendet hrc snspicio ; mirè enim consentit descriptio, cujus partem hic subjungo, ut pro se judicent lectores, quos tamen iterum monitos velim, $F$. Griffithsii cum $l$. rotundo quoad crescendi modum iu plurimis convenire. " Non solitaiun unodo, sed omuino caspitose aggregatum vidi ; cauliculus tamen quisque propria semper super placenta radicali coriacea, et orbiculari attollebatur ad untın et sesquialterum pollicem, fastigiatus. Is caltilaginco-coriacea natura, grossiorisque fili linei crassitıdine, teres primum, tum ex tereti conıpres. siusculus, ad dinidium fere polliccm crectus (alias nol nisi unam ad lineam) assurgit simplicissinus, statianque dichotonus, per sexics, et octies iteratas deinceps dichotonias, tlabclliformis ad instar frondis, distentus dividitur, subdividiturquc ramosissinus, dichotomiis extinis al eandem omnibus altitudinem exaltatis, fere tastigiatus: lacinulis dichotomiarum nonnihil compressis, lineari-filifernibus. (color primum dilute, tum viivaceo-virens, ex viridi dein pallidius, aut saturatius rubens, atro denigue purpureus, et niger."

S. 9. 
citavi, reapse $\boldsymbol{F}$. Griffithsii exprimere. Hanc profecto optimè refert, sin ita sit, plantas tres certè distinctas conmiscuit; quoniam $\boldsymbol{F}$. fastigiatum verum in Herbario suo vidit Mertensius, et $\boldsymbol{F}$. rotundi var. $\gamma_{0}$ ab ipso acceptan olìm ad me misit Esperus.

a. F. Griffithsii, magn. nat.
b. pars frondis superior, magn. auct.

\section{7.-F U G US G R I F F I T H S I.}

Tucus Griffithsii, frond cartilaginous, cylindrical, filiform, dichotomous; branches of equal height; tubercles oblong, embracing the frond.

At Sidmouth, in Devonshire, near the Chit Rock, in a little channel formed by sea-water, as it runs off during the ebb tide. Mrs. Griffiths. Shore at Balbriggen, near Dublin. Dr. Scott.

Annual?-October-December.

Root, a small, expanded, blackish, callous disk.

FroNDs, numerous from the same root, cylindrical; filiform, two or three inches long, and in thickness but little exceeding a hog's bristle, branched with dichotomies beginning near the root, and afterwards six or seven times repeated at short, but uncertain distances, the forks patent, the upper ones divaricated, and occasionally deflexed, the segments all of equal height, the apices not unfrequently thickened and compressed.

Fructification, oblong, blackish purple, or even black, tubercles, surrounding the upper branches in an annular form, and often two or three upon a single one, covered with the same epidermis as the frond, and in appearance resembling warts: if dissected they appear wholly to consist of parallel, jointed filaments, their joints oblong, very closely placed together, and mixed with roundish seeds.*

CoLor, purple, subdiaphanous, sometimes blackish-purple: much darker when dry: turning white if exposed to the sun.

Substance, cartilaginous, pliant, tough : horny in a dry state.

OBs. Specimens are now and then, but, as it appears, by no means commonly found, provided with a few short lateral horizontal branches:-when dried the plant does not adhere in the least to paper.

Among the many Botanists who have lately directed their attention to the investigation of the submersed Algæ of Britain, I am acquainted with no one to whom this department of science is under greater obligations than to Mrs. Griffiths, of Ottery, in Devonshire, or to whose unwearied zeal and extraordinary acuteness I shall in the course of the present work have more repeated occasions to bear testimony. It is to her that we are indebted for the discovery of the Fucus before us, which I feel myself happy in the opportunity of laying before the public under her name. It appears to be a very scarce species, as, though some years are passed since she originally found it, she has not hitherto succeeded in detecting any second station for it; $\uparrow$ nor have I seen any specimens of it besides those communicated by her, excepting a single one, which was gathered on the Irish coast near Balbriggen by my friend, Dr. Scott, Professor of Botany to the University of Dublin, and in the size of all its parts greatly exceeded those produced by the shores of Devonshire. F. Griffithsii is the plant alluded to under $\boldsymbol{F}$. rotundus, as being intermediate between that Fucus and $F$. plicutus, nor indeed could $\mathrm{I}$ for some time satisfy myself that it ought to be considered as in reality distinct. It, however, certainly differs from the former in its purple color and horny substance; from the latter, in its regularly dichotomous mode of growth and branches of equal height; and from both in its fructification, when destitute of which it is not to be denied that it may escape the notice even of an attentive and experienced observer. I am

much

* I am in doubt whether what I have here called seeds are so in reality, and whether they ought not rather to be considered the scattered joints of broken filaments; in which ease I must acknowledge that $I$ have at present met with no seeds in this species, unless $I$ may be allowed to regard the filaments as such. However this may be, I feel no scruple in saying, that I consider the filaments as connected with the fructification, since they are found in the capsules of many Fuci, and noting else is observable in those of $F$. crenulatus, $t$. 40, or $F$. Norvegicus, t. $4 t$. - The tubercles of $F$. Grifithsii, when dissected and examined under a microscope, resemble those of $F$. Norregicus in being apparently comp sed of two strata of dissinilar substauces; between which, however. I have not been able to detect any difference.

+ Since the accomt of this Fucus was written, I learn from my friend, Mr. W. J. Hooker, to whom this work is so nuch iulchted for the drawings from which the engravings are made, that it has also been found growing by tise Rev.J. Jervis, near Exmonth. 

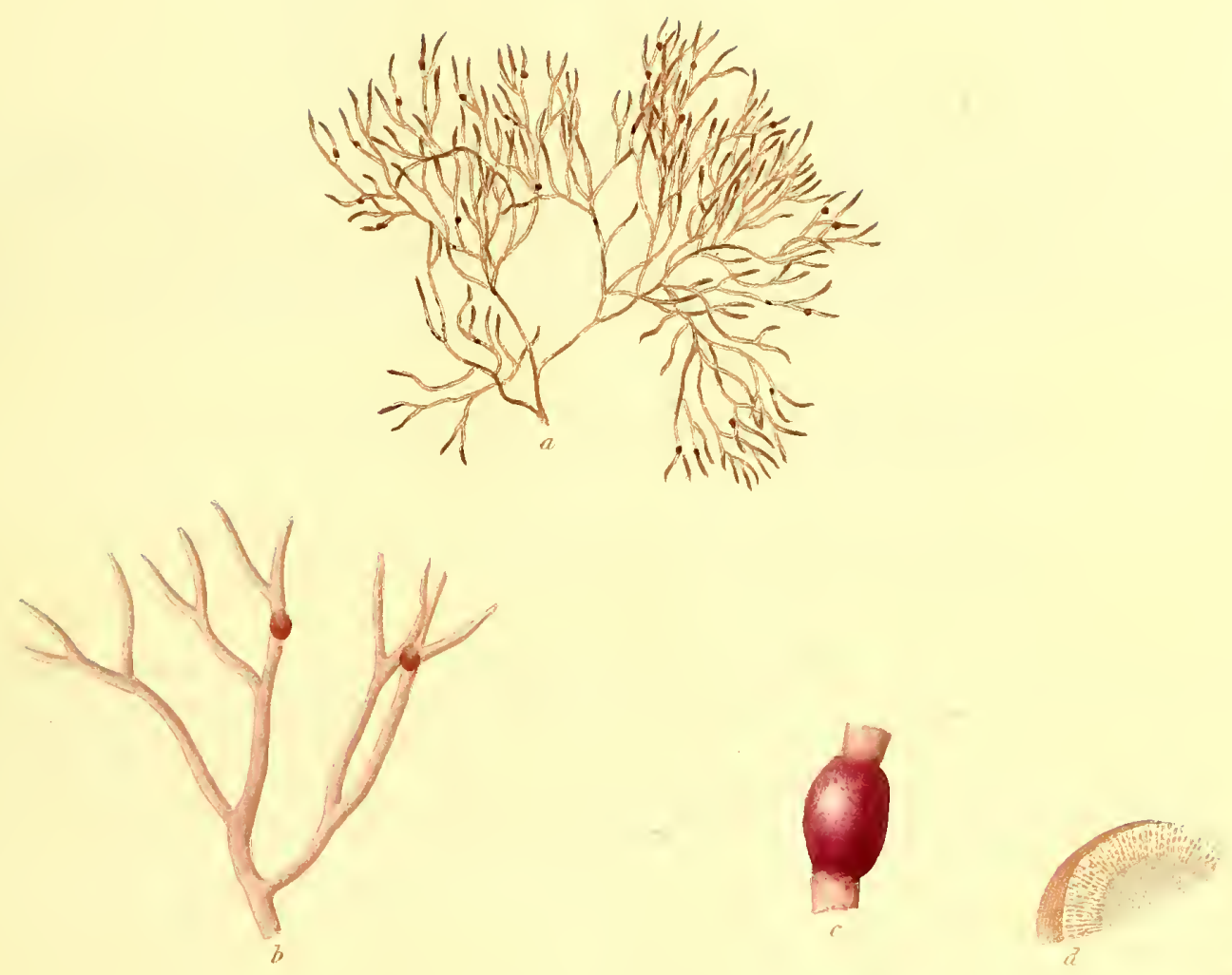

of 

much inclined to * suspect that Baron Wulfen was deceived by it in this barren state, and that the figure of the plant which he has called $\boldsymbol{F}$. fastigiatus, and which $\mathbf{I}$ have quoted tabove under $\boldsymbol{F}$. rotundus, was actually taken from a specimen of $\boldsymbol{F}$. Griffithsii. It certainly agrees best with this species; but, if such a suspicion be admitted, it must be allowed that the noble author had confounded three distinct species; since Professor Mertens saw the true $F$. fastigiatus of Hudson under that name in his Herbarium, and Dr. Esper sent me some time ago F. rotundus, var. $y$, which he had received from him under the same denomination.

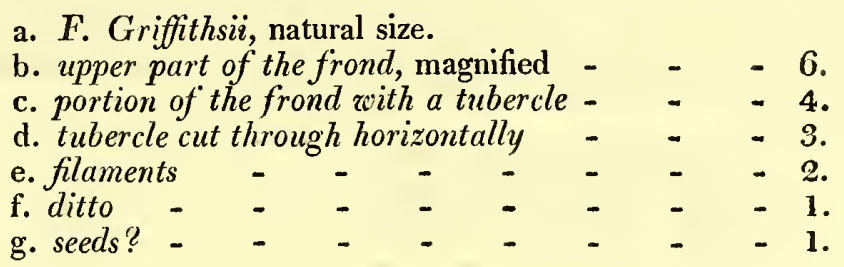

- This suspicion does not indeed altogether rest upon the figure, for the description also agrees remarkably well, and I here subjoin a part of it, that my readers may be enabled to judge for themselves; but I must beg leave again to observe to them, that the mode of growth is almost in every respect the same in $F$. Griffithsii as in $F$. rotundus. - " Non solitarium modo, sed omnino crspitose aggregatum vidi ; cauliculus tamen quisque propria semper super placenta radicali coriacea, et orbiculari attolebatur ad unum et sesquialterum pollicem, fastigiatus. Is cartilagineo-coriaceæ naturæ, grossiorisque fili linei crassitudine, teres primum, tunc ex tereti compressiusculus, ad dimidium fere pollicem erectus (alias non nisi unam ad lineam) assurgit simplicissimus, statimque dichotomus, per sexcies, et octies iteratas deincens dichotomias, flabelliformis ad instar frondis, distentus dividitur, subdividiturque ramosissimus, dichotomiis extimis ad ean dem omnibus altitudinem exaltatis, fere fastigiatus: lacinulis dichotomiarum nonnihil compressis lineari-filiformibus. Color primum dilute tum olivaceo-virens; ex viridi dein pallidius, aut saturatius rubers, atro denique purpureus, et niger." t p.9.

\section{8.-F U G U S G L A N D U L O S US.}

F'ucus, fronde membranaceâ, planâ, enervi, lineari, ramosâ ; ramis alternis, decurrentibus, sumınis bifidis, incurvis ; seminibus ramorum in apicibus oblongo-lanceolatis.

Fucus glandulosus. Herb. Banks. MSS.

HaвıтAт in Oceano Anglicano. Herb. Banks.-Inter rejectamenta maris apud Budleigh et Torquay, in Devoniâ, rarissimè. $\quad D^{\text {na }}$ Griffiths. - In littore prope Gades. D. Simon de Roxas Clemente.

Annua? Septembri fructiferam legit $\mathrm{D}^{\text {ia }}$ Griffiths.

RADix callus perpusillus.

Frons duos tresve pollices longa, compressa, vix semilineam lata, et latitudine ubique æquali, nervi venarumque expers, *fibras minutissimas radicantes per totam longitudinem e margine emittens, et inde repens, ramosissima, ramis alternis, remotiusculis, obsitis aliis brevioribus simili ratione dispositis, hisque non rarò tertiâ serie instructis, omnibus patulis vel lorizontalitèr patulis, ultimis perbrevibus, apicibus bifidis acutis, plerumque lenitèr incurvis, quandòque autem reflexis.

Frvetrficatio ramorum ad apices sita, qui tunc intumescunt, et capsulas lanceolatas vel oblongas referunt, seminaque aliquot subrotunda, e rubro fusca, serie interdum duplici, interdum absque ordine disposita, includunt.

Color coccineus, roseo immixtus, diaphanus; exsiccate coccineus.

Substantia membranacea, debilis, tenerrima.

Oвs. Exsiccata chartæ vel vitro adhæret.- F Frons tota sub lente pulcherrimè et manifestè reticulata, maculis subrolundis, serie triplici ut plurimum dispositis, interstitiis reliquâ fronde dilutioribus.

Diu extitit in Herbario Banksiano pulchelli hujus Fuci exemplar, cui $F$.glandulosi nomen, charactere quoque specifico adjecto, indiderat cl. Solander; cùm tamen sit parvun, nec tantum a reliquis primâ facie distinctum ut perlustrantium oculos ad se traheret, sitque chartæ agglutinatum, unde structura interna perspici nequeat, diu forsan indescriptum Botanicorum notitiam effugisset, nisi in oris Britamicis iterùm detexerit $\mathbb{D}^{\text {nd }}$ Griffiths, et pro novâ specie agnoverit. Hujus benevolentiæ exemplar hìc depictum debeo, quod cum aliquot aliis legit post procellam

vehementem

* Hæ fibræ, earum in F. bifidi varietate B Syn. Fuc. observatarum similes, non modo stirpi ad sese sustentảndam inserviunt, sed sæpe aliis ramorumo partibus affiguntur, frondemque totam hic illic per anastomosin conjungunt.

† "Medius quasi intcr Fucos et Confervas, internè enim glandulis subpellucidis repletur, sed triplici serie plerumque dispositis." MSS. Herl. Banks.

VOL. I. 
vehementem mense Septembri, MDCCCIII, in littore ejectum, nec nisi semel ab eo inde tempore reperit. Mandavit mihi per literas unum ex individuis Fuco rubenti esse innatum, eique perrepsisse, ut Erica vulgari Cuscuta Epithymum; frondes quoque implicitas sibimet ipsis, in plurimis locis, per fibras jam suprà memoratas adhæsisse; plantamque, dum recens in arenâ jaceret, Confervce rubré fasciculum primo aspectu retulisse. Specimina, quæe ex Hispanià accepi, erant Britannicis longè minora, nec unum pollicem longitudine superabant. Affinitatem maximam habet $\boldsymbol{F}$. glandulosus cum $F$. coronopifolio juniore, et cum eâ stirpe, quam pro $F$. alati var. $\gamma$ in Fiucorum Britannicorum Synopsi descripsi, quæ verò fortè est distincta species. Ab utroque horum differt substantiâ membranaceâ, fructificatione, et structurâ interiore, quæ nota est maximi ad discriminandum ponderis. Distinguitur etiam, vel in primâ æate et sterilis, a $F$. coronopifolio, quòd ramos omnes lineares patulosque habeat, nec sint primarì reliquis longè crassiores, nec seriores in illis horizontalitèr disponantur.

a. F. glandulosus, magn. nat.

b. frondis pars superior, magn. auct. - $\quad-5$.

c. ejusdem pars cum seminibus - $\quad-\quad-2$.

d. semina - $\quad$ - $\quad$ - $\quad$ - $\quad$ - $\quad$ - 1 .

\section{8.-F U C U G L A N D L O S US.}

Fucus glandulosus, frond membranaceous, flat, nerveless, linear, branclied; branches alternate, decurrent, the ultimate ones bifid, and incurved; seeds immersed in the oblongo-lanceolate apices of the branches.

Fucus glandulosus. Herb. Banks. MSS.

In the English Ocean. Herb. Banks.-Among the rejectamenta of the sea at Budleigh and Torquay. Mrrs. Griffiths.-On the shore near Cadiz. Don Simon de Roxas Clemente.

Annual? In September Mrs. Griffiths gathered it in fruit.

Rоoт, a very small callous disk.

FroND, two or three inches long, compressed, scarcely half a line wide, and every where linear, destitute of midrib or veins, putting forth throughout its whole length extrenely minute *root-like fibres from its margin, and consequently creeping, much branched; branches alternate, rather remote, beset with shorter ones disposed in the same manner, and these not unfrequently with a third series, all of them patent, or between horizontal and patent, the extreme ones very short, the apices bifid, acute, and generally slightly incurved, but occasionally reflexed.

Fructirication, placed at the ends of the branches, which then swell, and resemble lanceolate or oblong capsules, containing a few reddish brown, roundish seeds, arranged sometimes in a two-fold series, but more commonly without any order.

Co Lor, bright-red, strongly mixed with pink, semitransparent; when dry, bright red.

SUBSTANCE, membranaceous, flaccid, extremely tender.

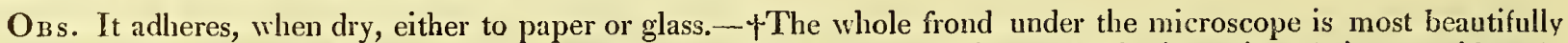
and evidently reticulated, with roundish neshes generally arranged in a triple row, the interstices being considerably paler than the rest of the plant.

There has long been in the Banksian Herbarium a specimen of this pretty Fucus, to which the name of $F$.glanditlosus was originally given by the late celebrated Dr. Solander, who had also prepared for it a specitic character; but, as the specimen was small, and not so strikingly different from other species as to attract notice, and was also fastened on paper, whence it was impossible to observe the singularity of its internal structure, it would in all probability long have continued to escape the observation of botanists, had not Mrs. Griffiths fortunately discovered it again upon the shores of Britain, and known it to differ from all that were previously described. I ann indebted to her kindness for the specimen here figured, which was gathered by herself at Budieigh, where she first found it among other rejectamenta of the sea in very sinall quantity, after a violent storm in September 1803, subsequently to which time she has only once observed it, and then also sparingly. She informs me, that one of the plants vas growing upon $F$. rubens, over which it crept in the same manner as Cuscuta Epithymum does over the common heath, and that the entangled frond adhered so strongly logether in different places, by means of the fibres already mentioned in the description, that it was impussible to separate it without laceration. She says also, that, when fresh on the beach, it looked at first sight like a small mass of Conferva rubra. The specimens scnt me from Spain were of less size than those found

\footnotetext{
* 'These fibres, similar to those observed in the varicty $\beta$ of $F$. bifidus, not only help the plant to support itself, but also frequently adhere to other parts of the branches, and cause the frond to anastomose in various places.

t The observation upon its magnified appearance in the Banksian Herbarinm is, "that the plaut is intermediate between the Fuci and Conferva, and is internally filled with subdiaphanous glands, generally disposed in a triple series."
} 

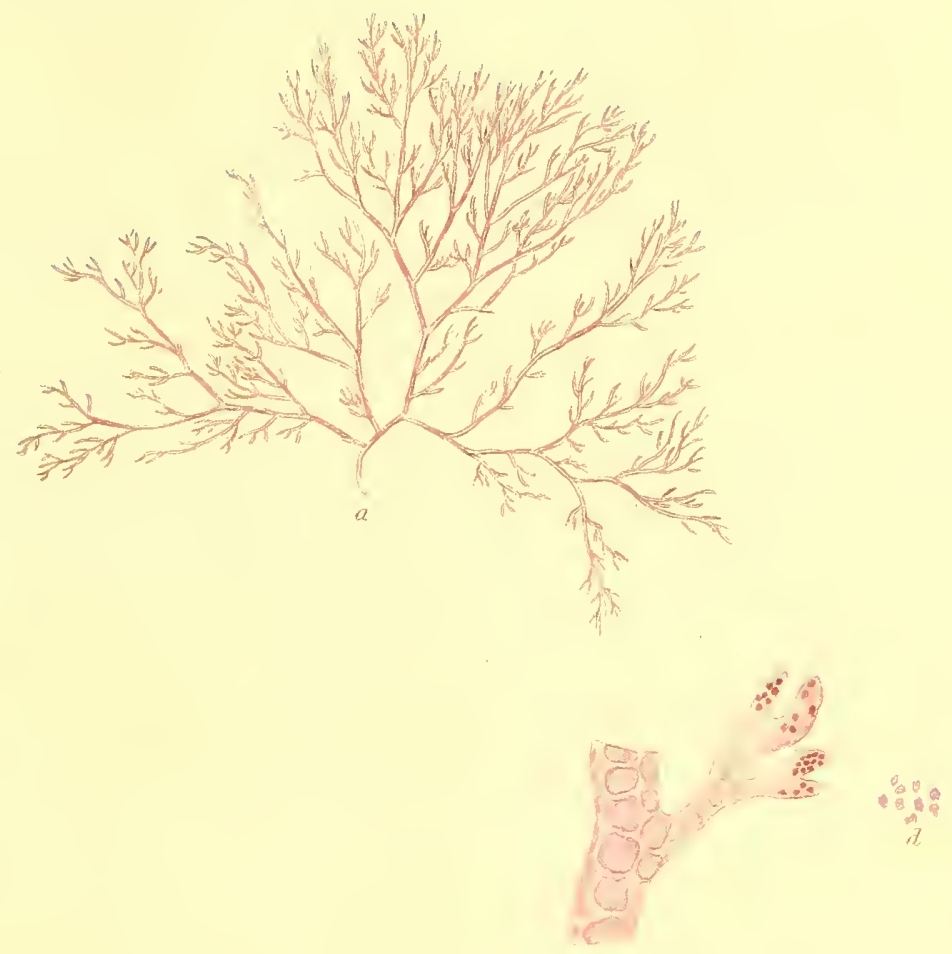

fuces glanduteress. 

found in England, and did not exceed an inch in lelngth. The plants, to which $\boldsymbol{F}$. glandulosus is most nearly allied, are $F$. coronopifolius, in an early stage of its growth, and the Fucus which is described in the Synopsis of the British Fuci as $F$. alatus, var. $\gamma$, but which ought probably to be regarded as a distinct species. From both these, it is distinguished by its thin membranous substance, its fructification, and its internal structure, which latter is the strongest character of the species. It may also be known from $\boldsymbol{F}$. coronopifolius, even when that plant is in its youngest state and destitute of any fruit, by the circumstance of its having all its branches linear or patent, instead of the primary ones being much thicker than the rest, and the ramuli often arranged in a horizontal direction along them.
a. F. glandulosus, natural size.
b. upper part of the frond, magnified - $\quad 5$.
c. part of ditto, with fruit - - $\quad$ - $\mathbf{2}$.
d. seeds - - _ - $\quad$ - 1 .

\section{9.-F U C U S P R I S T O I D E S.}

Hucus fronde cartilagineâ, planâ, obsoletè costatâ, lineari, denticulatâ, apice in folium oblongo-cuneiforme dilatatâ, e margine proliferâ, foliolis subrotundis, crispis, tuberculiferis.

Fucus serrulatus. WE BE et Moнr, Musei Index.

F. nitidus. Beiträge zur Naturkunde. I. p. 276.

\section{Ha вiтат apud Caput Bonæ Spei. D. Robertson, in Herb. Banks.}

RAD1X fibrosa, repens, fibris coloris dilutè carnei, incurvis, ramosis.

Fron des ex eâdem basi plurimæ, bi- tri-pollicares, planæ, aveniæ, caule instructæ lineari, latitudine unius circitèr lineæ, per totam longitudinem denticulato, dentibus tamen interdùm vetustate obsoletis, indiviso, sed obsito, præsertim in parte superiore, ramis sparsis, distichis, e margine exeuntibus, nunc confertis, nunc remotis, horizontalibus, longitudinis incertissimæ, ortu elongato-cuneiformibus simplicibusque, mox, progrediente ætate, basi caulem referentibus, et ramorum minorum simili ratione dispositorum serie instructis : rami omnes apice dilatantur in folium, ut ita dicam, oblongo-cuneiforme unguiculare, caule duplò latius, * nervo lato obsoleto percursum, e margine crenato-denticulato lenitèrque undulato proliferum, foliolis fasciculatis, perbrevibus, rotundato-cuneiformibus, crispis, dentatis, basi insignitèr attenuatis, non rarò iterum proliferis.

FRUCTIFICATIO tubercula perquàm exigua in foliolis posita, hemisphærica, rubra, intùs seminum minutissimorum, oblongorum, vel enormitèr tpyrifornium congeriem includentia.

CoLoR obscurè ruber purpureo immixtus; exsiccata atro-purpurascens ; soli expositce cito albescens.

SUBSTAN'rla cartilagillea, lenta, tenax.

Oв. Exsiccata chartæ nequaquàm adhæret.

Quadraginta licet anni jam propemodùm sint elapsi ex quo exemplaria hujus Fuci in Herbario Banksiano servata detexit ad Caput Bonæ Spei, in sinu False Bay dicto, D. Robertson, et licet post id tempus eundem ibi legerint Thunbergius et alii, nulla tamen, quoad scio, extat ejus vel icon, vel descriptio, vel etiam character specificus; solique illum inter auctores memoraverunt Weberus Mohriusque, qui obitèr modd, et tantùm ut nomen imponerent, perstrinxerunt. Cùm vero hoc nomen neutiquàm sit inter botanicos receptum, et nihil plantæe proprium exprimat, non dubitavi mutare, et in ejus locum substituere aliud, quod tyroni ad speciem discriminandam adjuvare potest, depromptum a similitudine, quæ, magnitudine demptâ, interest inter formam frondis illamque rostri piscis, quem Squalum Pristin Linnæus, Pristin antiqui, et nuper $\$$ Lathamius, nominaverunt. $\boldsymbol{F}$. pristoides est species pulchella, licet crescendi modus sit inelegans; adedque vel primo aspectu differt ab aliis, ut vix ulla sit quâcum affinis videatur. Quoad texturam suam proliferamque crescendi rationem quodammodo cum $F$. mbente convenit; eademque est utrique costa lata tam obsoleta ut dubitationi detur locus an Fucis fronde alatâ an iis fronde planâ enervi præditis rectiùs associarentur; longè tamen in reliquis recedunt, et recedit $F$. pristoides ab omnibus aliis hucusque notis Fucorum speciebus.
a. F. pristoides, magn. nat.
b. ramus, magn. auct. - _ - $\quad-\quad-6$
c. foliolum cum tuberculis - $\quad-\quad-\quad 4$.
d. tuberculum longitudinalitèr dissectum $\quad-\quad 2$.
e. semina - - - - _ - -1

* Hic licet nervus semper adsit frondi hujus Fuci aquè ac illi $F$. rubentis, pauci cum auctores memoraverunt, quia dum pronæe jaccnt plantæe, vel madidæ vcl siccæ, vix est conspiciendus, ideòque necessariè ex icone cxcluditur. Optimè de illo dicunt Goodenovius Woodwardinsque, "The ncrve we have spoken of as visiblc in the branches is discovered by holding the plant bcfore a very strong light. Indced this is the liest mode of cxaminiug Fuci in general : thc fuctification, and origimal color of any plant, be it to outward appearance, from drying, what it will, are most stirely detected by this method. When a plant has been once bleached by its cxposure to wind and weather, no art can restorc its color or discover it." -Act. Soc. Linn. III. p. 166.

† Ad amussim pyriformia, secundun Weberum et Molıium.-Beiträge zur Naturkunde. I. p. 276.

$\ddagger$ Act. Soc. Linn. II, p. 273. 
Fucus pristoides, frond cartilaginous, flat, obsoletely ribbed, linear, toothed, its apex extended into an oblongo cuneiform leaf; its margin proliferous with small roundish, curled, leaves, producing tubercles.

Fucus serrulatus. WeBER and MOHR, Index.

F. nitidus. Beiträge zur Naturkunde, I. p. 276.

\section{At the Cape of Good Hope. Mr. Robertson in the Banksian Herbarium.}

Root, fibrous, creeping, composed of pale flesh-colored, incurved, branching fibres.

Fron DS, numerous from the same base, two or three inches long, flat, veinless, furnished with a linear stem about one line wide, fringed throughout its whole length with minute teeth, which, however, are sometimes obsolete by age, undivided, but beset, especially towards the upper part, with scattered distichous branches, originating from the margin, in some cases clustered, in others remote, horizontal, of extremely uncertain lengths, of an elongated cuneiform shape at first, and simple, afterwards, as they grow older, similar to the stem at their base, and furnished with a series of smaller ones disposed in the same manner : all the branches are at their apices expanded into a leaf, if it may be so called, between oblong and cuneiform, half an inch long, twice as wide as the stem, furnished with a broad obsolete midrib, * the margin between crenate and toothed, slightly undulated, and proliferous with very short, clustered, curled leaves, of a roundish shape, approaching to cuneiform, remarkably attenuated at their bases, and not unfrequently again proliferous.

Fructification, minute, hemispherical tubercles placed upon the small leaves, of a red color, containing a mass of extremely small seeds, either oblong, or between foblong and pyriform, but not of a regular figure.

CoLor, a dark dull red tinged with purple ; turning when dry to blackish purple; and when exposed to the sun soon becoming white.

SuBSTANCE, cartilaginous, flexible, tough.

OBS. It does not in the least adhere to paper when dry.

It is now nearly forty years since the specimens of this Fucus, preserved in the Banksian Herbarium, were collecied in False Bay, at the Cape of Good Hope, by Mr. Robertson; subsequently to which time, the plant has been gathered in the same place by Thunberg and other botanists; yet, notwithstanding this, I am not aware that any tigure, or description, or even specific character of it has ever been published; nor do I find it mentioned by any author, excepting Weber and Molr, who have noticed it in the most cursory manner, merely for the sake of giving it a name by which it might afterwards be known. With regard, however, to this name, as it is not at present adopted among botanists, I have felt no hesitation in changing it; and have done so the more readily as it expresses no peculiarity of the plant, whereas the one here proposed may be serviceable in the discrimination of the species, being taken from the resemblance which the outline of the upper part of the frond bears in miniature to the beak of the fish called by Linnæus the Squalus Pristis, but by the more ancient writers only the Pristis. The habit of $F$. pristoides is indeed far from elegant, but it is nevertheless a pretty species, and even at first sight so unlike the others, that it would be difficult to say which it most approaches. If considered as to its texture and proliferous mode of growth, it agrees in some degree with F. rubens, and also agrees with it in the wide and obsolete midrib, which makes it doubtful whether these species should be arranged among the division of Fuci whose fronds are zinged, or that of those which have a flat and nerveless frond: in most other points, however, the two plants differ, and $F$. pristoides differs also no less widely from the whole of this extensive family.

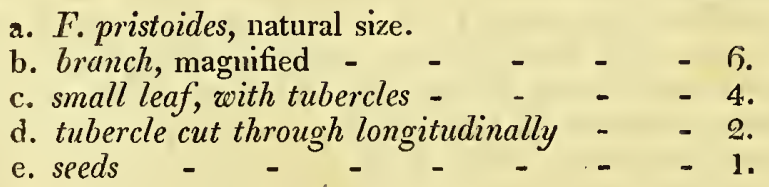

\footnotetext{
* Although this nidrib always really exists in the frond of this Fucus, as well as in that of $F$. rubens, it has even in the latter species escapcd the notice of most writers, bccause it is scarcely to be discovered, when the plant is lying fiat, either in a wet or dry state, and consequently is omitted in representations of the species. Dr. Goodenough and Mr. Woodward have rcnarked upon this subject very happily; " the nerve we have spoken of as visible in the branches is discovered by holding the plant before a very strong light. Indced this is the best mode of examining the Fuci in general: the fructification, and original color of any plant, be it to outward appearance from drying what it will, are most surcly detectcd by this method. When a plant has been once bleached by its exposure to wind and weather, no art can restore its color or discover it."-Act. Soc. Linn. III. p. 166.

Exactly pyriforn according to Weber and Mobr,-Beitrüge zur Naturlunde, I. p. 276.
} 

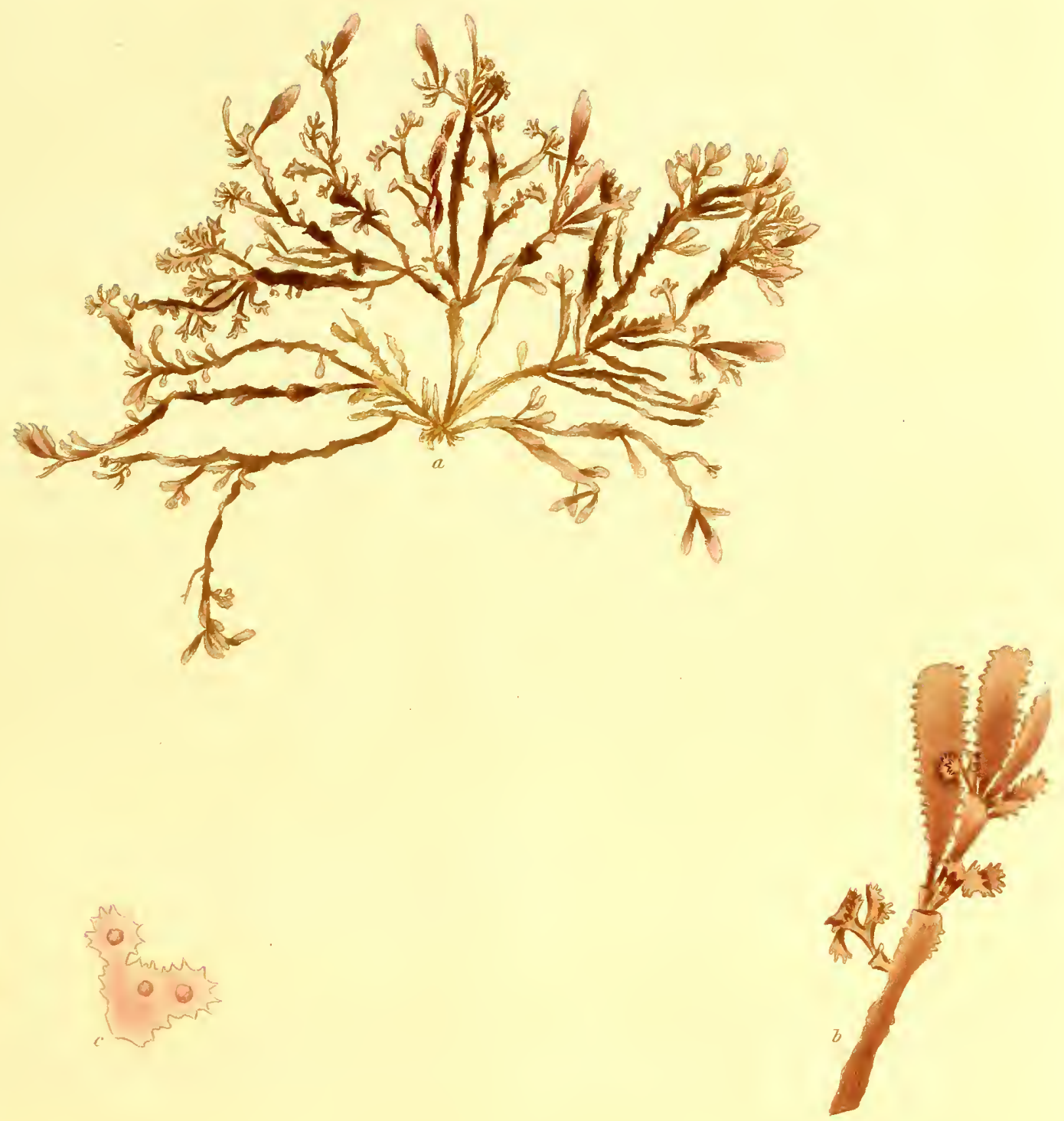

Tures fivistrides. 

Fècus fronde cartilagineâ enervi, dichotomâ; ramis linearibus, acutiusculis, margine incrassatis crenulatisque; tuberculis hemisphæricis disco insidentibus.

Fucus crenulatus. TurNer, in Linn. Trans. VI. p. 130. t. 8.

F. Norvegicus. Es PER, Ic. Fuc. II. p. 89. t. 153. f, 2.

Hавітат prope Durium flumen in Lusitaniæ littoribus.

Perennis? Augusto, Septembri.

RADIX callus expansus, fibrarum aliquot crassiuscularum rudimentis plerumque instructus.

FRONDES ex eâdem basi plurimæ, longitudine bi- tri-pollicares, quà radici proximæ teretes, pennâque passerinâ tenuiores, sese dilatantes priusquam lineæ unius alteræve altitudinem attigerunt, et, primùm compressæ, ferè statìm planæ, inde latitudinem circitèr bilinearem ubique æqualem ad apices usque servantes, nervi venarumque expertes, divisæ dichotomiis juxta basin incipientibus, mox sexies septiesve repetitis, intervallo inter singulas nunc brevissimo, nunc longiusculo; dichotomiarum anguli acuti; apices bifidi, segmentis oblongo-lanceolatis, acutis, erecto-patulis; margines hìc illìc, præsertìm apices versus, lenitèr incrassati, et minutissimè, sed perquàm manifestè, crenati.

Fructificatio *tubercula hemisphærica, Brassica Rapa seminum ferè magnitudine, utrique frondis paginæ, præcipuè in segmentis superioribus, satis copiosè insidentia, albida, exsiccata autem nigricantia, eâdem quâ frons epidermide nequaquàm tecta, intùs e fibris tenuissimis, parallelis, densissimè compactis constantia.

CoLor saturatè sanguineus, fusco immixtus; marcescentis aut Soli objecta in sordidè flavescentem transiens.

Substant1a coriaceo-cartilaginea, lenta, tenax.

Oвs. Exsiccata chartæ nulla frondis pars, tuberculis exceptis, adhæret.

Ex eo inde tempore quo hunc Fucum in Societatis Linnaana Actis primùm memoravi nulla ejus exemplaria accepi, unde niliil est quod sese descriptioni ibidem datæ nunc adjiciendum præstat, nisi quòd, propter causas sub specie insequente notandas, has stirpes hìc secernere sit visum. Non me equidem id fugit tubercula utriusque fructifera haud esse iisdem omninò verbis expressa: lectores autem monitos velim me persuasum habere hasce differentias verbis modo, non re ipsâ, existere, et inde pendere, quòd fuerint in diversis ætatis stadiis observata, atque ea $F$. crenulati esse principio frondi concolora, atque etiam ejus epidermide tecta, per quam maturescentia perrumpunt, et adulta speciem suprà memoratam præe se ferunt. In hoc statu referunt $F$. rotundi fructum, cùm colore, tùm substantiâ spongiosâ et glutinosâ, sed insignitèr ab hoc discrepant seminibus nullis intùs instructa. Quoad formam externam multum habet $F$. crenulatus affinitatis cum $F$. crispo et $F$. rubente, et est quasi medius inter hasce duas species natırâ parum conıexas : texturâ et substantiâ cum illâ, habitu cum hâc convenit, sed ab ambabus primo aspectu dignoscitur, non modò ramis ubique linearibus, apicibusque, earum $F$. bifidi quodammodò instar, bifurcis, verùm etiam colore utriusque dissimili, et margine incrassato minutissimè crenulato, notâ plantæ præ cæteris propriâ. Tubercula quoque ab iis F.crispi, quantumvis mutabilis, semper in eo discrepant, quòd sint nequaquàm in ipsâ plantæ substantiâ immersæ, sed superficiei semper insideant, unde frondem decadentibus illæsam manere versimillimum videtur.

a. F. crenulatus, magn. nat.

b. frondis apex, cum tuberculis. magn. auct. - $\quad-6$.

c. tuberculum seorsum - $\quad-\quad-\quad-\quad-4$.

d. idem longitudinalitèr dissectum - $\quad-\quad-2$.

e. filamenta - - - - $\quad$ - -1 .

*In Societatis Linnaana Actis hac tubercula, microscopio haud satis acri adhihito, seminibus repleta dixeram; attentiùs antem nunc inspiciens nihil in iis uisi filamenta reperio, et hæc filamenta nequaquàm suut ita manifestè articulata ut illa in cæeteris observanda, quod tamen
forsan e tuberculormm nimis provectorum atate peudet. 
Fucus crenulalus, frond cartilaginous, nerveless, dichotomous; branches linear, rather sharp, thickened and crenulated at their margin ; tubercles hemispherical, sessile on the disk.

Fucus crenulatus. TURNer, in Linn. Trans. VI. p. 130. t. 8.

F. Norvegicus. Es Pe R, Ic. Fuc. II. p. 89. t. 153. f. 2.

On the coast of Portugal near the river Douro.

Perennial? August, September.

Rooт, an expanded callous disk, generally furnished with the rudiments of a few thickish fibres.

Fronds, numerous from the same base, two or three inches long, cylindrical in the part nearest the root, and not so thick as a sparrow's quill, but becoming compressed before they are more than a line or two high, and then almost immediately flat, after which they preserve throughout their whole length an equal width of about two lines; they are altogether destitute either of midrib or veins, and are branched with dichotomies that begin near the base, and are afterwards six or seven times divided, the interval between each being in some cases extremely short, in others rather long: the angles of the dichotomies are acute: the apices bifid, their segments oblongo-lanceolate, sharpened, between erect and patent: the margin here and there, especially towards the apices, is slightly thickened, and very minutely, but at the same time very evidently, crenate.

Fructification, hemispherical *tubercles, almost as large as turnip seed, situated plentifully on both sides of the frond, particularly in the upper branches, whitish, but black when dry, by no means covered with the epidermis of the frond, consisting internally of extremely thin, parallel fibres, very closely matted together.

Color, a deep dull blood-red, tinged with brown; turning, when in decay or exposed to the sun, to a dirty yellowish hue.

SU BSTANCE, between coriaceous and cartilaginous, pliant, tough.

OBs. When dried no part of the frond adheres to paper, excepting the tubercles.

Having received no specimens of this Fucus since the tine when I first described it in the Limnæan Transactions, I am unable to add any thing to the account there given, except that, for the reasons mentioned under the following plant, it has appeared best to separate it as a distinct species. With respect to the difference observable in speaking of the fructification of the two, I think it right to mention, that I an convinced it arises only from their having been noticed in different periods of their growth; and that the tubercles of $\boldsymbol{F}$. crenulatus are at first of the same color as the frond, and even covered with its epidermis, through which they burst as they ripen, and then take the appearance mentioned in the description, resembling in their color, and in their spongy and glutinous nature, those of $F$. rotun$d u s$, from which they differ so strikingly in the ivant of seeds within them. F. crenulatus in its external appearance is allied to $\boldsymbol{F}$. crispus and rubens, thus connecting two species that have very little in common: in texture and substance it agrees with the former, in general habit with the latter; but may easily be distinguished from either at first sight, not only by the branches always preserving their linear form, and being divided at the extremities in a manner somewhat resembling those of $F$. bifidus, but by its color, which is different from that of either of them, and by the strong peculiarity of its thickened and minutely crenated enges. The tubercles, too, unlike those of any variety of $F$. crispus, are not immersed in the substance of the plant, but sessile upon its surface, so that in all probability their falling off is not attended with any injury to the frond.
a. F. crenulatus, natural size
b. upper part of the frond, with tubercles, magnified 6 .
c. tubercle separate - - $-{ }_{-}-{ }_{-}$.
d. ditto cut through longitudinally $\quad-\quad-2$.
e. filaments - - - - -1 .

\footnotetext{
- In describing this plant for the Linnacan Transactions, I had, from not employing sufficiently lighl microscopical pnwers, been led to regard the tubercles as filled with seeds; but now, upon a more careful cxamination, I find nothing in them except filaments, and even these are by no means so evidently jointed as those observable in other specics. 'This circumstance, however, may probably depend upon the too advanced state of the tubercles.
} 

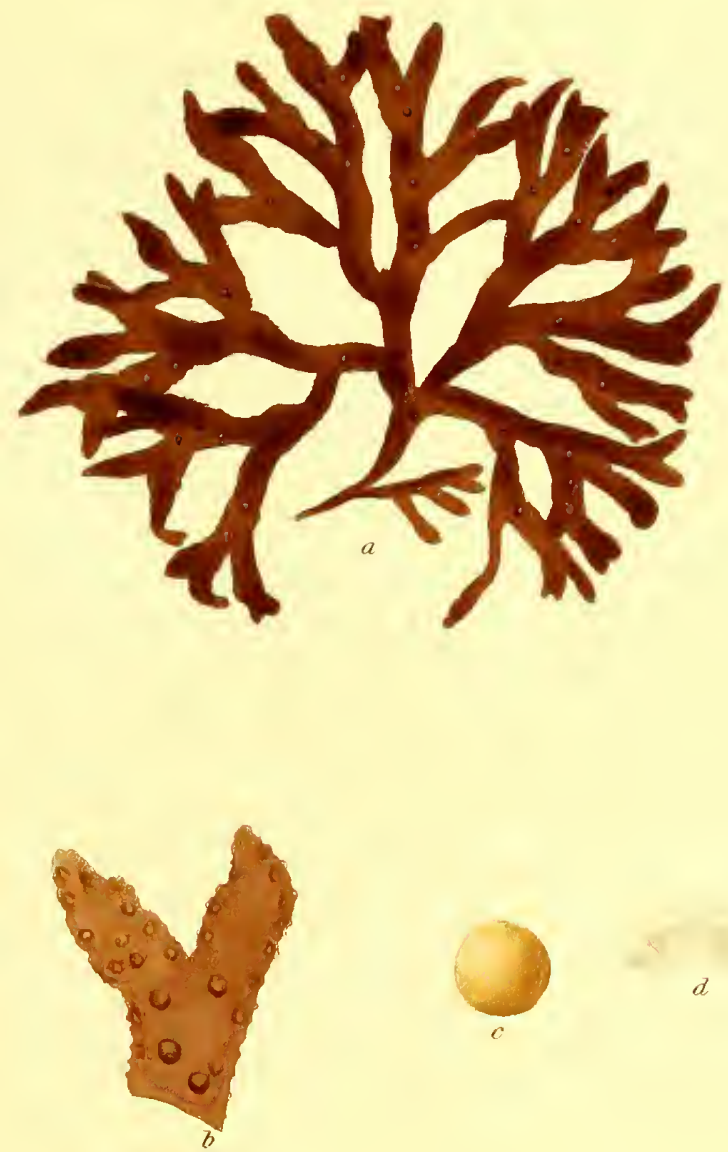

stucus crenetertus. 

Fucus, fronde cartilagineâ, enervi, dichotomâ; ramis linearibus, integerrimis, apice rotundatis; tuberculis hemisphæricis, disco insidentibus.

Fucus Norvegicus. Fl. Norv. II. p. 122. t. 3. f. 4. Syn. Fuc. II. p. 222. Eng. Bot. XV. t. 1080.
. EsPER, Ic. Fuc. II. p. 89. t. 153. f. 1. 3. 4.

F. crenulatus. $\beta$. TURNer, in Lim. Trans. VI. p. 130.

F. polymorphi var. Lamouroux, Diss. Fuc. t. 8. f. 19?

Haвıтат in Oceano Norvegico. Gunner.-Apud Dubrem. D. Dillwyn.-Copiosè nascentem prope Exmouth detexit D. T. Frankland, Baronet.-Apud Torquay, et Sidmouth, et in Cornubiæ oris. $D^{\text {na }}$ Griffiths. E Mari Mediterraneo accepit D. Prof. Mertens.

Perennis? Septemb.-Mart.

RADrX callus tenuis, expansus.

FRONDES ex eâdem basi plurimæ, nervi venarumque expertes, tri- quadri-pollicares, quà radici proximæ teretes, pennâque passerinâ tenuiores, intra duarum triunıve linearum a basi spatium compressa, moxque planæ, et inde latitudinem circitèr bilinearem ubique æqualem ad apices usque servantes : frons juxta basin bifurca, et postea dichotomiis sexies septiesve repetitis, intervallo inter singulas nunc brevissimo nunc longiusculo, divisa; rami patentes; apices bifidi, segmentis horizontalitèr patulis rotundatis ; margines semper integerrimi, nec ullo modo incrassati :frons plerumque contorta et subspiralis evadit.

FrUCTIFICATIO tubercula hemisphærica, papaveris seminis magnitudine, utrique frondis paginæ, præsertim in segmentis superioribus, insidentia, et sæpe tria vel quatuor in singulis, ejusdem quo frons coloris.

COLOR intensè sanguineus fusco aliquantùm tinctus, in surculis junioribus, et quandoque ad apices, pulchrè roseus et diaphanus; exsiccata intensior; soli expositce aut in aquâ dulci retenta in sordidè flavescentem transiens.

Su BSTANTIA cartilaginea, lenta, tenax, vetustioris ad coriaceam, junioris ad membranaceam accedens.

Oвs. Exsiccata cliartæe nequaquàm adhæret.

Tot licet tantisque formæ mutationibus $F$. crispus sit obnoxius ut optimè de illo prædicaverint Goodenovius Woodwardiusque " quidquid tangere esse idem," datur tamen huic regulæ exceptio quoad $F$. Norvegicum, qui multum cum illo congruit substantiâ et habitu, sed colore et fructu tantum recedit ut cautè observantibus se primo aspectu dignoscendum reddat. Neque tamen eo secius temperare mili possum quin suspicer Lamourouxium, qui ad $F$. crispum sub $F$. polymorphi nomine illustrandum quadraginta iconas impendit, utrumque aliquo modo commiscuisse, quoniam figura ejus suprà citata $F$. Norvegicum formâ optimè repræsentat. Dubitantèr tamelı citatur, cùm nihil de illâ in descriptione dixerit, nec vel pro varietate insigni habuisse videatur. Spero me rectè fecisse secernendo speciem hìc depictam a præcedente, quâcum primùn conjuuxeram : in plurimis quidem, iisque maximi momenti, notis arctissimè conveniunt, sed differunt substantiâ in $F$. Norvegico tenuiore, frondis margine integerrimo, nequaquàm incrassato crenulatove, dichotoniis magis divaricatis, et apicibus rotundatis obtusis, quæ notæ in onmibus a me hactenùs visis exemplaribus stabiles permanserunt. Esperi verò icon mala inter utrumque ambigit, et, quanvis ipsi insequens figuram secundam ad $F$. crenulatum reliquas ad $F$. Norvegicum retulerim, neutiquàm illis fidendum existimo. Gumnerus prinus hanc stirpem in Florâ suâ Norvegicâ descripsit, adjectâ icone, quæ, quantumvis haud optima, plantæe characterem satis exprimit. In descriptione profitetur se dubitare an sit a $F$. divaricato distincta, sed quid sub $F$. divaricati uomine vellet haud nobis liquet: quærit quoque vir cautissimus suique diffidentissinus annon sit Fucu: quidam jam notus atate juniore, quod tamen tubercula, vix unquam in ullâ nisi maturâ conspicienda, vetant.

a. F. Norvegicus, magn. nat.

b. frondis pars superior, magn. auct. $\quad-\quad-6$.

c. tuberculum longitudinalitèr dissectum - S.

d. filamenta - - - -2 -

e. eudem - - - - - - - 1.

* Unns modò, quod scio, Fucus sub $F$. diraricati nomine bactenùs descriptus extat, qui tantummodó $F$. resiculosi varietas, cui eum titulutra sodiderat Linnæus: cum hoc alitem nihil ferè labet $F$. Norregicus commune. 
Fucus Norvegicus, fiond cartilaginous, nerveless, dichotomous; branches linear, entire, rounded at their apices; tubercles hemispherical, sessile on the disk.

Fucus Norvegicus. Fl. Norv. II. p. 122. t. 3. f. 4. Syn. Fuc. II. p. 222. Eng. Bot. XV. t. 1080. EsPER, Ic. Fuc. II. p. 89. t. 153. f. 1.3. 4.

F. crenulatus. $\beta$. Turner, in Linn. Trans. VI. p. 130.

F. polymorphi var. Lamouroux, Diss. Fuc. t. 8. f. 19.?

In the sea near Norway. Gunner.-At Dover. Mr. Dillwyn.-At Exmouth, where it grows in plenty. Sir T. Frankland.-Torquay, and Sidmouth, and on the Cornish shores. Mrs. Griffitls.-Sent from the Mediterranean to Professor Mertens.

Perennial? September-March.

Roor, a thin, expanded, callous disk.

FroNDS, numerous from the same base, destitute of midrib or veins, three or four inclies long, cylindrical, and thinner than a sparrow's quill in the part nearest the root, but becoming compressed within the distance of two or three lines from the base, and then almost immediately flat, after which they preserve to the apices au everywhere equal breadth of about two lines, they are forked near their origin, and afterwards six or seveu times dichotomous, the space between each division being in some instances extremely small, in others rather long: the branches are patent: the apices bifid, with segments between horizontal and patent, rounded at their extremities; the margius always quite entire, and in no degree thickened:-the habit of the frond is in general twisted and approaching to spiral.

Fructification, hemispherical tubercles, about the size of poppy-seed, sessile upon both sides of the frond, especially in the upper segments, and oftell three or four on each, of the same color as the frond.

CoLOR, deep blood-red, somewhat tinged with brown, a beautiful transparent pink in the younger shoots, and sometimes at the apices; darker when dry; and soon turning to a dirty yellowish hue, if exposed to the sun, or kept ill fresh water.

SU BST A CE, cartilaginous, pliant, tough, approaching to coriaceous in the older, and to membranaceous in the younger plants.

Ons. When dried it does not adhere in the least to paper.

With whatever propriety the observation was made by Dr. Goodenough and Mr. Woodward, that $F$. crispus was liable to so many and to such extraordinary variations in its appearance, "that every thing that approached it was the same," it must nevertheless be allowed, that an exception is to be granted with respect to this rule in favour of $F$. Norvegicus; the substance and general habit of which strongly agree with those of that species, but the color aud fructification are so strikingly different, that a careful observer can have no difficulty in distinguishing them at first sight. I am nevertheless inclined to suspect that they have been in some degree confounded by Lamouroux, who, in the illustration of $F$. crispus, under the name of $F$. polymorphus, has eniployed no less thau forty figures, of which the one quoted above is an excellent representation of $F$. Norvegicus; though, as he has said nothing in his description relative to it, nor even pointed it out as a remarkable variety, I have not ventured upon referring to it without a sign of doubt. I trust that I have done right in separating the present plant from that which is the subject of the preceding plate, with which it had originally been united. They agree indeed in most points, and those of the greatest inportance, but differ in the substance of $\boldsymbol{F}$. Norvegicus being more thin, in the margin of its frond being quite eutire, and neither thicker than the rest, nor crenulated, in the angles of the dichotomies being more obtuse, and in the apices being blunt and rounded; the whole of which characters have held good in all the specimens that have at present fallen under my observation. Esper's figure, however, which is in itself far from excellent, seems to represent plants of an intermediate appearance; and though, in conformity to his own directions, I have referred his $\mathrm{N}^{\circ} 2$. to $F$. crenulatus, and the rest to $F$. Norvegicus, I should still be sorry to see too much confidence reposed upou them. The first account of $F$. Norvegicus is that by Bishop Gunner in the Flora Norvegica, where a figure is also given, which, though by no means the best possible, is at the same time not deficient in character. The learned author acknowledges in his description that he is in doubt whether it be distinct from * $F$. divaricatus, a question which we can now have no means of solving, as it is impossible to know what he meant to allude to under that name : and he also inquires with extreme caution and diffidence whether it may not possibly be some well known species in an early stage of its growth: this conjecture, however, the tubercles, the most certain proof of its maturity, forbid us to entertain.

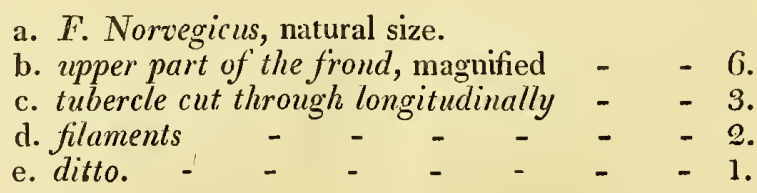

\footnotetext{
* I do not know that more than one Fucus has ever been described under the name of $F$. divaricutus, which is melely a trifing variety of $F$. vesiculosus, which was so called by Linnæus, but with this $F$. Norecgicus scarcely agrecs in a single point.
} 

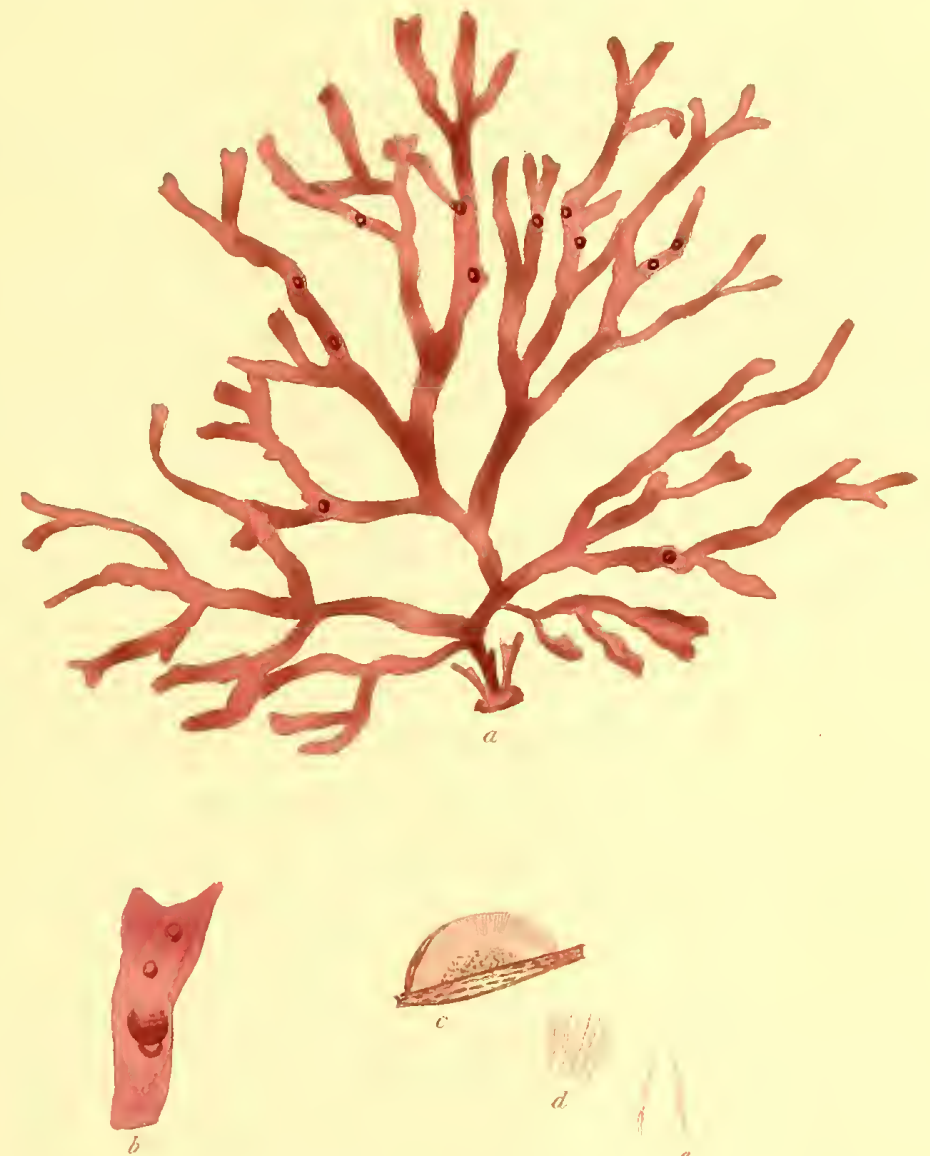

Fermes tereerquedes. 

Fucus, fronde sub-membranaceâ, obsoletè costatâ, e superficie catenato-proliferâ; ramis ellipticis, simplicibus bifurcisque ; foliolis subrotundis peltatis, tuberculisque hemisphæricis extrinsecùs rugosis disco insidentibus.

Fucus rubens. Linn. Sp.Pl. II. p. 1630. Syst. Nat. II.p.718. Syst. Nat. Ed. Gmel. II.p. 1387. Linn. Trans. III. p. 165. Syn. Fuc. II. p. 216. (excl. Syn. Morisoni et Ginanni.) Eng. Bot. XV. t. 1053. Es PE R, Ic. Fuc. II. p. 39. t. 129. Fl. Lus. II. p. 437.

F. crispus. Fl. Ang. p. 580. (excl. syn. Linn.)

F. prolifer. Fl. Scot. II. p. 949. t. 30. Wiтн. IV. p. 105. Fl. Fr. Ed. 2da. II. p. 29.

F. laciniatus. Gmelin, Hist. Fuc. p. 182. t. 22. f. 2. (excl. syn. Huds.) icon pessima.

F. epiphyllus. Fl. Dan. t. 708.

* F. miniatus. Fl. Dan. t. 769 .

F. membranaceus purpureus variè ramosus. Raı Syn..p. 47. n. 36.

MA B1тат in Britanniarum oris, satis frequens.-In Oceano Galliam septentrionalem alluente. Decandolle.In sinubus Norvegiæ. Oeder. Ad ostia Tagi et Durii. Brotero.

Perennis. Hyeme fert fructum.

RA DIX callus expansus, tenuis, durus, ut propemodùm corneus videatur, albicans.

FRON DES ex eâdem basi plurimæ, palmares, vel spithamææ, stipite instructæ tereti, lineam unam alteramve longo, sursum compresso, seque dilatante in folium longitudine circiter sesquipollicem latitudine tres lineas æquans, nunc ellipticum et simplex, nunc apicem versus dilatatum et bifurcum, furcarum angulis acutis obtusisque, segmentis sæpius rotundatis, quandoque acutiusculis : folii ad apices, nunquam tamen ex ipso margine, sed semper e superficie, oriuntur folia alia, interdum solitaria, interdum bina vel terna, primariorum omnimodè similia, et ipsa aliis simili ratione prolifera, quæ seriem tertiam quoque ferunt, et ita ad quintam vel sextam planta, progrediente æata, pervenit: foliorum horum longitudo incertissima a bilineari ad sesquipollicarem variat, nec sunt superiores semper brevissimi : aliquando etiam, sed hoc haud ita frequens, e mediâ foliorum parte nova folia germinant; ortu cuncta sunt subrotunda; omniun margines plani, integerrimi; medium percurrit fcosta lata, reliquâ fronde crassior, colorisque intensioris, maximè manifesta in foliis primaris, inde sensim magis magis que obsoleta' et in summis vix aut ne vix detegenda.

FrUCTIFICATIo tubercula hemisphærica, dilutè rosea, papaveris semine minora, utrique frondis paginæ copiosè insidentia, extrinsecùs rugosa, ut e foliolis perquàm exiguis implexis contortuplicatisque constare videantur, intùs seminum minutissimorum abnormitèr oblongorum congeriem includentia: præter hoc occurrunt quoque abundantèr in frondis superficie folia exigua, subrotunda, peltata, frondi appressa, in quibus haud raro, ut etiam aliquando in reliquâ fronde, conspiciuntur granula sparsa parva atro-rubentia:- anne autem vel folia peltata vel granula aliquid cum fructu commune habeanit prorsus nescio.

CoLor dilutè ruber, interdùm in foliis junioribus roseo immixtus; exsiccaic multo intensior et sanguineus; marcescentis pallidè fusco-flavescens.

- Substantra tenuis, attamen tenax, media quasi inter membranaceam et cartilagineam.

OBS. Ex aquâ extracta nitet dum madet quasi vernice obducta :-exsiccata chartæ nequaquàm adhæret :- habitus sæpe crispatus :- vix ulla datur Fuci species cui copiâ majore inhrent, non modo Flustra pilosa aliæque minores Zoophytorum species, sed etiam quidam e Fucis et Confervis; sæpe quoque Serpula spirorbis.

E descriptione hıjus Fuci suprà datâ liquet eum duplici gaudere formâ, foliis in unâ ellipticis simplicibusque, in alterâ sursus versus dilatatis et bifurcis. Harum utraque paritèr vulgaris, et plerumque ambarum exempla in eâdem froude occurrunt. Reperiuntur tamen quandòue specimina, quorum folia certa sunt ubique figuræ: et interdùm, sed rarò, et numquam nisi in immaturo ætatis stadio, vidi quæe non erant prolifera. I Neutiquam autem, me judice, ex injuriâ aliquâ pendet hæc prolifera crescendi ratio, ejus in Cacto Opuntiấ hand dissinilis, sed est ipsi stirpis naturæ insita, notamque spèciei quàm maximè propriam suppeditat, et quæe ab omnibus aliis, insequente modò demptâ, distinguit; unde fieri nequit quin doleamus extitisse ullam necessitudinem mutandi id nomen quod indiderat b. Lightfootius, qui, descriptione et icone optinâ in Florâ Scolicâ traditis, primus hanc plantam extra dubitationem posuit: F. ruberitis synonymia multùn et diù vexata haud facilè extricari potest; ad diversas enim stirpes Linnæi synonymon diversi auctores traxerunt; e quibus plurini $F$. sinuosum crediderunt, donec, ut jam sub illâ memoratur specie Goodenovius Woodwardiusque ex Herbarii Limnani autopsiâ solverunt litem, docendo hanc esse stirpem ab ipso designatam. Hos ego secutus pro tali accepi, licet descriptio in Speciebus Plantarum non bene quadret, quâ de re ßequco non suspicari summum virum plus unâ specie sub illo nonine commiscuisse. Esperus in $\$$ primo Iconum Fucorum tomo $F$, palmatum pro $F$. rubente depixit, et Flora Danica auctores $F$. rubentem citaverunt, ut synony-

\footnotetext{
* Dubitationis signum haic synonymo in Fucorum Britannicorum Synopsi subjeci, quò crescendi modum proliferum haud bene in icone

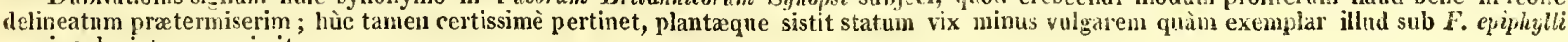
nomine depictuns exprimit.

+ De hâc costá consule qua suprà sunt dicta sub F. pristoidi, p. 83.

+ Dubitant de hoc Goodenovins Woodwardiusque, et dicunt, " it is a matter of curious inquiry whether the proliferous tcudency of this plant be its natural growth, or whether it be its natural power of repairing any injury (to which its tender ant brittie quality exposes it at all times) which it may have reccived. We have found entire plants bearing no ploliferous division at all." - Act. Soc. Lizan. Xil. p. 166.

t. 75. p. 148.

VOL.I. 
mon F.membranifolii, quem $F$. Palnettam appellant. Erravi et ipse, ut mihi nunc videtur, cùm in Fucorum Britannicorum Synopsi Ginannii Epatica spirale ad hanc specienı referrem, utpote quæ meliùs insequentem milhi tunc temporis ignotain sistit. Morisoni quoque Synonymon semper pro dubio habitum nunc ad $F$. palmati varietatem quandam pertinere existimo. De Buxbaumii figurâ (Cent. I. t. 60. f. 2.) ab Espero citatâ nihil est quod dicam, nisi quòd sit, sicut plurimæ aliæ Fucorum iı ejus Centuriis icones, tam manca ut minus detrimenti a neglectis rei botanicæ proventurum credam. Diversissimè de $F$.rubentis fructu judicaverunt auctores diversi; qui tamen ferè omnes pro re dubiâ in medio reliquerunt. Cùm verò semina, eorum in $F$. purpurascente similium, in tuberculis inclusa tandem repererim, nullus dubito quin hæc sint vera fructificatio; * suspicorque folia peltata tantummodò e proliferâ plantze vi oriri, novisque ramis producendis inservitura, si satis ætatis vel roboris stirpi suppeditetur. Forsan etiam fronde pereunte decidunt, et, bulborun instar in Allüs aliisque plantis phænogamis occurrentium, in novas frondes progerminant.-Quis scit ?-pauca sanè, eaque tenebrosè, nos adhuc de hujusmodi rebus scimus.-Granula in foliolis depicta, a nemine antehac, quod scio, observata, potiùs e casu pendere quàm aliquid cum fructu comnıne labere crederem.

a. F. rubens, magn, nat.

b. frondis pars cum foliolis peltatis et grannlis sparsis, magn. auct. 6 .

c. foliolum peltatum granulis aspersum - $\quad$ - $\quad$ - $\quad$ - $\quad 3$.

d. frondis pars in quấ costa cernitur cum tuberculis, magn. nat.

e. ejusdem portio, magn. auct. - $\quad$ - $\quad$ - $-\quad$ - 5 .

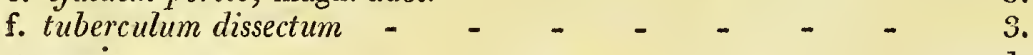

g. semina - - - $\quad$ - $\quad$ - $\quad$ - $\quad$ - -1 .

\begin{abstract}
* Cùm analogia e specie insequente deprompta alitèr suadeat, alitèrque ipse in Fucorum Brilannicorum Synopsi credideram ; neque omnino idem sentiat Dna. Griffiths, cui optima fuit facultas hunc Fucum nascentem observandi, sententiam suam suis verbis expressam hic repetendam existimo.- " I am inclined to think that the orbicular leaves on the surface produce the fructification, by what is at first a purple spot becoming in time a solid substancc or tubercle, and at length a granulated wart (the skin of which is strongly curled or plaited) containing sceds, when the membrane which before concealed or protected it falls off, and the warts only remain, in which, when near decay, pores may be seen : ont of these $I$ liave squeezed a pinky substance, like minutc grains in a transparent mucus, which $I$ take to be the seeds. The warts are placed on the surfuce of the frond precisely in the same situation as the flat orbicular leaves, from undcr which they appear to come out, and some may be observed surrounded with the membrane."
\end{abstract}

\title{
42.- F U G U R U B E N S.
}

Fucus rubens, frond submembranaceous, obsoletely ribbed, proliferous from the surface; branches elliptical, simple and forked; roundish peltate leares, and hemispherical externally uneven tubercles, sessile on the disk.

Fucus rubens. Linn. Sp.Pl. II. p. 1630. Syst. Nat. II. p. 718. Syst. Nat. Ed. Gmel. II. p. 1387. Fl. Norv. II. p. 69. Linn. Irans. III. p. 165. Syn. Fuc. II. p. 216. (excl. syn. Morisoni et Ginanni.) Eng. Bot. XV. t. 1053 . Esper, Ic. Fuc. II. p. 39. t. 199. Fl. Lus. II. p. 437.

F. crispus. H. Ang. p. 580. (excl. syn. Linn.)

W. prolifer. Fl. Scot.II. p. 949. t. 30. WI W. IV. p. 105. Fl. Fr. Ed. 2da. II. p. 29.

F. laciniatus. GMELIN, Hist. Fuc. p. 182. t. 22. f. 2. (excl. syn. Huds.) figure very bad.

F. epiphylius. Fl. Dan. t. 708.

* F. miniatus. Fl. Dan. t. 769 .

F. membranacens purpurens variè ramosus. $R_{A I I} S y n$. p. 47. n. 36.

On the shores of the British Islands, common.-Northern coast of France. Decandolle.-In the Bays of Norway. Oeder.-Moutss of the Tagus and Douro. Brotero.

Perennial. In the winter months.

Root, an expanded, thin, whitish, callous disk, so hard as to appear almost horny.

FRONDS, numerous from the same base, from three to seven inches long, furnished with a cylindrical stipes, not more than a line or two in length, compressed at its upper part, and expanding into a leaf about an inch and half long, and three lines wide, in some cases elliptical and simple, in others, dilated towards its apex, and forked, the angle of the division being either acute or obtuse, and the segments, though most frequently rounded at their extremities, occasionally sharp : towards the end of the leaf, but constantly from the surface, and never from the margin, are produced other leaves, solitary in some instances, in others, growing two or three together, precisely similar to the primary ones, and themselves again in the same manner proliferous with others, which in their turns give birth to a

* I had subjoined a mark of doubt to this synonym in the Synopsis of the British Fuci, having overlooked tlie proliferous mode of growth, which is indeed by no means clearly expressed in the figure. It, however, certainly belongs to $F$, rubens, and is designed to represent a state of the plast scarcely less common than that figured under the name of $F$. epiphyllus. 

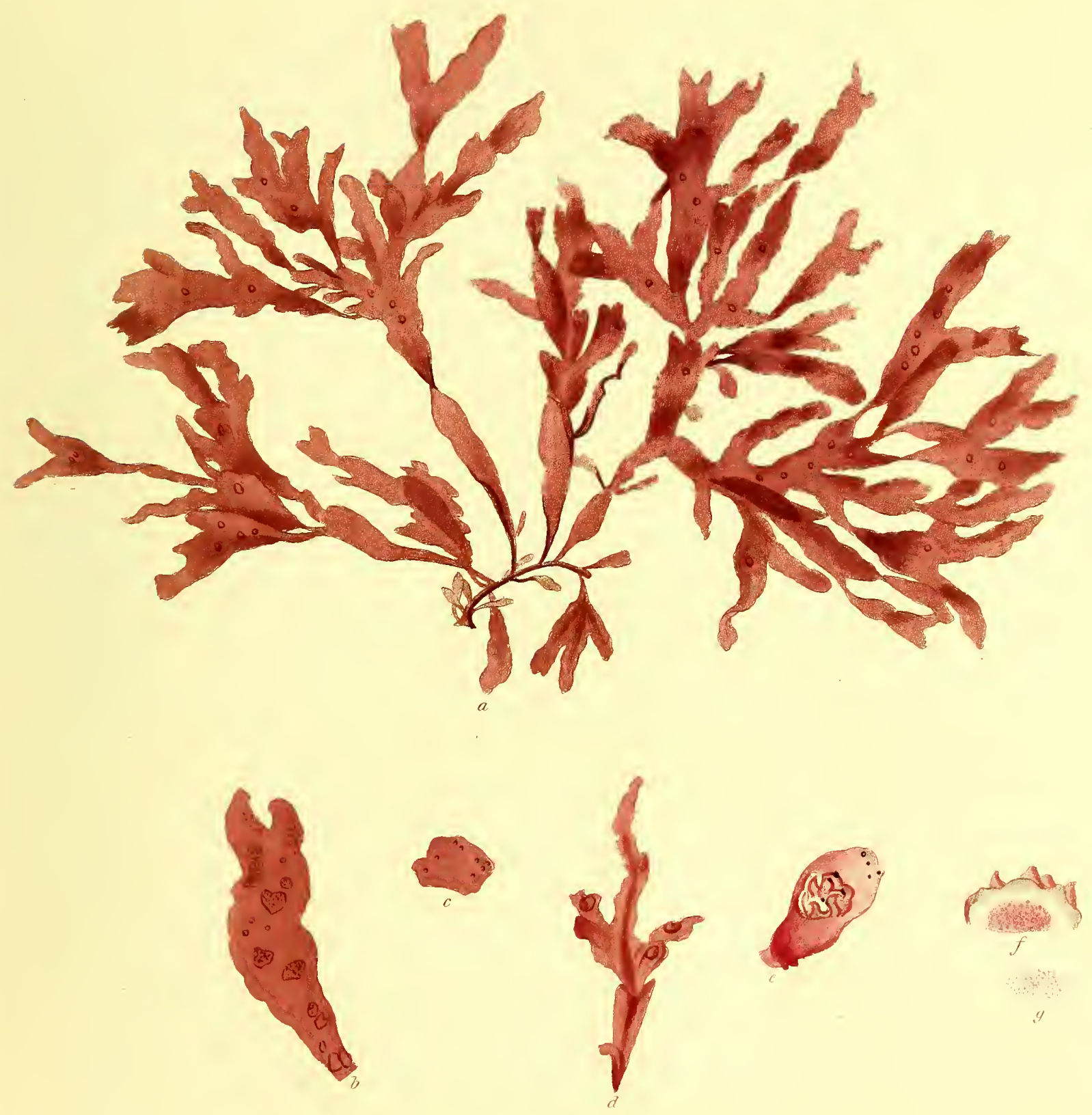

finces metens. 

third series, so that the plant, in course of time, arrives at a fifth or even a sixth : the length of these leaves is variable from two lines to an inch and half, and the uppermost are by no means always the shortest: it happens sometimes, but not often, that new leaves spring from the central part of the others: the whole of them at their origin are roundish: the margins of all are flat and quite entire: through their centre runs a wide *midrib, of a thicker substance and darker color than the rest of the frond, most conspicuous in the primary leaves, after which it grows gradually more and more obsolete, and in the upper ones is scarcely, if at all, to be perceived.

Fructification, hemispherical tubercles, of a pale pink color, smaller than poppy-seed, disposed plentifully on each surface of the frond, externally wrinkled, so as to look as if composed of minute leaves twisted together, internally containing a mass of extremely small seeds of an irregularly oblong form: besides these, but whether connected or not with the fructification is what I have no means of knowing, there are found in great abundance lying flat on both sides of the frond, small, roundish, peltate leaves, on which are frequently observable minute, dark-red, scattered granules, some of which are also sometimes to be seen on other parts of the plant.

Color, a pale, but dull and opaque, red, in the young leaves occasionally tinged with pink; much darker and blood-red when dry; and in decay turning to a light yellowish brown.

SUBSTA NCE, tlin, but tough, almost intermediate betweel membranaceous and cartilaginous.

Oвs. The frond shines while it is wet as if varnished :-in a dry state it by no means adheres to paper:-its habit is frequently curled:- scarcely any Fucus is more infested, not only with Flustra pilosa, and the lesser Zoophytes, but also with small Fuci and Confervæ, and often with Serpula spirorbis.

From the description above given of this Fucus it is evident that it is subject to two different appearances, the one producing elliptical and simple leaves, while in the other the leaves are widened towards their apices, and forked: both of these are equally common, and both generally to be met with upon the same frond. It, however, sometimes happens that individuals occur, the whole of the leaves of which are of one regular form; and I have occasionally seen plants that were not at all proliferous; but instances of this kind are very rare, and, 1 believe, never to be found where the plant has attained to its full size. TThis proliferous mode of growth, which is not unlike that observable in Cactus Opuntia, ought, in my opinion, by no means to be regarded as accidental, or the effect of injury, but rather as a peculiar property innate in the species, and as one that affords its most striking characteristic, it being in itself sufficient to distinguish it from every other, except the following; so that it is impossible not to lament the necessity of changing the appellation given to it by Lightfoot, by whose adnirable description and figure in the Flora Scotica, it was first removed beyond the reach of doubt. The synonymy of $F$. rubens has always been much perplexed, the name having been attributed to very different species by different authors, each of whom supposed his own to be the true plait so called by Linnæus : by most, however, it had been given to $\boldsymbol{F}$. sinuosus, and this opinion would probably have prevailed, had not Dr. Goodenough and Mr. Woodward, by an examination of the original specimeris, at length determined the point, and, upon the authority of the Linnæan Herbarium, declared the present to be the plant actually intended. With their decision I have judged it best to comply, although, as has been already noticed under $F$. sinuosus, the description in the Species Plantarm does not exactly suit, for which reason it is impossible not to suspect that more than one species was there confoinded under the same name. Professor Esper, in the first volume of lis $¥$ Icones Fucorum, has figured F.palmatus for F. rubens, and this latter is in the Flora Danica quoted as a synonym of $F$. membranifolius, the F. Palmetta of that work. It also appears to me that there is in the Synopsis of the British Fuci an error, in referring to the Fucus before us the Epatica spirale of Ginanni, as his figure seems better to express the subject of the following plate, with which I was not till lately acquainted. The synonym also of Morison, there quoted, but quoted as doubtful, I am now inclined to think was rather intended for one of the varieties of $F$. palmatus. With regard to Buxbaum's figure, (Cent. I. t. 60. f. . 2 .) applied to this plant by Esper, I have nothing father to say, than that, like most of the plates of Fuci in lis Centuria, it is so imperfect that less injury is likely to arise to science from their being altogether neglected than from any attempt to illustrate them. The opinions of various authors relative to the fruit of $\boldsymbol{F}$. rubens have been widely different, but the point has been looked upon by most of them as so obscure, that they have left it in the same uncertainty in which they found it. As, however, 1 have clearly seen in the tubercles seeds similar to those of $F$. purpurascens, \&c. I can entertain no doubt of these being the true fructification, and I \$suspect the peltate leaves owe their origin only to the proliferous tendency of the species, and would lengthen into branches, were theplant endued with sufficient vigor, or were its duration sufficiently protracted. It is also possible that, like the bulbs of Allia, and other phrenogamous vegetables, they fall

* Concerning this midrib refer to what has already been remarked under $F$, pristoides, p. 84 .

+ Upon this subject Dr. Goodenough and Mr. Woodward express doubts, and say, " it is a nuater of curious inquiry whether the pro. liferous tendency of this plant be its natural growth, or whether it be its natural power of repairing any injury (to which its tender and brittle quality exposes it at all times) which it may have reeeived. We have found entire plants bearing no proliferous division at all." $-A c t$. Soc. Linn. III. p. 166 .

t. 75. p. 148 .

An opposite opinion would indeed be suggested by the analogy of the following species, and such was entertained by ne in the Synopsis of the British Fuci. Mrs. Griffiths too does not altogether view the matter in the same light as I liave done here, and, as she has had the best opportunities of examining the plant while growing, I think it right to repeat her observations in her own words. "I an inclined to think that the orbicular leaves on the surface produce the fructification, by what is at first a purple spot becoming in time a solid substance or tubercle, and at length a granulated wart, (the skin of which is strangely curled or plaited) containing sceds, when the membrane which before concealed or protected it falls off, and the warts only remain, in which, when near decay, pores may be seen : out of these I have squeezed a pinky substance, like minute grains in a transparent mucus, which $I$ take to be the seeds. The warts are placed on the surface of the firond precisely in the same sitnations as the flat orbicular leaves fiom under which they appear to come out, and some may be observed sisromiled with the mensbrane." 
off when the frond decays, and shoot 11 p into new individuals, - Who can tell? - Certain it is that in all these matters ve see but little, and that little but very darkly. With respect to the granules represented on the small peltate leaves, and, I believe, never before noticed, I would rather attribute them to accident, than regard them as connected with the fructification.
a. F. rubens, natural size.
b. part of the frond, with peltate leaves, and scattered gramules, magnified - 6 .
c. peltate leaf, and scattered granules on it - $-{ }_{-}{ }_{-}-3$.
d. part of the frond, with midrib visible, and tubercles, natural size.
e. portion of the same, magnified - - - - _ - _ - 5 .

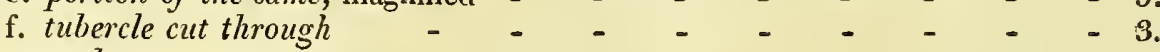
g. seeds - - - - - - - - - - - 1 .

\section{3.-F U G U N E R V S US.}

Fucus nervosus, frond sub-cartilaginous, flat, obsoletely midribbed, proliferous from its surface ; branches linear, both simple and forked, producing small peltate leaves, and sessile spherical tubercles.

Fucus nervosus. Fl. Fr. Ed. Qda. II. p. 29.

Epatica spirale. Ginanni, Op. Post. I. p. 26. t. 26. n. 61. (excl. syn. Raii.)

In the Mediterranean. Decandolle.-Near Agde. Professor Mertens.

Perennial?

Root, a pale-red, expanded, callous disk.

Fron D, a foot or more long, furnished with a short, cylindrical stipes, about the thickness of a crow's quill, and irregularly divided; branches nearly cylindrical at their base, but becoming compressed as soon as they attain to the height of a line, or a line and half, and almost immediately dilated into a flat leaf, preserving every where an equal width of about half an inch, nearly a foot long in some cases, in others much shorter, either simple or forked, or twice or thrice dichotomous, rounded at its apex, and quite entire at the margin, though so remarkably undulated as to appear sinuated, provided with a wide midrib, thicker than the rest of the frond, most visible at the base, but obsolete towards the apices: from the *surface of the leaf spring other leaves like the primary one, which are themiselves proliferous with others, and these again with others, thus proceeding in repeated series, and forming the natural increase of the plant : they grow either singly, or two or three together.-It sometimes happens that in old plants the midrib is stripped of its foliaceous membrane for the length of some inches, and looks like an old stem irregularly pinnated. witl scattered leaves.

Fructification, spherical tubercles, situated at the base of small, roundish, peltate leaves, which are found. plentifully on both sides of the frond, so as sometimes almost to cover it: these on dissection appear internally to. consist altogether of extremely minute, parallel, jointed fibres, very closely matted together.

Color, bright red, exceedingly fugitive: turning, when exposed to the sun or kept in fresh water, to a dull, dirty yellow, and at last to white.

SUBSTANCE, between cartilaginous and membranaceous, thin, flexible, and tough.

Oвs. The habit of this plant is much curled and twisted, and, if confidence may be placed in Ginanni's name, is spiral:- when dry it does not adhere in the least to paper:-it is extremely liable to be infested with the smaller species of Fuci, Confervæ, and Zoophytes.

What small confidence is to be reposed upon analogy in matters so little understood as the fructification of the Fuci, must, I think, be sufficiently obvious to every one, who will compare together the tubercles of the present species and those of $F$.rubens; for it is scarcely possible to conceive two plants gifted with such strong tpeculiarities more strikingly

\footnotetext{
These leaves agree with those of $F$. rubens in never originating from the margin, but always from the surface, but they differ from them in being gcnerally situated on the midrib, and in being scattered iudiscriminately over the whole leaf, instead of being confined to the part inearest the apices.

$\dagger I$ have not beeu able to detect in these tubercles any seeds, nor any difference between the two strata, of which, under the microscopc, they seem to be composed.-See Note to F. Griffithsii, p. 81 .

\pm There arc many Fuci, particularly of the division fronde tereti, of which the structure is so simple and uniform that their resembling each other is far from extraordinary, and it will perhaps never be known whether they are distinct species or ouly varieties; but if the peculiar substance, wide midrib, proliferous mode of growth, and round peltate leaves of $F$, rubens and nervosus are considered, this coincidence must appear very singular.
} 


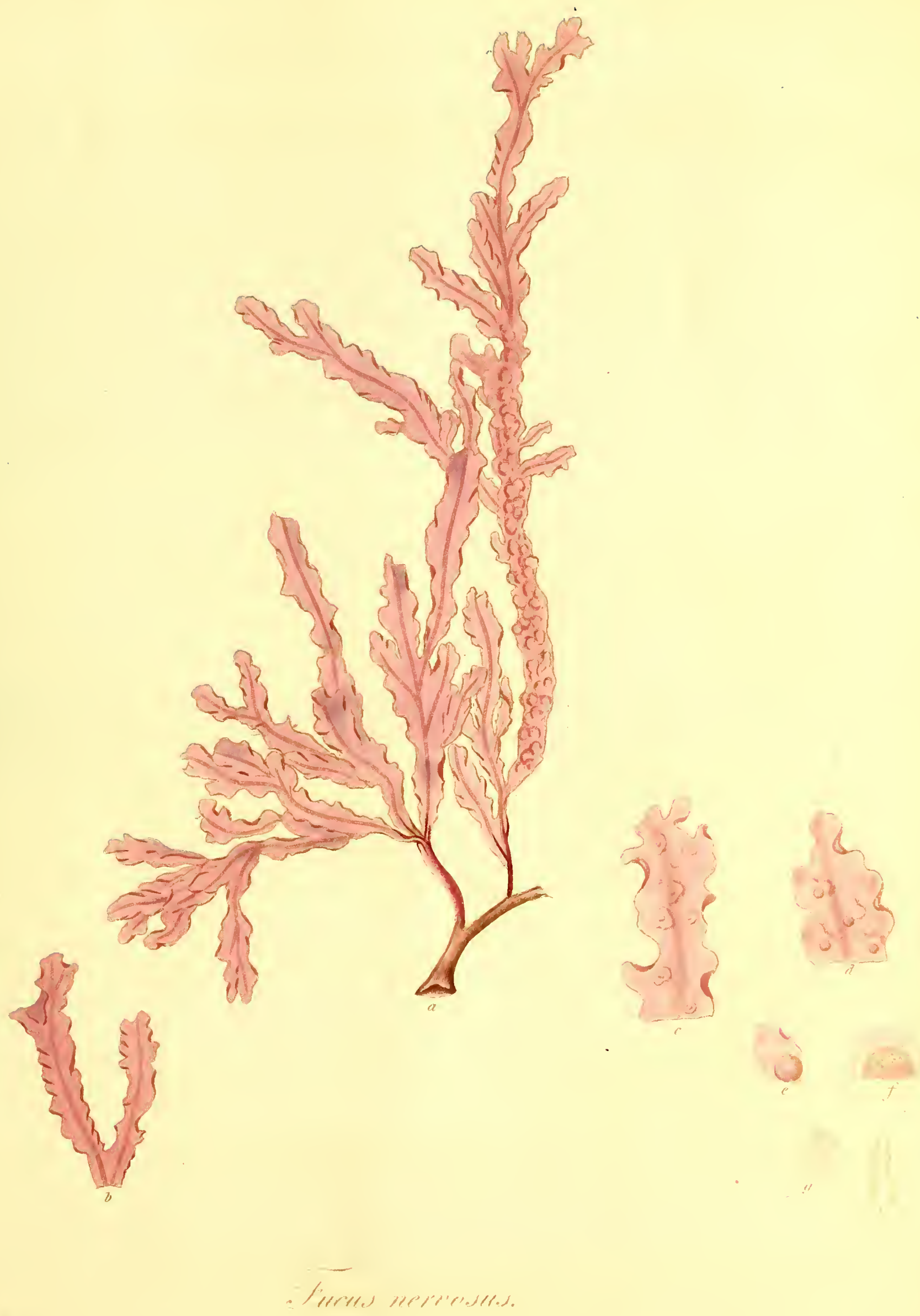



strikingly resembling each other in all important points, while at the same time, the fructification observed in them is widely different. It is, however, a curious fact that the fruit here figured exactly agrees with what has been said by * Mrs. Griffiths under the preceding Fucus, and I am therefore almost inclined to suspect that two kinds of tubercles must in reality exist in both these species. For my specimens of F.nervosus $I$ am indebted to the kindness of Professor Mertens, who observed to me, that it was the $F$. crispus of Draparnaud, and the French authors, to whom, however, I am unable to refer, as I do not find it published under that name in any work in my possession. The description given by Decandolle is too exact to leave any doubt of its being his $F$. nervosus, but both that tauthor and Professor Mertens have in my opinion been in error in referring it to the $F$. caulescens of Gnelin, the description and figure of which I cannot but consider as taken from some strangely battered specimens of $F$. vittatus, though I am at the same time by no means indisposed to admit that Gmelin probably confounded the two species, and borrowed some parts of his cliaracter from $F$. nervosus. Seba's figures also, (III. t. 102. f. 11. and III. t. 103. f. 5.) on which he places great reliance, appeared to me, when I had an opportunity of consulting that work, to belong to $F$. vittatus; but, not having it now at hand, I would not be understood as placing much confidence upon them, especiaily as I could account for what the learned author says of the latter, that "tenuia ejus folia de suâ superficie undequìque germina emittunt flosculis similia, only upon the supposition that this appearance was caused by some parasite. It has already been remarked under $F$. rubens, that $F$. nervosus is distinguished from every known Fucus, excepting that alone, by its proliferous mode of growth : from that it differs in its greater size, its crisped margin, its much more visible midrib, and the form of its leaves, which appear never to be dilated upwards, but constantly to. preserve their linear form.
a. F. nervosus, natural size.
b. upper part of the froud, barren.
c. upper part of the froud with peltate leaves and capsules, magnified 6.
d. portion of the same - - - - . - - - 5 .
e. peltate leaf and capsule separate - $\quad$ - $\quad$ - $\quad$ - $\quad$ - 4 - 4 .

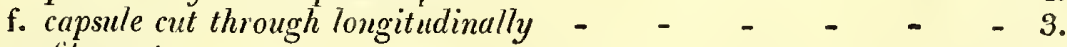

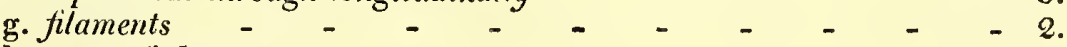

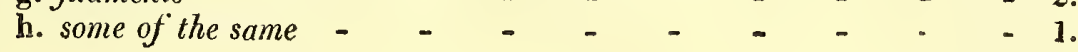

* See the Note to F. rubens, p. 90 .

$\dagger$ M. Decandolle, in the Flore Française, has divided F. nervosus into two varieties, which he separates thus, " $\alpha_{0}$. Marginibus undulatis.-6. Marginibus ciliato-tuberculatis," and it is to the Tatter of these that he quotes Gmelin's $F$. caulescens, $t$. 20. f. 2.-If, indeed, he has seen specimens of this latter, and traced their connection with the other, I have nothing farther to say, than that $I$ am surprised it shonld be so; but if as I suspect, he has only introduced his var. $\beta$ for the sake of including Gmelin's synonym from the general resemblance of the two plants, $\mathbb{I}$ must persist in my opinion that he has done wrong, and that $F$, nervosus is never proliferous from the margin.

\section{3.-F U CUS NER V O S S.}

Fucus, fronde sub-cartilagineâ, planâ, obsoletè costatâ, e superficie proliferấ; ramis linearibus, simplicibus bifurcisque, foliola peltata, tuberculaque sphærica sessilia gerentibus.

Iucus nervosus. Fl. Fr. Ed. 2du. II. p. 29.

Epatica spirale. GinanN1, Op. Post.1. p. 26. t. 26. n. 61. (excl. syn. Raii.)

Habitat in Mari Mediterraneo. Decandolle.-Prope Agde. D. Prof. Mertens.

\section{Perennis?}

RADIX callus explanatus, dilıtè ruber.

Frons pedalis, et ultra, stipite instructa pennæ corvinæ crassitie, brevi, tereti, vagè diviso; rami basi teretiusculi, priusquam lineæ unius alteræve altitudinem attigerunt compressi, et ferè statim dilatati in folium planum, unguem ferè latum, et ubique lineare, nunc propemodùn pedale, nunc multo brevius, vel simplex, vel bifurcum, vel etiam bis terve dichotomum, apice rotundatum, margine integerrimum, sed insignitèr undulatum, ut sinuatum videatur, nervo percursum lato, reliquâ fronde crassiore, maximè ad basin nianifesto, apices versus obsoleto : e folii *superficie oriuntur folia alia, ıunc solitaria, nunc bina aut terna, primarii similia, quæ ipsa aliis, et hæc quoque aliis, iterùm 
atque iterùm eâdem ratione prolifera, plantæ incrementum præbent.-Aliquando accidit in stirpe vetustâ foliorum primariorum nervum esse per aliquot pollicum longitudinem denudatum, elongatique caulis foliis sparsis pinnati speciem præ se ferre.

Fructificatio *tubercula sphærica adbasin foliorum exiguorum, subrotundorum, peltatorum, quæ frondis utrique paginæ copiosè insident, et sæpe totam cooperiunt, sita : hæc, si disseceutur, intùs e fibris minutissimis, articulatis, parallelis, densè compactis, tota constare videntur.

Color lætè ruber, fugacissimus; soli exposita aut in aquâ dulci servat a sordidè lutescens, et demùm albicans.

Substantra cartilagineo-membranacea, tenuis, lenta, tenax.

OBs. Habitus variè crispatus, et, si nomini a Ginannio dato sit fidendum, spiralis :-exsiccata chartæ nequaquàm adhæret :-frondi copiosè adhærent minores Fucorum, Confervarum, et Zoophytorum species.

Quam cæcus cæcæ viæ dux sit analogia in rebus tàm paullum cognitis quàm Algarum submersarum fructificatio satis, uti credo, inter omnes constabit qui hujus Fuci tubercula cum iis $F$. rubentis jam in tabulâ præcedente depicti conferant. Vix fieri potest ut mente effingamus duas Fucorum species, quas tnotis magis conspicuis a reliquis omnibus sejunxit et inter se connexit almâ natura ; fructu tamen, notà maximi nıomenti, longè discrepant. Est autem illud imprimis notatu dignum, fructificationem hìc sub $F$. nervoso delineatam omni ferè numero consentire cum illâ †quam sub $F$. rubente descripsit $D$ na Griffiths; quâ de re mens est ad suspicandum proclivis ambas has stirpes fructu duplice, licet unum modò adhuc ego viderim, reapse gaudere. $\boldsymbol{F}$. nervosi exemplaria quæ possideo Mertensii amicitia misit, adjectâ quoque observatione esse eandem Fuci speciem quam $F$. crispi nomine insignire sunt soliti Draparnaudius anctoresque plurimi Gallici, quos ut citem bibliotheca privata vix satis ampla negat. Optimè, de more suo, hunc Fucum descripsit Decandollius, ita ut, synonymon pro indubio habens, nomen ab ipso inditum sine hæsitatione asciverim, neque tamen vel §illi vel Mertensio adeo usque assentiri possum, ut illos secutus $\boldsymbol{F}$. caulescentem Gmel. sub hâc specie citem; cùm ejus plantæ descriptio et icon manca $F$. vittati exemplaria potiùs respicere mihi videantur ; fieri tamen potest, neque hoc vero est absimile, Gmeliuum utramque stirpem commiscuisse, et quædam ex iis que de $F$. caulescente tradidit a $F$. nervoso deprompsisse. Icones quoque Sebanæ, (III. t. 102. f. 11. et III. t. 103. f. 5.) quas pro optimis laudat, mihi olim sunt visæ, quum Sebæ Thesaurum adeundi est data facultas, ad $F$. vittatum pertinere; nequaquàm autem illis hìc nitor ad sententiam meam stabiliendam, quoniam neque librum ad manus habeo, neque, uti memini, bene intellexi quid vellet auctor, quum de posteriore memoraret, " tenuia ejus folic de suâ superficie undequaque germina emittere flosculis similia," nisi de Confervis seu Zoophytis parasiticis dictum crederem. Dignoscitur $F$. nervosus, ut jan sub F. rubente traditur, per proliferum crescendi modum ab omnibus aliis Fucorum speciebus, præcedente solâ exceptâ, a quâ statura major, margines crispi undulatique, costa manifesta, foliorumque forma semper linearis distinguunt.

a. F. nervosus, magn. nat.

b. frondis pars superior, sterilis.

c. frondis pars superior, capsulis foliisque peltatis instructa, magn. auct. 6.

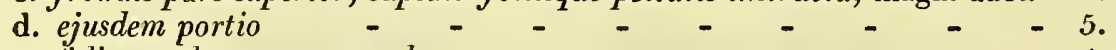

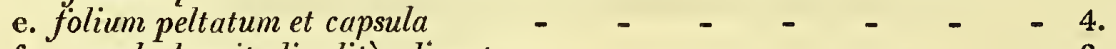

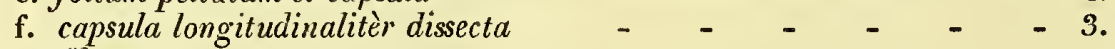

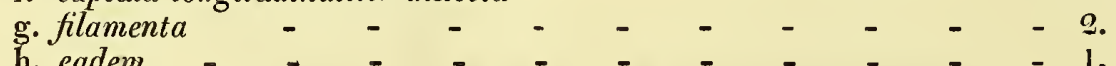

* Semina in Jis tuberculis nulla detcgere potui, nec ullum discrimen inter strata illa duo e quibus effingi videntar. Confer notam sub $F$. Griffithsii, p.81.

t Multæ sunt Fucorum species, præsertion $\mathrm{cx}$ is fronde tereti instructis, quarum structura est adco simplex et uniformis, ut nequaquam sit mirum si arctè inter se congruant, neque forsan unquam coustabit an pro distinctis specicbus an pro varictatibus habcri dcbeant ; sed $F$.

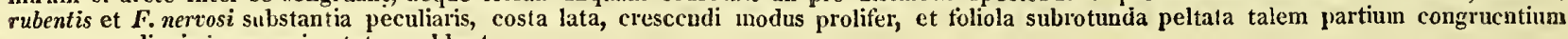
concursum dignissimum qui notetur reddunt.

$\ddagger$ Confer notam sub F. rubcnite, p. 90 .

\$ Decandollius in Florî Gallicî F. nervosum in duas varictates, quas sequente modo distinguit, dispertiit, " $\alpha$. Marginibus undulatis.- $\beta$. Marginibus ciliato-tuberculatis," et sub hac citat Gmclini $F$. caulescentem, t. 20. f. 2. cujus si exenplaria viderit, et cum primâ varietate reverà connexa sciat, nihil aliud dicendum restat $;$ scd in errore versor et rem ita sc habere miror:-sin, uti sispicor, similitudine quæ inter $F$. caulescentem et $F$. nervosum interest deceptus, varietatem $\&$ ideò modò construxit ut Gmelini iconcm proferret, in sententiâ meá permaneo, illumgue errare, et $F$. nereosum nunquam e margine esse proliferum credo. 
Fucus, fronde sub-membranaceâ, planâ, enervi, palmato-laciniatâ, margine proliferấ; laciniis linearibus; tuberculis sphæricis, immersis.

Fucus Sarniensis. Rotн, Cat. Bot. III. p. 103. t. 1.

ß. tenuissimus; ramis angustatis, summis subsetaceis.

Ha itтat in Sinu Eblanensi. D. Scott.-In Oceano Hibernico Occidentali. Herb. Banks.-In Scotix oris. D. Walker.-Ex Insulâ Sarniâ accepit D. Prof. Mertens, $-\beta$ in littore Hibernico, prope Belfast, legit $D$. Templeton.

Annua?

RADIx callus exiguus, flavescens.

FRONDES ex eâdem basi plurimæ, dodrantales, vel pedales, planæ, nervi venarumque prorsùs expertes, ortu angustissimæ, sed sese statim sensimque dilatantes, donec circiter unuın a radice pollicem latitudine fiunt unguiculares: quà radici proximæ indivisæ, at priusquam multarum linearum altitudinem attigerunt bifurcæ, et inde, vel per dichotomias vel palmatim, sæpe divisx, intervallis plerumque brevibus, attamen incertis, et quandoque longis : segmenta ferè linearia, summa angustissima, onınia subfastigiata, apice nunc obtusa, et quasi truncata, nunc acuminata, margine integerrima, nisi quòd dente uno alteroque brevi spiniformi interdùm sint instructa: aliquando etiam margines proliferi evadunt, laciniis sparsis, horizontalibus, iterum atque iterum divisis.

Fructificatio, teste Rothio, tubercula frondi immersa, subrotunda, atra, absque ordine sparsa, magnitudine seminis papaveris.

Co Lor purpurascens, subdiaphanus, fugacissimus; exsiccata intensior; soli exposita flavescens, et demùm albicans

Substa A TI A membranaceo-cartilaginea, tenax.

B varietas est notabilis; segmentis, ubi latissima, vix sesquilineam latis, summis acuminatis, et ita tenuibus, ut. propemodùm setacea videantur.

Oвs. Ob colorem fugacissimum planta plerumque versicolor occurrit:- exsiccata chartæ laxiùs adhæret :-optimè dicit Rothius, in apicibus laciniarum læsis vel detrusis novas sæpiùs lacinias propullulare, ut ita proliferi evadant.

Multi jam anni sunt elapsi ex quo primùm scivimus D. Woodwardius et ipse debere hunc Fucum inter species. Britannicas enımerari; specimina autem quæ tunc videramus aded erant *manca, ut neque cùm ille Observationes de Fucis Britunnicis, neque cùm harum plantarum . Synopsin ego scriberem, aliquid de illis proferre sustinuimus, veriti ne fieri possit ut sint tantummodd frustra alicujus speciei jampridem satis cognitæ et descriptæ. Extant quoque ejus exemplaria in Herbario Banksiano, sed vel hæc imperfecta; et, licet his nitens pro novâ specie agnoverit Solander, et $F$. multifidi nomen indiderit, diu tamen verisimilitèr Botanicorum notitiam indescriptus latuisset, nisi fortè ex Insulâ Sarniâ allatum acceperit Mertensius, qui, optimâ descriptione et icone adjectâ, tandem in Rothii Catalectis evulgavit. Hujus benevolentiæe exemplar hic depictum debeo, fructûsque analysin ab ipso traditam repetendam curavi. Dolendum quidem est, quòd, quamvis fructificationem e tuberculis constare dixerit, nihil tamen protulerit de illorum naturâ aut de seminibus in illis inclusis. Hæc tubercula quoad magnitudinem longè recedunt a sparsis Ulvarum seminibus; nec magis congruit $\boldsymbol{F}$. Sarniensis textura sub-cartilaginea cum eâ plantarum quæ illi generi ascribi solent. Plurimum habet in hoc affinitatis cum $F$. palmato, cum quo etiam convenit habitu crescendique modo perquam mutabili, quoniam segmenta lata atque angusta, longa atque brevia, dichotoma atque palmata non rarò in eâdem stirpe occurrunt. Frons quoque sæpe hìc illìc foraminibus exiguis oblongis pertusa, sed an hoc casu aliquo accidat, an ex ipsâ Fuci naturâ pendeat, nulla mihi dijudicandi datur potestas. Idem in pluribus exemplaribus vidi, eâque de re in posteriorem ire sententiam maximè propendeo. Planta, etiam in primo æatatis gradu, et lente accerrimâ observata, nunquain sese mihi reticulatam obtulit; et manifestò e duabus constat membranis, quæe, injuriâ aliquâ acceptâ, disjunguntur.

a. F. sarniensis, magn. nat.

b. frondis pars, magn. auct. $-\overline{-}-\overline{-} \mathbf{1}$.

c. frondis pars cum fructu, e Rothii Catalectis.

\footnotetext{
* Nequaquam hoc valet de omnibus exemplaribus qux sunt in littoribus Britannicis detecta; pulcherrimmm enim in Sinu Eblanensi legit D. Scott, aliudque formâ eximium nuper milhi benevolè misit $\mathrm{D}$. Wright, quod Scotiæ ad oras invenit $\mathrm{b}$. D. Walker, et Chartacece dichotomce nomine insignire statuit; nccdum autem talia videramıs.
} 
Fucus Sarniensis, frond sub-membranaceous, flat, without midrib, laciniated in a palmate manner, proliferous frors its margin; segments linear; tubercles spherical, immersed.

Fucus Sarniensis. Roтн, Cat. Bot. III. p. 103. t. 1.

ß. tenuissimus; branches very narrow, the upper ones almost setaceous.

In the Ocean west of Ireland. Herb. Banks.-In Dublin Eay. Dr. Scott.-On the Scotcl Coast. Dr. Walker.-Sent from Guernsey to Professor Mertens. $-\beta$ on the Irish Coast, near Belfast. Mr. Templetun.

Anmul?

Root, a small, yellowish, callous disk.

Fronds, numerous from the same base, nine inches or a foot long, flat, wholly descitute of midrib or veins, extremely narrow at their origin, but immediately widening, till at about an inch from the root they reach the width of six lines: in the part nearest to the base they are undivided, but become forked before they are many lines high, and afterwards repeatedly divided, either in a dichotomous or palmate manner, the intervals between each division being in general short, but of uncertain length, and sometimes long: the segments are alınost linear, the upper ones the most narrow, all of them of nearly equal height; their apices obtuse and subtruncate in some specimens, in orhers acuminated, their margins quite entire, except that they are occasionally furnished with one or two short spiniform teeth; they are also now and then proliferous, with scattered, horizontal segments, repeatedly divided.

Fructification, according to Roth, roundish, black tubercles, immersed in the frond, dispersed without order, and of the size of poppy-seed.

Color, purplish, semitransparent, very fugitive; darker when the plant is dried; on exposure to the sun turning to yellowish, and at length to white.

SUBSTANCE, between membranaceous and cartilaginous, tough.

$\beta$ is a remarkable variety, its broadest segments scarcely equalling a line and a half in breadth; the upper ones acuminated, and so thin as to appear almost setaceous.

Oвs. The frond on account of its fugitive tint appears in general party-colored:-in a dried state it adheres, but not strongly, to paper:-Dr. Roth observes very justly, that when the apices of the segments are injured they throw out a number of new shoots, and become proliferous.

This Fucus has been for many years known both to Mr. Woodward and myself as a nacive of the British coast, but known only by such * mutilated specimens, that neither of us, when writing on the subject of these plants, could velture upon noticing it, apprehending it might be some one already described in a singularly injured state. There are also some pieces of it in the Banksian Herbarium, but even these are almost equally imperfect, so that, though Dr. Solander had considered them as belonging to a distinct species, and called them $F$. multifidus, the plant would probably long have continued to escape the notice of Botanists, had not Professor Mertens received it from the Island of Guernsey, and published it with an excellent description and figure in the third volume of Dr. Roth's Catalecta. I am indebted to him for the specimen lere figured, and have borrowed his account and representation of the fruit which I never saw myself. One thing indeed I lament, that, though he describes the fructification as immersed tubercles, he has said nothing of their nature or contents, and has consequently left us in ignorance upon those important points. In their size they seem to differ essentially from the scattered seeds of the Ulvæ, and the sub-cartilaginous texture of $F$. Samiensis is also materially different from that of the submersed Algae generally referred to that genus. In this respect it approaches more nearly to $F$. palmatus, with which it also agrees in general habit, and in being very variable as to its mode of growth, the sane plant not unfrequentiy producing both broad and narrow, long and short, dichotomous and palmate segments. The frond is occasionally found perforated in places with small oblong holes; but whether this is caused by the fruit falling out, or is the effect of any casual injury, $I$ have no means of determining. I am inclined, however, to ascribe it to some cause peculiar to this species, as I have observed it in several specimens. The plant, even in its youngest state, seems to be destifute of any reticulated structure, and is evidently compused of two distinct membranes, which separate from each other in case of injury.

a. F. Samiensis, natural size.

b. portion of the firond, magnified - - -1 .

c. ditto with fructification, borrowed from Roth's Catalecta.

* This is by no means the case with all the specimens gatheret on the Rritish shores, for that foud by Dr. Scott, in Dnt;in Bay, is singnlari beautiful, and one viry recently communicsted to ine by Dr. Wrint, which was gatlered on the Scotch coast by the late Di. Waiker, and by him called Clat acea dichotoma, is both Iarge and perfect, but we had not then seen either of these. 


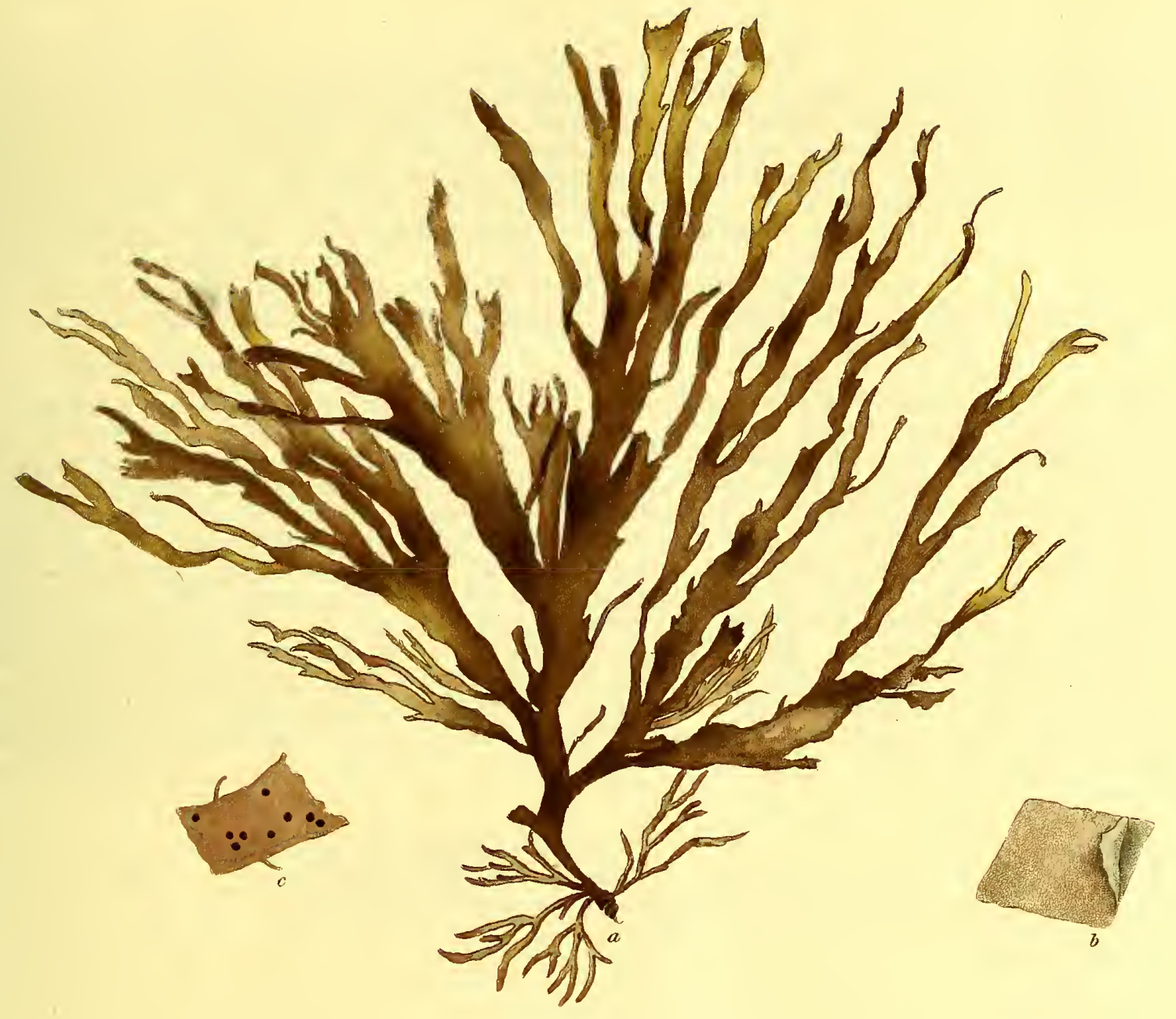

Tucus Lamiensis. 

Fucus, fronde membranaceâ, planâ, enervi, palmato-laciniatâ, margine proliferâ ; lacinïs sursùm dilatatis, summis apice multifido-incisis, dentibus brevibus sub-setaceis.

Fucus soboliferus. Fl. Dan. t. 1066.

Haвıт Aт in fundo maris Finmarkiæ. Vahl.-In Orcadum oris. D. C. Fothergill.

Annua?

RADIx callus exiguus.

FrONDES ex eâdem basi plurimæ, longitudine circitèr palmares, quà radici proximæ angustissimæ, teretiusculæ, eq setâ porcinâ vix crassiores, inde ferè statim compressæ, et mox planæ, ab ortu usque ad apices sensìm dilatatæ, ut segmenta summa sint propemodùm unguem lata : frons priusquam multarum linearuin altitudinem attigit fit ramosa, ordine nunc bifurco, nunc palmato, utroque ut plurimum in eâdem stirpe occurrente, atque hìnc sæpe dividitur simili ratione, intervallis brevibus, attamen incertis : segmenta omnia sursùm dilatata, et sub-cuneiformia, extrema apice incisa, dentibus plurimis, brevibus, sub-setaceis : frondis margines integerrimi, sed plerumque proliferi, segmentis basi. attenuatis, sub-cuneiformibus, sæpiùs iterum divisis, apice multifido-incisis.

Fructificatio hucusque ignota.

CoLOR roseus, diaphanus; marcescentis sordidè flavescens, et demùm albicans.

Substantia membranacea, tenuissima, et tenerrima, sub lente exquisitè reticulata, maculis subrotundis.

OBS. Exsiccata cliartæ arctè adhæret.

Primus hanc stirpem, non minùs formâ quàm colore spectabilem, in Florâ Danicâ descripsit b. Vahlius, qui se unum modò exemplar unquam detexisse memorat; nec plus quam unum legit $\mathbf{D}$. Fothergill, qui ad specierum Britannicarum numerum nuper ascripsit, et benevolè mecum communicavit. Perraram igitur esse plantam antumo, præsertim cùm neque in Linnæano, nec in Banksiano, nec in ullo alio, quod mihi invisendi contigit facultas, phytophylacio asservatam unquam viderim. Quoad substantiam et texturam Ulvas non minus quam Fucos referre videtur, nec mirarer, si, quando fructificatio latere desinit, illis potiùs censeretur; statui tamen in præsens insistere vestigiis Vahlii his annumerantis, donec aut patefiant semina, aut saltèm characteres qui utrumque secernunt genus rectiùs disgnoscantur, firmiùsque stabiliantur. Affinitatem arctissimam inter $F$. Sarniensem atque $F$. soboliferum intercedere neutiquam inficias eam : in multis certè conveniunt, et notas specificas ægrè erui expertus scio, credo verò satis inter se differe, cùm ob substantiam, quæ in hoc tenuissima et reticulata, in illo crassiuscula et ubique uniformis evadit, tùm ob segmenta in hoc sursum dilatata, in illo linearia : neque tamen is ego sum qui aliquid de plantis quarum perpauca modò exemplaria adhuc vidi ex tripode affirmare ausim. Hæ duæ stirpes longè a reliquis omnibus crescendi modo discrepant, nec quod dicit Vahlius, scilicet $F$. soboliferum $F$. bifido affinem videri, opus est ut hìc pluribusyerbis redarguam.

a. F. soboliferus, magn. nat.

b. frondis pars superior, magn. auct. $\quad$ - 6.

c. ejusdem pars, ut structura reticulata appareat. I, 
Fucus soboliferus, frond membranaceous, flat, without midrib, laciniated in a palmate manner, proliferous from the margin; segments dilated upwards, the extreme ones gashed at their apices with numerous short sub-setaceous teeth.

Fucus soboliferus. Fl. Dan. t. 1066.

At the bottom of the sea by Finmark. Vahl.-Upon the shores of the Orkney Islands. Mr. Charles Fothergill.

Annual?

Root, a small callous disk.

Fronds, numerous from the same base, about three or four inches long, at the part adjoining the root almost cylindrical, and scarcely thicker than a hog's bristles, but becoming almost immediately compressed, and soon flat, gradually widening froin the base to the extremities, so that the upper segments are nearly half an inch in width: tle frond becomes branched before it attains to the height of many lines, sometimes in a forked, and sometimes in a palmate manner, instances of both generally occurring on the same individual, and after this it is frequently again divided in a similar manner, at short but uncertain intervals : all the segments are dilated upwards, and sub-cuneiform, the extreme ones have their apices gashed, with several short nearly setaceous teeth: the margins of the frond are quite entire, but generally proliferous with segments attenuated at the base, sub-cuneiform, generally again divided, their apices gashed with numerous small teeth.

Fructification, hitherto unknown.

Color, pink, transparent; turning in decay to a dirty yellowish, and at length nearly to white.

SUBSTANCE, extremely thin and tender; under the microscope beautifully reticulated with roundish meshes.

OBs. When dried it adheres closely to paper.

The only account which I find of the present Fucus, a plant no less conspicuous for its delicate texture and elegant form than for its beautiful color, is that given in the Flora Danica, by the late Professor Vahl, who there observes, that he never met with more than a single individual, and it is a little extraordinary that only one plant of it should also have been gathered by Mr. Fothergill, who lately added it to the Flora of the British Islands, and obligingly conimunicated it to me. I am therefore led to suppose that it is a species of very rare occurrence, and what tends to confirm this conjecture is, that I have not observed any specimens of it, either in the Linnæan or Banksian Herbaria, or in any other which I have had an opportunity of examining. With regard to its substance and texture, it is no less closely allied to the Ulvæ than the Fuci, nor should I be surprized, if, when the fructification is discovered, it should be placed permanently in the former of these genera; though, at the same time, as Vahl has arranged it in the latter, I thought it best to follow his example, till either the seeds should be detected, or at least till the boundaries between the two families should be better understood and more definitively fixed. I am well aware that there exists a very strong resemblance between the present and the preceding Fucus, that they agree together in most points of importance, and that it is extremely difficult to discover satisfactory specific characters between them. It is nevertheless my opinion that they are really distinct, and I found this opinion no less upon the difference of their substance, which in $F$. soboliferus is almost as thin as gold-beater's skin, and curiously reticulated, while in $F$. Sarniensis it is rather thick and every where uniform, than upon the segments, which are linear in the one, and dilated upvards in the other; notwithstanding this, however, I would not be understood as speaking by any means decisively with respect to plants of which I have had so few opportunities of judging. In their mode of growth these two Fuci differ widely from all the rest, nor can there be any need to make use of arguments to do away the suspicion entertained by $V$ ahl, that $F$. soboliferus is nearly allied to $F$. bifidus of Hudson.

a. F. soboliferus, natural size.

b. upper part of the frond, magnified - 6

c. portion of the same, to shew the reticulated structure ]. 

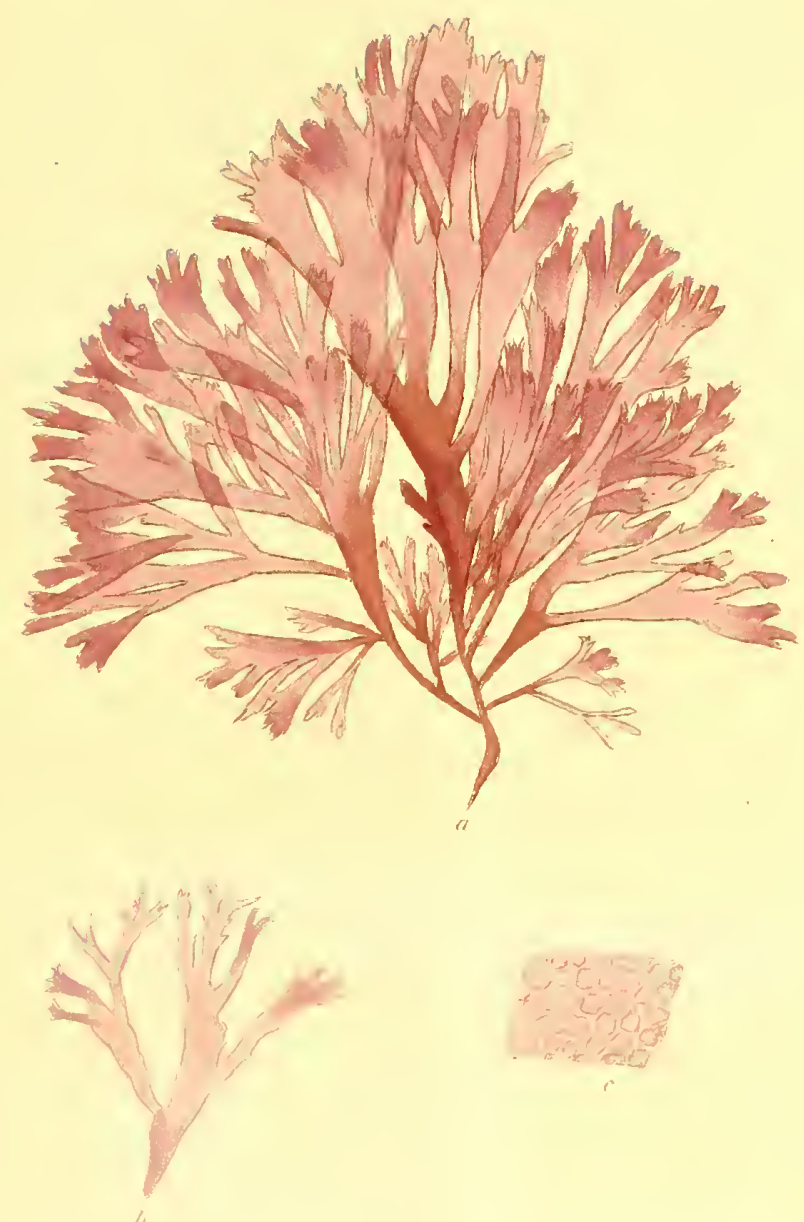

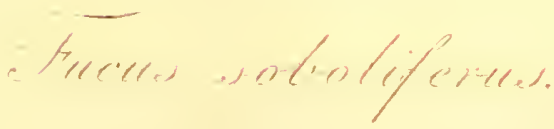



Fucus, caule compresso, filiformi, pinnato : ramis alternis, simplicibus : foliis lineari-lanceolatis, serratis : vesiculis sphæricis, petiolatis, petiolo plano : receptacnlis cylindraceis, racemosis.

Fucus natans. Linn. Sp. Pl. II. p. 1628. Syst. Nat. II. p. 715. Syst. Nat. Ed. Gmel. II. p. 1380. Fl. Zeyl. p. 184. Hort. Cliff. p. 478. Fl. Ang. p. 572. Linn. Trans. III. p. 107. W W It. IV. p. 86. Syn. Fuc. I. p. 48. Fl. Atl. II. p. 421 . Fl. Lus. Il. p. 434. Fl. Fr. Ed. 2da. II. p. $26 . \quad F l$. Ped. II. p. 330. Fl. Monsp. p. 458 .

F. Sargasso. var. 1. GM ELIN, Hist. Fuc. p. 93.

F. acinarius. var. ES PER, Ic. Fuc. I. p. 130. t. 66.

F. subrepandus. Fors K̊̊ L, Fl. Egypt. p. 192 ? Syst. Nat. Ed. Gmel. II. p. 1381?

F. folliculaceus serrato folio. BAR REL1 ER, Icones. t. 1122.

* Fuco Acinara con foglie di mezzana grandezza. Gina N 1, Op. Post. I. p. 18. t. 16. n. 31.

Fuco Acinara di foglie lunghe, e nella sommità dé rami florida. Gi Na N N I, Op. Post. 1. p. 19. t. 17.

ß. crispns; foliis confertis, ellipticis, denticulatis, undulatis, crispisque.

F. lendigerus. ESPER, Ic. Fuc. I. p. 37. t. 15.

F. crispus. Forsк立, Fl. Aigypt. p. 191?

F. undulatus; Syst. Nat. Ed. Gmel. II. p. 1381 ?

r. acanthicarpus; foliis lineari-ellipticis, dentatis; receptaculis spinosis.

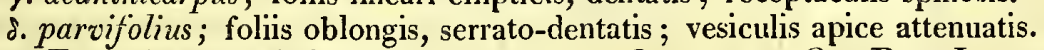

Fuco Acinara di foglie corte e strette. Gina n i, Op. Post. I. p. 19. t. 18.

.. integrifolius; foliis inferioribus lanceolatis, sub-integerrimis ; superioribus linearibus, dentatis.

$\zeta$. angustifolius; foliis linearibus, angustissimis, sparsis, hic illic dentatis.

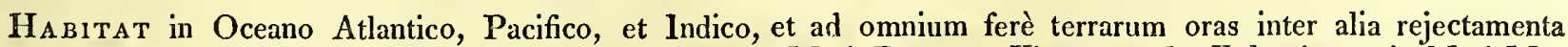
occurrit. $-\beta$ in Indiâ Occidentali. D. Wright. $\_\gamma$ in Mari Rubro. Vicecomes de Valentia. $-\delta$ in Mari Mediterraneo. Ginanni. $\sim_{-}$Bermudis Insulis accepi, $\longrightarrow$ in Novæ Hollandiæ oris. D. Velley. $-\zeta$ in Mari Rubro. Vicecomes de Valentia.

Perennis.

RADix discus lignosus, conicus, diametro ferè pollicaris.

FroNDES ex eâdem basi plurimæ, caule instructæ compresso, et propemodùm ancipiti, pedali, vel bipedali, pennæ columbinæ crassitie, flexuoso, plerunique simplice, rariùs bifurco, obsito per totam lengitudinem ramis compressis, distichis, e caulis angulis exeuntibus, simplicibus, bi- tri-pollicaribus, †alternis, spatio brevi, attamen incerto, sejunctis, folia resiculasque sustentantibus : folia lineari-lanceolata, vel linearia, interdùm et lineari-oblonga, latitudine ab unguiculari ad bilinearem variant, disticha, alterna, nunc remotiuscula, nunc conferta, sessilia, aut basi in petioluna perbrevem decurrentia, costâ tenui nigricante, nervos nullos laterales emittente percursa, poris mucifluis pertusa, margine argutè et absque ordine serrato-dentata: vesicula ramis quoque impositæ, et foliis immixtæ, haud ita frequentes, sphæricæ, Juniperi communis baccis aliquantùm minores, petiolis planis, angustissimis, sursùm dilatatis, lineam unam alteramve longis fultix.

Fructificatio receptacula bilinearia, cylindracea, in ramis sita, quandoque hic illic spinulosa, simplicia, vel bifurca, conferta, et in racemum disposita, extrinsecùs ubique inæqqualia, ob tubercula innata sphærica poro minutissimo pertusa ; semen in singulis tuberculis unicum, fuscum, subrotundum, limbo pellucido cinctum.

Color plantæ recentis olivaceus; exsiccate atro-fuscescens; rursus madefacte rufo-fuscus; sin frequentiùs sit elota, $\in t$ tempestatis mutationibus objecta fit aquosè spadiceus.

SubstaNTIA foliorum et vesicularun cartilaginea, tenuis; caulis sub-coriacea; ubique, etiam in exsiccatâ, mollis et flexilis.

$\beta$ varietas est primo aspectu notabilis ob folia insignitèr crispa et undulata :-folia conferta, elliptica, sesquinnguem longa, et tres quatuorve lineas lata; margo minutissimè dentatus; vesiculæe infrequentes, aliquando prorsùs desunt.

$\gamma$ ad tri-quadri-pedalem longitudinem excurrit; crescendi modus diffısus; rami semipedales, et ultrà ; folia laxè disposita, longitudine subpollicaria, latitudine quatuor linearum; nargo profundè absque ordine incisus, dentibus majoribus quàm in reliquis varietatibus; vesiculæ sparsæ, frequentes; receptacula copiosa, insignitèr spinosa; color pallidior quàm in $\alpha$ et $\beta$, magisque rufescens.

$\delta$ elerantissima est varieias, pracedentibus tenuior et magis delicata ; rami breves; folia approximata, longitudine vix unguem, latitudine vix duas lineas æquant ; receptacula perquìn exiguti:; vesiculæ satis copiosæ, apice attennata, et plerunıque mucrone brevissimo aristatæ :-nana videtur planta.

s stirps sesquipedalis illud habet notatu dignissimum folia basin versus e caule orta esse lanceolata, dios vel tres pollices longa, quatuor lineas lata, et margine sub-integerrima, dum ramea sunt triplo breviora et angustiora, et nianifestè dentata; substantia pertenuis; color fuscus ; vesicnla ncquaquì̀n ́́requentes, spliærica.

$\zeta F$. natantem

Hoc synonymon ad Fucum Acinariam retulit Gmelinus, sed, me judiee, injuriâ; Guamvis enim folia icon integerrima sistat, Fucum Bautini folliculacum serruto folio, et Leníiculam Lobelii marinam serratis folits sub co citavit liobilissimus auctor, iconesque in opere omnes sunt iudes. et guibus haud nimis fidendum. Has omnes, scilicet, t. 16,17, 18, et 19, ad $\%$. Acinaritm pertinere eredit wultenius.

$\dagger$ Caulis ut p'mimun contortus cvadit, unde sape accilit ramorum dispositionem alternam non statim patere. 
$\zeta$ F. natantem cum F. Acinariâ connectit:-longitudo bipedalis; folia remota, sesquipollicem longa, unam nodơ Jineam lata, dentibus sparsis majusculis; vesiculæ oblongo-sphæricæ in petiolum decurrunt: crescendi modus diffusus: fructum non vidi.

Oвs. Exsiccata chartæ ne minimum adhæret.

$\mathrm{Si}$, dum Fucorum species ordinarem, meis tantummodò votis obtempcrandum putavissem, certc̀ voluissem descriptionem iconemque illius lic depictæ potiùs ad hujus operis distulissc finem quàm in ipso limine sistitisse; quoniam de plantâ, quæ in omnibus ferè maribus abundè provenit, licet sperare, ut, novis exemplarium copiis sæpe acceptis, notitia nostra quotannis augcatur, et ut terminos melius definitos inter illas stirpes, quæ, quantumvis distinctæ, jam sub uno $F$. natantis nomine commiscentur, tandem statuere valeamus. Magnum dari harum stirpium numerum, et in plures varietates specicsque distribui debcre jamdudùm mihi persuasum habui, nec quivis, uti credo, in re tantillùm vcrsatus facilè luic sententiæ inficias ibit; quamvis haud sit dissimulandun, similitudinem inter hasce omnes intercederc talem, qualis maximo sit ad intelligendum impedimento. Hâc de re, ut nodum pro virili solverem, et simul, Botanicorum aliorun animos hùc alliciendo, omni quo potis est auxilio fruar, visum est, *morâ nullâ interpositâ, exhibcre iconas corum Fucorum $F$. natanti affinium quorum jam extant descriptioncs; quo facto, apertios patebit pro iis campus, qui, licet liactenus sint ab auctoribus prætermissi, specierum distinctarum prærogativam jure non minus aquo sibi asserunt. De notis quæ varietates suprà meınoratas distinguunt tam fusè dum tulamquamque describercm tractavi, ut plura nunc proferre supcrvacaneum vidcatur. Quidquid hujus Fuci synonymiam variaque a congeneribus discrimina spcctat, ad illas stirpes, et præscrtim ad $F$. bacciferum retuli; ca modò hujus loci adjecturus quæe de univcrsali, ut ita dicam, $\boldsymbol{F}$. natante traduntur; quorum plurima jam olim enumeravit Gmelinus, qui omnia, quæcunque vetcres mcmincrunt, summâ diligentiâ collecta cxhibuit. Monendus tamen est lector, me stirpem hic dcpictain câ primùm de causâ selegissc cui $F$. natantis nonten multis debitum imponeren, quòd reliquis omnibus vulgatiorem credcren, insequentc nodo dcmptâ, quæ non nisi sterilis hucusque est reperta; et quod has tantìm duas in herbario suo loc titulo insignitas servaverit Limnæus, qui $\boldsymbol{F}$. Sargasso nomen, per quod diu inter Lusitanos imnotuerat, natanti mutavit, credcns sempcr liberè iu occano natare, nec ullis ıuquam affixam inhærere scopulis. A tali sententiâ Botanici reliqui cito et merito dissentierunt, nec opus est ut aliquid ad efficaciùs refellendam nunc adjiciatur; quoniam plurimas e varietatibus cum radicibus, et quasdam etiam loco suo natali innascentes tempus insequens nelioribus auspiciis detexit. Brownius, Sloanius, Morisonius, atque itidem auctores cæteri, qui $F$. natantem congencresque memoraverunt, descriptionibus sunt usi tam brevibus, ut, rem ultra spem positam existimans, nihil ad eorum synonyma extricanda sim conatus; cùm non fieri possit ut conjecturâ assequamur quemnam inter omnes hoc vel illo nomine perstringere velint. Neque adeo magis necesse est ut multis hìc verbis exponatur quidquid fuit olìm de harum plantarum fructu somuiatum. Ipsum etiam Gmelinum haud fugit vesiculas sphæricas, quas pro fructificatione habnerunt + Linnæus Vahliusque, non posse ad talem a Naturâ finem constitui ; et verarum illarun capsularum deprehensio, ob quam sibi tantum gratulatur $¥$ Ruizius, adeo repugnat rationi ut semet satis ipsa refellat. \$Immensam $1 \%$ natantis copiam, quæ in Oceano Atlantico provenit, multi non sine admiratione memoraverunt navigatores, inter quos \#Columbus et Lerius, qui per talcs ejus acervos transierunt, ut mare pratum referret, et vel navitum cursus tardaretur. Similc quiddan tradiderunt Osbeckius Rumpliusque, quorum ille addit, aceto conditum sapore vix cederc Crithmo maritimo, quo nos utimur; et hic in Herbario Amboinensi inquit, fieri ex hoc Fuco aliisque Algis acetaria cruda, quæ limonum succo, pipere, atque zingibere condiuntur. Præter hos Ruizius, ipse expertus, esculcutum laudat, et presertim juniorem atque caulium extremitates comınendat: in Regno quoque Chilensi ferculum ex ipso effici tradit. Medicinæ loco ab aliis adhibetur; unde Bonlarius, in suo Naturalis Historia Lexico, narrat esse apcrientem, diureticum, et antiscorbuticum; necnon Kalmius in itinerario refert, in Americâ uti incolas Sargasso ad fcbres profligandas, et parturientes pulverem comedere exsiccatum ut partus promoveatur. Sed licet lıac planta sese hisce lumano generi utilem præestet, talem finem non risi secundarium respexisse videtur Summus Omnium Creator, cùm eam effingcret; dum enim per occanun copiâ penè incredibili fluitat, ministrat victum atque refugium piscibus Molluscisque innumeris; qui ex hoc vegetabili nutriti, ex eodem defensi, SNTIS ENTIU1, per quem creantur et creati proteguntur, curam nuli animalculo, denegatam testantur.

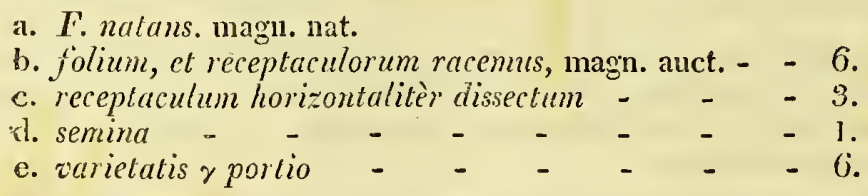

Ill:d etiam me ad has plantas lìc delineandas movit, nt starem pronissis jam olim in Fucorum Lrilannicorum Synopsi datie, me illarun iuvestigationi quàm citissine memet aecincturun, quod tamen ne maturiùs faeerem plurima impediverunt.

+ Limæus quidem aliquam veræ fruetificationis notitiam babuisse videtur, quonian dicit in Systemate Natura, "in quibusdam individuis ex alis folionum racemi brccissimi siliculis minut is verrucosis:" cui verò sententiae Vahilius se assentiri negat, inųuiens; " vacemos brerissimos siliculis minut is verracssis in alis foliorum non nisi rudimenta ramorum esse eo certius affirmare queo, ckm specimina plura ad manus sunt, ubii alii ramuli racemurum fulififeri, alii resicziliferi sit."

\pm Repertum sum talis momenti eredidit hie Botaniens, ut Commentarium, de vera $\boldsymbol{F}$. nafuntis fructificatione inseriptum, ad id illustranduns ederet, enjıs ad finem tria $F$, bacciferi exenılaria sistit, qnorum mni innascitur Sertularice rolubilis, quan maseulos flores dicit, alteri $S . p$. quam firnimeos, tertio $S$. Pluma, quam pro hermapluoditis labet. IIulta tamen notatu digna, quorum sub specie inseçuente fit inentio, libellus includit.

De hâe stime, iı Speciebus Plantarum, dieit Limnæiıs, "veæe tabile, ni fallor, inter omuia in orbe, numerosissinum."

Cüm ipse libros, e quibus hæ observationes depromuntur, nurquau viderim, quod Gnelintus de re seripserit lie exscribere cogor: "quum Cur. Colvm вus, (eelare enim nefas esset quod tantam Surgasso famam eonciliavit) Ao. 1492, investigaret mundum, et ab Insulis Canariensibus ad veedentalem trajieeret plazan, mare mox tot refertum deprehendebat herbis, ut prat mon referret, dicitgue herbam esse flavescentem, iustar f́ni semisicci, folia gerentem rutæ vulgaris, eui adpendantur copiosæ bacca niyertimæ, quæ siceatæ juniperinas referebant.-LAerius in jtineratio suo refert, çuorl per vigin ti quinque dics pèr illam herbam, nisi securibus vi.rm aperissent, nives remorari debuissent, ianponebatģue arga ma:im, per illas herbas turbida, esse se in paludibus cœnosis depulsos."-Gmenin, Hist. Fuc. p. 94. 


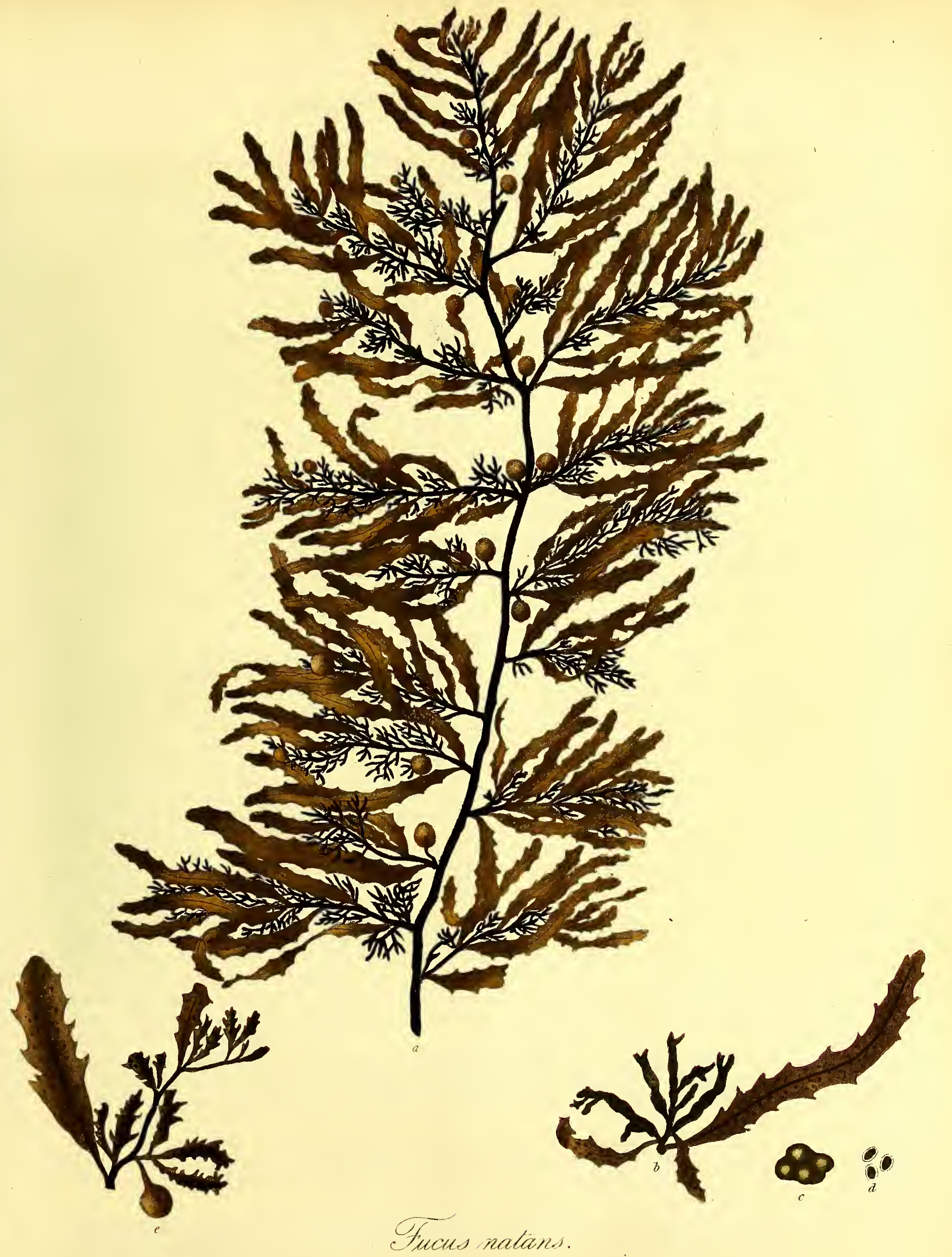



Fucus natans, stem compressed, filiform, pinnated: branches alternate, simple: leaves lineari-lanceolate, serrated: vesicles spherical, on flat petioli : receptacles cylindrical, racemose.

Fucus natans. LiNn. Sp. Pl. II. p. 1628. Syst. Nat. II. p. 715. Syst. Nat. Ed. Gmel. II. p. 1380. Fl. Zeyl. p. 184. Hort. Cliff. p. 478. Fl. Ang. p. 572. Linn. Trans. III. p. 107. Witu. IV. p. 86. Syn. Fuc. I. p. 4S. Fl. Atl. II. p. 421. Fl. Lus. II. p. 434. Fl. Fr. Ed. 2da. II. p. 96. Fl. Ped.II. p. 330. Fl. Monsp. p. 458.

F. Sargasso. var. 1. GMELIN, Hist. Fuc. p. 93.

F. acinarius. var. EsPER, Ic. Fuc. I. p. 130. t. 66 .

F. subrepandus. Fors Kàl, Fl. Egypt. p. 192? Syst. Nat. Ed. Gmel. II. p. 1381 ?

F. folliculaceus serrato folio. Barrelier, Icones. t. 1122.

* Fuco Acinara con foglie di mezzana grandezza. Ginan ni, Op. Post. I. p. 18. t. 16. 11. 31.

Fuco Acinara di foglie lunghe, e nella sommità de' rami florida. Ginan i, Op. Post. I. t. 19. f. 17.

$\beta$ crispus; leaves clustered, elliptical, slightly toothed, waved and curled,

F. lendigerus. EsPER, Ic. Fuc. I. p. 37. t. 15 .

E. crispus. Fors к̊̊̆ , Fl. Egypt. p. 191?

F. undu'atus. Syst. Nat. Ed. Gmel. II. p. 1381?

\%. acanthicarpus; leaves between linear and elliptical, toothed; receptacles thorny.

\$. parvifolius; leaves oblong, serrato-dentate; vesicles attenuated at their apices.

Fuco Acinara di foglie corte é strette. Ginann , Op. Post. I. p. 19. t. 18.

є. integrifolius; lower leaves lanceolate, nearly entire; upper ones linear and toothed.

३. angustifolius; leaves linear, very narrow, scattered, here and there toothed.

In the Atlantic, Pacific, and Indian Oceans, whence it is carried among other rejectamenta of the sea to the shores of almost every country. $-\beta$ in the West Indies. Dr. Wright. $-\gamma$ in the Red Sea. Lord Valentia. $-\delta$ in the Mediterranean. Ginunni.-I have received it from the Bermuda Islands. $-\varepsilon$ on the shores of $\mathbb{N e w}$ Holland: Col. Velley.- $\zeta$ in the Red Sea. Lord Valentia.

Perennial.

Root, a woody, conical disk, almost an inch in diameter.

Fronds, several from the same base, furnished with a flattened and nearly two-edged stem, one or two feet long, about as thick as a pigeon's quill, flexuose, generally simple, but occasionally forked, beset throughout its whole length with compressed, falternate, distichons branclies, arising from the edges of the stem, separated by a short, but uncertain, distance, and supporting both leaves and resicles: leaves lineari-lanceolate or linear, or sometimes between linear and oblong, varying in breadth from two lines to half an inch, distichous, alternate, in some cases rather remote, in others clustered, sessile, or attenuated at their base into a very short petiolus, provided with a thin blackish midrin which sends out no lateral veins or nerves, their surface dotted with mucifluous pores, their margin serrato-dentate, with sharp teeth disposed in no certain order: vesicles also placed upon the branches, and mixed with the leaves, not very numerous, spherical, somewhat smaller than Juniper-berries, supported upon very narrow flat petioli, which are dilated upwards, and one or two lines long.

Fructification, cylindrical receptacles, placed on the branches, two lines long, occasionally beset with a few small spines, either simple or forked, clustered, and disposed in a racemus, externally every where uneven from the innate globular tubercles, perforated with a very minute pore, each containing a single roundish, brown seed, surrounded by a pellucid limbus.

Color, of the plant when recent, olive; dark-brown, when dry; after it is again moistened, reddish-brown; but if frequently washed and exposed to the action of the air tuming to a light brown.

SUBSTANCE, in the leaves and vesicles thin and cartilaginous, in the stem inclining to coriaceous; but every where, even when dry, soft and flexible.

$\beta$ is a variety remarkable at first sight, on account of the singularly curled and mululated leaves :-leaves clustered, elliptical, three quarters of an inch long, and three or four lines wide; their margin most minutely toothed; vesicles scarce, sometimes altogether wanting.

$\gamma$ extends to three or four feet in length : its mode of growth is diffuse; its branches lialf a foot and more long; its leaves loosely arranged, about an inch long, and four lines wide; their margin deeply and irregularly notched, with teeth larger than in the other varieties: vesicles scattered, numerous: receptacles abundant, remarkably thorny: color paler than in $\alpha$ and $\beta$, and more reddish.

$\delta$ is a nost elegant variety, more thin and delicate than the preceding ones:-branches short;--leaves placed close to each other, scarcely half an inch long, or two lines wide; receptacles very sinall; vesicles tolerably plentiful, attenuated at their apices, and most frequently tipped with a short awn:-it seems a dwarfish plant.

* Gmelin has referred this synonym to $F$. Acinaria, but, in my opinion, without eause; for, thongh the leaves are represented in the fioure as entire, yet the anthor has qnoted under it Bauhin's $\vec{F}$. folliculaceus serrato folio, and Lobel's Lenticula marina serratis foliis, and it needs scarcely be remarked that all the figures in the work are so rude, that great dependenee is not to be placed on them in nice points. Wnlfen considers both ' $6,17,18$, and 19 as belonging to $F$. Acintria.

$f$ The stem is most frequently twisted, on which account the altemate disposition of the branches is seldom visible at first sicht. 
8 is about a foot and half long, and remarkable for having towards its base lanceolate leaves, two or three inches in length, and four lines in width, and almost entire, while those on the branches are shorter and narrower by two thirds, and have their margins visibly toothed: substance very thin: color rusty brown: vesicles by no means numerous, spherical.

$\zeta$ connects $F$.natans with $F$. Acinaria:-length two feet; leaves remote, an inch and half long, but not above a line wide, the margin furnished with largish scattered teeth: vesicles between oblong and spherical, decurrent into a petiolus : mode of growth diffuse :- I have seen no fruit on it.

Ons. When dried it does not adhere in the least to paper.

Had I considered it right to be guided altogether by my own inclination in the arrangement of the different species of Fuci for publication, I should certainly have been tempted rather to have reserved the present for the conclusion of this work, than to have given it a place at the very commencement; since, from the circumstance of its being found in such immense quantities in almost every sea, there might be reason to hope that fresh supplies of specimens may be frequently received, and opportunities consequently afforded for better defining the limits between the different varieties and species hitherto comprehended under the one general name of F.natans. That such varieties and species do really exist, and exist in considerable quantity, is a thing of which $\mathbb{I}$ have long been persuaded, and which will, I believe, very readily be admitted by every Botanist who has been in the habit of directing his attention to the subject. It mist not, indeed, be denied, that the numerous points of similarity between these, oppose great obstacles to our understanding them properly; but at the same time to effect in this matter as much as possible by drawing the notice of Naturalists more particularly to them, it seemed advisable to figure * without delay such of the affinities of the present plant as have been described by preceding authors, and thus to clear the way for gradually introducing the others, which, though hitherto neglected, ought, in my opinion, to be regarded as no less ccrtainly distinct. Upon the peculiar appearances which distinguish the varieties above noticed, so much has already been said under each of them, that it cannot be necessary here to dwell farther upon the subject; and for most of the observations touching the synonymy of $F$. natans, and its difference from its congeners, 1 must refer my readers to those plants, and especially to $F$. bacciferus, merely confining myself in the present instance to general remarks, which have been very much exhausted by Gmelin, who with great assiduity collected whatever he found written respecting it. I feel it, however, necessary to observe, that my reasons for selecting the Fucus here represented as the true $F$. natans, in preference to others which may perhaps be regarded as equally deserving of the appellation, have been, that $I$ believed it more common than any of the rest, except, perhaps, the following, to which I preferred it on account of its fructification; and that these two are alone preserved under this title in the Herbarium of Linnæus, who changed the name of $F$. Sargasso, by which it was known among the Portuguese, to that which it now bears, under the idea that it floated about in the ocean, without being attached to any particular spot; an idea which was soon generally and deservedly exploded, and which in later times has been quite controverted by most of the varieties having been actually found with roots, and some even gathered in their loci natales. I have abstained above from any endeavor to mravel the confused synonyms of Brown, Morison, and the older vriters respecting $F$. natans and its congeners, their ciescriptions being in general so short as not to furnish the means of guessing to what they allnde; nor is it necessary to dwell at length upon the mistaken notions that have prevailed as to the fruit of these plants: even Gmelin was aware that the spherical vesicles which + Linnæus and Vahl regarded as the fructification, could not have been designed by nature for this purpose, and the discovery, upon which $\downarrow$ Ruiz prided himself, is so absurd, that the very mentioning of $i$ is in itself a sufficient refutation. \&Numerous are the accounts given by navigators of the immense quantily in which $\boldsymbol{F}$. natans is found it the Atlantic. Among these $\|$ Columbus and Lerius inet with it in sucli prodigious masses that it made the ocean appear like a meadow, and impeded the progress of their ships. Observations nearly similar are made by Osbeck and Rumphius, the formcr of whom remarks that, if prepared with vinegar, it furnishes a pickle not inferior to Samphire, and the latter informs us in his Herbarizim Anboincnse, that of it and other Algæ are made salads, which are eaten seasoned with the juice of lemons, pepper, capsicum, and ginger. Ruiz also, from his own experience, praises its esculent nature, especialiy that of the youiger shoots, and says that it is eaten in the lingdom of Chili. It is likewise in some places employed medicinally, and is particularly mentioned

\footnotetext{
* I was also the more induced to do this by the promise given in the Symopsis of the British Fuci, (I. p. 51 .) that I wonid as early as possible direct ny attention to this tribe of plants; a promise which 1 have fom different circumstaliees bcen prevented from fulfiling sooner.

$\uparrow$ Linnzus indeed seems to have becn in a measure acquainted with the true fitit, for lie says in the S.stema Natura, "in quibuslam in. dividuis ex alis foliorum rucemi brexissimi siliculis minutis varucosis " Vall, liowever drjeets this, and observes, "racemos brexissimos siliculis minutis verncusis in ulis foliorum non nisi rudimenta ramorum esse eo certius affimare greo, cum specimina plus' ad munus sunt ubi alii ramuli race. mor'um folifferi, alii vesiculiferi sint."

f 'This Rotanist considered lis diseovery of so muelı eonsequenee that lie publislied a pamphlet to illustrate it, entitled, "de vera Fuci naianis fructificatione Commentarius," at the end of wlich he figures three speeimens of F. bacciferus, the ore infested with Sertularia volubilis, whicl he ealls the male Alowers, the seeond with Sertularia pumila, which he eonsiders the female flowers, and the third with Sertularia Plumu, which le rcgards hermaphrodite llowers. Independently, however, of flis strange error, his work eontains many useful observations, and mueh if furmation, of which I have availed myself under the fullowing speeies.

Linnans says of this plant in the Species Plantarum, "Vegetabile, ni fallor, inter omn;a in orlse, numerosissimum."

if Never having myself seen the works troin whieh these observations are taken, I am under the necessity of transeribing what Gmelin las

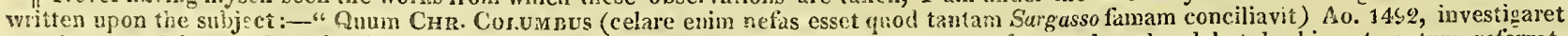
mundum, et ab insuhs Canariensibus ad oecidentalem trajiseret plagam, mare mox tot refertum deprehendebat herbis, ut pratum referret, dicrige herbam esse favescentem, instar foni semisicci, folia gerentem rutæ vulgatis, cui adpendantur copiosa bacca nigerrima, quæ siccata jumerinas referebant.-LAERIUs in itinerario suo refert, quod per viginti quinge dies per illam herbam, nisi seeuribus viam aperuisscnt,

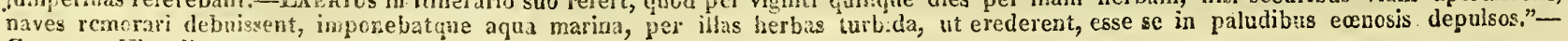
GuEis, Fist, fuc, p. 94.
} 
mentioned by Bomare, in his Dictionary of Natural History, as being both aperient, diuretic, and antiscorbutic, and by Kalm, in his travels, as being used among the natives of America to cure fevers, and as being eaten in a dry and powdered state by the women in childbirth, to facilitate parturition. Its serviceable qualities to mankind seem, however, to be but very secondary among the beneficent purposes which the Great Creator of all has designed it to answer in the economy of nature; for while it thus floats about in such almost inconceivable quantity, it affords both food and shelter to myriads of fishes and mollnsca, who, at once deriving from it their sustenance, and finding in it a refuge, hear testimony to the wisdom and goodness of that Being by whom they are created, protected, and preserved.

a. $F$. natans, natural size.

b. leaf, and cluster of receptacles, magnified - 6 .

c. receptacle cut through horizontally - $\quad 3$.

d. seeds - - - - _ - - 1 .

e. piece of var. $\gamma \quad-\quad-\quad-\quad-\quad-6$.

\section{7.-F U G U S B A G G I F R US.}

Fucus; caule tereti, filiformi, bipinnato: ramis alternis, simpliciusculis: foliis linearibus, serratis: vesiculis sphæricis, petiolatis; petiolis teretibus.

Fucus bacciferus. Syn. Fuc. I. p. 55.

* F. natans. Esper, Ic. Fuc. I. p. 49. t. 23. Wulfes, Crypt. Aquat. 11. 2. VAil, Skrift. af Naturhistorie Selskabet. V. pars 2da. p. 36. Ru iz, Commentarius de F. natante, cum icone.

F. denticulatus. Forsк⿺辶, Fl. Egypt. p. 191. Syst. Nat. Ed. Gmel. II. p. 1381.

F. Sargasso. GMELin, Hist. Fuc. p. 92 .

Lenticula marina vnlgaris. PARKINson, Thes. p. 1281.

B. oblongifolius; foliis oblongis, obtusis, serrato-dentatis.

Ha bitat utraque varietas in Oceano Atlantico, Pacifico, et Indico, unde ad omnium ferè terrarum oras inter alia rejectamenta vi fluctuum fertur.-Copiosè in Ocerno Septentrionali a 22 ad 38 gradus. Ruiz.

+ Perennis.

$\ddagger$ RA DIX nondùm cognita.

Frons pedalis et ultra, sed longitudo incertissima, cum nihil quod basi proximum videtur hactenùs sit visum, caule instructa tereti, filiformi, pennæ passerinæ crassitie, flexuoso, plerunque bis terve diviso, segmentis elongatis, fastigiatis, obsitis per totam longitudinem ramis teretibus, patentibus, alcernis, laxiusculè dispositis, ut plurimùm simplicibus, quandoque autem divisis, longitudinis incertæ, sed sæpiùs quatuor vel quinque pollicum, folia vesiculasque sustentantibus: folia plana, linearia, sed apices versus acutiuscula, $\S$ pollicem unum alterumve longa, et vix lineam lata, sessilia, remotiuscula, alterna, costá tenui nigricante nervos nullos laterales emítente percursa, poris mucifluis rariùs, si unquam, pertusa, margine serrato-dentata, dentibus majnsculis, sparsis: $\tau$ esicula sphæricæ in ramis frequentes, grani piperis nigri magnitudine, nunc solitariæ, nunc binæ ternæeve, \|intus omnino cava et lævigatæ, petiolo tereti lineari seu bilineari fultæe, apice ut plurimum, nequaquàm vero semper, mucrone brevi setaceo aristatæ.

Fructificatio nondum detecta.

CoLor plante recentis ferrugineo-pallidus, supernè luteo-virescens; exsiccate nigricans; rursùs madefacte intensè fuscus.

* Substantia

- Reetiùs forte fecissem, si synonyma omnia jam sub F. uatante citata, hic quorue repetivissem, quoniam dubitationi non datur locus, quin Linuæus et plurimi anctores, qui $F$. natanten memoraverunt, ntrumque paritèr respexeriut. Ir falui verò ea nodò proferre quae pro certis Labui, ut nos tandem e synonymorum ambagibus, quantum id fieri potest, cxolvere conemur.

$\dagger$ Annuam modò credit Ruizius, qui dicit, " nou ideo ausim affirmare, Fucum nut antem in aliis anni tenpestatibus supra aquas in pelago non inveniri; fortasse in aliis maris tractibus, polis aut æquatori magis approxinatis, lize planta in diversis mensibus, sed neutiquam toto anno viget."-Addit quoque, "Quinimo non desunt quæ suadeant, singulis annis perire in maris littotibus a tiuctibus ventisque in ingentes veluti acervos sub hyemis adventum convolutas, atque rcjectas, ut scilicet semina emittant, et dcnuo in rup:bus et nuaris findo gerniuent, quonsque per æstatem inde ventis divulsæ in pelagum propellantur, ubi perfectiontem suam assequautur, frue tifieentque, et in littora iteratis vicibus protrusæe destruantur."-Comment. de F. natante, p. $20 \& 21$.

$\ddagger$ Scabritiem hìc illie in fronde notabilem esse solam planta vadiccu credit Ruizius, cujus sic stat de hâc re sententia, "In his Algis nulla radices observantur, sed earum loco quasdam scabrities inferius labent, quibus certissimè saxis, et naris fundo, dum juniores essent, adhæserunt, quousque vegetiores, ct vesiculis cavis numerosis, quas a natura accepermut, preditæ, iteratis impulsibus, quos jair adulta sursum subeunt, a rupibus et profundioribus locis evelluntur, et super aquas emergunt, ut aere atmospherico, Ince, et calore gandentes perfectionem acquiraut, et fructus ferant, prout accidit in aliis paltudum, stagnorum, et fluviorum stirpibus, quaruu fores salten cx aquis ad lune finem exsurgunt, ellatautque."-Comment. de Fuco natante, p. 17.

$\$$ Ipse saltem longiora nunquam vidi, sed palmaria dicit Ruizins.

if De his vesicnlis dicit Ruizins se ipsas accuratissimc̀ introspexisse, atque e millenis, quas priñs diebus observavit, nullam inverisse, qua pilos

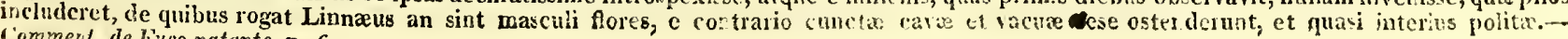
commert. de lice natante, p. 6 . 


\author{
* SubStanta caulis coriacea, foliorum et vesicularum cartilaginea; exsiccata ubique rigida, fragilis, et flecti \\ nescia.
}

$\beta$ in eo tantummodo discrepat ab a, quod folia habet oblonga, duas lineas lata.

OBs. Præter varietatem illam jam memoratam ludere solet hic Fucus foliis vix semilineam latis, et quandoque ramis vesicularum tantâ copiẩ onustis ut toti ferè cooperiantur :- chartæe ne minimùm adhæret:- habitus in exsiccatâ implexus et tortilis, nec uliâ arte in rectum revocandus :-copiosè ei innasci solent Sertularia Pluma, quadridentata, volubilis, aliæque e minoribus Zoophytorum speciebus; aliquando etiam Serpula quædam.

Hunc Fucum, semper antehac cum stirpe in tabulâ præcedente depictâ commistum, primo ab illâ sejuuxit Fucorum Britannicorum Synopsis, mde quidquid est a veteribus traditum, sive de immensâ, quâ $F$. natans provenit, copiâ, sive de ejus proprietatibus cibo medicinæve inservientibus, †non minùs unam harum quàm alteram respicit, et fortasse possit referri ad plurimas ex illis, quas, mox in hoc opere secernendas, capax illud $\boldsymbol{F}$. natantis nomen hucusque includit. Hrec Fucorum familia, si mihi liceat pro distinctâ familiâ habere, complectitur multas stirpes, arctissimè inter se formâ connexas, et reliquarum valdè absimiles, imo characteribus tam insignibus notatas, ut proprium ferè constituere genus, idque naturæ maximè conveniens, primo aspectu videantur. Attentiùs verò inspicienti patebit, necesse esse has conjungi cum is, quas Fucós proprios appellaverunt Weberus Mohriusque; fructificationem enim utrisque esse eandem, darique catenam, cujus sunt annuli $F$. turbinatus et quædam aliæe species nondùm hic delineatæ, per quam cunctre devinciuntur. Neque tamen idcirco est negandum, inesse $F$. natanti congeneribusque notam vix in aliis reperiendam, scilicet folia nunquam in ramos mutari, sed formam sui propriam semper servare, quamvis, $u t f^{\prime}$ jam est sub $F$.turbinato observatum, et ut liquidissimè ea $F$. ilicifolii icone, $t$. 51 , constat, receptacula jam effceta in nova folia vesiculasque abeunt. Multa ex is qua sunt suprà de $F$. baccifero tradita e Ruizio excerpsi, cujus descriptio et figura hanc plantam bene exprimunt, et cujus tractatus, quamvis nomine parùm idoneo Commentarius de $\S v^{\prime} e r \hat{a} \cdot F$. natantis fructificatione inscribatur, multa tamen includit dignissima quæ memorentur, qualiacunque ipse de recente notavit, cum sit illi data facultas, quæ, ut jure prædicat, paucis aliis contigit, per duos menses viventem observandi. Vesiculæ aereæ in $F$. natante et congeneribus prorsùs vacuæ fibrilloso illo contextu interno penitùs carent, quo sunt instructæ eæ $F$. vesiculosi, plurimorumque Fucorum propriorum qui nostrum mare incolunt. In exemplaribus a Ruizio visis |harum numerus aded erat ingens, ut e navi conspectæe uvularum immaturarum racemos referrent: has omnes a quibusdam individuis abscidit, quò certiùs stabiliretur sententia, esse a naturâ datas ut natantibus auxiliarentur. Rectè in hoc judicâsse probavit exitus, cum stirpes omnes sic mancæ rursùs immersæ maris fundum illicò peterent. De nominibus hujus Fưci et præcedentis est **animadversum, nec, ut verum fatear, injuriâ, utraque commutata plantis

\footnotetext{
* "Dum hæc Végetabilia recentia persistunt, membranacca apparent, tencra, et gelatinosa: sed arefacta icthyocollæ consistentiam acquirunt, et ejusdem substantiæe instar fragilia evadunt. In utroque statu saporem prae se ferunt viscidum, minimè ingratum, nec nauseabundum, et gari odoren."-Comment. de Fuco natante, p. 27.

† Forsan ex lis excipi debet D. Lardizabal, qui de F. baccifero tantum agere videtur, et rem tam fusè tractavit, ut me lectoribus morigeraturum credo, si quidquid Ruizius ex illo exscripsit hujus loci repetam. " D. Vinccutius Lardizabal, Regiæ Cantabricæ Societatis Mcdicus, Dissertationem Physico-Medicam de ejusdem viribus et proprietutibus lispanicè cvulgavit, Matriti, anno 1772, sub titulo Consuelo de Navegantes. Hic eandem descriptionem et iconem ab Acosta mutuatam exhibet, nihil in hac parte de suo adjiciens: plures scriptores memorat, qui de hac planta marina egerunt, et nonnulla loca ejusdem natalia, quin assignet anni tempestatem, qua supra aquas sese ostenclit: qualitatcs, et usus addit, ab Acosta observatos: quaccumque ille de ejus virtute antiscorbutica tradit mordicus amplectitur, usus medicos et oconomicos commendiat, et iteratis argumentis suadcrc conatur: rationem $F$. natcentis gari odore, et nonnullis impuritatibus spoliandi, methodumque ex eo Acetaria preparandi et condiendi docet. Addit eum ad aves et pecora in navigatione alenda inservire posse, et non sine utilitate ad carnes et pisces salitos marisque aquam brevi colulcorandam adhiberi. Haud meminit incrustationum calcarearum, neque cochlearum, quibus maximam partem in littoribus et pelago hujusmodi plantæ conteguntur . . . . Hortatur autem, ad præparandum acetarium coctuı, primùm Fuci herbam lavare, deinde in frusta consciudere, mox in olla coquerc cum sufficienti aquæe dulcis quantitate, et post unam aut alteram ebullítionem priori aqua effusa aliam denuo addere cum pauxillo salis, et allii, in qua coquatur ad unollitiem, et denique illi in disco collocatæ olci incocti aut cum a!liis firixi, ct aceti quantum sufficiat admisccre. Suadet quoque, aqua dulcis defcctu, adhibere maris aquau, in qua licrba cocta insipida fè è evadit, et nonnilil gari odoris tantummodo retinet, quod minime accidit cunı aqua dulci."-Comment. de Fuco natante, p. 28.

† Suprà p. 50 .

6. Confer notam sub pracedontc spccie, p. 100. Id quod Ruizius sigillatim de hoc crrore dicit est tam singulare ut hic verbatim transcribere dncor:- "quoniam igitur satis mili exploratum jam erat post tot dierum iteratas investisationes, venas illas, et inflorescentias non essc quidquam a Fuco ipso alienum, sed ipsins plantæ partes; ad eas describendas, qua res postulabat, diligentia me accinxi, et pro 1 rloribus masculis calyculos solitarios" (Sertulcriam rolubilcm) "statui; pro Femineis spiculas absque calyculis" (Sertulariam pumilan) " et pro Hermaphroditis spiculas cum calyculis," (Sertulariam Plamam) "floribus solitariis similibus. Rationes autem, quæ me impulerunt ad lujusmodi florum distributionem, liae fiere: eorun dispositio, fiuma, et affinitas cum alis diversorum sexum plantis. Vocavi igitur Flores masculos Vascula illa solitaria, quippe numerosiores erant, quam flosculi spicati aliorum duorum sexuum, prout fit in plantis monoicis, dioicis, ct polygamis ; accedebat etiam, in illis includi quandam substantiam luteo-sulphuream, antherarum pollini aliarum plantarum quodammodo similcm. $F$ lores $F e$ mineos ideo constitui spiculas corporibus conicis conflatas, quia lıæc forma pistillorum absque stylo quidani, sed cum germine, et stigmate, aliorum vegctabilium gerninibus, et stigmatibus plus minusve similibus, referelant. Denique pro Floribus hermaphroditis spicatos flosculos, vasculis masculorum similibus stipatos habui, proptereaquod spicati cssent, et minus copiosam continerent substantiam luteo-sulphuream, quani 1losculi masculi, qui semper solitarii conspiciebantur, et hujusmodi substantia abundabaut. Nudis oculis, quos satis perspicaces a natura sortitus sum, ne quidem vitro adjutis, nullam aliam differeutiam in lis fructificationibus detegere potui."-Comment. de Fuco natante, p. 12.

II "Vesicularum vero rotundarum et cavarum, penitusque inanium, quibus replentur singulæ plantæ, adeo ingens erat numerus, ut e navi prospicientibus uvularum immaturarum racemulorum speciem exhiberent. Hæ vesiculæ, ntpote materia omni manifesta, quæ pondus eis conciliet, vacur, plantarum e rupibus, quibus inuscuntur, evulsionem juvant, et ex aqua superficie emersionem supernatationemque, donec transactis vitae terminis a natura prescriptis marcescere in mari incipiunt, penitusque in littoribus destructionem subeunt. Si hujusmodi vesiculis orni substantia pondcroso destitutis non instructæe essent planta, neque energere, neque enatare possent, ni caules et folia poris scaterent aere plenis, qui eas aqua leviores efficerent. Ut hoc experimento comprobarem, pluribus plantis vesiculas abstuli, aliisque dirupi, omnesque illico mais fundum petierunt, neque ad superficiem adscendcrunt, impedita scilicet caulium, et fuliorum solidissimorun, et poris manifestis expertinu gravitate."-Comment, de Fuco nutante, p. 22.

** Hac animadversio occurrit in recensione Wulfenii Crypitoganorum Aquaticorum, in opere, cui titulus, Allgemeine Literatur-Zeitung, III. 1805. p. 456. Dicit Censor, “ " Da diescr letztere ( $F$. bacciferus) aber wirklich fast inmer schwimmend, und olne Bcfestigungspunkt, ersterer
} 
aptiùs conventura ; quoniam $F$. bacciferus hactenùs non nisi liberè natans est detectus, et sic vagans, non modò vivere, sed etiam crescere videtur; plurimum ad eorum opinionem ita faciens qui negant Fucorum radices nutrimen aliquid afferre. Doleo quidem quòd talem non acceperim notationem, donec causæ jam sub specie præcedente memoratæ impulerant ut alitèr facerem; et nimis scio quantum e multiplicatis confusisque synonymis detrimenti in rem botanicam fluxit, ut ullum unquam nomen jam cognitum atque receptum sine causâ gravissimâ permutem. Fieri potest ut sint qui suspicentur $F$. bacciferum haud satis distinctam esse speciem, quia nulla vel radix vel fructificatio, ad quam edendam affines haud segnes, hucusque est reperta: tali autem sententiæ assentiri nequeo: licet enim, donec hæ deteguntur, res quodammodd in medio maneat, nullus dubito quin sit a reliquis diversa, cùm ob habitum crescendique modum, tùm præsertim ob texturam et caulem petiolosque cylindraceos.

a. F. bacciferus, magn. nat.
b. rami pars, magn. auct.

4.

(F. natans) abcr häufig mit einen scheibenförmigen Basis versehen, angetroffen wird: so hätten, durch eine Umwechselung, beide Namen an Bedeutung gewonnen, Dass über die wahren Fruchttheile an diesen Arten keine Zweifel mehr sind, braticht kaum erwälnt zu werden: Die nicht bis zur Truchtbringung ausgebildeten, oder dieselbe vollendet labenden tubercula gehen in Vesica iiber, die zur Aufrechthaltung des Strauchs im Wasser dienen. Obgleich dem Rec. ganze Säcke voll dieses letzten aus dem atlantischen Meere eingeliefert worden sind, so faud er ilun immer als äpp! కos und äxapros."

\section{7.-F U C U S B A C I F E R US.}

Fucus bacciferus, stem cylindrical, filiform, bipinnate: branches alternate, mostly simple: leaves linear, serrated: vesicles spherical, on cylindrical petioli.

Fucus bacciferus. Syn. Fuc. I. t. 55.

*F. natans. Esper, Ic. Fuc. I. p. 49. t. 23. Wulfen, Crypt. Aquat. n. 3. Vaul, Skrift. af Naturhistorie Selsliabet. V. pars $2 d a$. p. 36. Ruiz, Conment. de F. natante, cum icone.

F. Sargasso. Gmelin, Hist. Fuc. p. 92.

F. denticulatus. Forsio̊r Fl. Egypt.p. 191. Syst. Nat. Ed. Gmel. II. p. 1351.

Lenticula marina vulgaris. PAR KNson, Thes. p. 1281.

$\beta$. oblongifolius; leaves oblong, obtuse, between serrated and dentate.

Both varieties are found in the Atlantic, Pacific, and Indian Oceans, and are thence washed, among other rejectatmenta, upon the shores of almost every country.--. Plentiful in the Northern Ocean, from 22 to 38 degrces. Ruiz.

\section{+ Perennial.}

†Root, not at present known.

Fron D, a foot and more long, (but to what length it may extend it is impossible to say witl any certainty, as nothing has at present been seen that indicated a positive proxinnity to a base) furnislıed with a cylindrical, filiform, flexuose stem, about the thickness of a sparrow's quill, in general twice or thrice divided, will long segments nearly of equal height, and beset throughout their whole length with cylindrical, patent, alternate branches, at small distances from each other, for the most part simple, but sometimes divided, and supporting leaves and vesicles : leaves flat, and linear, but sharpish towards the apices, an §inch or two long, and scarceiy a line wide, sessile, rather remote, alternate, provided with a thin blackish midrib, which is destitute of lateral nerves, but seldom, if ever, perforated with VoL. I. mucifluous

* It would probably have been best to have repeated here all the synonyms already quoted under $F$. nutans, as there cannot be the least doubt but Linnæus and most of the authors who have mentioned this latter intendcd their descriptions to be equally applicable to both. Upon consideration, however, I preferred referring to those only which I regarded as certain, hoping that this might be the neaus of enabling us in time to extricate ourselves firom the present perplexity of synonyms.

$\dagger$ Ruiz is of opinion that this plant is only annual, and says, " non ideo ausin affirmare, Fucum natantem in aliis anni tenıestatibus supra aquas in pelago non iuveniri; fortasse in aliis maris tractibus, polis ant aequatori magis approximatis, hac planta in diversis mensibus, sed nentiquam toto anno viget."-and again he says, "Quinimo non desunt qua suadeant, singulis annis perire in maris littoribus a fuctibus ventisque in ingentes veluti acervos sub hyemis adventum convolutas, atque rejectas, nt scilicet semina enittaut, et denuo in rup bus et maris findo germinent, quousque per astatem inde ventis divulsa in pelagum propellantur, ubi perfectionem suam assequantur, fructificentque, et in littora iteratis vicibus protrisae destruantur."-Comment. de F.natante, p. 20 \& 21 .

† The ronghness observable in different parts of the plant is considered as the only root by Ruiz, who remarks on this subject, "In his Alyis nullæ radices observantur, sed earum loco quasdam scabrities inferius habent, quibıs certissimè saxis, et maris fundo, dnm juniures essent, adhæese. runt, quonsque vegetiores, et vesiculis cavis mmmerosis, cuas a natura acceperunt,'præditæ, iteratis impulsibus, quos jam adulta sursum subeunt, a rupibus et profundioribus locis evelluntur, ct super aquas emcrgunt, ut aere atmospherico, luce, et calore gaudentes perfectionem acquirant, ct frnctus ferant, pront accidit in aliis paludum, stagnorum, et fluviorum stirpibıs, quarum flores saltem ex aquis ad liunc finen exsurgunt, eua tantque."-Comment. de Fuco natante, p. 17.

\$At least I lave never seen them longer, but Ruiz calls them palin long. 
mucifluous pores, their margin serrato-dentate, with largish scattered teeth: vesicles splierical, numerous, about the size of black pepper-corns, either solitary or growing two or three together, *internally quite hollow and polished, supported upon a cylindrical petiolus, a line or two long, their apex most frequently, but by no means constantly, tipped with a short setaceous mucro.

Fructification, not yet discovered.

CoLOR, when fresh, pale and ferruginous, of a yellowish green in the upper parts ; when dried blackish; turning, if again moistened, to a very dark brown.

+ SUBSTANCE, in the stem coriaceous, in the leaves and vesicles cartilaginous; in a dried state every wliere rigid and brittle.

$\beta$ differs from a only in having its leaves oblong instead of linear, and two lines wide.

OBs. Besides the variety here mentioned, this Fucus is apt to vary in producing leaves scarcely half a line wide, and in laving its branches sometimes furnished with such a profusion of vesicles as to be almost covered with them: -it does not adhere in the least to paper:-its habit in a dried state is remarkably twisted, and can by no means be bronght to straight:- Sertularia Pluma, quadridentata, and volubilis, as well as others of the smaller Zoophytes, are found upon it in great abundance, and occasionally some of the Serpula.

The first mention made of this Fucus, as distinct from the preceding one, is in the Synopsis of the British Fuci, so that whatever the more early writers have said with respest to the immense quantity in which $F$. natans is found, as well as concerning its medicinal or esculent nature, must be considered as equally applicable to $\ddagger$ both species, and might perhaps be extended to the greater part of those, which, though heretofore confounded under one general name, it will be necessary in the course of this work to point out as really distinct. The tribe of $F$. natuns, if $I$ may be allowed to use such an expression, comprehends a considerable number of individuals, so closely allied to each other, and so considerably different from the rest of the Fuci, that they seem at first sight sufficiently marked to constitute a separate and very natural genus. It will, however, be found upon more attentive examination that they cannot be disjoined from those that Weber and Mohr have called the Fuci proprii, with which they agree in fiuctification, and to which they are united by a series of links formed of $F$. turbinutus, and several other species not at present figured. They have at the same tine a strong character almost peculiar to themselves, which is that the leaves do not appear in any case to lengthen into branches, but constantly to preserve their original form, though the receptacles, as has $\S$ already been noticed under $F$. turbinatus, and as is most visible in $F$. ilicifolius, t. 51 , "are metamorphosed both into new leaves and vesicles. In the account above given of $F$. bacciferus, much has been borrowed from Ruiz, whose description and figure are most evidently designed for the present plant, and whose work, though most erroneously termed a Treatise upon the \|true fructification of $F$. natans, is valuable on account of the particulars that he observed while it was yet fresh; in which state lie justly remarks that few botanists, have, like him, enjoyed the opportunity of examining it for two continued montlss. There seems also to be another circumstance in which $F$. natans and its congeners are naturally different from $F$. vesiculosus and most of the Fuci proprii of our seas; which is, that the vesicles are altogether empty, and destitute of the fibrous lining, which is so conspicuous in

our

* Upon the subject of thesc vesicles, Ruiz says, " se ipsas accuratissimè introspexisse, atque e millenis, quas primis diebus observavit, nullam invenisse, quæ pilos includerct, de quibus rogat Linnæus an sint masculi florcs, e contrario cunctæ cavæ et vacuæ sese ostenderunt, et quasi interius politæ.-Comment. de Fuco natante, p. 6.

+ "Dum hæc Vegetabilia recentia persistunt, membranacea apparcnt, tenera, et gelatinosa: sed arefacta icthyocollæ consistentiam acquirunt, et ejusdem substantiæ. instar fragilia evadunt. In utroque statu saporem præ se ferunt viscidum, minimè ingratum, nec nauseabundum, et gari odoren."-Comment. de Fuco nutante, p. 27.

¥ There seems to bc an exception to this observation in $\mathbf{D}$. Lardizabal, who appcars to refer only to $F$. bacciferus, and has dwelt so much at large upon the subject, that I think it may be gratifying to my readers if I extract what Ruiz has written concerning it:- " D. Vincentius Lardizabal, Regiæ Cantabricæ Societatis Medicus, Dissertationem Physico-Medicam de ejusdem viribus et proprietatibus lispanicè evuigavit, Matriti, anno 1772, sub titulo Consuelo de Navegantes. Hic eandem descriptionem et iconem ab Acosta mutuatam exhibet, nihil in hac parte de suo adjiciens : plures scriptores memorat, qui de lac planta marina egerunt, et nonnulla loca ejusdem natalia, quin assignet anni tempestatem, qua supra aquas sese ostendit : qualitates, et usus addit, ab Acosta observatos; quæcumque ille dc ejus virtute antiscorbutica tradit mordicus amplectitur, usus medicos et œconomicos commendat, et iteratis argumentis suadere conatur: rationem $F$. nutantis gari odore, ct nonnullis impuritatibus spoliandi, methodum ue ex eo Acetaria præparandi et condiendi docet. Addit eum ad aves et pecora in navigatione alenda inservire posse, ct non sine utilitate ad carnes et pisces salitos marisque aquam brevi edulcorandam adhiberi. Haud meminit incrustationun calcarearum, neque cochlearum, quibus naxinam partem in littoribus et pelago lujusmodi plantæ conteguntur . . . . Hortatur autem, ad præparandum acetarium coctum, primùm Fuci herbam lavare, deinde in frusta conscinderc, mox in olla coquere cum sufficienti aquæ dulcis quantitate, et post unam aut alteram ebullitiouem priori aqua effusa aliain denuo addere cum pauxillo salis, et allii, in qua coquatur ad mollitiem, et denique illi in disco collocatæo olei incocti aut cuu alliis firixi, et aceti quantum sufficiat admisccre. Suadet quoque, aqua dulcis defectı, adhibere maris aquam, in qua herba cocta insipida fè è evalit, et nonnihil gari odoris tantummodo retinet, quod uninime accidit cum aqua dulci."-Comment. de Fucon atante, p. 28.

$\$$ p. 50 .

II See the note under the preceding species, p. 100. The obscrvations madc by Ruiz upon his tliree kinds of fructification are so detailcd and curious, that I am tempted here to transcribe then at length:-- "6 quoniam igitur satis mihi exploratum jam erat post tot dierum iteratas investigationes, venas illas, et inflorescentias non esse quidquam a Fuco ipso alicnum, sed ipsius planta partes; ad eas describendas, qua res postulabat, diligentia me accinxi, et pro Floribus masculis calyculos solitarios" (Sertulariam volubilem) "statui; pro Femineis spiculas absque calyculis" (Sertularium pumilam) " et pro Hermaphrnditis spiculas cum calyculis," (Sertularium Plumam) "floribus solitariis similibus. Rationes autem, quæ mc impulerunt ad hujusmodi florum distributioncm, liæ tuere : eorum dispositio, figura, et affinitas cum aliis diversorum sexnun plantis. Vocavi igitur Flores masculos Vascula illa solitaria, quippe numerosiores erant, quam flosculi spicati aliorum duorum sexuum, prout fit in plantis monoicis, dioicis, et polygamis; accedebat etiam, in illis includi quandam substan tiam luteo-sulphurcam, antlıerarum pollini aliarum plantarum quodanımodo similem. Flores Femineos idco constitui spiculas corporibus conicis conflatas, quia hac forma pistillorum absque stylo quidam, sed cum germine, et stigmate, aliorum vegetabilium gerninibus, et stigmatibus plus minusve similibus, referebant. Denique pro Floribus hermaphroditis spicatos flosculos, vasculis masculorum similibus stipatos labui, proptereaquod spicati cssent, et minus copiosam continerent substantiam luteo-sulphuream, quam flosculi masculi, qui semper solitarii conspiciebantur, et hujusmodi substantia abundabaut. Nudis oculis, quos satis perspicaces a natura sortitus sum, ne quidem vitro adjutis, nullam aliam differentiam in lis fiuctificationibus detegere potui,"-Comnent. de Fuco nutante, p. 12. 


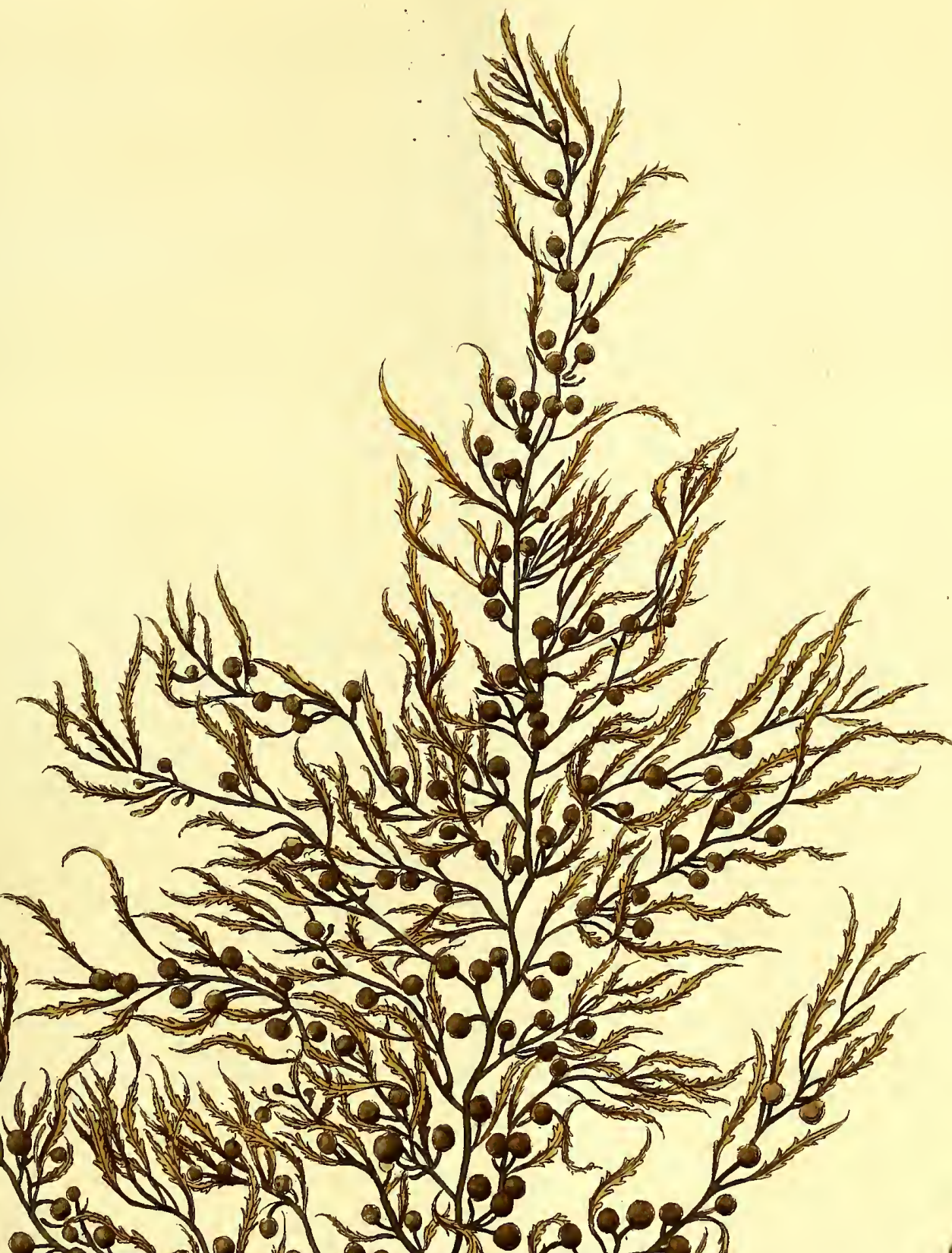

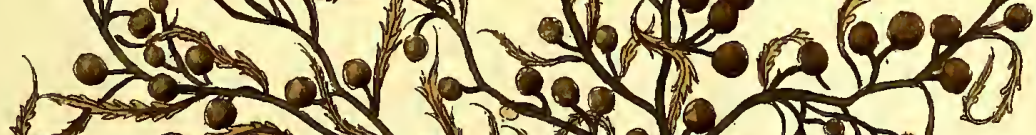

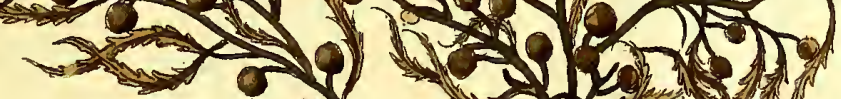
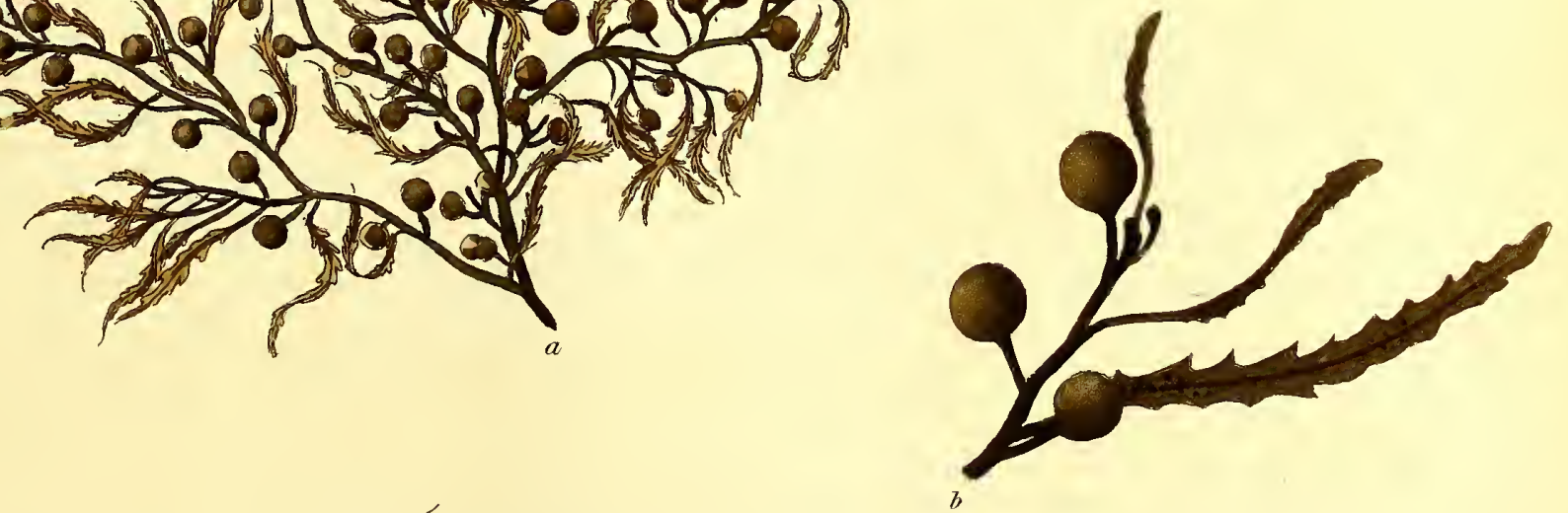

Tuaus bacaferus. 

our European species. In the specimens noticed by Ruiz, they are so *numerous, that, he says, they appeared, as he looked at the Fucus from the ship, like bunches of unripe grapes; and, to satisfy himself that they were designed by nature to assist the plant in swimming, he cut them off from some individuals, which, upon being again thrown into the sea, immediately sunk to the bottom. HIt has been observed, and, I must own, not without an appearance of justice, that, instead of giving the name of $F$. natans to the preceding species, it would have been better to have applied it to the one here figured, which has never yet been found except swimming about, in which state it appears certain that it continues to live and increase, thus affording the strongest argument in favour of the opinion of those who maintain that the roots of Fuci are not organs of nourishment. This observation unfortunately did not reach me till, for reasons already mentioned under the preceding species, I had done otherwise; and I know too well how much botany has suffered from the multiplication and constant confusion of its synonymy, ever to change witliout the most decisive cause a name already known and established. It is certainly extraordinary that F. bacciferus should never have been seen with either root or fructification, especially as its congeners seem by no means unwilling to produce their fruit. The species may possibly be regarded as in some degree unsettled till this is discovered, but $I$ at the same time feel no doubt in giving it as my opinion, that it is essentially distinct from all others, differing in its mode of growth and general habit, and still more in its texture, and cylindrical stem and petioli.

a. F. bacciferus, natural size.

b. part of a branch, magnified - $\quad-4$.

\begin{abstract}
" "Vesicularum vero rotundarum et cavarum, penitusque inanium, quibus replentur singulæ plantæ, adeo ingens erat nnmerus, ut e navi prospicientibus uvularum immaturarum racemulorum speciem exhiberent. Hæe vesicula, utpote nateria omni manifesta, quae pondus eis conciliet, vacuæ, plantarum e rupibus, quibus innascuntur, evulsionem juvant, et ex aquxe superficie emersionen supernatationemque, donec transactis vitæe terminis a natura prascriptis marcescere in mari incipiunt, penitusque in littoribns destructionem subeunt. Si hujusmodi vcsiculis omni substantia ponderoso destitutis non instructæe essent plantæ, neque emergcre, neque enatare possent, ni caules et folia poris scaterent aere plenis, qui eas aqua leviores efficerent. Ut hoc experimento comprobarem, pluribus plantis vesiculas abstuli, aliisque dirupi, omnesque illico maris fundum pctierunt, neque ad superficiem adscenderunt, impeditæ scilicet caulium, et foliorum solidissimorum, et poris manifestis expertium gravitate."-Comment. de Fuco natante, p. 22.

$\dagger$ This observation is made in the Review of IVulfen's Cryptogama Aquatica, in the Allgemeine Literatur-Zeitung, III. 1805. p. 450. Tlie Critic says, - - Da dicser letztere $(F$. bacciferus) aber wirklicl fast immer schwimmend, und ohne Befestigungspunkt, ersterer ( $F$. natans) abcr häufig mit einen scheibenförmigen Basis versehen, angetroffen wird: so hätten, durch eine Umwechselung, beide Nanen an Bedeutung gewonnen. Dass über die wahren Fıuchttheile au diesen Arten keine Zwcifel melır sind, braucht kaum erwälıut zu werden: Die nicht bis zur Fruchtbrigung ausgebildeten, oder dicselbe vollendet habenden tubercula gelen in Vesica über, die zur Anfreclithaltung des Stranclıs im Wasser dienen. Obgleich dem Rec. ganze Säcke voll dieses letzten aus dem atlantischen Meere cingeliefert worden sind, so faud er ilın

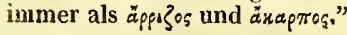

\title{
48.-F U G U S L E D I G E R U S.
}

Fucus, caule tereti, filiformi, simplicissimo, foliis obsito oblongis; sparsìn serrato-dentatis : vesiculis nullis : receptaculis cylindraceis, racemosis; racemis compositis.

Fucus lendigerus. Linn. Sp. Pl. II. p. 1628. Syst. Nat. II. p. 715. Syst. Nat. Ed. Gmel. II. p. 1380. Gálin, Hist. Fuc. p. 101.

Ha B Iт A ad Insulam Adscensionis. Osbeck.

Peremis.

RA Dix callus expansus.

FroNDES ex eâdem basi plurimx, caule instructa terete, filiformi, recto, pennâ passerinâ tenuiore, vel simplice, vel ramum unum alterumque breveın, vagum, apices versus emittente, infernè per dimidiam ferè longitudinem nudo, aut foliis aliquot alternis prædito, supernè semper folioso, foliis crebris, confertis, oblongis, brevissimè petiolatis, poris, inucifluis hic illic pertusis, nervo tenui obscuro percursis, apice rotundatis, margine serrato-dentatis, dentibus exiguis sparsis-vesicula, ut videtur, nullæ.

FR UCTIF I CATI o caulis juxta apices, et sapiùs foliorum ad alas sita, e receptaculis constat cylindraceis, bilinearibus, simplicibus, vel bifurcis, pluribus in racemum iterùm atque iterùm aliquando divisum congestis, extrinsecùs ubique inæqualibus ob tubercula innata sphærica, poro ninutissimo pertusa, sub quo latet semen unicum, oblongum, limbo pellucido cinctum :-racemus haud rard foliolosus evadit.

Color recentis olivaceus, exsiccate nigricans.

SUBSTANTIA in caule coriacea, in foliis cartilaginea, tenax.

Oвs. Exsiccata chartæ ne minimum adhæret.

An debeat hic Fucus pro specie distinctâ haberi, res est, quæ, ut verun fatear, nequaquàm mihi extra dubitationern posita videtur. Exemplaria nulla observandi hactenus est data facultas, præter ea in Herbario Linnæano inclusa, in quo ditissimo phytophylacio quatuor hujus Algae servantur specimina, ad quae satis liquet Linnaum elaborâsse jescriptionem in Speciebus Plantarum traditam. Horum maximun hæc nostra-sistit icon: cuncta conveniunt in staturæ parvitate, racemis compositis, vesicularumque absentiâ; neque est negandum quin lıæ notæ, si modo stabiles 
permaneant, ad speciem discriminandam satis superque suppeditent: anne autenı sint stabiles non est e quatuor individuis dijudicandum, et, si non sint, vereor ut hanc stirpem a $\boldsymbol{F}$. natante distinguamus; quoniam summa inter utramque certè similitudo interest, et, notis jam memoratis deficientibus, nullum, nisi caulis in unâ teretiusculıs in

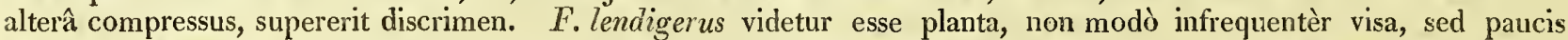
cognita. Gmelinus, qui tantùm Linnæi fide recensuit, ejusque verba, ut ipse palàm prædicat, exscripsit, se eam planè ignoravisse fatetur; stirpsque, quam sub eodem nomine depinxit Esperus, I. t. 15, est ad F.natantem .referenda, et jam in hoc opere ad ejus var. $\beta$ citatur. Species ab utrâque, ut mihi videtur, diversa pro F. lendigero in Herbario Banksiano servatur.

a. F. lendigerus, magn. nat.

b. receptaculorum racemus, et folium, magn. auct. - 6 .

c. receptaculum horizontalitèr dissectum. - - 3.

\section{8.-F U C U S L E N D I G E R US.}

Fucus lendigerus, stem cylindrical, filiform, quite simple, beset with oblong leaves, here and there serrato-dentate: vesicles none: receptacles cylindrical, collected into compound raceni.

Fucus lendigerus. Linn. Sp. Pl. II. p. 1628, Syst. Nat. II. p. 715. Syst. Nat. Ed. Gmel. II. p. 1380. Guelin, Hist. Fuc. p. 101.

On the shore at Ascension Island. Osbeck.

Perennial.

Roот, an expanded callous disk.

FroxDs, numerous from the same base, furnished with a cylindrical, filiform, straight stem, more thin than a sparrow's quill, either simple, or sending out near its apex one or two short scattered branches, and either naked in its lower part for nearly half its length, or only producing a few alternate leaves, but in its upper part always leafy ; leaves numerous, clustered, oblong, supported upon extremely short petioli, here and there perforated with mucifluous pores, provided with a thin dark midrib, rounded at their apices, at their margins serrato-dentate, with small scattered teeth:- -vesicles, apparently, none.

Fructification, situated near the end of the stem, and generally in the axillæ of the leaves, consisting of cylindrical receptacles two lines long, some simple, some forked, many of them collected into a racemus, which is frequently again and again divided, externally unequal all over on account of the innate spherical tubercles, each of which is perforated with an extremely minute pore, under which lies a single, oblong seed, surronnded with a pellucid limbus.

CoLOR, in the fresh plant, olive-green; blackish when dry.

SubSTANCE, coriaceous in the stem, in the leaves cartilaginous and tough.

Oss. When dried it does not in the least adhere to paper.

How far this Fucus ought really to be considered as a distinct species is, I must confess, a matter of some doubt to me. I have hitherto had the opportunity of examining no specimens, except those in the Linnæan Herbarium, where there are preserved four, from which it is evident that the description in the Species Plantarum was composed, and of which the present figure represents the largest. The whole of these specimens agree in their dwarfish size, compound racemi, and total want of vesicles, circumstances so striking, that, if constant, they would of course be sufficient to keep it separate from its affinities. Among these $F$. natans is the plant to which it is most closely allied, and of which, provided the marks just mentioned do not prove permanent, I apprehend it must be considered a variety, as there will remain only the cylindrical or compressed stem to separate them. F. lendigerus appears to be a Fucus, not only of rare occurrence, but very little known: Gmelin has inserted it in his work avowcdly upon the authority of Linnæus alone, merely copying his description, and what Professor Esper has figured under this name, I. t. 15, is nothing more than $F$. natans, to the variety $\beta$ of which it is quoted above. In the Banksian Herbarium, too, is preserved another still different species.

a. F. lendigerus, natural size.

b. cluster of receptacles, and leaf, nuagnified - $\quad-6$.

c. receptacle, cut through horizontally - - $\quad 3$. 


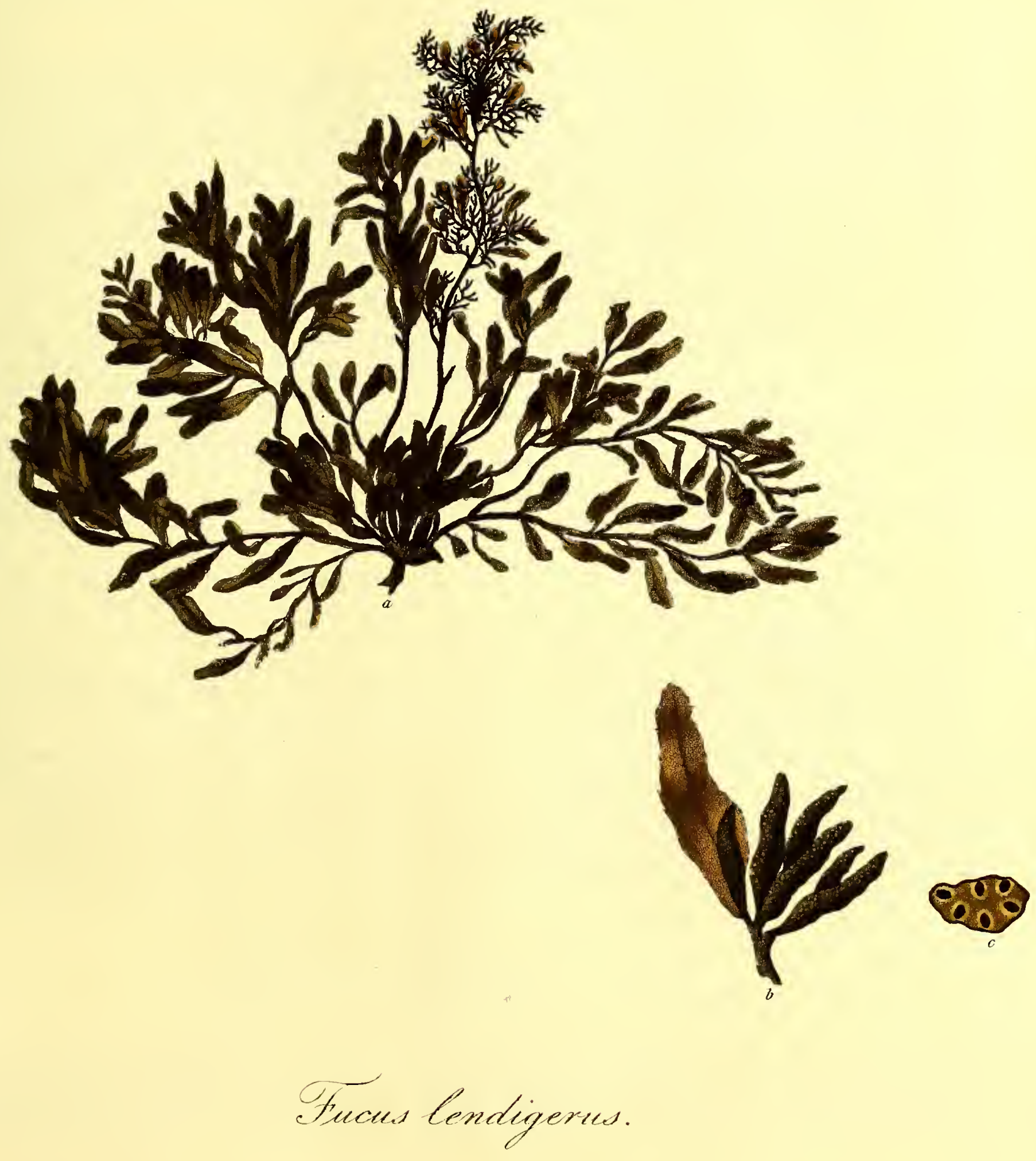



Fucus, caule teretiusculo, filiformi, bipinnato : ramis sub-alternis, simplicibus : foliis linearibus integerrimis : vesiculis oblongo-pyriformibus, petiolatis ; petiolis planis : receptaculis cylindraceis, sub-solitariis.

Fucus acinarius. Lin N. Sp. Pl. II. p. 1628. (excl. syn. ommibus.) Syst. Nat. II. p. 715. Syst. Nat. Ed. Gmel. II. p. 1380. Mant.p. 508.

B. pycrocistus; foliis oblongis.

F. pycnocistus. MerTENS, MSS.

\%. megalocarpus; receptaculis oblongis, undulatis, spinulosis.

Habitat \& in Oceano Australiori. Linnceus.-In Mari Rubro, unà cum var. $\%$. Vicecomes de Valentia.-. Ex Indiâ Orientali accepit D. Smith. $-\beta$ in Mari Coreano. D. Homer.-Ex Egypti oris accepit D. J. Banks, Baronet.

Perennis.

RADIX callus expansus, satis magnus, quandòque hic illìc torosus, et sub-repens.

Frondes vel solitariæ, vel binæ, ternevæ, bi-tri-pedales, instructæ caule nunc simplice, nunc semel iterumve diviso, e tereti compresso, filiformi, Merulæ pennæ crassitie, flexuosè erecto, basin versus nudo, inde per totam longitudinem pinnato ramis patentibus, sub-distichis, ut plurinum alternis, iuferioribus sub-dodrantalibus, semper longissimis, atque iterùm simili modo pinnatis, reliquis qud magis ad apicem adpropinquant ed brevioribus, unde totius plantæ peripheria pyranidata, omnibus simplicibus, vel rarissimè bifurcis, spatio brevi sejunctis, foliis vesiculisque copiosè obsitis : fotia linearia sessilia, pollicem longa, atque haud lineam lata, poris mucifluis pertusa, nervo tenui nigricaute percursa, margine semper integerrima: vesicula creberrimæ, oblongæe, basi decurrentes, Cannabis sativa seminibus aliquantùm minores, intùs omnino vacuæ, petiolo brevi plano fultæe, qui mox elongatus in folium mutatur, unde vesiculæ foliorum ad apices sitæ non rard occurrunt.

FRUCTIFICATIO in ramis foliorum ad alas sita, e receptaculis eonstat cylindraceis, vix lineam longis, vel solitariis, vel duobus tribusve in racemum congestis, subsessilibus, extrinsecùs ubique torulosis, ob tubercula imnata, sphærica, poro minutissimo pertusa, singula semen unicum, oblongum, limbo pellucido cinctum includentia.

Color, qui recentis verisimillimè intensè fusco-viridis, exsiccate nigricans.

Sudstantia in caule coriacea, basin versus lignosa, in foliis cartilaginea, crassiuscula, tenax.

$\beta$ in eo præsertim ab a discrepat qudd folia liabeat dupld latiora, breviora, oblonga, et coloris dilutioris :-exemplar hujus varietatis a Mertensio missum ramos habuit vesiculis fructuque ferè totos coopertos, sed ea ex $\mathbb{E g y p t o}$ accepta his maximâ ex parte caruerunt, et foliis sunt instructa solito longioribus, aliquando bifurcis.

$\gamma$, cujus unum modo exemplar vidi, folia eorum in a similia gerit, sed sparsa : magıa contrà receptaculorum copia, quæ oblonga, duas lineas longa, et propemodùm unam lata, planiuscula, lenitèr crispa, atque undulata, margine spinulosa.

Овл. Exsiccata chartæ uоn adhæret:- receptacula effoeta in folia transire indubium videtur, et hoc vel in $\gamma$ valere, cujus fructus tum spinas exuit:- - tota planta insignitèr lævis.

De hoc Fuco, sicut olìn de F. fastigiato et F. rubente, Linnæi Herbario potiùs quam scriptis iterùm sum confisus, iterùmque dubito, an, sic faciendo, rectè necne fecerim. Planta hìc delineata, cujus nulla, quod scio, hactenùs extat icon, ut habitu longè alieno gaudet, ita specie certè satis discrepat ab *illâ, cui $F$. Acinaria nomen indere solent Botanici, et quam liquet ipsum Linnæum primitùs respicere voluisse. Ea stirps maris Mediterranei incola, sese caule muricato vesiculisque magnis sphæricis conspiciendam præstat. Folia utrique paritèr integerrima erroris ansam fortasse præbuerunt. Conveniunt in hoc cum nullâa aliâ inter $F$. natantis familiam hucusque detectâ, dempto $F$. heterophyllo, Herb. Banks., cui etiam foliorum minorum et receptaculorum forma eadem, sed; quod ejus speciei proprium, folia quoque habet latè oblonga, reliquis, quibus immista nascuntur, multoties majora, et vesiculæ sunt splæricæ, atque aristâ terminatæ. Petiolorum, quibus vesiculæ insident, in folia metamorphosis nullibi magis liquidò quàm in $F$. Acinariá conspicitur, an verò idem per omnes huic congeneres valeat nequaquàm constat. $V$ arietas $\beta$ in Herbario Linnæano eidem cui $\alpha$ agglutinata chartæ servatur: specie forsan differt, sed, licet habitu discrepet, characteres nullos specificos in præsens perspicio.

a. F. Acinaria ramus, magn. nat.

b. ejusdem pars, maon. auct. - - - - 6 .

c. receptacula, cum vesiculis, et folio - $-\quad-4$.

d. receptaculum horizontalitèr dissectum -2.

e. var. $\beta$ portio, magn. nat.

- Iconas Fuci quondam $F$. Acinaria nuncupati, bonas tradiderunt Donatius atque Esperus, descriptionemque optiman Wulfenius, unde stips satis cognita. Veliem tancn hic delineatam sistere, faceremque, ni vetarent exemplaria va nimis manca ; quà dc re est expectandum donec pax rediens literarum commcreị portas cum botanicis exteris rursùs aperiat. Hune Fucum $F$. linarie folio nominavit Banhinus, quamobrem i. lineariffolius mihi audit. 
Fucus Acinaria, stem sub-cylindrical, filiform, bipinnate: branches mostly alternate, simple: leaves linear, quite entire : vesicles between oblong and pyriform, on flat petioli : receptacles cylindrical, generally solitary.

Fucus acinarins. Lin N. Sp. Pl. II. p. 1628. (excl. syn. omnibus.) Syst. Nat. II. p. 715. Syst. Nat. Ed. Gmel. II. p. 1380. Mant. p. 508.

B. pycnocistus; leaves oblong.

F. pycnocistus. Mertens, MSS.

$\gamma$. megalocarpus; receptacles oblong, undulated, spinous.

In the Southern Ocean. Linnaus.-In the Red Sea, together with var. $\gamma$. Viscount Valentia.-Sent from the East Indies to Dr. Smith. $-\beta$ in the Straits of Corea. Dr. Horner.-Shores of Egypt. Sir Joseph Banks.

Perennial.

Rooт, a largish, expanded, callous disk, sometimes swelling out here and there into knobs, and inclining to creeping.

Fronds, either solitary, or growing two or three together, from two to three feet long, furnished with a stem in general simple, but occasionally once or twice divided, between cylindrical and compressed, filiform, about the thickness of a blackbird's quill, rather flexuose, naked towards the base, but afterwards pinnated throughout its whole length with patent, sub-distichous branches, for the most alternate, the lowest about nine inches long, always longer than the rest, and again pinnated in the same manner as the stem, the rest gradually shortening as they approach the apices, so that the outline of the whole plant is pyramidal, all of them simple, or very rarely forked, separated from each other by short spaces, and plentifully beset with leaves and vesicles : leaves linear, sessile, an inch long, and not a line wide, perforated with mucifluous pores, and furnished with a narrow blackish midrib, their margins quite entire : vesicles very numerous, oblong, decurrent at the base, somewhat smaller than Hemp-seed, altogether empty within, supported upon a short, flat petiolus, which in time lengthens, and changes into a leaf, so that the vesicles are not unfrequently found placed upon the ends of the leaves.

FrUCTIFICATION, situated upon the branches at the axilla of the leaves, consisting of cylindrical receptacles, scarcely a line long, either solitary, or collected two or three together into racemi, nearly sessile, externally uneven on account of the innate spherical tubercles, which are perforated with a minute pore, and contain each a single, oblong seed, surrounded with a pellucid limbus.

CoLOR, in the fresh plant most probably a deep brownish green, when dried, blackish.

SUBSTANCE, of the stem coriaceous, inclining to ligneous near the root, of the leaves cartilaginous, thickish, and tough.

$\beta$ differs from $\alpha$ principally in having leaves much shorter, and of double the width, of an oblong form, and paler color :-the specimen of this plant sent me by Professor Mertens had its branches nearly covered with fructification and vesicles, both which were almost wholly wanting in those from Egypt, which latter liad longer, sometimes forked leaves.

Of $\gamma$, I have seen only a single specimen, the leaves of which were like those of $\alpha$, but thinly scattered; on the other hand there was a great quantity of receptacles, of an oblong shape, two lines long, and nearly one wide, flattish, slight tly curled and waved, and beset with small spines at their margins.

Oвs. When dried it does not adhere in the least to paper:-there appears no doubt of the receptacles turning into leaves after they have discharged their seeds, or of the same being the case in the var. $\gamma$, the fructification of which then loses its spines:- the whole plant is remarkably smooth.

In the case of this Fucus, as before in those of $F$. fastigiatus and F. rubens, I have relied upon the authority of the Herbarium, in preference to that of the writings of Limnæus, but I must again express my doubts how far it was right to do so. The plant here figured, of which no representation has ever yet been given, and which appears to be known to no author upon the subject, has a habit widely different from that of the * species which comnonly passes among botanists under the title of $F$. Acinaria, and to which there can be no question but that Linnæus himself originally intended to apply that name, as in the Species Plantarum he particularly refers to the older writers, who apparently knew no other. The latter plant is a native of the Mediterranean, and is remarkable for its rough exterior, muricated stem, and spherical vesicles, while on the other hand, the smooth, almost polished, surface, and oblong, or sub-pyriform, air-bladders are no less characteristic of the Fucus before us. Both of them have leaves equally entire, which in all probability gave rise to the confusion between them, as in this circumstance they differ from every otler individual of the family of $F$. natans at present known, excepting only $F$. heterophyllus of the Banksian Herbarium, which has also its smaller leaves and receptacles of the sane shape, but bears, in addition to these, leaves of a widely oblong form, many times larger than the others, among which they grow mixed, and produces splerical vesicles terminated by an arista. The changing of the footstalks of the air-bladders into leaves is in no species more conspicuous than in $F$. Acinaria : it may, however, at the same time, admit of doubt whether the same takes place in all

* Good figures of this plant have been giveu by Donati and Esper, and an excellent description by Wulfen, so that it is a Fucus sufficiently known. At the same time, I should have been very glad to have fixured it at once, and I wonld have done so, had not my specimens been unluchily too imperfect, on which account it is neressary to wait till the return of peace restores our intercoursc with foreign Botanists Bauhin, and the older naturalists, called this species Fucus Linarice folio, which name, changed ouly to $F$. linariifolius, I purpose to contince. 
Win

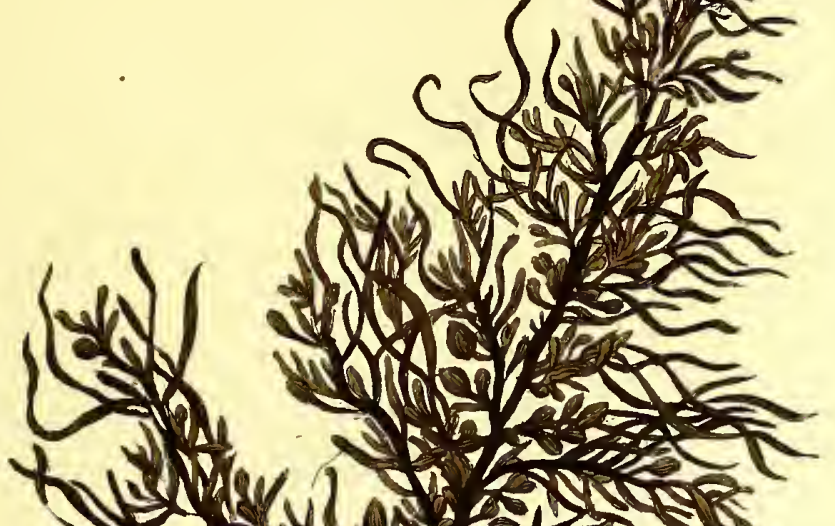

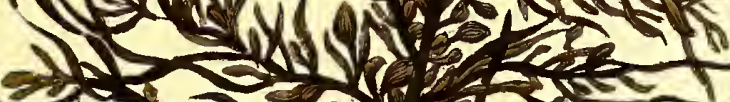

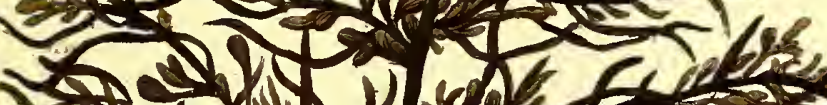

ag 10

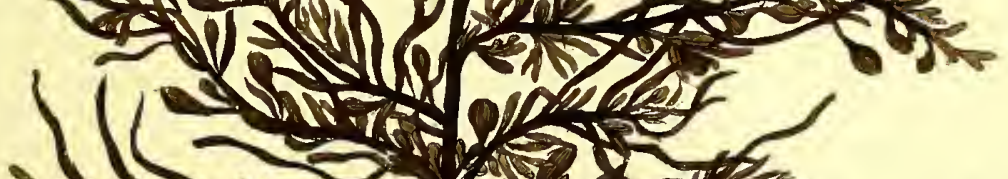

-M
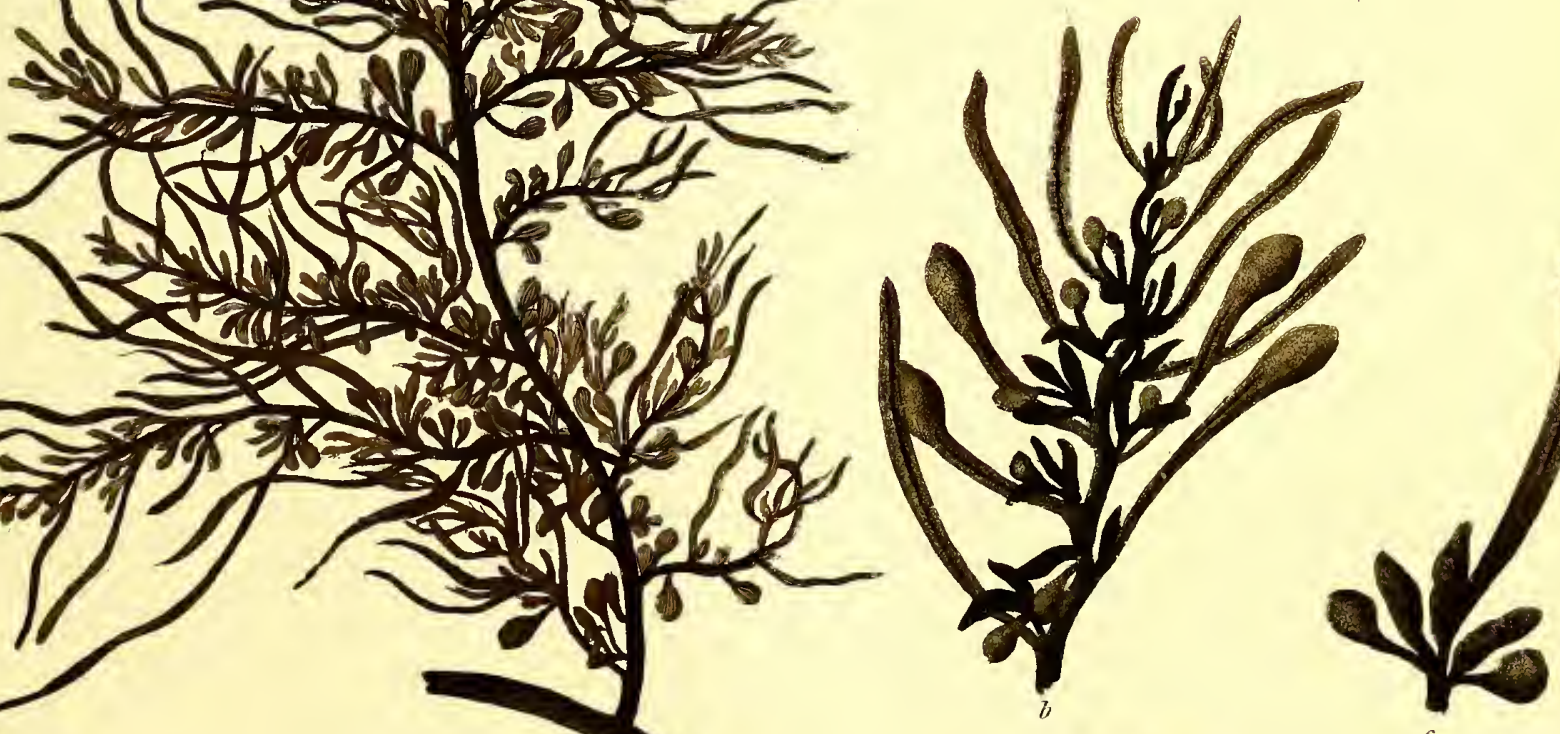

Fucus extanaria. 

the congeners of this plant. The variety $\beta$ is preserved in the Linnæan Herbarium, attached to the same sheet of paper with the more common appearance of the Fucus: it is probably a distinct species, but I at present see no characters upon which I could depend in making it so.

a. Branch of F. Acinaria, natural size.

b. part of the same, magnified - - $\quad-\quad 6$.

c. receptacles, with a leaf, and vesicles - $\quad-\quad 4$.

d. receptacle cut through horizontally - - $\quad$ - 2.

e. Piece of var. $\beta$, natural size.

\section{0.-F U G S A Q U I F O L U S.}

Fracus, caule filiforni, compresso, pinnato; ramis alternis, simplicibus; foliis oblongo-spatulatis, repando-dentatis; vesiculis petiolatis, sphæricis, mucronulatis; petiolis compressis ; receptaculis cylindraceis, racemosis.

Ha bita in Mari Indico, in Freto Insularum Sunda. D. Watts.

\section{Perennis?}

RADIX nondùm a me visa.

Frons longitudinis hactenùs incognitæ, (cùm ea quæ adhuc accepi exemplaria, quamvis tripedalia et ultrà, tantummodò stirpis majoris essent partes, basi apiceque paritèr carentes) caule instructa plano-compresso, ubique lineari, diametro sesquilineæ, semper, quantum vidi, indiviso, sed ramis alternis, disticlis, intervallo inter singulos circitèr bipollicari, per totam longitudinem instructo, cætera nudo; rami longitudine vix tripollicares, compressi, caule tenuiores, lineares, simplices, vel basin versus ramulo uno alteroque brevissimo instructi, foliosi, et vesiculiferi ; folia nunc solitaria, nunc, ut sæpiùs accidit, bina, majore cum duplo minore associato, alterna, ex oblongo spatulata, sessilia, pollicem longa, nervo nigricante tenui mediotenùs percursa, margine repando-dentata; vesicula sphæricæ, Pisi sativi seminis magnitudine, foliorum ad alas sitæ, sparsæ, nequaquànı frequentes, intùs omnind cavæ et lævigatæ, petiolo brevi compresso fulta, apice mucronatæ mucrone exiguo.

FrUctificatro in ramis disposita, axillaris, e receptaculis constat-exiguis, teretiusculis, filiformibus, simplicibus bifurcisque, plurimis in racemum congestis, extrinsecùs inæqualibus, pertusisque undique poris exiguis, sub quibus latent receptacula globosa, innata, singula semina duo vel tria fusca pyriformia includentia.

Color, qui recentis forsan olivaceus, est in exsiccatâ, æquè atque iterùm madefaetâ, intensè spadiceo-fuscus: caulis niger.

Substantia ubique coriacea, lenta, tenax.

Oвs. In hoc quoque Fuco, sicut est olim sub $F$. natante observatum, ramorum foliorumque dispositio alterna, ob totius plantæ habitum sub-spiralitèr tortum, non semper liquet;-exsiccata chartæ neutiquàm adhæret.

Exemplaria hujus Fuci, commista aliquot aliis $\boldsymbol{F}$. natanti affinibus speciebus, benevolè mihi septem abhìnc annis misit D. G. Watts, qui ex Indiâ Orientali redux legit. Stirpem visu raram esse suspicor, cùm in Herbario observârim nullo, neque aliunde unquam acceperim, sitque planta quæ, vel sicca vel madida, aded primo aspectu est notabilis, ut etian minus cautorum oculos ad se trahat; quâ de re, quanivis, uti suprà memoratur, specimina nostra sint ad utramque extremitatem manca, persuasum mili habeo esse revera a reliquis distinctissimam, nec dubitavi pro novâ specie hic agnitam exhibere. Quantum e crescendi modo, substantiâ, partiumque singularum magnitudine conjicere licet, verisimile videtur ad magnam accrescere molem, vixque ullum extare in hâc familiâ Fucum qui vel majore vel etiam pari gaudeat. Foliorum forma, totius plantæ color, et textura coriacea, necnon vesicularum infrequentèr sparsarum magnitudo notas, per quas a congeneribus dignoscitur, certissimas suppeditant. Dentes, qui foliorum margines cingunt, sunt variabiles; plerumque magni, acuti, et numerosi occurrunt, sed aliquando propemodùm sunt obsoleti. Nomeu deprompsi a similitudine, quæ interest summa, inter folia lujus Fuci madida atque ea Ilicis aquifolii, quam Aquifolium modó Tournefortius et veteres dixerant.

a. F. aquifolii pars, magn. nat.

b. folium, et rcceptaculorum racemus, magn. auct. 6 .

c. receptaculum horizontalitèr dissectum. - - $\mathbf{Q}$. 
Ficcus aquifolius, stem filiform, compressed, pinnated; branches alternate, simple ; leaves between oblong and spatulate, repando-dentate; vesicles petiolate, spherical, tipped with a small point; petioli, compressed; receptacles cylindrical, racemose.

In the Straits of Sunda. Mr. Watts.

Peremial?

Root, I have never yet seen.

FroND, of unknown length, (as the specimens which I have received, although three feet and more long, were only parts of larger plants, and equally imperfect at both' ends,) furnished with a stem between flat and compressed, about a line and half in diameter, and every where linear, never, as far as I have observed, divided, but beset throughout its whole length with alternate distichous branches, separated from each other by intervals of nearly two inches, in other respects naked; branches scarcely three inches long, compressed, linear, more narrow than the stem, either simple, or torvards the base provided with one or two extremely short ramuli, bearing both leaves and vesicles; leaves, in some instances, solitary, but more frequently growing in pairs, in which a larger is joined with one not half its size, alternate, sessile, of a form betiveen oblong and spatulate, an inch in length, funished with a thin blackish nerve that does not in general extend above half way through them, their margins repando-dentate; vesicles spherical, about the size of the seeds of Pisum sativum, situated at the alæ of the leaves, scattered, unfrequent, altogether hollow and smooth within, supported upon a short and compressed petiolus, and tipped at their apices with a small point.

Fructificatios, placed upon the branches, axillary, consisting of small, cylindrical, filiform receptacles, either simple or forked, many of them collected into a racemus, externally uneven, and every where perforated with minute pores, under which lie globular, imnate receptacles, each of them cuntaining two or three brown pyriform seeds.

CoLOR, though probably an olive green when fresh, turns in drying to a deep rich chocolate brown, and continues so after it is again moistened; in the stem black.

Substance, throughout the whole plant coriaceous, flexible, and tough.

OBs. In this Fucus, as well as in F. natans, as has been already remarked under that species, the alternate arrangement of the branches and leaves is by no means always perceptible at first sight, because the whole plant is twisted in a spiral manner:- -when dry, it does not adhere in the least to paper.

It is now seven years since I received my specimens of the present plant, which were very obligingly communicated to me by Mr. George Watts, who gathered it in small quantities, mixed with some others of the affinities of $F$. natans, upon his passage through the Straits of Sunda, when returning from India to England. Having received it from no other quarter, nor observed it in any Herbarium, I am led to apprehend it is a Fucus of unfrequent occurrence; and this opinion derives some confirmation from the circumstance of its being sufficiently unlike the rest, whether in a dry or moist state, to attract the notice of even a superficial observer; on which account I feel the strongest persuasion of its being a distinct species, and have consequently not hesitated here to publish it as such, although my speciniens, as above mentioned, are unfortunately imperfect at each extremity. From its mode of growth, its substance, and the size of its several parts, a probable conjecture may be formed that it attains to a considerable magnitude, and yields in this respect to few, if any, of the same family. Its most striking characteristic marks consist in the color and coriaceous texture of the whole, the form of the leaves, and the unusual size of the scattered vesicles. No dependence is to be placed upon the teeth that fringe the edges of the leaves, as, though they are in general both large, sharp, and numerous, they are sometimes the very reverse of these, and are occasionally almost obsolete. The name is derived from the strong resemblance in shape and appearance, between the leaves, when wet, and those of the Holly, which, although referred by Limmeus to the genus, Ilex, had with Tounefort, and the more ancient botanists, passed inder the single name of the Aquifolium.

a. part of $F$. aquifolius, natural size.

b. leaf; and cluster of receptacles, magnified -

c. receptacle cut through horizontally
- 6.

- 2. 


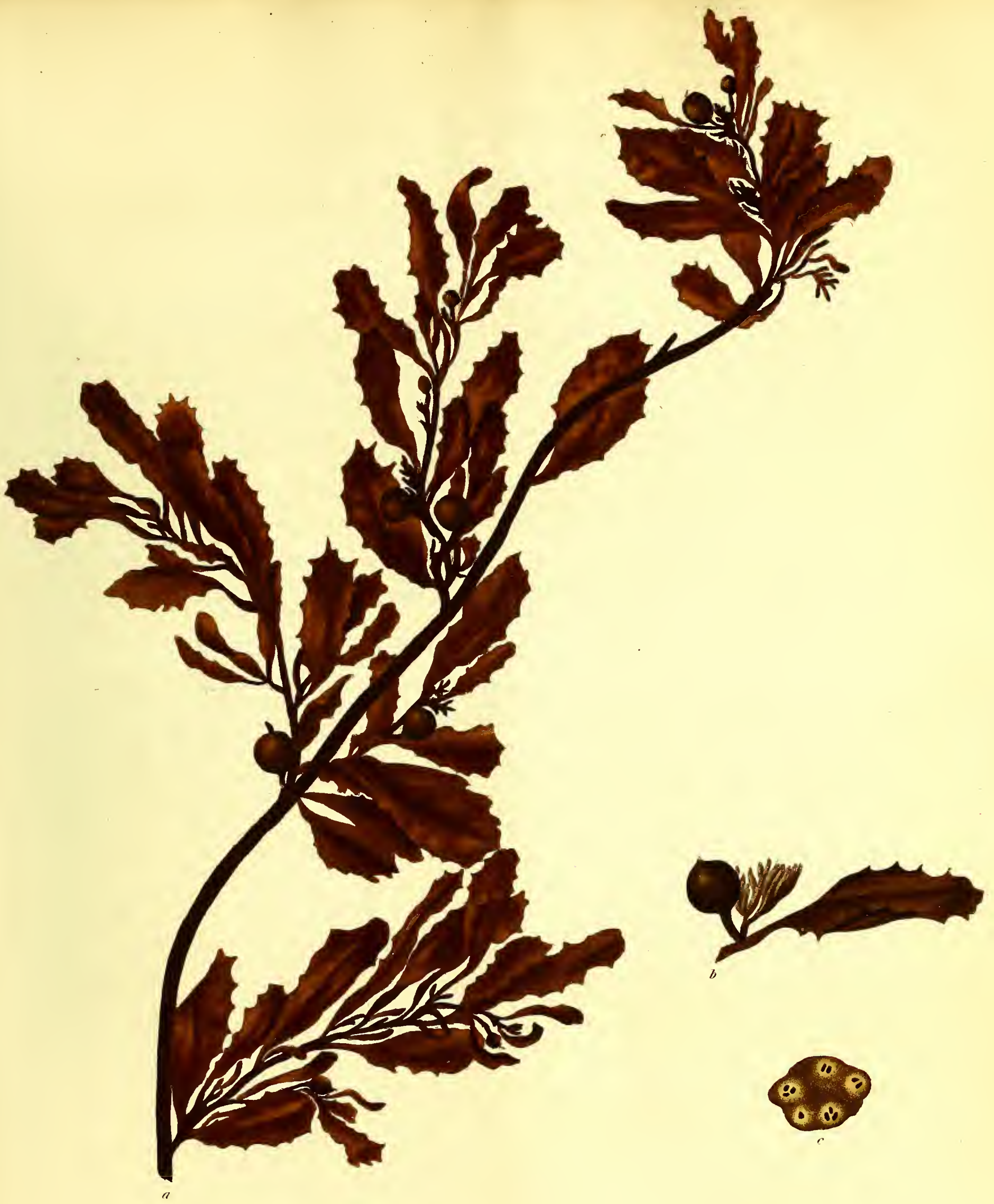

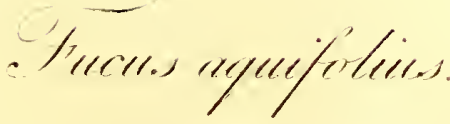



Fucus, caule filiformi, terete, pinnato ; ramis alternis, simplicibus; foliis elliptico-subrotundis, repando-dentatis ; vesiculis petiolatis, sphæricis, petiolis planis; receptaculis compressis, linearibus, serratis.

Haвiтat in Mari Indico, in Freto Insularum Sunda. D. Watts.

\section{Perennis?}

Radix nondum mihi visa.

Fro N s tri- quadri-pedalis, et ultrà, caule instructa terete, vel levitèr compresso, filiformi, Merula pennæ crassitie, nunquam, quantum vidi, diviso, sed ramis alternis, sub-distichis, horizontalibus, remotiusculis, per totan longitudinem obsito, cætera, nisi ad apicem, nudo; rami basi proximi palman et ultrà longi, hìnc seusìm breviores, superiores simplices, inferiores aliis brevissimis, alternis, laxè dispositis pinnati, omnes folia vesiculasque sustentantes; folia numerosa, alterna, sessilia, unguem circitèr longa, figuræ latè ellipticæ, vel ex ellipticâ subrotundæ, poris frequentibus pertusa, nervo tenui, nigricante, juxta medium evanescente instructa, margine crispatula, et repando-dentata, dentibus exiguis crebris; vesicula foliis immixtæ, copiosæ, sphæricæ, Vicia sative seminibus aliquantùm minores, nunc solitariæ, nunc binæ ternæve, petiulo perbrevi, plano, sursùm dilatato insidentes, membranâ angustâ foliaceâ sæpiùs ciuctæ, intùs omninò cavæ.

FRUCTIF1CAT1O foliorum ad alas in ramis sita, e receptaculis constat compressis, linearibus, lineam unam alteramve longis, profundè serrato-dentatis, in racemum congestis, sessilibus, simplicibusque, extrinsecus inæqualibus, et poris exiguis pertusis, sub quibus latent receptacula sphærica, innata, singula semina aliquot subrotunda, fusca, limbo pellucido cincta includentia.

CoLOR plantæ recentis fortè dilutè olivaceus; exsiccata, æquè ac iterùm madefacta, amœeǹ̀ herbaceo-fuscescens, et diaphanus.

SUBSTANTIA in caule coriacea, succosa, in foliis, et vesiculis, membranacea, tenuis, et, si in aquâ dulci retineatur, flaccida.

Oвs. Habitus totius plantæ crispatulus:- exsiccata chartæ nequaquàm adhæret.

Omnes licet Fuci $F$. natanti congeneres formæ habitûsque insigniantur elegantiâ, vix una inter hos hactenus innotuit species cui palmam in hisce cedit $F$. ilicifotius, neque, si ejus indolem crescendique modum spectes, unam reperies, quæ luculentiùs demonstrat œconomiam Naturæ in his plantis fingendis, quầ receptacula, seminibus jam sparsis, in nova folia vesiculasque mutantur. Obtinet profecto idem in plurimis aliis individuis, et præsertim in iis, quæ ad eandem, cui hæc, familiam annumerantur; id quod satis cuivis erit manifestum qui vel tantillum temporis in his stirpibus investigandis insumpserit, et hìnc quoque liquidd patet, unde pori in foliorum plurimorum superficie notabiles originem trahunt, cùm hi sint nihil aliud quàm foraminum istorum exiguorum reliquiæ, per quæ olim sunt elapsa semina. Quantumvis autem latè loc diffundatur principium, est nililominus, sicut* jam olìm in hoc opere animadverti, nequaquàm universale, neque ullus datur error, a quo cautiùs est cavendum, quàm ille eorum, qui, quia Fucorum quorundam receptacula effeta in folia vesiculasque transire viderunt, ducunt idcircò pro indubio folia vesiculasque omnes tale exordium habere; quum contrà sæpe reperiuntur exemplaria his onusta quæ nihil unquam tulerunt fructûs, horumque ortus, nisi valde fallor, illum fructificationis nunquam non antecedit. Per receptaculorum in folia metamorphosin faciem $F$. ilicifolius perquàm singularem induit, et stirps inde quasi foliis heteromorphis, his latis, subrotundis, ambitu denticulatis, illis exiguis, angustis, linearibus, et profundè serratis instructa apparet. Verisimile videtur plurima ex his minoribus, dummodd ad majorum unquam staturam excrescant, decidere solere, quod ni fiat planta tantâ foliorum copiâ gravata evaderet, quantæ nullum reperimus inter Fucos exemplum. Arctissimam habet F. ilicifolius affinitatem cum $\mathscr{F}$. natantis var. $\beta$, a quâ distinguunt folia subrotunda, color, substantia tenuis, et receptacula spinosa, qua, simùl considerata, speciei characteres maximè essentiales ministrant. Nomen non tàm ducitur a similitudine cum aliquâ ex ilicibus Linnæanis, quam ab illâ, quæ interest maxima, cum Quercu Ilice, et Quercu

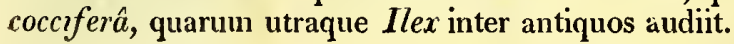
a. F. ilicifolius, magn. nat.
b. ramus, cum receptaculis, magn. auct. $\quad$ - $\quad-6$.
c. receptacula - - - - - -4 .
$\begin{array}{lllll}\text { d. receptalum horizontalitér dissectum } & - & - & - & - \\ \text { e. semina } & - & - & - & -\end{array}$
f. ramus cum receptaculis jam in folia vesiculasque abe- untibus, magn. nat.
g. ejusdem pars, magn. auct. $\quad-\quad$ - $\quad$ - $\quad$ - $\quad$ - 5 .

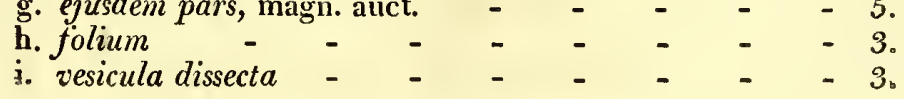

- Confer Notam sub F. turbinato, p. 50. 
Fucus ilicifolius, stem filiform, cylindrical, pinnated; branches alternate, simple; leaves between elliptical and roundish, repando-dentate; vesicles petiolate, spherical, petioli flat; receptacles compressed, linear, serrated.

In the Straits of Sunda. Mr. G. Watts.

\section{Perennial?}

Root, I have not yet seen.

FroND, three or four feet, or eren more, in length, provided with a filiform stem, either cylindrical, or slightly compressed, of the thickness of a blackbird's quill, never, as far as I have seen, divided, but beset throughout its whole length with alternate, sub-distichous, horizontal, rather remote branches, in other respects naked, except towards the apices; branches, nearest the base, a palm and more long, thence gradually shortening, the upper ones simple, the lower ones loosely pinnated with others, which are alternate, and extremely short, all of them bear leaves and vesicles; leaves, numerous, alternate, sessile, about half an inch long, in form widely elliptical, or inclining to roundish, perforated with many pores, and furnished with a thin dark midrib, which disappears about the centre, their nıargins curled, and repando-dentate, with frequent small teeth; vesicles mixed with the leaves, plentiful, spherical, somewhat smaller than the seeds of Vicia sativa, in some cases solitary, in others growing two or three together, supported upon a very short, flat petiolus, widened upwards, generally surrounded with a narrow foliaceous membrane, internally quite hollow.

FRUCTIFICATION, situated upon the branches at the axillæe of the leaves, consisting of compressed, linear receptacles, one or two lines long, deeply serrato-dentate, sessile, simple, collected into racemi, externally unevell, and perforated with minute pores, under which lie innate spherical receptacles, each containing a few roundish, brown seeds, surrounded with a pellucid limbus.

Color, in the recent plant, probably a pale olive-green; when dry, as well as if again moistened, a pleasant, pale, greenish brown, and semitransparent.

SUBSTANCE, of the stem, coriaceous, of the leaves and vesicles, membranaceous and thin, if kept in fresh water, soon becoming flaccid.

Oвs. The liabit of the whole plant inclines to curled:-when dry, it does not in the least adhere to paper.

The whole of the Fuci allied to $F$. natans are remarkable for the elegance of their form and general appearance, but, perhaps, scarcely any one among them is in these respects so conspicuous as the present, and certainly, if regarded as an interesting species, no one is more deserving of our attention; for it is impossible that any should afford a more decisive proof of the economy of nature in the growth of these plants, as far as relates to the changing of the pods, after they have discharged their fructification, both into vesicles and leaves. That such is the case in many other Fuci, and especially in those which are congeners to $F$. ilicifolius, is a point of which a little attention will be fully sufficient to persuade us, and we may hence satisfactorily account for the pores that are observable upon the surface of their leaves in general, which are in reality the remains of the apertures through which the seeds have escaped: but, however prevalent this principle nay be, I have * already in the course of this work had occasion to express my conviction, that it is not universal, and I would wish particularly to guard my readers against being hurried into the conclusion, that, because the receptacles of some Fuci turn, when empty, into leaves and air-bladders, it must therefore of necessity follow, that the latter are indebted for their origin to the former. No conclusion can be more erroneous, for both leaves and vesicles may be seen upon individuals, in which there neither is, nor ever has been, any fructification, and I feel no doubt that each of these parts naturally precedes the fruit in the growth of the plants. The metamorphosis of the receptacles gives $F$. ilicifolius a very singular appearance, making it look as if it were furnished with two different kinds of leaves, the one wide, roundish, and fringed with minute teeth, the other small, narrow, linear, and deeply serrated. It seems probable that, if these latter ever attain to the size of the former, some of them drop off, or the specimens must be crovded in a manner of which no other species affords an instance. The nearest affinity of $F$. ilicifolius is the var. $\beta$ of $F$.natans, from which it differs in its roundish leaves, its color, its thin substance, and its spinous receptacles, which together afford the strong characters of the plant. Its name is derived, not so much from the resemblance of the leaves to any of the Linnæan Ilices, as to those of the Quercus coccifera and Quercus llex, each of which was originally called an Ilex.

a. F. ilicifolius, natural size.

b. branch, with receptacles, magnified - - - $\quad 6$.

c. receptacles - - - - - - - -4.

d. receptacle cut through horizontally - $\quad$ - $\quad$ - 2.

e. seeds - - - - - - - - - 1 .

f. branch with receptacles turning to leaves and vesicles, natural size.

g. part of the same, magnified - $\quad$ - $\quad$ - $\quad 5$.

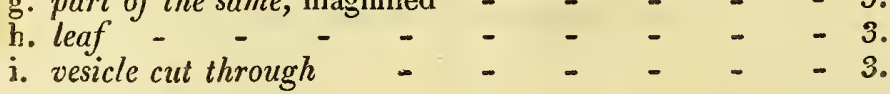



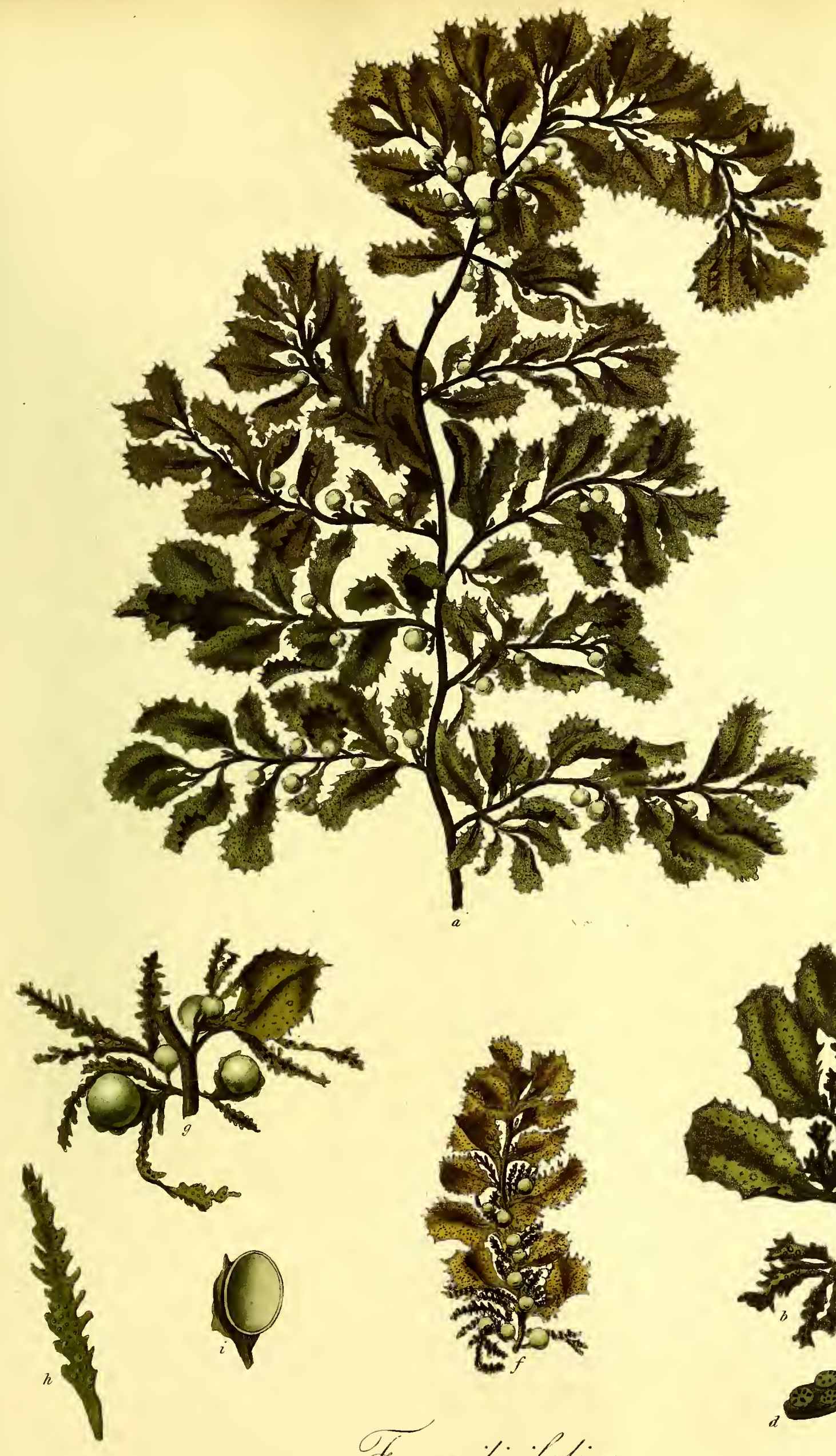

Fucus ilicifolies.

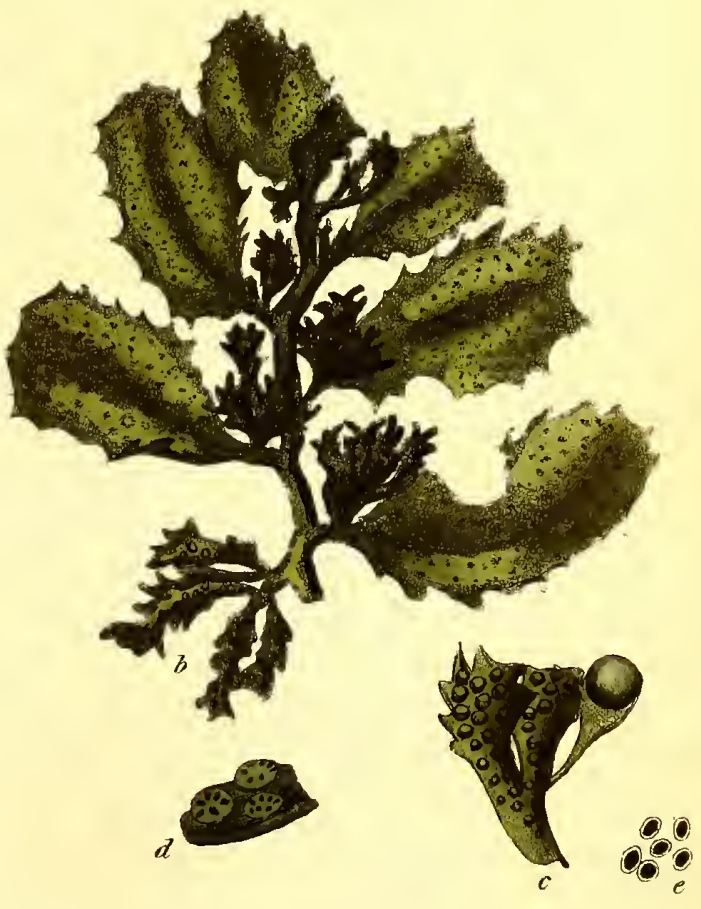



Fucus, fronde coriaceâ, filiformi, terete, dichotomâ, apicibus obtusis ; vesiculis sparsis, innatis, ellipticis, solitarïs, fronde latioribus.

Ha вıтат inter rejectamenta maris apud Cunnamara in Hiberniâ. D. J. T. Mackay.

Perennis.

RADIX discus explanatus.

Frons longitudine spithamæa, vel dodrantalis, vel etiam pedalis, basin versus levitèr compressa, pennæque corvinæ crassitie, hìnc ferè statìm cylindrica, et sensìm, sed lenissimè, attenuata, ut apices vix pennæ passerinæ magnitudinenn superent, dichotomiis juxta basin incipientibus, novies, decies, vel pluries, intervallo brevi, attamen incerto, repetitis, divisa, furcis patentibus, summis patenti-divaricatis, segmentis fastigiatis, apicibus rotundatis obtusis : ramis, præesertim superioribus, innascuntur $V$ esicula solitariæ, ellipticæ, Cannabis sativa seminis magnitudine, in ipsâ frondis sub. stantiâ immersæ, et ejusdem cum illâ coloris, juxta furcas plerumque dispositæ, intùs cavæ, nisi quodd fibris aliquot albis reticulatis sint instructæ.

Fructificatio nondùm visa.

Color olivaceo-viridis, prope basin intensior et nigricans, apices versus dilutior, flavescenti tinctus, et subdiaphanus ; exsiccate nigrescens.

SuBSTA NT I A coriaceo-cartilaginea, lenta, tenax; exsiccatæ rigida et fragilis.

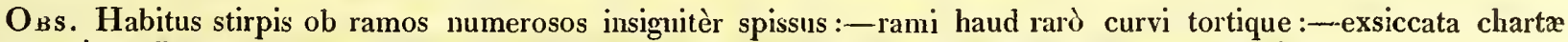
nequaquàm adhæret :-aquam dulcem colore flavicante tingit, et in hâc servata odorem acrem spirat.

Primus hunc Fucum, a nemine antehàc, quod scio, observatum, Nereidi Britannicæ adjecit. D. Jacobus Townshend Mackay, cui exemplar hìc depictum debeo, et cujus nomine, cùm nulla ejus hucusque descriptio extet, insignivi; memor quantum ille ad harum Insularum scientiam naturalem promovendam præstitit, et præestìm quot * stirpes peregrinas in Hiberniâ detexit, dum regiones ejus australes, vix aut ne vix unquiam anteà a botanico lustratas pede, singulari studio et successu, auspiciis Dni Scott, plus unâ vice investigaret. Iter per has partes æstate MDCCCV faciens invenit stirpem quam hæc tabula sistit, in parvâ quâdam crepidine juxta terminum superiorem sinûs "Birtebui" dicti, prope collem Cahil in Cunnamarâ, sed nusquàm alibi. Facit me per epistolas certiorem se haud unum exemplar quod rupibus innascebatur deprehendere potuisse, sed omnia liberè in littore jacere, et tantâ quidem copiâ ut totum ferè spatium quâ sunt a mari rejecta cooperirent. Adfuit etiam $F$. nodosus, qui, quantumvis esset saxorum finitimorum frequentissimus incola, non nisi pari modo, nihilo scilicet affixus, hujus loci occurrit, et uterque in pilas, vi fortè æestûs, est volutatus, neque tamen propter illud desierant crescere, sed surculis creberrimis a radice, quæ globuli centrum occupavit, emicantibus, se habitu spisso jam suprà memorato induerunt. Ex $F$. Mackaii texturâ necnon consuetudine illarum, quibus maximè est affinis, specierum, augurari licet fructum hyeme modò provenire, et hâc de causâ fructiferum in præsens cernere vix est quod speremus, cùm nemo botanicus prope locum ejus natalem habitet, vel iter ibi facere eâ anni tempestate sibi facilè in animum inducat. Est autem stirps quả notis nimis conspicuis insignitur ut sit locus ad timendum ne detur ulla in discriminandâ difíicultas, nec dubitare. possumus quin sit ad illam Fucorum releganda tribum, quam Fucos proprios appellant Weberus Molniusque, feratque receptacula frondis ad apices sita, similia eorum in $F$. canaliculato et $F$. disticho observatorum. Sedes ei in Fucorum Britannicorum Catalogo inter $\boldsymbol{F}$. nodosum et $\boldsymbol{F}$. canaliculatum media debetur, talemque habet cum his, quorum unus et alter in eodem quo F. Mackaii loco abundè provenit, affinitatem, ut, si inter Algas submersas aliquid liybridè generari credamus, suspicari esset in promptu originem notham ab his duobus commistis trahere. Quoad habitum, formam, colorem, magnitudinem, ramorum divisionem, et crescendi modum, cum posteriore convenit, a quo frons teres, nunquain vel minimum canaliculata, primo aspectu distinguit; ut vesiculas taceam, qux characterem maximè essentialem subıninistrant. Hæ, magnitudine nodd demptâ, eas $F$. nodosi omnimodè referunt, et, sicut illæ, e totâ frondis substantiầ tumidâ conflantur. In quibusdam surculis penitùs desunt: planta medium versus plerumque occurrunt, ramorunque partem süperiorem non longè a dichotomiis sæpiùs occupant : semper, quantum vidi, solitariæ reperiuntur, quanvis fieri potest ut dentur exemplaria in quibus dux, ramis diversis innata, tintum sibi invicem adpropinquent ut propemodum in unam confluere videantur.

a. F. Mackaii, nıgn. nat.

b. vesicula dissecta, magn. auct. - _ _ - $\quad 5$.

c. fibre reticulata e vesiculâ excerpte - $\quad-\quad 1$.

\footnotetext{
Ex his plurima sunt Musci Lichenesque, necdum evulgantur, sed satis aupla messis librum, cui titulus Engrlish Botany, jamjam ditavit ut nullus sit dubitationi locus quin laudes nostras hic optimè nereatur. Testes lujus, Saxifraga Geum, Arcnaria ciliata, Turritis alpina, Schanus
fuscus, necnon Hymenophyllum alatum capsulis instructum.
} 
Fucus Mackaii, frond coriaceous, cylindrical, filiform, dichotomous, the apices blunt; vesicles scattered, innate, elliptical, solitary, wider than the frond.

Among the rejectamenta of the sea in a sheltered bay at Cunnamara, in the county of Galway. $M r . J$. T. Mackay.

Perennial.

Root, an expanded callous disk.

Fron D, generally from five to nine inches, but sometimes reacling to a foot in length, slightly compressed, and about the size of a crow's quill, near the base, but soon becoming cylindrical, and gradually narrowed, though too slightly to be perceptible, so that at the extremities the size is scarcely equal to a sparrow's quill: the frond is divided nine or ten times, or even more frequently, with dichotomies that begin near the base, and are afterwards repeated at short, but uncertain, distances; the forks are patent, and the upper ones between patent and divaricated, the segments all of equal height; the apices short, rounded, and blunt: the branches, especially towards the upper part of the frond, are here and there swelled into solitary elliptical vesicles, of the size of Hemp-seed, of the same color as the rest of the plant, generally disposed near the dichotomies, internally hollow, excepting a few white reticulated fibres.

Fructification, at present unknown.

Color, olive-green, darker and blackish near the base, towards the apices pale, tinged with yellow, and somewhat transparent; blackish, when dry.

SUBSTANCE, between coriaceous and cartilaginous, flexible and tough; in a dry state, rigid and brittle.

OBs. Habit very thick and bushy:--branches not unfrequently recurved and twisted:-when put into fresh water it gives out a great deal of color, and has a strong smell:-when dry it does not adhere in the least to. paper.

For the present very interesting addition to the catalogue of British Fuci, we are indebted to Mr. James Townshend Mackay, to whom I am also obliged for the specimen here figured, and by whose name I have ventured to call it, as I find no description of it in any preceding author, in memory of the services that he has rendered to the botany of these Islands, particularly by his * discoveries in Ireland, the south-west districts of which, a part hitherto least known to Naturalists, he has more than once, under the auspices of Dr. Scott, explored with extraordinary zeal and success. It was in one of these excursions, in the summer of 1805 , that he met with the plant here figured, in a small creek at the upper end of Birtebui Bay, near the hill of Cahil, Cunnamara, but no where else. He. informs me, that he could not find a single specimen attached to the rocks, but it was all lying in loose balls upon the shore, and in snch quantity as entirely to cover that part of the strand upon which it was thrown. With it was $F$. nodosus, which, though produced in great abundance upon rocks in the neighbourhood, seemed to exist at that place only in a similar manner, without being fixed to any thing; both of them being rolled up, as if by the action of the waves, and in that state apparently continuing to grow, and throwing out from the root, which was in the centre, a prodigious number of shoots in all directions, so as to give the thick and bushy appearance above described. From the texture and affinities of F. Mackaii there seems litle doubt of winter being the time in which it bears its fruit, and we can therefore entertain no hope of soon seeing it with fructification, as no botanist lives in the 1eighbourhood, or would easily be persuaded to travel there in such a season. It is a plant, however, too strongly marked for there to be any difficulty in distinguishing it, nor would any naturalist feel a hesitation in referring it to the Fuci proprii of Weber and Mohr, or in concluding that the receptacles are situated at the extremity of the frond, and are similar to those of $F$. canaliculatus or $F$. distichus. Among the British Fuci its natural place would be between $F$. nodosus and F'. canaliculatus, to both of which it is so much allied, that, if hybrid productions may be allowed to exist among the submersed Alga, I should be tempted to suppose it was indebted for its origin to an union of these two species, both which abound in the neighbourhood. In habit, form, color, size, ramification, and mode of growth, it agrees with the latter, from which its sub-cylindrical frond, never in the least inclining to channelled, would alvays be sufficient at first sight to distinguish it, even in the absence of the vesicles, to which it is indebted for its strongest character, and which, except in size, altogether resemble those of $F$. nodusus, being, as in that species, actual swellings of the vhole substance of the frond. These in some shoots are altogether wanting: in general they are found about the middle of the plant, and almost always towards the upper end of the branch, where it beconies forked: they are also regularly solitary, as far as I have seen, although occasionally two may be placed so near to each other oll different branches as to be in soine measure confluent.

a. F. Mackaii, natural size.

b. vesicle cut open, magnified - - - - $\quad 5$.

c. reticulated fibres from the interior of the vesicle - 1 .

" Of these a considerable portion is confined to the Mosses and Lichens, and not at present published, but a sufficient number has been given to the public in English Botany, fully to justify my assertion. Among them are Saxifraga Geum, Arenaria ciliata, Turritis alpina, Echanus fuscus, and Hymenophyllum alatum with fiuit. 

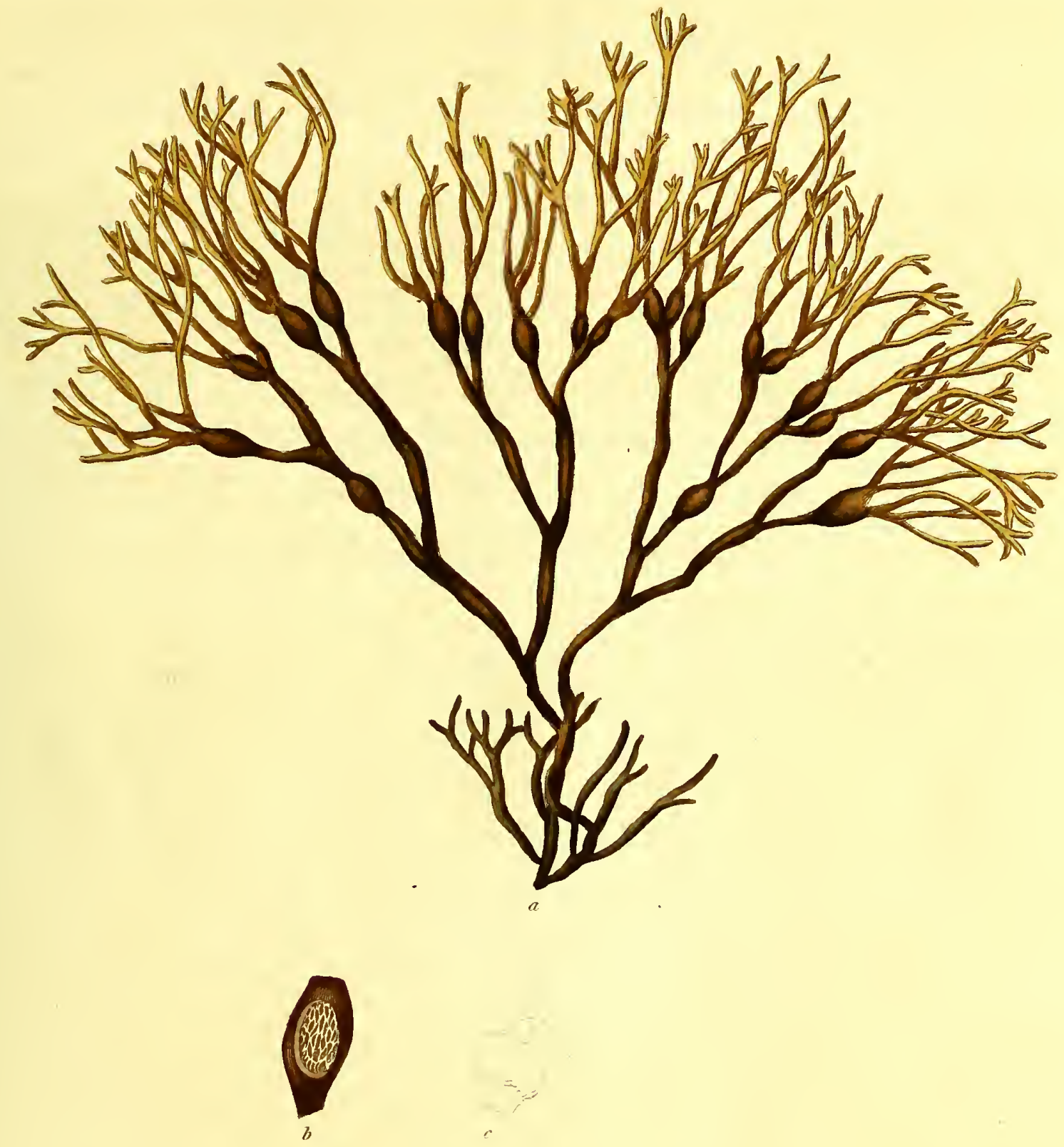

Sturrus. Nuctruie: 

Fucus, caule terete, prostrato, repente, ramosissimo ; ramis erectis, simpliciusculis, pinnatis ; pinnis approximatis, patentibus, oppositis, cylindraceis, obtusis.

Fucus pinnatus. Linn. Suppl. p. 452. Syst. Nat. Ed. Gmel. II. p. 1390.

F. plumaris. ForsKâL, Fl. Agypt. p. 190. Linn. Syst. Nat. Ed. Gmel. II. p. 1988.

Haвıтат in Zeylonâ, in Freto Chilas sub mare. Koenig.-In Mari Rubro. Vicecomes de Valentia.

\section{Perennis?}

RADIx fibrosa, ortu simplex, mox in fibras aliquot semiunguiculares, teretes, lutescentes, ramosas divisa.

Frons * teres, filiformis, pennæ Merulæ crassitie, instructa caule prostrato, repente, pedali, et ultrà, simplice, vel semel atque iterum dichotomo, intervallis haud certis per totam longitudinem e parte inferiore radices, e superiore ramos emittente, cætera nudo; rami vagi, erecti, longitudine palmares, seu dodrantales, plerumque simplices, aut tantùm bifidi, interdùn enormitèr divisi, onnes a basi usque ad apices vestiti pinnis distichis, patentibus, lenitèr falcatis, simplicibus, bi- tri-linearibus, ejusdem ferè cum ramis crassitiei, cylindraceis, sed basi aliquantùm attenuatis, integerrimis, obtusis, approximatis, ut plurimùm oppositis.

FrUCT1FICATIo, teste Iinnæo, " est racemus ex verticillis cum fructificationibus pedicellatis, peltatis, planis ;"quidnam sit hoc nescio, ipse certè nihil simile vidi : in quibusdam exemplaribus, sub lente observatis, maculæ aliquot, tubercula innata referentes, apparuerunt, sed semina nulla, et e plantæ indole hæc non esse fructunı crederem.

Color pulcherrimè gramineo-viridis, sıb-diaphanus, in caule dilutior et stramineus; in aquá dulci asservata, vel soli exposite albescens; exsiccata nitens, quasi vernice obductus.

SuBSTANTiA membranacea, tenuis, tenerrima; in caule, æquè ac in totâ plantâ exsiccatâ, fragilis.

Oвs. Cavendum est ne stirpes juniores tyroni fucum faciant: hæ pinnarum penitus expertes reperiuntur, et ramis filiformibus nudis, ut etiam colore, texturâ, substantiâque, Char ๕ flexilis exemplaria manca mirè simulant:-stirps siccata chartæ ne minimum adhæret.

Cùn omnes illæ stirpes, quotquot sunt a Botanicis Fucorum generi annumeratæ, hujus operis materiem ministrent, postuletque ejus ratio cunctas, quantumvis inter se texturâ vel fructu discrepantes, hìc delineatas sistere, quo nostra Algarun marinarum cognitio firmiori demùm fundamento nitatur, habes, lector botanice, in hâc tabulâ depictam primam e tribu quâdam, quæ formâ et indole adeo a reliquis abhorret, ut sit nemo, vel tantillùm in hâc scientiâ versatus, qui dubitet quin novum propriumque genus summo jure constituat. Plantæ, e quibus hæc constat tribus, omnes, nisi fallor, intra tropicos, qui dicuntur, circulos reperiuntur, neque rupibus saxisque subnıarinis, reliquorum instar Fucorum, infixæ adhærent, sed littora arenosa colunt, atque ea præsertim loca ubi non nisi summo maris æstu alluuntur, per quæ, radicibus in terram sabulosam intrusis, latè perrepunt. Singularis harum indoles Fucos cum † vegetabilibus terrenis quodammodo connectit; sed arctior adhuc inter has amplamque \$Zoophytorum familiam similitudo interest, et quidem tam arcta ut in quibusdam individuis limites ægrè definiantur. Distinguuntur ab omnibus iis Fucorum familïs quæ nobiscum nlagis frequentèr occurrunt per caules prostratos repentes, et per radicum naturam; quamvis enim non desint inter hasce posteriores aliquæ stirpes, quæ saxa plantasque vicinas rependo obtegunt, est tamen earum radix nihil unquam aliud uisi frons ipsa continuata, quæ, simul atque laxatur, in novos surculos elongata assurgit, id quod satis cuivis patebit Botanico $F$. lumbricalem vel $F$. ciliatum inspicienti; dum e contrario $F$. pirnati affiniunıque radices a reliquâ frondis substantiâ toto cœelo discrepant, et ad eum tantummodò finem a naturâa comparatæ videntur, ut plantas in loco sustentent natali, vel fortassè aliquid nutrimenti afferant. Totius quoque frondis textura, utpote quie nihil habet in se gelatinosi aut tenacis, ei Fucorum cæterorum est absimilis, extatque causæ cur hæ species semel exsiccatæ faciem pristimam nunquam recuperent. Inest etiam aliud discrimen, nempe color pulclerrimè gramineo-viridis, qui, si luci objiciatur, citissimè in albunı diaphanum cornei similem mutatur. Tribum haud numerosam crederem, quoniam $\S$ quinque nodo species sunt ab auctoribus recensitæ, nec multæ aliæ jam describendæ hactenùs sunt detectæ. De fructificatione nihil omnind, uti milii apparet, hucusqne innotuit, cùm neque illud, quicquid id est, quod sub plantâ hìc depictâ Jinnæus, neque id quod sub $F$. Chemniziâ suo Esperus pro fructu labuit, receptacula mihi videantur vera, vetetque horum vegetabilium indoles peculiaris, ne aliquid ex analogiâ depromptunı proferre auderemus. Illud tantumıodò hariolari licet, non minùs capsulis quàm structurâ universali a reliquis algis submersis discrepare. De notis quæ $F$. pimnatum ab $F$. taxifolio distinguunt sub

- Ita mili quidem videtur, sed anne sese res ita reverà labeat nequco pro certo dicere, cùm nilhil sit de recente traditum, et stirps iterum madefacta haud bene reviviscat.

† Accuratiùs forsan sim locutus si " cum Charis" dixeram, in qno genere dure saltcm sunt species, $C$. nidifica et $C$. flexilis, quas $F$. pinnatus insignitèr refert; quinam autem sit ille Fucorum naturalis ordo cui lıæ plantæ paritèr sunt aftines nequaquain facile foret dictu. Ab ounibus mirè abludunt; neque ita, quàm solent, auspicatò observâsse milì videntur Wcberus Moluriusque, cùm de lis plantis in opere, Neue Beiträge dicto, p. 318, menorarent, "ilire gesammte Vegetation scheint sich der Fuci corallini Gmelins, oder der Draparnaudischen Zonarien, auffallend zu nähern. Die Frondes ode die Blättclıen sind eben so fein längsgetrichelt, Farbe und Substanz scheint merklich überein zlı kommen." Utriusqne familia color et substantia, quibus nituntur, mihi semper quam diversissimi cunt visi, et licet $F$. Ophioglossum lineis parallelis, $\boldsymbol{U}$. flabelliformis instar, distinguatur, ne una tamen alia species simili modo striata hucusque innotuit, desuutque vel in lác circuli illi concentrici unde nomeu summ aptissimum Zonarice deducunt.

$\ddagger$ Præter similitudinem ex stirpium habitu universali, ut ita dicam, depromptam, quàm tantummodò hìc perstringere volui, optimè est a Webero Mohrioque observatum, “ derstamm verrätb, so zu sagen, äusserlich wenig vegetabilisclien Organismus, ist strohgelb und spröde."

Hæ quinque species sunt $F$. pinnutus L., $F$. taxifolius et $F$. cupressoides Vahl, $F$. Ophioglossum Web. et Mohr, necnon $F$. Chennizia Esper, quibus fortasse est annumeraudus $F$. urarius L., vegetabile, dummodò sit vegetabile, loci perquam dubii, atque etiam, judice Lamourouxio, $F$. sertulurioides Gmel., quæ eadem atque F. taxifolius mihi videtur. Erraverunt Weberus Mohriusque, qui F. triangulurem eiden faniliæ ad. jungendam censuerunt. Stirpes aliquot magnificas his affines e Novâ Hollandiâ secum attulit D. Brown. 
illâ memoratur specie, neque ulla alia datur quâcun fieri potest ut commisceatur. $F$. plumaris Forskaliani nulla in Herbario suo reperiuntur exemplaria, neque tamen eo seciùs pro synonymo indubio citavi, quoniam * descriptio cunctis numeris conveniens scrupulos, me judice, satis omnes exinit.

a. F. pinnatus, magn. nat.

b. rami pars, magn. auct. - - - - - 6 .

c. pinna seorsum, maculata - _ _ _ $\quad$ - 6 .

- Quo meliùs ii e lectoribus quibus Floram AEgyptiaco-Arabicam adeundi non datur facultas de hâc re judicare possint, descriptionen in illo opere datam hìc exscripsi-

" $F$. plumaris; caule tereti, repente, sursum ramosa, ramis plumiformibus; foliis distinctis; vesicis nullis.

66 Color to tius graminen-viridis. C'aulis flavescens, repens, vel prostratus, fundo incumbens: ramis sparsis, confertis ; bipoll. plumiformibus : i. e. foliolis filiformious, distichis, patentibus, confertissimis; rami unguis spatio simplices, dein divisi in 2 vel 3 similes plumas lineari-lanceolatas, sesquipollicares, Singularis prorsus structura."

\section{3.-F U G US PIN N T US.}

Fucus pinnatus, stem cylindrical, prostrate, creeping, much and irregularly branched; branches erect, mostly simple, pinnated; pinna close to each other, patent, opposite, cylindrical, obtuse.

Fucus pimatus. Linn. Suppl. p. 452. Syst. Nat. Ed. Gmel. II. p. 1390.

F. plumaris. Forskår; Fl. Egypt. p. 190. Linn. Syst. Nat. Ed. Gmel. II. p. 1388.

In the Indian Ocean, by Ceylon, under the sea. Koenig.-In the Red Sea. Viscount Valentia.

\section{Perenial?}

Rоот, fibrous, simple at its origin, but afterwards divided in several cylindrical, straw-colored, branching fibres, about a quarter of an inch long.

FroND, * cylindrical, filiform, of the thickness of a blackbird's quill, furnished with a procumbent creeping stem, a foot or more long, either simple, or once or twice dichotoinous, sending forth at uncertain intervals, throughout its whole length, roots from its under, and branches from its upper side, in other respects naked; branches scattered, erect, from five to nine inches long, in general simple or only bifid, but sometimes irregularly divided, all of them beset from base to summit with distichous, patent pinnæ, which are slightly curved, simple, two or three lines long, about the same thickness as the branches, cylindrical, except that they are somewhat attenuated at the base, quite entire, obtuse, placed near to each other, and for the most part opposite.

FrUCtificATION, according to Linnzus, is a racemus, with peltate, fat pedicellate fruit:- what this may allude to, I own, I do not know: I certainly have seen nothing like it:-in some specimens, which $I$ examined under the microscope, there appeared a few spots resembling innate tubercles, but I could discover no seeds, and from the nature of the plant $\mathbf{I}$ do not apprehend that these were the fruit.

Color, a very beautiful bright glass-green, pale and jellowish in the sten ; turning white, if kept in fresh water, or exposed to the sun; when dry shining.

SUBSTANCE, membranaceous, thin, and very tender; brittle in the stem, and also in the whole plant after it is dried.

Ов. Caution is necessary to the unexperienced Botanist, lest he be misled by young specimens of this Fucus, which are entirely destitute of pinnæ, and resemble in their naked filiform branches, as well as in their color, texture, and substance, battered plants of Chara flexilis:-when dry it does not adhere at all to paper.

In compliance with the original intention of this work, in which it was proposed to include whatever plants have been generally considered by botanists as belonging to the tribe of Fuci, however anomalous in their texture and fruit, that thus the foundation may be laid for the better understanding of the marine Algæ in future, I here present my readers with the first species of a family, so widely removed from all the rest, that it would be impossible for the most sceptical to doubt of the propriety of hereafter removing them into a separate genus. The plants which constitute this family are, I believe, all natives of tropical climates, where they grow, not upon rocks, but upon the

\footnotetext{
* This is as it appeared to me, but $I$ would wish to be understood as speaking by no means positively upon the subject, for $I$ find nothing relative to it mentioned by these who have seen it fresh, and the plant, after it has been once dried, recovers very imperfectly in water, which must serve as nyy apology if the description be found to be more than tisually inaccurate。
} 
53.
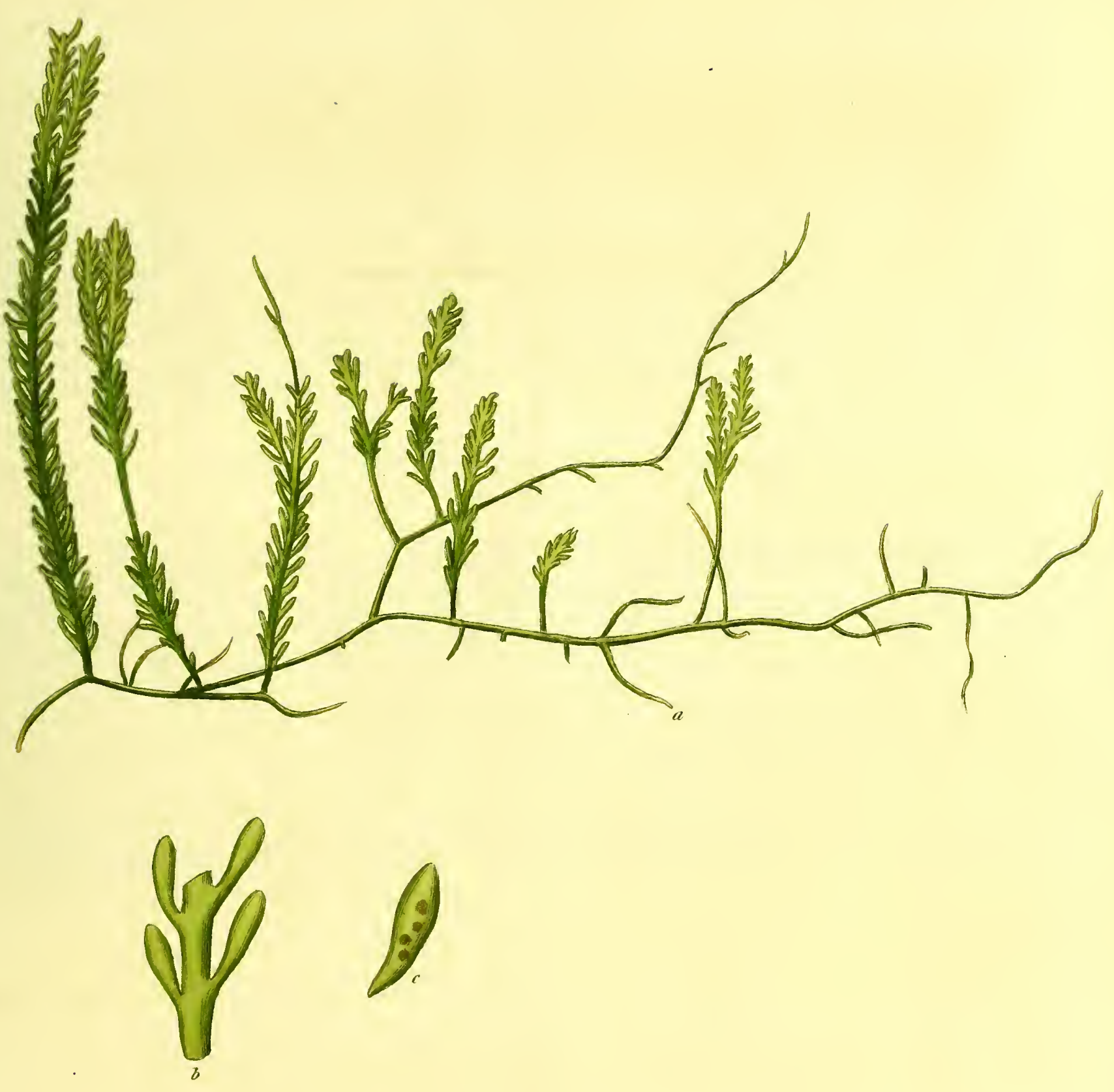

Tucus fienuales. 

sandy shores, and generally near high water mark, creeping in the loose soil, and by their peculiar nature connecting the Fuci in a measure with the * vegetables of the earth, but still more so with the numerous tribes of + Zoophytes, to which some of them are so closely allied that the boundary between them is drawn with difficulty. It will immediately be seen that they differ from the more common families of Fuci in their prostrate creeping stems, and in their roots; for, though there are not wanting among these latter some individuals which also creep along the rocks and neighbouring plants, yet their roots are never any thing more than mere continuations of the frond, which, upon being detached from their hold, immediately lengthen, and expand into new shoots, as may be seen by any botanist who troubles himself to examine $F$. lumbricalis or $F$. ciliatus; whereas in $F$. pinnatus and its congeners, the roots are of a substance wholly unlike the rest of the plant, and are obviously designed to answer no other purposes, besides those of fixing them in their stations, and, probably, of providing sustenance. The texture, too, of the whole frond is dissimilar to that of other Fuci, being altogether destitute of any gelatinous or viscid property, so that they never recover their original appearance after they have been once dried; and, in addition to these peculiarities, the color of the whole is a beautiful grass-green, particularly liable fiom exposure to the air to turn to a transparent hornywhite. I am inclined to think that the family is not a numerous one, only $f$ five species being described by preceding authors, and not many more known to exist. Their fructification I cannot help considering as altogether unknown; for what Linnæus has attributed to the present plant, or Esper to his $F$. Chemnizia, appears to me to be most probably unconnected with the fruit, and the nature of these vegetables is so peculiar, that it is impossible to hazard a conjecture as to the sort of capsules that they are likely to produce. This alone we may venture to say, that they in all probability recede from the other submersed Algre no less in this circumstance than in their general structure. Of the characters that separate $\boldsymbol{F}$. pinnatus from the subject of the following plate, mention is made under that species. There is no other that it in any wise resembles. No specimens of Forskăl's F. plumaris exist in his Herbarium, but I have nevertheless ventured upon quoting it above as a $\$$ certain synonym, his description being so accurate as to leave no doubt in my mind upon the subject.

a. $F$. pinnatus, natural size.

b. part of a branch, magnified - - - - $\quad 6$.

c. pinna separate, marked with spots - - - 6.

* It would perliaps have been more correct to have said, "with the Chare," to some of which, especially $C$. fiexilis and $C$. nidifica, the pre. sent species is considerably allied. To point ont to what other natural division of the Fuci this tribe bear equal resenblance might be difficult, they are so mueh removed from all; and the remark made by Weber and Mohr, in their Neue Beiträge, p. 318, that "in their general pro. perties they approach strikingly to the Fuci corallini of Gmolin, or the Zonaria of Draparnaud," is not, in my opinion, delivered with the usulal accuracy of these acute Botanists. The color and substance of the two families, upon which they rely, have always appeared to nie widely different, and, though $\boldsymbol{F}$. Ophioglossum is marked with parallel lines like $U$. fiabelliformis, I am acquainted with no other species that is so, nor even in this are there any traces of the concentric circles, whenee the Zonaria take their name.

$t$ Besides the resemblance in general habit, to which $I$ intended to allude, it has been justly observed by Weber and Mohr, that the stiff straw-colored stem betrays externally few traces of vegetable organization.

† These five are, the plant here described, F.taxifolius, and $\boldsymbol{F}$. cupressoides, Vahl ; F. Ophioglossum, Weber and Mohr; and $\boldsymbol{F}$. Chemnizia, Esper; to which number is probably to be added, F. uvarius, L., a plant of very doubtful place (if indeed it be a plant at all) and, in the opinion of Lamouroux, $F$. sertularioides, Gmel. which appears to me the same as $F$. taxifolius. The idea cntertained by Weber and Molir, that $F$. triangularis also belongs to the same family is certainly crroneous. Mr. Brown has brought two or three very splendid species of this tribe with him from New Holland.

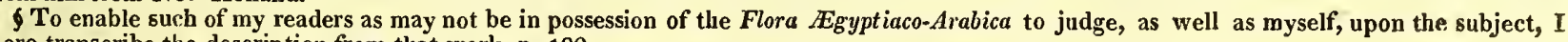
here transeribe the deseription from that work, p. 190.

"F. plumaris; caule tereti, repente, sursum ranıso, ramis plumiformibus; foliis distinctis ; vesicis nullis.

"Color totius gramineo-viridis. Caulis flavescens, repens, vel prostratus, fundo incumbens: ramis sparsis, confertis; bipoll. plumiformibus : i. e. foliolis filiformibus, distichis, patentibus, confertissimis; rami unguis spatio simplices, dein divisi in 2 vel 3 similes plunıs lineari-lanceolatas, sesquipollicares. Singularis prorsus structura." 
Fucus taxifolius, stem cylindrical, prostrate, creeping, much and irregularly branched; branches erect, mostly simple, pinnated; pinnæ close to each other, patent, falcate, opposite, cylindrical, acute.

Fucus taxifolius. VAu , in Skrivt. af Naturhistorie-Selskabet. V. pars 2da. p. 36.

F. sertularioides. Gmelin, Hist. Fuc. p. 151. t. 15. f. 4 ? Linn. Syst. Nat. Ed. Gmel. II. p. 1385?

F. abietinus. KoENIG, MSS.

Near the City of Adampatnam. J. G. Koenig. M. D.-Shores of the Isle of St. Croix. West.-In the Red

Sea. Viscount Valentia.-Coast of New Holland. Mr. Brown.

\section{Perennial?}

Roот, yellowish-brown, half an inch and more long, simple at its origin, but afterwards divided into a few incurved, generally simple fibres.

FROND, cylindrical, filiform, scarcely so thick as a blackbird's quill, furnished with a prostrate, creeping stem, a foot or more long, cylindrical when wet, when dry contracted, and wrinkled, so as never afterwards to recover, in general simple, but occasionally here and there dichotomons, putting forth throughout its whole length at uncertain intervals, roots fron its under and branches from its upper side, in other respects naked; branches scattered, erect, varying in length from three inches to a foot, compressed, filiform, more thin than a sparrow's quill, simple in some specimens, in others bifid, or trifid, or even irregularly divided, naked for the distance of a line or two from their base, afterwards pinnated; pinna distichous, patent, falcate, simple, quite entire, about equal in thickness to the branches, compressed, linear, acute, close to each other, opposite, those towards each extremity of the branches shortest, the intermediate ones longest, and almost half an inch long.

* Fructificatios, at present unknown.

CoLOR, in the pinnæe grass-green, tinged with brown, in the stem pale yellow, and in the branches, particularly towards the base, blackish : the whole plant turns white, if exposed to the sun, or kept in fresh water; when dry, it is destitute of any gloss. dry.

SUBSTANCE, cartilaginous in the stem, in the pinnæe membranaceous, but not very thin; stiff and brittle after it is

OBs. Although this plant in drying does not adhere in the least to paper, the ends of the pinnæ not unfrequently then stick together, so that it is difficult to separate without tearing them.

The resemblance between the present and the preceding Fucus is so strong, and the characters that distinguish them are of a nature so easily to be overlooked, that the description of either, unless written with the greatest caution, and with an actual comparison of specimens, will probably be so drawn up as to be, at the same time, applicable also to the other. After an acknowledgment of this nature, it may reasonably be asked, what are the grounds upon which I have ventured to separate them, and to such a question a more satisfactory answer may be given, by referring to the figures, than by any words which it might be in my power to employ. That the plants are in reality very different, I have no doubt myself, nor could any one doubt it who had ever seen them. The habit, texture, and substance of the two are dissimilar: $F$. pinnatus, when dry, is almost as thin as goldbeater's skin, and floats about with the slightest breath of air, whereas $F$. taxifolius is comparatively stiff and rigid; the color of the latter is darker and more brown than that of the former; the pinnæ are more falcate, not half so thick, by no means attenuated at their bases, and acute, instead of obtuse, at their apices; besides which, they have, when dry, the peculiarity, above noticed, of folding in a measure over each other at the points and adhering together. Koenig, who gathered them both, had distinguished them, and the specimen in the Banksian Herbarium, which is here figured, was communicated by him, under the name of $F$. abietinus. I am, however, inclined to believe that they were confounded by Linnæus; who, though he has preserved in his Hortus Siccus only the subject of the preceding plate under the name of $F$. pinnatus, lad nevertheless given to Acharius the F. taxifolius of Vahl for the same-species, as was observed by + Weber and Mohr during their tour through Sweden. These Botanists consequently consider the two Fuci as synonymous, and I ouglit in justice to observe, that $I$ have no means of disproving their opinion, having never inyseif seen any authentic specimen of Vahl's plant; in spite of which, however, I lave ventured to differ from them, the name of F. taxifolius, which is most happily applied to the one, being by no means equally applicable to the other, and particular mention being made of the acuteness of the pinnæe in the description, which is copious, and contains also other differences of an inferior nature. I have subjoined a mark of doubt to Gmelin's synonym above quoted, and have not even hazarded the adopting of the name used by him, though admirably expressive, because both his figure and description are made from individuals so imperfect, that it is impossible to speak with certainty upon the subject. I am, however, inclined

* West, according to Vahl, was of opinion that he had detected fructification in tlis Fucus; but it is added by Valıl, that the vesicles which that Botanist nistook for the frnit, arc unquestionably the eggs of some testaceous animal, being easily separable from the frond, instead of growing upon it, and being in substance and color quite different from it. They are rather coriaceous than membranous; and are filled with the same matter as is found in other dried eggs of testacea ; similar ones are also sometimes met with upon other Fuci, that are furnished with true capsules. Their size is about equal to that of mustard seed, their color grey, their form oblong, in the middle thcy are covered with an orbicular lamina, and are perforated with a pore at one extremity: in drying they shrink.-Such are the observations of Vahl, which $I$ have been induccd to repeat, principally as they afford me the opportunity of remarking low frequently the egus of marine insects, or the lesser Zooplytes adliere to Fuci, and give the appearance of fructification, and consequently how much care is necessary in our observations. The same very frequently liappens in fresl-water Confervæ.

+ Nat urhistorische Reise durch einen Theil Schwedens. p. 78. 


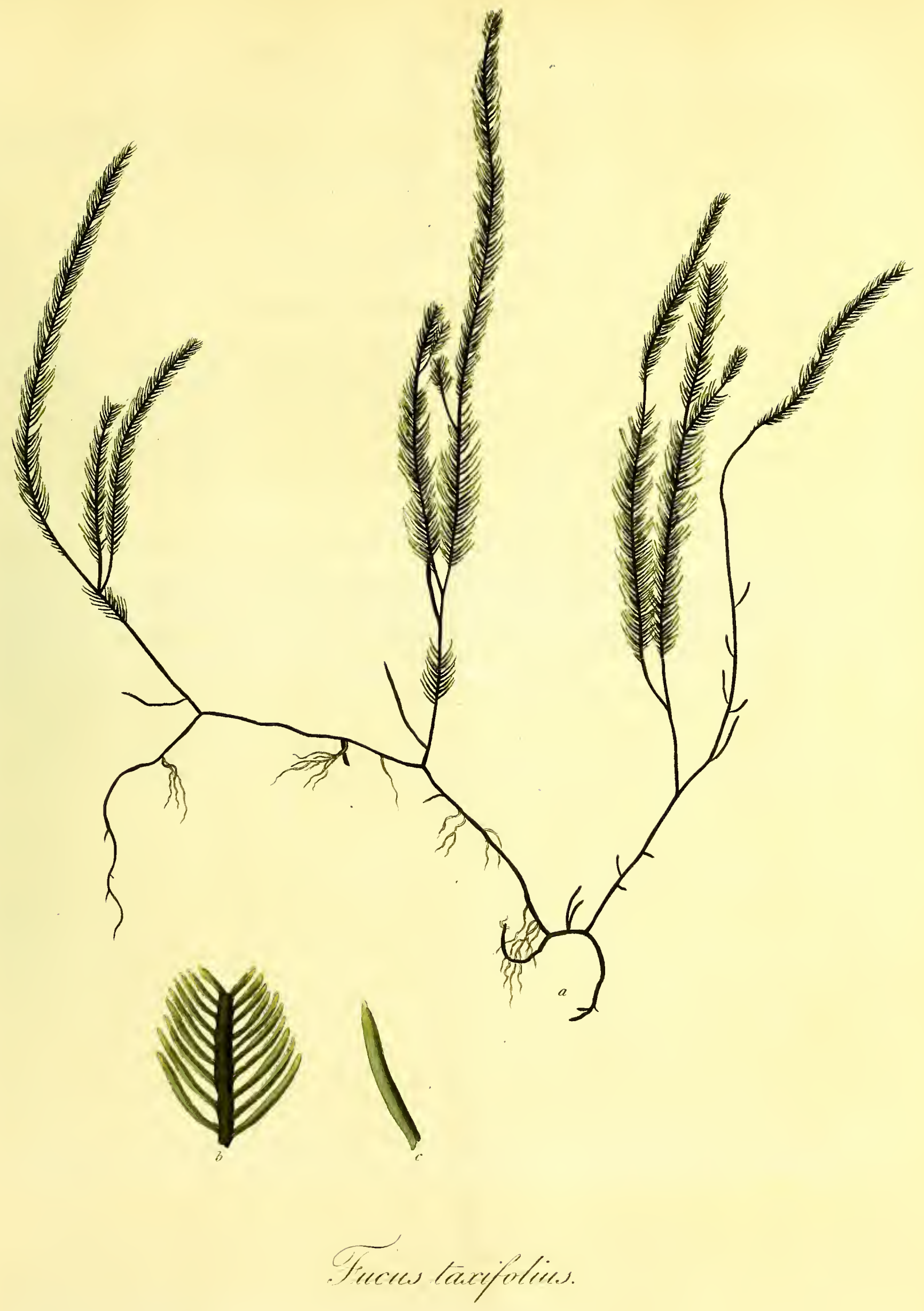



to believe that his plant is the same as ours, there being in Lord Valentia's collection a specinen considerably resembling that which he has represented.
F. taxifolius, natural size.
b. upper part of a branch, magnified - - $\quad-5$.
c. pinna - - - - - - - - 4.

\section{4.-F U C US TA X I F L I U S.}

Fucus, caule terete, prostrato, repente, ramosissimo; ramis erectis, simpliciusculis, pinnatis ; pinnis approximatis patentibus, falcatis, oppositis, cylindraceis, acutis.

Fucus taxifolius. V VнL, in Skrivt. af Naturhistorie Selskabet. V. pars 2da. p. 36.

F. sertularioides. GMELIN, Hist. Fuc. p. 151. t. 15. f. 4?

F. abietinus. Koenig, MSS.

Ha Bitat in Freto Chilas, prope Civitatem Adampatnam. J. G. Koenig. M. D.-In Insulâ Sanctæ Crucis. West.-In Mari Rubro. Vicecomes de Valentia.-In Novæ Hollandiæ oris. D. Brown.

\section{Perennis?}

RADIX lutescenti-fusca, unguem et ultrà longa, ortu simplex, mox in fibras aliquot simpliciusculas incurvas divisa.

Frons teres, filiformis, pennâ Merulæ aliquantùm tenuior, instructa caule prostrato, repente, pedali, et ultrà, madore terete, siccitate collabente et ruguloso, neque posthàc reficiendo, plerumque simplice, sed quandoque hìc illic dichotomo, intervallis haud certis per totam longitudinem e parte inferiore radices, e superiore ramos emittente, cætera nudo; rami vagi, erecti, longitudine a tripollicarem ad pedalem variabiles, compressi, filiformes, pennâ pas serinâ tenuiores, nunc simplices, nunc bifidi, trifidive, vel etiam enormitèr divisi, basi per unam alteramque lineanı. nudi, cætera pinnati ; pinnæ distichæ, patentes, falcatæ, simplices, integerrimæ, ejusdem ferè cum ramis crassitiei, compressæ, lineares, acutæ, approximatæ, oppositæ, eæ rami apiceln basinque versus minores, intermediæ longiores, et propemodùm unguiculares.

* Fructificatio hactenus latet.

Color, qui pinnarum gramineo-viridis fuscescenti-immixtus, est in caule stramineus, et in ramis, præsertim basin versus, nigricans; per totam stirpem in aquâ dulci asservatam vel soli objectam albescens; in exsiccatâ nitoris expers.

Su BSTANTIA caulis cartilaginea, pinnarum membranacea, neque tamen ita tenuis; exsiccatione rigida et fragilis.

OвS. Quanquam planta siccata chartæ nequaquam adhæret, pinnarum apices non raro tunc agglutinati inter se cohærent, nec nisi divellendo disjungủntur.

Tantam habet hic Fucus cum præcedente affinitatem, et notæ quæ unum ab altero secernunt tam æegrè verbis capiuntur, ut in singulis describendis summâ curâ amborumque exemplaribus est opus, ne, characteribus per quos invicem distinguuntur prætermissis, talis conficiatur descriptio, qualis utrique paritèr conveniat. Hoc prædicato, quæret fortè aliquis, quânam igitur sum adductus causâ ut disjungam; cui tamell ego nullâ promptiùs efficaciùsve ratione respondendum existimo, quàm referendo ad iconas, ubi luculentiùs quàm quod verbis fieri potest exponuntur discrimina. Plantas has, quantumvis inter se plurimis congruentes, esse revera distinctas nullus dubito; nec dubitabit ille, quisquis utriusque exemplaria vidit. Habitu, texturâ, et substantiâ discrepant: exsiccatione enim $F$ : pinnatus fit quâvis ferè membranâ tenuior, plumæque instar lenissimo agitatur halitu, contrà verò $F$. taxifolius rigidus crassiusculusque evadit. Hujus etiam color intensior, fuscescente tinctus; pima quoque magis falcatæ, is $F$. pinnati dupld̀ angustiores, basi nequaquàm attenuatæ, atque apice nọ modú non obúusæ verùm acuminatæ; præter quod, harum extremitates, uti suprà memoratur, in plantâ siccatâ quodammodò sunt imbricatæ, cohærentque. Koenigius, qui ambos nascentes legit, pro diversis habuit, et exemplar hic depictum est ab ipso ad Herbarium Banksianum sub $F$. abietini nomine communicatum. Suspicor verd utrumque esse a Liniwo commistum, qui, licet illam modò stirpem in tabulâ præcedente adumbratam pro $F$. pinnato in phytophylacio suo servaret, miserat tamen olìm ad Acharium $F$. taxifolium eodem titulo insignitum, quod, dum + Sueciam peragrarent, viderunt Weberus Mohriusque, qui inde duos hos Fucos aliumque et eundem crediderunt. Mihi quidem $F$. taxifolii Vahliani exemplaria nulla, auctoritate, quod aiunt, rata, hucusque sunt visa, neque tamen eo secius pro hujus nostræe stirpis, potiìs quàm præcedentis, synonymo indubio habeo, cùm quod nomen uni convenientissimum alteri malè congruat, tùm quod in descrip-

$$
\text { Vol. } 1 \text {. }
$$

* Vahlius refert credidisse Westium se fructificationem in hoc fuco detexisse ; vesiculæ verò, quas pro fructu habrit, " sunt," ut ipsius verbis utar, " certo certius ovula cujusdan animalis testacei: facile enirs a frondc separantur nec ei connatæ, substantia et colorc gandent omnino diverso, coriaceæ potius sunt quam membranaceæ, materia simili repletæe ac iỉa çuæ in aliis ovulis exsiccatis testaccornm reperitur, denique similes in aliis fucis reperio, veris vesiculis instuctis. Shmi mag!itudine scaivis sinupi, grisea, parum oblonga, medio lamina orbiculata auctæ, altera cxtremitatc poro perforatæ, siccitnte collap̧æ:."-Hisce Vahhi observationes eâ præsertım de causá hic repetii, ut monerem

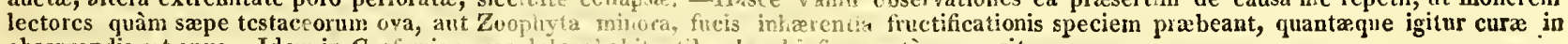

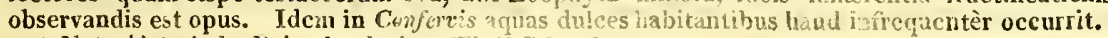

t Naturhistorische Reise durch cinen Theil Schwedens. p. 78. 
tione suâ ubere pinnas acutas, et quædam alia minoris momenti, memoret Botanicus ille acutissimus, fato nimis, eheu! propero præreptus. Gmelini synonymo suprà citato dubitationis signum subjeci; neque nomen ab eo impositum, quantumvis aptissimum, asciscere sum ausus, quia descriptio æquè ac icon ad exemplaria plus æquo manca confectæe nihil de hâc re certi proferendum relinquunt. Ad hanc autem pertinere stirpem credo, cùm in Herbario nobilissimi Vicecomitis de Valentia specimen quod ei a Gmelino depicto satis respondeat asservatum extet.

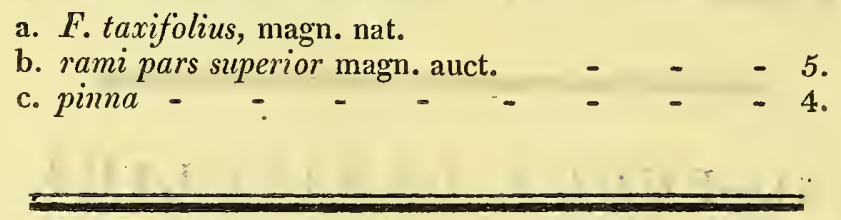

\section{5.-F U C U S S E L A G O.}

Fucus Selago, stem cylindrical, prostrate, creeping, much and irregularly branched; branches erect, mostly siinple, every where covered with ramuli between erect and patent, closely imbricated; cylindrical, and acute.

In the Red Sea. Viscount Valentia.

\section{Perennial?}

Rоoт, pale straw-color, three or four lines long, at first simple, afterwards divided into a few incurved unbranched fibres.

FroN D, cylindrical, filiform, of the thickness of a sparrow's quill, furnished with a prostrate creeping stem, more than four inches long, but how much more I am unable to say, smooth, dichotomous, shrinking and wrinkled when dry, throwing out at short, but uncertain intervals, branches from its upper, and roots from its under side, in other respects naked; branckes scattered, erect, nearly half a foot high, either simple, or irregularly beset with one or tivo shorter ones, all consisting of a narrow compressed midrib, clothed on all sides, from base to summit, with closely imbricated * ramuli between erect and patent, simple, quite entire, straight, three or four lines in length, about the same thickness as the midrib, compressed, linear, and acute.

Fructification, at present unknown.

CoLOR, a beautiful grass-green in the ramuli, in the stem pale-yellow; destitute of gloss when dry ; if exposed to the sun, or kept in fresh water, turning to white.

SUBSTANCE, of the stem, cartilaginous, of the leaves membranaceous; after drying rather stiff and brittle.

Oвs. When dry it does not adhere in the least to paper :-the ramuli are so closely imbricated as altogether to cover and conceal the nerve of the branches.

If under the preceding Fucus it has been necessary to point out that it is really distinct from $F$. pinnatus, and carefully to particularise the characters by which these two plants are essentially distinguished, it is on the other hand scarcely less important to observe, under the present, that the marks which separate it from $F$. taxifolius seem to me to exist more strongly in appearance than in reality, and that, independently of the disposition of the ramuli, which are in the one completely distichous, and in the other closely imbricated on all sides, there is nothing that would lead to make them considered as distinct species, the slight dissimilarity of color, and the circumstance of the ramuli being straight or somewhat falcate, not being of themselves more than sufficient to constitute small, varieties. It is upon this account principally that I have been induced to figure $F$. Selago, without having seen more specimens than the one here represented, in order that, by placing it next to F. taxifolius, botanists may have a better opportunity of forming their opinion how far these two Fuci are to be considered distinct; and I will only observe that, in my opinion, they are truly so, though, till an opportunity is afforded of examining a greater number of individuals, the point must be considered as in a measure undetermined. Mr. Brown, who has brought from New Holland some beautiful plants of a Fucus, which, though much larger than the present, seems scarcely to be specifically, different, will, when he examines this part of his Herbarium, probably enable us to decide it. For the specinen now figured I am indebted to Lord Valentia, whose kindness I shall have repeated occasions to acknowledge in the course of this work, for the furtherance of which, he has most obligingly communicated the whole of the submersed Algæ, collected by himself in the Red Sea. Upon the name of $F$. Selago, it can scarcely be necessary to offer any remark, as it must be sufficiently obvious to every botanist that it is taken from the resemblance which the plant bears, when moist, to the Lycopodium Selago of Iimneus.

a. F. Selago, natural size.

b. upper part of the frond, magnified - $\quad-\quad 5$.

c. ramulus - _ - - - - 3.

* The parts here called ramuli are precisely the same as those which under the two preceding species are termed pinna, the change of name being occasioned only by their disposition, which is not distichous. In form and situation these almost exactly agree with the ramulialready deseribed under $F$. pinostroides and $F$. lycopodioides, but their nature is quite different, nor are they ever, like them, divided, or lengthened into branches. 
<smiles>CC(C)(C)[Tl]</smiles> 
Fucus, caule terete, prostrato, repente, ramosissimo ; ramis erectis, simpliciusculis, undique obtectis ramulis erectopatulis, densè imbricatis, cylindraceis, acutiusculis.

Haвitat in Mari Rubro. Vicecomes de Valentia.

Perennis?

RADIX coloris dilutè straminei, tres quatuorve lineas longa, ortu simplex, mox in fibras aliquot incurvas simplices dfvisa.

Fro $\mathrm{NS}$ teres, filiformis, pennæ passerinæ crassitie, instructa caule prostrato, repente, palmari, et ultrà, sed longitudinis hactenus mihi ignotæ, glabro, dichotomo, siccitate collabente, et ruguloso, intervallis brevibus, attamen incertis, e parte superiore ramos, ex inferiore radices emittente, cætera nudo; rami vagi, erecti, altitudine ferè semipedales, nunc simplices, nunc uno alterove breviore sparsìm instructi, omnes e nervo constantes angusto, compresso, undequàque, a basi usque ad apices, obsito * ramulis densè imbricatis, erecto-patulis, simplicibus, integerrimis, rectis, tres quatuorve lineas longis, ejusdem ferè cum nervo crassitiei, compressis, linearibus, acutis.

Fructificatio hucusque latet.

CoL OR, qui ramulorum amœeǹ gramineo-viridis, est in caule stramineus; exsiccatce nitoris expers; soli objecta, $l$ in aquâ dulci asservatce albescens.

SuBSTANTrA caulis cartilaginea, ramulorum membranacea; exsiccatione rigidiuscula et fragilis.

OBS. Exsiccata chartæ nequaquàm adhæret:-ramuli tam densè sunt imbricati ut ramorum nervorum omnind cooperiant et celent.

Si Fucum præcedentem tractanti imprimis necessarium sit visum lectoris animum ad ea advertere discrimina per quæ sese a $F$. pinnato dignoscendum præstat, ut de duabus stirpibus, reapse distinctis, quamvis inter se simillimis, nulla in posterum errori suppeditaretur ansa, haud minùs est de plantâ hìc depictâ observandum, characteres, qui ab F. taxifolio secernunt, videri majoris, quàm reverà sint, momenti; si enim ramulorum dispositio in hoc disticha in illo undique imbricata excipiatur, tantum abest ut ulla maneat nota, quæ sufficiat ad species duas constituendas, ut omnind cædem evadant; quoniam ob coloris exigguum discrimen et ramulos vel erectos vel lenitèr falcatos vix essent in varietates dispertiendi. Hæc igitur me primùm impulit causa, ut, licet unum modd $F$. Selaginis exemplar hucusque viderim, hìc nihilominus depictum sisterem, quò, ambabus stirpibus unà exhibitis, melior daretur occasio de iis dijudicandi. Nihil ultrà ipse pro me prædicabo nisi quòd diversas putem, neque tamen huic sententiæ impensiùs instarem, donec plura observandi exemplaria contigerit facultas. Litem, quamprimùm hanc sui Herbarii perlustràverit partem, fortè dirimet $\mathrm{D}$. Brown, qui e Novâ Hollandiâ redux secum attulit pulcherrimum quendam Fucuın, hujus certè affinem, si non omninò eundem, quamvis habitu aliquantùm, staturâ multumn discrepet. Specimen hìc adumbratum nobilissimo Vicecomiti de Valentia acceptum refero, cujus in me benevolentiam nequeo satis laudare, quâ Algas submersas omnes, quotquot in Mari Rubro legit, ad hoc opus promovendum misit. Nomen, uti satis cuivis patebit botanico, a similitudine, quæ inter hanc stirpem et Iycopodium Selaginem Linnæanum interest maxima, depromitur.

a. F. Selago, magn. nat.

b. frondis pars superior, magn. auct. - - $\quad-5$.

c. ramulus - - - - - - 3 .

* Partes ex hic ramuli dictæ omninò sunt exdem atque illæ quæ sub duabus speciebus præcedentibus pinna audiunt; nomenque idcircò modò mutatur quia situs haud distichus. Utut verò formá situque conveniant, longè indole recedunt a ramulis jam sub $F_{0}$ pinastroide et lycopodioide descriptis, ncque, illorum instar, unquam sunt divisi, vel in ramos elongantur. 
Fucus ericifolius, stem prostrate, creeping; much and irregularly branched; branches erect, irregularly divided, every where covered with ramuli, closely imbricated, between erect and patent, elliptical, hollow, tipped with an extremely short mucro.

Found at the Bermuda Islands. Herb. Banks.

\section{Perennial?}

Root, pale yellowish, at first simple, afterwards divided into a few fibres.

FroN D, cylindrical, filiform, nearly as thick as a crow's quill, furnished with a prostrate, creeping, smooth, and glossy siem, which is most probably cylindrical when recent, but in drying collapses, and becomes deeply longitudinally furrowed, so as never afterwards to recover, it throws out branches from its upper, and roots from its under side, in other respects it is naked; branches scattered, erect, three or four inches, or more, high, either forked, or beset with other smaller ones, cylindrical, naked for the space of a line or two from the base, afterwards covered every where, even to the apices, with ramuli closely imbricated on all sides, between erect and patent, about a line long, elliptical, inflated, tipped with an extremely mimute mucro, externally smooth, but appearing under a microscope most delicately striated, internally quite hollow :-in drying they collapse, and are variously wrinkled.

Fructification, at present unknown.

Color, of the ramuli grass-green, destitute of gloss, of the stem whitish-yellow, and shining; the whole plant, if kept in fresh-water or exposed to the sun, turns white.

SubSTANCE, in the stem cartilaginous, hard and tough, in the ramuli between membranaceous and cartilaginous; when dry firm, stiff, and brittle.

OBs. The plant contains nothing whatever viscid, and in drying does not adhere in the least to paper.

Of this species also, as well as of the last, I have at present seen only a single specimen, but it appears to be a plant so extremely different from all others, that it is impossible to mistake it; and I have therefore felt no hesitation in publishing it here, being anxious to bring together all that $I$ at present know respecting the extraordinary family to which it belongs. Its texture is very unlike that of its congeners, being so hard and thick as to seem, when dry, almost ligneous, a circumstance, which added to the strong resemblance that it bears in general appearance to a bunch of Erica vulgaris, or tetralix, makes it an excellent connecting link between this tribe of Algæe and the phænogamous vegetables of the earth. The inflated ramuli, which look, when magnified, like the leaves of Sedum acre or sexangulare, bring this plant near to $F$. uvarius of Linnæus, from which it is completely different in its habit, and in the form of its parts. The description above given is necessarily very incomplete, having been drawn up merely from a single individual, and from the fragment of another, both preserved in the Banksian Herbarium, where alone $I$ have at present seen this Fucus, which does not appear to be known to any foreign author. Many deficiencies might, indeed, safely be supplied from analogy; judging from which, there can be no doubt, that the mode of growth is precisely similar to that of the three preceding species. It is unfortunate that the name of $F$. ericoides had been previously given to a different Fucus much less deserving of it; in consequence of which, it was necessary to apply to the present that of $F$. ericifolius, which is by no means equally applicable, the resemblance consisting more in habit and in general appearance than in the form of the leaves, though these also, especially in a dry state, are not unlike those of the Erica.

a. F. ericifolius, natural size.

b. upper part of the frond, magnified -

c. portion of a ramulus cut throngh

4.

a. 
50
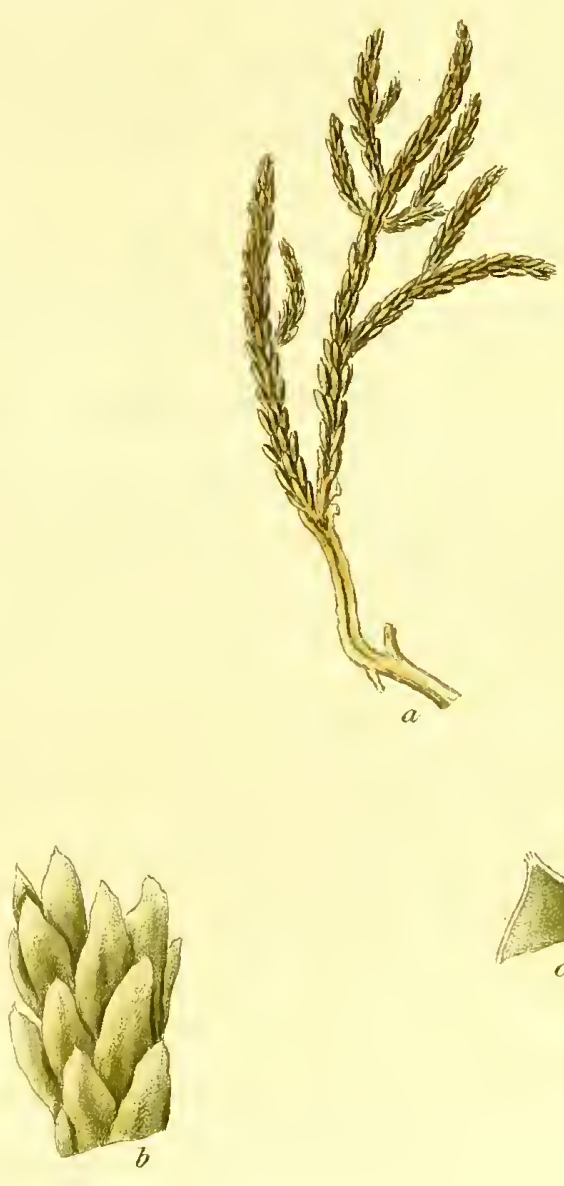<smiles>C1[C@H]2C[C@@H]12</smiles>

chenes ericifolius.

I H. Fis? :idel' 



\section{6.-F U CUS ERICIFOLIUS.}

Fucus, caule prostrato, repente, ramosissimo; ramis erectis, vagè divisis, undique obtectis ramulis erecto-patulis, densè imbricatis, ellipticis, cavis, brevissimè mucronulatis.

Ha Bitat ad Insulas Bermudas. Herb. Banks.

Perennis?

RADIX lutescens, ortu simplex, mox in fibras aliquot divisa.

FRONs teres, filiformis, pennæ corvinæ ferè crassitie, instructa caule prostrato, repente, łævi, nitidoque, madore verisimillimè terete, siccitate collabente et profundè longitudinalitèr sulcato, neque posthàc reficiendo, e parte inferiore radices, e superiore ramos enittente, cætera nudo; rami vagi, erecti, tri- quadri-pollicares, et ultra, vel bifurci, vel aliis minoribus obsiti, teretes, basin versus, per unius duarumve linearum longitudinem, nudi, inde ubique, usque ad apices, vestiti ramulis undique densè imbricatis, erecto-patulis, circiter lineam longis, ellipticis, inflatis, mucrone · minutissimo apiculatis, extrinsecùs glabris, sed sub lente tenuissimè striatis, intùs omninò cavis :- -siccitate collabuntur et variè rugulosi evadunt.

Fructificatio hactenùs latet.

COLOR ramulorum gramineo-viridis, nitoris expers, caulis albo-stramineus, nitidus, per totam stirpem in aquâ dulci asservatam vel soli objectam albescens.

Su BSTA NTı caulis cartilaginea, dura, telax, ramulorum membranaceo-cartilaginea ; exsiccata firma, rigida, et fragilis.

OBs. Stirps ue minimum in se viscidi habens siccitate chartæ nequaquàm adhæret.

Hujus quoque Fuci, sicut præcedentis, unicum mod’ exemplar adhuc vidi, neque tamen eâ de causâ hìc evulgare dubitavi, cùm quodd videatur planta primo aspectu a reliquis dignoscenda, tùm quod vellem omnes hujus familiæ stirpes, quotquot mihi hucusque innotuerunt, simùl depictas sistere. Texturâ multùm a congeneribus recedit, constatque substantiâ aded durâ et crassâ, ut exsiccata propemodùm lignosa appareat. Huic si adjicias similitudinem, quam præ se fert cum Ericá vulgari et tetralice, statim agnosces unum ex annulis in Naturæ catenâ Algas submersas ad vegetabilia terrena phænogama alligantibus. Per ramulos inflatos, qui sub lente conspecti folia Sedi acris vel sexangularis quodammodò referunt, appropinquat $F$. ericifolius ad $F$. uvarium Linn. a quo partium figurâ et habitu toto cæalo discrepat. Descriptio suprà data, ad unum modo exemplar atque alterius frustulum, utrumque in Herbario Banksiano servatum, confecta, necessariè manca reperietur, neque plantam ab ullo auctore memoratam invenio, unde aliquid ejus indolem historiamve illustrans depromere possim. Facile quidem foret, et fortasse etian tutum, plurima ex iis quæ hìc desunt analogiâ supplere, neque hâc nisus dubitaret aliquis credere crescendi modunı esse omnind ejus similem jam sub Fucis tribus præcedentibus descripti. Dolendum est $\boldsymbol{F}$. cricoidis nomen esse olim a Botanicis alii inditum speciei, cui multò minùs aptè quadrat; unde nihil restavit aliud, nisi ut hanc nostram $F$. ericifolium nuncuparemus, quod tamen nequaquàm paritèr idoneum, quoniam similitudo major in plantæ habitu et facie totâ externâ quam in foliorum formâ sit posita, quamvis et hæc quoque, præsertìm siccata, ea Ericarum haud ita malè referant.

a. $\boldsymbol{F}$. ericifolius, magn. nat.

b. frondis pars superior, magn. auct. - - - 4 .

c. ramuli dissecti pars - - $\quad-\quad$ - 2 . 
Fucus clavifer, stem cylindrical, filiform, prostrate, creeping, much and irregularly branched; branches erect, mostly simple; ramuli between erect and patent, imbricated on all sides, pyriform, hollow.

Fucus racemosus: Forsk ̊ , Fl. Egypt. p. 19l? Syst. Nat. Ed. Gmel. II. p. 13S2?

In the Red Sea. Viscount Valentia.

Rooт, pale straw-colored, an inch and more long, in some cases simple, in others divided, and occasionally bese with small fibres.

FroND, cylindrical, filiform, about the thickness of a blackbird's quill, furnished with a prostrate, creeping stem, from nine inches to a foot in length, either simple, or here and there irregularly divided, cylindrical when moist, when dry collapsing and wrinkled, throwing out, at short, but uncertain distances, throughout its whole length branches from the upper, and roots from the under surface, in other respects naked; branches irregularly scattered, erect, one or two inclies long, so constantly simple, that $I$ have seen only a single instance in which they were forked towards the base, almost cylindrical, filiform, of nearly the same thickness as the rest of the frond, naked for the space of a line or two from the stem, but afterwards covered with ramuli, loosely placed on all sides, between erect and patent, of a pyriform shape, and about a line long, their apices either quite entire, or slightly emarginate.

Fructification, hitherto undiscovered.

COLOR, every where, except in the roots, grass-green, most commonly, but by no means always, tinged with yellow in the stem ; when dry dark, dull, and destitute of gloss; turning, if exposed to the sun, or kept in fresh water, to pale-yellow, and finally to white.

Substance, cartilaginous in the stem, in the ramuli thin, and membranaceous, flexible after the plant is diy.

Овs. No part of the frond adheres in a dry state to paper; the ramuli collapse then remarkably, and are generally pressed close to the stem, and look as if they were spherical.

With regard to substance, texture, and mode of growth, the Fucus here figured accords 'so exactly with those represented in the four preceding plates, that the resemblance between them can scarcely fail to strike even the most incautious observer, nor can the slightest doubt be entertained of their belonging to the same natural family. The form of the ramuli, however, is in $F$. clavifer so extremely unlike that of any of the others as immediately to distinguish it, not only from these, but from every other species of submersed Alga, at present known, excepting only $F$. Chemnitzia of Esper, to which I was at first inclined to refer it as a synonym, till a more attentive examination of a specimen communicated to me by the learned Professor limself, induced me to adopt a contrary opinion. The lower and youngest ramuli are, according to the figure in the Icones Fucorum, cylindrical and acute, but the * rest are clavate at their apices, yet not like those of $\boldsymbol{F}$. clavifer, for they appear to preserve their cylindrical form to their extremities, where they suddenly expand. They are also longer, and more thin; and, in addition to this, Dr. Esper has described and figured his plant as arising from a membranaceous base, a circumstance, which, if correct, tends to deprive us of the strongest character of this singular tribe of vegetables, with which $F$. Chemnitzia agrees so precisely in all other points, that I cannot help apprehending he is in this instance mistaken, though the specimen that he has sent me, being small, does not afford the means of confirming my suspicion. He particularly dwells upon its resemblance to $F$. Gartnera of Gmelin, which is generally supposed to be the same as $F$. pedunculatus; but, whether such a supposition be correct or not, there can be no necessity to enlarge upon the points of difference between them, as the principal character of $F$. Gertnera depends upon the tufts of Conferva-like filaments that terminate its branches, and of these it is almost needless to say that there is not the least trace in $F$. clavifer or $F$. Chemnitzia. With respect to the synonym of + Forskal above quoted, I should scarcely have considered it requisite to subjoin to it a mark of doubt, had not that accurate Botanist expressly noticed the racemose disposition of the vesicles as its essential character. The $F$.racemosus figured by Esper, I. t. 98, is, as that author himself observes, a widely different species, and seems to me to be probably only a łbattered stem of $F$. nucronatus or granulatus, stripped of its leaves and branches. The name of F. clavifer has been taken fron the appearance of the plant when recent, in which state the branches look as if merely a cluster of small clavate bodies: had it been allowed to have borrowed an appellation from the form it assumes after it is dried, it might have been aptly denominated F. Trichomanes. I am indebted to the kindness of Lord Valentia for the individual here figured, nor have I ever seen any specimens uf this Fucus besides those brought by lim froul Egypt.

a. I'. clavifer, natural size.

b. upper part of a branch, magnified - -6 .

* Dr. Esper considers the inflated ramuli as the fructification, in which opinion, I am sorry to say, I do not see sufficient cause to coincide witl: him. I should be tempted licre to transcribe a considerable part of lis description, but that I liope for a more favonrable opportunity of trcating upon the subject, when $F$. Chemnitzia shall be figured in this work, and I will thereforc now merely copy that part of the specific character which relates to what he considers the fruit:- "frnctificationibus confertis ex corpusculis pedunculatis tubeformibus, limbo companulato."

+ Weber and Mobr in thcir enumeration of Forskal's Fuci (Archiv fïr die syst. Naturgeschichte, I. p. 134.) say nothing morc of this plant than that it diffcis toto calo from what Esper has figured under the samc name. It is entirely upon the following description in the $F$. $R$ Egyt. that I found niy opinion of its being the same as $F$. clavifer:

" Fuces RACEmosus : caule tereti, repente-ramoso; vesicis obovatis, a confertè racemosis, folizs nullis.

"Totus viridis. Caulis repens in fundo. Racemi vesicularum tripollicarcs, undique vesiculis viridibus imbricati." Fl. $E g y p t$. p. 191.

\$ It was something similar to this that was described in Dr. Withcring's Botanical Arrangements, IV. p. 111, under the name of $F$. nodiculis. 


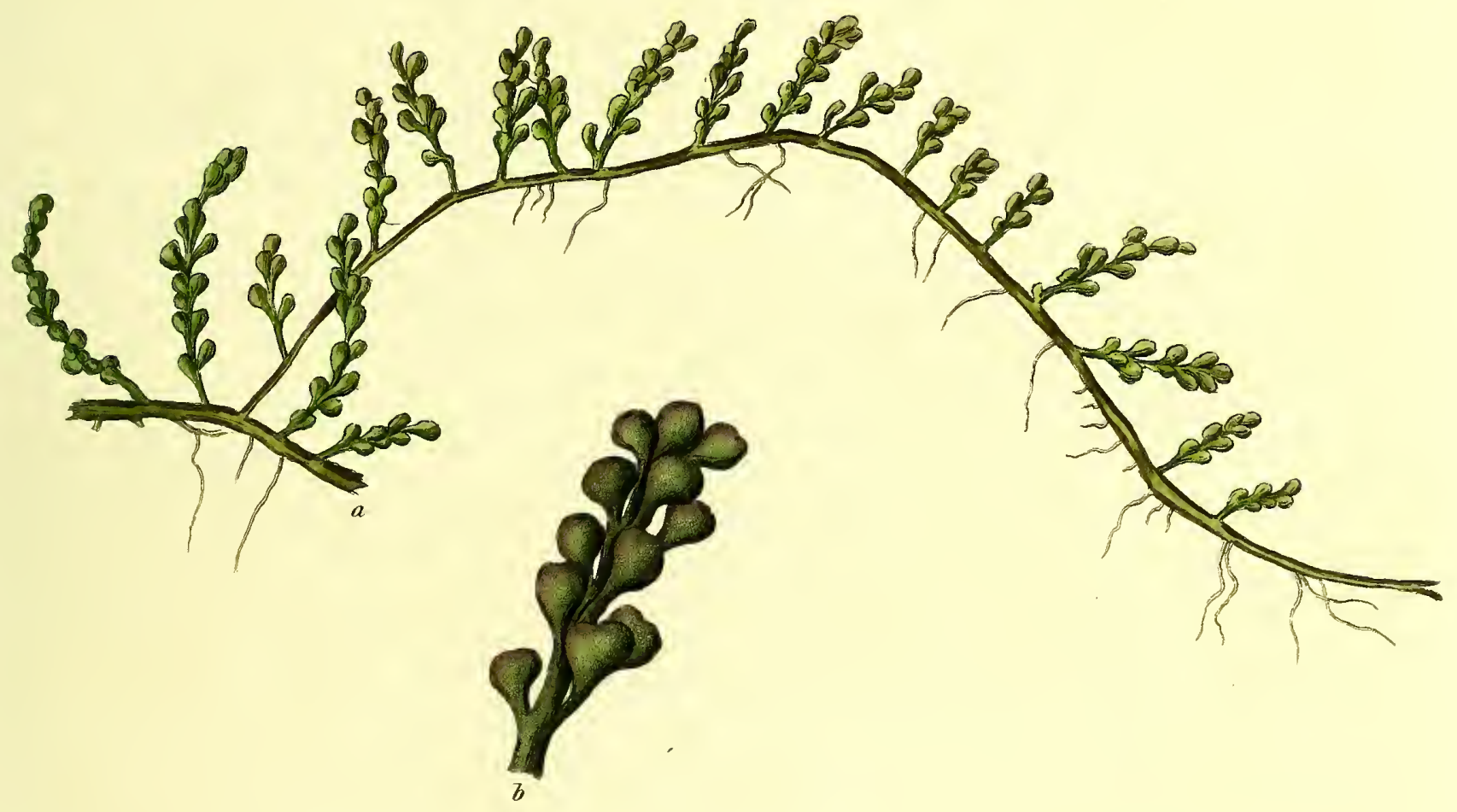

Hucus clarifes. 

Frtcus caule terete, filiformi, prostrato, repente, ramosissimo ; ramis erectis, simpliciusculis ; ramulis erecto-patulis, undique imbricatis, pyriformibus, cavis.

Fucus racemosus. Fo s к ̊̊, Fl. Egypt. p. 191.? 'Syst. Nat. Ed. Gmel. II. p. 1382?

Ha вiтAт in Mari Rubro. Vicecomes de Valentia.

\section{Perennis?}

$R_{A}$ IXX coloris dilutè straminei, pollicem et ultrà longa, nunc simplex, nunc divisa, vel interdùm fibrillis obsita

Frons teres, filiformis, pennæ Merulæ crassitie, caule instructa prostrato, repente, dodrantali, aut pedali, sinnplice, vel hìc illic vagè diviso, madore terete, siccitate collabente et ruguloso, intervallis brevibus, attamen incertis, per totam longitudinem e parte superiore ramos, ex inferiore radices emittente, cretera nudo; rami vagi, erecti, longitudine pollicares, et quandoque bipollicares, plerumque simplices, ita ut unum modo juxta basin bifurcum viderim, teretiusculi, filiformes, ejusden ferè cum reliquâ fronde crassitiei, basi per unam alteramve lineam nudi, inde obsiti ramulis undique laxè dispositis, erecto-patulis, lineam circitèr longis, pyriformibus, apice nunc integerrinis, nunc lenitèr emarginatis.

Fructificatio nulla hactenùs detecta.

CoLOR ubique, nisi in radicibus, gramineo-viridis, in caule sæpiùs, sed nequaquàm semper, stramineo tinctus ; exsiccata obscurus, et nitoris expers; soli objecta vel in aquâ dulci servata lutescens, et demùm albescens.

SUBSTANTIA in caule cartilagineâ, in ramulis membranacea et tenuis; in exsiccatâ flexilis.

Ов . Nulla stirpis exsiccatæ pars chartæ adhæret : ramuli tum insignitèr collabuntur, caulique sæpiùs adpressi, et sphærici apparent.

Si substantia, textura, crescendique modus respiciantur, maxima inter Fucum hic depictum atque illos in tabulis quatuor præcedentibus delineatos similitudo intercedere reperietur; unde quantum inter se conveniunt patebit cuivis vel obitèr inspicienti, nec dubitationi dabitur locus quin ad eandem familiam naturalem ascribi debeant. Quantumvis verò hæc similitudo valeat, ramulorum formâ aded singulari gaudet $F$. clavifer, ut statìm per hanc dignoscatur, non modo a reliquis omnibus hujusce tribûs individuis, sed a cunctis hucusque detectis Algarum submersarum speciebus, Fuco Esperi Chennitzià nodd excepto, quem tam insignitèr refert, ut primo eundem crediderim, donec, speciminibus ab ipso Professore missis attentiùs lustratis, de hâc sententiâ discedere sum coactus. Tabula in Iconibus Fucorum ramulos inferiores et juniores teretes acutosque sistit; neque sunt * reliqui, licet apices habeant clavatos, eorum $F$. claviferi onnind similes, cùm formam cylindraceam ad extremitates usque servent, seque ibi derepentè dilatent. Sunt etiam longiores tenuioresque. Præter hæc plantam suam e basi membranaceâ oriri tradit Esperus, sed in hoc optimum auctorem aliquid humani esse passum nequeo $110 n$ suspicari, quoniam $F$. Chemnitzia in omnibus aliis arctissimè accedit $\boldsymbol{F}$. pinnato et congeneribus, quibus caulis repens maximi momenti notam suppeditat. Fortasse exemplaria manca erroris extitere causa, et certè ex illo quod ad me misit vir cl. nihil est de hâc re dijudicandum. Multis Esperus verbis disserit quantum sit affinis $F$. Gartnera Gmel., quem pro $F$. pedunculati synonymo plurimi citant; sed non est opus ut eum in his sequeremur, quoniàm horum Fucorum cliaracter essentialis iil tibrillarum confervoidearum fasciculis ramos terminantibus conspicitur, et tales in $F$. clazifero vel Chemnitziâ incassùm quæres. +Forskalii synonymo suprà citato dubitationis signum vix subjecissem, nisi ad speciem discriminandam Botanicus ille accuratissimus vesicularum dispositione racemosâ imprimis sit nisus. Fucus, quem sub $F$. racemosi nomine depinxit Esperus (I. t. 98,) est, uti ipse prædicat, a plantâ ejusdem nominis Forskalianâ distinctissimus, et est forsàn tantummod $\dot{F}$. mucronati vel $F$.granulati faulis maris æstu ita denudatus ut sit foliis ramisque omnind orbatus. F. claviferi nomen a plantæ recentis facie, quum ramulis claviformibus rami undique obsiti conspiciuntur, deprompsi : $F$. Trichomanem aptiùs dixissem, si titulum ad exsiccatam confectum imponere licuisset. Stirpem hìc depictam nobilissimi Vicecomitis de Valentia benevolentia debeo, neque ulla hactenùs vidi liujus stirpis exemplaria præter ea ab ipso ex Ægypto reportata.

a. F. clavifer, magn. nat.

b. rami pars superior, magn. anct. $\quad-\quad-6$.

* Kamulos hos clavatos pro fructu habet Esperus; meque piget quòd causam perspiciam nullam ob quam luuic senteutia assentirem. Volu* issem hìc magnâ de parte exscribcre quidquid de bis tradidit, nisi talia tractandi occasionem sperarem fore meliorem, cùm $r$. Chemıitziam in boc opere sisterem. Hâc igitur de causá nihil lunjus loci repetendun existimo, lisi id quod in descriptione specificá de fructificatione dixit: " fructificationitus confert is ex corpusculis pedunculatis tubxformibus, limbo campanulato."

† In Fucorum Forskalianorum recensione (Archir. für die Syst. Naturgeschichte I. p. 134.) nihil ultıà de hâc stirpe dicunt Weberus Molıriusque, quàm quòd toto cælo discrepet ab illá, cui idem nomen Esperus indidit; quamobrem descriptiune hic subjectâ onnis nitor quòd eundem cum $F$. clavifero credam :-

"Fucus Racemosus; caule tercti, repente-ramoso, vesicis obovatis, confertè racemosis, foliis nullis.

"Totus viridis. Canlis repens in fundo. Racemi vesicularum tripollicares, undiqne vesiculis viridibus imbricati."-Fl. Egypt. p. 191.

\$ Simile quiddaul est a b. Witheringio in opere suo, Botanicul Arrangements dicto, IV. p. 111, sub F. nodicaulis nomine descriptum, 
Fucus Ophioglossum, stem cylindrical, filiform, prostrate, creeping, much and irregularly branched; branclies membranaceous, flat, nerveless, between linear and elliptical, quite entire, proliferous from their margin and surface.

Fucus Ophioglossum. Beiträge zur Naturlunde. I. p. 317. W в в $u$. MoнR, Archiv für die Syst. Naturgeschichte. I. p. 136.

F. prolifer. Forsk̊L, Fl. Agypt. p. 193. Syst. Nat. Ed. Gmel. II. p. 1390.

Shores of the Mediterranean, by Alexandria. Forsk ̊. -Near Barcelona. Professor Mertens.

Perennial?

Roor, pale-yellow, half an inch and more long, consisting of several fibres, either simple or branched.

Fro D, furnished, apparently, with a prostrate, creeping stem, of what length I am unable to say, cylindrical, filiform, more thin than a sparrow's quill, striking root here and there, its apex expanded into a leaf wholly destitute of midrib or veins, between linear and elliptical, quite entire, three or four inches long, and scarcely the half of one wide, rounded at its extremity, proliferous from botl its margin and surface, with other scattered leaves, similar to the primary ones, which in their turns produce in the same manner a third series, the last being smallest, and the youngest roundish :- In addition to this, new filiform stems are also produced from the leaves, and in some cases the leading stem, instead of being cylindrical, is flat, narrow, and linear.

FRUCTIFICATION, at present unknown; for, though some brownish specks are observable in places upon the leaves, yet notling can be discovered in them that may be taken for seeds.

Color, grass-green, sometimes variegated with brown, and sometimes with whitish, to which latter it turns from exposure to the sun, or from being kept long in fresh water: when dry the frond shines, as if varnished.

SuBSTANCE, as thin as goldbeater's skin, and extremely tender; appearing, if examined under the microscope, beautifully reticulated.

OBs. In a dry state it adheres slightly to paper.

There can be 110 question of $F$. Ophioglossum being the plant to which Dr. Weber and Dr. Mohr intended particularly to allude, when, as has been already quoted under $F$. pinnatus, they remarked that there existed a close connection between this tribe of Algæe and the Fuci corallini of Gmelin, made by Draparnaud into a genus under the name of * Zonaria; nor is it to be denied that it bears in general appearance a considerable resemblance to some of the individuals of that family, or that the parallel lines, with which the frond is marked, seem to indicate a natural affinity to then. At the same time, it must be observed, that it differs from them in the two most essential points, the want of the concentric circles, from which the Zonaria derive their name, and the root, which in them is a disk thickly covered with brown matted woolly fibres, but in $F$. Ophioglossum altogetler resembles that of the other congeners of $F$. pinnatus, so as, if considered together with its texture and its color, to leave no doubt of the tribe to which it appertains, however it may differ from all the rest in the shape, and the reticulations of the frond, in which latter respect, it agrees precisely with $F$. soboliferus, $F$. Phyllitis, and several others of the membranaceous Fuci. The description given in the Flora Agyptiaco-Arabica is so short, that Forskal's plant might well have been regarded as an uncertain synonym, had there not fortunately been specimens preserved in his own Herbarium. These Dr. Weber and Dr. Mohr have seen, and they propose at some future time to illustrate more fully the history of this plant, which I hope and trust they will do ; as probably no botanist now living has had equal opportunities of investigating it, and its singular nature well deserves any pains that may be bestowed upon it. They remark that leaves are occasionally met with devoid of any proliferous tendency, and that in this state the plant bears some resemblance in form to F. Fascia.

a. F. Ophioglossum, natural size.

b. portion of the frond, magnified - - - 1 .

c. root - - - - - - a

With respect to this genus, which, I believe, has never yet been published, many interesting partieulars are to be found in the $B$ eiträge sur Naturkunde, I. p. $246-253$. The plants that it is intended to comprise are a very natural tribe, consisting of Ulia paronia, atomaria, fiabelliformis, squamaria, and their congeners, the principal character of which depends upon tlie concentric circles in the frond. To illustrate these, was the intention of the late M. Draparnaud, of Montpellier, who gave the genus its very apposite name, and whose premature death has depriyed parine Botany of one her most zealous, acute, and useful followers. 

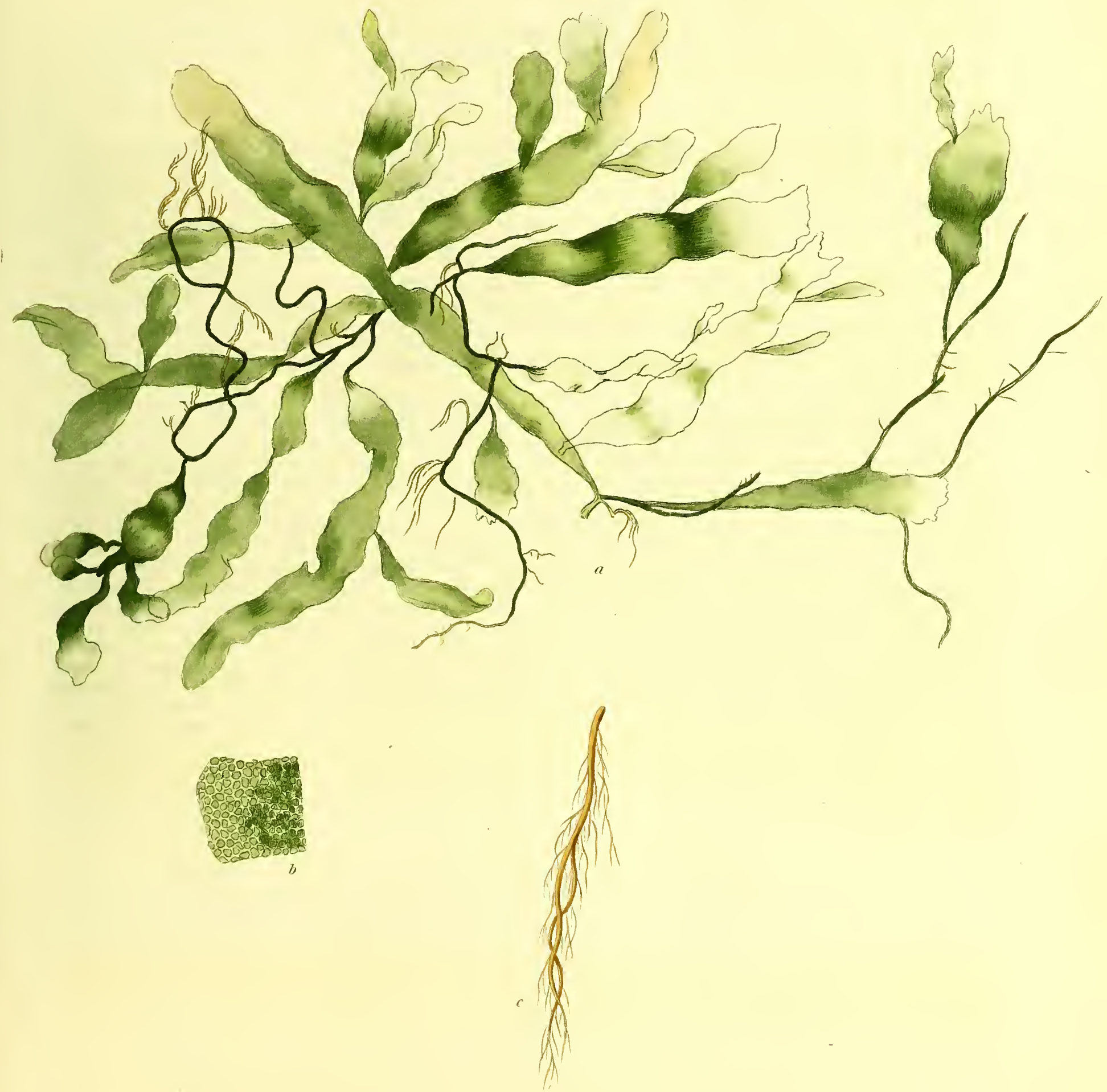

Fucus, caule terete, filiformi, prostrato, repente, ramosissimo; ramis membranaceis, planis, enervibus, lineariellipticis, integerrimis, e margine et superficie proliferis.

Fucus Ophioglossum. Beiträge zur Naturkunde. I. p. 317. Wевев u. Mонг, Archiv.für die.Syst. Naturgeschichte. I. p. 136.

F. prolifer. ForskåL, Fl. Ėgypt.p. 193. Syst. Nat. Ed. Gmel. II. p. 1390.

Haвıтат Alexandriæ, ad littora maris Mediterranei. Forskal.-Prope Barcelona lectam accepit D. Prof. Mertens.

Perennis?

RADIX lutescens, fibrosa, unguem et ultrà longa, e fibris plurimis, nunc simplicibus, nunc ramosis, constans.

Frons caule, ut videtur, instructa prostrato, repente, longitudinis mihi ignotæe, terete, filiformi, pennâ passerinâ tenuiore, hic illic radicante, apice expanso in folium nervi venarumque prorsus expers, lineari-ellipticum, integerrimum, longitudine palnare, latitudine vix unguiculare, apice rotundatum, e margine et superficie proliferum, foliis aliis sparsis, primariorum similibus, ipsis tertiam eâdem ratione edentibus seriem, ultimis minoribus, junioribus subrotundis :- preter hoc novi quoque caules filiformes e foliis oriuntur, et interdùm caulis non teres, sed planus angustus et linearis evadit.

FRUCT1FICAT1O hactenùs latet: quamvis enim maculæ quædam fuscescentes sese hìc illic in foliis observandas præestiterint, nihil tamen in his seminum simile erat detegendum.

COLOR gramineo-viridis, interdùm fusco, interdùm albicante variegatus; soli diu expositce aut in aquâ dulci servatce albescens; exsiccatce nitens quasi sit frons vernice oblita.

SUBSTANTIA quâvis ferè membranâ tenuior, tenerrima; sub lente pulcherrimè reticulata.

Dubitari nequit quin $F$. Ophioglossum sit ea stirps quan præcipuè ante oculos habuerunt Weberus Mohriusque, quando, uti suprà sub F. pinnato memoratur, affinitatem esse affirmârunt arctam inter hanc Algarum tribum et Fucos Gmelini corallinos, quos pro novo genere, * Zonaria nomine insigniendo, Draparnaudius proposuit; neque is ego sum qui negare pergerem hunc Fucum externâ facie similitudinem præ se ferre magnam cuin quibusdam ejus familiæ individuis, lineolasque parallelas, quibus frons striata conspicitur, plantas naturâ connexas indicare videri. Alterâ tamen est ex parte notandum discrepare duabus summi momenti rebus; circulis scilicet concentricis, unde nomen suum Zonariæ ducunt, et radice, quæ in his est callus discoideus fibris fulvis tomentosis densissimè implexis omnino coopertus, dum in $F$. Ophioglosso aliorum $F$. pinnati congenerum instar evadit. Huic si colorem texturamque adjiciamus, scrupulus statim eximitur omnis de hujus stirpis in Fucorum dispositione loco, quantumvis frondis figurâ et facie reticulatâ a reliquis affinibus abhorreat, et in hoc accedat $\mathbb{F}$. sobolifero, $\boldsymbol{F}$. Phyllitidi, et plurimis aliis fronde membranaceâ præditis. Descriptio in Florâ Ȧgyptiaco-Arabicâ plus æquo brevis plantam a Forskalio designatam quodammodd dubiam fortè reliquisset; nisi exemplaria auspicatò in phytophylacio suo servata extarent. Hæc Weberus Mohriusque viderunt, qui se mox hujus Fuci historiæ indolique absolutiùs illustrandæ accincturos promittunt; quod ut citò præstent quàm maximè mihi est in votis, quoniam nulli forsàn nunc in terris Botanico par eum investigandi contigit facultas, neque ulla datur Alga cujus natura singnlaris indagantis curam magis rependet. Hi memorant specimina quandoque reperiri quorum folia simplicia vim nullam in se proliferam arguunt, et plantam in hoc statu F. Fasciam formâ externâ aliquo modo referre.

a. F. Ophioglossun, magn. nat.

b. frondis pars, inagn. auct. - $\quad-\quad$ - 1 .

c. radix - - - - - :

- Multa de hoe genere, quod nemo, quantum scio, Botanicus adhuc publici juris fecit, eximiè pro more disseruerunt Weberus Mohriusque, in opere suo, Beiträge zur Naturkunde, I. p. 246-253. Plantæ sub illo disponenda, (U. pavonia, atomaria, flabclliformis, squamaria, harumque congeneres,) familiam perquàm naturalem constituunt, cujus character essentialis e circulis in fronde concentricis constat. Nomen generi aptissimum indidit b. Draparnaudius, qui mox ad illustrandum omni curâ incubuisset, nisi mors immatura scientiam nostram amabilem discipulo privasset, qui, ob summum in Algis submersis indagandis studium, mentisque acumen singulare, magnum sui inter omnes Botanicos desiderinm reliquit. 
Fucus coccineus, frond compressed, between membranaceous and cartilaginous, much and irregularly branched; ramuli subulate, disposed in alternate parcels of three or four each; spherical sessile capsules, and lanceolate siliquæ.

Fucus coccineus. Nl. Ang. p. 586. Linn. Trans. III. p. 187. Wiтh. IV. p. $119 . \quad$ Ner. Brit. p. 106. t. Frontispiece. Syn. Fuc. II. p. 291. Eng. Bot. XVIII. t. 1242.

F. Plocamium. Gmelin, Hist. Fuc. p. 153. t. 16. f. 1. (excl. syl. Linn.) Fl. Scot. II. p. 957. Fis Per, Ic. Fuc. I. p. 18. t. 2. Fl. Fr. Ed. $2 d a$. II. p. 31.

F. cartilagineus. OEner, Enum. Plant. Fl. Dan. n. 131.

Ceramium Plocamium. Rotн, Fl. Germ. III. p. 458. Cat. Bot. II. p. 161. III. p. 107.

Fucoides rubens variè dissectum. RaII Syn. p. 37. n. 1.?

On the sliores of the British.Isles, plentifully.-On the shores of France, both where washed by the ocean and the Mediterranean. Decandolle.-Coast of Spain, near Cadiz. Don Simon de Roxas Clemente.

Perennial. June-October.

Rоот, fibrous, consisting of several pale-pink, branching fibres, closely matted together.

FroNDs, numerous from the same base, compressed, filiform, generally nearly half a foot, but sometimes not above three inches, and at others a foot long, their width about half a line, every where gently flexuose, * much and irregularly branched from the very base, the whole of the branches and ramuli being placed in the same plane; branches separated by very uncertain intervals, all distichous, irregularly alternate, and patent, those nearest the root longest, and pimated with other small ones, disposed in the same manner, which in their turns produce a third, or even a fourth, series; along the sides of the extreme branches are arranged the ramuli, two or three lines long, patent, subulate, and slightly incurved, growing in alternate rows, three or four on one side, and then as many on the other, in all which the lowest one is always simple, the rest fringed upon their upper side with others still smaller, so as to give them a pectinated appearance : these rows of ramuli, constantly preserving their alternate dispostion, and constantly growing on the convex part of the frond alone, not unfrequently occupy the spaces between the branches in the primary and secondary shoots, thus adding greatly to the beauty of the plant.

Fructification, two-fold, upon +different individuals, the one consisting of sperical capsules, about the size of Foppy-seed, $¥$ sessile upon the sides of the branches, especially the upper ones, of a deep blood-red color, containing a cluster of extremely minute numerous seeds; the other very small lanceolate capsules, sessile upon the upper branches, in some cases solitary, in others, racemose, each producing four or five largish and roundish seeds, surrounded by a pellucid limbus, and marked with rings internally, if examined under a powerful microscope.

Color, a most beautiful subdiaphanous tint, between crimson and scarlet, darker when dry; if exposed to the sun, or kept in fresh water, it grows pale, and turns to a greenish yellow or greenish, and at length to whitish.

SUBSTANCE, between cartilaginous and membranaceous, extremely thin and tender; membranaceous and flaccid after it is dried.

Oss. This plant is remarkable for the smoothness of its appearance :-in drying it adheres, though rather loosely, to paper or glass:-Sertularia anguina is most frequently found on this species :-my friend, Mr. Dillwyn, sent me seme time ago from South $W$ ales a variety, most probably accidental, with all the ramuli simple.

Of the zeal, with which the study of Marine Botany has been cultivated during the few years that have elapsed subsequently to the publication of the Nereis Britannica, and the Synopsis of the British Fuci, some idea may be formed from the circumstance of the double fruit of $F$.coccineus, being at that time regarded as a curiosity, and as so extraordinary to be in itself almost sufficient to justify the $\S$ dividing of the plant into two distinct species, whereas a similar appearance is now known to be observable in several of its congeners, and we have every reason to believe, that in the course of time it will also be discovered in many others. It has already been mentioned above, that a single specimen ilas been sent me by Mr. Brodie, bearing upon the same branches capsules of both forms, but I have ncver either seen or lieard of any other instance of a like kind; and certainly in the plants found at Yarmouth, the remark made in the Synopsis of the British Fuci holds good, that the frond of those that produce the lanceolate siliquæ is in general, though by no means always, more narrow than that of the globuliferous ones. My excellent correspondent, Mr. Pigott, who, unfortunately for the cause of science, has been detained many years a prisoner in France, observed to Mr. Stackhouse, that he had seen the lanceolate capsules, after the discliarge of their seeds, lose their color, and turn yellow. I am, however, still inclined to believe, that, instead of their falling off, as might be supposed from such an observation, they rather lengthen into new branches, a tendency to which I have more than once noticed. In a specimen

* The description given of this plant in the Flore Franģaise is so elatacteristic as to its mode of branehing, that I am tempted here to transeribe a eonsiderable part of it:- "Sa tige est très rameuse, et toujours dans le même plan : l'ordre des ramifieations est très remarquable; cliaque rameau est légerènent flexuenx, et n'émet de ranifications que du eôté convexe: la preni re est un filet simple et pointu; la deuxième est un filet qui a trois dents du eôté antérieur; la troisième est un filet qui a deux dents, et qui au lieu de la troisième dent pousse un filet muni d'une dent en delıors; la quatrieme est un filet qui n'a qu'ıne deut, la deuxième dent est devenne un filet à une dent, et la troisième un filet rameux. Apres ees quatre ramifieations il y a un espaee vide, et la tige émet des rameaux semblables du eôté opposé."

+ I have seen a single instaree of both being lound on the sange frond in a speeimen sent me by Mr. Brodie from the North of Seotland.

‡ Dr. Goodenough and Mr. Woodwarit say, that they are oecasionally, t'iongh very rarely, peduneulate.

Mi. Stacklouse, in eonsequence of the two-fold fruit, has made it, in the Nereis Britannica, a part of the spceifie eharaeter of tise plant, that it bears polymorphous fiuctitieation; and subsequently to the publieation of that work, he stated it to me as his opinion, that it would hereafter be neeessary to divide thia Fucus into different species: such vere also my sentiments, when in the Synopsis of the British Fuci, I sepurated it ipon this aecount into two varieties. 


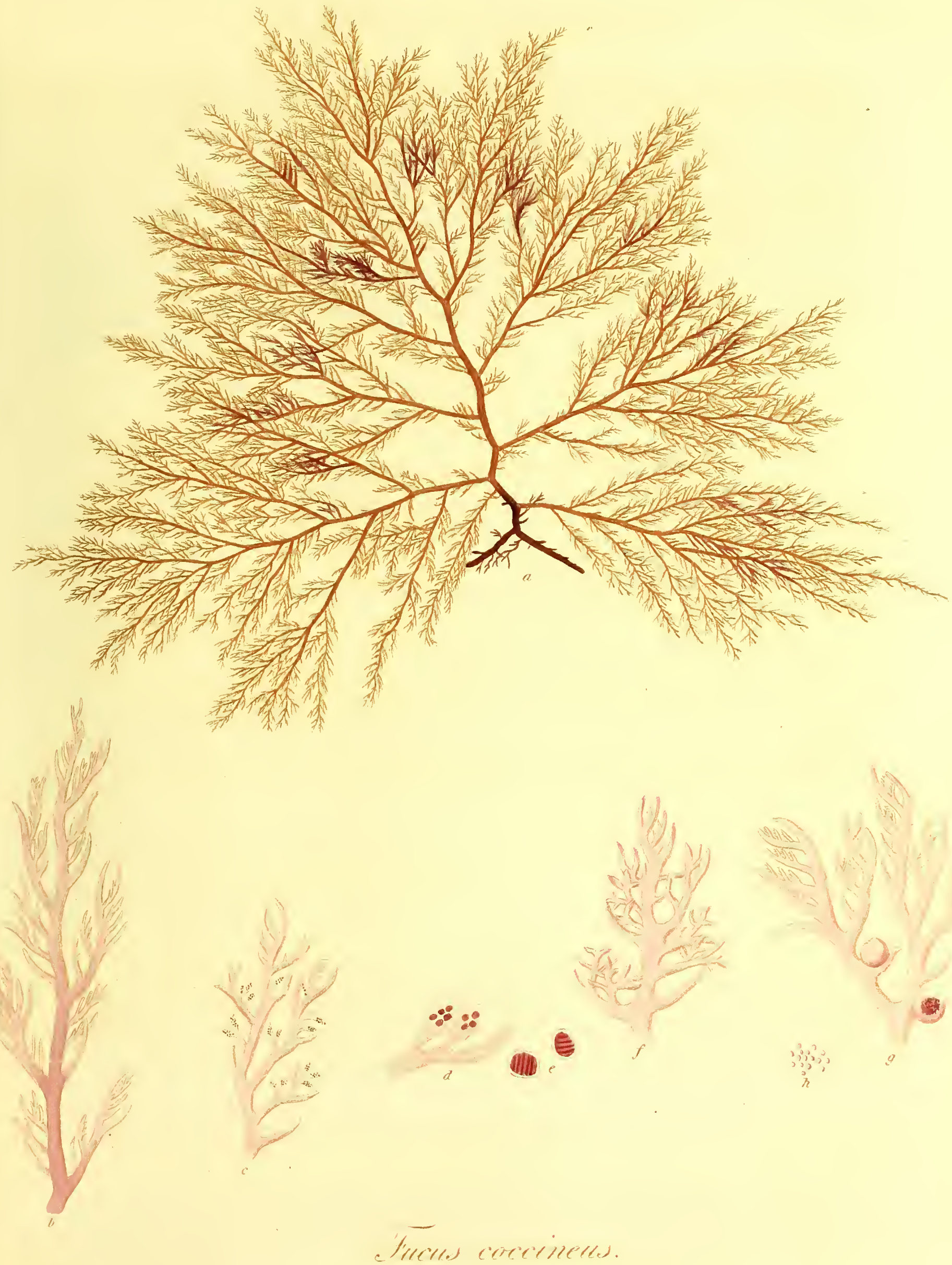



specimen found many years since upon the Yarmouth beach by Mr. Mason, they are not only elongated and repeatedly branched, but singularly twisted, so as to form nearly globular clusters. $F$. coccineus is one of the most beautiful and most elegant of all the Fuci, and is also one of the most universal favorites with those who collect marine productions. It is liable to considerable variations in point of size, form, and color, but is always readily distinguishable by the peculiar arrangement of the ramuli, the shape and disposition of which first gave rise to the name of F. pectinatus being bestowed upon it in the Banksian Herbarium, a name so extremely apposite, that the necessity of changing it, and of substituting in its place the unmeaning appellation it now bears, cannot fail of being regretted. The specimens sent me from Spain are considerably smaller and more deeply colored than any $I$ have met with on our coasts, but seem to resemble what Dr. Goodenough and Mr. Woodward have observed growing upon $F$. vesiculosus, fibrosus, and crispus, in which state they say " it frequently forms thick tufts not exceeding an inch in height, and might easily be mistaken for a different plant." It is singular that no mention should be made in any of the works of Linnæus of a species so extremely common upon the British shores; and, with regard to the synonym of Ray, there is considerable doubt, as he appears to have confounded together $F$. coccineus and Conferva coccinea, upon which subject some observations by Mr. Dillwyn may be found at the end of the history of this species, in the $S y-$ nopsis of the British Fuci.

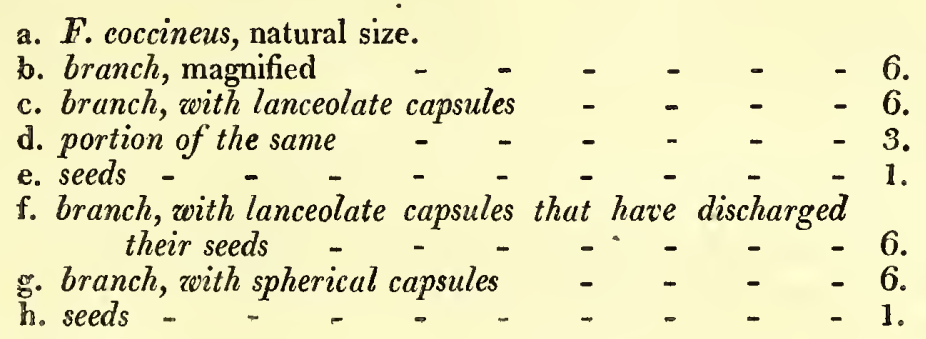

\section{9.-F U C U G O G I N E U S.}

Fucus, fronde compressâ, membranaceo-cartilagineâ, ramosissimâ ; ramulis subulatis, tripli-quadrupli-cato alternis ; tuberculis sphæricis, sessilibus, siliquisque lanceolatis.

Fucus coccineus. Fl. Ang. p. 586. Linn. Trans. III. p. 187. W1тн. IV. p. 119. Ner. Brit. p. 106. t. ad front. operis. Syn. Fuc. II. p. 291. Eng. Bot. XVIII. t. 1242.

F. Plocamium. Gmelin, Hist. Fuc. p. 153. t. 16. f. 1. (excl. syn. Linn.) Fl. Scot. II. p. 957. EsPeR, Ic. Fuc. I. p. 18. t. 2. Fl. Fr. Ed. 2da. II. p. 31.

F. cartilagineus. OEder, Enum. Plant. Fl. Dan. n. 131.

Ceramium Plocamium. Roтн, Fl. Germ. III. p. 458. Cat. Bot. II. p. 161. III. p. $10 \%$.

Fucoides rubens variè dissectum. RAII Syn. p. 37. n. 1.?

Haвıт а т in Britanniarum oris, copiosè.-In Galliæ oris, et oceano et Mari Mediterraneo circumlutis. Decandolle.-Ad Hispaniæ littora prope Gades. D. S. de Roxas Clemente.

Perennis. Jun.-Oct.

RADIX fibrosa, fibris plurimis, dilutè roseis, ramosis, densè fasciculatim implexis.

FroNDES, ex eâdem basi plurimæ, compressæ, filiformes, longitudine plerumque semipedales, sed aliquuandò vix tripollicares, atque aliquando pedales, latitudine ut plurimum circitèr semilineari, ubique lenissimè flexuosæe, ab ipsâ basi * ramosissimæ, ramis ramulisque omnibus in eodem plano progredientibus; rami intervallis incertissimis sejuncti, cuncti distichi, vagè alterni, patentesque, ii magis basi proximi longiores, aliisque minoribus simili ratione dispositis pinnati, qui seriem tertiam et quandoque quartam ferunt; ramorum extremorum latera occupant ramuli, duas tresve lineas longi, patuli, subulati, levitèr incurvi, in fasciculis collocati alternis, singulis duos tres aut quatuor includentibus, e quibus inferiores semper sunt simplices, creteri superficie supernâ aliis brevioribus obsiti, ut pectinati appareant: in surculis quoque primariis secundariisve intervalla inter ramos sæpe occupant hi ramulorum fasciculi, nunquam non alternatim positi, frondisque parti convexæ innascentes, unde stirpis facies longè pulchrior evadit.

Fructificatio

\footnotetext{
- Traditur hujus Fuci in Flora Gallicâ descriptio, quæ plantæ characterem quoad ramorum dispositionem adeò bene exprimit ut hìc maximnâ ex parte exscribendarn crediderim :-_" Sa tige est très rameuse, et toujours dans le nême plan : l'ordre des ramifications est très remarquable ; cliaque ranieau est légeremènt flexueux, et n'émet de ramifications que du côté convexe : la première est un filet simple et pointu; la deuxième est un filet qui a trois dents du côté antérieur; la troisième est un filet qui a deux dents, et qui a licu de la troisième dent pousse un filet muni d'une dent en delıors; la quatrième est un filet qui n'a qu'une dent, la deuxième dent est devenıe un filet à une deut, et la troisic̀me un filet rameux. Après ces quatre ramifications il y a un espace vide, et la tige émet des rameaux semblables du côté opposé."
} 
Fructrficatro duplex, in * diversis individuis, hac e capsulis constans sphæricis, papaveris seminis magnitudinè, ad latera ramorum, præsertìm superiorum, † sessilibus, coloris intensè sanguinei, seminum plurimorum, minutissimorum congeriem foventibus; illa e capsulis lanceolatis perquàm exiguis, ramis superioribus insidentibus, nunc solitariis, nunc racemosis, singula semina quinque vel quatuor majuscula subrotunda, limbo pellucido cincta, sub lente acerrimâ internè annulata, includentibus :-hæ capsulæ effoetæ producuntur, lineares fiunt, atque aliquando repetitoramosæ; vidi quoque quæ erant contortæ.

CoLOR pulcherrimè coccineus, sub-diaphanus; exsiccuta intensior; soli objecta vel in aquấ dulci servata citò pallescit, et in virescenti-luteum vel virescentem, et demùm in albicantem transit.

Su BST AN TIA cartilagineo-membranacea, tenuissima, tellerrima; siccitate flaccida et membranacea.

Ors. Planta glaberrima:- - exsiccata chartæ vel vitro laxiusculè adhæret:-Sertularia anguina huic præcipuè Fuco innascens reperitur:-varietatem fortè ex aliquo casu pendentem ramulis ferè omnibus simplicibus e Cambriâ Australi olìm misit amicissimus L. W. Dillwyn.

Quantâ curâ quantoque studio Algis submersis investigandis incubuere botanici, per paucos illos jam elapsos annos ab illo inde tempore quo Nereis Britannica et Fucorum Britannicorum Synopsis primùm publici juris sunt factæ, ex hoc judicare licet, quòd, cùm hi libri evulgarentur, F. coccinei $\ddagger$ fructificatio duplex res ita singularis sit habita ut ad duas species constituendas propemodùm per se sufficere censeretur; nunc verò innotuit idem in plurimis aliis huic affinibus Fucis, et forsan in multis aliis tempus insequens deteget. Citatur suprà exemplar, ab amiciss. D. Brodie missum, cujus in ramis occurrunt utriusque formæ capsulæ; nihil tamen simile unquam aliàs vidi, et certè in iis apud Yarmouth lectis individuis non modo frondes dioicæ apparent, sed illud valet, quod est in Fucorum Britannicorum Synopsi observatum, scilicet plantas siliquis lanceolatis instructas plerumque (nequaquàm autem semper) globuliferis angustiores reperiri. D. Pigott, vir mecum olìm de his stirpibus literarum consuetudine devinctus, nunc, eheu, quod scientia dolet botanica, multos per annos captivus in Galliâ detentus, Stackhousium certiorenı fecerat, se vidisse capsularum lanceolatarum, seminibus jam emissis, colorem in flavescentem evanescere. Crederet fortasse ex hoc aliquis effoetas decidere; sed e contrario in novos ramos produci suspicor, et plus unâ vice offendi specimina tale aliquid arguentia, quorum in uno, quod multis ante amis inter maris rejectamenta apud Yarmouth legit b. D. Mason, non tantùm erant elongatæ, iterùmque atque iterùm ramosæ, sed, quod magis inusitatum, modo prorsùs singulari in formam quasi sphæricam contortæ. Locum sibi $F$. coccineus inter Fucos pulcherrimos elegantissimosque summo jure vindicat, et est species, quæ, licet magnitudine formâ atque colore multùm ludat, se per ramulorum dispositionem semper dignoscendam præstat. Horum figura atque situs $F$. pectinati titulo, quo in Herbario Banksiano designatur, extiterunt causæ; fierique nequit quin lugeamus quòd nomen tam idonēum tali quale nunc fert mutare cogeremur. Exemplaria ex Hispaniâ accepta Britannicis, iis saltèm quæ ego vidi, sunt minora, et colore intensiore fucata ; crederem verò ad ea appropinquare, quæ $F$. vesiculoso, fibroso, et crispo innascentia observârunt Goodenovius Woodwardiusque, qui de his dicunt, plantam sic parasiticam densos sæpe confingere cæspites vix pollicem altos, speciemque diversam mentiri. Singulare quidem est quòd stirpis, quâ ne una in littoribus Britannicis frequentiùs occurrit, nuspiàm in operibus suis meminerit Linnæus; neque Raii synonymon dubio omni vacat, quoniam $F$. coccineum et $C$ on fervam coccineam commiscuisse videtur, de quo consulendum est quod ad hujus speciei historiæ finem in Fucorum Britannicorum Synopsi disseruit cl. Dillwyn.
a. F. coccineus, magn. nat.
b. ramus, magn. auct
c. ramus, cum capsulis lanceolatis
d. ejusdem pars - - -
e. semina
f. ramus, capsulis lanceolatis jam effutis
g. ramus, cum capsulis spharicis - -
h. semina

- Semel quidem, in exemplare e Scotiâ septentrionali a D. Brodie misso, in eodem vidi.

† Has capsulas nonnunquam, sed rarissimè, pedunculatas dicunt Goodenoviıs Woodwardiusque.

‡ Stackhousius, hâc fructificatione duplici commotus, fructum polymorplum ad plantæe characterem specificum in Nereille Brifannicà ascivit, sententiamque suam nuperiùs mihi retulit, fore necessarium plantam in plures dispertire species. Idem et ipse sensi, cim haxic ob ciusam in Fucorum Britannicorum Synopsi duas ex illá varietates construxi. 
Fucus, fronde compressâ, cartilagineâ, ramosissimâ; ramis supra-decomposito-pinnatis ; ramulis oppositis, apice fructiferis ; seminibus nudis, ramulorum apicibus quadrifidis septis.

Fucus plumosus. LiNn. Mant. p. 134. Syst. Nat. II. p. 718. Syst. Nat. Ed. Gmel. II. p. 1385. Fl. Ang. p. 587. Gмецin, Hist. Fuc. p. 15z.? Fl. Dan. t. 350. Fl. Scot. II. p. 955. Wiтн. IV. p. 120. Es e r, Ic. Fuc. I. p. 92. t. 45. Fl. Norv. II. p. 91. Linn. Trans. III. p. 188. Syn. Fuc. II. p. 296. Fl. Lus. II. p. 436. Eng. Bot. XIX. t. 1308. Fl. Fr. Ed. 2da. II. p. 31.

F* pectinatus. Fl. Norv. II. p. 122. t. 2. f. 8. Esper, Ic. Fuc. I. p. 97. t. 47. (excl. syn. Gmel.)

F. * ptilotus. Fl. Norv. II. p. 135. t. 2. f. 15. EsPER, Ic. Fuc. I. p. 96. t. 46.

Ceramium plumosum. Rотн, Cat. Bot. III. p. 133.

ß. capillaris; fronde tenuissimâ, teretiusculâ, articulatâ.

F. plumosus. Ner. Brit. p. 105. t. ad front. operis.

Fucoides purpureum elegantèr plumosum. RAI Syn. p. 38. n. 2. t. 2. f. 5.

I A в гт ат Insularum Britannicarum ad oras, $F$. digitati stipitibus non rard parasiticus, copiosissimè in Scotiâ et in Hiberniâ Septentrionali.-E freto, Davis's Streights dicto, quoque accepi--In fundo maris Islandici. Oeder. -In Oceano Septentrionali. Gunner.-In Oceano Atlantico. Koenig.-Ad Insulas fortunatas. Bory de St. Vincent.-Ad Ostia Tagi. Brotero.- $\beta$ in Scotiâ Septentrionali, prope Lossiemouth. D. Brodie.-Anglia Australis in littoribus, haud infrequens.

Perennis. Jul.-_Oct. Hudson.

RA DIX callus exiguus, dilatatus, nigricans.

Frons compressa, nervi venarumque expers, tres vel sex pollices longa, latitudine subæquali, in ramis primariis nunc vix semilineam, nunc lineam æquante, apices versus tantillùm angustata, ab ipsâ basi ramossima, ramis ramulisque omnibus distichis in eodem plano progredientibus; rami absque ordine sparsi, primarii plerumque elongati, ditri-chotomi, vel aliis minoribus, ipsis quoque vagis, nunc densè nunc laxè obsiti, et hi quoque alïs, utrâque serie præcedente tenuiore; ramorum extremorum forma elongato-lanceolata; totam frondem obsident pinnæ horizontales, duas tresve lineas longæ, indivisæ, lineari-lanceolatæ, approximatæ, oppositæ, ipsæ eâdem ratione. pinnatæe aliis aded minutis ut oculum inermem ferè fugiant, unde stirpis facies pulcherrimè plumosa : in ramis extremis et pinnis genicula sub lente apparent obsoleta, pallida, ramos in articulos sub-quadratos dividentia, quorum in reliquâ fronde nullum conspiciendum vestigium.

Fructificatio † semina aliquot majuscula, coloris intensè sanguinei, limbo pellucido perquàm manifesto cincta, pinnarum apicibus insidentia, et † capsulâ inclusa nullà; pinnæ verò apex tunc finditur, et involucrum quadri-sex-partitum, semina, quibus multo est longius, cingens refert. Semina hæc diffracta granula aliquot exigua subrotunda effundunt.

Color saturatè purpureo-ruber, fusco tinctus, in ramis primariis aliquandò ferè nigricans, in extremis dilutior, et subdiaphanus; exsiccata fit intensior, et in aquâ dulci servata sordidè fusco-virescit.

Subst A N I a cartilaginea, in surculis annosioribus crassiuscula et tenax, in junioribus tenuior.

$\beta$ faciè multùm discrepat; est ubique plusquam duplo angustior, et substantiæe ferè membranaceæ; color intensior, et ramuli sub lente evidentissimè geniculati, geniculis pellucidis, articulis sub-quadratis. Fructificatio in hâc nulla est hucusque detecta similis ejus jam sub var. a descriptæ, sed pinnarum apicibus haud rarò infixum adhæret semen unicum, majusculum, sphæricum, liberum, et involucro nullo septum, sed limbo cinctum pellucido, atque intus lineis albis distinctum quæ in septem octove partes subrotundas dividunt.

Oвs. Exsiccata chartæ adhæret.

Magnitudine atque figurâ tantum ludere solet $F$. plumosus, ut fieri nequeat quin cuivis Botanico, qui plurima ejus exemplaria observavit, species perquàm mutabilis videatur; atque idem etiam satis inter omnes quibus talis negatur facultas constabit, dummodo inter se conferre velint iconas Oederianas Stackhousianasque.suprà citatas, hanc minimum illam maximum plantæ statum sistentem. Has, si seorsùm contempleris figuras, adeò facilè pro stirpibus reverà distinctis haberes, ut solas respicienti major appareret in sententiâ adversâ difficultas; sed longè hoc a vero abest, quoniam ne unus datur in toto Algarum catalogo Fucus, cujus diversæ facies, a tenerrimâ et tenuissimâ ad latissimam maximèque cartilagineam, gradationibus tan certis atque conspicuis inter se conjunguntur. Hanc ob causam nemo adhuc in plures varietates dispertire est conatus, neque ipse tale aliquid nunc sim periclitatus, nisi sua-

deret

* Hac duo synonyma forsitàn ad varietatem meam $\beta$ pertinent, sed nihil est vel in icone vel in descriptione e quo res certè dijudicari potest.

† An semina, an capsulae rectiùs dicenda?-sane nescio; sed, cùm aliorum Fucorum semina, qua dicuntur, in plures partes dividantur, ita hæc etiam in presens semina nuncupavi.

‡ Capsuliferam hanc plantam dicit Rothius, qui plurimùm fructificationi impendit curam ; egn verò, licet anxius quæram et multa exennplaria perlustrem, nulla capsularum vestigia detegere possum, quà de re quicquid ille de his scripserit hic exscribendum puto, nescins tainen quales sint illæ stirpes quas pro masculis habet :- "Juniores," inquit, " capsulæ, ovatæ vel subrotundæ, atropurpurea, rcreptaculo tuberculoso insident, quod successu temporis segmenta producit quatuor, quinque, sen nonnunqnam sex, diversæ longitudinis, filiformia, subtorulosa, et evidentissime geniculata, demum capsula duplo longiora, et ad apicem conniventia evadunt, quarum articuli e granulis duobus compositi videntur. Disruptâ capsulâ post granuloruın contentorum dispersionem, tauquam inanis vesicula membranacea et lacerata per segincntorum interstitia transparet, et demùm macerata fere plauc evanescit, receptaculum verò cum segmentis persistit, et ex eorım numero constanter unicuin tantum elougatur in pinnam ita, ut tandem in annosio. ibus speciminibus pinnæ inferiores ramorum alternatim distichx, supra basin ad alterius latus fasciculo segmentorum setiformiun, subalternorum, brevi pedunculo quasi insidente, auctæ conspiciartur. In qubusdarn fasciculus pal matus evadit, et in novum ramum demum excrescere videtur. In vesiculiferis, et pro masculis venditatis individuis inunquill observifur segmentorum fasciculus ad interius latus pinnarum inferiorum ramis insidentimn."-- Cat. Bot. III. p. 136. 
deret summa * D. Brodiæi auctoritas, qui utramque abundè varietatem in littoribus sibi vicinis legit, et cui indies observandi haud deest occasio. Diu sunt rerum naturalium indagatores de hujus stirpis fructificatione omnes hallucinati, credentes illam e capsulâ constare sphæricâ, quæ matura in quatuor vel quinque dissilit partes, apice modò, Andraarum ad instar, connexas. Primus hunc errorem discussit Rothius, neque tamen ipse, viri tanti pace, rem ad amussim rectè intellexisse mihi videtur, cùm nullus dubitem quin fructus eum Conferva corallina et Conferva setacea referat, atque lææ plantæ, cum aliquot aliis Algis, quarum pars Fucis pars Confervis nunc annumeratur, genus pulcherrimum idemqne naturæ convenientissimum mox constituant, cujus character essentialis in seminibus nudis, involucro capsulæ loco septis, atque limbo maximè manifesto cinctis, constet. Qualem de individuis illis pro †masculis vesiculiferisque a Rothio habitis sententiam feram dubius omnino hæreo. His ille $\boldsymbol{F}$. plumosum Gmelini relegat, quem tamen synonymum dubium, et fortè rectiùs sub Confervâ coccineâ citandum, nequeo non putare. Quod si Gmelini opus perlustrans meo unius judicio fidendum existimarem, crederem $\boldsymbol{F}$. confervoidis iconem, quam Mohrii auctoritati obtemperans sub $F$. cristato suprà laudavi, esse ad $\boldsymbol{F}$. plumosi exemplar confectam. Habitus ille plumosus, cui nomen suum aptissimum hæc species debet, multum etiam ad discriminandam adjuvat, et optimè memoraverunt Goodenovius, Woodwardiusque, $F$. plumosum, colore licet fulgido $F$. coccineo cedat, ramorum tamen dispositione elegante ei longè antecellere, et ob hanc plumæ pulcherrimè ramosæ speciem præ se ferre, et satis ab omnibus affinibus distingui. Notatur quoque ab iisdem, exemplaria, quorum ramuli intervallo solito longiore sunt dissiti, aliquas e F. cornei varietatibus quodammodò referre, semper verò se per ramorum primariorum formam dignoscenda prabere, hos enim esse constantèr filiformi-compressos, coloris reliquâ fronde intensioris, et opacos, dum in F. corneo, quan= tumvis angusto, plani, ramis aliis concolores, et nunquam non subdiaphani conspiciuntur.

\begin{tabular}{|c|c|c|c|c|}
\hline b. ramus, magn. auct. & - & - & - & - \\
\hline c. ejusdem pars - & - & - & - & - \\
\hline d. rami pars cum fructu & & - & - & - \\
\hline e. semina - - & - & - & & - \\
\hline f. granula in illis inclusa & & - & - & - \\
\hline g. var. $\beta$ ramus - & - & - & - & - \\
\hline ejusdem pars - & - & - & - & - \\
\hline i. pars rami cum semine & - & - & - & - \\
\hline k. semen seorsùm - & - & - & - & - \\
\hline
\end{tabular}

- Se nunquam in distinguendis gravari dicit D. Brodie, qui de lis refert:- " the one (a) is cartilaginous, rough, always covered with Flustræ, the stem and branches compressed, the branches divaricated, and both these and the ramuli acute at each extreme, and swelling in the middle. The other $(\beta)$ is rather membranous, soft to a great degree before being wasled, the stem branclies, and ramuli, from the root to the top, perfectly round in every part, the delicate branches uncommonly long in proportion to the plant, and coming off from the stem in a very acute ascending angle, incurving as they ascend. The whole plant has (most strongly when fresh) the habit of a most beautiful Conferva; and this not only in the minute ramuli, but in the midrib of the branches, which has the appearance of a beaded spherical process, with a transparent line on each side."

+ Dicit de his Rothius, " exceptis speciminibus hic descriptis fructiferis observantur alia, habitu quidem quodammodo aliena, at structurâ omnimode cum illis convenientia, quæ pro masculis non possum non labere.

" Fila cum ramis obtecta ramulis subimbricatis:

" Pinna pinnulaque pariter oppositæ, at magis approximatæ, subimbricatæ, subincurvæ, apice non rarò subincrassatæ, evidentius geniculatæ.

“Vesicula in pinnis terminales, globosæ, subpellucidæ, coccineæ, breviter pedunculatæ, solitariæ, nunc et plerumque plane nudæ, nunc bas! utrinque pinnula patula suffultæ." -Cat. Bot. III. p. 135. 


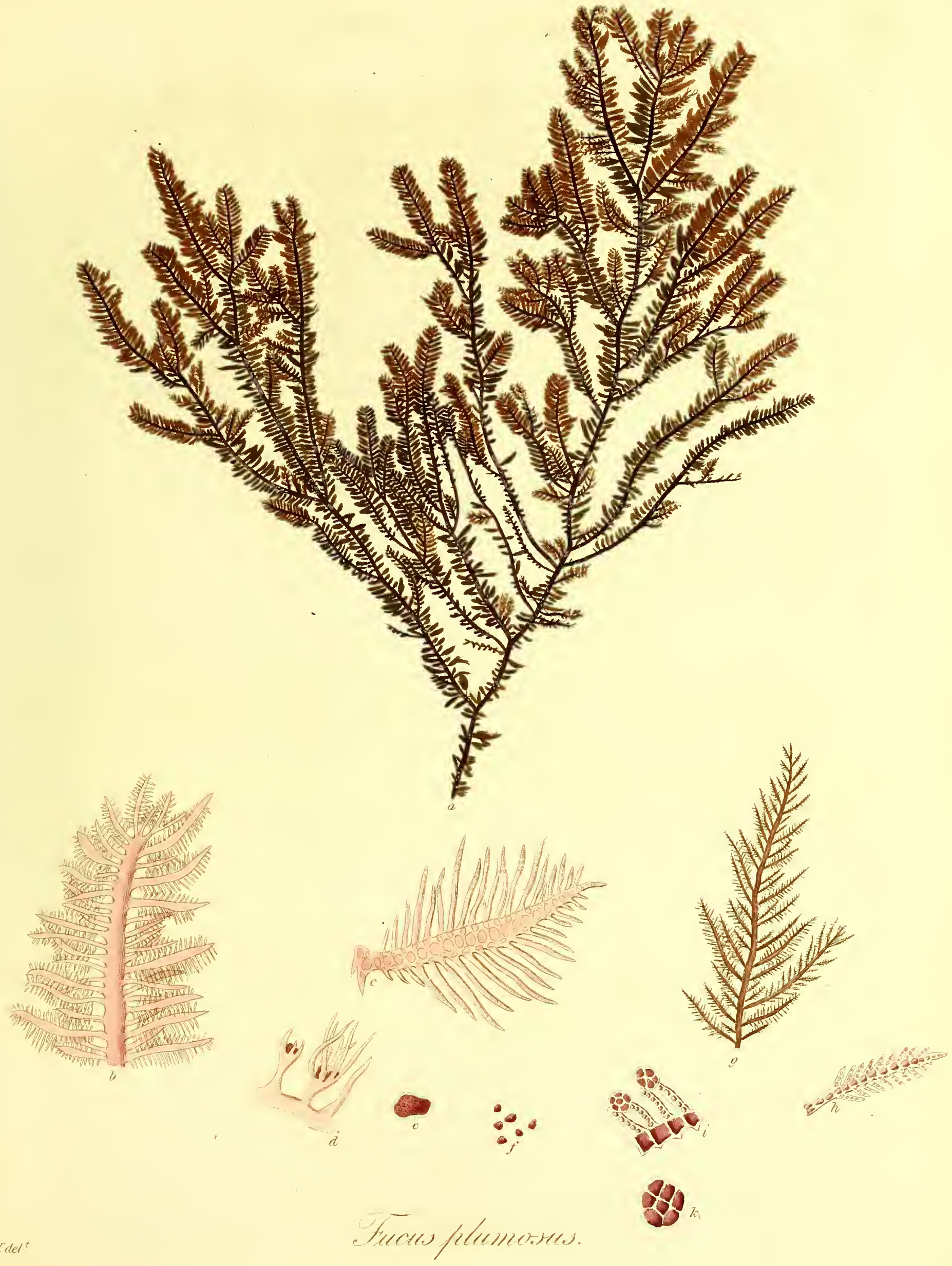



Fucus plumosus, frond compressed, cartilaginous, much and irregularly branched; branches repeatedly pinnated; ramuli opposite, bearing the fruit at their apices; seeds naked, surrounded by the quadrifid ends of the ramuli

Fucus plumosus. IIN M. Mant. p. 134. Syst. Nat. II. p. 718. Syst. Nat. Ed. Gmel. II. p. 1385. Fl. Ang. p. 587. Gmelin, Hist. Fuc. p. 152.? Fl. Dan. t. 350. Fl. Scot. II. p. 955. WiTh. IV. p. 120. Esper, Ic. Fuc. I. p. 92. t. 45. Fl. Norv. II. p. 91. Linn. Trans. III. p. 188. Syn. Fuc. II. p. 296. Fl. Lus. II. p. 436. Eng. Bot. XIX. t. 1308. Fl. Fr. Ed. 2da. II. p.31.

F. * pectinatus. Fl. Norv. II. p. 122. t. 2. f. 8. Esper, Ic. Fuc. I. p. 97. t. 47. (excl. syn. Gmel.)

F. *ptilotus. Fl. Nort. II. p. 135. t. 2. f. 15. Esper, Ic. Fuc. I. p. 96. t. 46.

Ceramium plumosum. Roth, Cat. Bot. III. p. 133. ß. capillaris; frond very narrow, nearly cylindrical, jointed. F. plumosus. Ner. Brit. p. 105. t. ad front operis. Fucoides purpureum elegantèr plumosum. Raii Syn. p. 38. n. 2. t. 2. f. 5.

On the shores of the British Isles; most plentifully in Scotland and the North of Ireland, often found growing on the stems of $F$. digitatus. - I have also received it from Davis's Streights.- In the sea about Iceland. $O E$ der.In the Northern Ocean. Gunner.-In the Atlantic Ocean. Koenig.-At the Canary Islands. Bory de St. Vincent.-At the Mouth of the Tagus. Brotero.- $\beta$. near Lossiemouth, in the Nortli of Scotland. Mr. Brodie.-Not uncommon on the southern shores of England.

Perennial. July-October. Hudson.

Rоот, a small, expanded, blackish, callous disk.

Frond, compressed, destitute of midrib or veins, from three to six inches long, its width in the primary branches nearly equal throughout, being scarcely half a line in some instances, in others, above a line, towards the apices somewhat narrowed, much and irregularly divided with branches beginning very near the base, all of them distichous, and disposed in the same plane; branches scattered without order, the primary ones in general elongated, and either ditri-chotomous, or beset with other smaller ones, which are themselves irregularly disposed, and these also with others, each series being narrower than the preceding one; the form of the extreme branches is lineari-lanceolate; the whole frond is pinnated with horizontal pinnæ two or three lines long, undivided, lineari-lanceolate, opposite, placed close to each other, and in their turns also pinnated with others so minute as almost to escape the naked eye, whence the plant has a most beautiful feathered appearance: in the extreme branches and pinnæe there appear under the microscope pale obsolete dissepiments which divide the branches into nearly square joints, but of these there are no vestiges in the rest of the frond.

Fructification, a few largish tseeds, of a deep blood-red color, surrounded with a very conspicuous pellucid limbus, placed upon the apices of the pinnæ, and inclosed in $\$$ no capsule, instead of which the end of the pinna splits into four or five parts, so as to resemble a tetra-, or penta-, phyllous involucrum, which is considerably longer than the seeds, and surrounds them.--The seeds, if broken, pour out a few small roundish granules.

Color, deep purplish-red, tinged with brown, sometimes almost blackish in the primary shoots, in the extreme ones paler, and subdiaphanous; in drying it becomes darker, and, if kept in fresh water, turns to a dirty brownish green.

SUBSTANCE, cartilaginous, thickish and tough in the elder shoots, more thin in the younger ones.

$\beta$ differs considerably in appearance, and is every where more than twice as narrow, and of a substance nearly membranaceous; its color is darker, and the branches under the microscope most evidently jointed, the dissepinents being pellucid, the joints almost square. In this no fructification lias yet been discovered, similar to that already described under var. $a$, but there is not unfrequently found attached to the ends of the pinnæ a single largish spherical seed, not inclosed by any involucrum, but surrounded by a pellucid limbus, and internally marked with white lines, which divide it into seven or eight roundish parts.

OBs. When dried it adheres closely to paper.

That $F$. plumosns is an extremely variable plant in point of shape and size is an observation wlich can scarcely fail of being made by every Botanist who is in the least acquainted with it, and which to those who are not so will receive sufficient

* 'Tliese two synonyms belong, perliaps, more properly to my var. $\beta$, but there is nothing eitler in the descriptions or the figures by means of which the point can bc ascertained.

† Whether these ought more properly to be tcrmed capsules ar seeds is a point that I confess myself at a loss to determine; but, as what we called the seeds in other Fuci may be observed to divide into different parts, I have for the present given thcse the same name.

₹ Dr. Roth, who has bestowed great attention upon the fructification of this Fucus, says, that it does produce capsules; but, though I have sought for them with much care, and examined very many specinens for the purpose, I never could discover traces of any; on which account I think it best to copy what he las written upon the subject, observing, lowever, that I have no idea $u$ hat it is that he means by male plants. "Juniores," inquit, " capsulæ, o vatæ vel subrotundæ, atropirpureæ, receptaculo tuberculoso insident, quod successu temporis segmcnta producit quatuor, quinque, seu nomnunquam sex, diversæe longitudinis, filiformia, subtorulosa, et evidentissime geniculata, demum capsulâ duplo longiora, et ad apicem conniventia evadunt, quorım articuli e granulis cuobus compositi videntur. Disruptâ capsulâ post cranulorum coǹtentorum dispersionem, tanquam inanis vesicula membranacea ct lacerata per segmentorum interstitia transparet, et demım inacerata fcre plane evanescit, receptaculum verò cum segmentis persistit, et ex eorum nunero constanter unicum tantum elongatur in pinnan ita, nt tandem in aunosioribus speciminibus pinnæ inferiorcs ranırum altcrnatim distichæ, supra basin ad alterius latus fasciculo scgmentorum setifornium sıbalternorum, brevi pedunculo quasi insidente, auct conspiciantur. In quibusdan fasciculus palmatus evadit, et in novmm rainum denum excrescere videtur. In vesiculiferis, et pro masculis venditatis individuis nunquam observatur segmentorium fasciculus ad interius latus piuna. tum inferiorum ramis insidentium."-Cat. Bot. III. p. 136. 
sufficient illustration by a comparison of the figures given in the Flora Danica and the Nereis Britannica, where the two opposite extremes are represented. These, if considered separately, might easily be mistaken for two distinct species, and a Naturalist who had seen no others might even have a difficulty in persuading himself that they are not so; and yet, so far is this from being the case, that no Fucus whatever exhibits more regular gradations between the most narrow and delicate, and the broadest and most cartilaginous individuals; in consequence of which 110 attempt was ever previously made to separate it into different varieties, nor should I now have ventured upon the so doing, except under the sanction of the opinion of* Mr. Brodie, who finds both the appearances plentiful in the vicinity of his own house, where he has continual opportunities of observing them. The error relative to the fructification of this plant, which was for a long time universally believed to consist of a capsule, which at maturity burst into four or five segments conniving or colnected at their tips, as in the genus Andraa, was first rectified by Dr. Roth; yet even he, in my opinion, has not exactly understood it. On the contrary I am satisfied that it is precisely like that of Conferva corallina and setacea; and that, together with these and a few more submersed Algæ, some of them now arranged among the Fuci, others among the Conferva, $\boldsymbol{F}$.plumosus will hereafter constitute a beautiful and natural genus of plants, distinguished by their naked seeds, surrounded by an involucrum instead of a capsule, and bordered by an extraordinarily large limbus. I have no idea what Dr. Roth can mean by his + male vesiculiferous individuals, to which he refers $F$. plumosus of Gmelin, a synonym that I still cannot help regarding as uncertain, and as probably belonging to Conferva coccinea. Were I inclined to trust to my own opinion, I should be inclined to think that the figure of $F$. confervoides, which on the authority of Dr. Mohr is quoted above as belonging to F.cristatus, was in reality copied from the plant before us. The appearance, whence $F$. plumosus derives its name, furnishes also one of its strongest characteristics, and it is well remarked by Dr. Goodenough and Mr. Woodward, that, "if it cannot rival $F$. coccineus in brilliancy of color, it is far superior in the elegant form of its ramitications, giving it the appearance of a beautifully branched feather, which sufficiently distinguishes it from all in the same division." The same gentlemen also observe, that "when the extreme ramuli are more distant than usual, it somewhat resembles some of the varieties of $F$. corneus; but that it may nevertheless always be distinguished by the form of the main branch and its subdivisions, wlich are always between filiform and compressed, of a darker color than the rest of the frond, and opake; whilst in the narrow varieties of $F$. corneus they are flat, alike in color, and have always some degree of transparency.

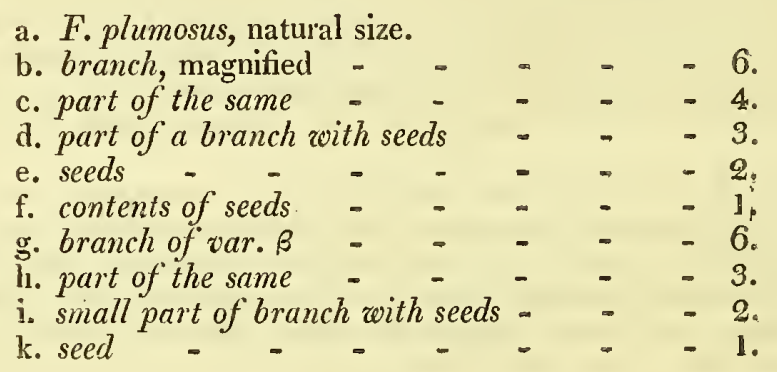

* Mr. Brodie says he never finds any difficulty in distinguishing them: that " the one (a) is cartilaginous, rough, always covered with Flus træ, the stem and branclies compressed, the branclies divaricated, and both these and the ranuli acute at each extreme, and swelling in the middle. The other $(\beta)$ is rather membranous, soft to a great degree before being washed, the stem, branches, and ramuli from the root to the top perfectly round in every part, the delicatc branches uncommonly long in proportion to the plant, and coming off from the stem in a very acute ascending angle, incurving as they ascend. The whole plant has (most strongly when fresh) the habit of a most beautiful Conferva; and this not only in the minnte ramuli, but in the midrib of the brancles, which has the appearance of a beaded spiral process, with a transparent line on each side."

+ Respecting these Dr. Roth says, " exceptis speciminibus hic descriptis fructiferis observantur alia, habitu quidem quodammodo aliena, at structurâ omnimode cum illis convenientia, quæ pro masculis non possum non habere.

"Fila cum ramis obtecta ramulis subimbricatis.

“ Pinnc pinnuleque pariter oppositæ, at magis approximatæ, subimbricatæ, subincurvæ, apice non rarò subincrassatæ, evidentius geniculatio.

“Vesicula in pinnis terminales, globosæ, subpellucidæ, coccineæ, breviter pedunculatæ, solitariæ, nunc et plerumque plane nudæ, nunc bas utriaque pianula patula suffultæ."-Cat, Bot. III. p. 135. 
Fucus, fronde cartilagineâ, debili, planâ, enervi, lineari, ramosissimâ ; ramis pinnatis ; ramulis lineari-lanceolatis, approximatis, apice seminiferis; seminibus nudis, ramulorum apicibus multifidis cinctis.

Ha вitat ad Caput Bonæ Spei, Fucis majoribus adnascens. D. C. Brand, in Herb. Banks.

RADIX callus exiguus.

FRONDES ex eâdem basi plurimæ, longitudine circitèr semipedales, planæ, nervi venarumque expertes, singulæ caule assurgentes unico, nunc indiviso, nunc semel, bis, terve vagè diviso, segmentis subfastigiatis, semper prope basin et apices aliquantùm attenuato, cætera latitudinem unius circitèr lineæ ubique æqualem servante, parte radici proximô nudiusculo, hìnc per totam longitudinem pinnato ramis lineari-lanceolatis, approximatis, distichis, horizontalitèr patulis, quoad longitudinem perquàm variis, et nunc vix duas tresve lineas, nunc pollicem et ultrà æequantibus, illis simplicibus, his ramulis brevissimis iterùm simili ratione pinnatis :-interdùm etiam sed rariùs, rami tripinnati evadunt.

FruCT1F1CAT10, ramorum minorum ad latera sessilis, constat e duobus vel tribus seminibus majusculis, sphæricis, liberis, coloris intensè sanguinei, singulis limbo pellucido cinctis, et granula plurima subrotunda fusca includentibus, omuibus septis setis aliquot brevissimis, incurvis, involucri faciem præ se ferentibus.

Co LOR purpureus, fusco tinctus, subdiaphanus; exsiccata intensior, magisque ad rubrum accedens; marcescentis aut in aquấ dulci servata sordidè albicans.

Su B ST A т т1 A cartilaginea, lenta, debilis.

Oвs. Planta glaberrima, quæ exsiccata chartæ laxiusculè adhæret:-nulla geniculorum in totâ stirpe, ne quidem in spinulis involucriformibus, species.

Exemplar, quod lææc exhibet icon, et quod unicum hujus Fuci hucusque vidi, in Herbario servatur Banksiano, ubi posuit D. Brand, qui quadraginta ferè ablìnc annis, (A. D. MDCCLXX.) legit. Nomen eidem, F. flaccidus, subscribitur, quod eâ de causâ retinendum judicavi, quoniam, quanvis plurimæ sint Fucorum species quibus illud ex* siccatis paritèr vel etiam magis convenire videtur, fieri tamen potest ut nullius in statu recente characterem aptiùs exprimat. F. flaccidus arctissimè est $F$. corneo affinis, et colore habitu atque texturâ stirpem illam mutabilem aded refert, ut inter varietates ejus majores forsan esset a Botanicis recensitus, nisi vetaret fructificatio, quæ statim $2 b$ eâdem eximit familiâ, et $\boldsymbol{F}$. plumoso, Conferva corallina, horumque congeneribus annumerandum docet: stabilitur quoque hìnc illud quod est jamdudùm de his plantis in Fucorum Britannicorum Synopsi memoratum, scilicet paullùm modò in Algis submersis disponendis valere structuram articulatam continuamve, et necesse fore, priusquàm ad systema omnibus numeris absolutum attingere possimus, ea quæ nunc recipiuntur genera in unum redigere, neque de ullâ stirpe quærere utrum sit hactenus Fucis, an Confervis, an Ulvis associata, sed cunctas simul oculis subjicere, et rem totam de integro elaborare.

a. F. flaccidus, magn. nat.

b. ramus, magn. auct. - - - - - 6 .

c. ramulus, cum fructificatione - - - 5 .

d. semina - - - - - - - 3 .

e. semen granula effundens - $\quad$ - $\quad 1$. 
Fucus flaccidus, frond cartilaginous, flaccid, flat, nerveless, linear, much and irregularly branched; branches pinnated, ramuli linear-lanceolate, placed close to each other, bearing seeds at their apices; seeds naked, surrounded by the multifid ends of the ramuli.

At the Cape of Good Hope, parasitical on the larger Fuci. Mr. C. Brand, in the Banlssian Herbarium.

Root, a small callous disk.

Fronds, numerous from the same base, about half a foot long, flat, destitute of midrib or veins, each rising with a single stem, in some instances undivided, in others once, twice, or thrice, irregularly cleft into segments of nearly equal height, always slightly attenuated near the base and apices, but otherwise preserving a nearly equal width of about a line, towards the root naked, but afterwards pinnated throughout its whole length with lineari-lanceolate branches, placed close to each other, distichous, between horizontal and patent, in point of length very variable, some of them being scarcely above tivo or three lines, while others are more than an inch long, the former are simple, the latter pinnated with extremely short ramuli, disposed in a similar manner:-sonietimes also, though rarely, branches are found tripinnate.

Fructification, sessile upon the sides of the smaller branches, consisting of two or three largish spherical seeds, not inclosed in a capsule, of a deep blood-red color, each bordered by a pellucid limbus, and containing several roundish brown granules: the clusters of seeds are surrounded by about eight extremely short, incurved, spiniform setæ, which have the appearance of an involucrum.

Color, purple, tinged with brown, semitransparent; darker, and more inclining to reddish brown when dried; turning, in decay or from exposure to the sun, to a dirty white.

SubSTA NCE, cartilaginous, but flexible and flaccid.

OBs. The plant is remarkably smooth, and in drying adheres slightly to paper:- there is no appearance of a tendency to be jointed in any part, not even in the ramuli which look like an involucrum.

The specimens, from which the present figure was taken, the only ones of this Fucus that I have ever had an op portunity of seeing, are preserved in the Banksian Herbarium, to which they were communicated by Mr. Brand, who gathered them so long since as the year 1770 . They are marked with the name of $F$. flaccidus, which I have therefore thought it proper to retain, as, though many other species may appear, after they are dried, equally, or even more deserving of such an appellation, it is nevertheless possible that it may be peculiarly characteristic of the present in a recent state. The nearest affinity of $F$. flaccidus is with $\boldsymbol{F}$. corneus, among the larger varieties of which it would in all probability have been enumerated, since both in color, habit, and texture, it bears a striking resemblance to some of the appearances of that very variable plant, had it not been for the fructification, which at once removes it from the same division, and brings it near to F. plumosus, Conferva corallina, and their congeners; thus affording an additional proof in favour of the observation made some time since in the Synopsis of the British Fuci, that in the arrangement of the submersed Algæ the jointed or unjointed structure is of small importance, and that, previously to any permanent system being established upon this subject, it will be necessary to reduce to one mass the present genera of Fucus, Ulva, and Conferva, and to proceed in nearly the same manner as if nothing had been done before.
a. F. flaccidus, natural size.
b. small branch, magnified -
c. ramulus, with firuit
d. seeds
c. seed discharging its contents

$\begin{array}{llll}- & - & - & -\end{array}$




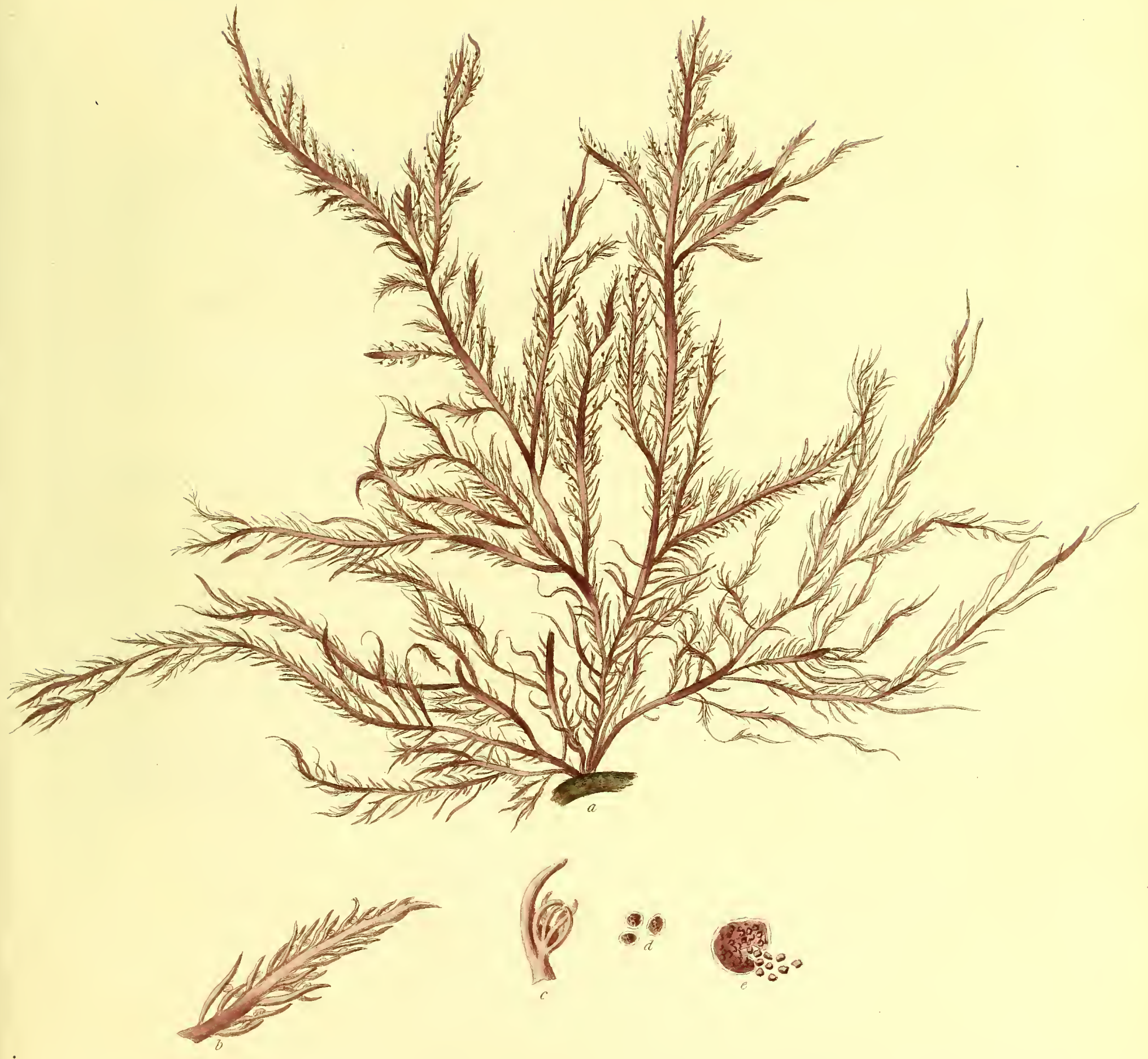

Surus flaccides. 

Fucus, fronde membranaceâ, planâ, sub-enervi, lineari, ramosissimâ; ranis horizontalibus, pinnatis; ramulis alternis, lineari-lanceolatis, serratis, margine superiore seminiferis; seminibus nudis, denticulorum apicibus multifidis cinctis.

Fucus asplenioides. Esper, Ic. Fuc. II. p. 78. t. 147.

Hа вıтат in Americæ Septentrionalis orâ Occidentali, in loco " Prince William's Sound" dicto. D. Menzies.In littore Kamtschatico. D. Horner.-In Novæ Hollandiæ oris Australibus, ad Fretum "Bass' Streights" dictum. D. Brozen.

\section{Perennis?}

RA D IX callus exiguus, dilatatus.

FroNs plana, costâ obscurâ tenuissimâ vix nisi lentis ope conspiciendâ percursa, longitudine semipedalis, vel dodrantalis, latitudine unius circitèr lineæ, et ubique ferè æqualis, surculis primariis bis, ter, vel pluries vagè dichotomis, segmentis sub-fastigiatis, omnibus a basi usque ad apices pinnatis ramis distichis, horizontalibus, aut liorizontalitèr patulis, approximatis, oppositis, alternisque, longitudine nunc tripollicaribus, nunc vix unguicularibus, majoribus minoribus absque normâ immixtis, cunctis per totanı longitudinem pinnatis ramulis, duas tresve lineas longis, lineari-lanceolatis, obtısiusculis, lenitèr incurvis, horizontalitèr patulis, semper alternis, margine utrinque serratis, intervallo inter singulos vix lineam superante:-e ramis inter ramulos haud rarò pullulant rami alii ninimi, ortu lanceolati, et simplices, ut siliquas nudo oculo mentiantur, mox sese in ramos pinnatos elongaturi.

Fructificatio ramulis, et tantummodo lateri eorum superiori, imposita, e * seminibus constat liberis, denticulorum, qui tunc pedicellorum vice funguntur, ad apices sitis, septisque setis plurimis, articulatis, minutissimis, involucri polyphylli faciem prabentibus.

CoLOR obscurè coccineus fusco aliquantùm tinctus; exsiccatre multò intensior; marcescentis aut soli objecta sordidè lutescens.

SU BSTANTIA membranacea, tenera, in surculis tamen primarïs crassior et sub-cartilaginea.

Oвs. Exsiccata chartæ laxiusculè adhæret :-exemplaribus a Menziesio lectis sunt infixa Zoophyta quædam rotundả, plana, perquàm exigua, albicantia, Lecidea effusa patellılarum formâ atque colore simillima.-A nnon novum Zoophytorum genus?

Áded sese hæc pulchra Fuci species a reliquis omnibus lucusque detectis facilè dignoscendum præstat, ut nullus sit in discriminandâ labor. Quoad formam habitumque magis forsàn insequenti quàm ulli alii accedit; sed quantum hæ duæ stirpes inter se discrepant quivis statim agnoscet Botanicus, qui crescendi rationi, ramulorum figuræ, et fructui animum intendit, ut silentio præteream surculos illos angustos cirrhiformes, in quos unius rami modo maximè insigni excurrunt, qui verò in aliâ penitùs desiderantur. Habet etiam $F$. asplenioides aliquam cum $F$. corymbifero similitudinem, sed hujus fructificatio atque ramuli magis quàm ii $F$. cirrhosi primo aspectu abludentes reperiuntur. Inter species Britannicas ne uni arctiùs affinis videtur quàm $F$. plumoso; neque est negandum quin illam ejus; stirpis varietatem, quam sub F. Ptiloti nomine depinxit Essperus, plurimum colore habituque referat, dummodo sit iconi omnimodò fidendum. Fructificatio quoque utrique eadem; illud tamen habet $F$. asplenioides proprium, quod seta hane involucri instar cingentes sint perquàm manifestè geniculatæ, reliquæ vero frondis partes nihil articulati ostendant. Exemplar hic delineatum, cl. Mensiesio, qui primus detexit, acceptum refero. Verisimile putarem Fucum in oris tam dissitis lectum olim fore a Botanicis inter vulgatiores recensitum, licet omnium de his plantis auctorum notitiam hucusque latuerit, Espero uno excepto, ad quem ipse misi, et qui, quantum ad Aspleniorum quorundam similitudinem accedat observato, $F$. asplenioidis nomen imposuit.
a. F. asplenioides, nagn. nat.
b. ramus, cum fructu, magn. auct. - $\quad-\quad-6$.
c. ramulus, cum fructu - - $\quad$ - $\quad-4$ - 4
d. fructus - - - - - - -2 .
e. semina? - - - - _ - 1 .
f. una e setis semina cingentilus - $\quad-\quad 1$.
g. ramus, e quo novi rami capsulas referentes nri-

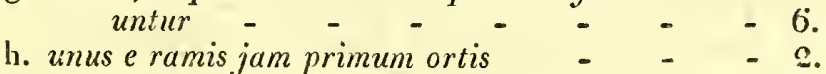

\footnotetext{
- In exemplare hìc depicto, æequè ac in omnibus iis hujus Fuci quæe hactenus vidi, fructificationis ætas nimis provecta granula modò subro. tunda, eorum in $F$. plumosi et $F$. flaccidi seminibus inclusorum sinilia, ostendebat. Nullus tamen dubito quin fructus illum barum plantarus. ad anussim referat.
} 
Fucus asplenioides, frond membranaceous, flat, almost nerveless, linear, much and irregularly branched; branches horizontal, pinnated; ramuli alternate, lineari-lanceolate, serrated, producing seeds on their upper margin; seeds naked, surrounded with the multifid ends of the serratures.

Fucus asplenioides. EsPER, Ic. Fuc. II. p.78. t. 147.

In Prince William's Sound, on the North West coast of America. Mr. Menzies.-Sliores of Kamtschatka. Dr. Horner.-. On the South side of New Holland, by Bass Streights. Mr. Brown.

\section{Perennial?}

Rоoт, a small, expanded, callous disk.

FRON D, flat, provided with an extremely thin dark midrib, scarcely discernible without the assistance of a microscope, from six to nine inches long, and every where preserving an equal width of about a line, the primary segments twice, thrice, or even more frequently irregularly dichotomous, with segments of nearly the same height, all of them pinnated from base to summit with distichous branches, horizontal, or between horizontal and patent, situated close to each other, both opposite and alternate, varying in length from scarcely half an inch to three inches, large and small being mixed together without any order; the whole of them are throughout their whole length pinnated with ramuli two or three lines long, of a lineari-lanceolate form, bluntish, slightly incurved, between horizontal and patent, constantly alternate, their margins serrated, and separated from each other by intervals of not more than a line:--in the spaces between the ramuli are not unfrequently observable other exceedingly small branches, lanceolate and simple at their origin, so as to have to the naked eye the look of capsules, but afterwards lengthening into pinnated branches.

Fructifycation, situated only upon the upper side of the ramuli, consisting of * seeds not inclosed in any capsule, placed on the apices of the serratures, which then perform the office of pedicelli, and split into several most minute jointed setæ, surrounding the seeds like a polyphyllous involucrum.

Co sok, dark scarlet, somewhat tinged with brown, much deeper when dry, and turning in decay, or from exposure to the sun, to a pale and dirty yellow.

SUBSTANCE, membranaceous and tender, but thicker and inclining to cartilaginous in the primary shoots.

OBs. When dried it adheres, though slightly, to paper :-to the specimens gathered by $\mathrm{Mr}$. Menzies were attached some very small, circular, flat, whitish Zoophytes, in shape and color very much resembling the shields of Lecidea effusa.-May not these prove a new genus of Zoophytes?

There is little danger of confounding this beautiful species with any other at present known, among all which there seems to be none to which it is so closely allied as to the following, though even fron this it requires but slight attention in any botanist to perceive how widely it differs in its mode of growth, in the form of its ramuli, and in its fructification; not to mention those narrow shoots which so remarkably terminate the branches of the one, but are altogether wanting in the other. It has also some affinity with $F$. corymbiferus of Grmelin, but still less than with $F$. cirrhosus, the fruit and the ramuli being at first sight more strikingly dissimilar. Among the British species it, perhaps, approaches most nearly to $F$. plumosus, and in general habit, but not in any other particular, except color, considerably resembles that variety of this plant which Professor Esper has figured under the name of $F$. Ptilotus. It also agrees with it in fructification, and is remarkable for the circumstance of the setæ that surround the seeds being most evidently jointed, while no other part of the frond displays the least appearance of a similar tendency. 'To Mr. Menzies, who first found this Fucus, I am indebted for the specimen here figured, nor should I, if we may judge from its having been gathered upon shores so widely distant from each other, be surprized at its proving at some future time to be by no means an uncommon species, though it appears at present to have escaped the observation of all authors upon the subject, excepting Prufessor Esper, to whom it was communicated by myself, and who gave it the name of $F$. asplenioides from its resemblance to some species of Asplenium.

a. F. asplenioides, natural size.

b. branch, with fruclification, magnified $\quad-\quad 6$

c. ramulus, with fiuctification - $\quad-\quad-4$.

d. fiuctification - $\quad$ - $\quad$ - $\quad$ - $\quad 2$.

e. seeds? - - - - - _ - $\quad$ - 1 .

f. one of the involucriform filaments - $\quad-\quad-1$.

g. branch with young shoots between the ramuli resembling capsules - $-{ }_{-}-{ }_{-}-6$.

h. one of the young shoots in its earliest stage of growth - - - - - - -

- In the spccimen here painted, as well as in all the others that $I$ have yet seen of this Fucus, the fructification was too far advanced, and nothing was observable but roundish granules, similar to those contained in the seeds of $F$. plumosus and $F$. flaccidus. I have, however, not the least doubt but the fruit of all these three Fuci is the same. 

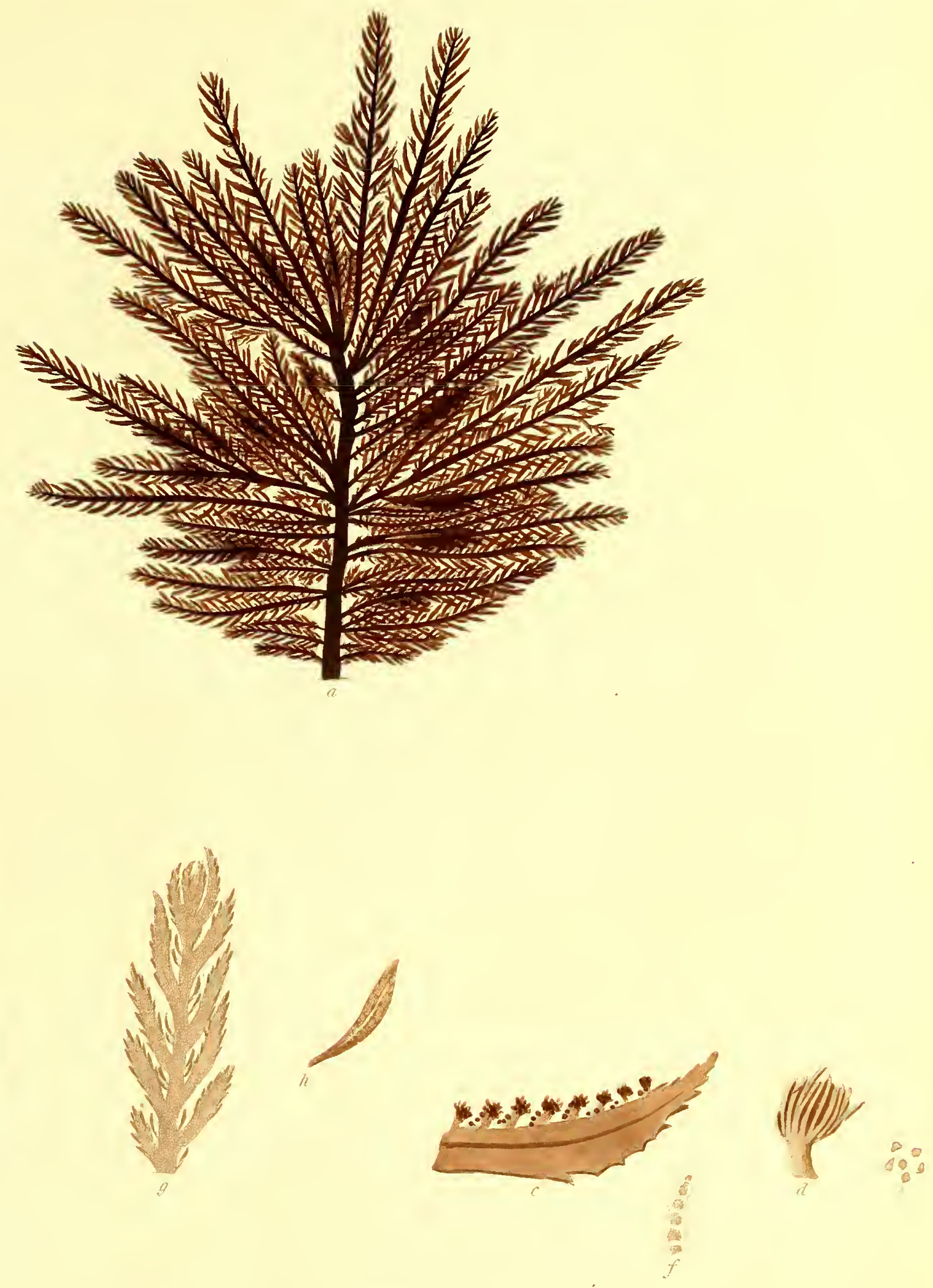

Fucus, fronde membranaceâ, planâ, enervi, lineari, ramosissimâ ; ramis pinnatis, apice in surculos dentatos flagelliformes attenuatis; ramulis alternis, lineari-lanceolatis, alternatim simplicibus pectinatisque.

Ha вiтat in Novæ Selandiæ oris, in sinu " Dusky Bay." D. Andrews, in Herb. Banks.

\section{Perennis?}

RADIX nondùm cognita.

Frons plana, * costæ venarumque omninò expers, longitudine pedalis, et ultrà, latitudine circitèr sesquilinearis, et ubique æqualis, in ramos aliquot distichos, sparsos, situ atque longitudine quàm maximè varios, plerumque tamen elongatos et simpliciusculos, vagè divisa ; rami omnes per totam longitudinem pinnati ramulis distichis, sub alternis, approximatis, horizontalitèr patulis, linearibus, apice tamen aliquantùm attenuatis, lenitèr incurvis, circiter semiunguem longis, alternatim pectinatis, scilicet cuivis simplici proximus exoritur alius longior, ipse iterum aliis longè minoribus obsitus, quasi sit in novum ramum abiturus, unde pectinata facies; ramuli pectinati sunt integerrimi, simplices margine superiore integerrimi, inferiore serrati ;-ramorum apices haud raro in surculos elongatos, latitudine vix semilineares, simplices, vel bifurcos, dentibus brevissimis recurvis utrinque vagè obsitos, attenuantur.

Fructificatio ramulorum ad alas sita, e capsulis aliquot cylindraceis, perquam minutis, confertis, bi- tri- fidis, coloris dilute carnei, constat.

Color coccineus aurantiaco immixtus, subdiaphanus; exsiccate intensior; marcescentis aut soli objecta sordidè lutescens.

Su Bst A N Ti a membranacea, tenerrima, et tenuissima.

OBs. Frons lenti acerrimæ subjecta obsoletè reticulata apparet :-exsiccata chartæ adhæret.

Ad calcem exemplaris, quod in Herbario Banksiano servatum hæc exhibet icon, $\boldsymbol{F}$. dentati nomen scripserat $b$. Lightfootius, qui optimam ejus stirpis descriptionem in Florâ suâ scoticâ tradiderat, et cui tot recentem observandi facultates erant oblatæ, ut fieri nequeat quin talem ejus admiremur errorem, idem licet in alio quovis naris minùs emunctæ Botanico nequaquàm mirum videretur, quoniam formâ habituque, ut aiunt, generali multum inter se conveniunt. Utut verd hæc similitudo valeat, cuivis, vel mediocritèr in hâc re versato, statìm patebit quantum sit in colore, et quantum in ramulorum formâ discrimen. Hi sunt in $F$. dentato omnes uniformes atque integerrimi, excepto quodd apices habeant incisos, dum, contrà, ii $F$. cirrhosi alternatim simplices ramosique conspiciuntur. Præeter hæc nemo unquam aliquid in illo vidit simile surculorum angustorum spinosorum in quos hujus rami attenuati abeunt, neque fructus ambobus idem; cujus tamen, cum sit in unico quod in præsels vidi $F$. cirrhosi exemplare valde imperfectus, vix ullam mentionen facere sustulissem, nisi capsulas omnind similes in alio quoque vidissem Fuco, quem a Capite Bonæ Spei acceptum mox sub $F$. Corallorhiza nomine in hoc opere describere est in animo. Interest etiam in plurimis magna inter $\boldsymbol{F}$. cirrhosum et $\boldsymbol{F}$. asplenioidem similitudo ; de quâ, et simul de characteribus per quos dignoscuntur, jamjam est sub hoc tractatum. Nomen ducitur a ramorum apicibus attenuatis, cirrhos formâ quodammodò referentibus, et forsitan ad idem ninisterium a naturâ comparatis. Nihil horum simile est hactenus in ullo alio Fuco fronde planâ membranaceâque instructo observatum, et hi stirpis characterem cuivis maximè obvium suppeditant, notam licet haud minùs certam, quantumvis minùs manifestam, in ramulorum formâ dispositioneque Botanicus attentiùs lustrans detegat. Planta sub $\boldsymbol{F}$. cirrhifolii nomine a Vahlio descripta, huic nostræ quoad nomen simillima, toto tamen colo indole discrepat, et est, ut ex descriptione et synonymo allato videtur, ad $F$. muscoidem Wulf. referenda.

a. F. cirrhosus, magn. nat.

b. frondis pars, magn. auct. - - = - 6 .

c. ejusdem portio, in quâ fructus, structura reticu-

lata, et costa conspiciuntur - - - -3.
d. - -1.

\footnotetext{
* Ramorum quorundam ad apices sub lente maximè augente lustratos costa tenuis albicans conspicitur, sed hoc nequaquam in omnibus ramis, et nunquam nisi snmmis vitri viribus utenti, quare plantam pro enervi habeo.
} 
Fucus cirhosus, frond membranaceous, flat, nerveless, linear, much and irregularly branched, producing at its apices narrow, flagelliform, dentated shoots; ramuli alternate, lineari-lanceolate, alternately simple, and pectinated.

At Dusky Bay, on the coast of New Zealand. Mr. Andrezes, in the Banksian Herbarium.

\section{Perennial?}

Root, not at present known.

FroN D, flat, destitute of * midrib or veins, in length a font or more, in width about a line and half, and every where equal, irregularly divided into a few distichous scattered branches, extremely uncertain in point of situation and length, but for the most part elongated and simple; all the branches are pinnated from top to bottom with distichous, sub-alternate, approximated ramuli, between horizontal and patent, linear, except that they are somewhat attenuated towards their apices, slightly incurved, about a quarter of an inch long, alternately pectinated, that is to say, next to every simple one is placed another longer than it, and beset with others much smaller, as if it were about to lengthen into a new branch, whence it has a pectinated appearance; the pectinated ranuli are quite entire, the simple ones entire in their upper, and serrated on the under side :- from the ends of the branches not unfrequently issue flagelliform shoots, an inch or two long, and not more than half a line wide, either simple or forked, irregularly beset on each side with very short recurved teetl.

Fructification, situated at the axilla of the ramuli, consisting of a few very minute, clustered, cylindrical, bifid, or trifid, pale-pink capsules.

CoLOR, scarlet, inclining to orange, semitransparent, darker when the plant is dry, and turning in decay, or from exposure to the sun, to a light and dirty yellow.

SubstanCF, membranaceous, extremely thin, and tender.

OBs. If examined with a strong microscope the frond appears obsoletely reticulated:-in drying the plant adheres to paper.

Under the specimen of this Fucus preserved in the Banksian Herbarium, of which a figure is here given, the name of $\boldsymbol{F}$. dentatus is written by the late Mr. Lightfoot, whose description of that species, which he had constant opportunities of observing upon the shores of Scotland, is so excellent, that from him such an error cannot fail to appear remarkable, though, with a less acute, or less careful Botanist, it would have been far from surprising, the two plants being in reality very closely allied in form and general habit. It will, however, be immediately perceived, that they differ essentially in their color, and still more so in the shape of their ramuli; those of $F$. dentatus being uniform, and quite entire, except that they are toothed at their apices, while in $F$. cirrhosus they are alternately simple and branched, and are all serrated in their lower margin, but entire in the upper. In addition to this, no appearance of the narrow spinous shoots, with which the branches of the present Fucus are so singularly terminated, has ever been noticed in the other, and the fructification of the two is likewise dissimilar; thongh this is so imperfect in the specimen of $F$. cirrhosus here represented, the only one which I have ever had an opportunity of examining, that I should scarcely have ventured upon noticing it at all, had I not met with capsules that seem altogether analogous in a species from the Cape of Good Hope, which I purpose shortly describing in this work under the name of F. Corallorhiza. F. cirrhosus bears also considerable resemblance in several particulars to the subject of the preceding plate, in the account of which are pointed out the differences that most obviously distinguish them. The name is derived from the long narrow shoots into which, as is above-mentioned, the extremities of the branches are attenuated, and which wear the appearance, and probably perform the office, of tendrils. It is upon these that the plant depends for its most striking character, nothing at all similar having been observed in any other flat and membranaceous Fucus; but an equally certain, though less apparent, distinction is to be found in the shape and disposition of the ramuli. From the similarity of names, it might be supposed, that the present plant is allied to F. cirrhifolius of Vahl, which is far from being the case, this latter being, according to the description, the same as $F$. muscoides of Wulfen.

a. $F$. cirrhosus, natural size.

b. part of the frond, magnified - - - - 6 .

c. portion of the same, to show the fruit, reticulated

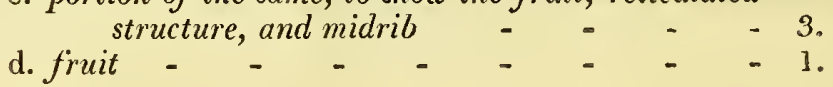

* Towards the end of some of the branches is observable, with the highest powers of the microscope, a thin whitish midrib, but this is not to be seen in all the shoots, and never without the assistance of very strong glasses, on which account I have thought it best to call the plant nerveless, 


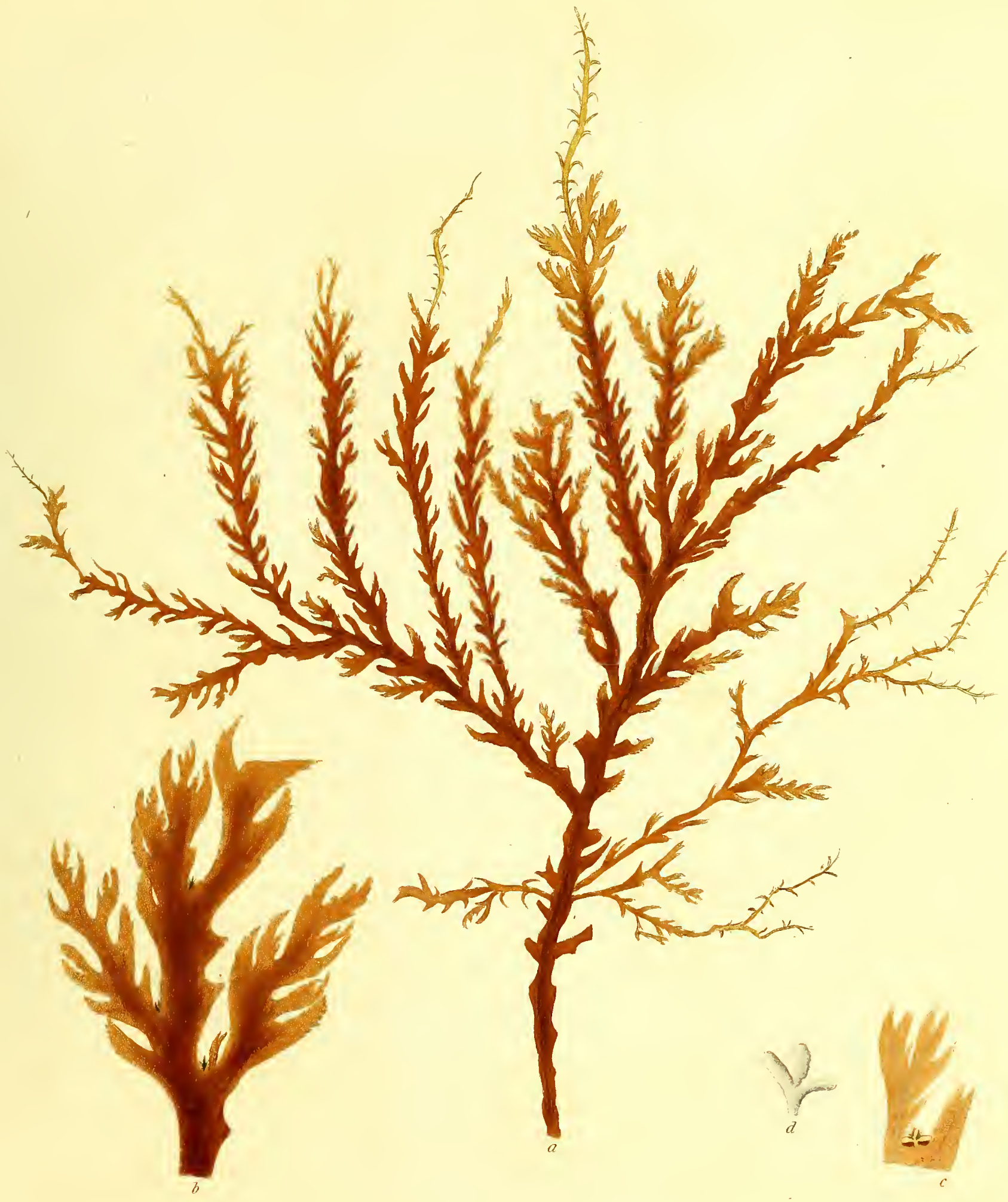

Gucer cerveluster. 

Frucus, fronde cartilagineâ, planâ, lineari, dichotomâ, costatâ, margine integerrinâ ciliatà ; ciliis teretiusculis, subsimplicibus, apice in capsulas sphæricas intumescentibus.

Furus vittatus. LinN. Syst. Nat. II. p. 718. Syst. Nat. Ed. Gmel. II. p. 1387. Fl. Norv. II. p. 35. ESPER, Ic. Fuc. II. p. 53.

E. ornatus. LinN. Mant. p. 312.

F. ciliatus. Esper, Ic. Fuc. I. p. 21. t. 4. (quoad fig. 1, o, 4, excl. syn. forte omnibus.)

F. caulesceus. Gmelin, Hist. Fuc. p. 173. t. 20. f. 2.?

F. marinus, ramosus, caule folioso, foliis angustis, ad margines pilosis. Sе в A, Thes. III. p. 192. t. 102. f. 11.? Alga marina, foliis longis, angustis, germinantibus, tenui tomento in ambitu ornatis. SЕ в А, Thes. III. p. 192. t. 103. f. 5.?

Habitat ad Caput Bonæ Spei. Linnaus,-In Americæ Australis oris. D. Cavanilles.

Perennis?

RAD1X callus majusculus, dilatatus, purpurascens.

FroNDEs ex eâdem basi plurimæ, planæ, lineares, longitudine pedales, sesquipedales, et ultrà, latitudine circitèr unguiculares, aveniæ, sed costâ crassiusculâ apices versus attenuatâ et obsoletâ percursæe, nunc omninò simplices, nunc bis terve dichotomæ, nunc ramis distichis patulis e margine exeuntibus vagis sparsìm pinnatæ, nunc aliis e costâ natis proliferæ, sed hoc, nisi fallor, vix nisi plantâ casu aliquo læsâ accidit, quamvis, uti in exemplare hìc depicto, stirps non raro iterùm atque iterùm prolifera vim talem a naturâ accepisse videatur; rami omnes ortu tenuissimi et teretiusculi, sed ferè statìm plani, longitudinis quàn maximè incertæe, vel indivisi, vel dichotomi, vel aliis minoribus e margine costâque ortis instructi, apices versus lenitèr angustati ut minores oblongo-lineares evarlant : Membranâ frondis ad basin fluctibus sæpe detritâ, costa ibi denudata stipitis brevissimi teretis faciem præ se fert:-frondis margines ubique * planos et integerrimos per totam longitudinem cingunt ramenta ciliiformia, teretiuscula, lineari-elliptica, lineam aut sesquilinean longa, approximata, quædam simplicia, alia minoribus eâdem ratione ciliata, alia enormitèr divisa : similia quoque aliquando, sed rariùs et non nisi sparsim, costæ vel etiam frondis utrique paginæ innascentia reperiuntur.

FrUCtificatro in cilïs sita, qua tunc intumescentia formam sphæricam vel ellipticam induunt, et semina plurima subrotunda exigua intensè purpurascentia intùs fovent.

Color pulchrè purpureus subdiaphanus; exsic'catc intensior, et ad violaceum accedens; in aquâ dulci servate vel soli objerte sordidè lutescens, et denùm albicans.

Su bST A Ti a cartilaginea, crassiuscula, lenta, et tenax; in exsiccatâ sub-cornea.

OBs. Planta glaberrima, per siccitatem sæpe nitida, quasi sit vernice oblita:- frons haud infrequentèr versicolor apparet, colore hic integro, illic deperdito :-chartæ nequaquàm adhæret.

Ex iconibus suprà citatis non desunt aliquæ quæ $F$. vittati formam characteresque satis bene exprimunt, vix una tamen dubio prorsùs vacavit, unde factum est plantæ hujus historiam semper fuisse apud auctores dubiorum nebulis Involutam, ipsa licet magis quam Fuci plerique exotici Botanicis innoluerit. Errorum horum prima cansa est in Linnæi operibus quærenda, qui primitùs in Systemate Natura sub nomine hìc servato descripsit, et mox pro novâ specie, F. ornatus dictâ, in Mantissâ protulit, quæ duæ demùm sunt pro varietatibus in Systemate Plantarum recensitæ, quamvis, uti ex + Herbario suo constat, ne minima inter utramque dissimilitudo interest; dum in eodem opere (quod confusionem cumulat) $F$. ciliati icon Oederiana, cùm sub $F$. vittato, tùm sub $F$. ciliato, citatur, Gmelini verò $F$. caulescens, illius $\$$, me judice, synonymon indubium, ad hunc refertur, a quo toto coelo discrepat. Talibus in secundo Iconum Fucorum tomo nititur Esperus ad sese culpâ liberandum, quòd sub F. ciliati nomine stirpem hic depictam in primo delineaverit. Gunneri synonymon nequeo pro certo habere, quoniam characterem modo Linnaanum specificum repetiit, nihilo mutato adjectove, totusque ex auctoritate Tonningii, $F$. vittatum in \$tractatu de rarioribus Norvegic enunerantis, pendere videtur. Haud igitur ei usque aded fidere sum ausus, nt Norvegiæ oras inter locos natales memorem ; neque enim temerè nec nisi summâ cum curâ in stirpium nostrarum Europearum numerum ascribere debenus plantam, quæ tantummodo ad Caput Bonæ Spei vel ad Americæe Australis littora, unde olim ad Stackhousium b. Cavanilles misit, hucusque est reperta. Quod ad $F$. vittati affinitates attinet, nulli forsitan arctiùs est a naturâ connexus Fuco quàm $F$. erinaceo, sub quo jam suprà traditur Linnæum ambos in Herbario suo commiscuisse, ibidemque simul exponuntur notæ per quas inviccn dignoscuntur. Ab F. ciliato, quocum etiam est comnistus, in omnibus ferè dissentit, et a reliquis Fucis frons linearis fimbriata costataque semper ad distinguendum sufficient.

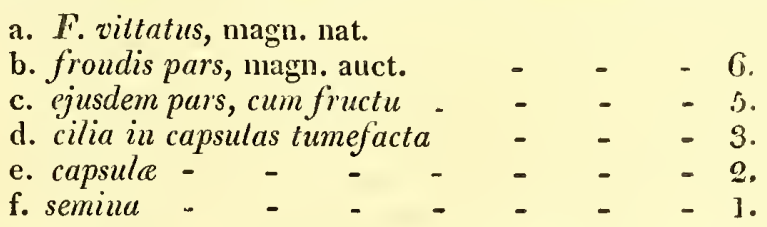

"Dicit de hàc stirpe Linnæus in Systemate Natura, "frondes dentato-crispatæ," quod cùm maximè a vero ablıorreat, suspicari licet illun olim sibi sub lıoc nomine plantam proposuisse diversam, quam postea cum hâc commiscuit.

t Extant in phytophylacio Linnaano quinque hnjus Fnci exemplaria, duobus papyri agghlutinata foliis, utroque aciculâ conjuncto ; hcrum unius ad calcem, cujus specimina colorem pesdiderant, $F$. viltat $i$ nomen scripserat Linnaus, alterun verò, in quo perfecta renanserunt, $F$. ornatus nominatur.

$\ddagger$ De Gmelini Sebaxque synonymis confer ea quæ jam sunt scripta sub $F$, nerroso, p. 93.-Dubitationis signa, quæ aliorum auctoritati cedens, his subjeci, tritissimè aliquis, nisi fallor, sustolleret.

Ancanitutes Academica VII. p. 477. 
Fucus vittatus, frond cartilaginous, flat, linear, dichotomous, midribbed, quite entire, and ciliated at its margin; cilia sub-cylindrical, mostly simple, their ends swelling into spherical capsules.

Fucius vittatus. Linn. Syst. Nat. 1I. p. 718. Syst. Nat. Ed. Gmel. II. p. 1387. Fl. Norv. II. 1. 35. Esper, lc. Fuc. II. p. 53.

F. ornatus. LINN. Mant. p. 312.

F. ciliatus. Esper, Ic. Fuc. I. p. 21. t. 4. (quoad fig. 1, 2, 4, excl. syn. forte omnibus.)

F. caulescens. GMEL1N, Hist. Fuc. p. 173. t. 20. f. 2.?

F. marinus, ramosus, caule folioso, foliis angustis, ad margines pilosis. SEBA, Thes. III. p. 192. t. 102. f. 11.?

Alga marina, foliis longis, angustis, germinantibus, tenui tomento in ambitu ornatis. SEв A, Thes. III. p. 192. t. 103. f. 5.?

At the Cape of Good Hope. Linnaus.-.Shores of South America. Cavanilles.

Perennial?

Rоот, a largish, expanded, purplish, callous disk.

Frowds, numerous from the same base, flat, linear, a foot, or foot and half, or even more, long, about half an inch wide, veinless, but provided with a thickish midrib, which towards the apices grows more thin and obsolete; they are in some instances quite simple, in others, twice or thrice dichotomous, in others, irregularly pinnated witl scattered, distichous, patent branches arising from the margin, and again in others proliferous with similar branches originating from the midrib, but this latter, I suspect, is only the case in injured specimens, though it not unfrequently happens that individuals are found, which, like the one here figured, are so repeatedly proliferous as to justify the belief that such is the natural growth of the plant; all the branches are at their origin very narrow, and nearly cylindrical, but they almost immediately expand, and become flat, their length is most uncertain, and they are either undivided, or dichotomous, or furnished with others produced from their margin or midrib, towards their apices they are slightly narrowed, so that the form of the smaller ones is between oblong and linear:- at the base of the frond the membrane is generally worn away by the action of the waves, and the naked midrib then wears the appearance of an extremely short cylindrical stipes:- throughout the whole length of the frond the margin, which is constantly*flat and entire, is fringed witl ramenta resembling cilia, sub-cylindrical, of a lineari elliptical form, a line, or a line and half long, placed close to each other, some simple, others ciliated in the same manner with still smaller ones, and others irregularly branched: similar ones are also occasionally, but not commonly, observable, scattered about the midrib and membrane of the frond.

FruCTIFICATION, situated in the cilia, which then swell into a spherical or elliptical shape, and contain several roundish, minute, deep-purple seeds imbedded in their substance.

Color, a beautiful semitransparent purple, darker and approaching to violet when dry, and turning, from exposure to the sun, or from being kept in fresh water, to a dirty yellowish, and at last to white.

Substance, cartilaginous, thickish, flexible, and tough; almost horny after it is dried.

Ors. The plant is remarkably smooth, and, when dry, often shines as if it had been varnished:-the frond has not unfrequently a speckled appearance, from the color being lost in some places, though it remains perfect in others:it does not adhere to paper.

$F$. vittatus is one of the species that are most generally and most certainly known among Botanists, but its history has, nevertheless, always been involved by authors in great confusion, and it will be observed, that of the figures above quoted, some of which are far from unfaithful representations of it, there is not one which lias not been in some measure perplexed with doubt. The primary cause of these errors is to be traced in the writings of Limmæus, who first described this plant in lis Systema. Natıra under the name here given, and then again introduced it in his Mantissa by the name of $F$. ornatus, as a distinct species, whereas afterwards, in the Systema Plantarum, these two are made varieties of each other, though, according to the toriginal specimens in his Herbarium, there does not appear to be the least difference between them, and, to complete the obscurity, Oeder's figure of $F$. ciliatus is in the same work quoted as a synonym both of $F$. vittatus and $F$. ciliatus, while Gmelin's $F$. caulescens, which, in $\neq$ my opinion, belongs to the former, is referred to the latter, with which it cannot possibly have any connection. It is npon these circumstances that Professor Lisper rests his justification for having figured the present Fucus as $F$. ciliatus, in the first volume of his Icones, a mistake which he has corrected in the second. Gumer's synonym appears to me far from a certain one, since, without giving any description or figure of the plant, he merely quotes the Linriaan specific character, and seems to rely altogether upon the authority of Toming, who simply enumerates it in his $\S$ Treatise on the Rariora Norvegia. I have not therefore ventured so far to trust to him, as to mention the shores of Norway among its loci natales, such authority being, in uny opinion, too slight to justify us in claiming as a denizen of our Northern Flora, a species which has hitherto been gathered only at the Cape of Grood Hope, and upon the opposite coast of Spanish South America, whence specimens were sent by Cavanilles to Mr. Stackhouse. Witl regard to the natural affinities of $F$. vittatus, it does not seem to be so strongly allied to any other Fucus as to $F$. erinaceus, under

* Linnæus in his Systema Natura, says of this plant, "frondes dentato-crispatæ," whieh is so far from accurate, that it may lead to the idea of his having originally intended a different speeies, and afterwards cosfounded the present with it.

t There are in the Linnæan Colleetion, five speeimens of this Fueus, fastened on two sheets of paper, botls which are pinned together; on the one, which is named $F$. vittatus, the plants have lost their color; those of the other are perfect in this respect, and these are ealled $F$. ornatus.

$\ddagger$ Respeeting the synonyms of Gmelin and Seba, see what has been said under $F_{0}$ nervosus, p. 93. The marks of doubt subjoined to these referenees might, $I$ believe, safely be removed.

Amanitalcs Acudemica. VII. p. 477 . 


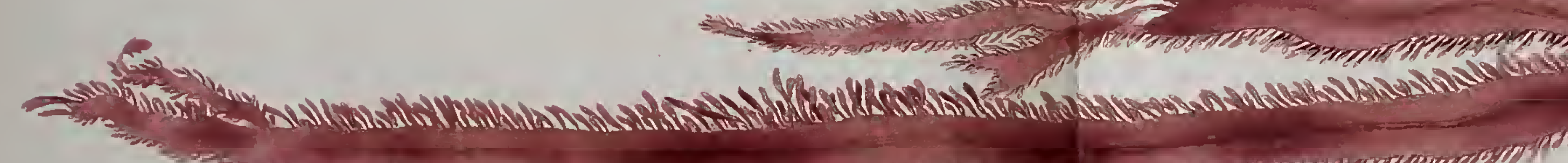

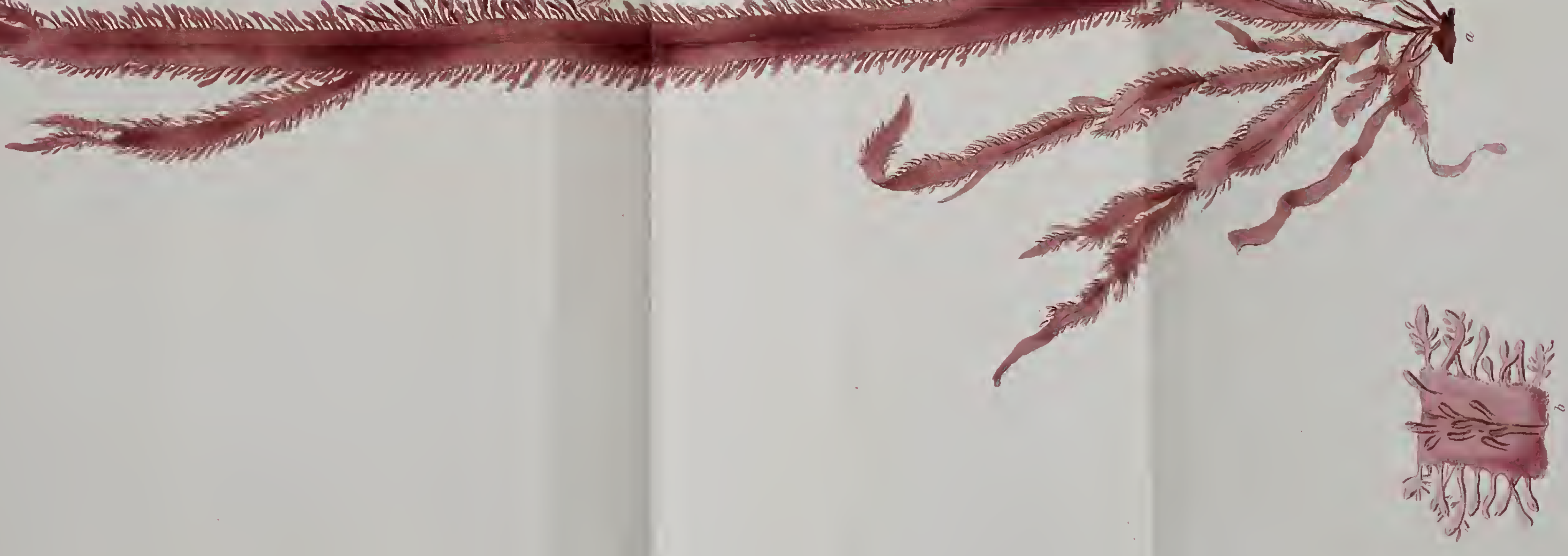



which is already noticed the circumstance of their being joined together in the Linnæan Herbarium, as well as the points which distinguish them. F. ciliatus, with which this species has also been confounded, differs too strongly in almost every particular for it to be necessary here to mention any single one; and from all other Fuci the fringed linear frond, pervaded with a midrib, will sufficiently serve to separate it.

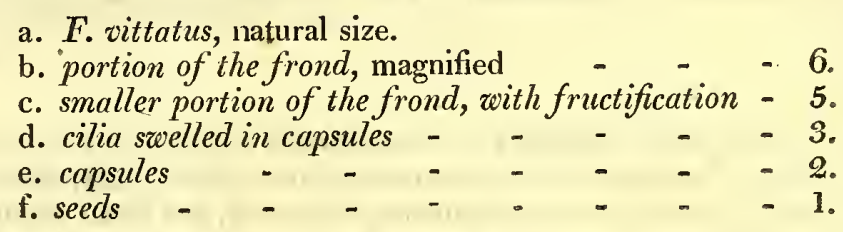

\section{5.-F U C U S P I L U L I F E R.}

Fucus, caule filiformi, compresso, pinnato; ramis alternis, simplicibus; foliis angustis, linearibus, dichotomis, integerrimis; vesiculis sphæricis, petiolatis; petiolis planis.

ß. major; vesiculis utrinque levitèr attenuatis, apice foliiferis.

Ha в Iт а т utraque varietas in Portu Nangasaki. D. Horner.

Perennis?

RADIX nondùm a me visa.

FroNs longitudine bi- tri- pedalis, et ultrà, forsàn et multo longior, cùm nihil quod basi proximum appareret viderim, caule instructa compresso, ancipiti, latitudinem æqualem unius ferè lineæ ubique servante, in meis saltèm exemplaribus indiviso, sed per totam longitudinem laxè obsito ramis spiralitèr alternis, singulis intervallo circitèr pollicari sejunctis, horizontalibus, flexuosis, simplicibus, vix duos pollices longis, caulis similibus, nisi quod dupld sint tenuiores, folia vesiculasque sustentantibus ; folia tantummodo in ramis orta, laxè disposita, alterna, horizontalitèr patula, sessilia, plana, linearia, longitudine pollicem, latitudine semilineam sub-æquantia, ter quater dichotoma, nervo tenui nigricante percursa, margine integerrima ; vesicula in ranis sparsæ, 3-7 in singulis, plerumque foliorum ad alas sitæ, splıæricæ, Pilulariæ globuliferæ nucularum magnitudine, üsque haud absimiles, extrinsecùs læves, intùs omninò cavæ, petiolo plano, bi- tri- lineari fultæ.

Fructificatio hactenus latet.

Color foliorum et vesicularum olivaceus fusco immixtus, caulis intensior; exsiccate ubique nigricans.

SuBSTANTia caulis coriacea, lenta, foliorum vesicularumque sub-membranacea et tenuis, ubique insignitèr debilis.

$\beta$ variat partium omnium staturâ duplò majore; vesiculis infrequentibus, ut rarò plus quam una in eodem ramo occurrat, figuræ inter ellipticam et sphæricam, utrinque attenuatis, Pisi sativi seminum magnitudine, et nunquam non terminatis folio reliquorum simili, quamvis hoc quandoque abruptum mucronis modò faciem præ se ferat.

OBs. Exsiccata cliartæ nequaquàm adhæret.

F. Pilularia nomen, nisi esset jamdudùm a Gmelino alii multùmque diversæ speciei inditum, huic certè ascriptum voluissem, quæ, quantum ex icone judicare licet, talem longè optimè titulum merere videtur; et non modd vesicularun formâ, uti suprà memoratur, Pilulariam globuliferam refert, verùm etiam harum situ, totiusque stirpis habitı, quod aiunt, generali, nomen inde ductum summo sibi jure vindicat. Fructificatio licet in præsens lateat, nemo est Botanicus qui dubitabit quin deceat hanc plantam in $F$. natantis asciscere familiam, quâcum convenit crescendi modo notisque essentialibus omnibus, exceptis modd foliis, quæ, angusta, linearia, et repetito-divisa, iis $F$. mucronati $110 n$ sunt primo aspectu absimilia. Naturâ tamen prorsùs discrepant; quoniam in $F$. mucronato et afỉnibus folia nulla vera locum habent, partesque eæ, quæ, ortu planæ, foliorum speciem præ se ferunt, nihil sunt aliud nisi rudimenta ramorum, quorum in formam maturescentes cito turgent, dum $F$. piluliferi folia figuram suan primordialem nunquam non retinent, nullique suit mutationi obnoxiæ. Varietates duas hic descriptas misit olìm Mertensius, qui utramque eandem credidit, et cujus occasiones lıanc stirpem observandi adeò meis antecelluerunit, ut tali assentiri sententice non dubitarem, quamvis frondis totius et præsertim vesicularum magnitudine tantum inter se discrepant quantum cuivis utriusque specinina modo singularia lustranti scrupulos facilè injiceret.

a. F. pilulifer, magn. nat.

b. frondis pai's, magn. auct. - - - 6 .

VoL. I. 
Fucus pilulifer, stem filiform, compressed, pinnated; branches alternate, simple; leaves narrow, linear, dicho tomous, entire ; vesicles spherical, petiolated ; petioli simple.

в. major; vesicles slightly attenuated at each end, and producing leaves at their apices.

Both varieties are found in the Harbour at Nangasaki. Dr. Horner.

\section{Perennial?}

Roor, I have not yet seen.

FROND, two or three feet, or more, long, perhaps even considerably longer, as $\mathbf{I}$ have at present observed nothing that indicated any proximity to a base, furnished with a compressed two-edged stem, which preserves every where an uniform width of nearly a line, and is, at least in my specimens, undivided, but beset throughout its whole length with branches disposed in a spirally alternate order, separated from each other by intervals of about an incl, horizontal, flexuose, siniple, scarcely two inches long, similar to the stem, except that they are twice as narrow, and bearing leaves and vesicles; leaves growing only upon the branches, placed rather loosely, alternate, between horizontal and patent, sessile, flat, linear, about an inch long, and half a line wide, three or four times dichotomous, provided with a thin blackisl midrib, quite entire at their margins; vesicles scattered over the branches, from three to seven upon each, generally situated at the axillæ of the leaves, spherical, of the size of the fructification of Pilularia globulifera, and not unlike it, externally smooth, internally quite hollow, supported upon a flat petiolus two or three lines in length.

FrUCTIFICATION, at present unknown.

COLOR, in the leaves and vesicles olive-green, tinged with brown, in the stem darker; when dry, everywhere blackish.

SUBSTANCE, coriaceous and flexible in the stem, in the leaves thin and almost membranaceous, throughout the whole plant weak and flaccid.

$\beta$ differs in the greater magnitude of all its parts, which is equal to double that of $\alpha$; it has also much fewer vesicles, so that seldom more than one is observable on the same branch ; the form of these is betiveell elliptical and spherical, and they are attenuated at each extremity; their size is not less than that of the seeds of Pisum sativum, and they are constantly terminated with a leaf similar to the others, though this in. some instances, from being broken off, appears only like a short mucro.

Oвs. When dried the plant does not adhere in the least to paper.

Had not the name of F. Pilularia been unfortunately bestowed long since by Gmelin upon a very different species of Fucus, and one that, according to his figure, seems to have very little right to it, I should undoubtedly have wished to have seen it appropriated to the present, which not only resembles the Pilularia globulifera in the form of its vesicles, as is above mentioned, but, also from their situation, and from something in its general habit, scems to lay peculiar claim to such an appellation. In spite of the fructification being unknown, there can be no besitation about referring this plant to the tribe of $F$. natans, with the individuals constituting which, it agrees in its mode of growth, and in every other essential character, though it differs from them in the form of its repeatedly divided leaves, which are in this respect not unlike those of $F$. mucronatus. In this latter Fucus, however, and its congeners, no real leaves can be properly said to exist, the parts that are at first flat and wear the resemblance of leaves, being nothing more than the beginning of branches, into which they soon naturally swell, while in $F$. pilulifer they seem constantly to preserve their original appearance, without being subject to any change whatever. The two varieties, above described, were sent me as the same species by Professor Mertens, whose opportunities of examining this Fucus have been so much superior to mine, that I have felt no hesitation in following his opinion, though the difference in their general size, and particularly in the size of their vesicles, might reasonably excite doubts in the mind of any botanist who had seen no more than single specimens of each.

a. F. pilulifer, natural size.

b. part of the frond, magnified : - 6 : 

Fucus, caule filiformi, terete, pinnato; ramis alternis, simplicibus ; foliis lineari-spatulatis, sub-integerrimis, enervibus; vesiculis pyriformibus, mucronulatis, sub-sessilibus; receptaculis cylindraceis, solitariis.

Ha Bitat in mari Coreano. D. Horner.

Perennis?

RADIX nondùm a me visa.

Frons instructa caule terete, filiformi, pennæ corvinæ crassitie, (sed quàm sit longus, et an divisus necne dicere nequeo,) ramis ubsito spiralitèr alternis, pollicem unum alterumve longis, simplicibus, horizontalitèr patulis, caulis sinilibus, nisi quòd triplo sint tenuiores, infernè nudis, vel tantummodo petiolorum diffractorum reliquiis exasperati, supernè foliis, vesiculis, fructuque dellsè obsiti ; folia in ramis, præsertìm juxta apices, frequentia, undique imbricata, nervi venarumque expertia, figuræ inversè lanceolatæ, apice plerumque lenitèr rotundata, quandoque autem acutiuscula, basi in petiolum brevem teretiusculum attenuata, margine nunc integerrima, nunc hic illìc enormitèr minutè denticulata, superficie sparsìm * nigro punctata ; vesicula foliis copiosè immixtæ, nunc solitariæ, nunc binæ ternæve, pyriformes, Gymnostomi pyriformis capsulis, operculo adhuc insidente, formâ haud absimiles, sed duplo majores, eæe ramoruin basin versus maximæ, et figuræ magis ad sphæriçam accedentis, reliquæ minores, et magis elongatæ angustatæque, omnes infernè in petiolum perbrevem teretem attenuatæ, apice umbonatæ, umbone tenui, vix lineam longo, et nunquam, quantum vidi, sese in folium producente aut dilatante, extrinsecùs læeves, intùs omnino vacuæ.

FRUCT1F1CAT1 o ramis, precipue foliorum ad alas, innascens, e receptaculis constat cylindraceis, plerumque solitariis, apices versus levitèr attenuatis, obtusiusculis, duas circitèr lineas longis, sessilibus, † poris minutissimis ubique pertusis, sub quibus latent semina atra, figuræ haud certæ, limbo nullo cincta, nec in tuberculis sita, sed serie simplice juxta peripheriam, sicut in $F$. lumbricali, disposita.

CoLOR in caule'nigricans, cætera fulvescens, ubique luridus et nitoris prorsùs expers.

Su Bstan Tia caulis ad ligneam accedens, attamen pulposa, ramorum tenera et succosa, foliorum et vesicularum cartilagineo-membranacea, flaccida, tenuis.

Овs. Exsiccata chartæ nequaquàm adhæret, sed caulis ramique tum insignitèr contrahuntur, et rugosi fiunt.

Costæ folia percurrentis absentia notam certam, et cuivis, vel in sterilibus, satis obviam suppeditat, quâ Fucus hìc depictus, unà cum insequente, et aliquot aliis, quos nondùm descriptos e mari Coreano simul retulit $\mathrm{D}$. Horner, ab F. natantis familiâ priıno statim aspectu dignoscuntur. Discrepant etiam in hoc ab F. Horneri, suprà depicto, t. 17, cujus fructus omnino idem, nisi quòd $F$. fulvelli et $F$. pallidi semina magis ad ea $F$. lumbricalis formâ coloreque accedant, et illorun instar in tres partes demùm dehiscere videantur. Dubitationi nullus datur locus quin, quum Fuci in plura dispertientur genera, hæ stirpes olim familiam Naturæ convenientissimam constituant, quæ $F$. natantis et affinium quoad formam simillima, erit tamen ab iis per fructificationem disjuncta. Inest etiam in omnium texturấ aliquid proprium atque peculiare quod verbis capi nequit; et color, si non cunctis idem, ab eo Fucorum reliquorum differt : folia vero, quod habent cum $F$. natante commune, neutiquàm in ramos transeunt. Vesicularum foliorumque forma $F$. fulvellum a congeneribus distinguit. Sub $F$. fulvescentis nomine misit Mertensius; quod cùm nomen esset ab Espero jamdudùm speciei diversissimæ inditum hìc fulvello mutavi.

a. F. fulvellus, magn. nat.

b. rami pars, magn. auct. - - _ - 6 .

c. receptaculum horizontalitèr dissectum - $\quad-3$.

d. semina - - $-\ldots-1$

Videntur hæc puncta quiddam in se peculiare habere, et differre cum ab is $F$. natantis et congenerum, quorum plurima a receptaculorum poris nondum clausis originem ducunt, tùm ab iis $F$. serrati, $F$. vesiculosi, et aliorum, quæ fibras minutissimas enittentia forsau planta alendie
inserviunt.

+ Non obstant hi pori quominus receptacula sint extrinsecus prorsus teretia, et nequaquàm hic illic, sicnt in Fucis propriis, torulosa, 
Fucus fulvellus, stem filiform, cylindrical, pinnated; branches alternate, simple; leaves lineari-spatulate, nearly en tire, nerveless; vesicles pyriform, mucronated, sub-sessile ; receptacles cylindrical, solitary.

In the Streights of Corea. Dr. Horner.

\section{Perennial?}

Root, I have not yet seen.

Fron p, provided with a cylindrical, filiform stem, (about the length of which, or its being branched or not, I am unable to say any thing,) as thick as a crow's quill, beset with alternate branches, disposed in a spiral manner, an inch or two long, simple, between horizontal and patent, similar to the stem, except that they are not more than a third of its thickness, towards their lower part either naked, or only rough with the remains of broken petioli, but upwards thickly clothed with leaves, vesicles, and fructification; leaves numerous, especially towards the extremities of the branches, imbricated on all sides, destitute of midrib or veins, of an inversely lanceolate shape, for the most part slightly rounded at their apices, but sometimes sharpish, attenuated at their base into a short sub-cylindrical petiolus, their margins entire in some specimens, in others minutely and irregularly denticulated, their surface marked with scattered black * dots; vesicles plentifully mixed with the leaves, in some cases solitary, in others, growing two or three together, pyriform, in appearance not unlike the capsule of Gymnostomum pyriforme, while still covered with its operculum, but twice as large, those placed towards the base of the branches largest, and most approaching to a spherical shape, the others smaller, more elongated, and more narrow, all of them tapering at their base into a very short cylindrical petiolus, and umbonated at their apices with a thin nucro, which is scarcely a line long, and never, as far as I have seell, lengthens or widens into a leaf; externally they are smooth, and internally completely empty.

FrUCTIFICATION, placed upon the branches, principally at the axillæ of the leaves, consisting of sessile, cylindrical, mostly solitary, receptacles, slightly attenuated at their extremities, but bluntish, every where perforated with most minute +pores, under which lie black seeds, of no fixed shape, and neither surrounded by a limbus, nor disposed in turbercles, but arranged in a single row immediately under the surface, as in F. lumbricalis.

CoLOR, blackish in the stem, in other parts a pale tawny brown, every where lurid, and quite destitute of gloss.

Substance, of the stem somewhat ligneous, but soft and juicy, of the branches tender and full of moisture, of the leaves and vesicles between cartilaginous and membranaceous, flaccid and thin.

OBs. In drying it does not adhere in the least to paper, but the stem and branches shrink remarkably, and become wrinkled.

The Fuci which are the subject of the present and the following plate, together with a few others, that were collected at the same time by Dr. Horner in the Streights of Corea, but are not at present described, may immediately. and satisfactorily be distinguished from the family of $F$. natans, even when barren, by the circumstance of their leaves being completely destitute of any appearance of a midrib; in which respect they differ also from $F$. Horneri, already figured in this work, t. 17, with which they agree in their fruit, except that the seeds of $F$. fulvellus and F. pallidus approach in their form and color still more closely to those of $F$. lumbricalis, and seem, like them, ultimately to split into three parts. There can be little doubt but that, when the Fuci shall be separated into several genera, founded. upon the fructification, the only certain mark of generic distinction, these plants will hereafter form an extremely natural genus, separated from $F$. natans and its affinities, by means of their fruit, though closely allied to them in point of external appearance, and strikingly so in the circumstance of the leaves never growing into branches. There is also a strong peculiarity in their texture, which I feel it impossible to define by words, but which will be allowed, by those Botanists who are acquainted with them, to furnish a striking characteristic of the whole family. The present species is distinguished from its congeners by the shape of the vesicles and the leaves: it was sent me by Professor Mertens under the name of $\mathbb{F}$. fulvescens, a name previously appropriated by Dr. Esper to an entirely dissimilar plant, on which account I changed it to $F$. fulvellus, retaining, as far as I was able, the original intention of my valued friend.
a. F. fulvellus, natural size.
b. part of a branch, magnified - $\quad-\quad-6$.
c. receptacle cut through horizontally - -3.
d. seeds - - - -2 .

\footnotetext{
* These dots seem to have something peculiar in their nature, and to be different, as well from those of $F$. natans and its congeners, the greater part of which originate from the unclosed pores of the receptacles, as from those of $F$. ses'rutus, $F$. vesiculosus, and others, out of which grow tufts of minute white fibres, that probably contribute towards the sustenance of the plant.

+ These pores do not prevent the exterio: of the receptacles from being completely cyliudrical and even, and by no means swollen in places, as in the Fuci proprii of Weber and Mohr.
} 


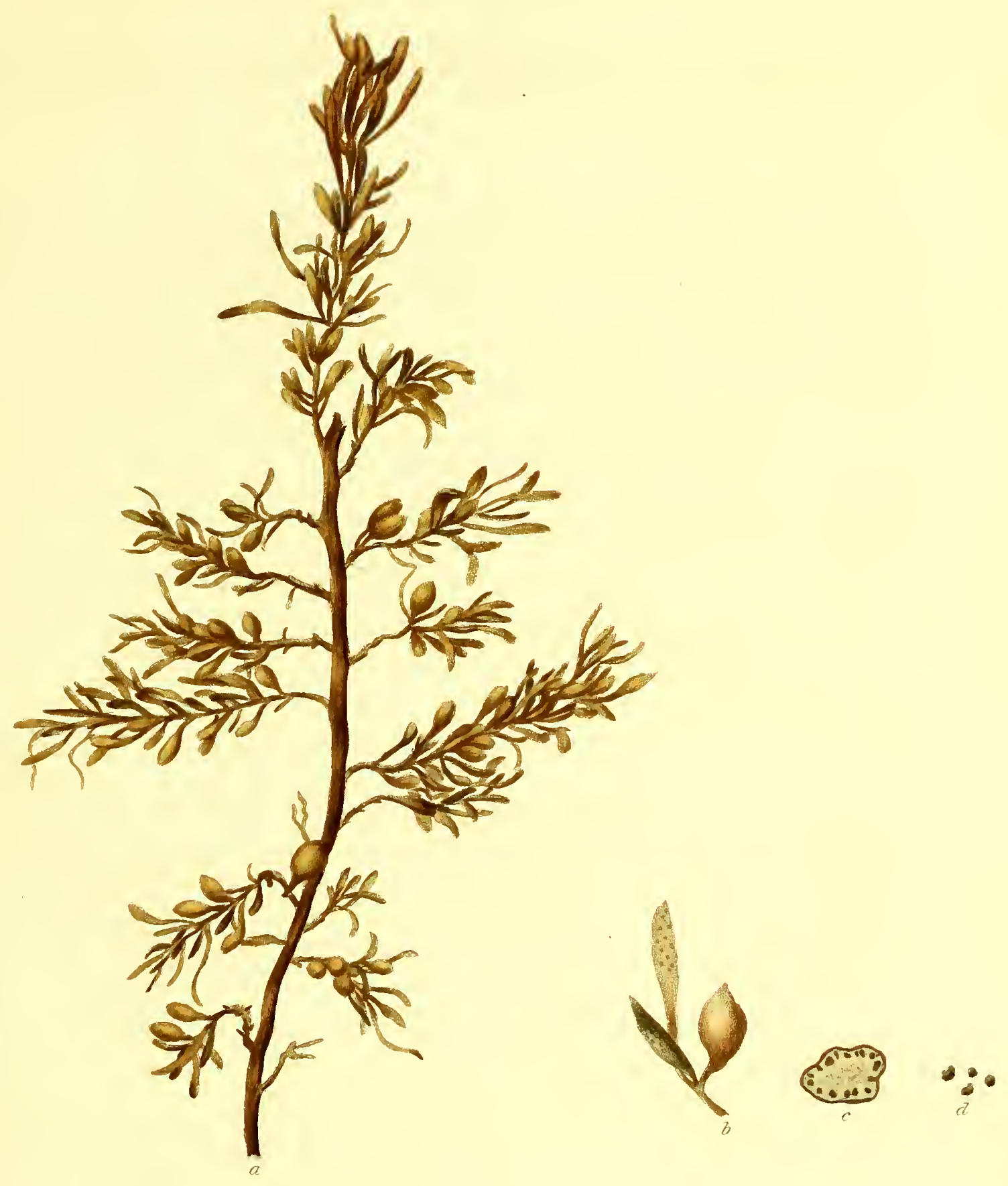




\section{.}


E'ucus, caule filiformi, compresso, pinnato ; ramis sub-alternis, simplicibus; foliis elliptico-linearibus, integerrimis, enervibus, pertusis; vesiculis sphæricis, petiolatis; receptaculis cylindraceis, solitariis.

\section{Hавітат in mari Coreano. D. Horner.}

\section{Perenuis?}

RADIX callus parvus, explanatus, nigricans.

FroNs instructa caule sesquipedali et ultrà, e plano compresso, ancipiti, basi ferè lineam lato, et inde usque ad apices adeò sensìm attenuato ut potiùs ubique æequalem diceres, indiviso, sed per totam longitudinem, excepto quà radici proximus, ramis obsito; rami plani, filiformes, semilineam lati, distichi, horizontalitèr patuli, plerumque, nequaquàm tamen semper, alterni, intervallis sejuncti brevibus, vix unguicularibus, simplices, inferiores longiores, et dodrantales, vel pedales, inde gradatim breviores ut summi vix duos pollices æquent, cuncti folia, vesiculas, fructumque ferentes: folia in ramis laxè sparsa, ut sit spatium inter singula ferè semiunguiculare, disticha, sub-alterna, sessilia, linearia, aut elliptico-linearia, acutiuscula, semiunguem vel unguem longa, et lineam vel sesquilineam lata, nervi venarumque expertia, sed poris majusculis plerumque pertusa, margine integerrima; vesicula foliis immixtæ, haud ita numerosæ, sphæricæ, piperis nigri granorum magnitudine, petiolis brevissimis, planis fultæ, extrinsecùs læves, intùs omnind vacuæ.

Fructificatio receptacula solitaria, cylindracea, semiunguem longa, ramorum nunc ad apices nunc ad latera sita, pedunculis tenuibus, bi- tri- linearibus, vel etiam pollicaribus insidentia, extrinsecùs lævia, æqualia, et poris nullis pertusa, intùs semina foventia plurima, fusca, enormitèr subrotunda, nequaquàm limbo cincta :-si receptaculum horizontalitèr dissecetur, semina in tubercula subrotunda obsoleta conglomerari videntur; sed hoc neutiquàm in omuibus ex æquo manifestum.

Co cor foliorum et vesicularum pallidè lutescens, fusco immixtus, et sub-diaphanus, caulis aliquantùm intensior, receptaculorum fusco-nigricans.

Substantia caulis et ramorum cartilaginea, foliorum et vesicularum membranacea et tenuissima, ubique debilis et flexilis.

Oвs. Exsiccatæ caulis et receptacula minimè, ut in præcedente, contrahuntur, vel rugosi fiunt, sed contrà tota stirps faciem lævem etiam tunc servat:-chartæ haud adhæret.

Omne illud, quicquid sub Fuco præcedente de ejus indole, fructu, affinitatibusve memoratur, jure non minus æquo ad hunc pertinet, cujus vesiculæ eas $F$. natantis formâ magis referunt, et cujus folia illud in se proprium habent, quodd pori in foraminula non rarò dilatati dehiscant, quorum margines nigricantes faciem præ se ferunt eandem semiustam in iis $F$. Agari notabilem, quâ de re neque in uno nec in altero e casu modò pendere, sed potiùs aliquid ipsi frondis indoli insitum designare verisimillimum apparet. Per receptacula ubique extrinsecùs clausa neque meatibus ullis pertusa videtur $F$. pallidus arctiùs $F$. Horneri quàm $F$. fulvello esse affinis, dum per semina in tuberculis posita neque serie simplice juxta peripheriam disposita, dunmodò se res ita verè habeat, ab utroque recedit. Ut verum tamen fatear tuberculorum vestigia adeò obsoleta apparuerunt ut nihil sit pro certo de iis proferendum, et fortasse lıæc seminum dispositio receptaculorum medium versus tantunmodò e fructificationis æatate nimium provectâ pependit, quoniam idem ferè de $F_{0}$ lumbricali (descriptione et icone jam in hoc opere evulgatis) nuperrimè observavit vir amicissimus, D. G. R. Leathes, qui me, cùm per literas tùm per exemplaria missa, certiorem fecit, semina, fructu deliquescente, mutare situm, et per totam receptaculorum substantiain diffundi; de quo tamen erit pleniùs in alio disceptandum loco, quum omnia qquæcunque de Fucorum fructificatione hucusque imnotuerunt in medium proferre couabinur.
a. F. pallidus, magn. nat.
b. rami pars, magn. auct. - - - - - 6 .
c. folium - - - - - - 5.
d. receptaculum horizontaliter dissectum - - 3.
e. semina - - - . - - 1 . 
Fucus pallidus, stem filiform, compressed, pinnated; branches mostly alternate, simple; leaves between elliptical and linear, entire, nerveless, perforated; vesicles spherical, petiolated; receptacles cylindrical, solitary.

In the Streights of Corea. Dr. Horner.

Perennial?

Ro oт, à small, expanded, blackish, callous disk.

FROND, provided with a stem a foot and half and more long, between flat and compressed, two-edged, nearly $\approx$ line wide at the base, and thence to the apices so imperceptibly narrowing, that it may almost be called filiform, undivided, but beset with branches throughout its whole length, except in the part nearest to the root; branches flat, filiform, half a line wide, distichous, between horizontal and patent, in general, but by no means constantly, alternate, separated by intervals of scarcely half an inch each, simple, the lowest longest, and nine inches or a foot in length, thence gradually shortening, so that the upper ones do not exceed two inches, all of them furnished with leaves, vesicles, and fructification: leaves so loosely scattered over the branches, that there is almost the space of a quarter of an inch between each, distichous, sub-alternate, sessile, linear, or between elliptical and linear, rather sharp, from a quarter of an inch to half an inch long, and from a line to a line and half wide, destitute of midrib or veins, but generally perforated with largish pores, their margins quite entire; vesicles mixed with the leaves, not very numerous, spherical, of the size of pepper-corns, supported upon very short, flat petioli, extremely smooth, internally quite hollow.

Fructification, solitary, cylindrical receptacles, a quarter of an inch long, situated both on the ends and sides of the branches, and placed upon peduncles, which in length vary from two or three lines to an inch, in their outside smooth, even, and not perforated with any pores, but within containing numerous brown irregularly roundish seeds, unprovided with any limbus :- upon cutting a receptacle through, in a horizontal direction, the seeds appear to be collected into obsolete roundish tubercles, but this appearance is far from equally obvious in every specimen.

COLOR, of the leaves and vesicles, pale yellowish, tinged with brown, and semitransparent, of the stem, somewhat darker, of the receptacles, blackish brown.

SUBSTANCE, cartilaginous in the stem and branches, membranaceous and very thin in the leaves and vesicles, every where weak and flexible.

Oвs. In a dried state the stem and branches are by no means contracted and wrinkled, as in the preceding species, but on the contrary, the whole plant even then preserves its uatural smoothness :-it does not adhere to paper.

The whole of what has been mentioned under the preceding Fucus, with regard to its nature, its fructification, and its affinities, may be considered as scarcely less applicable to the present, which, in addition to the peculiarities there noticed, has vesicles still more like those of $F$. natans, and leaves remarkable for the circumstance of their pores not uncommonly widening into small cavities surrounded by a blackish margin, with the same singed appearance as those of F.Agarum; on which account I am led to conclude that these perforations are neither in the one species nor in the other the effect of accident alone, but are most probably the result of some property essentially inherent in the nature of the plants. The completely closed receptacles of $F$. pallidus seem to indicate a more near affinity in point of fructification to $F$. Horneri than to $F$. fulvellus, while the apparent existence of immersed tubercles, and the disposition of the seeds in these, instead of their being situated in a single row immediately under the epidermis, would tend to remove it equally from both. I must, however, candidly confess that I entertain the greatest doubts how far these tubercles have any real existence; and that, in all the receptacles which I have dissected, the traces of them have been so faint, that I am rather inclined to believe that the arrangement of the seeds towards the centre of the capsules may depend altogether upon the advanced age of the individual; since the Rev. G. R. Leathes has observed something similar in F. lumbricalis, subsequently to the publication of that species, and has shewn me, by his observations and specimens, that, as the fructification decays, the seeds lose their original position, and become scattered indifferently through the whole substance of the receptacles; upon which subject I shall have occasion to enlarge in the general observations that I propose prefixing to this work respecting the fruit of the Fuci.

a. F. pallidus, natural size.

b. part of a branch, inagnified - $\quad-\quad-6$.

c. leaf - $-\quad-\quad-\quad-\quad-5$.

d. receptacle, cut through horizontally - -3.

e. seeds - - - - - - - 1 . 


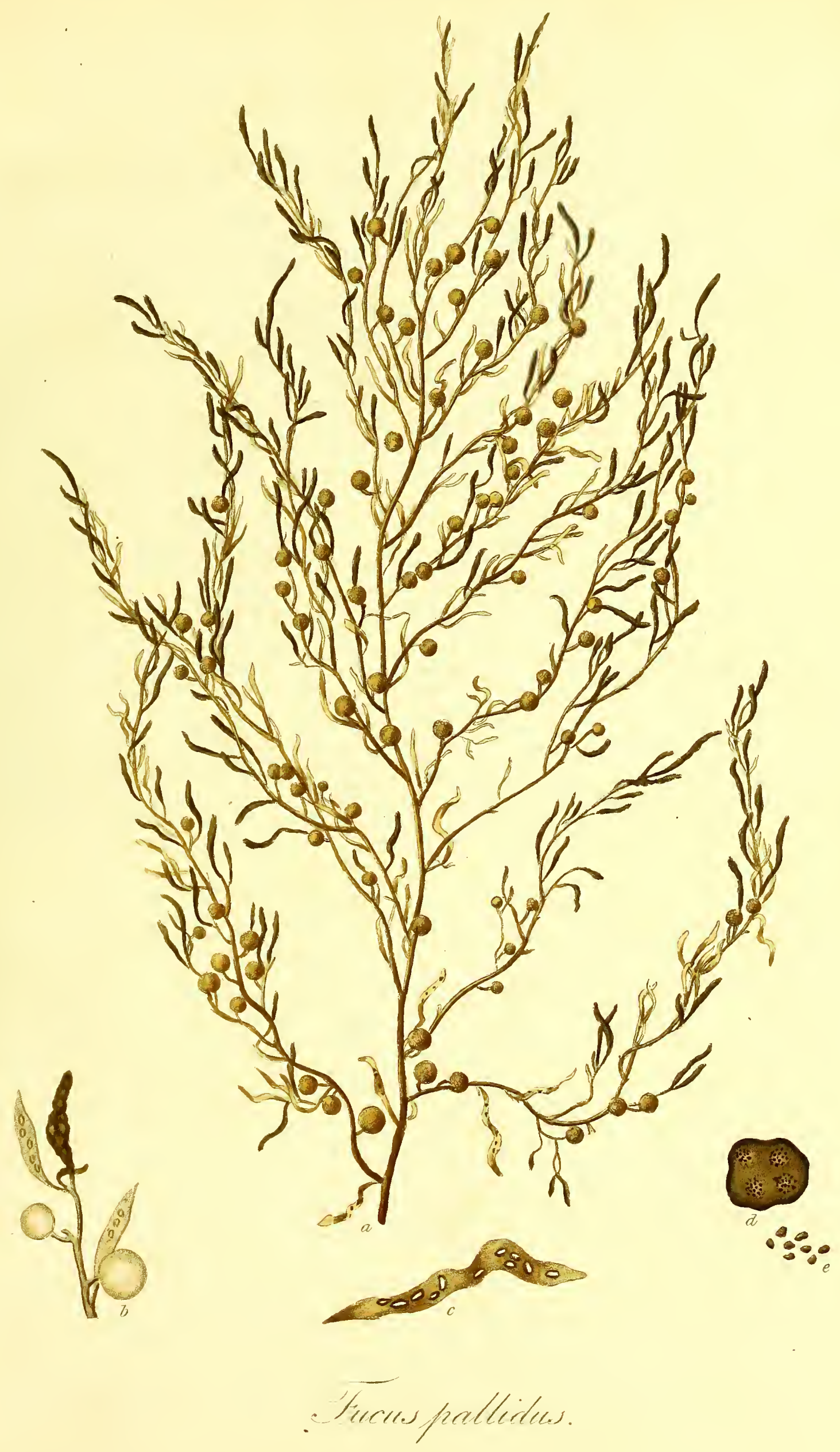



Fucus, fronde membranaceâ, tenerrimâ, planâ, venosâ, sub-dichotomâ; ramis sub-linearibus, apice rotundatis, margine crispo-lacinulatis, undulatis : tuberculis hemisphæricis, immersis, seminibusque nudis in maculas oblongas dispositis.

Fucus laceratus. Gmelin, Hist. Fuc. p. 179. t. 21. f. 4. Syst. Nat. Ed. Gmel. II. p. 1387. Linn. Trans. III. p. 155. (excl. var. y, ejusque synonymis.) Ner. Brit. p. 77. t. 13. Syn. Fuc. I. p. 154. Eng. Bot. XV.t. 1067. Fl. Fr. Ed. 2da. II. p. 28. (excl. var. \&, et s, eorumque synonymis, necnon syn. Stack.) Fl. Lus. II. p. 437.

F. crispatus. Fl. Ang. p. 580. Linn. Syst. Nat. II. p. 1718. Syst. Nat. Ed. Gmel. II. p. 1387. Wu Lfen, in Jacq. Coll. III. p. 162. t. 16. f. 2. Wulfen, Crypt. Aquat. n. 11. Esper, Ic. Fuc. I. p. 130. t. 90. (excl. syn. Buxb. et Fl. Dan.) Fl. Norv. II. p. 32.

F. cristatus. Wiтн. IV. p. 103. (excl. syn. Fl. Dan.)

F. endiviafolius. Fl. Scot. p. 948. t. 32. Wiтн. IV. p. 103.

F. volubilis. GmeiIN, Hist. Fuc. p. 180.? (excl. syn. omnibus.)

* F. tener, gelatinosus, per siccatem spiralis. RAII Syn. p. 49. u. 4.3.

F. gramineus, parvus, ramosissinus, fuscus. BuDDLE, H. S. I. fol. 2. B. papyraceus; ramis ramulisque linearibus, tenuioribus, sub-sinuatis.

F. laceratus. $\beta$. Linn. Trans. III. p. 155. Syu. Fuc. I. p. 154.

$\gamma$. granateus; fronde subrotundâ; ramis sursùm dilatatis, sub-indivisis, apice lobatis.

F. laceratus. $\gamma$. Syn. Fuc. I. p. 154.

F. granateus. Lamouroux, Diss. Fuc. p. 68. t. 33. f. 3, 4.

১. elegans; fronde subrotundâ ; ramis sursùn dilatatis, repetito-divisis, apice sinuatis.

. fimbriatus; ramis linearibus, margine proliferis.

ร. uncinatus; ramis linearibus, angustis ; apicibus cartilagineis, uncinatis.

ᄁ. lingulatus; ramis sursùm dilatatis, apice palmatis; segmentis simplicibus, oblongo-lanceolatis, semina lineis duabus parallelis disposita ferentibus.

9. multifidus; ramis sub-linearibus, repetito-divisis ; segmentis ultimis plurimis, angustis, elongatis, ramosis.

1. incrassatus; ramis sub-linearibus, planiusculis, apicibus bifurcis, furcis patentibus, lineari-lanceolatis, acutis.

Hа вітат $\alpha$ in Britanniarum oris, haud infrequens.-In Franciæ oris Septentrionalibus, copiosè. Decandolle.Tergesti. Baro de Wulfen.-Ad ostia Tagi et Durii. Brotero.- $\beta$ apud Ilfracombe in comitatu Damnoniensi. Goodenough et Woodward.-Apud Torquay, et in Cornubiâ. Dna Griffiths.- $\gamma$ inter rejectamenta maris apud Yarmouth.-In Insulæ Vectis littoribus. D. G. R. Leathes.-\&, ף, et „apud Bantry Bay. Dna E.

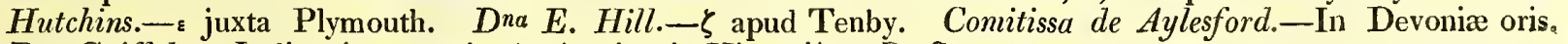
Dna Griffiths.-In littoribus comitatûs Antrim, in Hiberniâ. D. Scott.

Perennis? +Jul.-Oct.

RAD1X callus exiguus, explanatus.

Frondes vel solitariæ, vel ex eâdem basi plurimæ, planæ, costâ nullâ percursæ, sed venis aliquot, frondi nunc concoloribus, nunc magis obscuris, tenuibus, sub-parallelis, a radice incipientibus, et usque ad apices attingentibus instructæ, longitudine a palmari ad dodrantalem, latitudine ab unguiculari ad sesquiunguicularem variabiles, ubique propemodùm lineares, ab ipsâ basi plerumque ramosæ, sed hoc nequaquàm certum ; rami nunc, et quidem sæpissimè omnes dichotomi, furcis erecto-patulis, sexies septiesve repetitis, iutervallo inter singulas circitèr pollicari, nunc bini ternive ordine palmato dispositi, utrumque non rard in eodem individuo occurrit, quandoque etiam, quod plerumque juxta apices occurrit, frons laciniis alternis, brevibus, decurrentibus sparsim obsita, apices rotundati, margines undulati, in his integerrimi, in illis crispo-lacinulati, vel minutissimè crenulati, ut ciliati appareant, vel processubus exiguis ovatis fimbriati, vel, præsertim extremitates versus, levitèr sinuati.

Fructificatıo tubercula hemisphærica, in ipsâ frondis substantiâ immersa, hìnc gibbosa, illìnc plana, coloris reliquâ fronde intensioris, Brassica Rapa seminum ferè magnitudine, diaphana, nunc ubique per ramos superiores sparsa, nunc juxta margines modo sita, et nunc tantummodo in processubus marginalibus disposita; semina in his plurima, enormitèr subrotunda, intensè rubra; reperiuntur quoque non rarò semina, jam memoratis majora, et sub lente in tres partes dehiscentia, iisdem quibus tubercula frondis partibus imposita, membranâ nullâ obtecta, sed in formam rotundam congesta, unde oculo inermi vix sunt a tuberculis dignoscenda.-Q Quidnam est de his judicandum?anue est huic stippi, sicut $F$. Hypoglosso et aliis, fructificatio duplex ?-suadet quidem analogia, sed obstat seminum forma :- an semina, membranâ deperditâ, nuda frondi insident, et in majorem molem excrescunt?-In priorem ego sententiam propendeo.

CoLor ruber, nunc dilutior, et ad roseum, nunc inteusior, et ad fuscum accedeus, nunquam non diaphanus; $e x-$ siccata intensior; marcescentis sordidè lutescens.

SuBstanTia membranacea, tenuissima, et tenerrima, ut rarò iuveniatur exemplar, nisi aliquâ parte laceratun, unde nounen.

Var. $\beta$, quam Goodenovii Woodvardiique auctoritati obtemperans recenseo, "omnia," ut eorum verbis utar, " cum a communia habet, at ab omni parte minor et tenuior.-In ramulos plurimos sæpius dividitur.- Hi autem non rarò perbreves sunt, adeo ut rami sinuosi potiùs quanı raunosi videutur."

Forma

* Hoe synonymon et insequens amieissimi Dillwynii fide, qui exemplaria in Herbario Buddleano vidit, citantar.

$\dagger$ Semel etian mense Martio fructiferam legi. 
Forma frondis in var: $\gamma$ multùn ab eâ præcedentium abludit, altitudine vix pollicem vel sesquipollicem superat, finditurque juxta basin in tres quatuorve ramos, basi angustatos, inde levitèr dilatatos, integerrimos, nisi quòd apice sint lobati, lobis oblongis rotundatis; color pulchrè roseus; substantia ut in $\alpha_{0}$ - Crescendi modo et formâ hæc varietas ad $\boldsymbol{F}$. laciniatum, a quo color et textura diversissinus, accedit: speciem distinctam sinulat, præsertim cùm venæ non sint detegendæ, nisi luci objiciatur vel sub lente observetur. Lamourouxii synonymon, suprà citatum, hùc retuli Mertensii fide, qui utriusque exemplaria accepit. Icon tamen plantam nostram haud bene exprimit, et nihil * tubercu* lorum ab ipso depictorum simile unquam ego vidi.

Var. \& est præcedente aliquantùm major, et longè ab illâ diversa, quamvis peripheria sit ferè eadem : finditur ad ipsam basin in ramos multos ortu tenuissimos, hìnc sensim ampliatos, iterùm atque iterùm palnatos, segmentis brevissimis, apice sinuatis; color infernè fusco-ruber, sursum versus dilutior, et quasi flavicante perfusus, unde stirps pulcherrimè bicolor; substantia ut in præcedentibus; venæ oculo inermi obsoletæ.

Var. $\varepsilon$ in eo modd $a b a$ discrepat, quod ramos habeat, non, ut in illâ, ciliatos, sed aliis ramis, nunc simplicibus, nunc divisis, unguem ferè longis, per totam longitudinem vagè proliferis.

Var. $\zeta$ in omnibus cum $\beta$ convenit, excepto quod multi ex apicibus, non tamen omnes, sint, falcis in formam, introrsùm curvati, et, quòd maximè singulare, substantiam habeant cartilagineam, reliquâ fronde multoties crassiorem. Credit Dna Hill plantam per hos aliis Fucis inhærere solere.

Ad F. bifidi var. $\gamma$ formâ accedit var. $\eta$, cujus duo modò specimina a Borrero missa in præsens vidi : longitudo his sesquipollicaris, frondis figura et rami var. $\gamma$ similes, sed apices palmati, segmentis plurimis elongatis, oblongo-lanceolatis, quibus imposita jacent semina, in duas maculas oblongas parallelas intervallo brevi cartilagineo et reliquâ fronde crassiore sejunctas, ut in F. Hypoglosso, congesta ; substantia et color sicut in a; venæ obsoletæ.

Var. 2 per frondis apices in segmenta plurima elongata angusta repetito-ramosa ab a differt: facies huic ob ramorum multitudinem singularis.

Annon var. ' pro distinctâ specie sit habenda multùm dubito, sed, cùn $F$. lacerati varietatem putet Dna Hutchins, acutissima harum plantarum indagatrix, hìc in præsens posui. Longitudo ferè palınaris; latitudo trium linearum, ubique æqualis; rani constantèr dichotomi ; margines planiusculi, integerrimi ; apices bifurci, acuti ; venæ obsoletæ ; color dilutè ruber; substantia reliquis crassior:-inter $F$. laceratum et $\boldsymbol{F}$. bifidum ambigit.

Oвs. Habitus in stirpe recente mirè cripatus, ut Lightfootii nomen, F. endiviafolius, sit aptissimum:-frons singulari modo repit, sese per margines saxis vel Fucorum majorum, quibus inuasci solet, stipitibus affigens, nunquam tamen, quantum vidi, per hos sibimet ipsi hærens, in quo differt ab F. bifido :- exsiccata chartæ laxiusculè adhæret:sub lente pulcherrimè est reticulata, ut, vitro maximè augente inspecta, Confervam reticnlatam membranæ roseæ superimpositam referat;-- venæ frondem percurrentes sunt in omnibus varietatibus notabiles, plantæque characterem maximè essentialem ministrant; nequaquàm tamen sunt in ounnibus ex æquo manifestæ, et in quibusdam, præsertìm junioribus, non nisi lentis ope dignoscuntur.

Fuci, præ plurimis mutabilis, varietatibus jam in longum descriptis, pauca hìc modò de synonymiâ adjiciam, relicturus characteres, per quos ab F. laciniato, $F$. ulvoide, et $F$. bificlo dignoscitur, sub is speciebus memorandos. Nomina suprà citata satis superque ostendunt quantum fuit hrec stirps ab auctoribus vexata et cum aliis commista. Gmelini synonymon eâ de causâ dubium censet Mertensius, quia vir in describendo accuratissimus frondes ei avenias tribuat; quod tamen me paullum movet. Nonne enim idem dixerunt Hudsonus, Lightfootius, et Wulfenius, nonne Decandollius, nonne Goodenovius Woodwardiusque, viri, si qui alii, summâ laude dignissimi, qui omıes has venas paritèr prætermiserunt. Lamourouxii $F$. laceratus, quem pro novâ ille specie recenset, videtur mihi ad $F$. Sarnien sem referendus, et sub hoc citavissem, nisi malè cautus neglexissem.

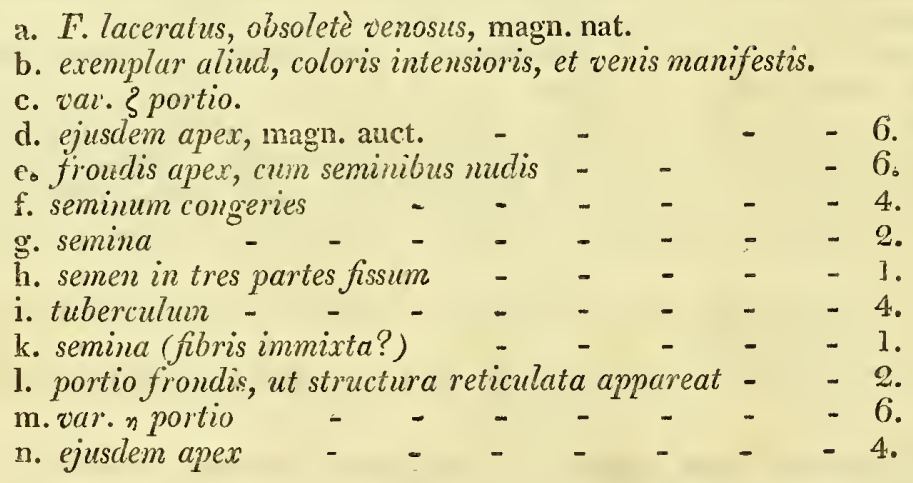

* Dieit de his Lamourouxius, "Lorsque le tubercule commence a parôitre, vu au microscope, il présente au sommet une petite pointe émoussée ; cette pointe grossit avec l'âge, s'ouvre et forme, quelques jours avant la maturité des semences, une couromme membraneuse, cré. nato-dentee, presque semblable à celle des grenades."-Diss. Fuc. p. 69. 

Cozor, red, in some specimens pale, and inclining to pink, in others darker, and tinged with brown, in all transparent; deeper when dry, and turning in decay to a dirty yellowish white.

SuBSTANCE, membranaceous, so extremely thin and tender, that plants are seldom met with free from injury, from which circumstance the name is derived.

The variety $\beta$, which I introduce upon the authority of Dr. Goodenough and Mr. Woodward, has, according to them, every thing in common with $\alpha$, but is in all its parts smaller and more thin :--it is generally divided into several ramuli, but these are not uncommonly so short, that the branches seem rather to be sinuose, than again branched.

The variety $\gamma$, differs extremely from the preceding ones in the form of its frond; its height scarcely exceeds alz inch or inch and half, and it is divided near the base into three or four branches, narrow at their origin, and thence gradually dilated, quite simple and entire, except that at the apices they are lobed, with oblong roumded lobes: the color is a beautiful pink; the substance like that of a.-In its mode of growth, and form, this variety approaches $F$. laciniatus, from which its color and texture are widely different: it looks like a distinct species, especially as the veins are seldom to be detected, except when the plant is held to the light, or examined under a microscope. The synonym of Lamouroux rests upon the authority of Professor Mertens, who has seen specimens both of his plant and of mine, of which latter his figure is not a happy representation in general, nor did I ever meet with any thing similar to the * tubercles that he describes.

The frond of var. $\delta$ is somewhat larger than that of the preceding variety, which it resembles in its outline, but by no means in other respects : it is cleft down to the very base into several branches, extremely narrow at their origin, but thence gradually widening, and repeatedly palmate, witl very short segments, sinuated at their apices; the color at the lower part is a brownish red, which grows upwards more pale, and has a yellowish tinge, which adds greatly to the beauty of the plant; the substance is like that of the foregoing ones; the veins appear to tlie naked eye obsolete.

The variety $\varepsilon$, differs from $\alpha$ only in having its branches not ciliated; but irregularly proliferous throughout its whole length witl other branches, either simple or divided, and nearly lialf an inch long.

The variety $\zeta$, agrees in every respect with $\beta$, except that several of its apices, but by no means all, are bent inwards like a sickle, and what is very remarkable, are of a cartilaginous substance much more thick than the rest of the frond. Miss Hill is of opinion that the plant fastens itself by means of these to other Fuci.

Of var. $\eta, \mathbb{I}$ have at present seen only two specimens, both sent by $\mathrm{Mr}$. Borrer, which are in form not unlike $F$. bifidus var. $\gamma$; their length is an inch and lialf; the shape of the frond and the branches resembles that of var. $\gamma$, but the apices are palmate, with numerous oblongo-lanceolate segments, upon which the seeds lie in two oblong parallel rows, as in $F$. Hypoglossum, separated by a narrow interval of a cartilaginous texture, and thicker than the rest of the frond; the substance and color are like those of $\alpha$; the veirs obsolete.

The variety $\vartheta$, differs from $\alpha$ in having the apices of the frond cleft into numerous, elongated, narrow, and repeatedly branched segments, the multiplicity of which gives this plant a singular appearance.

With regard to var. ', I have great doubts whether it ought not to be regarded as a distinct species, but in referring it to $F$. laceratus, I follow tlie opinion of Miss Hutchins, who sent it to me, and whose knowledge of these plants is most accurate and extensive. Its length is three or four inches; its width three lines, every where equal; its branches constantly dichotomous; its margins nearly flat, and quite entire; its apices forked and acute; its color pale red; its substance thicker than the rest. It seems almost intermediate between $F$. laceratus and $F$. bifidus.

Oss. The habit of $F$. laceratus is, when fresh, extraordinarily curled, so that lightfoot's name of $F$. endiviafolius is peculiarly expressive :- the frond creeps in a singular manner, attaching itself by means of its edges to the rocks, or to the stems of the larger Fuci that it frequently grows upon, but never, as far as "I have seen, thus adhering together, like $F$. bifidus, in different parts :- when dried it sticks slightly to paper :-it is so beautifully reticulated, that, under a powerful microscope, it looks like a specimen of Conferva reticulata laid upon a pink membrane :-.-the veins in the frond are to be seen in all the varieties, and afford the most essential character of the plant, but they are far from being equally observable in all, and in some, particularly in a young state, are scarcely distinguishable without a glass.

Having already described at considerable length the most striking varieties of this very changeable Fucus, I will merely subjoin a few remarks tonching the synonymy, and reserve any observations upon the manner in which it differs from $F$.laciniatis, $F$. ulvoides, and $F$. bifidus, to be mentioned in the history of those species. How completely this plant has been perplexed by authors, and how frequently confounded with others, is obvious from the different names that have been assigned to it. Professor Mertens is inclined to regard Gmelin's F. laceratus as a doubtful synonym, because, contrary to his usual accuracy, he has described the frond as destitute of veins: this, however, I must confess, appears to me of little moment ; for the veins have also been overlooked by Hudson, Lightfoot, Wulfen, and Decandolle, and even by Goodenough and Woodward, men whose accuracy of observation no one will call in question. The Fucus, which is named by Lamouroux F. laceratus, and is by him regarded as a new species, ouglit,

- Respecting these, Lamouroux says, "Lorsque le tubercule commence à parôitrc, vu au microscope, il préscnte au sommet une petite pointe émoussée ; cette pointe grossit avec l'âge, s'ouve et formc, quelques jours avant la maturité dcs semences, une couronne mcmbrancuse, crénato-dentée, presque semblable à celle des grenades."-Diss. Fuc. p. 69. 


\section{9.-F U G US LA CI N I A T US.}

in my opinion, to be referred to F. samiensis, and would have been quoted above as a synonym of that plant, had it not unintentionally been omitted.

a. F. laceratus, specimen in which the veins are obsolete, natural size.

b. another specimen, of a darker color, with veins very apparent.

c. portion of var. $\zeta$,

d. apex of the same, magnified - $\quad$ - $\quad$ - $\quad$ - $\quad$ - $\quad$ - 6 .

e. apex of the frond, with naked seeds - _ - $\quad$ - $\quad$ - $\quad 6$.

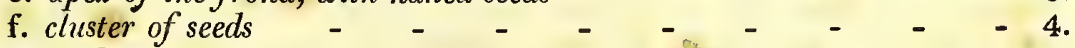

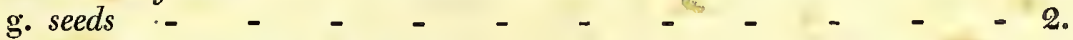

h. seed split into three parts - $\quad$ - $\quad$ - $\quad$ - $\quad$ - $\quad-1$.

i. tubercle - - - - - - - - - 4 .

k. seeds (mixed with fibres?) - - - - - - - 1 .

1. portion of the frond, to shew the reticulated structure $\quad-\quad-2$.

m. part of var. $n$ - - - _ - - _ _ - 6 .

n. apex of same

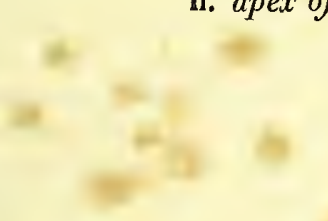

\section{9.-F U C U S L A G I N I A T U S.}

Fucus, fronde cartilagineo-membranaceâ, plan̂a, enervi, ramosâ ; ramis dilatatis, apice palmatis, obtusis, marginibus planis, crenatis, proliferisque; tuberculis hemisphæricis, marginalibus, immersis; seminibusque nudis ubique sparsis.

Fucus laciniatus. Fl. Ang. p. 579. Fl. Scot. II. p. 947. Wiтн. IV. p. 102. Syn. Fuc. I. p. 161. Eng. Bot. XV. t. 1068 . EsPer, Ic. Fuc. II. p. 63. t. 140.

F. ciliatus. GMELIN, Hist. Fuc. p. 176. t. 21. f. 1. (excl. syn. omnibus.)

F. crispus. EsPER, Ic. Fuc. I. p. 41. t. 18. (excl. syn. omn. præter Gmel.)

F. crispatus. Ner. Brit. p. 92. t. 15.

F. laceratus. $\gamma$. Lins. Trans. III. p. 156.

F. laceratus. \&. Fl. Fr. Ed. 2 da. II. p. 28.

B. ovalifolius; fronde margine proliferâ, processubus elliptico-subrotundis, simplicibus, brevissimè petiolatis.

Нав1тат $\alpha$ in Britanniarum oris, haud ita infrequens.-In Galliæ Septentrionalis littoribus. Decandolle.-B apud Port-Rush, in comitatu Antrim, in Hiberniâ. D. Scott.

Perennis. Feb.-Jul.

RADIX callus discoideus, explanatus, nigricans.

Fros̃des, nunc solitariæ, nunc ex eâdem basi plurimæ, nervi venarumque omnino expertes, longitudine plerumque circitèr tripollicares, aliquand divisæ, ramis tribus vel quatuor basi aliquantùm attenuatis, inde sensim, quod tamen magis in quibusdam individuis quàm in aliis valet, lenitèr dilatatis, latitudinis, ubi maxima, plus quam unguicularis, intervalloque brevi divisis, ordine vel dichotomo, vel, ut sæpiùs accidit, palmato, deinceps iterùm atque iterùm simili ratione ranıosis, ita ut totius frondis explanatæ peripheria circuli segmentum majusculum exlibeat; apices nuıquam non palmati, segmentis brevibus, reliquâ fronde angustioribus, linearibus, levitèr rotundatis, vel sub-truncatis; margines plani, ne minimum quidem crispati undulative, in his integerrimi et nudi, in illis minutè crenati, in aliis processubus perquàm exiguis, ovatis, densissimè per totam longitudinem dispositis fimbriati, in aliis demùm sparsìm proliferi, surculis ortu subrotundis, basi angustissimis, mox elongatis, linearibus aut dilatatis, et palmatis. - Exemplaria vetusta ab aliis in hoc discrepant, quod ramos habeant longiores, sub-divaricatos, vix aut ne vix sursùm dilatatos, ita ut tota frons, apicibus demptis, sit linearis.

Fructificatio tubercula lemisphærica, processubus tantummodo marginalibus inmersa, exigua, frondi fere concolora, seminum rubrorum subrotundorum minutissimorum congeriem intùs foventia.--Præter hæc sunt semina enormitèr sphærica, saturatè rubra, nuda, per frondis şuperficiem, nullo ordine servato, sparsa, sed ita parva ut oculum inermem penitùs fugiant.

COLOR inter sanguineum et coccineum medius, perpulcler, nequaquàm diaphanus, fugacissimus; exsiccata multo intensior, magisque ad sanguineum accedens, sæpe quoque nitens; in aquâ dulci servata cito fit pallidior, lividoque immixtus; et soli objecta protinùs sordidè albescit.

Su Bsta N I A membranaceo-cartilaginea, crassiuscula, tenaxque; siccitate fit tenuior magisque membranacea.

Var. $\beta$ formâ tantum ab a recedit ut vix hujus loci credidissem, nisi vir acutissimus, D. Scott, qui recentem legit, ad 
ad F. laciniatum referendam docuisset:- color et substantia idem, sed frons in duas modd lacinias oblongas, hanc simplicem, illam bifurcam, finditur, utramque margine proliferam, foliis simplicibus, elliptico-subrotundis, sesquiunguem longis, et unguem latis, margine integerrimis, petiolo angusto, vix semilineari fultis.

Овs. Exsiccata chartæ arctè adhæret:- -frons sub lente medioritèr augente obsoletè reticulata apparet, quod tamen evanescit, si microscopium potentius adhibeatur, atque prorsùs uniformis evadit.

Cùm Goodenovii Woodwardii Decandolliique sententïs obstaverim, F. laciniatum ab F. lacerato in Fucorum Britannicorum Synopsi disjungendo, nullam, illo opere jam evulgato, occasionem prætermittendam duxi, quò meliùs satisfacere mihi possem an sic faciendo, rectè necne fecerim. Observationibus igitur nuperioribus nisus nunc pro distinctis magis confidentèr propono, neque dubito quin ii Botanici, qui solent recentes videre, huic opinioni assentiantur. Minus quidem est in exsiccatis compressisque discrimen, quando hujus crispatus tortusque habitus penitùs deletur, et substantiarum discrepantia agriùs detegitur. Frondis quidem forma et ramorum dispositio pluribus sunt in utroque mutationibus obnoxiæ, ut, si ex his solùm penderent diagnoses specificæ, nemo ferè Botanicus diversas declarare auderet. Timendum tamen est, ne, dum Charybdin, ut aiunt, effugere conamur, in Scyllam incidere periclitemur ; et, quia non est talibus omnind fidendunı, idcircò spreta rejectaque pro nihilo habeamus : certum enim est, quantumvis exemplaria singula figurâ ludant, $F$. laciniati frondem longè frequentiùs quàm ea $F$. lacerati palmatìm findi, et gaudere peripheriấ constantiùs ad orbicularem accedente, Characteres qui maximè in dignoscendis valent, ni fallor, hi sunt; substantix dissimiles, nota haud minùs in junioribus quàm in adultis obvia, neque tamen, nisi in madefactis et simùl ante oculos positis, probè observanda; venæ pellucidæ, quæ in uno manifestæ, in altero desunt; textura sub microscopio diversa; color non ambobus idem, qui quoque nequaquàm solet æequè in algis submersis ac in vegetabilibus terrenis variare, maximique sæpe est in Fucis investigandis momenti ; denique, et ante omnes, fructificatio, cùm tubercula tantummodò in processubus marginalibus sint sita, neque, eorum $F$. lacerati instar, per ramos superiores enormitèr spargantus, contrà verò semina nuda ubique supra frondem solitaria, sicut in Ulvis, occurrant, nec in maculas figurâ certâ donatas collecta reperiantur. De $F$. laciniati synonymî̀ multùm est inter auctores erratum, et perpaucæ sunt species quæ minùs Botanicis innotuerunt. Auctores omnes vetustiores latuisse videtur, quod non mirum, quoniam in littoribus nostris infrequentèr occurrit. Hallucinatus est Gmelinus, quod sub Fuco suo ciliato, de quo, cùm ex icone tum e descriptione, nil dubium quam rectè fecerit Flore Anglick auctor ad hunc nostrum referendo, Raii Morisoni Hudsonique stirpes citaverit. E contrario Fucus, qui illi F. laciniatus audit, suprà in hoc opere pro $F$. rubentis synonymo habetur. Nec minus erravit Esperus, qui in primo Iconum Fucorum tomo F. laciniati exhibet iconem, subdito F. crispi L. nomine, docetque esse ad eundem referrendam Morisoni t. 8. f. 5 ., quæ noster F. dentatus, F. miniatum Fl. Dan. t. 769, qui ad F. rubentem pertinet, Ulvamque Gunneri delicatulam, quam vir summoperè reverendus $F$. crispi varietatem autumat, quæ tamen aliquas Ulva ligulate formas tam bene exprimit ut ejus exemplar repræsentare crederem.

a. F. laciniatus, magn. nat.

b. frondis pars, marginibus proliferis, magn. auct. - 6 .

c. frondis apex, cum capsulis - - - - $\quad 6$. 6

d. capsula longitudinalitèr dissecta $\quad$ - $\quad$ - $\quad$ - 3 .

e. semina - - - - - - - - 1.

f. frondis pars, cum seminibus sparsis - $\quad$ - 5.

g. semina - - - - - $\quad-\quad$ - 1. 

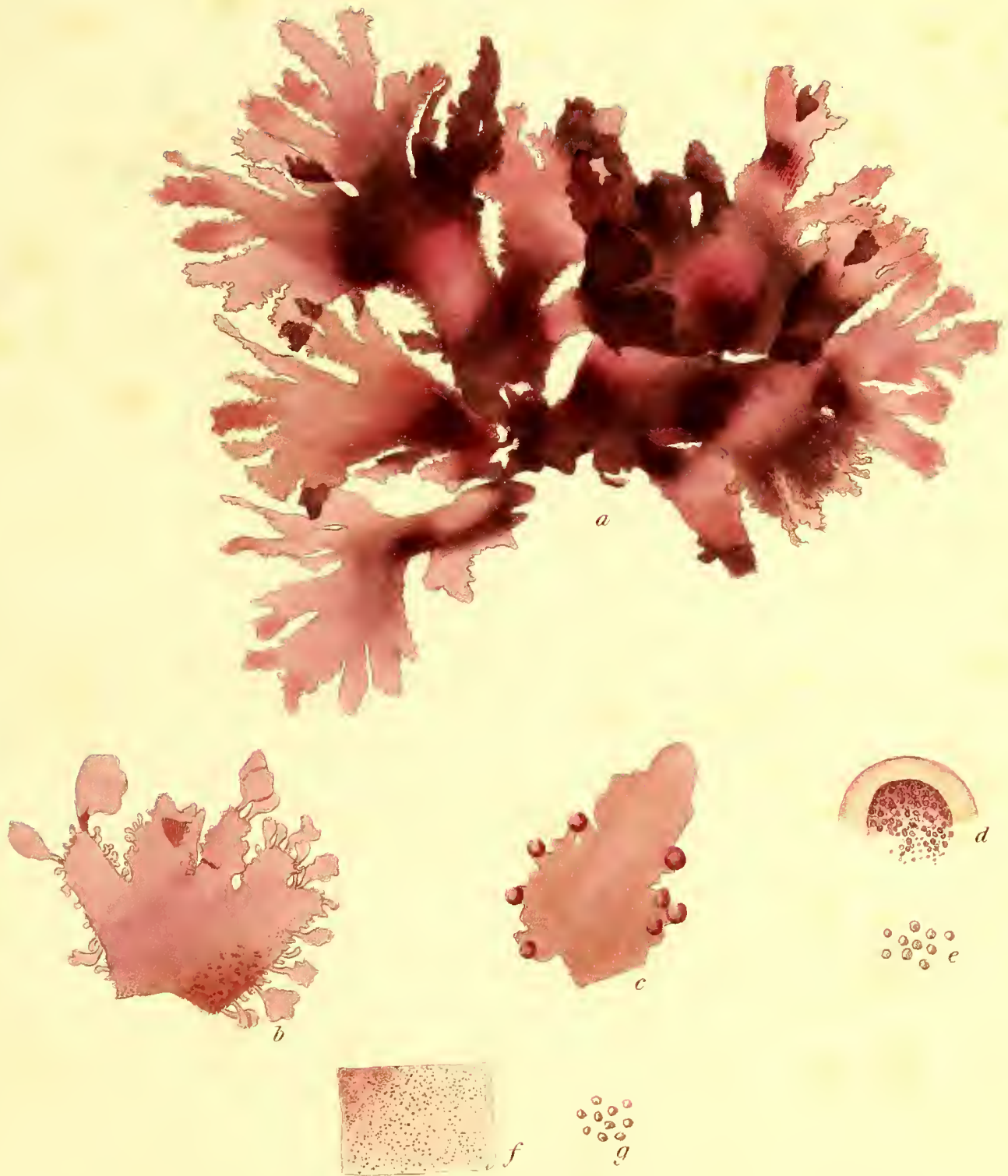

Hucus lacinialus. 

I'ucus laciniatus, frond between cartilaginous and membranaceous, flat, nerveless, branched; branches dilated upwards, palmate and blunt at their apices, their margins flat, crenate, and proliferous ; immersed hemispherical tubercles in the marginal processes, and naked seeds scattered all over the frond.

Fucus laciniatus. Fl. Ang. p. 579. Fl. Scot. II. p. 947. Wiтн. IV. p. 109. Syn. Fuc. I. p. 161. Eug. Bot. XV. t. 1068. EsPer, Ic. Fuc. II. p. 63. t. 140.

F. ciliatus. GMelin, Iist. Fuc. p. 176. t. 21.f. 1. (excl. syn. cmnibus.)

F. crispus. Esper, Ic. Fuc. I. p. 41. t. 18. (excl. syn. omn. præter Gmel.)

F. crispatus. Ner. Brit. p. 92. t. 15.

F. laceratus. $\gamma$. Linn. Trans. III. p. 156.

F. laceratus. \&. H. Fr. Ed. $2 d a$. II. p. 28.

B. ovalifolins; frond proliferous at its margin, with simple processes, of a form between elliptical and roundish, placed upon extremely short petioli.

$\alpha$ is found on the shores of the British Isles, not very uncommonly.-On the Northern coast of France. Decandolle. - $\beta$ at Port-Rusl, in the county of Antrim. Dr. Stott.

Perennial. Feb.-July.

Root, an expanded, blackish, callous disk.

Fron Ds, either solitary, or numerous from the same base, completely destitute of midrib or veins, generally about three inches long, but occasionally extending to laalf a foot, and in particular situations to nine inches, divided down to the very root into three or four branches, somewhat attenuated at their bases, and thence gradually (but more strikingly in some specimens than in others) widening upwards, so as in their greatest width to exceed half an inch, always divided at a short interval either in a dichotomous or palmate manner, and afterwards again and again branched in a similar mode, so that the outline of the whole frond, when expanded, forms a large segment of a circle; the apices are constantly palınate, with short, linear, slightly rounded, or truncated segments, considerably more narrow than the other branches; the margins are flat, never in the least inclining to be curled or undulated, in some instances entire and perfectly naked, in others minutely crenated, in others very thickly fringed throughout their whole length with extremely small ovate processes, and again, in others, proliferous, with scattered shoots, roundish in their first stage, and quite narrow at their base, but afterwards elongated, linear, or dilated, and palnated.-Old specimens of this plant differ from the others in having their branches longer, nearly divaricated, and scarcely perceptibly widened upwards, so that, excepting the apices, the whole frond is linear.

FRUCTIFICATION, hemispherical tubercles, only to be found immersed in the marginal processes, small, nearly of the same color as the frond, containing a cluster of very minute, roundish, red seeds :-besides these, otlıer seeds, of an irregular spherical shape, and deep red color, are observable, scattered naked, without any order, all over the surface of the frond, but they are so small as to be invisible to the naked eye.

Coror, a bright and pleasant, but opaque red, intermediate between scarlet and blood-color, exceedingly fugitive; in a dried state darker, and not unfrequently glossy; if kept in fresh water it soon becomes pale and acquires a livid hue; and, when exposed to the sun, turns almost inmediately to a dirty whitish.

SUBSTANCE, between cartilaginous and membranaceous, thickish, and tough; more thin and membranaceous after it is dry.

The variety $\beta$ differs so much in its form from $\alpha$, that I should scarcely have suspected it of belonging to the same plant, but for the opinion of Dr. Scott, who gathered it fresh:-it agrees in its color and substance, but the frond is divided only into two oblong segments, the one simple, the other forked, each of them proliferous at its inargin, with undivided leaves, of a shape between elliptical and roundish, three quarters of an inch long, and half an inch wide, quite entire, and supported upon a narrow petiolus, scarcely half a line in length.

Oв. This plant, when dried, adheres closely to paper:-if examined by a common pocket magnifier, the frond appears obsoletely reticulated, but all appearance of this kind vanishes under a powerful microscope, when it looks completely uniform.

Since the publication of the Synopsis of the British Fuci, I have neglected no opportunity that might enable me more fully to sotisfy myself respecting the specific difference been $F$. laciniatus and $F$. laceratus, and the result of all my observations has been, that they are really and essentially distinct. I believc, too, that every Botanist, who is in the habit of examining the two plants in a recent state, will accede to this opinion; for the characters that separate them are at such a time far more obvious than after they have been dried and subjected to pressure, when the curled and twisted habit of the latter ceases to be observable, and the dissimilarity of their substances becomes less apparent. * The form, indeed, of the frond and mode of ramification are in both liable to considerable variation, so that, were there no better criterion for distinguishing them, few naturalists would venture upon pronouncing them different species: and yet, at the same time, that this is granted to be the case, it would be no less wrong to run into the opposite extreme, and, because implicit credit is not to be placed on these circumstances, therefore to reject thern entirely, and allow them no weight whatever; as, however single specimens may vary, it is neverthelcss certain that the branches of $F$. laciniatus are more generally palmate than those of $I^{\prime}$. laceratus, and the outline of its frond inore 
regular. The most important proofs of distinction between them appear to consist in the difference of the substance, a mark no less conspicuous in young than in old specimens, but one that cannot be properly judged of, unless they are examined together in water; in the pellucid veins, so singular in the one species, but wholly wanting in the other; in the dissimilar appearance they exhibit under a microscope; in the diversity of their colors, which are much less liable to variation in aquatic than in terrestial plants, so that in the investigation of the marine Algæ, considerable dependence must often be placed upon them; and, above all, in the fructification, the tubercles of $F$. laciniatus being confined to the marginal processes, and not scattered, like those of $F$. laceratus, indifferently over the upper branches, while its naked seeds, instead of being collected into regular spots, are dispersed in the same manner as those of the Ulvæ. The synonymy of $F$. laciniatus has been much confused, and few species have been in general less understood. Its being a Fucus of by no means common occurrence will account for its having escaped the observation of the older writers. From Gmelin's description, as well as his figure, there can be little doubt of Hudson's being right in considering it the $F$. ciliatus of that author, though he has unfortunately erred in his references to Ray, Morison, and the Flora Anglica. His F. laciniatus, on the other hand, seems to be our F. rubens, under which it is above quoted. Professor Esper has, in the first volume of his Icones Fucorum, figured the present plant as F. crispus of Linnæus, in which he is no less mistaken, and has quoted Morison t. 8. f. 5., our $\boldsymbol{F}$. dentatus, and the $\boldsymbol{F}$. miniatus of the Flora Danica, t. 769., which belongs to F. rubens, together with Gunner's Ulva delicatula, Fl. Norv. t. 8. f. 2., which, though supposed by the reverend author to be only a variety of $F$. crispus, seems intended for $\mathrm{Mr}$. Woodivard's Ulva ligulata, and is a good representation of some appearances of that plant.

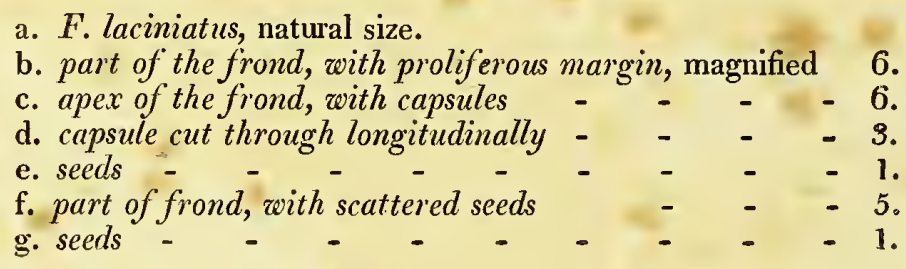

a. F. laciniatus, natural size.

b. part of the frond, with proliferous margin, magnified 6 .

c. apex of the frond, with capsules - - - -6 .

d. capsule cut through longitudinally - $\quad-\quad-\quad-3$.

e. seeds - - - - - - -

f. part of frond, with scattered seeds
g. seeds - $-\quad-\quad-\quad-5$

\section{0.-F U G U S GILIA T US.}

Fucus ciliatus, frond between membranaceous and cartilaginous, flat, nerveless, generally lanceolate, branched in as pinnated manner, ciliated at its margins and surface; cilia mostly simple, patent, subulate, producing tubercles at their apices.

Fucus ciliatus. Fl. Ang. p. 580. Iin n. Mant. p. 136. et p. 519. (excl. syn. Gmel.) Syst. Nat. II. p. 718. Syst. Nat. Ed. Gmel. II. p. 138\%. (excl. var. B, ejusque syn.) Fl. Scot. II. p. 944. Fl. Dan. t. 353. Linn. Trans. III. p. 160. (excl. F. ciliati Gmel. syn.) Fl. Norv. II. p. 96. Ner. Brit. p. 90. t. 15. (excl. var. \&, ejusque syn.) Syn. Fuc. I. p. 169. Eng. Bot. XV.**t. 1069. Fsper, Ic. Fuc. II. p. 55. t. 136. Wu lFEN, Crypt. Aquat. n. 41. (excl. syn. Esp.)

F. holosetaceus. GMelin, Hist. Fuc. p. 17\%. t. 21. f. 2. Syst. Nat. Ed. Gmel. II. p. I387. With. IV. p. 104.

F. ligulatus. Gmelin, Hist. Fuc. p. 178. t. 21. f. 3. (quoad ic.) Syst. Nat. Ed. Gmel. II. p. 1387.

Ulva ciliata. Fl. Fr. Ed. $2 d a$. II. p. 13. (excl. syn. omn. sub var. a citatis.)

Fucus membranaceus rubens angustifolius, marginibus ligulis armatis. RA1I Syn. p. 47. n. 33.

F. humilis membranaceus acaulos elegantissimus ruber, capillis longis finbriatus. Moß1s. Hist. Ox. III. p. 646. n. 10.

३. pinnatifidus; frond lanceolate, pinnatifid; segments lanceolate, elongated, unbranclied.

F. ciliatus. $\beta$. Syn. Fuc. I. p. 169.

\%. palmatus; frond lanceolate, almost naked, either undivided, or palmated.

F. ciliatus. \%. Syn. Fuc. I. p. 170.

\&. jubatus; frond bordered with numerous, long, thin, filiform, cylindrical, branching cilia.

F. ciliatus. \&. Syn. Fuc. 1. p. 170.

F.jubatus. Linn. Trans. III. p. 162. t. 17. f. 2. Ner. Brit. p. 51. t. 11. EsPer, Ic. Fuc. II. p. 35. t. $12 \%$.

s. lanceolatus; frond lineari-lanceolate, narrow, much and irregularly branched; cilia long, compressed, linear, acuminated, branched. 


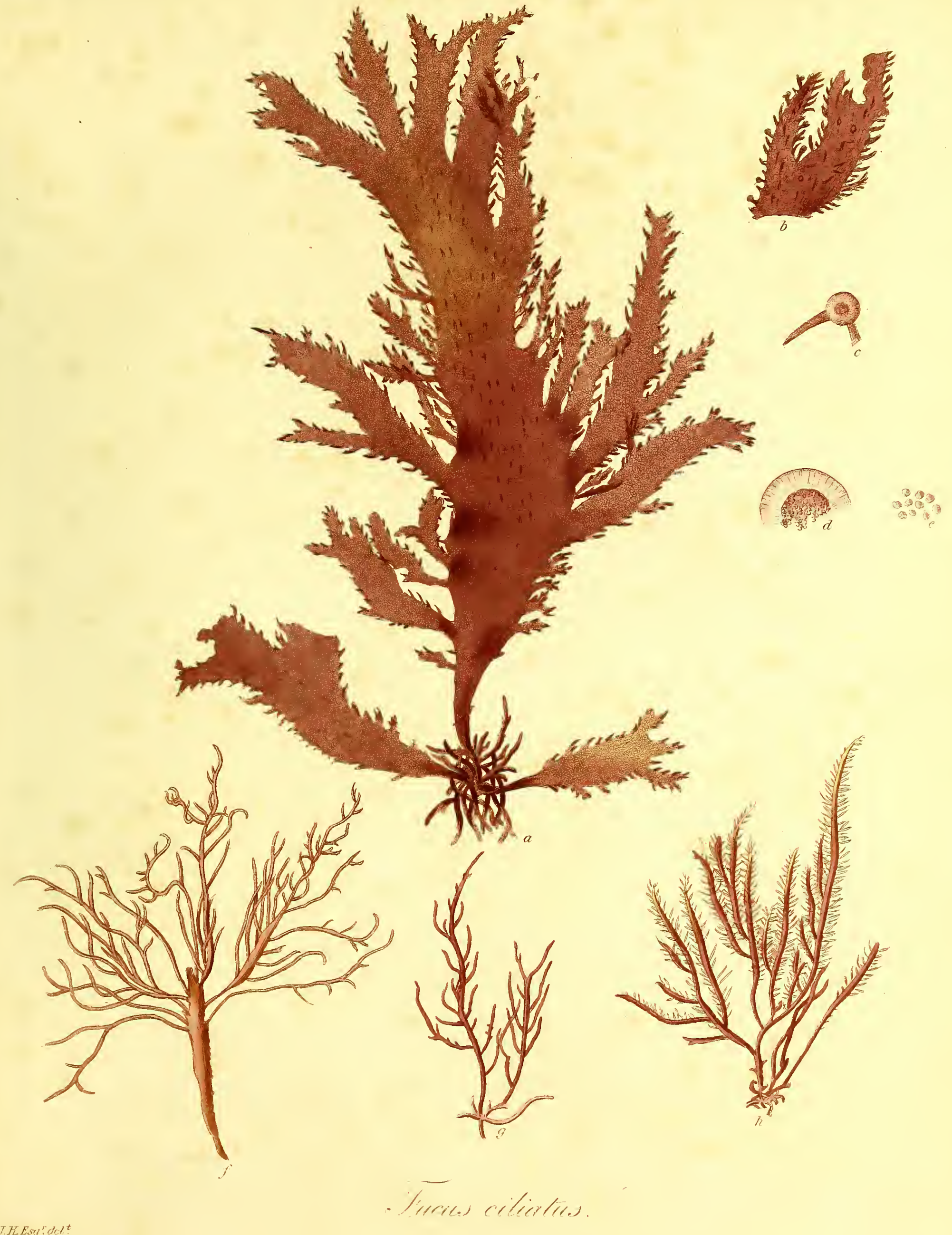





\section{0.-F U GUS CI LIA TUS.}

F. ciliatus. \&. Syn. Fuc. I. p. 170 .

F. ciliatus. B. Fl. Scot. II. p. 946. Linn. Trans. III. p. 161. Ner. Brit. p. 91. t. 15.

F. ciliatus. $\gamma$. Ner. Brit. p. 91. t. 15.

F. ciliatus. var. EsPer, Ic. Fuc. II. t. 136. A.

F. lanceolatus. Wiтн. IV. p. 104.

$\zeta$. angustus; frond linear, much and irregularly branched; branches extremely narrow, compressed.

F. ciliatus. $\zeta$. Syn. Fuc. I. p. 170.

\%. spinosus; frond linear, compressed, much and irregularly branched, every where covered with short, simple, subulate, spiniform ramuli.

On the shores of the British Isles, not uncommon. Coasts of France exposed to the Ocean. Decandolle.--In the Northern Ocean. Oeder.- In the Mediterranean and Adriatic. Wulfen.- $\beta$ on the shores of New Zealand. Sir Jos. Banks.-At the Isle of Wight, together with $\gamma_{0}-\delta$ and $\varepsilon$ in Devonshire and Cornwall. Mrs. Griffiths.- $\delta$ at Port-Rush, in the county of Antrim. Dr. Scott.- $\varepsilon_{\varepsilon}$ on the coast of Guernsey.-At Bayonne.

Professor Mertens.-弓 at Exmouth. Sir Thomas Frankland.--n Devonshire coast. Mrs. Griffith.

Perennial? October-February.

Root, * fibrous, composed of several narrow, cylindrical, long, branched fibres, closely matted together, of a pale pink color, creeping, and at length rising into numerous frolids.

FroN Ds, flat, destitute of veins or midrib, half a foot, or more, long, filiform and narrow in the part nearest the root, but immediately expanding, so as to be in general half an inch wide before they are four lines in height, and thence gradually growing wider and wider, till they equal one or two inches; their form is either lanceolate, or between linear and lanceolate, or occasionally oblong, with sharp apices, and they are in some instances simple, in others, variously cleft into several segments of unequal depth, all which preserve nearly the same form, and are either simple, or bitid, or themselves divided in a similar manner; all along the margins of the frond are disposed compressed subulate cilia, of the same color and substance with it, between horizontal and patent, slightly curved, in general about a line long, and simple, and separated by very short intervals, but sometimes remote, and forked, or variously branched, and not unfrequently growing to a much greater size, and expanding into lanceolate leaves, themselves also ciliated, whence the plant acquires a proliferous appearance : other cilia, similar to the marginal ones, but ferw in number, are also in general scattered over both surfaces of the frond.

Fructification + , spherical tubercles, of the size of a small pin's head, placed upon the apices both of the marginal and superficial cilia, of a pale pink color, transparent, containing a mass of very minute roundish seeds: the ends of the cilia not uncommonly protrude beyond the tubercles, which then become lateral, like those of $F$.gigartinus.

Color, a deep, semitransparent red, very permanent; so much darker in a dried state, as to look of a chocolate brown, unless held to the light ; in decay it turns paler, and fades into a dull white.

SUBSTANCE, between cartilaginous and membranaceous, firm and tough.

The frond of var. $\beta$ is lanceolate, and undivided, but pinnated on both sides with long simple lanceolate shoots, placed near to each other; the margins are every where fringed with short, subulate, simple cilia.

Var. $\gamma$ has a very singular appearance, and is, in point of form, intermediate between $F$. ciliatus and $F$. palmatus; it agrees in size with $\alpha$ and $\beta$, but is more remarkably attenuated at each extremity; its outline is lanceolate, in some instances undivided, in others bifid or trifid, in a palmate manner; its cilia are few and scattered, so that the margins appear almost naked.

The frond of $\delta$ is narrower than that of the preceding varieties, so as to be scarcely four lines wide, and is at the same time of humbler growth, so as to be seldom three inches high; what, however, is most remarkable in it is, that its narrow and filiform cilia frequently extend to an inch and half, or two inches in length, and are repeatedly branched: the plant employs these like tendrils, and attaches itself, by means of them, to other plants. Miss Hill, who has had the best opportunities of examining it when growing, is of opinion that they finally break of , and become new individuals.

$\varepsilon$ is an extremely elegant variety, and very different in appearance from the others: its length is from two to three inches; its form between linear and lanceolate; its apices acuminated; its width scarcely two lines in the widest part; it is repeatedly branched in a sub-pinnated manner, and has long cilia, but shorter than those of var. $\delta$.

With respect to var. $\zeta$, I am at a loss what to say, and I can hardly believe that it really belongs to $F$. ciliatus; its frond is much and irregularly branched, compressed rather than flat, filiform, not above a line wide; its branches long, and acuminated, beset with a few scattered spiniform cilia.

* Wulfen, whose description of this Fucus is in other respects a pattern for elegance and accuracy, calls the reot a small expanded disk, but I have never seen any thiug of the kind.

$\dagger$ Weber and Mohr have given a very detailed account, in their Neue Beitrige, p. 279, of the microscopic appearance of this frucification, in which they bave seen a great deal more than I could do. For all this, I must refer my readers to my purposed disscrtation upon the fruit of the Fuci. 


\section{0.-F U G US-GIL I A T US.}

Var. $\eta$ has the same size and form as $\varepsilon$, but is every where covered with simple subulate cilia, about a line long.

Oвs. The plant in dying adheres very slightly to paper.

From the description, as well as the figure, here given, it must be sufficiently evident, that $F$. ciliatus is in point of form an extraordinarily changeable plant; nor can it be a matter of wonder if different opinions have prevailed among Botanists how far some of those, which are now regarded as varieties, ought not more properly to be considered as distinct species. It has *already been observed, that there is at first sight much less affinity visible betiveen the third and fifth appearances above noticed, than the former of these bears to $F$. palmatus, or the latter to $F$. confervoides, and that there is scarcely any Fucus in which the transitions through the several gradations are detected with greater difficulty. To the Naturalist, however, who has an opportunity of collecting specimens from distant places, this difficulty will vanish, and the var. 8 in particular, which even Dr. Goodenough and Mr. Woodward considered as really distinct, will be found to be so connected with the broadest and most frequent form of the plant, as to leave no doubt of their identity. It seems most probable that both this and all the more narrow varieties originate from some peculiarity in their places of growth, which, instead of allowing the fructification to be produced $\uparrow$ as usual, gives rise to an unnatural and sterile luxuriance. 'This idea is greatly confirmed by Miss Hill's opinion, already mentioned, that the cilia of 8 actually tend to propagate the plant in a proliferous manner. F. ciliatus, if dried, without sufficient care being taken to wash out the saline particles, will be found covered with a whitish efflorescence, like $F$. saccharinus: if boiled, it fixes, like $F$. tenax or $F$. crispus, into a firm gelatine, which becomes again liquid from exposure to heat. It is eaten, according to Lightfoot, both by the Scotch and Irish, promiscuously with F. palmatus. With regard to its synonymy, there has been great confusion, as may naturally be expected with so variable a species. Gmelin's $F$. ciliatus has already been quoted under the preceding Fucus: his figures of $F$. holosetaceus and $F$. ligulatus are both excellent representations of that here figured, but his description of the latter is far from agreeing with the plate, and seems to be designed for a different plant, an error, of which, there is unfortunately more than one instance in his excellent work. It is not a little extraordinary that Linnæus, who has preserved the true species in his $\ddagger$ Herbarium, should at the same time have overlooked both these figures, and quoted as a synonym Gmelin's F. caulescens, thus giving rise to the errors noticed under $F$. vittatus. Wulfen, who is quite correct in his other references, has himself been mistaken in supposing Esper's t. 4. f. 3. to be copied from the present plant, whereas it seems designed to represent a singularly battered fragment of $F$. laceratus; nor have the authors of the Flore Francaise escaped error in joining together F. ciliatus, ligulatus, and holosetaceus of Gmelin. These Botanists confess that they are unacquainted with the fructification, and this can alone account for their having referred $F$. ciliatus to the Ulva. From Mr. Stackhouse's figure of his var. $\delta$, I have no doubt of its actually belonging to $F$. corneus, with which he remarks that he found it intermixed. Ceramium Teedii of Roth is a very near affinity of $F$. ciliatus, and scarcely distinguishable, except by its discoid root, its color, and its more membranous substance.
a. $F$. ciliatus, natural size.
b. apex of frond, in fructification.
c. capsule, magnified - - - _ - - 5.
$\begin{array}{lll}\text { d. the same, cut through longitudinally } & - & - \\ \text { e. seeds - } & - & -\end{array}$
f. part of frond of var. $\delta$, natural size.
g. plant of var. $\varepsilon$.
h. plant of var. $n_{\text {. }}$

- Synopsis of the British Fuci, I. p. 173.

$\uparrow$ Only the first and second appearances here described have been found in fruit, except two single specimens of var. $\delta$ at different times, one by Mrs: Grifithith, the other by Miss Hill.

$\ddagger$ In the Linnaan Herbarium are four specimens under the name of $F$. ciliatus, one of which, on a single sheet of paper, is the real plant, the other three are $\boldsymbol{F}$. corneus. 
Fucus, fronde membranaceo-cartilagineâ, planâ, enervi, sub-lanceolatâ, pinnato-ramosâ, superficie marginibusque ciliatâ; ciliis simpliciusculis, patentibus, subulatis, apice globuliferis.

Fucus ciliatus. Fl. Ang. p. 580. Lins. Mant. p. 136. et p. 519. (excl. syn. Gmel.) Syst. Nat. II. p. 718. Syst. Nat. Ed. Gmel. II. p. 1387. (excl. var. B, ejusque syn.) Fl. Scot. II. p. 944. Fl. Dan. t. 353. Linn. Trans. III. p. 160. (excl. F. ciliati Gmel. syn.) Fl. Norv. II. p. 96. Ner. Brit. p. 90. t. 15. (excl. var. 8, ejusque syn.) Syn. Fuc. I. p. 169. * Eng. Bot. XV. t. 1069. Esper, Ic. Fuc. II. p. 55. t. 136. Wulfen, Crypt. Aquat. n. 41. (excl. syn. Esp.)

F. holosetaceus. Gmelin, Hist. Fuc. p. 177. t. 21. f. 2. Syst. Nat. Ed. Gmel. II. p. 1387. Wiтh. IV. p. 104.

F. ligulatus. Gmex1N, Hist. Fuc. p. 178. t. 21. f. 3. (quoad ic.) Syst. Nat. Ed. Gmel. II. p. 1387.

Ulva ciliata. Fl. Fr. Ed. $2 d a$. II. p. 13. (excl. syn. omn. sub. var. a citatis.)

Fucus membranaceus rubens angustifolius, marginibus ligulis armatis. $\mathrm{R}_{\mathrm{AII}}$ Syn. p. 47. n. 33.

F. humilis membranaceus acaulos elegantissimus ruber, capillis longis fimbriatus. Moris. Hist. Ox. III. p. 646. n. 10.

B. pinnatifidus; fronde lanceolatâ, pinnatifidâ, segmentis lanceolatis, elongatis, indivisis.

F. ciliatus. $\beta$. Syn. Fuc. I. p. 169.

$\gamma$. palmatus; fronde lanceolatâ, indivisâ, palmatâve, marginibus sub-nudis.

F. ciliatus. $\gamma$. Syn. Fuc. I. p. 170.

8. jubatus; fronde margine superficieque ciliata, ciliis plurimis, elongatis, tenuissimis, filiformibus, cylindricis, ramosis.

F. ciliatus. 8. Syn. Fuc. I. p. 170.

F.jubatus. Linn. Trans. III. p. 162. t. 17. f. 2. Ner. Brit. p. 51. t. 11. Esper, Ic. Fuc. II. p. 35. t. 127.

. lanceolatus; fronde lineari-lanceolatâ, angustatâ, ramosissimâ ; ciliis elongatis, compressis, linearibus, acuminatis, ramosis.

F. ciliatus. \&. Syn. Fuc. I. p. 170.

F. ciliatus. $\beta$. Fl. Scot. II. p. 946. Linn. Trans. III. p. 161. Ner. Brit. p. 91. t. 15.

F. ciliatus. $\gamma$. Ner. Brit. p. 91 . t. 15.

F. ciliatus. var. Es PER, Ic. Fuc. II. t. 136. $A$.

F. lanceolatus. WITH. IV. p. 104.

ร. angustus; fronde lineari, ramosissimâ ; ramis compressis, angustissimis.

F. ciliatus. ?. Syn. Fuc. I. p. 170.

n. spinosus; fronde lineari, compressâ, ramosissimâ, ubique obtectâ ramulis brevibus, simplicibus, subulatis, spiniformibus.

H а в Iт ат $a$ in Britanniarum oris, haud infrequens.-In Galliæ oris, ubi alluitur Oceano. Decandolle.-In Oceano Islandico. Oeder.-In Mari Mediterraneo et Atlantico. Wulfen.- $\beta$ in Novæ Selandiæ littoribus. D.J. Banks Baronet.-Ad Insulam Vectis, unà cum var. $\gamma_{-}-\delta$ et $\varepsilon$ in Devoniâ et Cornubiâ. Dna Griffiths.$\delta$ apud Port-Rush, in comitatu Antrim. D. Scott.- in Sarniæ oris.-Lapurdi. D. Prof. Mertens.-弓 apud Exmouth. D. T. Frankland, Baronet.-n in Devoniæ oris. Dna Griffiths.

Perennis. Oct.-Feb.

RADIX + fibrosa, fibris plurimis, densè implexis, teretibus, angustissimis, elongatis, ramosis, coloris dilutè rosei, repentibus, et demùm assurgentibus in

Frondes plurimas, planas, nervi venarumque expertes, longitudine semipedales, et ultrà, quâ basi proximæ, filiformes et angustas, sed statim ampliatas, nt priusquàm trium quatuorve linearum altitudinem attigerint in latitudinem plerımque unguicularem excreverint, exinde sensim magis magisque latescentes, donec pollicem unum duosve æquent ; figura his lanceolata, vel lineari-lanceolata, vel quandoque oblonga, apicibus acutis, et sunt nunc simplices, nunc variè in plures inæqualitèr profundas dissectæ lacinias, quæ omnes eandem ferè formam servant, et hæ quoque vel simplices, vel bifidæ, vel ipsæ simili ratione divisæ; frondis totius margines obsident cilia homogenea et concolora, compressa, subulata, horizontalitèr patula, lenitèr incurva, plerumque circiter lineam longa, simplicia, et intervallis brevissinis sejuncta, aliquandd tamen remota, et bifurca, vel variè ramosa, nec raro in molem multo majorem excrescentia, seque in folia lanceolata, ipsa eodem modo ciliata, dilatantia, unde stirpis facies prolifera; utrique etiam frondis paginæ sæpiùs innascuntur cilia alia, marginalium similia, sed enormitèr sparsa, et haud ita magno nunıero.

†FUCT1FICAT10 tubercula spliærica, aciculæe capite minora, ciliorum marginalium superficialiumque apicibus insidentia, coloris dilutè rosei, diaphana, seminum minutissimorum sub-rotundorum congeriem intùs foventia : cilii apex haud raro ultra tuberculum producitur, quod tunc fit, $F$. gigartini capsularum instar, laterale.

CoLor saturatè ruber, semidiaphanus, diu persistens ; exsiccata intensior, ut, nisi luci objiciatur, castaneus videatur; in marcescente pallescit, et demùm in sordidè albicantem evanescit.

SuBSTANTIA cartilagineo-membranacea, lenta, tenax.

* Hac icon, in se nequaquam optima, inter a et $\beta$ ambigit.

+ Radicem exigukm placentulam dicit Wulfenius, ego verò nihil in stirpe discoideum unquam vidi: descriptio ejus cæetcra optima omncm laudem meretur.

\$ Fusè et optimè de hâc fructificatione sub microscopio visâ disseruerunt, in opere " Neue Beiträge" dicto, p. 279, Weberus Mohriusque, qui longè plura quam ego in capsulis viderunt. Hæc autem omnia ad dissertationem de Fucorum fructu relinquo.

VOL. I. 
Var. $\beta$ frondem habet lanceolatam, indivisam, sed utrinque pinnatam surculis approximatis, elongatis, ipsis simplicibus lanceolatisque; margines ubique ciliati, ciliis brevibus, subulatis, simplicibus.

Var. $\gamma$ facie est prædita perquàm singulari, et est quoad formam inter $F$. ciliatum et $F$. palmatum intermedia ; staturâ cum $\alpha$ et $\beta$ convenit; sed frondes utrinque multò insigniùs attenuantur; figura lanceolata, in lis indivisa, in illis bifida, vel palmatìm trifida; cilia rara et sparsa, unde margines nudiusculi apparent.

Frons in var. \& præecedentibus angustior ut latitudine vix quatuor lineas, humilior ut altitudine raro palmum superet, sed, quod maximè singulare, cilia angusta filiformia in sesquipollicarem bipollicaremve longitudinem sæpe producuntur, et sunt ramosissima : his, sicut cirrhis, planta utitur, et horum ope sese aliis stirpibus affigit : credit quoque Dna Hill, cui optima fuit recentem observandi facultas, hæc demùm abrumpi, et in novas proles excrescere.

\& est varietas summoperè elegans, et qua facie a reliquis diversissimâ gandet; longitudo bi- tri- pollicaris; figura lineari-lanceolata; apices acuminati; latitudo, ubi latissima, vix bilinearis ; sub-pinnatim est ramosissima, ciliaque habet elongata, sed iis var. 8 breviora.

De var. $\zeta$ nescio quid dicam, et vix mihi persuadere possum ut sit hujus vere loci ; frons ramossissima, compressa potiùs quam plana, propemodùm filiformis, vix lineam lata, ramis elongatis acuminatis, ciliis aliquot sparsis spiniformibus obsitis.

Var. y staturam formamque habet eandem quæ ह, sed frons ubique obtegitur ciliis densè dispositis, simplicibus, subulatis, circiter lineam longis.

OBs. Exsiccata chartæa laxè adhæret.

Quàm summoperè sit $F$. ciliati inconstans forma, et qualibus præcipuè mutationibus sit obnoxia, icon et descriptio nostra satis declarant, nec mirum si diversè statuerint Botanici, annon aliquæ ex illis hic pro varietatibus habitis rectiùs species distinctæ prædicarentur. * Alibi janı memoratum extat, similitudinis apparere minus inter eas, quæ $\gamma$ et $\varepsilon$ titulis designantur, quàm quæ illi cum $F$. palmato vel huic cum $F$. confervoide intercedit ; Fucumque dari vix ullum cujus facies discrepantes gradationum serie minùs apertâ connectantur. Exemplaria autem e locis dissitis accipienti talis extenuatur et evanescit difficultas, et var. ipsa $\delta$, quam viri cautissimi, Goodenovius Woodwardiusque, disjungendam censuerunt, in $\alpha$ transire liquebit. Verisimillimum quidem milhi videtur hanc et omnes fronde angustâ præditas ex eo modo pendere, quod loci natales aliquid in se peculiare habeant, propter quod fructum non, ut natura jussit, ferunt, sed monstrosè sterilitèrque luxuriant; cui etiam opinioni favet Duæ Hill sententia, quæe ciliis in \& cirrhiformibus novas frondes proliferè generari credit. Tantum in se salis marini $\vec{F}$. ciliatus includit, ut nisi cautè sit elotus, priusquàm exsiccetur et comprimatur, F. saccharini instar, frons efflorescentiâ albâ olìm obducta reperietur. Fix elixo, sicut ex $F$. tenace vel ex $F$. crispo, spissa fit gelatina, qua quotiescunque calori objicitur liquefacta solvitur. Comedi etiam a Scotis et Hibernis, unà cum F. palmato, testem habemus Lightfootium. Fuci præ ceteris mutabilis Gynonymia multùm est ab auctoribus confusa. Stirps, quæ Gmelino $F$.ciliatus audit, jam sub specie præcedente citatur ; contrà vero earum, quas $\mathbb{F}$. holosetaceum et $F$. ligulatum appellat, icones huic nostræ optimè respondent. Fateri tamen necesse est posterioris descriptionem plantam a delineat $\hat{a}$ diversam respicere videri, qualismodi hallucinationes plus unâ vice in opere egregio offendes. Linnæus, harum utrâque præternissâ, genuinæ licet in $\ddagger$ Herbario suo stirpis exemplar servaret, $\boldsymbol{F}$. caulescentem Gmel. pro $\boldsymbol{F}$. ciliati synonymo citavit, quo sunt fonte derivati errores jam sub $F$. vittato memorati. Erravisse etiam Wulfenium suspicor, dum Esperi t. 4. f. 3, quæ tantummodo $F$. lacerati frustum variè diffractum mihi videtur, ad $F$. ciliatum verum depictum censet; nec magis mendo caruerunt Flore Gallice aucteres, Gmelini $F$. ciliatum, ligulatum, et holosetaceum conjungendo. Prædicant hi palàm se fructificationem nunquam vidisse, quod ni sit jure mirum haberetur quâ de re commoti plantam globuliferam Ulvis 2ssociaverint. Varietatis suæ \& iconem a Stachhousio datam perpendenti scrupulus nullus restat, quin ad $F$. corneum, quocum immixtam legit, jure pertineat. Rothii Cerumium Teedii est $F$. cilinto summoperè affine, et vix, nisi radice aiscoideâ, colore, et substantiâ tenuiore membranaceâ, dignoscendum.

a. F. ciliatus, magn. nat.

b. frondis capsulifera apex.

c. capsula, magn. auct. $\quad=\quad-\quad-\quad-5$.

d. eadem longitudinaltèr dissecta - - $\quad-3$.

e. semina - - - - - - - 1 .

f. var. \& frondis portio, magn. nat.

g. var. $\varepsilon$.

h. var. $\%$.

\footnotetext{
- Syn. Fuc. I. p. 173 .

+ E varietatibus hic descriptis $\alpha$ modò et $\beta$ sunt in præsens capsuliferæ detectæ, exceptis duobus var. \& exemplaribus, quorum unum Dna Griffiths, alterim Dna Hill legit.

¥ Quatuor in Phytophylacio Linnæano sub F. ciliati nomine specimina servantur: e quibus unum, chartæ folio separatim agglutinatum, est inse Fucus, reliqua tria ad $F$. corneum pertinent.
} 


\section{-}


Fucus, fronde membranaceâ, tenerrimâ, planâ, enervi, sub-dichotomâ ; ramis sub-linearibus ; apice bificlis, obtusis ; margine plauis integerrimis; tuberculis hemisphæricis, immersis, ubique sparsis, seminibusque nudis in maculas oblongas congestis.

Fucus punctatus. WIтн. IV. p. 405. Eng. Bot. XXII. t. 1573.

F. ocellatus. Lamouroux, Diss. Fuc. p. 65. t. 32.

Ulva punctata. ST acknouse, in Linn. Trans. III. p. 236.

Ulva ocellata. Fl. Fr. Ed. 2da. Il. p. 12.

Haвгтат in Cornubix oris. Dna Griffiths.-Inter rejectamenta maris apud Weymouth. D. Stackhouse.-In Cambriæ Australis littoribus, apud Swansea. D. Dillwyn.-Apud Larne in Hiberniâ. D. Drummond.-Lı Sinu, " Bantry Bay" dicto. Dna Hutchins.-In Hispaniæ, Galliæ, Corsicæque oris. Lamouroux.

Annua. Æstate.

RADIX callus exiguus, nigricans.

FroN DEs nunc solitariæ, nunc ex eâdem basi plurimæ, planæ, nervi venarumque prorsùs expertes, longitudine a palmari ad semipedalem, latitudine ab unguiculari ad tripollicarem variabiles; crescendi quoque modus in diversis individuis diversus, in his enim est frons a basi usque ad apices dichotoma, furcis erecto-patulis septies octiesve repetitis, intervallo inter singulas brevi, ramis sub-linearibus, in illis, sicut in exemplare hìc depicto, ad dimidium altitudinis indivisa assurgit, ibique vel dichotomè vel palmatìn finditur in aliquot ramos, ipsos quoque iterùm palmatos, aut bis ter dichotomos, utrâque ramorum serie præcedente angustiore, apicibus bifidis, segmentis brevibus, sub-divaricatis, obtusis; margines semper integerrimi, aliquandò levitèr undulati, sed nunquam crispati.

Fructificatio * tubercula elliptica vel hemisphærica, Brassica Rapa seminum magnitudine, utrique frondis paginæ a basi usque ad apices + sparsìm, copiosè tamen, innascentia, semper solitaria, e membranâ adeò tenui constantia, ut semina, quæ includunt, subrotunda intensè rubra transluceant: præter hæc, et quidem sæpiùs, occurrunt in fronde semina nuda, congesta in maculas ejusdem quầ tubercula formæ, eodemque omnino modo sita, ut discrimen inter utraque vix ullum oculo inermi detegatur, sub lente in duas vel tres partes dehiscentia:- anne sit Fuco fructus duplex, an semina, tuberculorum membranâ deperditâ, frondi adhæreant, neque de hâc stirpe, neque, uti suprà dicitur, de $F$. lacerato adhuc satis liquet.

Color lætè roseus, iı quibusdam individuis sanguineo immixtus, diaphanus; exsiccata nitens; marcescentis in luteo-virescentem transiens.

Substastia membranacea, tenuissima, et tenerrima.

Oвs. Frons sub lente, $F$. lacerati et $F$. ulvoidis instar, pulcherrimè reticulata:-_exsiccata chartæ tam arctè ad.hæret, ut, integritate salvâ, non sit, vel madefacta, avellenda.

Primus, sedecim abhìnc annis, hujus Fuci exemplar inter alia maris rejectamenta apud Weymouth legit cl. Stackhousius, qui mox Societati Linnæanæ descriptum impertivit, et, seminibus nudis modo visis, Ulva generi, nec tamen sine scrupulis, ascribendum censuit; in quâ et ipse certè fuissem sententiâ, nisi stirpes tuberculis veris præditas videndi nuper fuerit facultas. Magno mili hoc fuit gaudio, quod, his detectis, fructificatio ejus $F$. lacerati omnind similis appareat, nec ulteriùs opus sit ut duas plantas naturâ evidentissimè inter se connexas in duo genera distrahamus. Ea quidem est hæc affinitas, ut dubitet Lamourouxius an hæc stirps, quam optimo nomine $F$. ocellatum appellat, et $F$. lacerati var. nostra $\gamma$, quæ illi $F$. granateus audit, sint reverâ distinctæ. Discrepant autenı $F$. punctati colore lætiore, venarum omnium frondem percurrentium absentiâ, marginibus planis, nequaquàm crispatis crenatisve, substantiâ longè tenuiore, ut vix ulla sit adeò tenuis membrana cui conferri recuset, et fructificatione per totam frondem sparsâ. Arctiùs adhuc speciei insequenti accedit, de quo sub illâ tractabitur. $F$. punctatus, quamvis in multis per Britanniarum oras locis detectus, nullibi, quod scio, nisi perparcè occurrit. Exemplar hic depictunı, solito majus pulchriusque, benevolè misit Dna Hutchins : formâ quàm nnaximè discrepat illud a Lamourouxio delineatum, cujus rami elongati sunt et angusti, sed inæqualis ubique latitudinis, et frons variè absque normâ divisa. De synonymo tamen locus est dubitationi nullus. Fructificationis iconem ad lit. $f$. sub lente maximè augente et ad exenplar adhuc recens adumbratam Dillwynii amicitia debeo.
a. F. punctatus, magn. nat.
b. frondis pars, cum seminibus nudis, magn. auct. 5 .
c. ejusdem portio - $-\quad-\quad-\quad-3$.

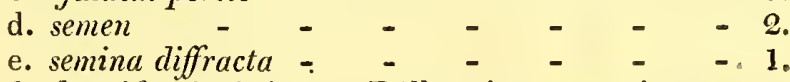
f. fructificationis icon a Dillwynio communicata.

\footnotetext{
Hac tubercula corum $F$. lacerati et $F$. ulvoidis omninò sunt similia, sed uulla nunc sunt ad manus quæe hic delincata exhibere possun.

† Non semper sunt enormitèr sparsa, sed in quibusdam exemplaribus, præsertim angustioribus, lineis duabus sub-paraliclis, sicut Stack. housius descripsit, disponuntur.
} 
Fucus punctatus, frond membranaceous, very tender, flat, nerveless, mostly dichotomous; branches nearly linear, bifid and obtuse at their apices, at their margins flat and entire; hemispherical immersed tubercles, scattered all over the frond, and naked seeds collected into oblong spots.

Fucus punctatus. WIтн. IV. p. 405. Eng. Bot. XXII. t. 1573.

F. ocellatus. Lamouroux, Diss. Fuc. p. 65. t. 32.

Ulva punctata. ST A с кHоU E, in Limn. Trans. III. p. 236.

Ulva ocellata. Fl. Fr. Ed.2da. II. p. 12.

Among the rejectamenta of the sea at Weymouth. Mr. Stackhouse.-Coast of Cornwall. Mrs. Griffiths.Swansea.-Mr. Dillwyn. Larne, near Belfast. Mr. Drummond.-Bantry Bay. Miss Hutchins.-Shores of France, Spain, and Corsica. Lamouroux.

Annual. In the summer inonths.

Rоoт, a small, blackish, callous disk.

FRONDS, either solitary, or numerous from the same base, flat, quite destitute of midrib or veins, varying in length from a quarter to half a foot, and in width from half an inch to three inches; the mode of growth is also different in different individuals, in some the frond is regularly dichotomous from base to summit, the segments being all nearly linear, between erect and patent, and the divisions seven or eight times repeated at sliort intervals, in others, as in that here represented, the frond continues for half its height undivided, and is there cleft in a palmate or dichotomous manner into a few branches, which are themselves again once or twice divided in the sanle way, every succeeding series of branches being more narrow than that below it, and the apices of all being bifid, with short, sub-divaricated segments; the margins are constantly quite entire, and, though sometimes slightly undulated, are never curled.

FrdCtification, elliptical or hemispherical *tubercles, as large as turnip-seed, +scattered plentifully over both sides of the frond from base to summit, always solitary, and composed of so delicate a membrane, that the dark-red roundish seeds which they contain are perfectly visible: besides these, and much more frequently, are seen upon the frond naked seeds, collected into clusters of the same form as the tubercles, and arranged in the same manner, so that scarcely any difference between them is discernible to the naked eye, appearing under a microscope composed of two or three parts :- whether the Fucus has a twofold fructification, or wliether the seeds continue to adhere to the frond, after the membranous coat of the tubercle is destroyed, I have no means of determining, either as to this plant, or $F$. laceratus.

Color, a bright pink, tinged in some specimens with blood-red, transparent; glossy when dry; and, in a state of decay, turning to a pale greenish yellow.

SUBSTANCE, menibranaceous, extremely thin and tender.

Oв. The frond is most beautifully and distinctly reticulated under a microscope, like F. laceratus and $F$. ulvoides: -in drying, it adheres so closely to paper, that it cannot be separated, even by subsequent immersion, without injury.

It is now sixteen years since Mr. Stackhouse first collected a specimen of this Fucus among other rejectamenta of the sea upon the beach at Weymouth, and communicated a description of it to the Linnæan Society, referring it, though not without hesitation, to the genus Ulva. The same would also unquestionably have been my opinion, had I, like him, seen only individuals with naked seeds; but, very fortunately, others have lately been detected bearing real tubercles, and altogether agreeing in point of fructification with $\mathbb{F}$. laceratus, so that there can no longer be any necessity to do violence to natural affinities, by separating into different genera two plaits so evidently intended by nature to be placed together, that Lamouroux, who has described the present under the very characteristic name of $F$. ocellatus, has even been led to doubt how far it is specifically different from the var. $\gamma$ of $F$. laceratus, his $F$. granateus; and it appears from his work, that he would in all probability have united them, but that he never found the one except with scattered seeds, nor the other, except with closed tubercles. There is, however, no room for doubt upon this subject, for they differ in the brighter color of $F$. punctatus, in its frond being wholly destitute of veins, in its flat margins neither curled nor crenated, in its substance so much more thin as to equal in this respect almost any known membrane, and in the situation of its fruit, which, instead of being confined to the upper branches, is scattered indifferently over the whole frond. F. punctatus is still more closely allied to the following plant, as will there be mentioned. It has been found upon several parts of the British shores, but no where, I believe, except extremely sparingly. For the specimen here figured, which is both larger and more handsome than any other I ever saw, I am indebted to Miss Hutchins; it is as widely removed as possible from that copied by Lamouroux, the branches of which are long and narrow, but of very unequal width, and the frond divided without any regular order. There is however, no doubt attending the synonym. Mr. Dillwyn obligingly communicated the highly magnified drawing of the fruit at $f$, which was done from a recent specimen gathered by himself at Swansea.
a. F. punctatus, natural size.
b. part of the frond, with naked seeds, magnified - 5
c. portion of the same. - - - - - 3 .
d. seed - - - - - - - - 2 .
e. seeds broken into three parts - $\quad-\quad$ - 1 .
f. drawing of the fruit from Mr. Dillwyn.

* 'These tubercies are precisely like those of $F$. laceratus and $F$. ulvoides, but $I$ have no specimen of them now at hand to figure.

+ They are not always irregularly scattered, but in some specimens, especially those which are most narrow, may be occasionally met with disprosed in two nearly parallel rows, as described by Mr. Stackhouse. 


\section{ง}

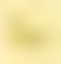






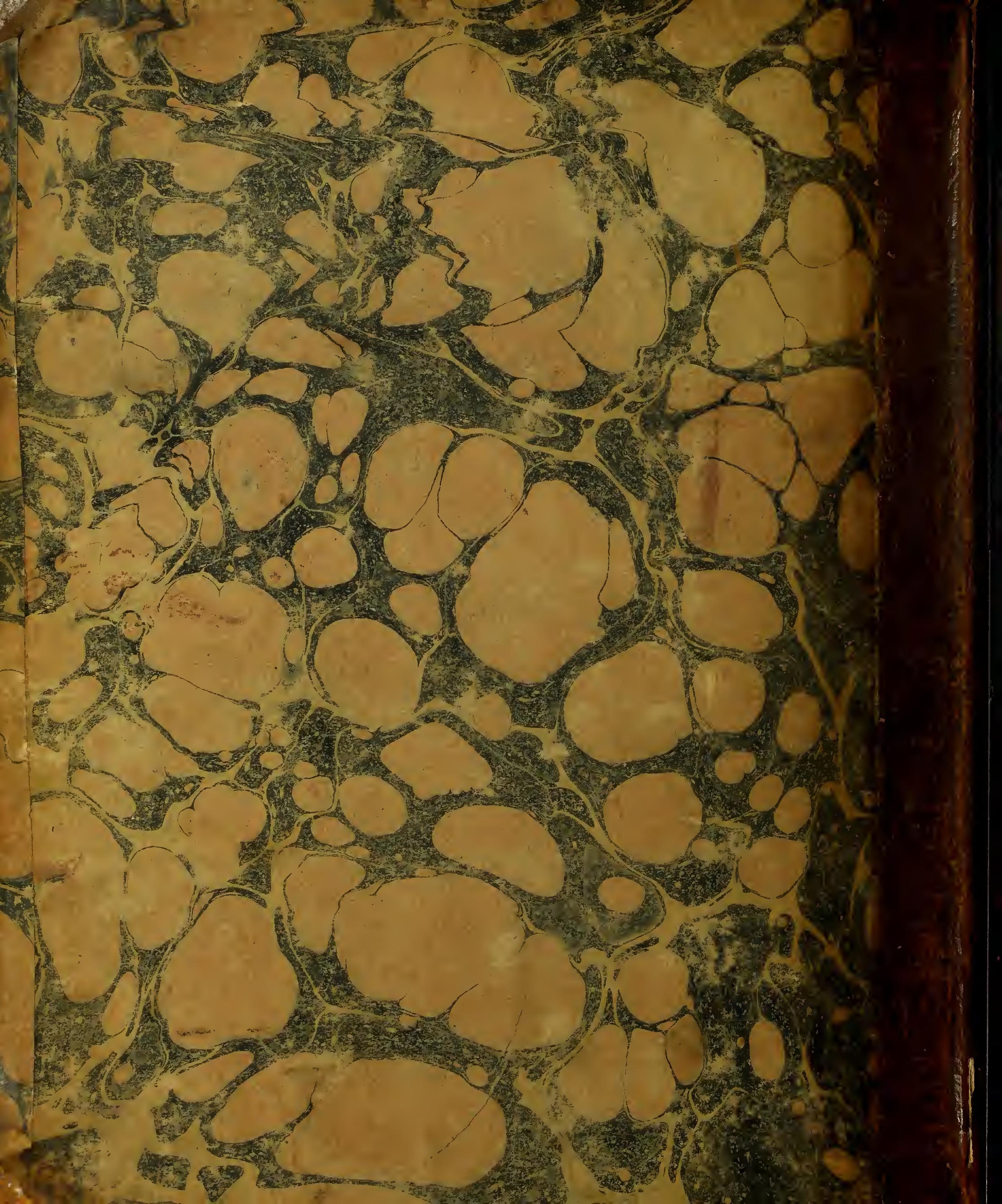

